\section{RUSSIAN JOURNAL OF AGRICULTURAL AND SOCIO- ECONOMIC SCIENCES}

ISSN 2226-1184

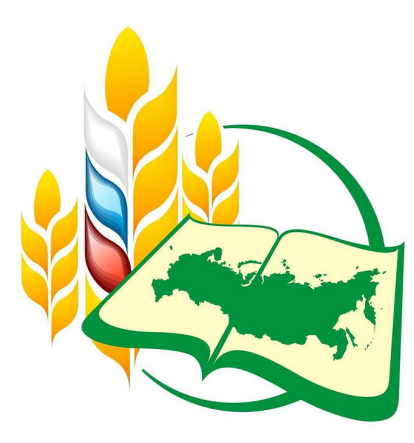

\title{
August 2017
}

"RJOAS is an interdisciplinary open accessjournal of agriculture and socioeconomic studies. The journal aims at establishing a bridge between theory and practice in the fields of agriculture and socio-economic research..." 
OPEN

ACCESS 


\section{TABLE OF CONTENT}

Prasetya H.D., Saraswati E., Ghofar A.

- CORPORATE SOCIAL RESPONSIBILITY DISCLOSURE AND CORPORATE FINANCIAL PERFORMANCE: A META-ANALYSIS; pp. 3-11

- Crossref DOI: 10.18551/rjoas.2017-08.01

\section{Astakhova E.V.}

- FEATURES OF THE DEVELOPMENT OF THE AGRICULTURAL MARKETING SYSTEM; pp. 12-15

- Crossref DOI: 10.18551/rjoas.2017-08.02

\section{Kuzubov A.A.}

- CRITERIA FOR ASSESSING THE INVESTMENT ATTRACTIVENESS OF THE AGROINDUSTRIAL COMPLEX'S ENTERPRISES; pp. 16-20

- Crossref DOI: 10.18551/rjoas.2017-08.03

Agusti R.R.

- FINANCIAL REPORTING AND CORPORATE TAX AGGRESSIVENESS: IMPACT ON FIRM VALUE; pp. 21-27

- Crossref DOI: 10.18551/rjoas.2017-08.04

\section{Shashlo N.V.}

- STRATEGIC MANAGEMENT IMPERATIVES FOR BALANCED DEVELOPMENT OF THE AGRO-INDUSTRIAL ENTERPRISE; pp. 28-33

- Crossref DOI: 10.18551/rjoas.2017-08.05

Pambudi Y.S., Sudaryantiningsih C.

- PUSH FACTORS OF COMMUNITY PARTICIPATION IN THE MANAGEMENT OF WASTE BANK IN THE CITY OF SURAKARTA, CENTRAL JAVA PROVINCE, INDONESIA; 34-40

- Crossref DOI: 10.18551/rjoas.2017-08.06

Suwana M.A.J., Purnomosidhi B., Mardiati E.

- THE EFFECT OF CORPORATE GOVERNANCE MECHANISM, OWNERSHIP STRUCTURE, AND EXTERNAL AUDITOR TOWARD CORPORATE SOCIAL RESPONSIBILITY DISCLOSURE WITH EARNING MANAGEMENT AS MODERATING VARIABLE; pp. 41-52

- Crossref DOI: 10.18551/rjoas.2017-08.07

Apriyanto G., Firdiansjah A.

- RECONSTRUCTION OF PENSION FUND PERFORMANCE MODEL AS AN EFFORT TO WORTHY PENSION FUND GOVERNANCE; pp. 53-62

- Crossref DOI: 10.18551/rjoas.2017-08.08

\section{Kurube E.H., Hakim A., Sujarwoto}

- THE PLANNING OF HUMAN RESOURCES (STATE APPARATUS) QUALITY IMPROVEMENT IN THE PERSPECTIVE OF GOVERNANCE: A STUDY ON REGIONAL EMPLOYMENT BOARD OF MALANG; pp. 63-69

- Crossref DOI: 10.18551/rjoas.2017-08.09

Wasana M.T., Samudro B.R., Soesilo A.M.

- THE EFFORTS OF KLATEN REGENCY GOVERNMENT IN ENHANCING COMMUNITY WELFARE THROUGH PEOPLE-BASED ECONOMY PROGRAM REALIZATION; pp. 70-80

- Crossref DOI: 10.18551/rjoas.2017-08.10

Prilukov A.N.

- EFFECTIVE ALGORITHM OF MULTIPARAMETRIC FUNCTIONAL-STATISTICAL ANALYSIS AND ITS COMPUTER VERSION; pp. 81-103

- Crossref DOI: 10.18551/rjoas.2017-08.11 
Usman A., Nagu N., Syahrir, Sundari S.

- DETERMINANTS ON AUDIT QUALITY OF CITY INSPECTORATES IN SOUTH SULAWESI PROVINCE; pp. 104-113

- Crossref DOI: 10.18551/rjoas.2017-08.12

Novikov S.V.

- INNOVATIVE METHODS FOR WORK PROCESS DESIGN IN A HIGH TECHNOLOGY ENTERPRISE; pp. 114-117

- Crossref DOI: 10.18551/rjoas.2017-08.13

Susilo H., Astuti E.S., Wiyata

- ANALYZING AND MODELING THE ROLE OF HUMAN RESOURCE INFORMATION SYSTEM ON HUMAN RESOURCE PLANNING AT HIGHER EDUCATION INSTITUTION IN INDONESIA; pp. 118-124

- Crossref DOI: 10.18551/rjoas.2017-08.14

Primastuty I.H.I., Noor I., Mindarti L.I.

- THE IMPLEMENTATION OF INDONESIAN NATIONAL QUALIFICATION FRAMEWORK CURRICULUM IN HIGHER EDUCATION INSTITUTION; pp. 125-130

- Crossref DOI: 10.18551/rjoas.2017-08.15

Pratama B.I., Kriyantono R., Febriani N.S.

- IDENTIFYING LOCAL WISDOM IN ANTI-CORRUPTION EDUCATION OF MALANG'S ELEMENTARY SCHOOL; pp. 131-141

- Crossref DOI: 10.18551/rjoas.2017-08.16

Gani I.F., Irianto G., Achsin M.

- COMPARATIVE ANALYSIS OF TAX OBJECT SALES VALUE ON LAND AND BUILDINGS WITH INDONESIAN VALUATION STANDARD (SIP)-BASED VALUATION IN MALANG CITY; pp. 142-151

- Crossref DOI: 10.18551/rjoas.2017-08.17

Bestaraya B., Hidayat S., Wedyantadji B.

- ANALYSIS OF QUALITY CONTROL IN SEPAKU PETUNG ROAD IMPROVEMENT THROUGH RIGID PAVEMENT BY PT BONE BORNEO; pp. 152-157

- Crossref DOI: 10.18551/rjoas.2017-08.18

Wibowo R.A., Hidayat S., Santosa A.A.

- ANALYSIS OF RELATIONS BETWEEN KNOWLEDGE ON SAFETY AND HEALTH TOWARDS CONSTRUCTION WORKERS' BEHAVIOR ON SEPAKU-PETUNG ROAD IMPROVEMENT PROJECT IN EAST KALIMANTAN PROVINCE; pp. 158-166

- Crossref DOI: 10.18551/rjoas.2017-08.19

Fitria L., Hariadi B., Roekhudin

- EFFECT OF JOB SATISFACTION AND PERCEPTION OF WORK OPPORTUNITIES TO TURNOVER INTENTION WITH ORGANIZATION COMMITMENT AS INTERVENING VARIABLES: THE CASE OF HOTELS IN EAST JAVA, INDONESIA; pp. 167-178

- Crossref DOI: 10.18551/rjoas.2017-08.20

Suharto, Suhada B.

- THE INFLUENCE OF PRODUCT AND COMPANY IMAGE ON SAVING DECISION THROUGH TRUST VARIABLE AT THE PEOPLE'S CREDIT BANK EKA BUMI ARTHA IN METRO CITY; pp. 179-187

- Crossref DOI: 10.18551/rjoas.2017-08.21

Pradana G.Y.K., Parwati K.S.M.

- LOCAL-WISDOM-BASED SPA TOURISM IN UBUD VILLAGE OF BALI, INDONESIA; pp. 188-196

- Crossref DOI: 10.18551/rjoas.2017-08.22 
Handiyono M.Y., Sukoharsono E.G., Saraswati E.

- THE ROLE OF CORPORATE SOCIAL RESPONSIBILITY DISCLOSURE TOWARD COMPANY STOCK PRICE CRASH RISK; pp. 197-208

- Crossref DOI: 10.18551/rjoas.2017-08.23

Rudin M., Amir A.M., Bakarbessy M.L.F.

- REVIEW OF LOCALLY-GENERATED REVENUE AND CAPITAL EXPENDITURE IN IMPROVING DISTRICTS AND MUNICIPALITIES'S ECONOMY GROWTH OF NORTH MALUKU PROVINCE; pp. 209-216

- Crossref DOI: 10.18551/rjoas.2017-08.24

Hariadi K.L., Sutrisno, Rahman A.F.

- THE EFFECT OF CORPORATE GOVERNANCE DISCLOSURE ON INVESTOR REACTIONS WITH PROFITABILITY AS MODERATING VARIABLE; pp. 217-232

- Crossref DOI: 10.18551/rjoas.2017-08.25

Sugiono A., Arifianti R., Raharja S.J., Maulina E., Hapsari Y.D.

- DYNAMIC CAPABILITIES AND CREATING ORGANIZATIONAL KNOWLEDGE: IMPORTANT LINKAGE FOR BUILDING COMPETITIVE ADVANTAGE; pp. 233-241

- Crossref DOI: 10.18551/rjoas.2017-08.26

Hidayat R., Suman A., Sakti R.K.

- ANALYSIS OF FACTORS AFFECTING THE AMOUNT OF REMITTANCE DELIVERY TO HOMETOWN OF GOLD MINING WORKFORCES OF PT AMMAN MINERAL NUSA TENGGARA IN WEST SUMBAWA REGENCY; pp. 242-249

- Crossref DOI: 10.18551/rjoas.2017-08.27

Tolstikh N.A., Yushkov Y.G., Gordov V.S., Leonov S.V., Kashapova S.V.

- DEVELOPMENT OF EXTERNAL CONTROL BASED ON THE AVIDIN GENE OF BIRDS FOR POLYMERASE CHAIN REACTION IN REAL TIME; pp. 250-253

- Crossref DOI: 10.18551/rjoas.2017-08.28

Konovalova E.N.

- GENETIC DEFECTS OF BEEF CATTLE AND NECESSITY OF THEIR MANAGING; pp. 254-259

- Crossref DOI: 10.18551/rjoas.2017-08.29

Dewanti B.S.D., Wijana S., Hapsari R.N.

- THE EFFECT OF DRYING METHOD AND TYPES OF NATURAL FIXATIVE ON THE COIR OF KELAPA GADING (COCOS NUCIFERA EBURNEA) TOWARD COLOR INTENSITY AND COLOR DURABILITY OF BATIK CLOTH; pp. 260-269

- Crossref DOI: 10.18551/rjoas.2017-08.30

Telikh K.M., Bulyntsev S.V.

- THE INFLUENCE OF AGROTECHNICAL METHODS OF CULTIVATION ON PRODUCTIVITY OF NEW VEGETABLE AND FODDER BEANS' VARIETIES; pp. $270-275$

- Crossref DOI: 10.18551/rjoas.2017-08.31

Seregina N.V.

- THE INFLUENCE OF WEATHER CONDITIONS AND AGRONOMIC PRACTICES ON SEED PRODUCTION OF PHACELIA; pp. 276-280

- Crossref DOI: 10.18551/rjoas.2017-08.32

Osipov G.V.

- LEGAL BASIS AND POLITICAL NEEDS OF THE REFORM OF THE MANAGEMENT OF ACADEMIC SCIENCE AT THE TURN OF THE XX AND XXI CENTURIES; pp. 281-285

- Crossref DOI: https://doi.org/10.18551/rjoas.2017-08.33 
DOI https://doi.org/10.18551/rjoas.2017-08.01

\title{
CORPORATE SOCIAL RESPONSIBILITY DISCLOSURE AND CORPORATE FINANCIAL PERFORMANCE: A META-ANALYSIS
}

\author{
Prasetya Heru Dwi*, Saraswati Erwin, Ghofar Abdul \\ Faculty of Economics and Business, University of Brawijaya, Malang, Indonesia \\ *E-mail: herudwiprasetya@gmail.com
}

\begin{abstract}
This study aims to determine the effect of Corporate Social Responsibility Disclosure (CSRD) and corporate financial performance. This research use meta analysis with 60 sample of research result in Indonesia. The results of this study indicate that in general CSRD can improve the corporate financial performance. The relationship between CSRD and the corporate financial performance is weakened by one of the financial performance measurement models. Thus, the results of this study found that the influence of CSRD on corporate financial performance can be different due to differences in financial performance measurement model corporate.
\end{abstract}

\section{KEY WORDS}

Corporate social responsibility disclosure, corporate financial performance, meta-analysis.

The main purpose of the establishment of a corporate is to improve the welfare of shareholders. This welfare can be improved through good corporate performance. Corporate performance is divided into two types namely financial performance and non-financial performance. The financial performance of the corporate is an important factor to assess the overall performance of the corporate itself, because the financial performance is the results achieved by the corporate has been in accordance with the planning (Muntiah, 2013), and serves as a measure of the level of achievement of corporate goals and tools to decision making (Armstrong, 2014).

In making an economic decision, investors not only rely on the financial performance of the corporate but also require non-financial information in the process of making investment decisions. Investors include variables related to social issues and environmental sustainability. Investors tend to invest in corporate that have good business ethics, employees, care about environmental impacts, and have corporate social responsibility with stakeholders (Belkaoui, 1976 and Patten, 1990). Sustainability reporting is one of the reports that provide non-financial information (Eipstein and Freedman, 1994). Sustainability reporting is increasingly becoming a trend and a need for progressive corporate to inform their economic, social and environmental performance as well as to stakeholders of the corporate (Chariri, 2009).

Research on corporate social responsibility disclosure and corporate finance performance has been done. In Indonesia itself also has a lot of research that examines the relationship between CSRD and the financial performance of the corporate. However, there are different results from the studies that have been done. Some researchers suggest that CSRD can improve the corporate financial performance (Ahmed et al., 2012; Dahlia and Siregar, 2008; Purnomo and Widianingsih, 2012; Pustikaningsih, 2011). Other researchers argue that CSRD tends to reduce the corporate financial performance (Criso'stomo et al., 2011; Indrawan, 2011). Some researchers argue that CSRD has no effect on financial performance (Anggraini, 2006, Athanasia and Maria, 2010; Wijayanti et al., 2011; Yaparto et al., 2013).

Because of various findings and results in finding accurate conclusions on CSRD relationships with financial performance. This study aims to examine the relation of CSRD on the corporate financial performance and analyze the relationship is moderated by CSRD measurement model or corporate financial performance by using meta analysis. 


\section{LITERATURE REVIEW AND HYPOTHESES}

Financial Performance. Financial performance is the results achieved by the corporate has been in accordance with the planning (Muntiah, 2013). Financial performance is an important thing, because it serves as a measure of the level of achievement of corporate goals and tools to determine in making decisions (Armstrong, 2014). Financial performance also means an analysis conducted to see how far a corporate has been operating properly and properly (Fahmi, 2011). Another understanding of financial performance is the corporate ability to manage and control its own resources (IAI, 2007).

Legitimacy Theory. Legitimacy is a psychological state of people's and group's alignments to the environment. The legitimacy of a corporate can be seen as a given by society to the corporate and something the corporate wants or sought from society (O'Donovan, 2002). Community legitimacy is an important factor for the corporate to develop the corporate in the future (Hadi, 2014), so that the corporate will continue to grow if the community realizes that the corporate operates in accordance with the values and norms is exist.

Corporate activity should be in accordance with the social value of its environment, in order to gain legitimacy support from the community, in accordance with the existing system in society and make reporting activities that reflect social values (Dowling and Pfeffer, 1975). For legitimacy to be more effective, companies must communicate with the public continuosly. Communication will build perceptions about the corporate, also do the disclosure, especially related to social responsibilities (Patten, 1990).

Stakeholders Theory. Stakeholder theory, which is the theory that describes to whichever corporate is responsible (Freeman, 1983). The sustainability of a corporate's operations depends on the its ability to balance the diverse interests of its stakeholders. Companies capable of reaching stakeholder support, then market share, sales, and corporate profits will increase (Angela, 2015).

Corporate Social Responsibility. Corporate Social Responsibility (CSR) is a concept of social responsibility to show the public about the social activities of the corporate and its effects on society by considering the long-term sustainability of the corporate (Gray et al., 1995). CSR also means the corporate's commitment to contribute to sustainable economic development with due regard to corporate social responsibility and focuses on the balance between attention to economic, social and environmental aspects (Untung, 2009).

Social responsibility is a form of corporate concern for the external environment in which the corporate operates by engaging various activities undertaken with the aim of conserving or preserving the environment, community norms, participation in development, and other forms of social responsibility. CSR is identical with sustainability development like corporate in carrying out operational activities should be based on decisions that are not based on financial factors but on the basis of social and environmental factors for the moment as well as for the long term (Jamali, 2014).

Research Hypotheses. Considering about the previous literates, we expected the corporate social responsibility disclosure positively affects the corporate financial performance $(\mathrm{H} 1)$. The relationship of corporate social responsibility disclosure on corporate financial performance is moderated by CSRD measurement model $(\mathrm{H} 2)$. The relationship of corporate social responsibility disclosure on the corporate financial performance is moderated by the corporate financial performance measurement model $(\mathrm{H} 3)$.

\section{DATA AND METHODS OF RESEARCH}

The approach used in this study is by literature review which means to examine the results of research on the impact of corporate social responsibility disclosure on the corporate financial performance. The analytical tool used is a meta-analysis that aims to combine several similar research on the influence of CSRD on the corporate financial performance. Meta analysis is done by collecting previous research results with the same 
topic, then statistical results are processed to determine the effect size of CSRD with financial performance which will be used for moderation effect analysis.

Meta Analysis. Meta-analysis is a statistical technique for combining the results of two or more similar studies, to obtain a quantitative data summary (Anwar, 2005). In addition, meta-analysis is good for understanding the research literature by assessing the overall effect of existing research (Hunter and Schmidt, 1990). Thus, the meta-analysis technique is the most effective way to summarize, integrate, and interpret some of the results of research with a statistical approach to one area of science, or it may be called "an analysis performed on other analyzes already performed". The studies that have been conducted tend to have varied results such as having different sample sizes, time periods, and research methods (Glass, 1978).

Sensitivity Analysis. Sensitivity analysis is an analysis used to assess whether one meta-analysis result is relatively stable to the effect of change or not. These influences include research design, geographic location, time period, and quality of studies (Fanani, 2016). Meta-analysis studies allow for publication bias. In this study, the possible bias in the type of data sample research, the research published or unpublished. Sensitivity analysis attempts to answer whether there is a moderating effect on the publication status on the relationship between CSRD and the corporate financial performance.

\section{EMPIRICAL RESULTS AND DISCUSSION}

During the study period (2000-2016), 151 articles were collected according to the topic of CSRD's influence on the corporate financial performance. The study was then selected to find research with complete data in accordance with the needs of meta analysis. After going through the selection, 60 research samples are collected according to required criteria. The research is not included in the criteria because the research does not include the data required in the meta analysis, ie the number of samples, the operational variables, the statistical value $r$, and the statistical values that can be converted to $r$ (t-statistics, F-statistics, and p-value).

Table 1 - Sample Selection

\begin{tabular}{|c|l|c|}
\hline No. & Criteria & Total \\
\hline 1 & CSRD and corporate financial performance articles & 151 articles \\
\hline 2 & Required statistical data such as n, t and F are not available one or more. & $(91)$ articles \\
\hline \multicolumn{2}{|c|}{ Total Sample } & 60 articles \\
\hline
\end{tabular}

These studies use a variety of measurement models to measure both the dependent variable (financial performance) and the independent variables of Corporate Social Responsibility (CSRD). CSRD with measurement of Corporate Social Responsibility Index (CSRDi) and PROPER SRI KEHATI (Environmental Performance) index. Financial Performance with measurement Return On Equity (ROE), Return On Assets (ROA), Stock Return, Earning Per Share (EPS), and Profit Persistence.

The effect size in the meta-analysis is used to represent the findings of the sampled studies. Statistical data from each research in the form of r-statistics is included into effect size in the meta analysis. If r-statistics are not found, then t-statistics, F-statistics, and pvalues can be converted to r-statistics. In this research, there are no research samples that show r-statistics, so that the conversion of t-statistics and F-statistics to r-statistics is done. A total of 56 studies used t-statistics transformation to r-statistics, while 4 studies used transformation of F-statistics to r-statistics.

Meta Analysis on Explanatory Variable. Explanatory variable in this research using CSRD variable. Based on the results of meta analysis in Table 5.1, from 60 studies that examine the influence of CSRD on the corporate financial performance, the average correlation $(\bar{r})=0.1820$ with confidence interval of $95 \%(0.0858-0.2782)$. These results show that CSRD has a significant positive effect on the corporate financial performance, so it can be said that hypothesis $1(\mathrm{H} 1)$ is accepted. 
Table 2 - Meta-Analysis Result (General Meta Analysis)

\begin{tabular}{|c|c|c|c|c|c|c|c|}
\cline { 2 - 8 } \multicolumn{1}{c|}{} & $\sum \mathrm{Ni}$ & $\mathrm{K}$ study & $\mathrm{r}$ & Min & to & Max & $\mathrm{x}_{\mathrm{k}-1}^{2}$ \\
\hline General Meta Analysis & 6630 & 88 & 0,1820 & 0,0858 & - & 0,2782 & 436,0571 \\
\hline
\end{tabular}

Based on the calculation of Chi Square (X2k-1), obtained value 436,0571. The value is greater than the value of Chi Square table (X20.01), which is 88.379. This indicates a moderation effect that affects the relationship between CSRD and the corporate financial performance. Therefore, to know the existence of moderation effects, sub-group analysis of CSRD measurement and financial performance model is required.

Meta Analysis of Moderator Effect. Based on the results of Chi Square test that has been done before, the value of Chi Square statistic is greater than the value of Chi Square table (X2k-1> X20,01), so there is a moderation effect between CSRD and corporate financial performance. Table 5.2. Explains the effects of moderation with financial performance measurement models and CSRD measurement models.

Table 3 - Meta-Analysis Result (Meta Sub-group)

\begin{tabular}{|c|c|c|c|c|c|c|c|c|}
\hline & & $\sum \mathrm{Ni}$ & K study & $\bar{r}$ & Min & to & Max & $x 2$ \\
\hline & General Meta Analysis & 6630 & 88 & 0,1820453 & 0,0858575 & - & 0,2782330 & 436,0571951 \\
\hline \multirow{2}{*}{ 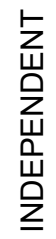 } & CSRDi & 5780 & 78 & 0,1949296 & 0,0957439 & - & 0,2941153 & 394,0591646 \\
\hline & Environmental performance & 850 & 10 & 0,0944319 & 0,0352961 & - & 0,1535677 & 36,1091977 \\
\hline \multirow{5}{*}{$\begin{array}{l}\text { 点 } \\
\text { 岂 } \\
\text { 岂 }\end{array}$} & ROE & 2398 & 38 & 0,2174754 & 0,1008310 & - & 0,3341198 & 195,2319018 \\
\hline & ROA & 3141 & 35 & 0,1500577 & 0,0965490 & - & 0,2035663 & 124,7465017 \\
\hline & Stock Return & 231 & 4 & 0,3754860 & 0,2789167 & - & 0,4720554 & 19,4240554 \\
\hline & EPS & 512 & 6 & 0,2318748 & $-0,0017598$ & - & 0,4655094 & 74,1638148 \\
\hline & Profit Persistence & 348 & 5 & 0,0249013 & 0,0205210 & & 0,0292816 & 5,7786932 \\
\hline
\end{tabular}

The results of the sub-group performed on the measurement of the variables of financial performance, that is ROE, ROA, Stock Return, EPS, and Profit Persistence vary. Based on the sample of research data in accordance with predetermined criteria, the measurement of corporate finance performance that is widely used is ROE. Of the 60 studies used as samples, 34 studies used ROE as a measure of the corporate financial performance. Measurements using ROE, ROA, Stock Return, and Profit Performance indicate significant influence between CSRD and corporate financial performance in the same direction as the general meta-analysis (positive) results. The measurement of corporate financial performance using EPS indicates the insignificant influence between CSRD and the corporate financial performance because of the confidence interval shows positive and negative value, so hypothesis $3(\mathrm{H} 3)$ is accepted. These varied results indicate the effect of moderation effects between CSRD and corporate financial performance.

Measurement of CSRD variables with sample research data in accordance with predetermined criteria, CSRD measurement is widely used is CSRDi. From 60 studies with 88 independent variables obtained, 59 samples used CSRDi with 78 variables as CSRD measurements and 7 studies with 10 variables of environmental performance as CSRD measurements. CSRD measurements using CSRDi and environmental performance indicate a significant positive effect between CSRD and the corporate financial performance, in accordance with the general meta-analysis results. Based on the measurement of independent variables do not vary, so it can be concluded that there is no moderate effect 
between the influence of CSRD and the corporate financial performance. Based on this it can be said hypothesis $2(\mathrm{H} 2)$ is not accepted. Sub-group results based on the measurement of independent variables do not vary, so it can be concluded that there is no moderate effect between the influence of CSRD and corporate financial performance.

The Relation of Corporate Social Responsibility Disclosure to the Corporate Financial Performance. The results of the meta-analysis in this study were consistent with the individual studies conducted by Lougee et. Al. (2008), Lin et al. Al. (2009), and Tang et. Al., (2012) stating that CSRD has a positive effect on the corporate financial performance. In addition, the results of the study are also in accordance with individual research in Indonesia as in the study conducted by Ahmed et. (2012), Dahlia and Siregar (2008), Purnomo and Widianingsih (2012), and Pustikaningsih (2011) who took data from Indonesian companies so that the results of this study became more relevant.

Not only that, the relationship of the disclosure of CSR to the corporate financial performance will have the maximum impact for long-term sustainability of the corporate as investors and stakeholders will see how the company in conducting its operational activities and what has been disclosed and the corporate's contribution to stakeholders of the previous year and current year. By consistently making the CSRD, then investors and other stakeholders will give more trust to the corporate (Lin et al., 2009).

Based on the results of general meta analysis in this study proves that CSRD has a significant positive effect on the corporate financial performance, where it has proved that CSRD affects the corporate financial performance. After seeing the result of general meta analysis, it is necessary to do moderation test to find out whether there is moderate effect of CSRD relationship to corporate financial performance either influenced by measurement model of CSRD and also model of corporate financial performance measurement.

The relation of Corporate Social Responsibility Disclosure to the Corporate Financial Performance is Moderated by the Corporate Financial Performance Measurement Model. Based on the meta analysis, it is evident that the influence between CSRD and the corporate financial performance is moderated by the corporate financial performance measurement model. This can be seen from the inconsistency of meta sub-group results for the measurement of the corporate financial performance. This means that the measurement of the corporate financial performance affects the results of previous studies.

Based on the results of the moderating effects sub-group research, the positive results are significant in the general meta analysis is Return On Equity (ROE), Return On Assets (ROA), Stock Return, Earning Per Share (EPS), and profit persistence for the measurement model of corporate financial performance. Significant positive CSRD measurement models in accordance with general meta-analysis are the Corporate Social Responsibility Disclosure index (CSRDi) and environmental performance. These ratios can be considered for the corporate in disclosing the optimal CSRD to improve the corporate financial performance. Investors can also pay attention to how the corporate that has a good level of disclosure to produce maximum financial performance.

Sensitivity Analysis. The results of the publication status meta-analysis in Table 5.3. States there is no publication bias between published research and unpublished research. Consistent with the results of general meta-analysis, the average correlation analysis $(\bar{r})$ for publication research is 0.2065 , whereas for non-publicized research is 0.0023 .

Table 4 - Publication status meta-analysis

\begin{tabular}{|c|c|c|c|c|c|c|c|}
\cline { 2 - 8 } \multicolumn{1}{c|}{} & $\sum \mathrm{Ni}$ & $\mathrm{K}$ study & $\mathrm{r}$ & Min & to & Max & $\mathrm{x}_{\mathrm{k}-1}^{2}$ \\
\hline General Meta Analysis & 6630 & 88 & 0,18204526 & 0,085857472 & - & 0,27823304 & 436,0571951 \\
\hline Published & 5464 & 76 & 0,2065332 & 0,1234953 & - & 0,2895711 & 328,5776104 \\
\hline Unpublished & 1166 & 12 & 0,00237924 & $-0,2832450$ & - & 0,2880034 & 181,9191744 \\
\hline
\end{tabular}

The quality of the study is one of the things that can cause publication bias in the meta analysis. Based on these results can be concluded that the influence of CSRD on corporate financial performance is not influenced by the type of research, both published and unpublished. 
Discussion. The main purpose of meta-analysis research for the influence of CSRD on the corporate financial performance is to seek consistency from the relationship of both. In addition, meta analysis can also help to determine the causes of inconsistencies in previous studies due to differences in the model of measurement of dependent and independent variables. Based on the results of this study, it is generally found that the influence of CSRD on the corporate financial performance is positive, which means, with the increasing disclosure of CSRD by the corporate will be directly proportional to the improvement of corporate financial performance.

In accordance with the theoretical basis, the theory of stakeholders conveyed by Freeman (1983), this study successfully proves that CSRD is a disclosure provided by the corporate with the aim to inform investors and stakeholders that the corporate has contributed in maintaining the environment and accountability in its operational activities. The results support the research conducted by Ahmed et. Al. (2012); Dahlia and Siregar (2008); Lougee et. Al. (2008); Lin et. Al. (2009); Purnomo and Widianingsih (2012); Pustikaningsih (2011); And Tang et. Al. (2012).

In practice, the implications obtained from the results of this study, the management can use CSRD as a factor that can improve the corporate financial performance. Managers must be able to create an optimal report in terms of the type of dividends paid, the composition of the corporate earnings are distributed for dividends or as a reserve of corporate investment, as well as the time of dividend payout.

The measurement of CSRD variables and the corporate financial performance. The diversity of these types of measurement can be a cause of inconsistency of the research results on the relationship between the two variables. Therefore, this research tries to know what variables are relevant by using moderation effect test. Based on the result of moderation effect test, it is found that the variables that are relevant to the influence of CSRD and the corporate financial performance are CSRDi and environmental performance for measurement of CSRD and ROE, ROA, stock return, and profit persistence for measurement of corporate financial performance.

The implication, managers can focus on the six ratios, so as to maximize the corporate financial performance. Corporate Social Responsibility Disclosure index (CSRDi) is obtained from the amount of disclosure made by the corporate in the sustainability report issued by the corporate annually in accordance with the provisions issued by GRI. The more complete and clear sustainability report issued by the corporate, investors and stakeholders can assess how the level of corporate responsibility, and gain more trust and become additional value for the corporate itself. While CSRD is measured by environmental performance is one form of supervision, transparency efforts, and increased contribution in environmental management submitted by the Ministry of Environment, so the company in its operation should also consider for the corporate if it gets the rating PROPER is good.

With the high return earned by the company then investors will judge that the corporate performance is good and profit. On the other hand, earnings persistence is a profit that has an indicator of future earnings generated by the corporate repeatedly in the long run. The high level of profit persistence will attract more investors to invest in a corporate.

\section{CONCLUSION AND FURTHER RESEARCH}

This study aims to determine the effect of CSRD on corporate financial performance, then analyze and test variations of research results on the influence of CSRD and corporate financial performance in Indonesia. This study used a meta-analysis approach with a sample of 60 studies in Indonesia in 2000-2016. The results of this study suggest.

In general, CSRD can improve the corporate financial performance. The results of this study is in accordance with the theoretical basis, the theory of stakeholders conveyed by Freeman (1983), this study successfully proves that CSRD is a disclosure provided by the corporate in the form of a report that aims to inform investors and stakeholders that the corporate has contributed in maintaining the environment and accountability has been done by the corporate from its operational activities. The results support the research conducted 
by Ahmed et. Al., 2012; Dahlia and Siregar, 2008; Lougee et. Al., 2008; Lin et. Al., 2009; Purnomo and Widianingsih, 2012; Pustikaningsih, 2011; and Tang et. Al., 2012.

Based on the results of moderation effect test, the influence of CSRD on the corporate financial performance is influenced by the model of corporate financial performance measurement models. This is because the result of moderation effect test using the measurement of corporate financial performance is not consistent. This means that the relationship between CSRD and the corporate financial performance is weakened by one of the financial performance measurement models. Based on the results of these studies, it is evident that the inconsistency of previous research results due to differences in corporate financial performance measurement models.

During the research there are several things that become limitations:

Previous articles on the effects of CSRD and corporate financial performance do not show the overall research information, variable measurements and detailed statistical data, thereby reducing the number of samples that can be processed into meta analysis. Subsequent research is expected to use more research data with a more varied measurement model and complete statistical information, so it can know the ratio or other types of measurements that affect the corporate financial performance.

Research in Indonesia generally use CSRDi and environmental performance PROPER SRI KEHATI. Though there is one more measurement model of CSRD is ISO 26000 which is still rarely that research in Indonesia. Further research is expected to use ISO 26000 in viewing CSRD, so that the analysis of CSRD and corporate financial performance can use more varied measurement model.

\section{REFERENCES}

1. Ahmed, K., \& Courtis, J.K. (1999). Associations between Corporate Characteristics and Disclosure Levels in Annual Reposrts: A Meta Analysis. British Accounting Review, 31(1), 35-61.

2. Ahmed, S.U., Islam, M.Z., Hasan, I. (2012). Corporate Social Responsibility and Financial Performance Linkage-evidence from the Banking Sector of Bangladesh. Journal of Organizational Management, 1(1), 14-21.

3. Angela. (2015). Pengaruh Kinerja Lingkungan terhadap Kinerja Finansial dengan Pengungkapan Corporate Social Responsibility (CSR) sebagai Variabel Intervening. Skripsi. Fakultas Ekonomi Universitas Sanata Dharma. Yogyakarta.

4. Anggraini, Fr. Reni Retno. 2006. Pengungkapan Informas Sosial dan Faktor-Faktor yang Mempengaruhi Pengungkapan Informasi Sosial dalam Laporan Keuangan Tahunan (Studi Empiris pada Perusahaan-Perusahaan yang Terdaftar di Bursa Efek Jakarta). Simposium Nasional Akuntansi IX. Padang.

5. Anwar, R. (2005). Meta Analisis. Bandung: Fakultas Kedokteran Universitas Padjajaran.

6. Armstrong, Michael. 2014. Armstrong's Handboo of Human Resource Management Practice 13th Edition. Ashford Colour press Ltd : United Kingdom.

7. Athanasia, Smprini V. dan O.F. Maria. 2010. Financial Performance and Corporate Social Responsibility: An Empirical Investigation in the Banking Industry. International Hellenic University.

8. Belkaoui, Ahmed. 1976. The Impact of the Disclosure of the Environmental Effects of Organizational Behavior on the Market. Financial Management, 5(4), 26-31.

9. Brine, Matthew, R. Brown, dan G. Hackett. 2007. Corporate Social Responsibility and Financial Performance in the Australian Context. Corporations and Financial Services Division, the Australian Treasury, 47-58.

10. Chariri, A dan Firman A. J. 2009. "Retorika Dalam Pelaporan Corporate Social Responsibility: Analisis Semiotik Atas Sustainability Reporting Pt Aneka Tambang Tbk". Simposium Nasional Akuntansi XII Palembang 4-6 November 2009.

11. Criso'stomo, V. Lima, F.S. Freire, dan F.C. de Vasconcellos. 2011. Corporate Social Responsibility, Firm Value and Financial Performance in Brazil. Social Responsibility Journal, 5(3), 129-138. 
12. Dahlia, Lely dan Sylvia Veronica Siregar. 2008. Pengaruh Corporate Social Responsibility terhadap Kinerja Perusahaan (Studi Empiris pada Perusahaan yang Tercatat di Bursaa Efek Indonesia pada tahun 2005 dan 2006). Simposium Nasional Akuntansi XI. Pontianak.

13. Dowling, J. Dan Pfeffer. 1975. Organizational Legitimacy: Social Values and Organization Behaviour. Pacific Sociological Review, 18(1), 122-136.

14. Eipstein, M.J. dan M. Freedman. 1994. Social Disclosure and the Individual Investor. Accounting, Auditing and Accountability Journal, 7(4), 94-108.

15. Fahmi, Irham. 2011. Analisis Kinerja Keuangan. Bandung: Alfabeta.

16. Fanani, Zaenal. 2016. Research Study Literature Using Meta Analysis: Teori dan Aplikasi. Seminar Kolegial Pendidikan Profesional Berkelanjutan (PPL). Universitas Negeri Malang.

17. Freeman, R. Edward. 2004. Stakeholder Theory and "The Corporate Objecive Revisited". Organization Science, 15(3), 364-369.

18. Garcia, Meca E., dan J. P. Sanchez.2009. corporate Governance and Earnings Management: A Meta- Analysis. Corporate Governance: An International Review, 17(5),594-610.

19. Glass, G. 1976. Primary, Secondary, and Meta Analysis of Results. Educational Researcher, 5(10) 3-8.

20. Gray, R., R. Kouhy, dan S. Lavers. 1995. Corporate Social and Environmental Reporting. A Review of the Literature and a Longitudinal Study of UK Disclosure. Accounting, Auditing, and Accountability Journal, 8(2),47-77.

21. Hadi, Nor. 2014. Corporate Social Responsibility. Yogyakarta: Graha IImu.

22. Hunter, J.E., dan F.L. Schmidt. 1990. Methods of Meta Analysis : Correcting Error and Bias in Research Findings. Beverly Hills, CA:Sage.

23. Ikatan Akuntan Indonesia. 2007. Standar Akuntansi Keuangan. Jakarta: Salemba Empat.

24. Indrawan, Danu Candra. 2011. Pengaruh Corporate Social Responsibility terhadap Kinerja Perusahaan. Minor Theses. Faculty of Economy Diponegoro University. Semarang.

25. Jamali, Hisnol. 2014. Pengaruh Tata Kelola Perusahaan dan Tanggung Jawab Sosial terhadap Kinerja Keuangan dengan Efisiensi Usaha sebagai Variabel Mediasi. Dissertation. Faculty of Economic and Business Brawijaya University. Malang.

26. Lin, Chin Huang, Ho Li Yang dan Dian Yan Liou. 2009. The Impact of Corporate Social Responsibility on Financial Performance: Evidence from Business in Taiwan. Journal Technology in Societ, 31(1), 56-63.

27. Lougee, Barbara dan James Wallace. 2008. The Corporate Social Responsibility (CSR) Trend. Journal of Applied Corporate Finance, 20(1), 96-108.

28. Lyons, Larry C. 2003. Meta Analysis: Methods of Accumulating Results Acros Research Domains. George Washington University Medical Center: Washington DC.

29. Muntiah, Siti. 2013. Pengaruh Mekanisme Corporate Governance terhadap Kinerja Perusahaan (Studi Perusahaan Manufaktur yang Terdaftar di Bursa Efek Indonesia Periode 2010-2012). Jurnal Akuntansi, 1(1), 1-17.

30. Novriyanti, Vesy dkk. 2011. "Pengaruh Corporate Social Responsibility dan good corporate Governance terhadap Kinerja Perusahaan". Riau. FKIP-Universitas Riau.

31. O'Donovan, G. 2002. Environmental Disclosue in The Annual Report: Extending the Applicability and Predictive Power of Legitimacy Theory. Accounting, Auditing \& Accountability Journal, 15(3), 571-610.

32. Patten, Dennis M..1990. the Market Reaction to Social Responsibility Disclosures: The Case of the Sullivan Principles Signings. Accounting, Organizations, and Society Oxford, 15(6), 575-587.

33. Purnomo, P. Karin dan L.P. Widianingsih. 2012. The Influence of Environmental Performaance on Financial Performance with Corporate Social Responsibility (CSR) Disclosure as a Moderating Variable: Evidence from Listed Corporate in Indonesia. Review Intergrative Business \& Economics Research, 1(1), 57-69. 
34. Pustikaningsih, Adeng. 2011. Analisis Hubungan Corporate Social Responsibility (CSR) terhadap Kinejra Keuangan pada Perusahaan Jasa (Studi Kasus Perusahaan Jasa di D.I. Yogyakarta). Jurnal Pendidikan Akuntansi Indonesia. 9(2) 32-39.

35. Sarwono, J. 2011. Teori Analisis Korelasi. Diakses, http://www.jonathansarwono.info/ korelasi.htm.

36. Tang, Zhi, Clyde Eirikur Hull dan Sandra Rothenberg. 2012. How Corporate Social Responsibilit Engeagement Strategy Moderates the CSR - Financial Performance Relationship. Journal of Managemet Studies, 49(7), 1274-1303.

37. Untung, Hendrik Budi. 2009. Corporate Social Responsibility. Sinar Grafika: Jakarta.

38. Wijayanti, F.T. Sutaryo, and M.A. Prabowo. 2011. Pengaruh Corporate Social Responsibility terhadap Kinerja Perusahaan. Simposium Nasional Akuntansi XIV. Aceh. Universitas Syiah Kuala Banda Aceh.

39. Yaparto, Marissa, D. Frisko, and R. Eriandani. 2013. Pengaruh Corporate Social Responsibility terhadap Kinerja Keuangan pada Sektor Manufaktur yang Terdaftar di Bursa Efek Indonesia pada Periode 2010-2011. Jurnal IImiah Mahasiswa Universitas Surabaya, 2(1), 1-17. 
DOI https://doi.org/10.18551/rjoas.2017-08.02

\title{
ОСОБЕННОСТИ РАЗВИТИЯ СИСТЕМЫ АГРАРНОГО МАРКЕТИНГА FEATURES OF THE DEVELOPMENT OF THE AGRICULTURAL MARKETING SYSTEM
}

\author{
Астахова E.B., кандидат экономических наук \\ Astakhova E.V., Candidate of Economic Sciences \\ Владивостокский государственный университет экономики и сервиса, \\ Владивосток, Россия \\ Vladivostok State University of Economics and Service, Vladivostok, Russia \\ E-mail: evastahova1@yandex.ru
}

\begin{abstract}
АННОТАЦИЯ
Развитие глобальной экономики характеризуется возникновением долгосрочного риска превышения темпов роста спроса на продовольственную продукцию над темпами роста предложения агропромышленной продукции. В то же время среднегодовые приросты продуктивности сельского хозяйства будут, по ряду прогнозов, снижаться, что актуализирует вопрос оптимизации внедрения технологических инноваций, усовершенствования системы организации маркетинга на агропромышленных предприятиях. Научно-теоретической основой для углубления исследований послужили методы научной абстракции, анализа и синтеза, методы количественной и качественной оценки, с помощью которых были определены содержание понятий маркетинга и его особенности в деятельности агропромышленных предприятий.
\end{abstract}

\section{ABSTRACT}

The development of the global economy is characterized by the emergence of a long-term risk of exceeding the growth rates of demand for food products over the growth rate of supply of agro-industrial products. At the same time, the average annual growth in agricultural productivity will, according to a number of forecasts, decline, which actualizes the issue of optimizing the introduction of technological innovations, improving the organization of marketing in agro-industrial enterprises. The scientific-theoretical basis for deepening research was the methods of scientific abstraction, analysis and synthesis, methods of quantitative and qualitative evaluation, with the help of which the content of marketing concepts and its features in the activities of agro-industrial enterprises were determined.

\section{КЛЮЧЕВЫЕ СЛОВА}

Аграрный маркетинг, менеджмент, агропромышленный комплекс, маркетинг услуг.

\section{KEY WORDS}

Agrarian marketing, management, agro-industrial complex, marketing of services.

Современные условия ведения бизнеса характеризуются более высокой динамичностью и неопределенностью, которые предъявляют к предприятию более жесткие требования по совершенствованию методов управления при фрормировании стратегии маркетинга. Маркетинг в сельском хозяйстве по сравнению с другими отраслями народного хозяйства является составным комплексом решений, объясняется особенностями агропромышленного комплекса. Значительное влияние и изменения производят новые технологии, данные изменения касаются многих аспектов, среди них: новые сорта растений, новые удобрения, усовершенствование средств защиты растений, биостимуляторы, новые породы, новые средства по поддержанию здоровья животных, добавки и др. Многие изменения также происходят в техническом уровне аграрных средств производства, техники и оборудовании.

Актуальность разработки эффективной технологии агромаркетинга в условиях перехода к рынку объективно возрастает, но в связи с тем, что система агромаркетинга еще не получила должного теоретического обоснования, крайне мало теоретических 
разработок по ее проектированию, организации и рациональному функционированию. В результате чего концепции агромаркетинга достаточно медленно входят в хозяйственный менеджмент руководителей, специалистов и владельцев.

Многие известные отечественные ученые - экономисты исследуют теоретические и практические проблемы формирования и функционирования аграрного сервиса и маркетинга услуг в сельском хозяйстве отражено в исследованиях ученых: П.И. Гайдука, В.А. Горемыкин, Б. Данилишина, А.А. Демка, П.А. Денисенко, В.И. Кравчука, А. Лисовского, М.И. Малика, Л.А. Мармуль, П. Макаренко, М.В. Молодого человека, П.А. Мосиюка, П.Т. Саблука, В.И. Топиха, И.Н. Топиха, И.И. и др. Отмечая значимость полученных научных результатов в области теории и практики организации маркетинга услуг аграрного сервиса, следует заметить, что в данный период остались недостаточно раскрытыми вопросы, связанные с определением необходимого уровня агросервисного обслуживания сельского хозяйства в том или ином регионе. Вместе с тем, как показывает анализ литературы, проблематика маркетинга услуг в аграрном производстве нуждается в совершенствовании, развитии новых направлений

Это лишь некоторые примеры изменения среды, определяющие и значение аграрного маркетинга сегодня. Маркетинг аграрного производства должен стать опорой продвижения продукции, диверсификации рисков экономической среды в современной мировой экономике. Поэтому учеными сегодня уделяется значительное внимание этим вопросам. Инновационный характер развития сельскохозяйственного производства влечет неравномерную динамику объемов производства различных видов продукции. Маркетинговое управление предприятием определяется концепцией маркетинга, выбранной предприятием .

Концепция маркетинга возникла в странах с высокоразвитой экономикой, но предполагает решение проблем, возникших в современных условиях предпринимательства в Российской Федерации. Развитие маркетинга прошло значительную эволюцию: возникнув как деятельность по распределению и сбыта товаров, маркетинг постепенно развился в многостороннюю систему принципов, на основе которых предприятия могут устанавливать производственно-экономические связи со своими рынками. Благодаря маркетингу производитель обнаруживает текущие и перспективные запросы, потребителей, фрормирует превращение покупательной способности в конкретный спрос на определенный товар или; услугу, достигает устойчивых длительных связей с потребителями.

Формирование и развитие маркетинговой деятельности в деятельности любого предприятия означает организацию своей работы в сфере производства и сбыта продукции по конкретной программе.

Маркетинг в области агропромышленного производства (агромаркетинг) как комплексная рыночная деятельность представляет собой систему взглядов и действий, связанных с изучением потребностей, возможностей производства и обмена с целью удовлетворения всех потребностей с наименьшими затратами ресурсов и наиболее полным потребительским эффректом. Маркетинг в АПК - это управленческий процесс и соответствующее осуществление мероприятий в основных отраслях, а также в социальной сфере на селе. Наряду с продовольственным маркетингом в АПК существует маркетинг сырья для перерабатывающей промышленности; промышленный маркетинг; банковский маркетинг, маркетинг услуг и др.

Маркетинг агроуслуг - это комплексное явление. Каждый производитель товаров и услуг имеет специфический маркетинг услуг, который отражает его нацеленность на своих покупателей, действия, выполнение определенной совокупности функций. Система агромаркетинга состоит из трех групп подсистем: фрункциональных, обеспечивающих и объектно-функциональных. Концепция маркетинга определяет работу предприятия на основе информации о потребительском спросе и его изменениях в ближайшей перспективе.

К основным составляющим системы агромаркетинга, которая сочетается с товарными, сырьевыми, информационными потоками и услугами в экономическом аграрном производстве относится определенная группа факторов. Эту совокупность 
субъектов системы агромаркетинга можно диффреренцировать в зависимости от методов передачи товаров, выбора и закрепления их в форму определенных каналов распределения продукции и услуг; специфики товаров и видов услуг, системы реализации; особенностей движения товаропотоков и особенностей услуг; количеством посредников на пути следования товара (услуги) к его владельцу; методов установления и регулирования отношений между ними; масштабов распространения деятельности субъекта и объемами его товарооборота; особенностей условий внешней среды.

Рыночные структуры функционируют в определенных социально-экономических, научно-технических, политических и культурных условиях. Их деятельность направлена на аграрное предприятие, которое, в свою очередь, активно влияет на рынок и его структуры. Основной задачей предприятий аграрного сервиса является предоставление сельскохозяйственным товаропроизводителям услуг для повышения эфффективности и прибыльности основных видов их деятельности.

Специфика агропромышленного производства и сбыта сельскохозяйственной продукции отдельными предприятиями определяет многообразие конкретных схем маркетинга. Однако все они базируются на совокупности главных принципов, среди которых изучение состояния и динамики потребительского спроса и использования полученных данных в процессе разработки и принятия хозяйственных решений; максимальное приспособление производства к требованиям рынка с целью улучшения эффрективности функционирования предприятия, в качестве критерия которого выступает прибыль как обобщающий показатель его деятельности; воздействие на рынок и потребительский спрос с помощью таких средств, как реклама, стимулирование сбыта и формирование их в направлении, необходимом для предприятия.

Таблица 1 - Комплекс необходимых стратегических решений для решения проблемных по маркетингу аграрных предприятий

\begin{tabular}{|c|c|}
\hline Проблемы & Пути их решения \\
\hline $\begin{array}{l}\text { Высокая затратность производства } \\
\text { и цена аграрной продукции }\end{array}$ & $\begin{array}{l}\text { Перспективные пути уменьшения себестоимости продукции - } \\
\text { расширение механизации и автоматизации, повысить масштабы } \\
\text { производства. }\end{array}$ \\
\hline $\begin{array}{l}\text { Изменения и колебания цены на } \\
\text { агропродукцию в зависимости от } \\
\text { условий рынка }\end{array}$ & $\begin{array}{l}\text { Разработка четкой ценовой политики, соблюдение технологии } \\
\text { расчета цен, прогнозирования спроса, выбор уровня цен учитывая } \\
\text { все имеющиеся методы ценообразования }\end{array}$ \\
\hline $\begin{array}{l}\text { Невозможность быстрого внедрение } \\
\text { новых видов продукции }\end{array}$ & $\begin{array}{l}\text { Невозможность быстрого внедрения новых ви } \\
\text { необходимость сформировать систему серви }\end{array}$ \\
\hline $\begin{array}{l}\text { Большое количество тов } \\
\text { заменителей на рынке }\end{array}$ & $\begin{array}{l}\text { При большом количестве заменителей акцент следует осуществлять } \\
\text { на ценовые а также и другие аспекты формирования спроса - } \\
\text { упаковка, качество и тому подобное. }\end{array}$ \\
\hline $\begin{array}{l}\text { Сложность формирования торговых } \\
\text { марок на рынка }\end{array}$ & $\begin{array}{l}\text { Объединение и укрупнение аграрных предприятий с целью } \\
\text { формирование торговой марки }\end{array}$ \\
\hline $\begin{array}{l}\text { Неэффективно определены } \\
\text { целевые аудитории сбыта } \\
\text { продукции }\end{array}$ & $\begin{array}{l}\text { Формирование организованной и отлаженной системы управление } \\
\text { сбытом продукции, оптимизация деятельности служб маркетинга в } \\
\text { новых условиях }\end{array}$ \\
\hline $\begin{array}{l}\text { Неразвитость рыночной } \\
\text { инфраструктуры АПК } \\
\end{array}$ & $\begin{array}{l}\text { Создание кластерных образований, организация аграрного портала } \\
\text { видами продукции и ценами на нее. }\end{array}$ \\
\hline $\begin{array}{l}\text { Сложность обеспечения качест } \\
\text { продукции, ее хранения }\end{array}$ & Организация кластерных образований в сельском хозяйстве \\
\hline $\begin{array}{l}\text { Позиционирование товаров } \\
\text { однородных товаров на рынке }\end{array}$ & $\begin{array}{l}\text { Объединение в крупные торговые марки, использо } \\
\text { рынков, использование прямого маркетинга }\end{array}$ \\
\hline
\end{tabular}

Принципы маркетинга должны стать главными в управлении, так как практически всем агропромышленным предприятиям в условиях рыночной экономики основное внимание приходится уделять вопросам реализации продукции, увеличении доходов, учитывать наличие жесткой конкурентной среды, колебания цен на энергоресурсы. и др. Использование этих принципов позволить создать предприятия, ориентированные как на реальных, так и на потенциальных потребителей. 
Изменения в сельском хозяйстве являются следствием тысяч управленческих решений, принятых менеджерами сельскохозяйственных предприятий на основе маркетинговых исследований, выбранной маркетинговой стратегии. Эти решения являются их ответом на динамические изменения среды, среди которых главными, на наш смотрит изменения в технологиях, формах собственности, изменения уровня цен и совокупность других экономических факторов. При этом следует отметить, что любое управленческое решение влечет негативные или позитивные экономические результаты.

Современными тенденциями развития агропредприятий в конкурентной среде, формируют проблематику маркетингового менеджмента является значительный уровень конкуренции в большинстве сегментов, особенно международной; недостаточность предложения аграрной продукции на рынке; относительно не прозрачное происхождение капитала и, соответственно, недостаточный уровень маркетинговой подготовки топ - менеджеров и владельцев предприятий; высокая зарегулированность некоторых сегментов отрасли. Решить имеющийся комплекс проблем можно сфрормировав комплекс необходимых стратегических решений, часть из которых систематизирована в таблице 1.

Основной задачей маркетинговой системы в современных условиях хозяйствования является создание условий для приспособления производства и сбыта сельскохозяйственной продукции в переменного и динамического спроса и наработки организационно - технологических изменений для интенсификации продаж.

Аграрный бизнес во всех сферах деятельности, то есть в производстве, переработке и сервисе, на современном этапе пореформенного периода переживает существенные трансформации, которые требуют совершенствования системы маркетинга в своевременных и эфрфективных решениях.

На данном этапе развития рыночных отношений в агропромышленном секторе любое предприятие не может нормально функционировать без применения системы агромаркетинга для определения своего положения на рынке, анализа своих возможностей, изучение рыночной среды, определение стратегии развития и тому подобное.

\section{БИБЛИОГРАФИЯ}

1. Бережная А.А. Современное состояние инновационного процесса на сельскохозяйственных предприятиях // Экономика АПК.- 2017. - №2. - с. 15

2. Иващенко Л.А. Особенности управления маркетинговой деятельностью в аграрной сфрере // Экономика АПК. - 2016. - №2. - с. 11

3. Недбалюк А.П. Роль научно обоснованной системы менеджмента в стратегической реструктуризации экономики аграрных предприятий // Региональная бизнесэкономика и управление. - 2017. - №3 (15) .- с. 50

4. Ортин В. Новая стратегия маркетинга зерна // Экономика АПК.-2015. - №9.-с. 25

5. Агромаркетинг как инструмент успеха. Агентство бизнес мониторинга, http://www.r52.ru/index?rid=22\&fid=183\&sid=47\&nid=27706

6. Макашев М.О. Спрос и виды маркетинга: принципы организации маркетинговой деятельности - [Электронный ресурс] - Режим доступа. - http://altmarketing.ru/

7. Маркин Р. Сетевой маркетинг и сельское хозяйство - [Электронный ресурс] Режим доступа. - http://mlm-udacha.ru/setevoj-marketing-i-selskoe-xozyajstvo/

8. Цыпкин Ю.А. Агромаркетинг и консалтинг: учеб. пособие. М.: ЮНИТИ, 2000. - 637 с.

9. Цыпкин Ю.А. Основы маркетинга в агропромышленном комплексе: (для агроэкон. специальностей) - М.: Изд. Междунар. ассоциации агромаркетинга, 2015. - 211 с.

10. Фетюхина О.Н. Маркетинговые стратегии неценовой конкуренции в глобальной цепи продукции АПК // Экономика сельскохозяйственных и перерабатывающих предприятий. - 2016. - №2. - с.58-61.

11. Хицков А.И. Методические основы использования маркетинга в сельскохозяйственном предприятии - Воронеж, 2012. - 61 с. 
DOI https://doi.org/10.18551/rjoas.2017-08.03

\title{
КРИТЕРИИ ОЦЕНКИ ИНВЕСТИЦИОННОЙ ПРИВЛЕКАТЕЛЬНОСТИ ПРЕДПРИЯТИЙ АГРОПРОМЫШЛЕННОГО КОМПЛЕКСА \\ CRITERIA FOR ASSESSING THE INVESTMENT ATTRACTIVENESS OF THE AGRO-INDUSTRIAL COMPLEX'S ENTERPRISES
}

\author{
Кузубов А.А., кандидат экономических наук \\ Владивостокский государственный университет экономики и сервиса, \\ Владивосток, Россия \\ Vladivostok State University of Economics and Service, Vladivostok, Russia \\ E-mail: alexceyk@gmail.com
}

\begin{abstract}
АННОТАЦИЯ
Целью исследования является обоснование основных параметров оценки инвестиционной привлекательности, характеризующих производственно-финансовую деятельность, и разработка методики определения рейтинга предприятий АПК. В статье обоснована необходимость разработки методики анализа инвестиционной привлекательности предприятий АПК. Предложенная методика проста в расчетах, не требует использования информационных источников, носящих конфиденциальный характер, характеризует как производственную, так и фринансовую стороны деятельности предприятия.
\end{abstract}

\section{ABSTRACT}

The purpose of the study is to substantiate the main parameters for assessing investment attractiveness, characterizing production and financial activities, and to develop a methodology for determining the rating of agricultural enterprises. The article substantiates the need to develop a methodology for analyzing the investment attractiveness of agricultural enterprises. The proposed methodology is simple in calculations, does not require the use of information sources that are confidential, and characterizes both the production and financial aspects of the enterprise.

\section{КЛЮЧЕВЫЕ СЛОВА}

инвестиции; сельскохозяйственные предприятия; производственный потенциал; финансовые показатели; доходность; рейтинг.

\section{KEY WORDS}

Investments, agricultural enterprises, production potential, financial indicators, profitability; rating.

Инвестиции являются основной причиной развития как отдельного субъекта хозяйствования, так и всего общества. Поэтому особый интерес вызывает анализ возможностей прироста капитала. Современное состояние предприятий аграрнопромышленного комплекса характеризуется значительной изношенностью основных средств, дефицитом оборотных средств, а в отдельных случаях осложняется низкой платежеспособностью. В условиях системного кризиса отрасли особого внимания требуют вопросы структурных изменений в хозяйственной деятельности предприятия. Эти изменения в первую очередь зависят от эфффективности реализации инвестиционных проектов.

Исследованию теоретико-методологических основ и разработке методики анализа инвестиционной привлекательности предприятий посвящены труды отечественных и зарубежных ученых [1-12].

Однако, как правило, созданные системы достаточно сложны для использования на уровне предприятия. По нашему мнению, в условиях риска и кризиса долгосрочные решения предопределяют необходимость новых подходов аналитического 
обеспечения. Поэтому актуальными являются вопросы совершенствования методики анализа, которые бы учитывали особенности деятельности и систему показателей инвестиционной привлекательности предприятия.

Одной из важнейших задач агропромышленного производства постиндустриального типа является не только существенное увеличение объемов сельскохозяйственной продукции для обеспечения продовольственной безопасности государства, а и значительное повышение доходности и конкурентоспособности отрасли на базе более эффективного использования экономического потенциала агроэкосистем, материальных, трудовых и финансовых ресурсов [13,14].

Инвестиционные возможности предприятия можно определить, как обобщенную оценку условий и результатов реализации инвестиционного проекта, которые формируются под действием внешних и внутренних фракторов, с позиции их соответствия критериям эфффективности и безопасности, системе ценностей и приоритетов инвестора как внутреннего, так и внешнего. Оценка значимости ожидаемых последствий и условий реализации инвестиционного проекта показала, что важнейшими среди них являются: получение доходов, прибыли, рентабельности; сохранения (повышения) финансовой устойчивости, ликвидности и платежеспособности; ускорение оборачиваемости оборотных активов; обеспеченность источниками фринансирования; эффрективность внедрение проекта, выполнение условий его абсолютной (относительной) приоритетности.

Анализ научных источников свидетельствует о наличии различных подходов методики анализа объекта инвестиции. Так Бланк И.А. предлагает использовать для оценки инвестиционной привлекательности объекта четыре группы показателей. Первая группа содержит оборачиваемость активов, вторая - анализ прибыльности предприятия, третья - анализ фринансовой устойчивости, четвертая - анализ ликвидности [15].

Куриленко Н.А. предложил проводить анализ по следующим направлениям: оборачиваемости активов; ликвидности и фринансовой устойчивости предприятия; денежных потоков; рентабельности. Анализ абсолютной и относительной приоритетности инвестиционных проектов проводить на основе таких показателей, как период окупаемости, чистая настоящая стоимость капитала, внутренняя норма рентабельности [16]

Шилова Н.П. предлагает способ определения интегральной оценки инвестиционной привлекательности сельскохозяйственного предприятия, которые учитывают такие группы показателей: имущественное состояние, ликвидность, фринансовая устойчивость, деловая активность, прибыльность, состояние и эффективность использования земли в рыночных условиях [17].

Ряд методов оценки и анализа инвестиционной привлекательности субъектов хозяйственной деятельности базируется на многих отдельных или объединенных в определенные группы показателях по направлениям деятельности. Совокупность различных показателей сводится к единой системе оценки через определение одного или несколько интегральных показателей. Определение определенного интегрального показателя и свое позиционирование по установленной шкале дает возможность инвестору понять, насколько инвестиционно привлекательным является то или другое предприятие. Важным становится также определение относительной значимости отдельных показателей или их групп с помощью методов ранжирования или определения их весомости.

Нами систематизированы показатели, которые характеризуют производственнофринансовую деятельность, применение которых позволит потенциальным инвесторам, не проходя подготовительного этапа, используя только данные финансовой и статистической отчетности, дать оценку инвестиционной привлекательности предприятиям АПК, в том числе сельскохозяйственным предприятиям (таблица 1).

Предложенная методика проста в расчетах, не требует использования информационных источников конфиденциального характера, характеризует как производственную, так и финансовую сторону деятельности предприятия. 
Многолетние исследования деятельности предприятий сельского хозяйства дали возможность выделить шесть основных групп показателей, анализ которых позволит установить целесообразность вложения инвестиций как внутренних, так и внешних. Эти группы показателей характеризующих производственно-финнансовую деятельность предприятия и содержат наиболее значимые показатели.

Таблица 1 - Основные критерии оценки инвестиционной привлекательности сельскохозяйственных предприятий

\begin{tabular}{|c|c|c|c|}
\hline $\begin{array}{c}\text { Группы } \\
\text { показателей и их } \\
\text { весомость, \% }\end{array}$ & Показатели в группах & $\begin{array}{c}\text { Весомость } \\
\text { показателя, \% }\end{array}$ & $\begin{array}{l}\text { Нормативное } \\
\text { значение и } \\
\text { (или) } \\
\text { направление } \\
\text { оптимизации }\end{array}$ \\
\hline $\begin{array}{c}\text { Производственный } \\
\text { потенциал, } 15\end{array}$ & $\begin{array}{l}\text { Коэффициент производственного потенциала } \\
\text { Коэффициент износа основных средств } \\
\text { Коэффициент мобильности } \\
\text { Коэфффициент отдачи основных средств }\end{array}$ & $\begin{array}{l}30 \\
30 \\
20 \\
20\end{array}$ & $\begin{array}{l}\max \\
\min \\
\max \\
\max \end{array}$ \\
\hline Ликвидность, 15 & $\begin{array}{l}\text { Коэффиициент покрытия } \\
\text { Коэффрициент быстрой ликвидности } \\
\text { Коэффициент абсолютной ликвидности } \\
\text { Коэфффициент утраты платежеспособности }\end{array}$ & $\begin{array}{l}25 \\
25 \\
25 \\
25\end{array}$ & $\begin{array}{l}1,8-2,0 \\
0,8-1,0 \\
0,25 \\
>=1\end{array}$ \\
\hline $\begin{array}{c}\text { Финансовая } \\
\text { стойкость, } 15\end{array}$ & $\begin{array}{l}\text { Коэффициент автономии } \\
\text { Коэффициент фринансового левериджа } \\
\text { Коэффициент маневренности собственного капитала } \\
\text { Коэфффициент финансирования } \\
\text { Коэффициент обеспечения запасов собственными } \\
\text { оборотными средствами } \\
\text { Коэффициент инвестирования }\end{array}$ & $\begin{array}{l}20 \\
15 \\
15 \\
15 \\
20 \\
15 \\
\end{array}$ & $\begin{array}{l}>0,5 \\
<1 \\
>0 \\
<1 \\
>=1 \\
\max \end{array}$ \\
\hline $\begin{array}{c}\text { Деловая } \\
\text { активность, } 15\end{array}$ & $\begin{array}{l}\text { Коэффициент оборачиваемости собственного капитала } \\
\text { Коэффициент оборачиваемости активов } \\
\text { Коэфффициент оборачиваемости запасов } \\
\text { Продолжительность оборота дебиторской задолженности } \\
\text { Продолжительность оборота кредиторской задолженности }\end{array}$ & $\begin{array}{l}20 \\
20 \\
20 \\
15 \\
15\end{array}$ & $\begin{array}{l}\max \\
\max \\
\max \\
\min \\
\min \end{array}$ \\
\hline Прибыльность, 20 & $\begin{array}{l}\text { Коэффициент рентабельности собственного капитала } \\
\text { Коэффициент рентабельности оборотных активов } \\
\text { Коэффициент рентабельности производства } \\
\text { Коэффрициент рентабельности продаж } \\
\text { Коэффициент рентабельности активов }\end{array}$ & $\begin{array}{l}20 \\
20 \\
20 \\
20 \\
20\end{array}$ & $\begin{array}{l}>0 \text { max } \\
>0 \text { max } \\
>0 \text { max } \\
>0 \text { max } \\
>0 \text { max }\end{array}$ \\
\hline $\begin{array}{l}\text { Состояние и } \\
\text { эффрективность } \\
\text { использования } \\
\text { земли, } 20\end{array}$ & $\begin{array}{l}\text { Балл бонитета почвы } \\
\text { Соотношение на } 100 \text { га сельскохозяйственных угодий: } \\
\text { чистого дохода; } \\
\text { производственных затрат; } \\
\text { трудовых затрат }\end{array}$ & $\begin{array}{l}40 \\
20 \\
20 \\
20\end{array}$ & $\begin{array}{l}\max \\
\max \\
\min \\
\min \end{array}$ \\
\hline
\end{tabular}

Так к группе производственного потенциала вошли показатели, которые характеризуют долю средств, которые участвуют в производстве предприятия, степень износа основных средств, соотношение оборотных и необоротных активов, а также эфффективность использования средств производства. Во второй группе отражены показатели платежеспособности предприятия и уровня потери возможности платить по текущим долгам. Третья группа характеризует фринансовую устойчивость предприятия. Наиболее значимыми показателями здесь являются коэффициенты фринансовой независимости и фринансовой устойчивости. Это обусловлено тем, что важным моментом при принятии решения об инвестировании является доля собственного капитала, вложенного в источники фрормирования средств предприятия и степень покрытия запасов собственными оборотными средствами. Деловую активность предприятия характеризует четвертая группа показателей, в которой наибольший вес принадлежит коэффрициентам оборачиваемости собственного капитала, оборотных активов и запасов.

Наиболее значимыми, на наш взгляд, являются группы пятая и шестая, которые характеризуют прибыльность предприятия и состояние эффективности использования земли. На эти группы приходится наибольший процент весомости, потому что они в наибольшей степени отвечают за уровень конкурентоспособности производственнохозяйственной деятельности, являются решающими при принятии решения о вложении в предприятие. 
Взвешенную балльную оценку следует трактовать следующим образом: от 0 до 39 баллов - предприятие инвестиционно неприглядное, вложения средств очень рискованное; от 40 до 79 баллов - предприятие имеет средний уровень инвестиционной привлекательности и соответствующую степень риска; от 80 до 100 предприятие инвестиционно привлекательное.

Выводы и перспективы дальнейших исследований. Показатели, которые внесены в группы, охватывающие основные виды деятельности предприятия, дают характеристику эффективности использования земли, производственного потенциала, финансовой устойчивости, платежеспособности и деловой активности. Такие расчеты позволяют самому предприятию определить слабые и сильные аспекты деятельности с целью мобилизации своего производственно-фринансового потенциала, а следовательно, и повышения своей инвестиционной привлекательности. Основными проблемами инвестиционного процесса в АПК является нестабильность и противоречивость законодательства, которое не способствует росту инвестиционной и деловой активности; недостаточность развития инфраструктурной сети обеспечения инвестиционной деятельности; территориальные диспропорции в поступлении инвестиционных ресурсов. Следует разрабатывать и реализовывать инвестиционно инновационную модель, которая будет основываться на максимально возможном привлечении инвестиций в отрасль и поиска стратегических резервов роста с целью создания условий для приоритетного развития отдельных отраслей аграрного сектора, а также отраслей с наиболее высокой стоимостью в объеме производства. Дальнейшие исследования будут касаться поиска действенной методики и совершенствования подходов проведение анализа инвестиционной привлекательности предприятий АПК с учетом их специфических особенностей.

\section{БИБЛИОГРАФИЯ}

1. Гончаров П.В. Современные концепции развития понятийного аппарата инвестиционной деятельности. /П.В. Гончаров/ Альманах «Научные записки ОрелГИЭТ» - 2013. - №2(8). С. 154-157.

2. Матвеев Д.М. Повышение эфффективности государственной поддержки технического переоснащения сельского хозяйства/Матвеев Д.М., Стадник А.Т., Крохта М.Г.//Вестник НГАУ. -2012. -Том -3 -№ 24. -С132-136.

3. Печатнова А.П. Методы оценки инвестиционных проектов // Молодой ученый. 2014. — №17. - С. 316-318.

4. Фаринюк Ю.Т., Глебова А.Г. Организационно-экономические усло-вия инновационного развития аграрного производства: монографрия. Тверь: АгросферА, 2011. $158 \mathrm{c.}$

5. Измайлова О.В., Щетинина Н.В. Инвестиционный анализ деятельности предприятия/ [Электронный ресурс]/ О.В. Измайлова, Н.В. Щетинина/ М.:IV Международная студенческая электронная научная конференция 15 февраля - 31 марта 2012 года. http://www.rae.ru/forum2012/193/682

6. Строева О. Управление инновационным развитием региональных экономических систем: моделирование процесса// Проблемы теории и практики управления. 2011. - № 5. - с. 63-72.

7. Бригхем Ю. Финансовый менеджмент [Текст] / Ю. Бригхем, Л. Гапенски. - [пер. с англ. под ред.В. В. Ковалева]. - СПб: Экономическая школа, 2000. - Том 2. - 669с.

8. Хелферт Э. Техника финансового анализа [Текст] / Э. Хелферт. - - [пер. с англ. под ред. Л. П. Белых]. - М.: Аудит, ЮНИТИ, 1996. - 663с.

9. Лытнева Н.А., Гончаров П.В. Учетно-аналитическое обеспечение контроля инвестиционной деятельности в капитальном строительстве [Текст]/ Н.А. Лытнева, П.В. Гончаров/ Альманах «Научные записки ОрелГИЭТ» - 2014. - №2(10). С.148152. 
10. Радионов Н. Прогнозирование доходности предприятия на основе инновационноинвестиционного подхода// Проблемы теории и практики управления. - 2011. - № 2. - С. 50-62.

11. Подгорный В.М. Государственное регулирование инвестиционной деятельности АПК / В.М. Подгорный/ авторефрерат диссертации на соискание ученой степени кандидата экономических наук / Воронеж. гос. аграр. ун-т им. императора Петра I. Воронеж, 2012, 26 с.

12. Аблеева А.М. Методические аспекты инвестиционной и инновационной стратегии развития предприятия// Соц. Политика и социологи. - 2010. - № 8. - С. 406-416.

13. Шашло Н.В Идентификация и развитие компетенций агропромышленных предприятий. // В сборнике: Актуальные проблемы экономической теории и практики. Сборник научных трудов. Под редакцией В.А. Сидорова. Краснодар, 2012. C. 84-90.

14. Кузубов А.А. Анализ системы управления конкурентоспособностью предприятий // Фундаментальные исследования. 2015. № 12-5. С. 1028-1031.

15. Бланк, И.А. Инвестиционный менеджмент / И.А. Бланк. - Киев: МП «ИТЕМ» ЛТД, 1995. - 448c.

16. Куриленко Н.А. Оценка инвестиционной привлекательности сельскохозяйственной отрасли региона // Вестник Белорусской государственной сельскохозяйственной академии. 2016. №4. С.19-22

17. Шилова Н.П. Организационно-экономические аспекты развития интегрированных агропромышленных формирований. Воронеж: Воронежский ГАУ, 2013. 244 с. 
DOI https://doi.org/10.18551/rjoas.2017-08.04

\title{
FINANCIAL REPORTING AND CORPORATE TAX AGGRESSIVENESS: IMPACT ON FIRM VALUE
}

\author{
Agusti Rosalita Rachma \\ Faculty of Administrative Science, University of Brawijaya, Indonesia \\ E-mail: rosalitarachma@ub.ac.id
}

\begin{abstract}
This research aims to study the market response to the aggressiveness of financial reporting and tax reporting conducted by the company. Investor's response is reflected in the market value of the company's stock. This study is an explanatory research using quantitative approach. Research's sample is a manufacturing company listed on the Indonesian stock exchanges from 2005 to 2015. The data were analyzed using multiple regression analysis. The data show that majority of sample companies' fall into the category of middle tax aggressiveness. Research's findings are both aggressive financial reporting and tax aggressiveness has a negative relationship with the market value of the company. However, only aggressive financial reporting that has a significant influence on the firm value. Based on these results it is concluded that tax aggressiveness does not directly affect the market in making decisions to assess the company's stock.
\end{abstract}

\section{KEY WORDS}

Financial reporting, aggressiveness, tax aggressiveness, firm, value.

Tax reform in Indonesia brought a change from the enactment of the official assessment system to self-assessment system. The system changes aimed at several things such as optimizing revenue, raising taxpayers' awareness and compliance, and administrative efficiency (Sarunan, 2015). Implementation Self-assessment system in Indonesia brings various impacts both positive and negative. The positive impact of the implementation of the system is the taxpayer has full trust in performing tax obligations. However, in addition to the positive impact the implementation of the system also has a negative impact that raises the possibility of doing tax fraud (Wahyuni, 2011).

Tax non-compliance is a condition in which taxpayers are reluctant to fulfill their obligations to the government to pay taxes (Utomo, 2012). Factors causing non-compliance of taxpayers among others arise because of agency relationships (Desai and Dharmapala, 2009). Shareholders who have interests in the profit want maximum profit so that the value of the stock is also maximized in accordance with the purpose of investment. While management has a responsibility to run the company in accordance with the interests of all stakeholders including shareholders and government.

Different interests between stakeholders encourage management to engineer financial statements. With regard to taxation interests, various ways of reducing tax liabilities include reducing recorded profits, inflating tax deductions and tax shelters in different jurisdictions due to different tax rates (Desai and Dharmapala, 2009). Therefore the tax obligation encourages the company to conduct tax aggressiveness.

Engineering financial statements with the aim of reducing taxation obligations motivate companies to perform aggressiveness of financial statements. The aggressiveness of such financial statements involves the management of earnings to reduce recorded profit. Such earnings engineering activity occurs because management has the motivation to record high profits as evidence of performance and performance. High earnings will attract investors to buy the company's shares so that the value of the company will also increase.

The company according to its objectives will seek to maximize the value of the company. The value of the company is determined by the shareholders. Shareholders will rate the company higher by the ability to generate good taxes. Therefore, management will try to generate high profits. Management in the business of generating high profits must also 
meet the interests of other stakeholders, namely the government. The government has an interest in the company of taxes. Taxes in accounting are a deduction of profits. Therefore, management will make efforts to manage taxes in order to maximize profits and increase the value of the company. Tax aggressiveness has an impact on corporate value (Utomo, 2012; Crocker and Slemrod, 2004; Frank et al, 2009; Desai and Dharmapala, 2009).

\section{LITERATURE REVIEW}

Agency Theory. Jensen \& Meckling popularized agency theory or agency theory in 1976. This theory is based on the relationship between the principal and the agent. Managers are empowered by the owners of the company, ie shareholders, to make decisions, and this creates potential conflicts over interests called agency theory (Brigham \& Houston, 2001: 22). According to Jensen and Meckling (1976), agency relationships arise when a person or more (principal) employs another person (agent) to do a job in the interests of the principal by delegating decision-making authority to the agent. Each party associated with the company has different interests, therefore the company is a place for meeting the interests terxebut. The company brings together the agency relationship between the company owner and management. In addition, the agency relationship in the company also involves the relationship between the creditor and the company owner.

Managers are appointed by shareholders (owners) to run the company, in order to achieve company goals, that is maximizing the value of the company or commonly described as shareholder wealth. In addition to achieving these objectives, management has a tendency to take action that is inconsistent with the aim of increasing shareholder wealth. Management often has interests that are different from those objectives so that it may create a conflict of interest between shareholders and management or the so-called agency problem.

Jensen \& Meckling (1976) mentions that agency problems will occur when company managers have less than $100 \%$ of the company's shares. If the company is a sole proprietorship, where the owner and manager, then the manager / owner will run the company to maximize its welfare. But for a public company whose shares are owned by outsiders other than managers (public) then the conflict will arise. Management will strive to meet its own interests rather than maximizing corporate value. Management tends to spend consumptive and unproductive expenditures to improve their welfare, such as an increase in salaries or bonuses.

Agency problems will arise when the company generates great free cash flow. Free cash flow is a net cash flow that can not be reinvested because there is no profitable investment opportunity (Sartono: 2001,14). Free cash flow will cause agency problems because the company owner (shareholder) wants the cash to be distributed to the shareholders, but the management wants the cash not to be shared so that it remains in management control. Another cause of conflict between manager and owner is regarding funding decisions. Husnan (1996: 277) disclose that the company's funding decision concerns decisions about the shape and composition of funding to be used by the company. Funding functions should be done efficiently. According Riyanto (1995: 5) financial managers should make sure the company can obtain the necessary funds with minimal cost and the most favorable terms.

According to Brigham \& Houston (2001: 23) there are several mechanisms that can be done to motivate management to work in the interests of shareholders. The mechanisms are (1) Managerial compensation, this compensation is done to attract and retain a capable manager and to direct the manager's actions to approximate the shareholder's interest in maximizing stock prices. (2) The threat of hostile takeover, hostile takeover is a condition of the company forcibly taken over by another party that occurs because the company's shares are rated too low due to poor management. In a forced takeover, the management of the foreclosed company will be dismissed. (3) The threat of dismissal for management that does not work in accordance with shareholder expectations. (4) Direct shareholder intervention. 
Shareholders have influence over the operations of the company and may use it, among others, to provide advice on how the company should be run.

Agency problems may occur also between the creditor and the shareholder. Both the creditor and the investor (shareholder) have a claim on the company's assets, but the creditor has a claim in advance of the investor. The lender provides loans to the company with a fixed income of interest and loan repayment. Regardless of the amount of profits earned by the company, the income received by the creditor is fixed. Instead, investors have different forms of return with creditors. Investors earn income from the excess on the obligations to be paid to the creditor. This is related to the nature of the investor as a residual claim. Thus, the investor's right will be granted after the liability to the creditor is paid.

If the company's earnings are less than the liabilities to the creditor then all profits will be used to pay the liability, while the investor does not get a share of the profits. The investor will receive an income if there is an excess of the liabilities to be paid to the creditor. This causes investors to encourage management to invest with high risk. High-risk projects are expected to generate high profits too, so shareholders' share is also getting bigger. If this high-risk project succeeds then the profit will fall to the shareholders, while the return to the creditor remains. But if the project fails then the creditor will incur losses. Increased return on investment and of course the greater the risk will benefit shareholders. On the contrary, high risk is not beneficial to creditors. To control it the creditor imposes higher interest to the company.

Aggressive Financial Reporting and Tax Reporting. The Company is a gathering place of interest from stakeholders who each have a different purpose. One of the stakeholders having an interest is the government in the tax framework. The Company has the possibility of engaging in various tax planning schemes to reduce tax liabilities (Balakrishnan et al, 2011).

There is no definition or size of tax aggressiveness that can be accepted thoroughly (Hanlon and Heizman, 2010). Some researchers and literature use different terms to describe corporate tax aggressiveness. Frank et al. (2009) defines tax aggressiveness as an act of manipulation to reduce taxable income through tax planning, whether related to tax evasion or not. Tax evasion is a barrier in tax collection so that State cash receipts are reduced. Balakrishnan, et al. (2011) states that companies that engage in tax aggressiveness may be characterized by lower transparency. The purpose of tax planning activities is to avoid paying taxes or making the tax burden to be lower.

There are various proxy measures of tax aggressiveness. But there is no proxy that captures perfectly the act of tax aggressiveness (Rego and Wilson, 2008). Proxy Effective Tax Rate (ETR) is the most widely used proxy in the literature. Crocker \& Slemrod (2004), Dyreng et al. (2008), as well as Lanis and Richardson (2012) using ETR as a proxy for measuring tax aggressiveness. A low ETR score can be an indicator of tax aggressiveness. Companies that avoid corporate taxes by reducing taxable income and keeping financial accounting earnings have a lower ETR score. In addition, the Book Tax Difference (BTD) proxy can be used as an alternative proxy for the measurement of tax aggressiveness. Book Tax Difference describes the difference between accounting profit and fiscal profit. The big difference between accounting earnings and taxable income in companies generally shows greater tax aggressiveness (Desai and Dharmapala, 2009).

Firm Value. The main goal of the company is to increase the value of the company through increasing shareholder wealth. The final goal to be achieved from the overall financial decision is to maximize shareholder wealth through the maximization of corporate value (Sartono, 2001: 6). The value of companies that go public is shown by the stock market price. If the stock market price increases the value of the firm increases as well. As for companies that do not go public, the value of a company can be measured at the selling price if the company is to be sold which not only reflects the value of the company's assets but includes the level of business risk, the prospect of the company, the management, the business environment and other factors (Sartono 2001: 12).

The market value of the stock is determined by the cash flow of the firm. Creating a positive cash flow can increase value. To increase the value of the company, the company 
has an interest in obtaining larger cash inflows. The value of the company consists of the value of debt and value of shares (Mamduh, 2004). Company value can be maximized if it is formed as a company for the following reasons (1) Limited liability reduces the risk borne by the investor. If other things are considered constant, the lower the risk of the company, the higher the value. (2) The value of a company depends on its growth opportunity, which in turn depends on the company's ability to gain capital. (3) The value of an asset depends on its liquidity, ie the ease of selling the asset and converting it into cash at "fair market value".

Brigham \& Houston (2008: 32) discloses factors affecting the firm's stock price. First, all financial assets are valued only to the extent to which they can generate cash flows. Second, the time of the cash flows, the faster the money is received the better because it can be reinvested. Third, investors usually dislike risks, so that if things are the same, they will pay more for a stock whose cash flows are relatively more certain than those whose cash flows are relatively riskier. Based on these three factors, managers can increase the value of the company by increasing the expected cash flow, accelerating its acceptance, and reducing the level of risk. The financial manager makes investment decisions and funding the company. The manager must determine the composition of debt and good equity through debt policy, and must decide the percentage of profit to be paid as dividend or retained and reinvested through dividend policy. Each of these investment and funding decisions will affect the level, timeliness, and risk level of the company's cash flow, and therefore will affect its share price as well.

\section{METHODS OF RESEARCH}

This research is an explanatory research with quantitative approach. The data used in this study is secondary data in the form of financial statements of manufacturing companies listed on the Indonesia Stock Exchange in 2005 to 2015. Research data were analyzed using multiple linear regressions after testing the classical assumption.

Tax aggressiveness is defined as an act of manipulation to decrease taxable income through tax planning, whether associated with tax evasion or not (Frank et al., 2009). This study uses Effective Tax Rates (ETR) as a measure of tax aggressiveness (Lanis and Richardson, 2012; Rusydi and Martani, 2014). ETR is calculated by:

$$
\text { ETR }=\frac{\text { Income Tax Expense }}{\text { Book Income }}
$$

ETR represents effective tax rate based on the amount of tax cash paid by the company in the current year. Income Tax Expense represents the amount of tax cash paid by company $i$ in year $t$ based on the company's financial statements. Book Income represents pre-tax income for firm i in year t based on company's financial statements.

The aggressiveness of financial reporting is shown by earnings management activities (Kamila and Martani, 2014). Measurement of aggressiveness of financial reporting is done using accrual (Decow et al, 1995 in Bergstresser and Philippon, 2006). Total accrual is calculated as follows.

$$
T A_{i, t}=\left(\Delta C A_{i, t}-\Delta C L_{i, t}-\Delta \operatorname{Cash}_{i, t}+\Delta S T D_{i, t}-\operatorname{Dep}_{i, t}\right) / A_{i, t-1}
$$

$\mathrm{Ta}_{i, t}$ represents the total accruals of firm i at time t. $\Delta C A_{i, t}$ represents change in current assets of firm $\mathrm{i}$ at time t. $\Delta C L_{i, t}$ represents change in current liabilities of firm $\mathrm{i}$ at time $\mathrm{t}$. $\Delta \operatorname{Cash}_{i, t}$ represents change in cash of firm i at time t. $\Delta S T D_{i, t}$ represents change in long term debt in current liabilities of firm i at time t. Dep $_{i, t}$ represents change in depreciation and amortization expenses of firm i at time t. $A_{i, t-1}$ is the lagged size (on assets) of firm i at time $\mathrm{t}-1$. 
Corporate value is defined as the perception of investors to the success of the company in managing its resources measured using the ratio of market to book value (Arifin, 2004).

$$
\text { Market to Book Value }=\frac{\text { market price per share }}{\text { bookvalue per share }}
$$

The equation model used to test the hypothesis is:

$$
M B V=\alpha_{0}+\beta_{1} E T R+\beta_{2} T A+\varepsilon_{1}
$$

Hypothesis 1 and 2 are accepted if $\beta_{1}$ and $\beta_{1}$ have probability values $<0.05(5 \%)$ or can be observed from the significance value $<0.05(5 \%)$. Hypothesis in this research formulated as follows:

$\mathrm{H}_{1}$ : tax reporting aggressiveness has an influence on firm value;

$\mathrm{H}_{2}$ : financial reporting aggressiveness has an influence on firm value.

\section{RESULTS OF STUDY}

Dyreng et al (2008) divide firm based on ETR into 3 groups: low ETR $(\leq 20 \%)$, mid ETR $(20 \%>$ ETR $\leq 40 \%)$ and high ETR ( > 40\%). Data on this research describe based on this category. Result shows that during 2005 until 2014, majority firm has mid ETR which is between $20 \%$ and $40 \%$. At 2015 the data show that majority firm is on low ETR condition. Descriptive analysis result shown below.

\begin{tabular}{|c|c|c|c|}
\hline & \multicolumn{3}{|c|}{ TAX GROUP } \\
\hline & Low & Mid & High \\
\hline Year & $n$ & $n$ & $n$ \\
\hline 2015 & 117 & 112 & 53 \\
\hline 2014 & 105 & 151 & 33 \\
\hline 2013 & 94 & 157 & 35 \\
\hline 2012 & 90 & 165 & 25 \\
\hline 2011 & 79 & 159 & 27 \\
\hline 2010 & 72 & 150 & 31 \\
\hline 2009 & 60 & 115 & 40 \\
\hline 2008 & 79 & 94 & 33 \\
\hline 2007 & 56 & 115 & 24 \\
\hline 2006 & 61 & 89 & 29 \\
\hline 2005 & 63 & 83 & 28 \\
\hline
\end{tabular}

Table 1 - ETR Descriptive

Classical assumption test includes normality test, multicolinearity test, heteroscedasticity test and autocorrelation test. Results of classical assumption shows that the data does not meet the normality assumption. The P-P chart shows residuals not spreading following diagonal lines. It means the regression equation does not satisfy the classical assumption of normality. To overcome this, the data is transformed into a natural logarithmic form.

The equation after being transformed into a natural logarithm becomes as follows:

$$
\text { LnMBV }=\alpha_{0}+\beta_{1} \text { LnETR }+\beta_{2} \text { LnTA }+\varepsilon_{1}
$$

Classical assumption test after the equation is transformed into natural logarithm shows that the regression equation model has fulfilled assumption of normality, heteroscedasticity, multicolinearity and autocorrelation. Therefore hypothesis testing can be done. The equation of the regression model that is formed is:

$$
\text { LgMBV }=-0.023 \operatorname{lgETR}-0.203 \lg T A
$$


Based on the equation, the effect of LGTA on IgMBV is -0.203 and the effect of IgETR on IgMBV is -0.023 . The negative regression coefficients for the two independent variables indicate that the increasing $\lg \mathrm{TA}$ and $\operatorname{lgETR}$ further decrease the IgMBV value. It means aggressiveness of financial reporting and aggressiveness of taxes has a negative relationship with the value of the company.

Table 2 - Hypothesis Testing

\begin{tabular}{ccc}
\hline Variables & Coefficient & Significance \\
\hline ETR & -0.023 & 0.722 \\
TA & -0.203 & 0.002 \\
\hline
\end{tabular}

The result of regression model test for hypothesis $1\left(\mathrm{H}_{1}\right)$ shows that $\lg T A$ effect on IgMBV has Sig value. 0.002. It means Sig. For testing $\mathrm{H}_{1}$ is smaller than the level of significance set at 0.05 so that $H_{1}$ is accepted and $H_{0}$ is rejected. The result is aggressiveness of financial reporting has significant negative effect to company value.

The result of regression model test for hypothesis $2\left(\mathrm{H}_{2}\right)$ shows that $\lg T A$ effect on $\operatorname{lgMBV}$ has Sig value. 0.722. It means Sig. For testing $\mathrm{H} 2$ is greater than the level of significance set at 0.05 so that $\mathrm{H}_{2}$ is rejected and $\mathrm{H}_{0}$ accepted. The result means that the tax aggressiveness has no significant effect on firm value.

\section{DISCUSSION OF RESULTS}

Hypothesis testing shows that the aggressiveness of financial statements has a significant negative effect on firm value. However, tax aggressiveness has no significant effect on firm value. This results shows that investors pay more attention to information about the aggressiveness of financial statements than information on tax aggressiveness.

The tax aggressiveness measured using tax evasion does not affect the firm's value. This finding is in line with Prasiwi (2015) that proves that tax evasion which is one form of tax aggressiveness has no significant effect on firm value. This shows that investors have not used information on tax aggressiveness in decision-making related to stock price assessment. In addition, tax aggressiveness can also be a form of aggressiveness of financial statements so that by taking into account the aggressiveness of financial statements includes tax aggressiveness.

\section{CONCLUSION}

The aggressiveness of financial statements influences investors' perceptions in assessing the company. The results show that the more companies do aggressive financial reporting, the investor will rate the company lower. The direction of the same relationship is also shown by the tax aggressiveness, but its influence proved to be insignificant. These results indicate that investors tend to use information aggressiveness of financial reporting as a basis for decision making. While tax aggressiveness does not affect the perception of investors directly in assessing the company.

\section{REFERENCES}

1. Arifin. 2004. Pengaruh Kepemilikan Manajerial dan Institusional terhadap Kebijakan Hutang, Kebijakan Hutang terhadap Nilai Perusahaan Serta Kepemilikan Manajerial dan Institusional terhadap Nilai Perusahaan yang Dimediasi oleh Kebijakan Hutang: Sebuah Perspektif Agency Theory (Studi Empiris Pada Perusahaan Real Estate and Properti di BEJ). Unpublished Thesis. Jurusan Akuntansi. Fakultas Ekonomi: Universitas Brawijaya.

2. Balakrishnan, K. Blouin, J. and Guay, W. 2011. Does Tax Aggressiveness Reduce Financial Reporting Transparency? University of Pennsylvania

3. Bergstresser, D. and Phillipon, T. 2006. CEO Incentives and Earning Management. Journal of Financial Economics 80 (2006) 511-529 
4. Brigham, E.F. and Houston, J.F. 2001. Manajemen Keuangan. Edisi kedelapan. Jakarta. Gelora Aksara Pratama.

5. Crocker, K.J. and Slemrod, J. 2004. Corporate Tax Evasion with Agency Costs. Pennsylvania State University

6. Dyreng, S.D., Hanlon, M., and Maydew, E.L. 2008. Long Run Corporate Tax Avoidance. The Accounting Review Vol. 83 No. 1 pp 61-82

7. Desai, M.A. and Dharmapala, D. 2009. Corporate Tax Avoidance and Firm Value. The Review of Economics and Statistics, August, 91(3): 537-546

8. Frank, M.M., Lynch, L.J., and Rego, S.O. 2009. Tax Reporting Aggressiveness and Its Relation to Aggressive Financial Reporting. The Accounting Review Vol 84 No 2 PP 467496

9. Ghozali, I. 2007. Aplikasi Analisis Multivariate dengan Program SPSS. Semarang: Badan Penerbit-Undip.

10. Hanafi, M.M. 2004. Manajemen Keuangan (Edisi 2004/2005). Yogyakarta: BPFE Yogyakarta

11. Heltzer, W., Mindak, M.P., and Shelton, S.W. 2012. The Relation Between Aggressive Financial Reporting and Aggressive Tax Reporting: Evidence From Ex-Arthur Andersen Clients. Research in Accounting Regulation.

12. Husnan, S. 1996. Dasar-Dasar Teori Portofolio. Yogyakarta: AMP YKPN

13. Jensen, M.C. and Meckling, W.H. 1976. Theory of The Firm: Managerial Behaviour, Agency Cost and Ownership Structure. Journal of Financial Economics 305-360

14. Lanis, R. and Richardson, G. 2012. Corporate Social Responsibility and Tax Aggressiveness: An Empirical Analysis. Journal Accounting and Public Policy.

15. Prasiwi, K.W. 2015. Pengaruh Penghindaran Pajak terhadap Nilai Perusahaan: Transparansi Informasi sebagai Variabel Pemoderasi. Unpublished Thesis. Universitas Diponegoro.

16. Rego, S.O. and Wilson, R. 2008. Executive Compensation, Tax Reporting Aggressiveness and Future Firm Performance. University of Lowa

17. Resmi, S. 2011. Perpajakan Teori and Kasus, Buku 1, edisi 6. Salemba Empat: Jakarta

18. Resmi, S. 2011. Perpajakan Teori and Kasus, Buku 2, edisi 6. Salemba Empat: Jakarta

19. Richardson, G., Taylor, G., and Lanis, R. 2013. The Impact of Board of Director Oversight Characteristics on Corporate Tax Aggressiveness: An Empirical Analysis. Journal Accounting and Public Policy.

20. Riyanto, B. 2001. Dasar-Dasar Pembelanjaan Perusahaan. Yogyakarta: Yayasan Badan Penerbit

21. Rusydi, M.K. and Martani, D. 2014. Pengaruh Struktur Kepemilikan terhadap Aggressive Tax Avoidance. National Symposium of Accounting 17, Mataram, Indonesia.

22. Sartono, R.A. 2001. Manajemen Keuangan. Yogyakarta: BPFE.

23. Sarunan, W.K. 2015. Pengaruh Modernisasi Sistem Administrasi Perpajakan terhadap Kepatuhan Wajib Pajak Orang Pribadi dan Wajib Pajak Badan pada kantor Pelayanan Pajak Pratama Manado. Jurnal EMBA, Vol. 3 No. 4 Desember 2015, Hal. 518-526

24. Sonnier, B.M.. Henig, C.J., Everett, J.O., Raabe, W.A. 2012. Reporting of Book-TaxDifferences for Financial and Tax Purpose: A Case Study. Journal of Accounting Education.

25. Suyanto, K.D. and Supramono. 2012. Likuiditas, Leverage, Komisaris Independen, dan Manajemen Laba terhadap Agresivitas Pajak Perusahaan. Jurnal Keuangan dan Perbankan.

26. Wahyuni, M.A. 2011. Tax Evasion: Dampak dari Self Assessment System. Universitas Pendidikan Ganesha. 
DOI https://doi.org/10.18551/rjoas.2017-08.05

\title{
ИМПЕРАТИВЫ СТРАТЕГИЧЕСКОГО УПРАВЛЕНИЯ СБАЛАНСИРОВАННЫМ РАЗВИТИЕМ АГРОПРОМЫШЛЕННОГО ПРЕДПРИЯТИЯ STRATEGIC MANAGEMENT IMPERATIVES FOR BALANCED DEVELOPMENT OF THE AGRO-INDUSTRIAL ENTERPRISE
}

\author{
Шашло Н.В., кандидат экономических наук \\ Shashlo N.V., Candidate of Economic Sciences \\ Владивостокский государственный университет экономики и сервиса, \\ Владивосток, Россия \\ Vladivostok State University of Economics and Service, Vladivostok, Russia \\ E-mail: ninelllsss@gmail.com
}

\begin{abstract}
АННОТАЦИЯ
В статье отражены результаты исследования процесса стратегического управления сбалансированным развитием агропромышленного предприятия. Сформированы этапы разработки и реализации стратегии управления сбалансированным развитием. Стратегию управления сбалансированным развитием предложено рассматривать в двух векторах: экономическом и социальном. Доказано возникновение оперативного эффректа синергии в процессе вхождения предприятия в новый уровень конкурентного управления.
\end{abstract}

\section{ABSTRACT}

The article reflects the results of a study of the process of strategic management of a balanced development of an agro-industrial enterprise. The stages of development and implementation of the balanced development management strategy have been formed. The balanced development management strategy is proposed to be considered in two vectors: economic and social. The emergence of the operational synergy effect in the process of entering the enterprise into a new level of competitive management is proved.

\section{КЛЮЧЕВЫЕ СЛОВА}

Стратегия, управление, агропромышленное предприятие, диагностика, социальная паспортизация.

\section{KEY WORDS}

Strategy, management, agro-industrial enterprise, diagnostics, social certification.

Деятельность агропромышленных предприятий России в современных условиях характеризуется динамизмом, неопределенностью и насыщенностью внешней среды, что обусловливает существенные изменения в экономике, технологиях и социальной жизни общества. Все эти фракторы препятствуют сбалансированному развитию. Однако влияние внешних и внутренних факторов может усиливаться или снижаться, а сами фракторы - трансформироваться. Предприятия, своевременно учитывающие и прогнозирующие изменения, имеют перспективы эффективного функционирования и дальнейшего развития. В этих условиях возрастает необходимость в формировании целевых стратегий с целью получения конкурентных преимуществ. Стратегия сбалансированного развития на уровне предприятия - важный инструмент для достижения целей и успешного функционирования. Исходя из чего, данное исследование посвящено исследованию направлений фрормирования и этапов стратегии сбалансированного развития агропромышленных предприятий.

Проблемы управления развитием предприятий были рассмотрены в научных трудах зарубежных и отечественных ученых, а также экономистов - практиков. Весомый вклад в исследование отдельных аспектов проблем развития предприятий внесли такие ученые, как К. Шваб [1], М. Портер [2], Р.Каплан, Д. Нортон [3], 
С. Свиридова [4], Е. Сибирская [5],К. Фримен, Л. Сэт [6], Ф. Лалу [7],В. Садовничий [8], Э. Дандон [9], Ю. Перский [10], В. Осипов [11], П. Самуэльсон, В. Нордхаус [12] и др. Несмотря на достижения вышеуказанных ученых, вопросы обоснования и формирования стратегии сбалансированного развития агропромышленных предприятий в динамичных рыночных условиях остаются недостаточно разработанными.

Каждое предприятие рассматривается как объект управления, который должен развивается с целью эффрективного функционирования в динамичной экономической среде. Стратегия позволяет предвидеть и учитывать изменения условий развития предприятий с учетом кризисных процессов. Поддержка стабильного развития происходит, с одной стороны, по критериям: «целостность», «системность», «устойчивость» и «сбалансированность», а с другой, - с помощью способности предприятия трансформироваться с учетом изменений различных факторов.

Сущность понятия «стратегия» содержит характеристику всех процессов, происходящих в системе рассматриваемого объекта. В целом стратегию трактуют как комплекс экономических, социальных, политических и других мероприятий, с помощью которых любое предприятие сможет не только противостоять угрозам в условиях неопределенности, но и спрогнозировать и обоснованно спланировать свою деятельность, опираясь на внутренние возможности развития [13].

Разработку стратегии сбалансированного развития агропромышленного предприятия целесообразно осуществлять во взаимосвязи с целями и задачами отдельных ффункциональных стратегий. Такая взаимосвязь позволяет проявиться эффекту синергизма управления, оценка и учет которого позволит предприятию выйти на новый уровень конкурентоспособного управления [14]. Синергетический эфффект проявляется, прежде всего, в увеличении суммарного эфффекта от реализации отдельных видов функциональных стратегий. Эффрект синергизма характеризуется технологическими и управляющими нововведениями предприятия, обусловленными направлениями общей стратегии развития. В результате синергетического эффекта достигаются экономия затрат при неизменном уровне технологий, улучшение потребительских свойств товара при неизменных расходах. В данном случае синергетический эффект стратегии сбалансированного развития будет характеризоваться тремя переменными с системными связями: увеличение прибыли в денежном выражении; снижение оперативных расходов; снижение потребности в инвестициях.

Учитывая вышеприведенные аспекты, сформируем основные этапы стратегии управления сбалансированным развитием, в пределах которых описан комплекс необходимых мероприятий - последовательных этапов (рисунок 1).

Разработка стратегии управления сбалансированным развитием предусматривает проведение экспресс - диагностики фринансового состояния предприятия, поскольку устойчивое фринансовое состояние - одна из важных характеристик производственно - фринансовой деятельности. В целом экспресс диагностика фринансового состояния представляет собой процесс оперативного анализа и идентификации состояния исследуемого объекта на основе ограниченного информационного обеспечения с целью сформировать предварительную оценку о его состоянии и параметры для принятия креативных управленческих решений. Применение экспресс - диагностики финансового состояния позволит своевременно распознать признаки кризиса на ранней стадии и принять необходимые меры для его устранения [17].

С целью создания реальных предпосылок для усиления стратегических планов предлагаем дополнить экспресс - диагностику фринансового состояния агропромышленного предприятия практикой внедрения социальной паспортизации. Социальный паспорт следует разрабатывать как на самом предприятии, так и за его пределами с помощью проведения социологических исследований. Одной из главных задач данного новшества является решение проблем, касающихся роли социальных 
аспектов в планировании фринансово-хозяйственной деятельности предприятия и содействие развитию его социальной инфраструктуры.

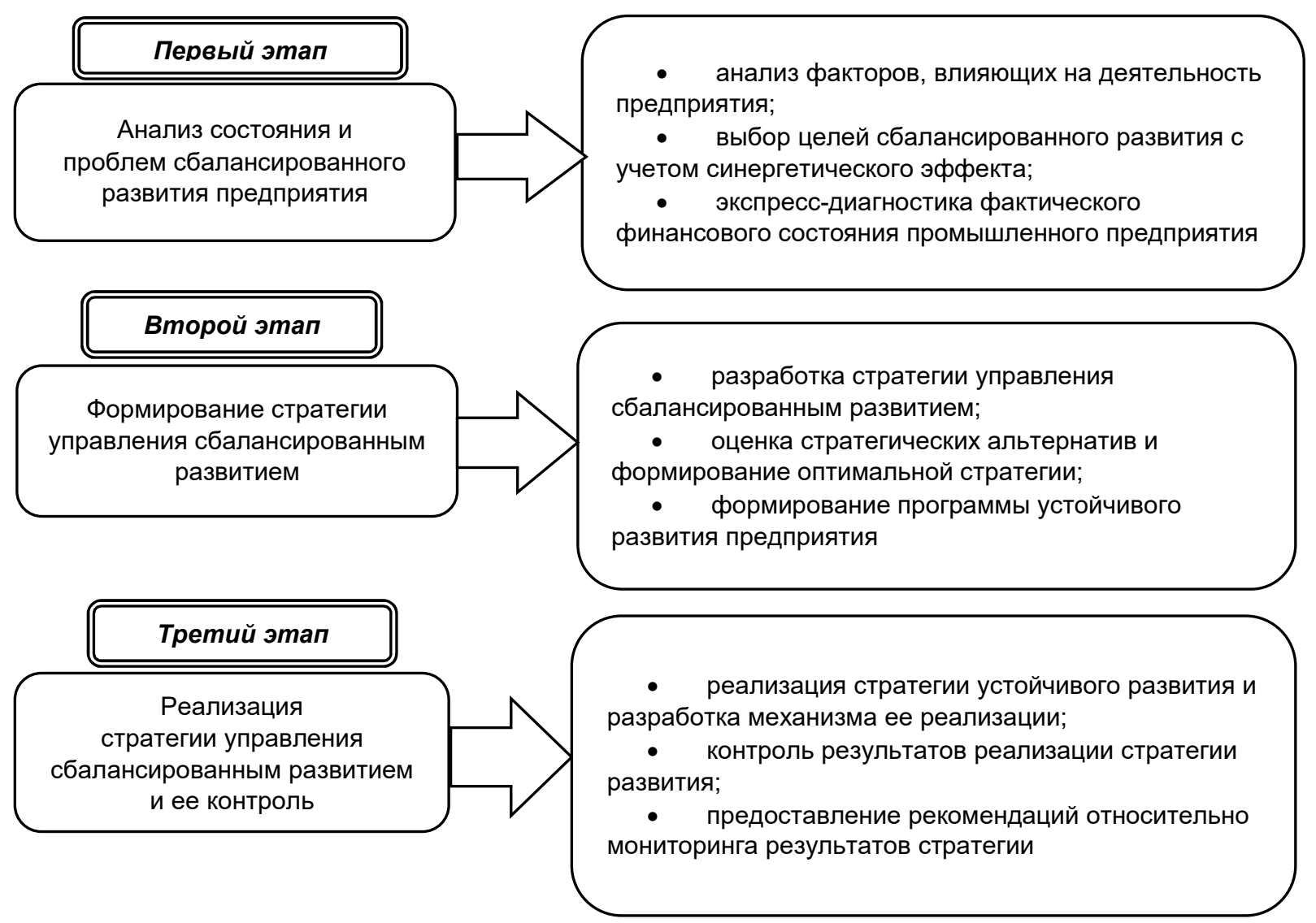

Рисунок 1 - Этапы формирования стратегии управления сбалансированным развитием агропромышленного предприятия. Составлено автором с использованием источников [15; 16]

Стратегию управления сбалансированным развитием целесообразно трактовать как систему, состоящую из подсистем и идей, принципов, представлений, которые предопределяют цель функционирования предприятия, механизм взаимодействия субъекта и объекта управления. Целью стратегии является определение главных направлений сбалансированного развития агропромышленного предприятия с учетом изменений внешних фракторов, которые во время кризиса существенно влияют на его внутреннее состояние.

Принципами стратегического управления сбалансированным развитием агропромышленного предприятия являются следующие: общие (системности, адаптивности, оптимальности, научности, взаимосвязи и взаимообусловленности и информационной обеспеченности) и специфические (гармонизации, гибкости, эфффективности, комплексности, рациональности, открытости к инновационным преобразованиям, результативности, контроля). Однако следует отметить, что все вышеперечисленные принципы необходимо внедрять в деятельность предприятия только при условии выполнения специфических принципов управления в целом, а также полномочий, ответственности, дисциплины.

Базисом стратегии управления сбалансированным развитием агропромышленного предприятия является обоснование внедрения методических основ системы стратегического управления через внедрение набора управляющих технологий и инструментария (оценочных показателей). Рассмотрение вышеуказанных вопросов позволяет сделать вывод, что стратегию управления сбалансированным развитием формируют для внедрения в деятельность предприятия основных 
стратегических направлений развития воздействия управляющей системы на управляемую.

С помощью данного подхода можно создать такую систему управления предприятием АПК, которая будет способна установить оптимальные соотношения между отдельными составляющими развития для выхода на новое качество управления. Процесс управления в указанных условиях позволит решать проблемы, касающиеся:

- определения дисбалансов и трудностей, которые деформируют систему функционирования предприятия;

- установления внутренних и внешних причин ухудшения деятельности предприятия;

- употребления мероприятий фринансового оздоровления для повышения реальной управляемости предприятия и его рыночной привлекательности;

- формирования программы действий по реализации стратегии, связанных с восстановлением фрункций управления и структуры предприятия;

- внедрения в практику принятых решений в виде планов текущего, среднесрочного и стратегического развития производственно-фринансовой деятельности, но на новом качественном уровне;

- внедрения плана контрольных мероприятий по реализации стратегии сбалансированного развития.

Таким образом, сорормирован подход к стратегическому управлению сбалансированным развитием предприятия, который предусматривает оценку стратегических альтернатив, выбор и разработку оптимальной стратегии. В связи с этим важным вопросом является анализ возникновения проблем, а уже потом реализация стратегии сбалансированного развития с помощью программ действий. Методологическую основу стратегии формируют через внедрение целостно ориентированного подхода к управлению и программно - целевого подхода. Что касается методических основ, то целесообразным является применение в расчетах сбалансированной системы показателей и формирование с их помощью прогнозных направлений в виде стратегических карт.

Во время реализации стратегии управления сбалансированным развитием агропромышленного предприятия целесообразным является фрормирование стратегических направлений, в частности:

1) в производственном развитии необходимо обеспечить: освоение технологий, технологических линий производства, проведение реконструкции существующего оборудования и внедрение нового, осуществление модернизации отдельных технологических узлов и утилизации старых, повышение требований, касающихся ухода за оборудованием, осуществление технического перевооружения предприятий на основе полномасштабного внедрение энергосберегающих технологий, фрормирование длительных партнерских отношений с поставщиками промышленной продукции;

2) в организации менеджмента постепенно внедрять инновационные управляющие технологии посредством: создания мобильных творческих групп, которые бы способствовали улучшению качества бизнес - планированияи прогнозирования, повышения квалификации кадров и фрормирования инициативности, креативности; совершенствование организации, применения действенных мер мотивации труда;

3) в сбытовой деятельности использовать: проведение мониторинга потребительских требований и предпочтений относительно конкретной промышленной продукции; совершенствование мер по фрормированию спроса и стимулированию сбыта продукции; пересмотр составляющих качества, внедрение логистических подходов к организации товарооборота промышленной продукции;

4) в фоормировании рыночной инфраструктуры целесообразно содействовать развитию интеграции научно - исследовательских учреждений и учебных заведений, 
посреднических структур с оптовыми и розничными звеньями; создавать информационно - аналитические центры распространения инноваций.

На заключительном этапе реализации стратегии необходим контроль обязанностей. На этом этапе выявляют соответствие фрактических результатов деятельности предприятия запланированным, и принимают меры по их корректировке. Контроль осуществляют по таким существенным показателям, как соблюдение объемов производства и продаж.

Подводя итоги проведенному исследованию, можно сделать вывод о том, что разработка стратегии управления сбалансированным развитием и реализация ее этапов для агропромышленных предприятий - эффективный механизм повышения уровня их конкурентоспособности. Стратегия состоит из запланированных действий (этапов), позволяющих предприятию адаптироваться к обстоятельствам, которые могут возникнуть в будущем прогнозируемом периоде. В процессе формирования стратегии запланированы технологические и управляющие нововведения как яркие проявления эффекта синергизма. Стратегия управления сбалансированным развитием агропромышленного предприятия должна соответствовать преобразованиям, происходящим в национальной экономике, гармонизировать влияние и взаимосвязи между факторами внутренней и внешней среды. Целесообразным в этих условиях является модификация методологических основ и методических прогнозных направлений. Практическое значение проведенного исследования заключается в возможности формирования и реализации стратегии управления сбалансированным развитием агропромышленного предприятия как эфффективной системы управления, что позволит своевременно предусматривать целенаправленное и постепенное совершенствование экономических, организационных, технико-технологических, производственных, социальных, управленческих, рыночных, экологических и других составляющих этой системы, которые в процессе внедрения инноваций будут приобретать новые качества.

\section{БИБЛИОГРАФИЯ}

1. Шваб К. Четвертая промышленная революция: Пер. с англ. / Дир. Ред. Е. Капьев М.: Изд-во Эксмо, 2016. 208 с.

2. Портер М.Э. Конкуренция, обновленное и расширенное издание: Пер. с англ. / Под ред. Я.В. Заблоцкого - М.: ООО «И.Д. Вильямс», 2010. 592 с.

3. Каплан Р. С., Нортон Д. П. Стратегические карты. Трансформация нематериальных активов в материальные результаты: Пер. с англ. / Под ред. Павловой М. - М.: Издво Олимп- Бизнес, 2005. 512 с.

4. Свиридова С.В. Моделирование стратегического развития промышленных предприятий: Монография. - Воронеж, ВГТУ, 2016. - 250 с.

5. Сибирская Е.В. Организационная оценка интеграционных процессов в инновационной среде промышленной корпорации // Экономика и предпринимательство. - 2016. - №1-1 (66-1). - С. 597-604.

6. Фримен К., Сэт Л. Развивая науку, технологию и инновационные индикаторы: Что мы можем узнать из прошлого: Политики Исследования, изд. 38, вып. 4, 2009, C. $583-589$.

7. Лалу Ф. Открывая организации будущего / Ф. Лалу - МИФ, 2016. - 425 с.

8. Садовничий В.А. Моделирование и прогнозирование мировой динамики: Монография / В.А. Садовничий и др. - М.: ИСПИ РАН, 2012. - 359 с.

9. Дандон Э. Инновации: как определять тенденции и извлекать выгоду / Э. Дандон; Пер. с англ. С.Б. Ильина; Под общ. Ред. М.Б. Шифрина. - М.: Вершина. - 2006. $304 \mathrm{c}$.

10. Перский Ю.К., Методика и модели оценки промышленного предприятия как устойчивой системы / Ю.К. Перский, В.В. Лепихин, Е.В. Семенова // Вестник Пермского Университета. Серия Экономика. - 2015. - №31 (24). - С. 103-110. 
11. Осипов В.А., Осипов А.В. Энергоэфрфективность как критерий эфрфективности промышленного производства // Актуальные вопросы экономических наук. 2016. №50-2. C. 127-133.

12. Самуэльсон П., Нордхаус В. Экономика / П. Самуэльсон, В. Нордхаус. - М.: «Вильямс», 2014. - 1360 с.

13. Лыгина Н.И., Рудакова О.В. Инновационный потенциал как основа конкурентоспособности российской промышленности // Социально- экономические явления и процессы. - 2014. Т. 9. - №5. - С. 35-43.

14. Колмыкова Т.С., Широкова Л.В., Галахов Д.И. Исследование вклада наукоёмких и высокотехнологичных производств в обеспечение экономического роста: Эмпирический аспект // Национальные интересы: приоритеты и безопасность. 2014. - №9. - С. 2-8.

15. Третьякова Е.А., Анализ методического инструментария оценки устойчивого развития промышленных предприятий / Е.А. Третьякова, Т.В. Алферова, Ю.И. Пухова // Вестник Пермского университета. Серия: Экономика. - 2015. - №4(27). C. $132-139$.

16. Шманев С.В., Домогацкая Е.А. Переход России на инновационный путь развития: проблемы и перспективы // Научные записки ОрелГИЭТ. - 2015. - №1 (11). - С. 5261.

17. Кузубов А.А. Анализ системы управления конкурентоспособностью предприятий / А.А. Кузубов // Фундаментальные исследования. 2015. №12-5. С. 1028-1031. 


\title{
PUSH FACTORS OF COMMUNITY PARTICIPATION IN THE MANAGEMENT OF WASTE BANK IN THE CITY OF SURAKARTA, CENTRAL JAVA PROVINCE, INDONESIA
}

\author{
Pambudi Yonathan Suryo*, Sudaryantiningsih Cicik \\ Environmental Engineering Study Program, University of Kristen Surakarta, Indonesia \\ *E-mail: ysp@uks.ac.id
}

\begin{abstract}
This study aims to determine the influence of internal and external factors on community participation in the management of the waste bank. The method used in this research is descriptive quantitative with the cross-sectional approach. The population of the research is a community of Surakarta in five sub-districts namely Serengan sub-district, Jebres subdistrict, Pasar Kliwon sub-district, Banjarsari sub-district, and Laweyan sub-district. The sample of the research is determined based on the random probability sampling with the Lemeshow method in order to obtain the minimum sample amount of 96 research sample. The amount of sample studied in this research is 125 respondents/head of household in five sub-districts in Surakarta. The data analysis technique used in this research is descriptive statistics and multiple linear regression test using SPSS software aid program to understand the influence of internal factors consisting of age, education, and gender, and the influence of external factors consisting of counselling, the activeness of environmental cadres, and the economic motivation of community of Surakarta against the community participation in the management of waste bank in Surakarta. The result of the research shows positive influence either internal factor consisting of age, education, and gender, and external factor consisting of access to information, the activeness of environmental cadres, psychological motive, social motive, economic motive against the community participation in the management of waste bank in Surakarta.
\end{abstract}

\section{KEY WORDS}

Community, participation, waste management.

Population growth, consumption pattern changes, and community's lifestyle in various cities especially in major cities in the world have improved the amount of heap, type, variety and characteristics of the waste. Most of the time, waste of urban area in developing countries are poorly managed. The research conducted by Mombon and Birgiwa (2017) state that there is a lot of waste poorly managed in the developing countries, the waste is often thrown out to the edge or side of the road, river bank, and open land. This becomes one of the challenges to create a healthier environment for the sake of the health and welfare of the community. Most of the cities in developing countries often lack the financial resources to provide adequate urban infrastructure for solid waste or waste management

As a developing country, Indonesia is facing the same issue as other developing countries in the world. In the case of domestic the solid waste or waste management, the government of Indonesia has a set of rules related to waste management, namely the Law of the Republic of Indonesia Number 18 of 2008 on Waste Management. In Article 28 Paragraph 1 of Law of the Republic of Indonesia Number 18 of 2008 on Waste management, it is stated that "community can participate in the waste management organized by the Government and/or local government." It means that the community participation in the waste management is required for the realization of a clean, healthy, organized and picturesque environment. One of the actual participations of the community in the case of waste management is the establishment of a waste bank.

Ministry of Environment and Forestry of the Republic of Indonesia (KLHKRI) stipulate waste bank program. This program is one of the assessment instruments for "ADIPURA" award. It is an award given by the central government to the cleanest and most organized city in Indonesia. The assessment is conducted not only on the cleanliness appearance in 
general but also on how the local government organizes their community in promoting the environmental health. The government of Indonesia has targeted that in 2014 all cities in Indonesia should have at least 5 units of waste banks to reduce the waste production in the surrounding area. The waste bank is a waste management program involving the community as the effort to increase the community participation independently by utilizing waste of economic value.

Waste bank management is similar to the management of the ordinary bank, however, in the waste bank the customer will not save their money but the household waste that can still be utilized. The result of the collection of sorted waste will be sold by the the administrator to the handicraft manufacturer of waste or to the waste collector. The profit will be collected and divided proportionally to each customer and every transaction will be recorded by the officer in the customer's account book. The waste bank is established based on the public concern on the environment which is filled with organic and inorganic waste. The increasing amount of waste will cause a lot of issues. Thus, it requires such processing in order to utilize the waste and turn it into useful materials. The waste management through waste bank system is expected to be able to help the government in managing the waste and improving the economy of the community (DLH municipal Surakarta, 2016).

The participation of the community of Surakarta in reducing household waste, one of which is the establishment of the waste bank. Since the issuance of the Regulation of Surakarta City Number 3 of 2010 concerning Waste Management, and Regulation of Surakarta City Number 2 of 2016 about the prevention and improvement of the quality of slum housing, the government of Surakarta keep promoting the establishment of the waste bank. The promotion of this waste bank, according to the data from the Environment Agency of Surakarta, dated February 2, 2016, there are about 75 community-based of waste banks scattered throughout Surakarta. They are divided into five sub-districts namely Banjarsari Sub-district (21 waste banks), Laweyan Sub-district (13 waste banks), Serengan Sub-district (18 waste banks), Pasar Kliwon Sub-district (7 waste banks), and Jebres Sub-district (16 waste banks). These five sub-districts in Surakarta have established a number of waste banks that vary and spread in each Ward (DLH Municipal Surakarta, 2016).

The research conducted by Artiningsih et al (2012) that examine the predisposing factors such as age, gender, and level of education against the participation in household waste management with case study in Sampangan and Jomblang, Semarang, show that most of the waste management is conducted by the community with low-level education background and those who work as self-employed, entrepreneur and housewife. A research conducted by Tanuwijaya (2016) examines the influence factors of community participation in waste management through a waste bank of Pitoe Jambangan Surabaya. The research shows that there are some factors that psychologically influence the community participation in waste management such as 1) psychology motive, 2) social motive, 3) religious motive, 4) economic motive, and 5) political motive.

The research on the waste management was conducted by Rachman et al (2016) on waste bank management in Karang Joang village, Balikpapan, which processing solid waste into compost. It is known that the activity of collecting and processing waste through the waste bank in village-scale can give economic value and can be turned into a business opportunity for some of the village members. This activity will improve the community's welfare and support the government program to reduce the amount of unemployment and poverty. Data collection technique in the research conducted by Rachman et al is through the distribution of a questionnaire to 500 residents and interviewed 5 housewives, as well as 1 owner of a grocery store.

Based on the background mentioned above, the researcher aims to conduct a research similar to a research conducted by Artiningsih et al (2012), and Tanuwijaya (2016) by combining several explanatory variables added to this research such as 1) What is the influence of internal and external factors on the community participation in the the waste management in Surakarta; 2) looking for the influence either partial and simultaneous between internal factors such as: age, education, gender and external factors such as: access to information, the activeness of environmental cadres, psychological motive, social 
motive, economic motive on the community participation in the waste management in Surakarta.

This research aims to describe the influence of internal factors such as; age, education, gender, and external factors such as access to information, the activeness of environmental cadres, psychological motive, social motive, economic motive on the community participation in the waste management in Surakarta. On the other hand, this research also aims to understand how the influence of internal factors such as age, education, gender and external factors such as: access to information, the activeness of environmental cadres, psychological motive, social motive, economic motive on the community participation in the waste management in Surakarta.

\section{THEORETICAL FRAMEWORK}

Based on the theoretical framework shown above, the proposed hypotheses are as follows:

There is partial influence between age, education, gender, access to information, the activeness of environmental cadres, psychology, social, and economy on the community participation in the waste management in Surakarta.

There is simultaneous influence between age, education, gender, access to information, the activeness of environmental cadres, psychology, social, and economy on the community participation in the waste management in Surakarta.

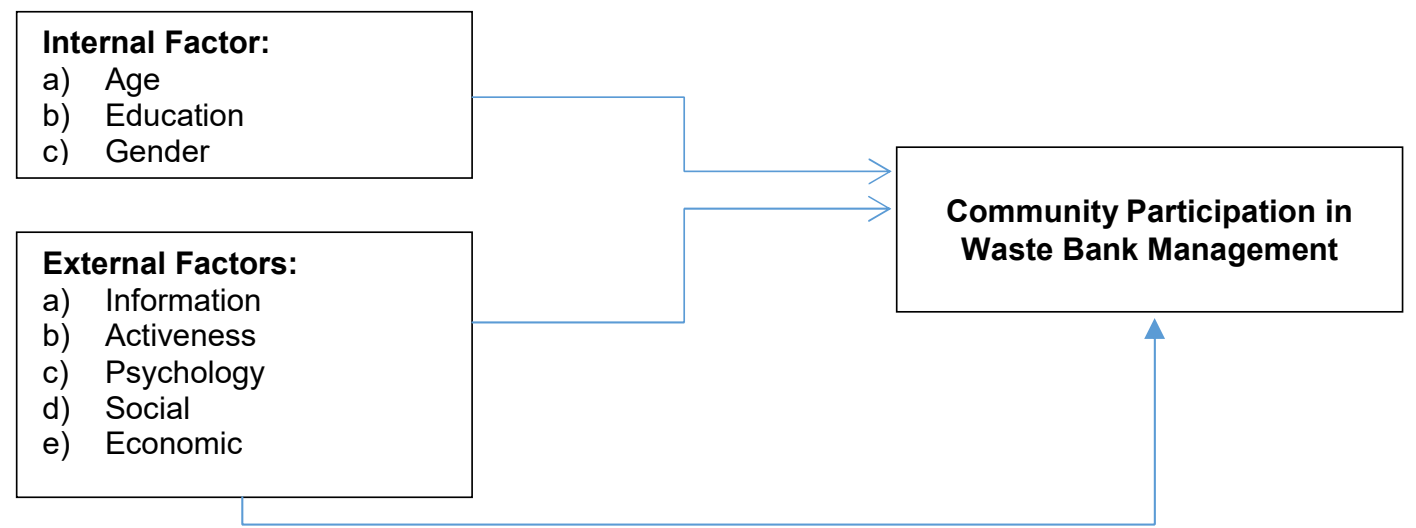

Figure 1 - Research Frame of Reference

\section{METHODS OF RESEARCH}

This research is a quantitative descriptive research with cross-sectional approach. Data collection technique is conducted by distributing the questionnaire to the community in Surakarta in five sub-districts namely: Serengan sub-district, Jebres sub-district, Pasar Kliwon sub-district, Banjarsari district, and Laweyan sub-district. The sample is determined based on random probability sampling with the Lemeshow method in order to obtain the minimum sample amount of 96 respondents. The data analysis technique used in this research is descriptive statistics, chi-square test, and multiple linear regression test using SPSS software aid program to understand the influence of internal factor consisting of age, education, and gender, and the influence of external factor consisting of counselling, the activeness of environmental cadres, and the economic motivation of community of Surakarta against the community participation in the management of waste bank in Surakarta. as follows:

The determination of research simple based on Lemeshow (Arikunto, 2016) theory is

$$
n=1 / 4\left(\frac{Z a / 2}{E}\right)^{2}
$$




\section{Description:}

$N$ - Number of samples;

$Z$ - Number indicating the deviation of a variable value from the mean count in the certain standard deviation;

E - Error.

The value of $\alpha$ (level of significant) used in this research is 0.05 . It is expected that the amount of error in the sample use (sample error) not more than $10 \%$. From the above formula, the number of samples can be determined as follows:

$$
\begin{gathered}
n=1 / 4\left(\frac{Z 0.05 / 2}{0.10}\right)^{2} \\
n=1 / 4\left(\frac{1.96}{0.10}\right)^{2} \\
n=96.04
\end{gathered}
$$

The number of samples from the above calculation is 96.04 respondents. Thus, in order to be the representative of the population then the required minimum sample is 96.04 respondents. In this research, 125 respondents are determined as the sample in order to make the number of respondents in each sub-district to be represented proportionally. Thus, the sample taken in each sub-district will be 25 people/Head of Household. This number is estimated to represent the population from 5 sub-districts in Surakarta.

\section{RESULTS AND DISCUSSION}

The partial test result of the push factors influence of the community participation in the management of the waste bank is discovered from the test result as follows:

Table 1 - Partial Test Result of Push Factors Influence of the Community Participation in the Management of Waste Bank in Surakarta

\begin{tabular}{|c|c|c|c|c|}
\hline \multicolumn{2}{|c|}{ Model } & Standardized Coefficients & \multirow{2}{*}{$\mathrm{t}$} & Sig. \\
\cline { 2 - 5 } \multicolumn{2}{|c|}{} & Beta & 4.757 & .000 \\
\hline \multirow{4}{*}{1} & 8.201 & -.514 & .608 \\
\cline { 2 - 5 } & (Constant) & -.036 & 2.166 & .032 \\
\cline { 2 - 5 } & Age & .149 & -2.409 & .018 \\
\cline { 2 - 5 } & Gender & -.170 & 3.872 & .000 \\
\cline { 2 - 5 } & Education & .381 & -1.654 & .101 \\
\cline { 2 - 5 } & Access to Information & -.146 & 2.539 & .012 \\
\cline { 2 - 5 } & Activeness & .222 & 2.568 & .012 \\
\cline { 2 - 5 } & Psychology & .235 & -2.964 & .004 \\
\hline
\end{tabular}

As it is known from Table 1 above, the age factor does not affect the participation of the community in the management of the waste bank. Gender, education, access to information, the activeness of environmental cadres, psychological, and economic factors have significant influence. The partial test result can be used in the estimation model as follows:

\section{Participation $=8.201-0.036$ Age +0.149 Gender -0.170 Education +0.38 Information -0.146 Activeness + 0.222 Psychological+0.235Social - 0204Economy.}

Constant shows that the constant value indicating the factors encourage the community participation in the management of waste bank by 8.201. This number shows that the community participation in the waste management exists. Although, there is no age, gender, education, information, activeness, psychological, social and economic factors.

Meanwhile, the age coefficient of 0.036 is a negative value indicating that the increasing in age will decrease the level of participation of the respondents. However, this 
doesn't significantly influence $(p>0.05)$ the community participation in the management of the waste bank. This research result is in line with the research conducted by Beni et al (2014) who state that age factor does not influence the level of community participation in the waste management.

The gender shows the coefficient value of 0.149 . The participation of women is higher than the man in the management of the waste bank. The reason is probably that housewives have more time at home and do the waste management in village level comparing to men who often spend most of their time outside the home to work. However, gender variable does not influence $(p>0.05)$ the respondents' participation in the waste management.

The research conducted by Beni et al (2014) on the gender variable also shows the same result. He concludes that gender does not influence the level of community participation in the waste management. Similar to the research conducted by Maulina (2012) who conclude that there is no influence from gender related to waste management. However, in Maulina's research, it is stated that the role of housewives is higher compared to the men's role in the participation in waste management.

Education coefficient value of -0.170 is the negative value indicating that higher education will cause lower interest of the respondents to participate in the management of the waste bank and it has significant influence $(p<0.05)$. It means that the community with lower educational background tends to be more active in participating in the management of a waste bank. The reason is that the community with the lower educational background will automatically think that waste bank will improve their life standard and welfare. In line with the research conducted by Beni et al (2014) who conclude that education significantly affects the level or participation in the waste management. Similarly, the research conducted by Maulina (2012) shows that the level of education affects the participation of the respondents in the waste management.

Access to information shows how often the community will get beneficial information about waste bank or information on the waste management. The coefficient value of 0.381 shows that the more information about the benefit of the waste bank given to the community, the higher the level of community participation in the management of the waste bank. It gives significant influence $(p<0.05)$. The research result conducted by Maulina (2012) shows that access information through socialization has a significant effect on the level of community participation in the waste management.

The activeness of environmental cadres has negative value but it does not significantly affect the community participation in the management of the waste bank. The result conducted by Maulina (2012) shows that the activeness of environmental cadres does not affect the level of community participation in the waste management. Contrary to the research conducted by Tanuwijaya (2016) who state that environmental cadres plays an important role and be a factor that encourages the community to participate in the activity in the waste management of the waste bank. It means that the activeness of environmental cadres has a significant role to encourage the community to participate in the management of the waste bank.

Psychological factor with coefficient value of 0.226 shows that higher psychological factor (achievement and self-satisfaction motives) will improve the community participation in the management of the waste bank. Psychological factor in the research conducted by Tanuwijaya (2016) is shown in the motives of achievement and self-satisfaction because the environment will be cleaner. That these two things are the psychological factors that have the influence to encourage the community to participate in the management of the waste bank.

The social factor with the coefficient value of 0.235 shows that higher social factor will improve the community participation in the waste bank. This factor has significant influence $(p<0.05)$. According to Asteria (2016), social factor such as the activity of mobilizing women is one of community-based society empowerment models with a gender perspective. As a social model, women will be able to mobilize individual and community to actively participate in the environmental management. Women can be the agent of change in the environmental management in the city. The socio-economic conditions of the community also influence the 
number and type of waste produced. Higher socioeconomic status of a community, because of sophisticated lifestyle, will generate more waste with different types (Suyanto, 2015).

Economic factor has the coefficient value of -0.204 shows that higher economic status of a community will decrease the community participation in the waste bank. Economic factors have significant influence $(p<0.05)$ on the community participation in the management of the waste bank. Based on the result of observation and interview in the field, the reason of the lower participation is because most of the respondents with higher economic status prefer to sell their recyclable waste directly to the collector rather than to the waste bank. Furthermore, respondents with the busy schedule usually do not have enough time and do not want to be bothered by directly participating in the social activities in their surroundings including the management of the waste bank.

The simultaneous test result of push factors of the community participation in the management of waste bank can be explained based on the result of $F$ test in Table 2 below:

Table 2 - The Simultaneous Test Result of Push Factors of the Community Participation in the Management of Waste Bank

\begin{tabular}{|c|c|c|c|c|}
\hline Sum of Squares & df & Mean Square & F & Sig. \\
\hline 333.803 & 8 & 41.725 & 12.610 & $.000^{\mathrm{b}}$ \\
\hline
\end{tabular}

Based on the data processing, it can be seen that the $F$ value of 12.610 with $P=0.000$ at the significant level $\alpha=5 \%$ significant $p<0.05$. Thus, it can be concluded that simultaneous factors such as age, sex, education, access to information, the activeness of environmental cadres, psychology, and economic significantly influence the community participation in the management of a waste bank.

The influence shows that the inherent factors in the individual influenced by the internal factors such as age, gender, or the level of education and external factors that directly or indirectly influence the individual in his or her activity to participate in the management of a waste bank.

\section{CONCLUSION AND SUGGESTIONS}

There is the partial influence of internal factors consisting of age and level of education and external factors such as information, psychological, social, and economic factors in encouraging the community participation in the management of the waste bank. Meanwhile, age factor and the activeness of environmental cadres do not have influence in encouraging the community participation in the management of the waste bank.

There is the simultaneous influence of internal factors consisting of age and level of education and external factors such as access to information, the activeness of environmental cadres, psychological, social, and economic factors in encouraging the community participation in the management of the waste bank.

Based on the research result, the researcher suggests that:

The government of Surakarta should develop a lot better method for the management of waste bank by involving the community and related stakeholders. Socialization on the management of waste and waste bank to the community should also be improved, so that the community of Surakarta will be more aware of the management of household waste through the waste bank.

The activeness and capacity of the environmental cadres and waste bank officer should be improved. Thus, intensive monitoring should be conducted by the government.

The government should encourage and improve the community participation in the management of green waste through $3 R$ principles (Reduce, Reuse Recycle). Thus, the possibly implemented strategy is improving the role of green community, the waste bank officer, and cadres/members of Family Welfare Movement (PKK) through the improvement of capacity, supporting facilities, and award in accordance with the target and achievement of the activities implemented in the field. 


\section{REFERENCES}

1. Artiningsih, N.K.A., Sudharto, H.P., Syafrudin. 2012. Peran Serta Masyarakat Dalam Pengelolaan Sampah Rumah Tangga, Studi Kasus di Sampangan dan Jomblang, Kota Semarang. Jurnal IImiah UNTAG, Pp. 107-114.

2. Asteria, D. \& Heru, H. 2016. Bank Sampah Sebagai Alternatif Strategi Pengelolaan Sampah Berbasis Masyarakat di Tasikmalaya. Jurnal Manusia dan Lingkungan. Vol. 23, No. 1 Maret 2016. Pp: 136-141.

3. Harningsih, T. 2010. Peran Gender Dalam Menangani Permasalahan Sampah. Publikasi Online. http://download.portalgaruda.org/article.php, retrieved on March 30, 2017.

4. Kim, H., Adisak, S., Seewo, M.S., and Pakkapong, P. 2016. Participation in Household Garbage Sorting of Baan Lao Yai Community, Kudchum District, Yasothon Province. International Journal of Agricultural Technology, Vol. 12 No. 5. Pp:827-840.

5. Maulina, A.S. 2012. Identifikasi Partisipasi Masyarakat Dalam Pemilahan Sampah Di Kecamatan Cimahi Utara Serta Faktor Yang Mempengaruhinya. Jurnal Perencanaan Wilayah dan Kota, Vol. 23 No. 3, pp: $177-196$.

6. Mombo, F. \& Birgiwa, D. 2017. The Role of Sub-Saharan Africa Countries' Households Waste Charges on Sustainable Cities Development. Int J Waste Resour, Vol. 7 No. 1, pp:1-6.

7. Notoatmodjo, S. 2010. Ilmu Kesehatan Masyarakat, Jakarta: Rineka Cipta.

8. Posmaningsih, D.A.A. 2016. Faktor-Faktor Yang Mempengaruhi Partisipasi Masyarakat Dalam Pengelolaan Sampah Padat di Denpasar Timur. Jurnal Skala Husada, Vol. 13, No. 1, April 2016. Pp: 59-71.

9. Ratiabriani, N.M. \& Purbadharmadja, I.B.P. 2016. Partisipasi Masyarakat dalam Program Bank Sampah: Model Logit. Jurnal Ekonomi Kuantitatif Terapan ,Vol. 9 No. 1, pp: 53-58.

10. Slamet, J.S. 2009. Kesehatan Lingkungan. Yogyakarta: Gadjah Mada University Press.

11. Suyono, B. 2010. Ilmu Kesehatan Masyarakat dalam Konteks Kesehatan Lingkungan. Jakarta: EGC

12. Suyanto, E. 2015. Model Partisipasi Green Community Dalam Perumusan Kebijakan Green Waste Lintas Rumah Tangga Mendukung Kota Hijau Purwokerto. IPB, Bogor.

13. Tanuwijaya, F. 2016. Partisipasi Masyarakat Dalam Pengelolaan Sampah di Bank Sampah Pitoe Jambangan Kota Surabaya, Jurnal Kebijakan Manajemen dan Publik, Vol. 4, No. 2, Mei-Agustus 2016. Pp: 230-244.

14. Tulit, B.M., Arjana, I.G.B., Ramang, R. 2014. Pengaruh Faktor-Faktor Sosial-Ekonomi Terhadap perilaku Pengelolaan Sampah Domestik Di Nusa Tenggara Timur. Jurnal IImu Lingkungan, Vol. 12 No. 2, pp: 105-117. 


\title{
THE EFFECT OF CORPORATE GOVERNANCE MECHANISM, OWNERSHIP STRUCTURE, AND EXTERNAL AUDITOR TOWARD CORPORATE SOCIAL RESPONSIBILITY DISCLOSURE WITH EARNING MANAGEMENT AS MODERATING VARIABLE
}

\author{
Suwana Monica Audrey Jaya, Purnomosidhi Bambang, Mardiati Endang \\ Faculty of Economics and Business, University of Brawijaya, Indonesia \\ *E-mail: monicaaudrey93@gmail.com
}

\begin{abstract}
The purpose of this study is to examine the moderating effect of earning management on corporate governance mechanism, ownership structure, and external auditor toward corporate social responsibility disclosure. This study finds that the increase of ownership structure (foreign ownership and institutional ownership) will increase corporate social responsibility disclosure. However corporate governance mechanism and external auditor is not affecting corporate social responsibility disclosure. Furthermore, this study provides additional empirical evidence for agency theory especially agency cost, that corporate governance mechanism, ownership structure, and Big Four audit firm do not have an effective role as agency cost to prevent or decrease earning management practice.
\end{abstract}

\section{KEY WORDS}

Corporate governance mechanism, ownership structure, external auditor, corporate social responsibility disclosure, earning management.

Corporate social responsibility (CSR) is a concept that gaining more attention from businesses, government and society. The Government of Indonesia also encourages the corporate social responsibility disclosures with the Law of Republic of Indonesia No. 40 of 2007 regarding Limited Liability Company and Government Regulation No. 47 of 2012 regarding Corporate Social Responsibility.

Currently, the company's CSR disclosure in Indonesia is regulated by the 4th Generation of Sustainability Reporting Guideline (G4). G4 Reporting Guideline is the result of a collaboration between the Global Reporting Initiative (GRI) and the National Center for Sustainability Reporting (NCSR), which is a CSR reporting guideline for the Southeast Asian region. However, this guideline has not been used by all companies in Indonesia. The uniformity of this guideline's usage is resulted in low report comparability. This low comparability will make it difficult for shareholders to assess the quality of company's sustainability reports that can influence their investment decisions.

The uniformity of this guideline's usage can be exploited by managers for opportunistic operations. Suyono et al. (2014) stated that CSR disclosure is used by managers for their personal interests. CSR disclosure supposed to be beneficial for the company, environmental sustainability, as well as the stakeholders. But if CSR disclosure is related with earnings management, the CSR disclosure' information will not be relevant for the shareholders.

In order to align shareholder and management interests, the companies use monitoring mechanisms such as corporate governance. Corporate governance can be divided into two aspects, which are ownership structure and corporate governance mechanism (Hadiprajitno, 2011). The ownership structure can be used to reduce agency conflict as it can improve the company's monitoring process. Corporate governance mechanisms are policies, guidelines, and control systems for managing organizations and reducing inefficiencies. In this study, the ownership structure variable is measured by institutional ownership and foreign ownership. Corporate governance mechanism variable is measured by the numbers of audit committee members, boards of directors' members, and independent board of commissioners members. 
Another factor that can influence CSR disclosure is company's external auditors. Barakat et al (2015) found that external auditor has an impact on the quantity and the quality of financial and non financial data. Big Four audit firms need more disclosures because they follow internal procedures and monitoring aspect of international audit standards.

The separation between company ownership by shareholders and controlling by managements can cause an agency problem. Agency problem can induce financial report manipulation and earning management practice. Gras-gil et al (2016) found that company which is more commited to CSR is rarely involved with earning management. However it is in contrary with Muttakin, et al (2015) which found that managers try to cover their opportunistic behavior by enhancing their CSR disclosure. This happened to Enron, which was actively involved in CSR activities but they got exposed with the biggest USA's earning manipulation scandal in 2000.

Along with the fact that there was an increase of CSR disclosure in Indonesia, Enomoto et al (2015) and Cai et al (2008) stated that Indonesia is on a high level of earning management. Suyono et al (2014) found that earning management does not mediate corporate governance mechanism effects towards CSR disclosures. Mediating variable has a role to form a process and help to conceptualize and explain the effect of independent variable towards dependent variable (Sekaran and Bougie, 2013:75). However, mediating variable has a reverse role with earning management role in this research because earning management can change the relationship between corporate governance mechanism and CSR disclosures. Therefore, earning management is more suitable as a moderating variable, which is a variable that has a strong contingency effect towards the relationship of independent and dependent variable (Sekaran and Bougie, 2013:71).

\section{LITERATURE REVIEW}

Corporate Governance Mechanism. Corporate governance is a procedure used for monitoring managers' behaviour. National Comittee of Governance Policy (KNKG, 2006) defined corporate governance as a process and structure that are used by a company to give an additional value for the company in a long term for shareholders, with regard to another stakeholders interest, according to the applied laws and norms.

Ownership Structure. Ownership structure reflects the power and authority distribution between the shareholder for company operational activities (Manengkey, 2011). There are some types of shares ownership in a company, such as institutional ownership and foreign ownership. Institutional ownership is a share ownership owned by institutions, such as insurance company, bank, investation company, and other institutions. According to the Laws of Republic Indonesia No. 25 of 2007, foreign ownership is a foreign individual, foreign company, and foreign government that invest their capital in Indonesia territory.

External Auditor. External auditor is an audit profession that examines company, government, individual, or any organization' financial reports. External auditor is a member of audit firms that give services to the client. According to Barakat et al (2015), audit firm is a formal external monitoring mechanism to provide an institutional legitimation.

Earning Management. According to Scott (2015:445), earning management is a manager's choice for accounting regulation or real action that affect earnings in order to gain a certain earning reporting purpose. Earning management can be seen from two perspectives, which are financial report perspective and contract perspective. Based on financial report perspective, manager uses earning management to avoid loss on the financial report and to fulfill earning estimation from the analyst therefore they can avoid reputation damage and negative reaction from capital market. In other side, based on contract perspective, earning management can be used to protect company from unexpected events when the contract is rigid and incomplete.

Corporate Social Responsibility Disclosure. Corporate social responsibility is a business practice that involved in company initiative to give some benefit for society. According to World Business Council for Sustainable Development (WBCSD, 2000), corporate social responsibility is a sustain business commitment to behave ethically and 
contribute to economy development along with employees' life quality enhancement, local community, and society

\section{CONCEPTUAL FRAMEWORK AND HYPOTHESIS DEVELOPMENT}

This study combines some constructs to understand the effect of corporate governance mechanism, ownership structure, and external auditors toward corporate social responsibility disclosure with earning management as moderating variable. The constructs used in this research are corporate governance mechanism, ownership structure, external auditor, earning management, and corporate social responsibility disclosure.

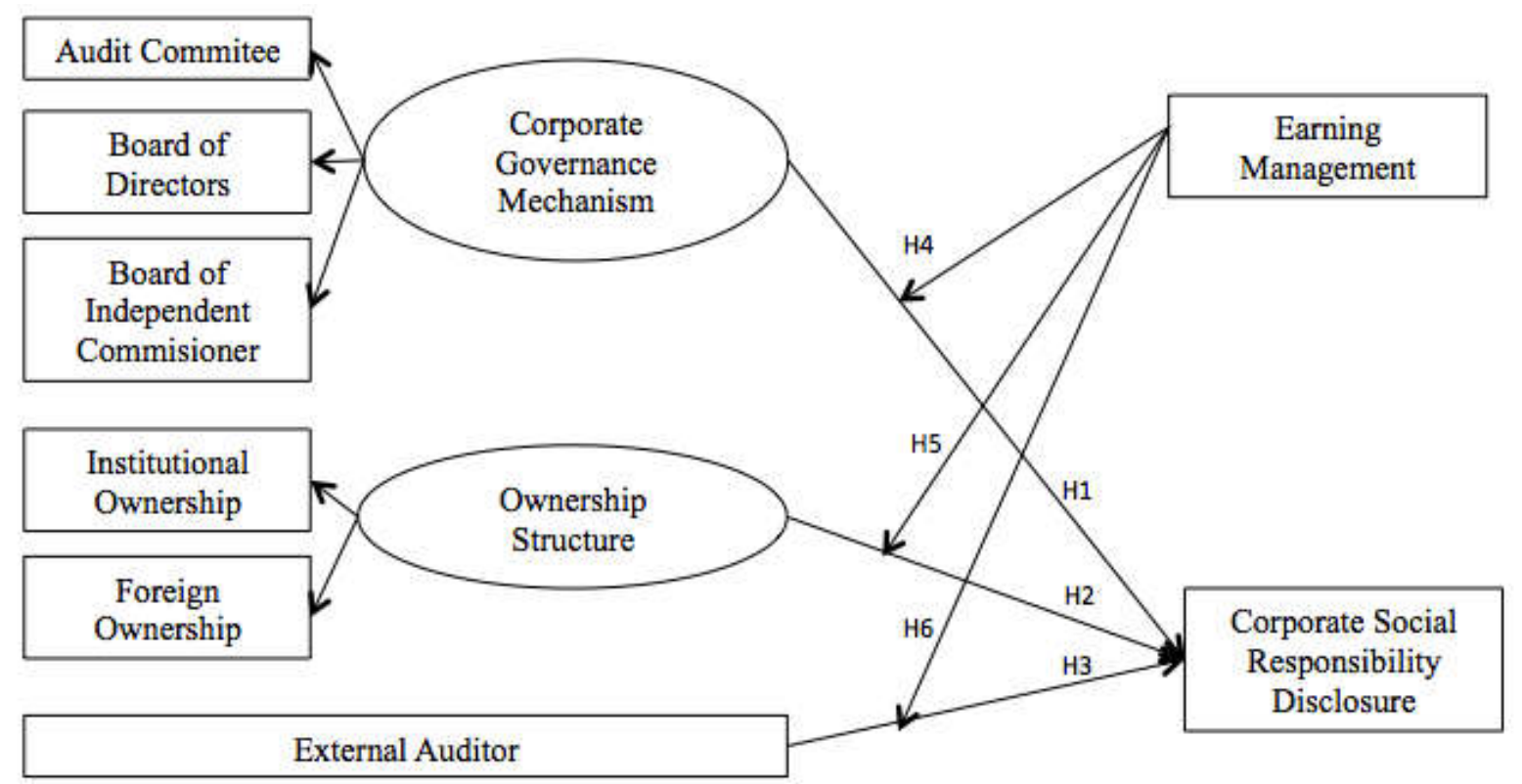

Figure 1. Research Model

The Effect of Corporate Governance Mechanism towards Corporate Social Responsibility Disclosure. Corporate governance mechanism in this study is measured with 3 variables, which are audit commitee, board of director, and board of independent commisioner. Tashakor (2014) found a positive effect of audit commitee size towards CSR disclosure. Therefore, the increase of audit commitee member make better monitoring process and broader corporate social responsibility disclosure. Akhtaruddin, et al (2009) stated that board of director's size positively affects level of voluntary disclosure. According to Pasaribu etc (2015), board of independent commisioner positively affects CSR disclosure. Based on that explaination, the first hypothesis is:

$\mathrm{H} 1$ : Corporate governance mechanism has a positive influence towards corporate social responsibility disclosure.

The Effect of Ownership Structure towards Corporate Social Responsibility Disclosure. Ownership structure is measured with institutional ownership and foreign ownership. Chakroun and Matoussi (2012) stated that a company with bigger insitutional ownership is more capable to do the monitoring for management's performance. The other type of ownership that affecting CSR disclosure is foreign ownership. Khan et al. (2013) stated that foreign investor has a different value and knowledge because of their foreign market's influence. Therefore, a company with foreign ownership will disclose more information. Based on that explaination, the second hypothesis is:

H2: Ownership structure has a positive influence towards corporate social responsibility disclosure.

The Effect of External Auditor towards Corporate Social Responsibility Disclosure. Audit firm provides accounting guarantee for the shareholders and therefore the chosen audit 
firm will affect the quantity and quality of financial and non-financial data. External auditors' function is to provide the guarantee for the shareholder about companys' accounting matters so there is a bigger possibilites that a company applying CSR criteria is being monitored by international audit firms. (Barakat et al.: 2015). Uwuigbe and Egbide (2012) found a positive influence of international audit firms toward CSR disclosure. Based on that explaination, the third hypothesis is:

H3: External auditor has a positive influence towards corporate social responsibility disclosure.

Earning Management Moderated The Effect of Corporate Governance Mechanism toward Corporate Social Responsibility Disclosure. Earning management practice is conducted by the management in a way to manipulate company's financial report as an entrenchment toward the active monitoring activity by shareholders that can affect manager position and potentially damage company's reputation (Prior et al.: 2008). Therefore, the management has an initiative to compansate shareholders using CSR disclosure. Based on agency theory, manager has an opportunistic behaviour so they will use CSR activities to cover earning management practice. A weak corporate governance mechanism will increase earning management practice and CSR disclosure to cover the earning management practice. Based on that explaination, the forth hypothesis is:

H4: Earning management weaken the effect of corporate governance mechanism towards corporate social responsibility disclosure.

Earning Management Moderated The Effect of Ownership Structure toward Corporate Social Responsibility. Earning management practice is a consequence from agency relationship. Agency theory concept by Jensen and Meckling (1976) about the relationship between principal and agent explained that in the moment when principal or shareholdes appointed an agent or manager, then the agency relationship arises. Ownership structure is one of the important factors that determine monitoring level and disclosure level of a company. A low ownership structure will increase earning management practice and increased CSR disclosure to cover the earning management practice. Based on that explaination, the fifth hypothesis is:

H5: Earning management weaken the effect of ownership structure towards corporate social responsibility disclosure.

Earning Management Moderated The Effect of External Auditor toward Corporate Social Responsibility Disclosure. Financial reporting is considered by stakeholders as a reflection of the company's performance. However, an agency problem that happens because of interest conflict between shareholders and manager can motivate a misrepresentation of a company's performance. Kim et al. (2003) stated that Big Four audit firms have effective monitoring role for managers that have an insentif to manipulate earning. Kouaib and Jarboui (2014) along with Ismail et al. (2015) found a negative influence of Big Four audit firms toward earning management. The type of external auditor that audits a company can affect the earning management practice. Manager can increase CSR social responsibility disclosure in order to cover earning management. Based on that explanation, the sixth hypothesis is:

H6: Earning management weakens the effect of external auditor towards corporate social responsibility disclosure.

\section{METHODS OF RESEARCH}

Population and Sample. Population in this research was non-financial companies listed in Bursa Efek Indonesia (BEI) on 2013-2016. 2013 was chosen as the first research year because the measure of CSR disclosure in this research was in accordance with GRI G4 standards that started to apply in 2013. Non-financial companies was chosen as the research population because this sector had more influence to the environmemnt as the consequence of company' activites. Financial company was not involved in the sample because financial company had different assets' characteristics (Eng and Mak, Y., 2003; Qiu et al., 2016; Cabeza-Garcia et al., 2017). Sampling technique used in this research was 
judgement sampling. Based on pre-determined sampling criteria, table 4.1 was presented below.

Table 1 - Judgement Sampling Result

\begin{tabular}{|l|c|c|c|c|c|}
\hline \multicolumn{1}{|c|}{ Criteria } & 2013 & 2014 & 2015 & 2016 & Total \\
\hline Non-financial companies that listed in Bursa Efek Indonesia (BEI) & 456 & 457 & 490 & 512 & 1.915 \\
\hline $\begin{array}{l}\text { Companies that not applied and disclosed CSR report using GRI } \\
\text { standards in their annual report }\end{array}$ & 408 & 408 & 408 & 456 & $(1.680)$ \\
\hline Companies that not published complete and audited annual report & 11 & 12 & 10 & 12 & $(45)$ \\
\hline $\begin{array}{l}\text { Data concerned with the variables used in the research is not } \\
\text { completely available in the annual report }\end{array}$ & 37 & 34 & 31 & 28 & $(130)$ \\
\hline \multicolumn{2}{|c|}{ Total sample } & & 60 \\
\hline
\end{tabular}

Operational Variables and Variables Measurement.

Exogenous Variable:

1. Corporate Governance Mechanism (MTKP). Corporate governance mechanism construct was measured with 3 manifest variable, which is audit commitee, board of director, and board of independent commisioner.

Audit commitee was a group formed by board of commisioner to help the function and the duty of board of independent commisioner. Audit commitee was measured by the number of audit commitee member in every company (Suyono et al., 2014; Pasaribu and Kowanda, 2015).

\section{$K O M A=$ number of audit commitee member}

Board of director was company' chairman chosen by the shareholder to represent their interest in the company in managing the company. Board of director was measured by the number of board of director member in the company (Suyono et al., 2014).

$$
D D=\text { number } \text { of board of director member }
$$

Board of independent commisioner consisted of commisioner that did not come from affiliated party. Board of independent commisioner was measured with the percentage of independent commisioner from total board of commisioner member (Suyono et al., 2014).

\section{$D K I=($ Independen commisioner member $) /($ Total board of commisioner member $) \times 100 \%$}

2. Ownership Structure (SK). This construct was measured with two manifest variables, which was institutional ownership and foreign ownership.

Institutional ownership was share ownership owned by institutional investors that covers financial institution, insurance, pension funds, mutual funds, foundations, and other institutions. Institutional ownership was measured with the percentage of total shares that owned by institutional investor from total outstanding shares (Suyono et al., 2014; Rustiarini, 2011).

$$
K I=\frac{\text { institutional investors' }{ }^{\prime} \text { hares }}{\text { total outstanding shares }} \times 100 \%
$$

Foreign ownership was total shares owned by foreign individuals or institution in Indonesian company. Foreign ownership was measured with the percentage of total shares owned by foreign investor from total outstanding shares (Khan et al., 2013; Rustiarini, 2011).

$$
K A=\frac{\text { foreign investors's shares }}{\text { total outstanding shares }} \times 100 \%
$$

3. External Auditor (AE). External auditor was measured with the size of audit firms that audit company's annual report. Audit firm size was divided into Big Four audit firm or non-Big 
Four audit firms. The Big Four audit firms in Indonesia are Tanudiredja, Wibisana \& Partners (PWC), Siddharta \& Widjadja (KPMG), Purwantono, Suherman \& Surja (KY), and Osman, Bing, Satrio \& Eny (Deloitte). Audit firm size was measured using dummy variable, 1 if the company was audited by Big Four audit firms and 0 if the companywas audited by Non Big Four audit firms (Barakat et al, 2015).

Endogenous Variable:

Endogenous variable in this research was corporate social responsibility disclosures which was a manifest variable that could be measured directly. The extent of CSR disclosure was measured using the Corporate Social Responsibility Disclosure Index (CSRDI) which refers to G4's Global Reporting Initiative Sustainability Reporting Standards (GRI Standards). The technique of data measurement was done by content analysis by giving score for each item GRI G4 which was disclosed (Sahla and Aliyah; 2016). The assessment criteria were as follows:

- A score of 0 was given if there was absolutely no disclosure of the item.

- A score of 0.5 was given if there was disclosure but is not perfectly disclose.

- A score of 1 was given if disclosure was done very well.

In total, the overall category and sub category of GRI G-4 were 149 items. If the categories and sub-categories were fully or completely disclosed, then the maximum value that could be reached was 149 .

Moderating Variable:

Earnings management as a moderating variable was a manifest variable that could be measured directly with a discretionary accrual. The models used to estimate discretionary accruals were the Kang and Sivaramakrishnan Models (1995), also called the Instrumental Variable (IV) approach. This model was used because several studies (Thomas and Zang, 2000; Yasa, 2007; Joni and Hartono, 2008) demonstrate that the use of Kang and Sivaramakrishnan models was a better method of measurement to detect earnings management. The IV approach formula was as follows:

$$
A B_{i, t}=\emptyset_{0}+\emptyset_{1}\left(\delta_{1, i} \operatorname{REV}_{i, t}\right)+\emptyset_{2}\left(\delta_{2, i} E X P_{i, t}\right)+\emptyset_{3}\left(\delta_{3, i} G P P E_{i, t}\right)+\mu_{i, t}
$$

With:

$$
\begin{gathered}
\delta_{1, i}=\frac{A R_{i, t-1}}{R E V_{i, t-1}} \\
\delta_{2, i}=\frac{I N V_{i, t-1}+O C A_{i, t-1}-C L_{i, t-1}}{E X P_{i, t-1}} \\
\delta_{3, i}=\frac{D E P_{i, t-1}}{G P P E_{i, t-1}}
\end{gathered}
$$

Where: $A B_{i, t}$ - accrual balance for firm $\mathrm{i}$ in year $\mathrm{t}$ calculated by the formula $A R_{i, t}+I N V_{i, t}+$ $O C A_{i, t}-C L_{i, t}-D E P_{i, t} ; A R_{i, t}$ - accounts receivable of company i in year $\mathrm{t} ; I N V_{i, t}$ - inventories of company $\mathrm{i}$ in year $\mathrm{t} ; O C A_{i, t}$ - other current assets (except cash, accounts receivable, and inventories) $\mathrm{i}$ in year $\mathrm{t}$; $C L_{i, t}$ - current liabilities (other than taxes and short-term portion of long-term debt) company $\mathrm{i}$ in year $\mathrm{t} ; D E P_{i, t}$ - depreciation and amortization of company $\mathrm{i}$ in year $\mathrm{t}$; $R E V_{i, t}$ - net sales of company $\mathrm{i}$ in year $\mathrm{t}$; $E X P_{i, t}$ - operating costs (cost of goods sold, cost of sales and administration before depreciation); GPPE $E_{i, t}$ - gross fixed assets of company $\mathrm{i}$ in year $\mathrm{t} ; \mu_{i, t}$ - discretionary accrual company $\mathrm{i}$ in year $\mathrm{t}$.

\section{DATA ANALYSIS METHOD}

Data analysis in this research was using PLS (Partial Least Square) with the help of WarpPLS 5.0 software. Based on Sholihin and Ratmono (2013: 7), PLS was a causal 
modeling approach that aimed to maximize the variance of the latent variable of explanatory criterion by the latent variables of predictors.

Based on Hartono (2016:175), testing of moderation effects and main effects in the research was conducted by using moderation regression analysis through a method called hierarchical regression analysis. This method consisted of two regression equations, which contained only the main effects and the second contains the moderation effect. Here are two regression equations in this study:

$$
\begin{gathered}
C S R D=\alpha_{1}+\beta_{1} M T K P+\beta_{2} S K+\beta_{3} A E+\beta_{4} M L+e_{1}(1) \\
C S R D=\alpha_{2}+\beta_{5} M T K P+\beta_{6} S K+\beta_{7} A E+\beta_{8} M L+\beta_{9} M T K P * M L+\beta_{10} S K * M L+\beta_{11} A E * M L+e_{2}
\end{gathered}
$$

Where: CSRD - Corporate Social Responsibility Disclosure Variables; MTKP - Corporate Governance Mechanism Variable; SK - Ownership Structure Variable; AE - External Auditor Variable; ML - Earning Management Variable; $\beta_{0 \ldots . .8}$ - Path coefficient; $e$ - Error.

Based on Hartono (2011: 85), moderation regression test in linear regression could be done gradually using Baron and Kenney approach (1986), which tested the main effect (dependent independent effect) that must be significant, then tested the influence of moderation variable to the dependent variable that must be significant, then interaction influence of interaction variable and moderator variable must be significant, while the main effect became insignificant.

\section{DATA ANALYSIS}

Outer Model Evaluation:

Convergent Validity Test. The requirement to meet the convergent validity is the loading value $(\lambda)$ above 0.55 (Pirouz, 2006:14) and p-value $<0.05$ (Sholihin and Ratmono, 2013:65). Table 5.1 shows that the model qualifies the convergence validity.

Table 1 - Outer Loadings

\begin{tabular}{|c|c|c|c|}
\hline- & MTKP & SK & $P$ value \\
\hline KOMA & $(0,768)$ & $-0,276$ & $<0,001$ \\
\hline DD & $(0,912)$ & 0,053 & $<0,001$ \\
\hline DKI & $(0,654)$ & 0,250 & $<0,001$ \\
\hline KI & 0,024 & $(0,832)$ & $<0,001$ \\
\hline KA & $-0,024$ & $(0,832)$ & $<0,001$ \\
\hline
\end{tabular}

Source: WarpPLS 5.0 Output.

Discriminant Validity Test. The requirement of the discriminant validity is that the AVE roots shown in parentheses for each construct is greater than the correlation between constructs and other constructs in the model (Ghozali, 2008). Based on the results shown in Table 5.2, all constructs in the estimated model meet the criteria of discriminant validity.

Table 2 - Correlations and AVE roots

\begin{tabular}{|c|c|c|}
\hline- & MTKP & SK \\
\hline MTKP & $(0,785)$ & 0,233 \\
\hline SK & 0,233 & $(0,832)$ \\
\hline
\end{tabular}

Source: WarpPLS 5.0 Output.

Reliability Test. Cronbach's alpha and composite reliability can be used in reliability test in PLS. Based on Table 5.3, Cronbach's alpha and Composite reliability values of MTKP and SK constructs are acceptable because they are greater than 0.6. Thus, it can be concluded that all constructs have good reliability. The value of the Full collinearity VIF which than 3.3 indicates that the model is free from multicolinearity problems. 
Table 3 - Latent Variable Coefficients

\begin{tabular}{|c|c|c|c|c|}
\hline- & MTKP & SK & ML $^{*} \mathrm{MTKP}$ & $\mathrm{ML}^{*} \mathrm{SK}$ \\
\hline Composite reliability & 0,826 & 0,818 & 0,734 & 0,749 \\
\hline Cronbach's alpha & 0,678 & 0,654 & 0,658 & 0,630 \\
\hline Avg. var. extrac. & 0,617 & 0,692 & 0,698 & 0,699 \\
\hline Full collin. VIF & 1,135 & 1,366 & 1,224 & 1,371 \\
\hline
\end{tabular}

Source: WarpPLS 5.0 Output.

Outer Model Evaluation. The criteria for goodness of fit model is p-values for APC and ARS should be less than 0.05 or significant. In addition, AVIF as a multicolinearity indicator should be smaller than 5 (Sholihin and Ratmono, 2013: 61). Table 5.4 shows that the goodness of fit model criteria have met.

Table 4 - General SEM Analysis Results

Average path coefficient (APC) $=0,120, \mathrm{P}=0,034$

Average $R$-squared (ARS) $=0,145, \mathrm{P}=0,006$

Average block VIF (AVIF) $=2,213$, acceptable if $<=5$, ideally $<=3,3$

Source: WarpPLS 5.0 Output.

Hypothesis Testing. The method used for hypothesis testing is a one-tailed test. Table 5.5 presents the result of hypothesis testing.

Table 5 - Hypothesis Testing Result

\begin{tabular}{|c|c|c|c|}
\hline Hypothesis & Path Coefficient $(\beta)$ & $P$ Values & Decision \\
\hline$(\mathrm{H} 1) \mathrm{MTKP} \rightarrow \mathrm{CSRD}$ & 0,02 & 0,43 & Rejected \\
\hline$(\mathrm{H} 2) \mathrm{SK} \rightarrow \mathrm{CSRD}$ & 0,27 & 0,01 & Accepted \\
\hline$(\mathrm{H} 3) \mathrm{AE} \rightarrow \mathrm{CSRD}$ & 0,17 & 0,08 & Rejected \\
\hline$(\mathrm{H} 4) \mathrm{MTKP}{ }^{*} \mathrm{ML} \rightarrow \mathrm{CSRD}$ & 0,12 & 0,16 & Rejected \\
\hline$(\mathrm{H} 5) \mathrm{SK}{ }^{*} \mathrm{ML} \rightarrow \mathrm{CSRD}$ & 0,31 & 0,99 & Rejected \\
\hline$(\mathrm{H} 6) \mathrm{AE}{ }^{*} \mathrm{ML} \rightarrow \mathrm{CSRD}$ & 0,16 & 0,09 & Rejected \\
\hline
\end{tabular}

Source: WarpPLS 5.0 Output.

\section{DISCUSSION OF RESULTS}

The Effect of Corporate Governance Mechanism towards Corporate Social Responsibility Disclosure. The results of hypothesis one found that corporate governance mechanisms did not affect the disclosure of corporate social responsibility. The results of this study do not support previous research (Tashakor: 2014; Ho and Wong: 2001; Akhtaruddin et al: 2009; Pasaribu et al: 2015). The corporate governance mechanisms in this study are measured by the constructs of audit committees, boards of directors, and independent board of commissioners. The results of the study are consistent with research by Suyono et al (2015) which stated that corporate governance mechanisms do not affect CSR disclosure.

The minimum requirement of independent board of commissioners as determined by the Indonesian regulation is $30 \%$ of the board of commissioners. This has led to the independent board of commissioners having insufficient strength to dominate company regulations. Fuente et al (2016) stated that the independent board of commissioners has no role in the decision-making of the company's sustainability strategy. Suyono et al (2015) also found the indications that almost all Indonesian companies have audit committees in order to meet the requirements of the capital market authority, regardless to the complexity of the company.

The Effect of Ownership Structure towards Corporate Social Responsibility Disclosure. The hypothesis test showed that the ownership structure had a positive effect on the disclosure of corporate social responsibility. The results of this study are supported by research of Alhazaimeh et al (2014), Chakroun and Matoussi (2012), Khan et al (2013), and 
Ghazali (2007). The ownership structure in this study was measured using institutional ownership and foreign ownership variables.

Large institutional ownership is more capable to monitor the performance of management. Thus, institutional ownership can improve the quality and quantity of voluntary disclosure to encourage companies to increase CSR disclosure. Based on Ghazali (2007), companies with foreign ownership are more 'visible' and more likely to be the subject of local government oversight. Disclosure of social information is used to avoid criticism that firms with foreign ownership only exploit resources from developing countries.

The Effect of External Auditor towards Corporate Social Responsibility Disclosure. The results of hypothesis testing found that the external auditor did not affect the disclosure of the company's CSR disclosure. The results of this study do not support the result found by Barakat et al (2015) and Uwuigbe and Egbide (2012). However, the results of this study are in line with Soliman (2013), Hossain and Hammami (2009), as well as Barako et al. (2006). This may be due to the external auditor's role that is limited to mandatory disclosure so that the external auditor does not have a strong influence in the disclosure of the company's voluntary information. Auditors in general will not ask their clients to report the data other than those required by accounting standards.

Earning Management Moderated The Effect of Corporate Governance Mechanism toward Corporate Social Responsibility Disclosure. The hypothesis testing showed insignificant results so that earnings management did not moderate the influence of governance mechanisms on corporate social responsibility disclosure. The results of this moderation test are also consistent with the results found by Guna and Herawaty (2010) along with Rahman and Ali (2006), who found that corporate governance mechanisms have no effect on earnings management. The board of directors is not effective in their monitoring role because of the management dominance that caused by the board of directors have inadequate knowledge of the company's problems.

The results do not support the agency theory which states that audit committees, boards of directors, and independent board of commissioners can reduce agency problem. However, the results of this study support the institutional theory that looks on the corporate governance mechanisms as a practice that occurs as a result of coercion from regulators that impose a number of practices in order to improve organizational effectiveness, or as a result of imitation processes (Yasser and Mamun, 2016 ).

Earning Management Moderated The Effect of Ownership Structure toward Corporate Social Responsibility. Hypothesis testing results showed that earnings management did not moderate the effect of ownership structure to corporate social responsibility disclosure. Sahin (2011) found that institutional investors have high portfolio turnover, high momentum strategy use, and high diversification. They cannot play an active role in monitoring company's management because they do not present in the company for a long term. Claessens and Fan (2002) also found that institutional investors have no active role in monitoring management activities.

Ji et al. (2015) also found that foreign ownership does not affect the quality of corporate earning. Based on the information asymmetry hypothesis in agency theory, distance can cause foreign investors to face difficulty to oversee the reporting process of the company's financial statements. The asymmetry information has resulted in foreign investors being unable to assist in monitoring earnings management practices that can be performed by managers.

Earning Management Moderated The Effect of External Auditor toward Corporate Social Responsibility Disclosure. The results showed that earnings management did not moderate the effect of external auditors to corporate social responsibility disclosure. The results of this moderation test are consistent with the results found by Ismail et al (2015) and Isaac et al (2011) who found no effect between external auditors and earnings management. They claimed that the existence of the Big Four auditor does not reduce the company's earnings manipulation activity. Bauwhede et al. (2003) argued that the tolerance of the external auditor to earnings management depends on the degree of the risk of the situation 
that causes the auditor to have less incentive to report the earnings management practices. This can be due to the low litigation of auditors and their fear of tax authorities.

In addition, external auditors tend to pay less attention to the practice of earning decreasing due to lower litigation risk associated with decreased earnings (Kim et al: 2003). This makes external auditors less effective in decreasing earnings management practices. The results of this study contribute to the agency theory, especially agency costs because the existence of Big Four audit firm does not act as an external mechanism that can prevent or reduce the practice of earnings management in the company.

\section{CONCLUSION}

The results of this study provide empirical evidence that CSR disclosure is not influenced by corporate governance mechanisms. This is due to the audit committee, the board of directors, and the independent board of commissioners who do not have sufficient power to influence the policies and practices of CSR within the company. The level of effectiveness of corporate governance mechanisms is also determined by experience, knowledge, training, and level of concern about environmental and social issues.

The results of this study also provide empirical evidence that the disclosure of CSR is influenced by the ownership structure. Foreign investors have different values and knowledge because of the influence of foreign markets and institutional investors that have a role in increasing the disclosure of CSR information. In contrast, external auditors do not affect the CSR disclosure because external auditors have no strong influence in the disclosure of the company's voluntary information.

In addition, the results of this study found that earnings management does not moderate the effect of corporate governance mechanisms, ownership structures, and external auditors on corporate social responsibility disclosure. These results provide additional empirical evidence for agency theory, especially agency costs, because corporate governance mechanisms, ownership structures, and the existence of Big Four audit firms does not play an effective role as agency cost because it cannot prevent or reduce the practice of earnings management in the company.

The sample in this study is non-financial companies listed on the BEI on 2013-2016 which are 60 samples in total. This is because there are few companies that have not reported their sustainability report in 2016 therefore the researcher cannot collect their corporate social responsibility disclosure data in that year and the sample must be eliminated. The next research may consider the timing of the study as some sustainability reports are published by the middle of the next year so that the number of samples obtained can be maximal.

\section{REFERENCES}

1. Akhtaruddin, M., Hossain, M.A., \& Yao, L. 2009. Corporate Governance and Voluntary Disclosure in Corporate Annual Reports of Malaysian Listed Firms. Journal of Applied Management Accounting Research. 7(1). 1-19.

2. Alhazaimeh, A., Palaniappan, R., \& Almsafir, M. 2014. The Impact of Corporate Governance and Ownership Structure on Voluntary Disclosure in Annual Reports among Listed Jordanian Companies. Social and Behavioral Sciences. 129. 341 - 348.

3. Barakat, F. S., Perez, M., \& Ariza, L. 2015. Corporate Social Responsibility Disclosure (CSRD) Determinants of Listed Companies in Palestine (PXE) and Jordan (ASE). Review of Management Science. 9(4). 681-702.

4. Barako, D., Hancock, P., \& Izan, H. 2006. Factors Influencing Voluntary Corporate Disclosure by Kenyan Companies. Corporate Governance. 14(2). 107- 125.

5. Baron, R. M. \& Kenny, D. A. 1986. The Moderator-Mediator Variable Distinction in Social Psychological Research: Conceptual, Strategic, and Statistical Considerations. Journal of Personality and Social Psychology. 51(6). 1173-1182.

6. Bauwhede, H.V., Wilekens, M., \& Gaeremynck, A. 2003. Audit firm Size, Public 
Ownership, and Firms' Discretionary Accruals Management. The International Journal of Accounting. 38. 1-22.

7. Cabeza-Garcia, L., Sacristan-Navarro, M., \& Gomez-Anson, S. 2017. Family Involvement and Corporate Social Responsibility Disclosure. Journal of Family Business Strategy. 6. $1-14$

8. Cai, L., Rahman, A., \& Courtenay, S. 2008. The Effect of IFRS and its Enforcement on Earnings Management: An International Comparison. Paper. Massey University. New Zealand

9. Chakroun, R. \& Matoussi, H. 2012. Determinants of the Extent of Voluntary Disclosure in the Annual Reports of the Tunisian Firms. Accounting and Management Information Systems. 11(3). 335-370.

10. Claessens, S. \& Fan, J. P. 2002. Corporate Governance in Asia: A Survey. International Review of Finance. 3(2). 71-103.

11. Enomoto, M., Kimura, F., \& Yamaguchi, T. 2015. Accrual-Based and Real Earnings Management: An International Comparison for Investor Protection. Journal of Contemporary Accounting dan Economics. 11(3). 183-198.

12. Eng, L.L. \& Mak., Y.T. 2003. Corporate Governance and Voluntary Disclosure. Journal of Accounting and Public Policy. 22. 325-345.

13. Fuente, J.A., Garcia-Sanchez, I.M., \& Lozano, M.B. 2016. The Role of the Board of Directors in the Adoption of GRI Guidelines for the Disclosure of CSR Information. Journal of Cleaner Production. 16. 1-62.

14. Ghazali, N. A. M. 2007. Ownership Structure and Corporate Social Responsibility Disclosure: Some Malaysian Evidence. Corporate Governance Journal. 7(3). 251-266.

15. Ghozali, I. 2008. Structural Equation Modeling Metode Alternatif dengan Partial Least Square (PLS) (Edisi 2). Semarang, Indonesia: Badan Penerbit Universitas Diponegoro Semarang.

16. Guna, W. \& Herawaty, A. 2010. Pengaruh Mekanisme Good Corporate Governance, Independensi Auditor, Kualitas Audit, dan Faktor Lainnya terhadap Manajemen Laba. Jurnal Bisnis dan Akuntansi. 12(1). 53-68.

17. Gras-gil, E., Manzano, M. P., \& Fernández, J. H. 2016. Investigating The Relationship between Corporate Social from Spain. BRQ Business Research Quarterly. 19(4). 289299.

18. Hadiprajitno, P. B. 2013. Struktur Kepemilikan, Mekanisme Tata Kelola Perusahaan, dan Biaya Keagenan di Indonesia (Studi Empirik pada Perusahaan di Bursa Efek Indonesia). Jurnal Akuntansi dan Auditing. 9(2). 97-127.

19. Hartono, J. 2011. Konsep dan Aplikasi Structural Equation Modeling Berbasis Varian dalam Penelitian Bisnis. Yogyakarta, Indonesia: UPP STIM YKPN.

20. Hartono, J. 2016. Metodologi Penelitian Bisnis: Salah Kaprah dan PengalamanPengalaman (Sixth Edition). Yogyakarta, Indonesia: BPFE.

21. Ho, S.M. \& Wong, K.S. 2001. A Study of The Relationship between Corporate Governance Structures and The Extent of Voluntary Disclosure. Journal Of International Accounting, Auditing dan Taxation. 10. 139-156.

22. Hossain, M. \& Hammami, H. 2009. Voluntary Disclosure in the Annual Reports of An Emerging Country: The Case of Qatar. Advances in International Accounting. 25. 255265.

23. Ismail, N. I., Zakaria, N. B., \& Sata, F. H. 2015. Auditors Roles towards the Practice of Earnings Manipulation among the Malaysian Public Firms. Procedia Economics and Finance. 28. 145-150.

24. Jensen, M. C. \& Meckling, H. W. 1976. Theory of The Firm: Manajerial Behavior, Agency Cost, and Ownership Structure. Journal of Financial Economics. 3(4). 305-360.

25. Ji, X.D., Ahmed, K., \& Lu, W. 2015. The Impact of Corporate Governance and Ownership Structure Reforms on Earnings Quality in China. International Journal of Accounting \& Information Management. 23(2). 169-198.

26. Kang, S.H. \& Sivaramakrishnan, K. 1995. Issues in Testing Earnings Management and an Instrumental Variable Approach. Journal of Accounting Research. 33(2). 353-367. 
27. Khan, A., Muttakin, M. B., \& Siddiqui, J. 2013. Corporate Governance and Corporate Social Responsibility Disclosures: Evidence from an Emerging Economy. Journal of Business Ethic. 114. 207-223.

28. Kim, J., Chung, R., \& Firth, M. 2003. Auditor Conservatism Asymmetric Monitoring and Earnings Management. Contemporary Accounting Research. 20(2). 323-359.

29. KNKG. 2006. Pedoman Umum Good Corporate Governance. Jakarta, Indonesia.

30. Kouaib, A. \& Jarboui, A. 2014. External Audit Quality and Ownership Structure: Interaction and Impact on Earnings Management of Industrial and Commercial Tunisian Sectors. Journal of Economics, Finance and Administrative Science. 19. 78-89.

31. Manengkey, J. J. 2011. Pengaruh Corporate Governance, Risiko Keuangan, dan Struktur Kepemilikan terhadap Manajemen Laba. Tesis. Universitas Brawijaya. Malang, Indonesia.

32. Muttakin, M. B., Khan, A., \& Azim, M. I. 2015. Corporate Social Responsibility Disclosures and Earnings Quality: Are They a Reflection of Managers' Opportunistic Behaviour. Managerial Auditing Journal. 30(3). 277-298.

33. Pasaribu, R., Kowanda, D., \& Kurniawan, D. 2015. Pengaruh Earning Management dan Mekanisme Good Corporate Governance terhadap Pengungkapan Corporate Social Responsibility pada Emiten Manufaktur di Bursa Efek Indonesia. Jurnal Riset Manajemen dan Bisnis. 10(2). 97-121.

34. Pirouz, D.M. 2006. An Overview of Partial Least Squares. Draft. University of California. Irvine, California. Diakses pada www.merage.uci.edu.

35. Prior, D., Surroca, J., \& Tribo, J. A. 2008. Are Socially Responsible Managers Really Ethical? Exploring the Relationship Between Earnings Management and Corporate Social Responsibility. Corporate Governance: An International Review. 16. 160-177.

36. Qiu, Y., Shaukat, A., \& Tharyan, R. 2016. Environmental and Social Disclosures: Link with Corporate Financial Performance. The British Accounting Review. 48 (1). 102-116.

37. Rahman, R.A. \& Ali, F.H. 2006. Board, Audit Committee, Culture and Earnings Management: Malaysian Evidence. Managerial Auditing Journal. 21(7). 783-804.

38. Rustiarini, N. W. 2011. Pengaruh Struktur Kepemilikan Saham pada Pengungkapan Corporate Social Responsibility. Jurnal Ilmiah Akuntansi dan Bisnis. 6(1).

39. Sahin, M.A. 2011. The Impact of Institutional Ownership and Board Structure on Earnings Management and Acquisition Performance of S\&P 500 Index Firms around Their Addition to the Index and an Experimental Approach to Buyer's Brokerage. Disertasi. University of Connecticut.

40. Sahla, W.A. \& Aliyah, S.S. 2016. Pengungkapan Corporate Social Responsibility Berdasarkan Global Reporting Initiative (GRI-G4) pada Perbankan Indonesia. Jurnal INTEKNA. 16(2). 101-200.

41. Scott, W. R. 2015. Financial Accounting Theory (Edisi 11). Toronto, Kanada: Pearson Prentice Hall.

42. Sekaran, U. \& Bougie, R. 2013. Research Methods for Business (Edisi 6). West Sussex, United Kingdom: John Wilet dan Sons Ltd.

43. Sholihin, M. \& Ratmono, D. 2013. Analisis SEM-PLS dengan Warp PLS 3.0. Yogyakarta, Indonesia: Penerbit ANDI Yogyakarta.

44. Suyono, E., Farooque, O., \& Wardani, S. 2014. On the Relationship between Governance Mechanisms, Earning Management and CSR Disclosure in the Indonesian Listed Firms. Proceedings of the Australian Academy of Business and Social Sciences Conference 2014.

45. Tashakor, S. 2014. The Influence of Audit Committee Characteristics on Voluntary Corporate Social Responsibility Disclosure: Australian Evidence. Tesis. Macquarie University. Sydney, Australia.

46. Uwuigbe, U. \& Egbide, B. 2012. Corporate Social Responsibility Disclosures in Nigeria: A Study of Listed Financial and Non-Financial Firms. Journal of Management and Sustainability. 2(1). 160-169.

47. Yasser, Q.R. \& Mamun, A. A. 2016. Audit Committee Structure and Earnings Management in Asia Pacific. Economics and Business Review. 2(1). 66-84. 


\title{
RECONSTRUCTION OF PENSION FUND PERFORMANCE MODEL AS AN EFFORT TO WORTHY PENSION FUND GOVERNANCE
}

\author{
Apriyanto Gaguk*, Firdiansjah Achmad \\ University of Merdeka, Malang, Indonesia \\ ${ }^{*}$ E-mail: apriyantogaguk@gmail.com
}

\begin{abstract}
This study aims to reconstruct the performance assessment model on Pension Fund by modifying Baldrige Assessment method that is adjusted to the conditions in Dana Pensiun A (Pension Fund A) in order to realize Good Pension Fund Governance. This study design uses case study analysis. The research sites were conducted in Dana Pensiun A. The informants in the study included the employer, supervisory board, pension fund management, active and passive pension fund participant as well as financial services authority elements as the regulator. The result of this research is a construction of a comprehensive and profound retirement performance assessment model with attention to aspects of growth and fair distribution. The model includes the parameters of leadership, strategic planning, stakeholders focus, measurement, analysis, and knowledge management, workforce focus, standard operational procedure focus, result, just and fair distribution of wealth and power.
\end{abstract}

\section{KEY WORDS}

Modified baldrige assessment, pension fund, governance.

The development of the pension industry, especially in Indonesia, is very encouraging. This is evident from the development of assets and investment activities undertaken by pension funds. With regard to investment, there has been a shift in pension investment from investments dominated by short-term investment instruments to long-term investment instruments (Word Bank, 2015; OECD, 2015). During 2015, the long-term investment portion of pension funds reaches $80.96 \%$ of the total investment (OJK, 2015: 16). Nevertheless, the role of Dana Pensiun As one of the capital market stabilizer industries can not be done optimally. As this is a few assets compared to stock exchanges capitalization in Indonesia. Thus there is still a considerable opportunity to develop pension fund industry in the future, in order for the pension fund industry to have a more significant role.

In the performance assessment, particularly in pension industry, existing problem is quite complex in general management, financial administration, accounting, and investment. The dominance of the element's role existing in pension fund has great potential to reduce employees interest (Riza, 2003: 9). Employees' interests or entitlements such as timely payment of pension benefits, the ease of accessing information particularly related to the transparency of pension fund management, and other types of rights. Therefore it is unfair should the performance assessment in pension industry as it is currently applied, as it only uses a financial performance approach such as Return on Investment (ROI), Operational Cost Efficiency, Investment Cost Efficiency, Investment Portfolio Optimization, Fund Adequacy Ratio (RKD) for DPPK-PPMP, Net Open Asset Growth Rate of Individual Participants for DPPK-PPIP and Pension Fund compliance aspects or compliance (Bureau of Pension Fund, 2015, Apriyanto, 2013). The performance assessment is not able to express fair distribution values of power and welfare. Therefore, a broader and more integrated perspective is needed in pension fund performance. Observing the complexity of existing problems in the pension fund required a performance assessment concept on pension funds which is capable of capturing in full and in depth every aspect in the pension industry. The concept of a modified Baldrige Assessment assessment is an appropriate performance assessment concept that will be able to solve the problem to be applied in the Dana Pensiun A. This concept is precise because it is very comprehensive and adaptable. It has been 
modified to be adjusted with the existing conditions in Dana Pensiun A. In addition, this performance assessment model is able to measure not only from the aspect of asset growth through financial parameters but also aspects of distribution justice especially related to the interests of stakeholders.

\section{LITERATURE REVIEW}

Baldrige Assessment Theory. Performance assessment methods that are currently widely applied in Indonesia is Baldrige Assessment. Along with that, many countries around the world are adopting the approach and criteria used by the Malcolm Baldrige Committee to measure performance excellence. The criteria they use are also known as the Seven Pillars (Baldrige, 2003) and when observed these seven criteria are indeed instrumental in determining the advancement of an organization (both business organizations and public organizations). The seven pillars or Malcolm Baldrige criteria used as the premise of this theory is the first pillar: Leadership. This criterion observes how company leaders display their capacities: how they define the organization's vision and objectives; And then communicate it to each member. Whether corporate leaders have the skills to manage and inspire their subordinates to achieve performance excellence. The second pillar: Strategic Planning. This criterion observes how strategy formulation process is defined within the organization. Do the substantive strategies respond appropriately to the changing dynamics of the business environment? This category examines how an organization develops a strategic plan and sets its action plan. Also select, execute, and change strategic planning and action plans should situation demands, as well as how progress is measured. Third pillar: Customer Focus. Are the products and services provided by the organization correct? Whether the product or service is established by an innovative organization; And make the customers satisfied? The fourth pillar: Measurement, analysis, and knowledge management. This category examines how organizations choose, collect, analyze, manage and refine knowledge, information, and knowledge assets to support key enterprise processes. Examines how organizations measure their performance. The fifth pillar: Workforce Focus. Focus on human resources (human resources focus). This category examines how organizations enable employees to develop their potential and how management and employees align with company objectives, strategies and action plans. Determining the extent to which an organization's efforts to build and maintain a work environment and employee support for good performance on personal and organizational development. The sixth pillar: Operation Focus. This criterion will measure how companies design and manage the work process. Is each process flow has been designed efficiently? Or is there still a lot of work processes that are too bureaucratic, not coordinated well, and it creates a lot of cross disputes among various departments/departments? The seventh pillar: Result. The seventh pillar looks at how the organization's performance ends: is it more competitive, more effective, and whether a performance of all aspects of an organization is improved.

Political Economy of Accounting (PEA) Theory. Performance assessment with Political Economy of Accounting (PEA) perspective should adhere of distribution fairness of power and welfare, as well as the relationship between the two. In a performance assessment based on Political Economy of Accounting (PEA) perspective, it focuses on the just and fair distribution of wealth, and the relationship between the distribution of power and the relation between power and wealth. The greater the power, greater welfare would follow suit (Tinker, 1980; Hoogvel and Tinker, 1978; Irianto, 2006; Irianto, 2007). This is in accordance with the purpose of pension funds establishment which is to provide prosperity to its participants in retirement age, due to disability or death both financially and non-financially (Act No. 11 of 1992). There is an influence between Pension Fund performance and participants' welfare level. The implication of the company's results in realizing Pension Fund performance is not free from the influence of a company's internal and external environment. This causes the social-political setting playing a role in maintaining the ongoing concern of said company (Sokarina, 2011; Rahman and Siregar, 2012). 


\section{METHODS OF RESEARCH}

This research employs the descriptive qualitative method. The study design used is a case study. This type of research is a social study; therefore case studies are more appropriate (Yin, 1996). Case studies have an advantage in a deeper understanding of complex social issues (Dooley, 2005: 335). Case study research is thorough and in-depth using a variety of data sources (Lincoln and Guba, 1985), further clarified by Stake (1994, 2005), then developed by Creswell $(1998,2007)$ and Dooley $(2002)$, Followed by Hancock and Algozzine (2006).

The sites in this research were conducted in Dana Pensiun A. The reason for choosing this research site was due to the fact that researcher did not encounter significant difficulties to obtain research data in the three site. The researcher is one of the figures in pension fund program. In addition, the researchers are a member of association board in Dana Pensiun Indonesia in Commissariat Region VI East Java and its surrounding areas. Related to the ease of accessing research data in the field as one of the considerations of researchers in selecting research sites, delivered by (Morse in Denzin and Lincoln, 1998: 60). Third, the scientific significance of three research sites will result in the development of a broader and more integrated pension performance assessment that will measure both the growth aspect of the Dana Pensiun Assets and the extent of distributional fairness related to stakeholder interests. Analyzed units in this study are performance assessment concept in Dana Pensiun A by modifying Baldrige Assessment method.

In order to obtain the necessary data, researchers used data collection techniques such as documentation, observation and interviews. Documentation includes financial data of investment portfolio report, net assets, net asset changes, balance sheet, business results, cash flow and notes on financial statements, membership data and Good Pension Fund Governance data. Observations researchers were conducted by involving themselves directly on the situation studied as pure observers and systematically observe various existing dimensions including interactions, relationships, actions, events, etc. (Mason, 1996: 60). Researcher interviews parties directly related pension funds activity as well as informants namely employers, pension fund administrators and pension fund participants.

In relation to informants in this study can be seen in the following table.

Table 1 - Research Informants

\begin{tabular}{|c|c|c|}
\hline Informants Identity & Organization Role & Pension Fund \\
\hline 1. $\mathrm{Ah}$ & Employer & \\
2. Su & Administrator & Dana Pensiun A \\
3. Sa & Participant & \\
4. $\mathrm{Ma}$ & Participant & \\
\hline
\end{tabular}

The pension funds informants represent employers, pension funds administrator, and pension fund participants. It is expected that the representatives of the informants will be able to critically explore all aspects of the pension fund, especially in relation to the information needed to formulate the concept of comprehensive and comprehensive pension performance assessment as well as to consider fairness aspects on power and welfare distribution.

Data analysis model used in this research was developed by combining Baldrige Assessment method and Political Economy of Accounting theory as described in Figure 1.

Figure 1 exhibits the steps researcher taken in performing an analysis of critical data exploration by combining Baldrige Assessment method and Political Economy of Accounting theory. Next step involved formulating the concept of assessing pension funds performance with a study combination of Baldrige Assessment method and the theory of Political Economy of Accounting. 


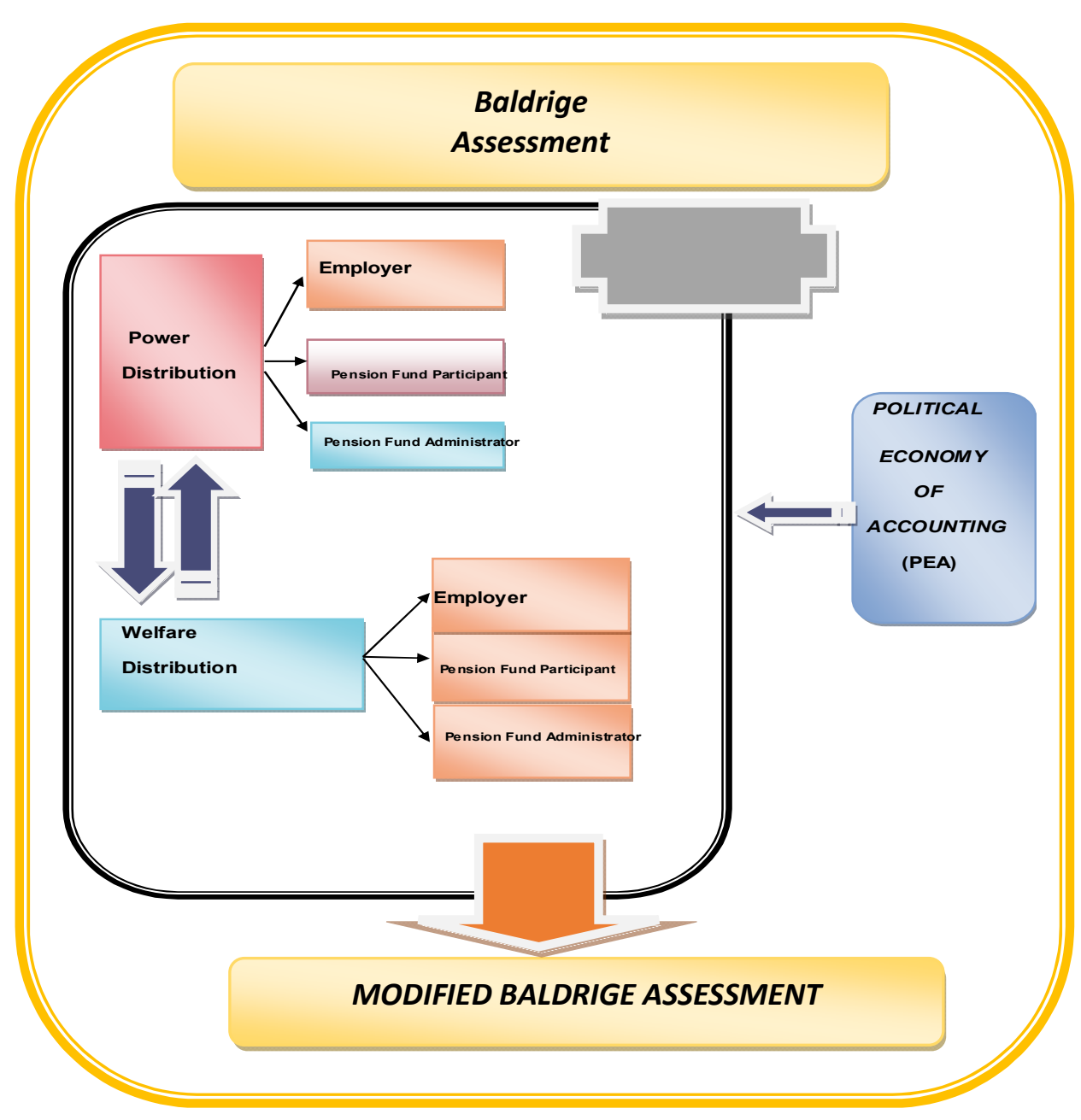

Figure 1 - Research Analysis Model

\section{RESULTS AND DISCUSSION}

The result and discussion in this research were conducted in two stages. The first phase involved analyzing critically the feasibility of concept on pension fund performance assessment. The second stage involved formulating a new concept of pension fund performance evaluation. The following is a description of this study.

Critical Analysis of Feasibility Concept on Pension Funds Performance Rating. The researchers conducted a critical analysis of the feasibility of concept-based performance assessment theory tailored to data available in the field. The condition of data in the field is reflected in every activity undertaken in each pension fund. These activities generally cover general management activities, membership, and general administration as well as accounting and investment activities.

Activity formulation and implementation of vision and mission on Dana Pensiun And the development of GPFG formulation and implementation. Applying Governance Guidelines and Pension Fund or GPFG was January 1, 2008. The decision was stipulated in Decree No. KEP-136 Chairman / BL / 2006 with the aim of drafting guidelines to encourage good governance on Dana Pensiun As well as providing a reference to the founder, employer, administrators and supervisors. This activity is an indicator in the leadership focus parameter. The formulation, application, management in formulating pension fund strategy development refers to pension fund vision and mission. As for the implementation of strategy development process, pension fund administrators use SWOT analysis as an analytical tool. In relation to the strategic objectives of the above pension funds, the strategic objective of 
the pension fund is to provide welfare for retired employee. To achieve these strategic objectives, pension fund management instituted a work program related to the development of investments in order to increase the retirement benefits for pension participants. In addressing strategic challenges such as uncertain macroeconomic conditions, funding poor employers, the management endeavor to apply pension fund general management well in order maintain sustainable organizational improvement. These activities include indicators in the parameters of strategic development.

Associated with membership activities include listening to participant and stakeholders complaints, determining satisfaction level and involvement of pension fund participants and stakeholders, pension fund services quality to pension fund participants and stakeholders as well as building a harmonious relationship between pension fund administrators with pension fund participants and stakeholders. To obtain sufficient information from pension fund participants, the pension fund manager listens to the complaints in order to obtain feedback from both active participants and stakeholders, either through written advice or verbally. In addition, Pension Funds Board needs to organize participants meeting, especially passive participants are gathered in the form of seminar forums. In order to obtain information on the satisfaction level of both pension fund participants and from stakeholders, pension fund administrators take approaches, both in the form of formal and non-formal approaches. Information on the satisfaction level of both the pension fund participants and stakeholders which are very useful as information to measure satisfaction pension service level so far. The less complaint from participants, the better the participant's satisfaction levels, and vice versa. For feedback activities, from pension fund participants in the framework of improving service quality and how well pension fund services quality to pension fund participants, is an indicator of the membership focus parameters.

Pension fund administrators in selecting, aligning and integrating data to track daily operations and overall organizational performance, coordinate with all sections covering the financial, membership, investment and accounting sections. The financial performance of the organization is measured by ROI financial parameter, operational cost efficiency, investment cost efficiency, optimization of an investment portfolio and fund adequacy ratio. This financial performance assessment following the terms of the regulator. The results of this organizational performance measurement, by Pension Funds Board, will be used as material to conduct an evaluation of organizational performance, in the framework of organizational improvement process in the future.

In analyzing organizational performance, pension fund administrator conducted it together with the supervisory board. The results of organizational performance analysis will be used as a material for decision making. In relation to audit findings, they are used as a material to evaluate organizational performance in the framework of organizational improvement. In addition to audit findings by pension fund administrators is used to evaluate organizational performance in the framework of organizational improvement, the audit findings are analyzed comparatively to project the organization's development, prioritizing sustainable organizational improvement in order to improve service quality to pension fund participants. In measuring, analyzing and developing the performance of Pension funds and certification of administrator and supervisory board including measurement, analysis, and knowledge management parameter.

In assessing the need for capacity and manpower capacity, including improving skills and competencies, the pension fund management refers to the organization's guidelines and work procedures, based on the evaluation results of the HR department. The above information is closely linked to recruiting, hiring and placing new personnel and ensuring that the existing workforce is in line with the needs of a pension fund. In order to create a conducive working climate, pension fund administrators maintain good communication with all parties. To support existing manpower, and in the context of implementing policies for excellent services, pension fund administrators engage workers in educational and training activities conducted by both central and regional ADPI. The above activities are included in the workforce focus parameters. 
Pension funds administrator designed overall work system, which is conducted by integrating the activities of the whole section into a single entity. To improve the organizational work system, pension fund administrators determine the main needs of the organizational system and accommodate input from stakeholders and utilize core competencies, based on the data being evaluated to determine the needs of the workforce. The organizational working system applied in the pension fund is a working system that refers to Good Pension Fund Governance, which is adjusted to pension fund conditions. To manage and improve work system in order to deliver value to pension funds participants well as other interested parties and in order to prevent repeated mistakes that harm the interests of pension fund participants, Pension fund administrators continually improve the work system.

To formulate crisis management, pension fund administrators formulate the basis of GPFG principles. In relation to its application, pension fund administrators do so by reference to risk management guidelines consisting the risk types and impacts, measurement and risk assessment and methods to deal with risks. Data security and documents, managed by applying the principles of good database management. In designing the organization's work processes to suit the needs of the organization, pension fund administrators do so by taking into account all aspects of the organization. New technologies and knowledge are combined in order to improve the effectiveness of the work process. In addition, the board also combines time management, productivity, cost management and effectiveness and efficiency factors into the work process is integrated. To determine the main needs in the work process, pension fund administrators do so base on evaluation results in the work process of the organization. The above activities are indicators of standard operating procedure parameters.

The results pension funds internal process, services effectiveness result to pension fund participant, three result of management efforts to improve pension funds performance, the results of the implementation of Good Pension Fund Governance, financial performance, and pension fund investment, is a measurement parameter of the result parameters. In analyzing pension payment, regulatory analysis is related to administrator role, analysis on implementation of Good Pension Fund Governance, analysis of administrator role in funds placement, analysis employer role in funds placement, regulatory analysis related to employer role, analysis of fines for late pension payment, analysis of employer role related to old-age benefits for new employees, analysis on employer role in investment targeting, is an indicator of distribution of power parameters. The distribution of wealth parameter indicators includes information analysis activities related to pension fund management, pension benefit analysis, payroll cost analysis on total operational costs, and employer profitability analysis.

After the researchers conducted a critical analysis of each indicator of the performance assessment parameters, the following step is to formulate a performance assessment concept on pension funds. The formulation of this performance assessment concept is a new construction built by researchers after researchers experienced, deepen and comprehensively understand and deeply about the characteristics of the pension industry. The formulation of the performance assessment concept on pension fund not only measures the growth aspect but also measures the extent of fair distribution both the power and welfare especially related to the interests of pension fund participants.

Formulating New Concepts of Pension Fund Performance Evaluation. The pension fund is one of the most important supporting institutions to provide social protection for most citizens. Philosophically, the pension fund system is transferring some of the resources a person acquires during his tenure to retirement when the income is no longer earned. In the performance assessment particularly in Pension Fund industry, the dominance of the role of elements existing in the pension fund has the potential to reduce employee interests (Riza, 2003: 9). Such employees' interests or rights such as timely payment of pension benefits, the ease of accessing information particularly related to the transparency of pension fund management, and other types of rights. Therefore, it is unfair if in the performance assessment in the Pension Fund industry as it is currently applicable, using only financial performance approach, consisting of Return on Investment (ROI), Operational Cost 
Efficiency, Investment Cost Efficiency, Investment Portfolio Optimization, Ratio Fund Adequacy (RKD) for DPPK-PPMP, Net Growth Rate of Individual Assets Participants for DPPK-PPIP and Pension Fund compliance aspects or compliance (Pension Fund Information, 2013). The performance assessment mentioned above has not been formulated comprehensively and integrated and has not been able to reveal the values of fair distribution. Therefore, another perspective is needed in the assessment of pension fund performance which perspective of performance assessment capable of revealing fair distribution, both power distribution, and welfare distribution.

In general, the basic concept of corporate performance assessment refers to the end result of the management process in relation to the ability of the organization to achieve its objectives by using the company's economic resources efficiently and effectively. The concept of corporate performance in accounting usually refers to only financial aspects such as profit, return on assets (ROA) and economic value added (EVA). Broader company performance measurement with Balanced Scorecard concept, where the idea is to balance the financial aspects with nonfinancial aspects in the company performance assessment (Kaplan and Norton, 1992; Venkatraman and Ramanujam, 1986).

Based on the performance assessment analysis in Dana Pensiun A mentioned above, to assess the performance as a whole requires a concept of integrated and comprehensive performance assessment by considering growth aspect as well as justice aspect distribution either power distribution or welfare distribution, which is beneficial for an employer, and pension fund participants as stakeholders. To formulate the performance assessment concept, a combination of performance assessment methods is required. As Mondy and Noe (1993: 414) point out that each method has its own weaknesses and advantages, so it is not good for the organization to rely its performance assessment on only one method. Instead, the organization incorporates several methods appropriate to the scope of its organization.

In this study, to formulate the performance assessment concept is done by combining Baldrige Assessment method with the theory of Political Economy of Accounting. Baldrige Assessment method was introduced in 1989. In this method, in order to assess the performance, using criteria known as the Seven Pillars (Baldrige, 2013) and if observed seven pillars of this criterion is indeed a very important role in determining the reciprocation of an organization (whether organizations Business or public organization). The seven pillars or the criteria of Malcolm Baldrige were as follows: Leadership, Strategic Development, Membership Focus, Measurement, analysis, and knowledge management, Workforce Focus, Standard Operating Procedure, and Result. Methods Baldrige Assessment is combined with Political Economy of Accounting (PEA), aims to measure the extent of fair distribution. It includes equal distribution of wealth or welfare (just and fair distribution of wealth), and the relation between the distribution of power and welfare (relations of power and wealth). This is in accordance with the purpose of the establishment of pension funds is to prosper pension fund participant in retirement age, due to disability or death both financial and non-financial (Act No. 11 of 1992). Based on the study of the combination of performance assessment methods above, the researcher proposes the concept of pension fund performance ratings as depicted in Figure 2.

Based on Figure 2, a pension funds performance assessment concept in detail. Leadership aspect consists of 1) formulation and implementation of vision and mission, 2) GPFG formulation and implementation. Strategic Development aspect consists of: 1) formulation of pension fund strategy development, 2) application of pension fund strategy development. The Membership Focus aspect consists 1) feedback from participants of the pension fund, 2) service quality to participants of the pension fund.

Measurement, analysis, and knowledge management aspects consist of 1) measuring, analyzing and developing pension fund performance, 2) administrator and supervisory board certification.

The Workforce Focus aspect consists of 1) building a conducive working environment, 2) training for pension fund employees. Standard Operating Procedure aspect consists of 1) formulation of Standard Operating Procedure, 2) effectiveness of Standard Operating Procedure implementation. Results aspect consists of 1) result of the internal process of 
pension funds, 2) service effectiveness to pension fund participants, 3) management efforts to improve pension funds performance, 4) implementation of Good Pension Fund Governance, 5) financial performance and pension fund investment.
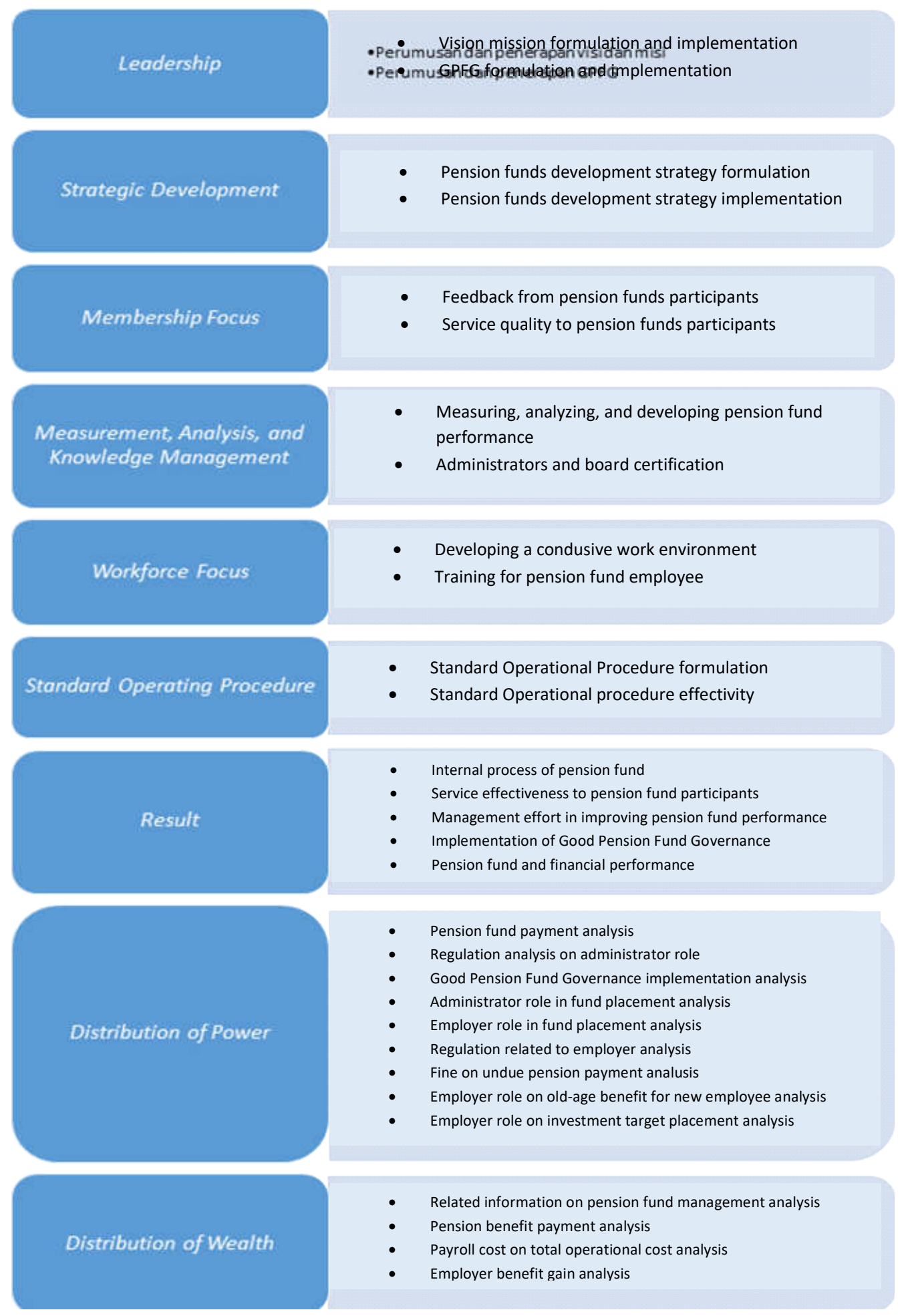

Figure 2 - Pension Fund Performance Assessment Model

The Distribution of Power aspect consists of 1) pension fee contribution analysis, 2) regulatory analyses related to administrator roles, 3)implementation of Good Pension Fund Governance analysis, 4) analysis of administrator roles in fund placement, 5) employer role in fund placement analysis, 6) regulatory analyses related to employer's role, 7) fine 
payment for late distribution analysis, 8) analysis of employer's role related to old age pension for new employees, 9) analysis of the employer's role in determining the investment target. Distribution of Wealth aspect consists of 1) analysis of information related to pension funding management, 2) pension benefit payment analysis, 3) salary cost analysis of total operational cost, and 4) employer benefit gain analysis.

\section{CONCLUSION AND SUGGESTIONS}

The current performance assessment concept is too narrow and only the smallest part of it were formulated by the researcher. The following is a comparison of the performance assessment concept in current pension funds compared to the performance assessment concept formulated. First, the assessment of financial performance and investment currently is one part of the five aspects performance assessment concept result that was formulated by the researchers. Both compliance aspects of the pension fund or compliance (GPFG) on the current performance assessment concept is one part of the Leadership aspect and the Result aspect of the performance assessment concept formulated by researchers. In the current performance assessment concept, many important aspects of performance assessments are not taken into account such as Leadership, Strategic Development aspects, Membership Focus aspects, Measurement Aspects, Analysis, and Knowledge Management, Workforce Focus aspects, Standard Operating Procedure aspects, Aspects of Distribution of Power and aspects of Distribution of Wealth.

By examining pension funds performance assessment so far, it requires effort to reconstruct performance assessment concept applicable with comprehensive and integrated performance assessment model concept and consider power and welfare aspects distribution including leadership, strategic planning, customer focus, measurement, analysis, and knowledge management, workforce focus, operation focus, result as well as just and fair distribution of wealth and power. This performance assessment model not only measures from the growth aspect of pension fund but also gives the description as far as distribution justice occurred both power and welfare distribution especially related with interest of pension fund participant.

For future purposes, this research is important, especially regarding the pension funds performance assessment both in Indonesia and elsewhere. The approach used in this study can be applied to different industries other than the pension fund industry. This study would be conducted better when it focused on one industry because each industry has different characteristics. In performance assessment, as has been disclosed in this study, not only judged from the financial aspects but also assessed from non-financial aspects (Cumby and Conrod, 2001; Kannan and Aulbur, 2004). It is recommended that future research is further developed with relevant aspects in addition to the seven criteria in Baldrige Assessment, as well as the disclosure of aspects of power and welfare are more equitably disclosed especially with regard to regulators. The phenomenon of performance assessment in a pension fund is a fact, which must be socially constructed and to understand social reality, therefore science is needed (Berger and Luckmann (1990: 28)

The Financial Services Authority as the regulator overseeing pension funds performance, the researcher suggests the need to consider aspects of Leadership, Strategic Planning, Customer Focus, Measurement, Analysis, and Knowledge Management, Workforce Focus, Operation Focus, and Result as well as aspects of power, welfare and hegemony - parties associated with pension fund in pension fund performance assessment which is currently in effect. The researcher's expectation, taking into account the abovementioned aspect, that pension fund's performance evaluation becomes more comprehensive and fair. 


\section{REFERENCES}

1. Apriyanto G. 2013. Anailisis Kritis Kinerja Dana Pensiun: Sebuah Kajian Dalam Perspektif Political Economy of Accounting. Research for Doctoral Dissertation. LPPM Unmer Malang.

2. Berger, P.L. \& Luckman T. 1990. Tafsir Sosial atas Kenyataan: Risalah tentang Sosiologi Pengetahuan. Translated by $\mathrm{H}$. Basri, The Social Construction of Reality. Jakarta: LP3ES.

3. Creswell, J.W. 1998. Qualitative Inquiry and Research Design: Choosing among Five Tradition. London: Sage Publications.

4. Creswell. J.W. 2003. Educational Research. Planning, Conducting, and Evaluating Quantitative and Qualitative Reserach, Second Edition. New Jersey: Pearson Merrill Prentice Hall.

5. Cumby, J. \& Conrod, J. 2001. Non Financial Performance Measures in The Canadian Biotechnology Industry. Journal of Intellectual Capital. Vol 2 No 3, pp 261-271.

6. Dooley, L.M. 2005. Case study research and theory building. Advances in Developing Human Resources, 4(3), 335-354, http://www.proquest.umi.com, retrieved on 12 January 2013.

7. Hancock, D.R. \& Algozzine, B. 2006. Doing Case Study Research. New York: Teacher College Press.

8. Hoogvelt, A. \& Tinker, A.M. 1978. The Role of Colonial and Post Colonial States in Imperialism-a Case Study of the Sierra Leone Development Company, The Journal of Modern African Studies, 16 (1):67-79.

9. Irianto, G. 2004b. A Critical Enquiry into Privatitation of State-Owned Enterprises: The Case of PT Semen Gresik (Persero) Tbk. PhD Thesis, Departement of Accounting and Finance, University of Wollongong, Australia.

10. Irianto, G. 2006. Dilema "Laba" dan Rerangka Teori Political Economy of Accounting (PEA), TEMA 7 (2): 141-53.

11. Irianto, G. 2004. Industri Semen di Indonesia: Ekspansi, Perangkap Utang (debt trap), dan Kepemilikan, Lintasan Ekonomi, Vol. XXI, No. 1, 1-12.

12. Kannan G. \& Aulbur, W.G.A. 2004. Intellectual Capital, Measurement Effectiveness. Journal of Intellectual Capital. Vol 5 No 3, pp $389-413$.

13. Lincoln, Y.S. \& Guba, E.G. 1985. Naturalistic Inquiry. Beverly Hills: Sage Publication.

14. Mason, J. 1996. Qualitative Research, London, Sage Publications.

15. Muhammad. I. 2009. Metode Penelitian IImu Sosial. Yogyakarta : Erlangga.

16. Neimark M. \& Tinker T., 1986, The Social Construction of Management Control System, Accounting, Organization and Society, Vol. 11 No. 4 Pp 369-395.

17. OECD. 2015. Survei Ekonomi OECD INDONESIA. Indonesia. Originally published by the OECD in English and in French under the titles: OECD Economic Surveys: Indonesia 2015. Étude économiques de l'OCDE.

18. OJK. 2015. Statistik 2014 dan Direktori 2015 Industri Keuangan non Bank Dana Pensiun. Jakarta.

19. Riza. Y. 2003. Pengaruh Keadilan Distributif, Keadilan Prosedur, Komitmen terhadap Tujuan, dan Motivasi terhadap Kinerja Manajerial dalam Penyusunan Anggaran. Simposium Nasional Akuntansi Vl: 707-719.

20. Stake, R.E. 2005. Case Study Methods in Educational Research: Seeking Sweet Water. In R. M. Jaeger (Ed.) Complementary methods for research in education, 2nd Edition (pp, 401-414). American Educational Research Association: Washington, DC.

21. Tinker, T., Merino, B. and Neimark M. 1982. The Normative Origins of Positive Theories: Ideology and Accounting Thought, Accounting, Organizations and Society, 7, 2: 167-200.

22. Tinker T. 1980. Towards A Political Economic Of Accounting: An Empirical llustration Of The Cambridge Controversies, Accounting, Organization and Society, Vol. 5 No. 1 Pp. 147-160. 


\title{
THE PLANNING OF HUMAN RESOURCES (STATE APPARATUS) QUALITY IMPROVEMENT IN THE PERSPECTIVE OF GOVERNANCE: A STUDY ON REGIONAL EMPLOYMENT BOARD OF MALANG
}

\author{
Kurube Elisa Hendrik*, Hakim Abdul, Sujarwoto \\ Master's Degree Program in Public Administration, \\ Faculty of Administrative Science, University of Brawijaya, Indonesia \\ *E-mail: elisahendrikk@gmail.com
}

\begin{abstract}
The main focus of this study is the Planning of Quality Improvement of Human Resources (State Apparatus) in the Perspective of Good Governance, A Study on the Program of State Apparatus Capacity Improvement in Regional Employment Board of Malang. This study used a qualitative research (naturalistic) with a research strategy of observation. The purpose of this study is to review and analyze the planning of human resources quality improvement in the perspective of good governance in the Regional Employment Board of Malang; to determine the supporting factors and improve the quality of resources in the planning of human resources quality improvement in the perspective of good governance in the Regional Employment Board of Malang. The development of employees' capacity carried out by the Regional Employment Board of Malang is intended to strengthen the organization and as an effort to establish a system of good governance. Given the number of local officials who must be served and managed by the employees of Regional Employment Board, this requires an effort of capacity building through the planning of human resources quality improvement in a systematic way and in accordance with the principles of good governance characteristics.
\end{abstract}

\section{KEY WORDS}

State apparatus, resources, planning, governance.

Given the need to improve the quality of public services and performance within the organization, qualified Human Resources $(\mathrm{HR})$ is one of the important factors at the Regional Government Institutions. With a clear planning of developing human resources quality, the organization can achieve its goals more effectively and efficiently with optimal performance in achieving good governance. According to the World Bank (in Wahab, 2002: 34), it is defined that good governance is an implementation of a solid and responsible development management that is in line with the principles of democracy and efficient market, the avoidance of investment funds misallocation, and the prevention of corruption both political and administrative, running a budget discipline and the creation of legal and political framework for the growth of business activities. Meanwhile, the United Nations Development Programme UNDP (in Mardiasmo, 2009) has given the sense that good governance is understood as an implementation of political authority, economic, and administrative management processes on various levels of public affairs in a country.

Sedarmayanti (2009: 103) further said that improving the quality of human resources apparatus is usually done with education and training. Education and training is a process of transformation in improving the quality of human resources apparatus where one of the specific objectives of education and training is to improve knowledge, skills, and attitudes to be able to perform professional duties based on the personality and ethics of civil servants according to the needs of the organization.

Based on previous research by Artika (2014, p.6) and Prasetia (2014, p.4), there are some problems related to the role of Regional Employment Board of Malang Regency in implementing its function. On the other hand, the demand for good governance is increasingly urgent. Therefore, the Regional Employment Board of Malang Regency is required to always strive to develop the ability and improve the performance of its internal 
employees to be more committed and professional in every excellent service from all aspects.

The development of employees' capacity carried out by the Regional Employment Board of Malang is intended to strengthen the organization and as an effort to establish a system of good governance. Given the number of local officials who must be served and managed by the employees of Regional Employment Board, this requires an effort of capacity building through the planning of human resources quality improvement in a systematic manner and in accordance with the principles of good governance characteristics.

\section{LITERATURE REVIEW}

The Improvement and Development of Human Resources (Peningkatan dan Pengembangan Sumber Daya Manusia or PPSDM) in government agencies should be able to see the whole dimensions of outer and inner life (Sulistyani, 2004: p.35). In her book, Sulistyani also described two basic orientations in PPSDM that must be applied in a balanced way, among others:

- Leads to the performance quality of government officials or employees that are closely related to the efforts of achieving productivity and performance of the bureaucracy;

- Leads to the preparedness of the mental and physical state of the employee which is closely related to the overall level of human dignity and prestige appreciation.

According to Tohardi (2002: 20), there are several factors that could affect the quality improvement of human resources including the level of education, discipline, work ethic, and motivation. In practice, these principles are a prerequisite for the creation of good governance. The government will be able to carry its functions within the framework of good governance when there is a system of public administration that is in line with the presence of qualified human resources. This happens because most of the principles contained in the good governance framework have not been implemented in the performance of the apparatus especially in the implementation of public services. The principles of good governance that have not been implemented are the principle of transparency, equality, accountability, effectivity and efficiency, and responsiveness. Meanwhile, the principles that have been implemented at the sub-district level consisted of the principles of participatory, law enforcement, and future insights. Thus, it needs to improve the quality of human resources in the perspective of good governance so that the public service is expected to be implemented properly.

\section{METHODS OF RESEARCH}

This study used a qualitative approach (naturalistic) with a research strategy of observation. The focuses of this research are:

1. Planning of the quality of human resources apparatus, viewed from:

- Employment planning

- Program planning

- Program planning follows the development of the staffing.

- Program planning includes coordinating programs.

- HR analysis accompanies the organizational strategy preparation of Regional Employment Board of Malang

- The classification of HR apparatus on Regional Employment Board of Malang

- Produce an alternative program to reach the goals

- Evaluate the alternative program

- Implement an integrated set of programs based on HR objectives achievement as effective as possible

2. Factors that support and inhibit the planning of human resources quality improvement are viewed from; 
- Supporting factors: institutional that handle particular field; regulations that underlie the program implementation and some activities;

- Inhibiting factors: nonoptimal use of information technology in the employment data management; less qualified human resources; less adequate budget.

In this research, the location of the research is Regional Employment Board in Malang. The data source of this research comes from informants, events, and documents. The technique of data collection is done through the interview, observation, and documentation. Next, in analyzing the research data, researchers refer to the theory of (Daymon and Holloway, 2008, p.369):

1. Sorting and selecting data by editing. This step is related to the selection of data that has been obtained and the data is then edited until it can be understood.

2. Providing the code in the selected data (coding) (Daymondan Holloway, 2008, h.369)

3. Giving interpretation of meaning to the data that has been selected (Daymondan Holloway, 2008, h.369)

\section{RESULTS AND DISCUSSION}

The Planning of Human Resources Quality Improvement in the Regional Employment Board of Malang. The demand for public services in this globalization era is the hope and desire of the community and, at the same time, is a picture of the quality of government bureaucracy performance that has wide implications for various aspects. The efforts in improving the service performance of the personnel on an ongoing basis continue to be improved to encourage the creation of a conducive situation in the implementation of apparatus management services that will provide welfare to the community.

An improvement on the service performance is a strategic decision of the Regional Employment Board of Malang that has wide implications in every aspect to the continual improvement as well as the services that are always focused on the customer either in whole State Civil Apparatus (Aparatur Sipil Negara or ASN) that existed on the Regional Work Unit (Satuan Kerja Perangkat Daerah or SKPD) that existed between the Government of Malang Regency and the community. Sulistiyani (2009: p.122) argued that human resources planning is designed to ensure that the organization's needs for employees can be met consistently and appropriately. In the theory, it is stated that the planning is based on the elements that build it. As known, "Planning of the quality improvement of human resources (apparatus)" is a system formed from the elements of planning, quality improvement, human resources, and apparatus.

Staff Planning on Regional Employment Board of Malang. Staff planning on the Regional Employment Board of Malang refers to the national policy that is on the macro target of development and on the priority of regional development with the enactment of Law Number 5 of 2014 on State Civil Apparatus by referring to the systemic bureaucracy reform which includes institutional improvement. The management of bureaucratic resources includes various levels ranging from the structure to the mindset and culture of bureaucracy. The staff planning process on the Regional Employment Board of Malang is done by paying attention to the Law Number 25 of 2004 on National Development Planning System.

The planning steps undertaken by the Regional Employment Board of Malang in preparing the staffing formation can be seen from the strength of ASN each year. From the formation, it can be known the total number of employees, the employees who prepare for retirement, and the needed employees which then are brought to be reported to the central office. The Regional Employment Board of Malang also performs the planning in accordance to the long-term needs, balance, procurement, and selection or dismissal as well as planning for employee development.

Program planning on Regional Employment Board of Malang. The program preparation of the Regional Employment Board of Malang refers to the Regional Medium-Term Development Plan (Rencana Pembangunan Jangka Menengah Daerah or RPJMD) principal agenda of Malang by optimizing the performance of the bureaucracy and public service. As mentioned earlier by Sjafrizal (2014: h.341), regional development is basically the action of 
the program (intervention) which is carried out by local government in order to realize the direction of the policy that has been set in the planning of concerned regional development.

The compulsory programs and supporting programs in Regional Employment Board of Malang are as follows:

1. Compulsory programs: Education Program; Human Resources (State Apparatus); Capacity Improvement Program; Development and Parenting Development Program;

2. Supporting programs: Office Administration Services Program; Infrastructure Improvement Program; Discipline Enhancement Program; Human Resources (State Apparatus) Capacity Improvement Program; Performance and Financial Reporting System Improvement Program.

Program Planning Follows the Development of the Staffing on Regional Employment Board of Malang. The development of personnel plan on Regional Employment Board of Malang to conduct programs and activities that can support national development policies as priority with a suitability to its area and support the mainstreaming of gender and child protection in the region, Regional Employment Board implemented an Education of Service program in 2016in which this has been like a routine for the office. The program is arranged as follows:

1. Routine activities: starting from the provision of correspondence services to the preparation of year-end financial statements.

2. Compulsory Business Activities: starting from Structural Gap Up to Monitoring, Evaluation, and Reporting.

Human Resources Analysis Accompanied by Organization Strategy on Regional Employment Board of Malang. The analysis of human resources on Regional Employment Board of Malang is seen from the service performance that is based on the main task and function based on Main Performance Indicator. Main Performance Indicator is done based on the mission of Regional Employment Board of Malang that is to expand innovation and bureaucratic reform for clean and effective governance in a poor district.

The Classification of State Apparatus on Regional Employment Board of Malang. The classification of human resources (state apparatus) on the Regional Employment Board of Malang. According to Sulistiyani (2009: p159), the classification of employees is about the categorization of employees, position according to the type of employee and skills, and that knowledge and skills required. In implementing the programs and activities, such resources are needed in order to realize the vision and mission of the area. Human Resources (State Apparatus) of the Regional Employment Board of Malang is a unity of individuals conducting cooperation in the activities to achieve the goals and objectives. To achieve success in achieving the goal, it requires capable, skilled, disciplined, and competent human resources.

Generate Alternative Programs to Achieve Goals. Produce an alternative program to achieve the intended purpose. Regional Employment Board in the interview said that the implementation of alternative programs is carried out in accordance with the goals and objectives to improve the quality of service in the field of personnel.

Sulistiyani (2009: p.137) suggested that in order to achieve the determined goals, it needs to generate alternative programs based on HR model. The strategic objectives and targets of the Regional Employment Board can be set in the annual work plan. In 2017, the work plan of the Regional Employment Board can be formulated in 1 (one) objective of improving the quality of service in the field of personnel with 2 (two) targets.

The Regional Employment Board of Malang conducted an alternative program analysis to achieve the strategic objectives gradually in the long-term, medium-term, and short-term plan in the form of priority programs in the annual work plan. According to Riyadi (2004: p.214), he argued that the analysis of alternative and priority setting is a technique to examine alternative programs that can be arranged to achieve certain desired conditions (goals), then, the priority of the determined program is implemented as a gradual action to achieve the objectives.

Evaluating Alternative Programs. Evaluation is seen as a way to obtain information as a decision-making material. Evaluators work with decision makers to identify the decision and collect information about the relative losses and rewards of each alternative decision to 
obtain the best decision. Evaluating alternative programs in accordance with the research of Sulistiyani (2009: p.138) pointed out that this activity is generated based on four criteria: the likelihood of success, the anticipated cost, the technical feasibility of the action, and the possible impact of the action on other parts of the organization.

Implementing an Integrated Set of Programs Based on Achieving Human Resource Goals Effectively. Implement an integrated set of programs based on achieving human resources objectives as efficiently as possible. Sjafrizal (2014: p.65) believed that the program can be further detailed in the form of one or more concrete, specific, and interconnected activities either at a particular location or spread over several locations.

Supporting and Inhibiting Factors in the Planning of Human Resources Quality Improvement.

Supporting Factors:

Institution. With the establishment of institutions in Malang including the Regional Employment Board, this gives an impact on the improvement of personnel management. Apparatus as the executing element in Malang governance should be noticed so that it will give impact to the work motivation and spirit to give service to society. The needs and rights of the apparatus must be well managed.

The existence of legislation. As stipulated in Article 55 of Law Number 5 The year 2014, management apparatus is one of the career development of employees. The Law mandates that the management of personnel should pay attention to the career of apparatus as an effort to increase the spirit and motivation of work to carry out services to the community. This also provides obligations to government organizations including the Regional Employment Board to perform the obligations in planning the quality improvement of the apparatus. The implementation of affairs and authority of the Regional Apparatus Organization must be based on legislation as its legal operation. Regional Employment Board of Malang as Regional Apparatus Organization in the Government of Malang Regency is a legal organization that has affairs, authority, duties, and functions in the field of employment in Malang.

Inhibiting Factors:

Nonoptimal use of information technology in data processing. The use of information technology in the Government is a demand for the implementation of effective, efficient, and accountable tasks as the embodiment of Good Governance Principles. The use of information technology in the data management will assist the data preparation of employee in Regional Employment Board that is factual and up to date. With such valid data, this will assist the Regional Employment Board in preparing the quality improvement of human resources through training and education activities. In this study, the use of information technology is not maximum in the data presentation. The media used is only a simple application in which still could not present the data related to the mobilization of employees. This means that the Regional Employment Board still encountered obstacles when presenting factual data related to employee mapping. For example, employees' placement and transfer have not been fully recorded with this existing application. Another obstacle is that there is no integrated system related to the management of employee data in each Regional Apparatus Organization. This is easier to record the presence of employees in an OPD. Besides that, there is no Training Needs Analysis (Analisis Kebutuhan Diklat or AKD) and Evaluation, Monitoring, and Alumni Utilization on Training (Monitoring dan Pendayagunaan Alumni Dampak Diklat or EMPADD). This non-optimal data will hamper the quality of the planning implemented by the Regional Employment Board.

Human resources do not meet the required specifications. Human factors in the implementation of organizational functions are very important because the work of an organization is strongly influenced by the implementing factor. When an organization's function does not meet the specifications of an affair, there will be the nonoptimal implementation of the function. Regional Employment Board that has the function of improving the quality of human resources in Malang regency is very dependent on the management. From the research, the personnel who manage the planning of training and education activities seems to be less optimal in carrying its function. The planning is still 
monotonous and the programs and activities undertaken tend to remain the same each year. There is no innovation in the type of training and education to improve the quality of human resources. Personnel who manage the planning should be able to read and predict related to the type of training and education including the materials for the quality improvement planning in Malang Regency. As stated by Danim (1996) in his book "Transformasi Sumber Daya Manusia" related to human resource improvement: Human resources quality is a resource that meets the criteria of physical and health quality, intellectual quality (knowledge and skills), and spiritual mental quality.

Inadequate Budget. Planning in the framework of quality improvement of human resources in Malang conducted by the Regional Employment Board will not be implemented and the expected results will not be obtained if it is not supported by the adequate budget. In the research, the planning of program and activity within the framework has been compiled based on the budget requirement plan, however, in the budget approval process; the budget ceiling is not suitable after it has been approved. There should be a policy in the budgeting system especially in the budget of human resources quality improvement in Malang. This is due to the fact that employee's performance gives a big impact on the performance of Local Government. In this case, the principle of consensus that is effective and efficient should be realized, meaning that the decision-making of a budget for particular program or activity must be executed carefully and able to produce a predetermined goal.

\section{CONCLUSION AND SUGGESTIONS}

Based on the results of the research, we can pull out a conclusion as follows:

The program of planning and activities on the Regional Employment Board have referred to the Regional Medium-Term Development Plan (Rencana Pembangunan Jangka Menengah Daerah or RPJMD) and Strategic Plan of Malang Regency especially in the plan of human resources (state apparatus) quality improvement in Malang. However, the plan is not optimal so that the achievement of program targets and activities is not in accordance with the intended purpose.

The planning of the development and improvement of human resources (state apparatus) has been implemented by the Regional Employment Board in accordance with the proposals of each Regional Apparatus Organization. However, the proposal is not optimal so that the apparatus who should follow the programs and activities related to the human resources improvement still cannot follow the program because the existing employment data in the Regional Apparatus Organization has not been properly managed.

In preparing the planning of personnel who have skills and capabilities to support the work of Regional Apparatus Organization, the analysis of employee needs has been preceded while the documents that have been prepared cannot be implemented completely because there are still political factors in realizing the results of the analysis.

Based on the discussion and conclusion above, the researchers suggest that:

There is a need to evaluate the programs and activities especially in synchronization with RPJMD and strategic plan of Malang so that the designed programs and activities are in accordance with the affairs, authorities, tasks, and functions of the Regional Employment Board and the goals can be realized.

A commitment from the Regional Employment Board to implement the results of the analysis is needed so that the plan can be arranged in accordance with existing needs.

It is necessary to evaluate the programs and activities specifically related to the improvement of the quality of the apparatus, thus, the evaluation can be done to improve the programs and activities and an innovation in supporting the achievement of the goals can be made.

An information technology in the field of employee data management needs to be built in each Regional Apparatus Organization with several servers located at the Regional Employment Board. By that, the program can be managed better and there will be an accountable employee data. 
There should be a budget policy in the field of apparatus quality development. If so, the future of professional and qualified apparatus in performing services to the community can be realized.

\section{REFERENCES}

1. Abdulwahab, Solichin. 1999. Analisis Kebijakan: Dari Formulasi ke Implementasi Kebijaksanaan Negara. Jakarta: PT Bumi Aksara.

2. Sedarmayanti (2009) Reformasi Administrasi Publik, Reformasi Birokrasi dan Kepemimpinan Masa Depan (Mewujudkan Pelayanan Prima dan Kepemerintahan Yang Baik). Refika ADITAMA

3. Daymon, Christine dan Immy Holloway. 2008. Metode-metode Riset Kualitatif dalam Public Relations \& Marketing Communications. Yogyakarta: Bentang.

4. Thompkins (2001), dalam Ambar Teguh Sulistiyani, Rosidah (2009) Manajemen Sumber Daya Manusia. Yogyakarta. Graha IImu.

5. Nawawi (2000), dalam Ambar Teguh Sulistiyani, Rosidah (2009) Manajemen Sumber Daya Manusia. Yogyakarta. Graha IImu. 


\title{
THE EFFORTS OF KLATEN REGENCY GOVERNMENT IN ENHANCING COMMUNITY WELFARE THROUGH PEOPLE-BASED ECONOMY PROGRAM REALIZATION
}

\author{
Wasana Muhammad Titis*, Samudro Bhimo Rizky, Soesilo Albertus Maqnus \\ Faculty of Economy and Business, University of Sebelas Maret, Indonesia \\ *E-mail: mtitismn@gmail.com
}

\begin{abstract}
The aims of the present research are: to comprehend the efforts of Klaten Regency government in enhancing community's welfare through realizing people-based economy program; to know what factors that influence the efforts of Klaten Regency government in enhancing community's welfare through realizing people-based economy program. This study uses qualitative research method focusing on the realization of People-based Economy in improving community's welfare comprising of Rice for Poor (Raskin), Poor Students Assistance (Bantuan Siswa Miskin/BSM), and Household-targeted Social Assistance (Program Keluarga Harapan/PKH). The findings found that the efforts of Klaten Regency government in enhancing community's welfare through realizing people-based economy program are by planning Social Protection Extension and Acceleration Program (also known as Program Percepatan dan Perluasan Perlindungan Sosial/P4S) as compensation of fuel price increase. The program is the social security net consisting of ricesubsidized program extension for low-income community (Subsidy in form of Rice for Poor), Household-targeted Social Assistance (Program Keluarga Harapan/PKH), and Poor Students Assistance (Bantuan Siswa Miskin/BSM). The factors that influence the efforts of Klaten Regency government in enhancing community's welfare through realizing peoplebased economy program are such as: Communication, Resources, Disposition or Attitude, and Bureaucracy Structure. As a conclusion, it can be stated that the programs have been running well but the problems are also along with its realization so that its realization system still needs to be improved.
\end{abstract}

\section{KEY WORDS}

Community, Klaten, people-based economy program, welfare.

Poverty until nowadays is still the biggest concerned problem of Indonesian that has not been solved completely yet. Hence, Poverty Reduction Program, both in Indonesia generally and in Central Java specifically, is indeed one of the urgent programs to implement. Poverty is a problem of development marked by unemployment, backwardness, and adversity. The case of unemployment also attracts attention in order to develop economy that requires equity. World Bank and UNDP (United Nations Development Programme) apply definition of poverty that covers aspects like basic needs, lifestyle determined by person, choice, asset, capability, social inclusion, inequality, human rights, settlement, vulnerability, empowerment, and subjective welfare (Locatelli, 2009; World Bank, 2008). World Bank has defined poverty in global parameter which is poverty is a matter of lackness with income minimum US\$ 1 per day (Albornoz, 2007).

Based on the data from Central Bureau of Statistics (BPS, 2015), the total of poor community in Central Java Province is 4.505 .780 people (the second highest in Java island) or $14,44 \%$ from the total of Central Java community. Many poverty reduction programs have been implemented by both Central Government and Central Java Province Government. In 2015, the government implemented Social Protection Extension and Acceleration Program (P4S) in the effort of decreasing poverty problems that arise because of fuel subsidy reduction.

P4S Program implemented in Central Java Province especially Klaten Regency consists of Rice for Poor (Raskin), Poor Students Assistance (Bantuan Siswa Miskin/BSM) and Household-targeted Social Assistance (Program Keluarga Harapan/PKH). The aims of 
conducting Rice for Poor program is to reduce Targeted Household (RTS) expense through fulfilling half of basic needs in form of rice. Poor Students Assistance (BSM) is a help of government in form of personal assistance given directly for students from all education levels (Elementary School/Islamic Elementary School, Junior High School/Islamic Junior High School, Senior High School/Vocational High School/Islamic Senior High School) coming from poor family based on the determined criteria. Household-targeted Social Assistance $(P K H)$ is a cash-giving program for a very poor household based on requirements and provisions that have been determined.

Rice for Poor and Poor Students Assistance programs have aims to fulfill poor families' needs directly, which are through staple food and education fee. While, Household-targeted Social Assistance program (PKH) focuses more on specific and targeted productive elements in which one of them can be done through Productive Economy Business (Usaha Ekonomi Produktif/UEP) by Joint Business Group (Kelompok Usaha Bersama/KUBE). The existence of Joint Business Group (KUBE-PKH) for a Very Poor Household (Rumah Tangga Sangat Miskin/RTSM) in community is a form of people-based economy program realization. This program will be the place to improve productive economy business especially in enhancing community welfare. Todaro (2005) expressed that there is a close relation between unemployment, income inequality, and poverty. Generally, those who do not get regular job are included to poor community group.

Even if some poverty reduction programs have been conducted, but the fact keeps showing that the total of poor society does not reduce significantly. Poverty rate in Klaten from 2011 to 2014 decreased in which it can be seen that the poverty rate in 2011 was $17,95 \%$, and in 2012 it was $16,7 \%$, in 2013 it became 15,6\%, and in 2014 it decreased to be $14,58 \%$. The highest total of poor people is in Bayat District as much 21.893 people, followed by Trucuk District as much 17.449 people.

Based on the aforementioned explanation, so evaluation is highly needed to know how far the effect of economy program realization in enhancing community's welfare. Besides, the result of the evaluation also can be used to make a decision whether the economy program realization can be continued or needs to arrange other programs for the sake of achieving society welfare of Klaten Regency.

The research questions in this study are: 1) how are the efforts of Klaten Regency government in enhancing community welfare through people-based economy program realization?; 2) what factors that influence the efforts of Klaten Regency government in enhancing community welfare through people-based economy program realization?

The objectives of this present research are: 1) to know the efforts of Klaten Regency government in enhancing community welfare through people-based economy program realization; 2) to know what factors that influence the efforts of Klaten Regency government in enhancing community welfare through people-based economy program realization.

\section{METHODS OF RESEARCH}

The present study focuses on the realization of People-Based Economy program in enhancing community's welfare in Klaten Regency, Central Java which is P4S program comprising of Rice for Poor (Raskin), Poor Students Assistance (BSM) and Householdtargeted Assistance Program $(P K H)$. The present research uses qualitative research method. According to Sugiono (1995: 4), qualitative research method is a research method used to analyze the experienced object condition in which the researcher is a key instrument. Hence, in analysis, it also needs a method that is different from qualitative research itself.

Regarding with this, the researcher utilizes interactive analysis model designed by Miles \& Huberman (1998: 45). In the analysis method, data consist of three componenets: data reduction, data presentation, and decision making and its verification (Sutopo, 2002: 91). Those three components' activities are in form of interactions with its data collection method uses cycle process. The three components are included in the analysis process, related each other as well as determining final analysis. The figure of the analysis is presented as following: 


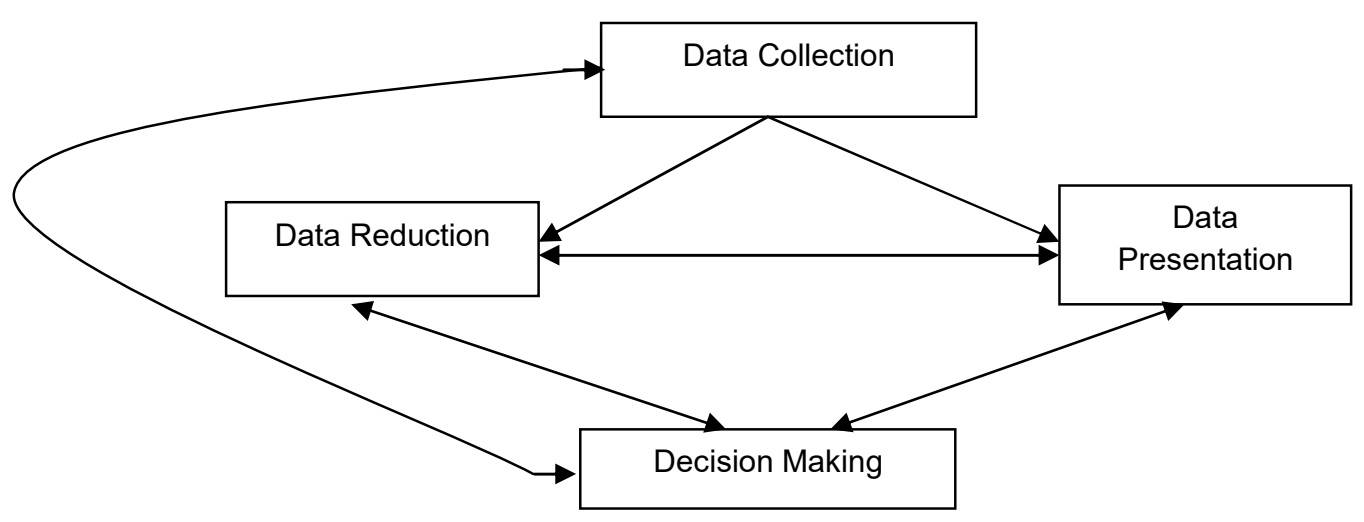

Figure 1 - Interactive Analysis Method

\section{RESULTS AND DISCUSSION}

The Efforts of Klaten Regency Government in Enhancing Community's Welfare through People-based Economy Program Realization. Based on the survey that has been done in the present study, the result regarding to informants' assessment towards indicators of peoplebased economy program realization in Klaten Regency is presented on the table as following:

Table 1 - Informants' Assessment towards Indicators of People-based Economy Program Realization in Klaten Regency

\begin{tabular}{|c|c|c|c|c|c|c|c|c|c|c|c|c|c|}
\hline \multirow[b]{2}{*}{ No } & \multirow{2}{*}{ Indicator } & \multicolumn{5}{|c|}{ Reality } & \multirow{2}{*}{ Average } & \multicolumn{5}{|c|}{ Expectation } & \multirow{2}{*}{ Average } \\
\hline & & 5 & 4 & 3 & 2 & 1 & & 5 & 4 & 3 & 2 & 1 & \\
\hline 1 & $\begin{array}{l}\text { Rice for Poor } \\
\text { - Punctuality } \\
\text { - Efficiency and Effectivity } \\
\text { - Reliability }\end{array}$ & $\begin{array}{l}10 \\
15 \\
15 \\
\end{array}$ & $\begin{array}{l}40 \\
20 \\
12 \\
\end{array}$ & $\begin{array}{c}6 \\
15 \\
6 \\
\end{array}$ & $\begin{array}{l}2 \\
4 \\
0 \\
\end{array}$ & $\begin{array}{l}0 \\
0 \\
0\end{array}$ & $\begin{array}{l}3,86 \\
3,86 \\
2,22\end{array}$ & $\begin{array}{l}50 \\
55 \\
55 \\
\end{array}$ & $\begin{array}{c}12 \\
12 \\
8 \\
\end{array}$ & $\begin{array}{l}3 \\
0 \\
3\end{array}$ & $\begin{array}{l}0 \\
0 \\
0\end{array}$ & $\begin{array}{l}0 \\
0 \\
1\end{array}$ & $\begin{array}{l}4,33 \\
4,46 \\
4,46 \\
\end{array}$ \\
\hline 2 & $\begin{array}{l}\text { Poor Students Assistance (BSM) } \\
\text { - Punctuality } \\
\text { - Efficiency and Effectivity } \\
\text { - Reliability }\end{array}$ & $\begin{array}{c}20 \\
15 \\
5 \\
\end{array}$ & $\begin{array}{l}32 \\
32 \\
40 \\
\end{array}$ & $\begin{array}{l}6 \\
6 \\
6 \\
\end{array}$ & $\begin{array}{l}2 \\
4 \\
4 \\
\end{array}$ & $\begin{array}{l}0 \\
0 \\
0 \\
\end{array}$ & $\begin{array}{l}4,0 \\
3,8 \\
3,6 \\
\end{array}$ & $\begin{array}{l}40 \\
55 \\
70 \\
\end{array}$ & $\begin{array}{c}20 \\
16 \\
4 \\
\end{array}$ & $\begin{array}{l}3 \\
0 \\
0\end{array}$ & $\begin{array}{l}0 \\
0 \\
1 \\
\end{array}$ & $\begin{array}{l}1 \\
0 \\
0\end{array}$ & $\begin{array}{c}4,26 \\
4,73 \\
5,0\end{array}$ \\
\hline 3 & $\begin{array}{l}\text { Household-targeted Social Assistance } \\
\text { (PKH) } \\
\text { - Punctuality } \\
\text { - Efficiency and Effectivity } \\
\text { - Reliability }\end{array}$ & $\begin{array}{c}10 \\
5 \\
10 \\
\end{array}$ & $\begin{array}{l}40 \\
40 \\
44 \\
\end{array}$ & $\begin{array}{l}9 \\
6 \\
0 \\
\end{array}$ & $\begin{array}{l}0 \\
4 \\
4 \\
\end{array}$ & $\begin{array}{l}1 \\
1 \\
0 \\
\end{array}$ & $\begin{array}{l}3,93 \\
3,66 \\
3,86\end{array}$ & $\begin{array}{l}60 \\
55 \\
65 \\
\end{array}$ & $\begin{array}{c}12 \\
16 \\
8 \\
\end{array}$ & $\begin{array}{l}0 \\
0 \\
0\end{array}$ & $\begin{array}{l}0 \\
0 \\
0 \\
\end{array}$ & $\begin{array}{l}0 \\
0 \\
0\end{array}$ & $\begin{array}{c}4,8 \\
4,73 \\
4,86 \\
\end{array}$ \\
\hline \multicolumn{2}{|r|}{ Total of Informants: 15 people } & \multicolumn{4}{|c|}{ Average Total } & & $\begin{array}{l}32,7 \\
3,64 \\
\end{array}$ & & & \multicolumn{2}{|c|}{ Average Total } & Average & $\begin{array}{l}41,6 \\
4,62\end{array}$ \\
\hline
\end{tabular}

Source: Processed Survey Data, 2016.

Based on Table 1 above, it can be known that the realization of people-based economy program expected by informants is as much 4,62 and the value in field which is in line with reality is still under average value expected by informants which is as much 3,64.

Rice for Poor (Raskin). The government plans Social Protection Extension and Acceleration Program (P4S) as the compensation of fuel price increase. To run this, Poverty Reduction Acceleration National Team (TNP2K) established in the beginning of 2010 through President Regulation Number 15 has responsibilities to respond the slow decrease situation of poverty level and the increase of discrepancy. The President Regulation is accompanied by the issue of Minister Regulation (Permen) no. 42 of 2010 regarding Organization Structure and Work Mechanism of Program Reduction Coordination Team is a social security net consisting of rice subsidy program extension for low-income community (Subsidy of Rice for 
Poor), Household-targeted Social Assistance Program (PKH), and Poor Students Assistance Program (BSM).

It can be seen from the fact of Social Protection Card holder in the field. Social Protection Card holder in Klaten Regency is based on 14 criterias of poor household determined by Central Bureau Statistics (BPS) as the recipient of Temporary Direct Assistance for Community (BLSM), which are as follows:

1. The width of house building is less than $8 \mathrm{~m}^{2}$ per person;

2. The floor type of house building is made from soil or bamboo or cheap wood;

3. The wall type of house building is bamboo or sago palm or low-quality wood and unplastered wall;

4. No toilet facility or having a toilet together with other households;

5. Lighting source of household does not use electricity;

6. Drinking water source is from a well or unprotected water springs or river or raindrop;

7. Fuel for daily cooking is firewood or charcoal or petroleum;

8. Only consuming meat or milk or chicken once a week;

9. Only buying a set of new clothes in a year;

10. Only being able to eat once or twice a day;

11. Not being able to pay medicine costs in Health Center or Polyclinic;

12. The income source of household head like farmers with land width $500 \mathrm{~m}^{2}$, farm workers, fishermen, construction workers, plantation workers and or other jobs with income under Rp.600.000 per month;

13. The highest education of household head is uneducated or not graduated from elementary school or only graduated from elementary school;

14. Having no saving asset or a property that can be sold easily with minimum price Rp.500.000 like credit/non-credit motorcycle, gold, livestock, motor boats, or other capital goods. following:

Furthermore, its realization mechanism will be explained in some steps which are as

1. Receiving Process of Social Protection Card (KPS) for Targeted Household (RTS) distributed by PT.POS;

2. Submitting Process of Social Protection Card (KPS) \& Identity Card of Targeted Household addressed to PT.POS;

3. Verification of Social Protection Card (KPS) payment data and Identity Card of Targeted House is by officers of PT.POS;

4. Benefit Obtaining of Social Protection Extension and Acceleration Program for Targeted Household (RTS);

5. Complaint Service.

Punctuality of Realizing Rice for Poor Program (Raskin). There are three indicators reviewed in this present research which are: always be punctual to distribute rice for poor, sometimes be punctual to distribute rice for poor, and not be punctual to distribute rice for poor. Based on the survey result, $53,3 \%$ informants state that rice for poor distribution is always punctual, $33,3 \%$ informants argue that rice for poor distribution is sometimes punctual, and $13,4 \%$ informants assume that distribution of rice for poor is not punctual. The assessments are presented on the following table.

Table 2 - Informants' Assessments on Punctuality of Rice for Poor (Raskin) Program

\begin{tabular}{|c|l|c|c|}
\hline No & Description & Total & $\%$ \\
\hline 1 & Always being punctual in distributing Rice for Poor program & 8 & 53,3 \\
\hline 2 & Sometimes being punctual in distributing Rice for Poor program & 5 & 33,3 \\
\hline 3 & Not being punctual in distributing Rice for Poor program & 2 & 13,4 \\
\hline Grand Total & 15 & $100 \%$ \\
\hline
\end{tabular}

Source: Processed Survey Data, 2016.

Based on the above table, it can be known that the realization of Rice for Poor (Raskin) distribution has been running well in Klaten Regency. Moreover, based on the observation in 
the field, the unpunctuality in realizing Rice for Poor (Raskin) in Klaten Regency is caused by delays and inadequate facilities. Based on the data from Central Bureau of Statistics (BPS, September 2013), the total of poor people in Central Java Province is as much 4.704.870 people or $14,44 \%$ from the total of Central Java people. The aims of conducting Rice for Poor program (Raskin) is to reduce Targeted Household (RTS) expense through fulfilling half of basic needs in form of rice.

Efficiency and Effectivity of Rice for Poor (Raskin) Program. Efficiency means the use of community fund can gain maximum output, while effectivity means the fund must be able to achieve target or public interest goal. Efficiency here is equalized to the definition of economical shopping which is savings on budget use; while shopping effectivity is considered as output use of the activity. Based on the survey result, there are $60 \%$ informants assessing that this Rice for Poor (Raskin) program has been conducted efficiently and $40 \%$ informants also state that the realization of this program is effective.

Table 3 - Informants' Assessments on Efficiency and Effectivity of Rice for Poor (Raskin) Program

\begin{tabular}{|c|c|c|c|}
\hline No & Description & Total & $\%$ \\
\hline 1 & It is effective & 9 & 60 \\
\hline 2 & It is efficient & 6 & 40 \\
\hline \multicolumn{2}{|c|}{ Grand Total } & 15 & $100 \%$ \\
\hline
\end{tabular}

Source: Processed Survey Data, 2016.

Based on the condition and the growth of Klaten Regency's economy in the years ahead, it will still be influenced by global economy that becomes the main challenge. In enhancing community's welfare especially in Klaten Regency, the economy of Klaten Regency in years ahead is directed to be an independent region economy supported by creative economy growth. In other words, it can be stated that region economy is expected to be made with the foundation and the structure of strong economy so that the community's welfare will be achieved easily.

Therefore, the improvement and the development of region economy will be concerned and be emphasized on (1) strengthening region's economy structure by balancing the development of primary, secondary, and tertiary sectors through integrated agriculture sector enhancement done by developing agroindustry and agribusiness based on agrominapolitan in order that productivity, added value, and competitiveness are more interested by local economic agents, (2) developing region-potency-based and market-oriented business in accordance with Micro, Small, and Medium Enterprises (UMKM), (3) growing and developing the competence of UMKM to be a strong and an independent enterprise by strengthening capital and market access through cooperatives movement and existing cooperatives type development such as: Saving and Loan Cooperative and Sharia Finance Service Unit, (4) empowering the roles of UMKM in region development, job vacancies, income equity, economy growth, and community poverty reduction, (5) motivating the speed of region economy growth based on investment increase and condusive business nuance making, and (6) increasing productive resource accesses.

Reliability of Rice for Poor (Raskin) Program. Based on the analysis in the field, it is noted that the total of poor people in Klaten Regency from 2011 to 2015 tends to decrease although it is relatively slow. The total of poor community in 2011 is as much 203.052 people $(16,21 \%)$, while in 2015 it decreases to be 175.480 people $(13,47 \%)$. The poverty condition in Klaten Regency is still above average of Central Java Province. In addition, its portrayal can be seen on the Figure 2 below.

Based on the survey result, 53,3\% informants assess that this Rice for Poor (Raskin) program is reliable even if $46,7 \%$ informants believe this program is not reliable yet.

The success parameter of this Rice for Poor (Raskin) program is improving community's welfare. The government of Klaten Regency through Head of Economy Division in Region Secretariat issued Circular Letter regarding Schedule of the $13^{\text {th }}$ Rice for Poor (Raskin) Allocation Realization in 2015. The letter is addressed to all local District Head in date of 28 September 2015 Number 511/523/02 made based on Letter of Central Java 
Governor No. 740/ND.Sek./Ek/2015 date 25 September 2015 regarding to Ceiling Addition of the $13^{\text {th }}$ and the $14^{\text {th }}$ Rice for Poor in 2015. In the letter received by Public Relation Office of Region Secretariat in 1 October 2015, Klaten Regency obtained addition of Rice for Poor allocation for two months (the $13^{\text {th }}$ and the $14^{\text {th }}$ Rice for Poor (Raskin)) each 108.527 for Targeted Household (RTS) and Benefit Recipients (PM) with rice quantum as much $3.255 .810 \mathrm{kgs}$. Thus, each Targeted Household (RTS) in this policy will obtain extra rice as much $30 \mathrm{kgs}$ for two months as in line with the provision applies.

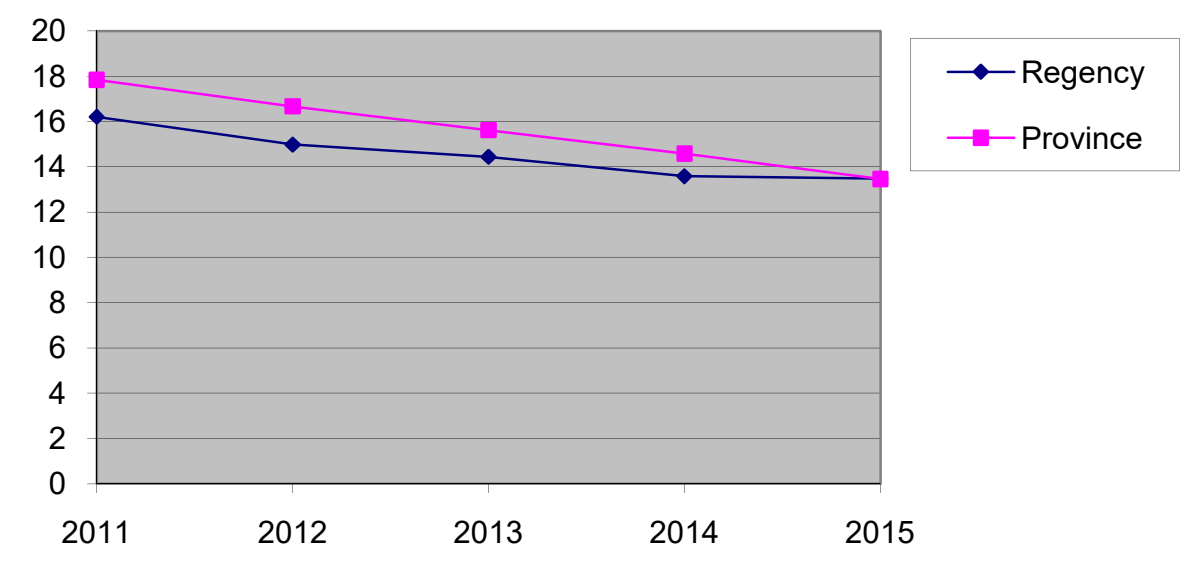

Figure 2 - Poverty Growth of Klaten toward Province in 2011-2015

Table 4 - Informants' Assessment on Reliability Rice for Poor (Raskin) Program

\begin{tabular}{|c|l|c|c|}
\hline No & \multicolumn{1}{|c|}{ Description } & Amount & $\%$ \\
\hline 1 & Reliable & 8 & 53,3 \\
\hline 2 & Not reliable & 7 & 46,7 \\
\hline \multicolumn{2}{|c|}{ Total } & 15 & 100 \\
\hline
\end{tabular}

Source: Processed Survey Data, 2016.

Poor Students Assistance Program (BSM). Poor Students Assistance Program (BSM) is a help of government in form of personal assistance given directly for students from all education levels (Elementary School/Islamic Elementary School, Junior High School/Islamic Junior High School, Senior High School/Vocational High School/Islamic Senior High School) coming from poor family based on the determined criteria. The aims of conducting this program is to eliminate the retardation for students to get education service access; to prevent dropout rate \& to attract poor students to attend school again; to assist poor students in fulfilling their personal needs in education activities and to support nine-year compulsory education and universal high school. While, the objective of realizing this program is that the poor children still can access education services especially in nine-year compulsory education and universal high school.

Punctuality of Poor Students Assistance (BSM) Program Realization. Based on survey, $53,3 \%$ informants state that the realization of BSM program is punctual, $26,7 \%$ informants mention that BSM distribution is sometimes punctual, and $20 \%$ informants believe that BSM distribution is not punctual yet.

Table 5 - Informants' Assessment on Punctuality of BSM Program Realization

\begin{tabular}{|c|l|c|c|}
\hline No & \multicolumn{1}{|c|}{ Description } & Total & $\%$ \\
\hline 1 & BSM Realization is punctual & 8 & 53,3 \\
\hline 2 & BSM Realization is sometimes punctual & 4 & 26,7 \\
\hline 3 & BSM Realization is not punctual & 3 & 20 \\
\hline Grand Total & 15 & $100 \%$ \\
\hline
\end{tabular}

Source: Processed Survey Data, 2016. 
Based on observation result in the field, BSM Program is a national program aiming to eliminate the problems of poor students to participate in attending schools by helping them to get proper education service access, to prevent dropout rate, to attract poor student to attend school again, to assist students fulfilling their basic needs in learning process, to support nine-year compulsory education (even until tertiary education), and to help school program run.

By this BSM Program, it is expected that school-aged children coming from poor households or poor familiies still attend schools and it is expected in future that the students can solve poverty which is suffered by their parents until nowadays. BSM Program also supports government's commitment to increase rate of education participation in remote and poor Regency/City.

BSM Funding is granted to students started from elementary school to Tertiary Education with details as follows:

1. BSM for Elementary School \& Islamic Elementary School is as much Rp 225.000 per semester or Rp 450.000 per year;

2. BSM for Junior High School/Islamic Junior High School is as much Rp 375.000 per semester or Rp 750.000 per year;

3. BSM for Senior High School/Vocational High School/Islamic Senior High School is as much Rp 500.000 per semester or Rp 1.000 .000 per year.

The targets of BSM Recipients are poor students which are the students of Elementary School, Junior High School, Senior High School, and Vocational High School whose parents are not able to pay their children's education free, poor parents or poor household in line with criteria as follows:

The criteria of BSM Recipients are as follows:

1. Students' Parents of Social Protection Card (KPS) holder;

2. Students of Recipient Candidate Card of Poor Students Assistance program;

3. Students' parents of Household-Targeted Social Assistance (PKH) Participant;

4. Students who are in danger of dropping out due to cost difficulties;

5. Orphans students;

6. Students who are from orphanage;

7. Students who are from the victims of accidents, disasters, work termination from a Very Poor Household and students from agricultural expertise (Vocational High School).

Efficiency and Effectivity of BSM Program Realization. Based on the survey result, $80 \%$ informants assess that BSM Program is extremely effective and efficient in helping community's welfare and $20 \%$ informants believe BSM Program is less effective and efficient.

Table 6 - Informants' Assessment on Efficiency and Effectivity BSM Program

\begin{tabular}{|c|l|c|c|}
\hline No & \multicolumn{1}{|c|}{ Description } & Amount & $\%$ \\
\hline 1 & It is efficient & 12 & 80 \\
\hline 2 & It is effective & 3 & 20 \\
\hline \multicolumn{2}{|c|}{ Total } & 15 & $100 \%$ \\
\hline
\end{tabular}

Source: Processed Survey Data, 2016.

Based on survey, $66,6 \%$ informants state that BSM Program realization is reliable to help community's welfare and $33,4 \%$ informants believe that BSM Program is not reliable yet in supporting community's welfare in Klaten Regency.

Table 7 - Informants' Assessment on Reliability BSM Program

\begin{tabular}{|c|l|c|c|}
\hline No & \multicolumn{1}{|c|}{ Description } & Amount & $\%$ \\
\hline 1 & It is reliable & 10 & 66,6 \\
\hline 2 & It is not reliable & 5 & 33,4 \\
\hline \multicolumn{2}{|c|}{ Total } & 15 & $100 \%$ \\
\hline
\end{tabular}

Source: Processed Survey Data, 2016. 
Referring to the observation result in the field, the aspect of responsibility is often related to the reliable budget management of regional government. In cases that are frequently found in the field on other government programs like program of Central Java government through Social Department, it can be stated that the government has been running poverty reduction in Central Java Province conducted by fund allocation from both Regional Government Budget (APBD) and Central Government Budget (APBN). For 2014, the poverty reduction programs conducted by Social Department of Central Java Province are:

1. Poor people handling program through Social Empowerment of Indigenous Communities Program (PS-KAT) as much 200 Families (20 Joint Business Groups/KUBE) spread in 5 Regencies covering Grobogan Regency, Blora Regency, Sragen Regency, Kendal Regency, and Wonosobo Regency with budget as much Rp. 400.000.000,- (four hundred millions rupiah).

2. Poverty Reduction of Village with total Rp. 3.377.000.000,- (Three Billions three hundreds seventy seven millions rupiah) with targets 1.200 people gathered in 120 Joint Business Groups/KUBE that will get assistance facilities @ Rp. 20.000.000,(Twenty thousand millions rupiah) with activity sites in Temanggung, Purworejo, Blora, and Jepara Regencies.

3. Poverty Reduction of Urban with total Rp. 2.350.520.000,- (Two billions three hundreds five thousand millions five hundreds twenty thousands rupiah) with targets 800 people gathered in 80 Joint Business Groups/KUBE that will get assistance facilities@ @p. 20.000.000,- (Twenty thousand millions rupiah) with activity sites in in Demak, Pati, and Pekalongan.

4. Even if some poverty reduction programs have been conducted, but the fact shows that the total of poor people do not decrease significantly. According to research done by Development and Research Board of Central Java Province, the problems faced in realizing poverty reduction can be classified into policy scale, concept, implementation, and participation.

5. From policy perspective, many policies issued by ministries and departments aiming to reduce poverty are not in line. On the perspectives of concept and implementation, poverty reduction programs are frequently not effective and there is no evaluation towards the success of the program.

6. The increase of budget and poverty activities is not in line with the decrease of poverty itself. On one side, budget politics both in center and in region do not support poverty reduction yet simply because there is a problem in determining the target of poverty reduction.

7. On the other hand, there are some problems that arise from poor people themselves, regarding to mindset, attitude, and culture that do not support changes. Mental attitude that does not expect changes becomes the main challenge.

8. The development of mindset and mental attitude are one of the most important ways to strive for poverty reduction. Therefore, in the policy concept of poverty reduction, empowerment needs to be the main approach by prioritizing independence concept. Poverty reduction should not prioritize direct assistance like Rice for Poor (Raskin) and Temporary Direct Assistance for Community (BLSM), but it should prioritize effective and specific productive elements in which it can be done through Productive Economy Enterprises (UEP) by Joint Business Group (KUBE).

Household-targeted Social Assistance (Program Keluarga Harapan/PKH). Based on the result of survey, it is found that there are $80 \%$ informants stating that the realization of $\mathrm{PKH}$ program is punctual and there are $20 \%$ informants assessing that the realization of $\mathrm{PKH}$ Program is not punctual yet.

Based on the research conducted in field, it is found that the recipients of $\mathrm{PKH}$ Program are required to sign an agreement in which its content is that the Selected Recipients Candidate must sign an agreement that in the period of getting assistance, they will: (1) Send children aged 7-15 years old and children aged 16-18 years old to attend school but they do not finisih nine-year compulsory education yet; (2) Bring children aged 0-6 
years old to health facility in accordance with health procedure of $\mathrm{PKH}$ for children; and (3) For pregnant mothers, they must check their health up and their fetus to health facility in accordance with health procedure of PKH for pregnant mothers.

Table 8 - Informants' Assessments on Punctuality PKH Program

\begin{tabular}{|c|l|c|c|}
\hline No & \multicolumn{1}{|c|}{ Description } & Total & $\%$ \\
\hline 1 & It is punctual & 12 & 80 \\
\hline 2 & It is not punctual yet & 3 & 20 \\
\hline \multicolumn{2}{|c|}{ Grand Total } & 15 & $100 \%$ \\
\hline
\end{tabular}

Source: Processed Survey Data, 2016.

Efficiency and Effectivity of PKH Program. Based on the result of survey, it can be known that $53,3 \%$ informants believe that PKH Program is highly effective to help improving the community's welfare and $46,7 \%$ informants assume that PKH Program is efficient.

Table 9 - Informants' Assessment on Efficiency and Effectivity of PKH Program

\begin{tabular}{|c|l|c|c|}
\hline No & Description & Amount & $\%$ \\
\hline 1 & It is efficient & 8 & 53,3 \\
\hline 2 & It is effective & 7 & 46,7 \\
\hline Total & 15 & $100 \%$ \\
\hline
\end{tabular}

Source: Processed Survey Data, 2016.

The components that become the main focus are health and education aspects. The main goal of PKH in Health is to enhance health status of mothers and children in Indonesia, especially for a very poor community, through incentives giving to have a preventive health visit (it is prevention and not a cure). All PKH participants are the recipients of free health service provided by Poor Health Assurance (Askeskin) Program and other programs that are for poor people. Thus, PKH card can be used as identity card to get the service. The education component in $\mathrm{PKH}$ is developed to increase participation rate of nine-year compulsory education and as an effort to reduce child workers in a very poor family. The children recipients of $\mathrm{PKH}$ in Education which aged 7-18 years old and do not accomplish nine-year compulsory education yet must register themselves first in formal school or non formal school and they must attend classes at least $85 \%$ meetings.

The reality in the field reveals that there are 25.878 Targeted Households (RTS) will be sent to join Household-targeted Social Assistance (PKH). The total is the validation result conducted by team. Previously, the total of Targeted Household (RTS) achieves 30.257 families, but after validation, it reduces to 4.379 families. The validation process was conducted by central government because the data was obtained from Social Protection Program Survey (PPLS) 2011. There are 4.379 families which are considered not fulfilling the requirements to join the program. The result is then followed up by team of Klaten Regency.

Reliability of PKH Program. Based on the survey result, it reveals that $86,6 \%$ informants assume that the realization of PKH Program is reliable and $13,4 \%$ informants assess that $\mathrm{PKH}$ program realization is not reliable yet.

Table 10 - Informants' Assessment on Reliability of PKH Program

\begin{tabular}{|c|l|c|c|}
\hline No & \multicolumn{1}{|c|}{ Description } & Amount & $\%$ \\
\hline 1 & It is reliable & 13 & 86,6 \\
\hline 2 & It is not reliable & 2 & 13,4 \\
\hline \multicolumn{2}{|c|}{ Total } & 15 & $100 \%$ \\
\hline
\end{tabular}

Source: Processed Survey Data, 2016.

$\mathrm{PKH}$ is an inter-ministerial and institutional program because its main actors are from National Development Planning Board, Department of Social, Department of Health, Department of National Education, Department of Religion, Department of Informatics and 
Communication, and Central Bureau of Statistics. PKH is more concerned on the effort to develop social protection system for community. This program is prioritized more on giving cash assistance for poor people (Very Poor Household (Rumah Tangga Sangat Miskin / RSTM) that fulfill requirements regarding to the effort to enhance human resources through education and health. The amount of cash assistance for PKH Participants is various depending on the numbers of family members counted in assistance targets, both components of health and education. The amount of this assistance can be changed depending on the condition of participant family in accordance with prevailing requirements.

The factors that influence the efforts of Klaten Regency government in enhancing community's welfare through people-based economy program realization:

Communication Factor. The interview result expresses that the problem of communication is shown by the problem in data collection. The problem in field makes communication not run well so that the effort to prevent is slow as well. The problems that arise are empty house, uncompleted address, unknown address, and the household moves. These should be handled soon and the data should be fixed immediately minimum once a year through data checking. Other problems that are also faced are in terms of distributing Rice for Poor (Raskin), BSM, PKH in the realization of people-based economy program, in the update of data if Targeted Household (RTS) is empty, address is not completed, address is not known, the household is moved, the delivery is rejected, and the household whose all family members have passed away, so that it needs long time in its realization.

Resources Factor. The whole data result either documentation or interview shows that there are two factors of human resources aspect which are (1) supporting factor is shown in form of the owned same competence so that all TKSK is considered being able to run a duty; guidance book and some coordination are conducted to help TKSK in running their responsibilities. (2) On the other hand, there is inhibiting factor which means inability of TKSK in giving punctual and sensitive roles on misappropriation of program realization if it is found; the inability to participate in supervising the realization, and be able to balance and to communicate the problems and the findings so that it can attract attention of project leader and implementers in order to make correction and evaluation; and the inability of TKSK in giving clear guidance for community.

Disposition or Attitude Factor. The whole obtained data on aspect of disposition or attitude reveals that there are inhibiting factors indicated by: (1) the short and the hurried socialization process so that many people do not understand about P4S Program (Rice for Poor (Raskin), Poor Students Assistance (BSM), and Household-targeted Social Assistance (PKH) (2) the attitude of most people who consider that the assistance is their right and it can be used anytime. These give obstacles for program goal achievement which is using the assistance as the business capital. (3) Tendency of village officials who feel ignorant to take responsibilities to verify data of Social Protection Card (KPS) holders.

Bureaucracy Structure. Based on the whole data above, it shows that there are inhibiting factors in bureaucracy structure which are marked by: (1) its implementation is less coordinative because its data collection does not involve local village head or local government, so that its distribution is considered not effective because its data is not in line with the fact in field. It can be seen tangibly from the community which actually do not deserve, but they get the card (2) the establishment of complaint center without giving clear information and authority will not help solving the problems.

\section{CONCLUSION}

The result of data findings mark that the efforts of Klaten Regency government in enhancing community welfare through people-based economy are conducted by planning Social Protection Extension and Acceleration Program (P4S) as compensation of increasing fuel price. The recipient targets of P4S Objectives are poor households. Every poor household will get Social Protection Card (KPS) without any charge. This card is the marker that they deserve to obtain benefits of social protection program which is in line with prevailing provisions of each program. The program is the social security net consisting of 
program extension of rice subsidy for low-income society (Subsidy of Rice for Poor/Raskin), Household-targeted Social Assistance/Program Keluarga Harapan (PKH), and Poor Students Assistance/Program Bantuan Siswa Miskin (BSM). The factors that influence the efforts of Klaten Regency government in enhancing community welfare through peoplebased economy are as follows: communication, resources, disposition or attitude, and bureaucracy structure.

\section{REFERENCES}

1. Albornoz, M. A., Becker, M., Cahyat, A., Cronkleton, P., Jong, W.d., Evans, K., Wollenberg, E., 2007, Menuju Kesejahteraan dalam Masyarakat Hutan: Buku Panduan untuk Pemerintah Daerah. Bogor: Cifor.

2. Badan Pusat Statistik (BPS). 2015. Indikator Sosial Ekonomi Indonesia. Badan Pusat Statistik Indonesia. Jakarta.

3. Locatelli, B., Kanninen, M., Brockhaus, M., Colfer, C. J., Murdiyarso, D., \& Santosa, H. 2009. Menghadapi Masa Depan Yang Tak Pasti: Bagaimana Hutan dan Manusia Beradaptasi terhdap Perubahan Iklim. Bogor: Cifor.

4. Miles, M.B dan Huberman. 1998. Analisis Data Kualitatif. Terjemahan T.R. Rohidi. Jakarta: UI.

5. Peraturan Menteri No. 42 tahun 2010 tentang Struktur Kelembagaan dan Mekanisme Kerja Tim Koordinasi Penanggulangan Program

6. Peraturan Presiden Republik Indonesia Nomor 15 Tahun 2010 Tentang Percepatan Penanggulangan Kemiskinan

7. Sutopo, H.B. 2002. Metodologi Penelitian Kualitatif: Dasar teori dan Terapannya dalam Penelitian. Surakarta: Universitas Sebelas Maret.

8. Todaro, Michael P dan Stephen C. Smith. 2008. Pembangunan Ekonomi. Edisi kesembilan. Jakarta: Erlangga

9. World Bank. 2008. Making the New Indonesia Work for the Poor. The World Bank. 
DOI https://doi.org/10.18551/rjoas.2017-08.11

\title{
ЭФФЕКТИВНЫЙ АЛГОРИТМ МУЛЬТИПАРАМЕТРИЧЕСКОГО ФУНКЦИОНАЛЬНО- СТАТИСТИЧЕСКОГО АНАЛИЗА И ЕГО КОМПЬЮТЕРНАЯ ВЕРСИЯ \\ EFFECTIVE ALGORITHM OF MULTIPARAMETRIC FUNCTIONAL-STATISTICAL ANALYSIS AND ITS COMPUTER VERSION
}

\author{
Прилуков А.Н., кандидат социологических наук \\ Prilukov A.N., Candidate of Sociological Sciences \\ Институт горного дела Дальневосточного отделения РАН, Хабаровск, Россия \\ Mining Institute of Russian Academy of Sciences, Khabarovsk, Russia \\ E-mail: a prilukov@mail.ru
}

\begin{abstract}
АННОТАЦИЯ
Рассматриваются два метода математической статистики, разработанные более тридцати лет назад: расширенная параметрическая регрессия (РПР) и анализ фрункционально-статистической динамики (АФСД). Несмотря на принадлежность к одному крупному разделу математики, данные методы принципиально различаются характером решаемых с их помощью задач. РПР, первоначально обозначавшаяся как толерантный регрессионный анализ, за счёт расширенного состава её задействуемых параметров позволяет объединить и оптимизировать традиционные и вновь появляющиеся многочисленные разновидности конкретных моделей, неоправданно часто выдаваемых за самостоятельные методы и использующихся при восстановлении осложнённых стохастичностью зависимостей. АФСД, также не вполне удачно наречённый вначале анализом коллинеарности, предназначен для сравнения между собой как функциональных, так и статистических зависимостей по их параметрам, являющимся ключевыми для такого сопоставления, - нормированным амплитудам, соотношению параметризованных масштабов и взаимного сдвига. Помимо принадлежности к одному разделу математики рассматриваемые методы объединяют во многом совпадающие составы использующихся в них расчётных параметров, включая варьируемую метрику Минковского, позволяющую унифицировать и оптимизировать механизмы агрегирования стохастических ошибок (остатков). В статье демонстрируется, что близкое совпадение составов параметров ведёт к схожести алгоритмов решения задач обоих видов анализа, что в свою очередь даёт возможность обойтись одной компьютерной программой, позволяющей без какихлибо ограничений реализовать особенности каждого из методов. Этим же обстоятельством оправдывается объединение двух рассматриваемых методов в заголовке статьи под общим названием мультипараметрического фрункциональностатистического анализа (МФСА). Кроме сокращённого описания алгоритма и его программной реализации в статье приведены практические примеры, иллюстрирующие возможности и особенности рассматриваемых методов, а также намечающиеся направления их совершенствования.
\end{abstract}

\section{ABSTRACT}

In the article two mathematical statistics methods are discussed that have been developed more than three decades ago: the Augmented Parametric Regression (APR) and the Analysis of Functional-Statistical Dynamics (AFSD). Despite affiliation to the same major branch of mathematical statistics these methods profoundly diverge with respect to the tasks being solved by them. APR, initially labeled as Tolerant Regression Analysis, due to its augmented set of parameters enables it to consolidate and optimize traditional and numerous currently emerging regression models, which are used for stochastically contaminated dependences recovery and often are unjustifiably being rendered as selfcontained methods. AFSD, also not quite aptly named at first as the Collinearity Analysis, is earmarked for functional and/or statistical dependences' mutual comparison according to their parameters, which play key roles in such juxtaposition, - their normalized amplitudes, 
parameterized scaling factors, and mutual shifts (lags). Alongside with belonging to the same mathematical branch both discussed methods share closely coinciding calculating parameters, including Minkowski metric that makes it possible to unify and optimize the stochastic residuals aggregation mechanisms. Parameters' sets close coincidence leads to substantial similarity of algorithms that are used in tasks solving within both analyses types. In its turn this procures possibility to dispense with a single computer program that without any limitations realize both methods peculiarities. The same circumstance justifies both methods embracing in the article title under generalized heading of Multiparametric Functional-Statistical Analysis (MFSA). In addition to algorithm and its computer program realization shortcut descriptions the article contains examples that illustrate performance capabilities and particularities of discussed methods, as well as their outlined directions of further development.

\section{КЛЮЧЕВЫЕ СЛОВА}

Расширенная параметрическая регрессия, анализ функционально-статистической динамики, мультипараметрический фрукционально-статистический анализ, сеточноградиентная оптимизация, алгоритм сеточной конвергенции.

\section{KEY WORDS}

Augmented parametric regression, analysis of functional-statistic dynamics, multiparametric functional-statistical analysis, gridding-gradient optimization, grid-converging algorithm.

Согласно одному из популярных обобщённых описаний, регрессионный анализ представляется выражением:

$$
y_{i}=f\left(X_{i} ; \Theta\right)+\varepsilon_{i}
$$

где $y_{i}-i$-е значение отклика (объясняемой переменной); $f$ - фрункция, определяющая собой конкретный вид регрессионной модели; $X_{i}=x_{1 i}, x_{2 i}, \ldots, x_{k i}-$ набор $i$-х значений векторов аргументов (объясняющих переменных или фракторов); $\varepsilon_{i}$ - i-е значение случайной компоненты уравнения (регрессионной ошибки); $i=1,2, \ldots$, $n$ - номер наблюдения; $\Theta=\left\{\theta_{1}, \theta_{2}, \ldots, \theta_{m}\right\}$ - параметры, в качестве которых обычно выступают расчётные коэфффициенты регрессионной модели.

Демонстрируемый в (1) способ введения в уравнение регрессионных ошибок $\varepsilon_{i}$ является аддитивным. При соблюдении определённых ограничений на характер совокупности $\left\{\varepsilon_{i}\right\}-$ их несмещённости, взаимной некоррелированности, независимости от величин $X_{i}$ и $y_{i}$, распределённости по нормальному статистическому закону этот способ обеспечивает возможность использования в ходе регрессионного анализа популярных методов наименьших модулей [1-2] и наименьших квадратов см., например, публикации в журнале RJOAS авторов Acquah De-Graft H., Acquah S., Akpan S.B., Jafrizal, Shinta A., Suharno P., Wongnaa C.A. и других. Особую привлекательность методу наименьших квадратов, предложенному в 1805 г. Лежандром [3], а также появившемуся позднее методу наименьших модулей придаёт то обстоятельство, что в простых случаях они позволяют обходиться без громоздких вычислений, требующих обращения к компьютерам.

Следующей по популярности, пожалуй, является модель, строящаяся на предположении о мультипликативном воздействии регрессионных ошибок [4,c.74]. Её можно представить в виде:

$$
y_{i}=f\left(X_{i} ; \Theta\right) \times\left(1+\varepsilon_{i}\right)=f\left(X_{i} ; \Theta\right) \times \gamma_{i}
$$

\footnotetext{
Здесь $y_{i}$ - измеряемая относительно единицы мультипликативная регрессионная ошибка; $\varepsilon_{i}$ - обычная, измеряемая относительно нуля, регрессионная ошибка аддитивного типа.
} 
В различных разделах математической статистики находят применение и другие способы учёта влияния, оказываемого случайными величинами, подобными регрессионным ошибкам. В последнее время появляются также примеры обобщения разных способов учёта случайных отклонений, основывающиеся на представлениях о средних степенных значениях, называемых обобщёнными средними, средними по Гёльдеру или Минковскому [5].

Обобщённая средняя по Гёльдеру, например, описывается выражением [6]:

$$
\bar{x}(m)=\left(\frac{1}{n} \sum_{i=1}^{n} x_{i}^{m}\right)^{1 / m}
$$

Здесь $m \in(-\infty ; \infty)$ - любое действительное число; $x_{i} i=1,2, \ldots, n$ действительные числа из диапазона $x_{i} \in[0 ; \infty)$.

Стоит отметить, что некоторым дискретным значениям $m$ в выражении (3) соответствуют разновидности средних величин, имеющие собственные имена:

$m_{\infty} \rightarrow \infty-\max \left\{x_{i}\right\}-$ "среднее" в метрике доминирования;

$m_{2}=2$ - среднеквадратичное $\left\{x_{i}\right\}$;

$m_{1}=1-$ среднеарифрметическое $\left\{x_{i}\right\}$;

$m_{0}=0$ - среднегеометрическое $\left\{x_{i}\right\}$;

$m_{-1}=-1-$ среднегармоническое $\left\{x_{i}\right\}$;

$m_{-\infty} \rightarrow-\infty-\min \left\{x_{i}\right\}$.

Особой значимостью обладает то обстоятельство, что во всём числовом диапазоне $m \in(-\infty ; \infty)$ средние значения (3) отвечают требованиям, предъявляемым к подобного рода мерам [7]: a) непрерывности; б) монотонности по каждому $x_{i}$; в) симметричности, выражающейся в неизменности среднего при перестановке аргументов; г) равенстве средней от набора равных чисел их общему значению; д) неизменности общего среднего значения при разбивке набора $\left\{x_{i}\right\}$ на подгруппы и использовании вместо них средних по подгруппам.

Кроме того, из известного неравенства о средних, гласящего, что при любых $m_{b}>m_{a}$ имеет место:

$$
\bar{x}\left(m_{b}\right) \geq \bar{x}\left(m_{a}\right)
$$

для любых наборов $\left\{x_{i}\right\}$ выводятся соотношения [5]:

$$
m_{\infty}=\max \left\{x_{i}\right\} \geq m_{2}\left\{x_{i}\right\} \geq m_{1}\left\{x_{i}\right\} \geq m_{0}\left\{x_{i}\right\} \geq m_{-1}\left\{x_{i}\right\} \geq m_{-\infty}\left\{x_{i}\right\}=\min \left\{x_{i}\right\}
$$

Перечисленные свойства обобщённых средних величин свидетельствуют о том, что все они являются легитимными инструментами (мерами) при оценке качества аппроксимации и сообразно условиям конкретной задачи могут использоваться в регрессионном анализе и других разделах математической статистики. Методической трудностью, возникающей при этом, является обоснование выбора конкретной разновидности средней величины, адекватной решаемой задаче.

Преобладающий в настоящее время выбор среднеквадратичных величин объясняется рядом очевидных обстоятельств: 1) основательной разработанностью старейшего по времени создания метода наименьших квадратов, на основе которого вычисляются популярные статистические оценки, проверяются и обосновываются рабочие гипотезы исследования; 2) хорошей согласованностью среднеквадратичных величин с предполагаемым во многих случаях, хотя зачастую не вполне обоснованно, гауссовским (нормальным) распределением случайных величин, присутствующих в 
вычислениях; 3) относительной лёгкостью вычислений, которые в простых случаях удаётся выполнять алгебраическими методами, в том числе без обращения к компьютерам.

В предложенных $и$ обосновываемых автором методах математической статистики, реализованных с помощью описываемого в статье компьютерного алгоритма, используется обобщённый вид функционала (1), в котором изменяющиеся в ходе вычислений случайные величины $\varepsilon_{i}$ включены в качестве аргументов, определяющих наряду с другими аргументами итоговый вид функции $f$ :

$$
y_{i}=f\left(X_{i} ; \varepsilon_{i} ; \Theta\right)
$$

Расположением случайных величин $\varepsilon_{i}$ в формуле (6) подчёркивается их двоякая природа. С одной стороны, как изначально независимые от исследователя величины $\varepsilon_{i}$ родственны переменным $X_{i}=x_{1 i}, x_{2 i}, \ldots, x_{k i}$ С другой стороны, с параметрами $\Theta$ ошибки $E=\left\{\varepsilon_{i}\right\}$ связывает способ, выбираемый исследователем для их влияющей на результаты вычислений обобщённой оценки.

С учётом последнего обстоятельства, а также того, что фригурирующие в уравнении (6) ошибки $\varepsilon_{i}$ приобретают свои конкретные значения только в ходе вычислений, вид данного уравнения может быть подвергнут дальнейшему упрощению за счёт удаления из него компоненты $\varepsilon_{i}$ и её включения в "сублимированном" виде в состав параметров $\Theta$ :

$$
y_{i}=f\left(X_{i} ; \Theta\right)
$$

Здесь $\Theta=\left\{\theta_{1}, \theta_{2}, \ldots, \theta_{m}\right\}$ - набор параметров, отличающийся от общепринятого своим расширенным составом. В него фактически входят все переменные и постоянные величины, определяющие собой и так или иначе влияющие на ход и результаты вычислений. В расширенном составе параметров присутствуют: указание на тип применяемой функции $f$ либо её формализованное описание, пригодное для автоматической расшифровки и программной реализации; начальные значения, диапазоны и шаги изменения функциональных коэффрициентов и аргументов; условия выполнения избранных процедур и критерии переходов между ними; способы выдачи результатов и взаимодействия с исследователем и т.д.

На значения параметров $\Theta$ не накладывается априорных ограничений за исключением тех, которые диктуются их функциональным назначением. В частности, любой из параметров $\theta_{i}$ может быть представлен абсолютной либо относительной числовой величиной, ранговым коэффрициентом, категориальной (номинальной) переменной, функциональным либо логическим оператором, простым либо составным критерием [8].

Одна из ключевых ролей в составе параметров $\Theta$ отводится варьируемой метрике Минковского $r \in(-\infty ; \infty)$, определяющей собой способ усреднённого агрегирования ошибок, осуществляющегося по формуле:

$$
D_{r}=\left(\frac{1}{n} \sum_{i=1}^{n}\left|\varepsilon_{i}\right|^{r}\right)^{1 / r}
$$

$D_{r}$ в выражении (8) представляет собой обобщённую среднюю ошибок (регрессионных остатков), подсчитанную при значении метрики Минковского равном $r$. От обобщённой средней по Гёльдеру (3) данное выражение отличается лишь переводом всех $\varepsilon_{i}$ в область положительных значений $\left|\varepsilon_{i}\right| \in[0 ; \infty)$. Наряду с сохранением у $D_{r}$ свойств обобщённого среднего такая операция существенно 
упрощает вычисления за счёт исключения из них действий с комплексными величинами, появляющимися при оперировании дробными степенями отрицательных аргументов.

При принятых условиях функционал, описывающий решение задачи регрессионного анализа, может быть компактно изображён в виде:

$$
D(Y ; X ; \Theta)=\left[\sum_{i=1}^{n} w_{i}\left|\left(y_{i}-\hat{y}_{i}\right) / z_{i}\right|^{r} / \sum_{i=1}^{n} w_{i}\right]^{1 / r} \Rightarrow \min
$$

Здесь $Y=\left\{y_{i}\right\}-$ набор заданных дискретных значений регрессанда; $\quad X=\left\{X_{i}\right\}-$ набор векторов значений независимых переменных; $\Theta=\left\{\theta_{i}\right\}$ - набор параметров, определяющих расчёты; $W=\left\{W_{i}\right\}$ - набор коэффрициентов, используемых для взвешивания и цензурирования выборочных совокупностей. $z_{i}$ в данном выражении представляют собой расчётные величины, с помощью которых производится нормирование регрессионных остатков, устраняющее по возможности их корреляцию с величинами $y_{i}$ и $\hat{y}_{i}$.

Анализ ффункционально-статистической динамики (АФСД). Целью сопоставительного анализа динамики функциональных зависимостей, в том числе представленных статистическими выборками, является отыскание ключевых параметров, в концентрированном виде отражающих расхождение либо, наоборот, сходство между зависимостями - соотношения их амплитуд и скоростей протекания, а также опережения (отставания) одной зависимости относительно другой.

В реализованном варианте АФСД в качестве ключевых расчётных параметров выбраны смещение (лаг) между условными началами процессов, описываемых зависимостями, и разницы в скоростях протекания этих процессов. Соотношение амплитуд сравниваемых зависимостей отсутствовало в составе расчётных параметров, поскольку во всех выполненных расчётах сопоставлялись однотипные зависимости, изначально нормированные по амплитудам. В то же время возможность программного нормирования либо выравнивания амплитуд была предусмотрена за счёт выбора весовых коэффициентов, применяемых по отношению к ординатам сравниваемых зависимостей.

Для количественной оценки степени расхождения между зависимостями в АФСД, также как и в расширенной параметрической регрессии, используются расстояния в метрике Минковского. В исходном виде, абстрагирующемся от операций взаимного смещения и масштабирования, расстояние между анализируемыми непрерывными зависимостями описывается выражением [9,с.107]:

$$
D_{r}(x, y)=\left[\int_{v} w(t)|x(t)-y(t)|^{r} d t\right]^{1 / r}
$$

Здесь $x(t), y(t)$ - сравниваемые зависимости; $t$ - их общий аргумент; $w(t)-$ весовая функция; $v$ - область определения фрункций $x, y, w ; r$ - показатель (метрика) Минковского.

При дискретном задании функций $x, y, w$ выражение (10) в статичном исходном состоянии и при условии совпадения абсцисс точек определения обеих зависимостей принимает вид:

$$
D_{r}(x, y)=\left[\sum_{i=1}^{n} w_{i}\left|x_{i}-y_{i}\right|^{r}\right]^{1 / r}
$$


где $x_{i}, y_{i}, w_{i}-$ заданные дискретные значения фрункций $x, y, w ; i=1,2, \ldots, n-$ номер очередной дискретной точки; $n$ - общее количество точек, для которых известны конкретные значения функций $x, y, w$.

Выбранные параметры, обозначаемые как $s$ (смещение) и $m$ (масштабирование), соотносятся с осью абсцисс, являющейся общей для сравниваемых зависимостей. В выражении (10) ось абсцисс присутствует явно в виде аргумента $t$, в (11) она играет роль виртуального континуума $t=(-\infty, \infty)$, вмещающего в себя наборы дискретных точек $\left(\left\{t_{i}\right\} \bigcup\left\{t_{j}\right\}\right) \subset t$.

Принципиально важно, что ось абсцисс в данном случае не обязана символизировать собой фризическую, календарную, историческую или какую-либо другую разновидность времени. Более того, ассоциируемые с аргументом $t$ переменные величины могут быть разными по своей субстанциальной природе, но при этом они должны играть ключевые роли в динамике сопоставляемых зависимостей и воздействовать на них в одном направлении.

Выражения (10), (11) являются заведомо упрощёнными, поскольку в них игнорируется разница в областях определения функций $x(t), y(t)$ либо соответствующих дискретных значений $\left\{x_{i}\right\}$ и $\left\{y_{j}\right\}$. В алгоритмах и компьютерных программах это преднамеренное упрощение устраняется за счёт внесения соответствующих корректировок в фрормулы, в том числе введением в них операций экстраполяции и интерполяции.

Для обеспечения несмещённости, повышения точности и унификации результатов расчётов функционалы (10) или (11) целесообразно пронормировать, как это иллюстрируется выражением (9). В результате этого, а также введения необходимых операций над переменными величинами выражение (11), например, принимает вид:

$$
D(X ; Y ; \Theta)=\left\{\frac{\sum_{i=1}^{n} p_{i} \hat{q}_{i}\left|\left(x_{i}-\hat{y}_{i}\right) / z_{i}\right|^{r}+\sum_{j=1}^{n} \hat{p}_{j} q_{j}\left|\left(\hat{x}_{j}-y_{j}\right) / z_{j}\right|^{r}}{\sum_{i=1}^{n} p_{i} \hat{q}_{i}+\sum_{j=1}^{n} \hat{p}_{j} q_{j}}\right\}^{1 / r} \Rightarrow \min .
$$

Усложнение фрунционала (12) по сравнению с предыдущим объясняется появлением семейства новых дискретных точек $J=\{\}$ на оси абсцисс, к которым привязывается "ведомая" зависимость в результате её вариативного смещения и масштабирования относительно "ведущей". А поскольку в результате названных двух операций семейства точек $l=\{l\}$ и $J=\{\}\}$ оказываются взаимно смещёнными, требуется рассчитывать новые значения функций $x$ и $y$ на обновлённых участках их интерполяции и экстраполяции. Аналогичным метаморфозам подвергаются весовые коэфрфициенты $w$, которые к тому же нуждаются в разбивке на два подмножества $P=\left\{p_{i}\right\} \bigcup\left\{\hat{p}_{i}\right\}$ и $Q=\left\{q_{j}\right\} \bigcup\left\{\hat{q}_{j}\right\}$, относящиеся соответственно к функциям $x$ и $y$.

В том важном и, следует думать, нередком случае, когда в качестве ведущей либо эталонной зависимости выбирается некая фрормализованная непрерывная функция $x(t)$, за счёт исключения необходимости применения операций интерполяции и экстраполяции по отношению к обеим функциям функционал (12) существенно упрощается:

$$
D(X ; Y ; \Theta)=\left\{\sum_{j=1}^{n} p\left(\hat{t}_{j}\right) q_{j}\left|\left[x\left(\hat{t}_{j}\right)-y_{j}\right] / z_{j}\right|^{r} / \sum_{j=1}^{n} p\left(\hat{t}_{j}\right) q_{j}\right\}^{1 / r} \Rightarrow \min
$$


Здесь $\hat{t}_{j}$ - дискретное значение аргумента функции $x(t)$, рассчитанное с учётом сдвига абсциссы j-го значения функции $y$ в результате применения к ней операций смещения и масштабирования.

Обращает на себя внимание значительная схожесть функционалов (9) и (13), различающихся между собой лишь характером фригурирующих в них переменных величин. Неявное различие состоит также в том, что в состав $\Theta$ в (13) входят варьируемые параметры смещения $s \quad$ и масштабирования $m$, отсутствующие в (9). Однако если придать этим параметрам фриксированные начальные значения $s_{0}=0$ и $m_{0}=1$, фрункционал (13) становится фрактически тождественным фрункционалу (9) и, следовательно, вполне пригодным для выполнения расчётов методом расширенной параметрической регрессии. Тем самым находит очередное наглядное подтверждение родственная природа регрессионного и корреляционного анализов.

Применительно к тем нередко возникающим ситуациям, когда требуется выполнить обобщённое сопоставление не одной, а множества однотипных пар зависимостей $X_{l}$ и $Y_{l}$, где $X_{l}=\left\{x_{l}\right\}, Y_{l}=\left\{y_{l}\right\}, \quad l=1,2, \ldots, L, L$ - количество пар сопоставляемых зависимостей, фрункционалы (12) и (13) должны быть откорректированы за счёт введения в состав их варьируемых параметров дополнительного элемента I. Естественно, это сопровождается добавлением цикла верхнего уровня в алгоритмы, реализующие фрункционалы (12) и (13), а также $L-$ кратным увеличением продолжительности работы программы.

Следует однако учесть, что в описанном варианте расчётов обеспечивается

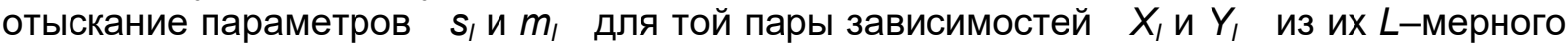
набора, которые изначально наиболее близки друг к другу. Для отыскания усреднённых $\bar{s}$ и $\bar{m}$, характеризующих статистические наборы зависимостей $X_{\text {I }}$ и $Y_{\text {I }}$ в целом, требуется либо выполнить их предварительное усреднение, сопровождающееся последующим сопоставлением полученных $\bar{X}$ и $\bar{Y}$, либо произвести тем или иным способом усреднение множества значений $\left\{s_{l}, m_{l}\right\}$, полученных по отдельности на основе функционалов (12) и (13).

Алгоритм вычислений. Описываемая работа основывалась на интенсивном использовании нескольких поколений отечественных ЭВМ, начиная от Минск-22 и заканчивая EC-1052, входившей в серию Ряд 1 и обладавшей параметрами [10-11]:

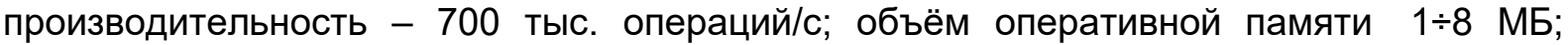
ёмкость одного накопителя на магнитных дисках - 27 МБ; вместимость бобины накопителя на магнитной ленте 100 МБ. При среднем времени доступа к пользовательской информации, хранившейся в основном на магнитных лентах, измеряемом десятками секунд, ЭВМ EC-1052 работала в многозадачном режиме, обслуживая одновременно до 15 клиентов аппаратно-программной системы коллективного доступа.

Для написания программ использовался универсальный язык программирования ПЛ/1 (Programming Language one), совмещающий в себе и существенно дополняющий возможности популярных специализированных языков ФОРТРАН, АЛГОЛ и КОБОЛ. Несмотря на чрезмерную усложнённость, которая, по мнению некоторых специалистов присуща ПЛ/1 [12,с.198], этот язык отличается компактностью, наглядностью и легко прослеживаемой логичностью своих программных листингов. Немаловажно также, что он позволял и, нужно думать, до сих пор позволяет получать эфффективно работающие программы, в максимальной степени реализующие вычислительные возможности компьютеров.

Работа по созданию алгоритмов и программ, перемежавшаяся с выполнением многочисленных пробных и реальных расчётов, иллюстрируются в упрощённом виде рисунком 1. 


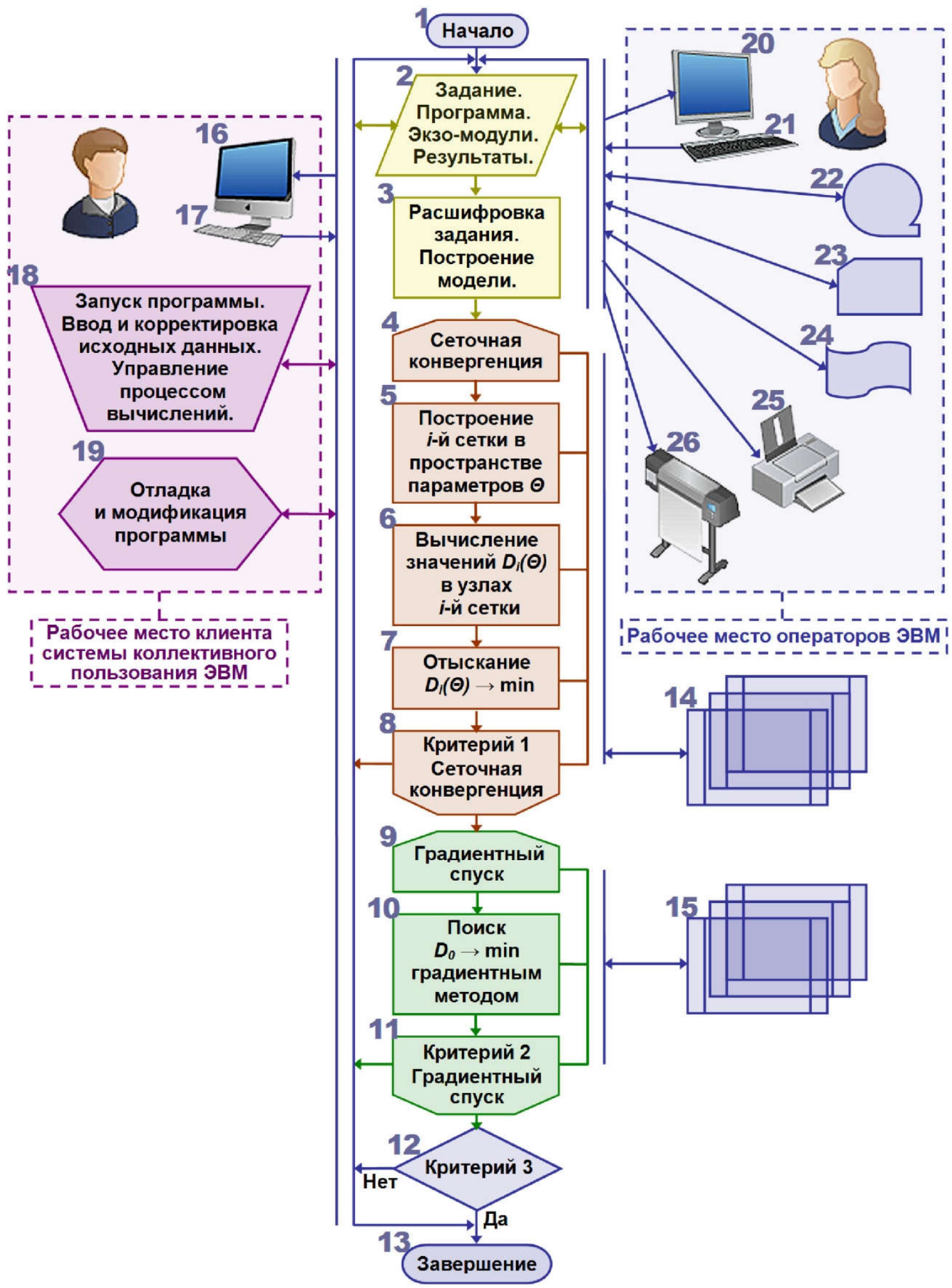

Рисунок 1 - Укрупнённая структура алгоритма мультипараметрического функциональностатистического анализа, совмещённая со схемой его разработки и реализации

Использование в обоих описываемых методах функционалов (7) - (13), а также варьируемой метрики Минковского исключило из арсенала способов решения соответствующих задач многие известные методы. Широко использующиеся в линейном регрессионном анализе матричные методы, например, несовместимы с общим видом названных функционалов, в которых на функции $f$ не накладываются необходимые в таких случаях ограничения. Градиентные методы поиска экстремумов 
функций, нашедшие широкое распространение при решении различных прикладных задач, также в данных случаях оказываются малопригодными; прежде.всего ввиду их невысокой надежности, а зачастую и непредсказуемости результатов, зависящих от выбора начальной точки и от конфигурации поверхности, отображающей целевую функцию пошагового поиска. Низкая надёжность градиентных способов объясняется в данном случае тем обстоятельством, что гиперповерхности, соответствующие в многомерных пространствах $\Theta$ минимизируемым функционалам $D$, нередко имеют сложный рельеф. Помимо мультимодальности, выражающейся в наличии многих локальных минимумов, в зависимости от применяемых способов интерполяции и экстраполяции на данных гиперповерхностях могут присутствовать резкие "изломы", значительно затрудняющие использование градиентных способов.

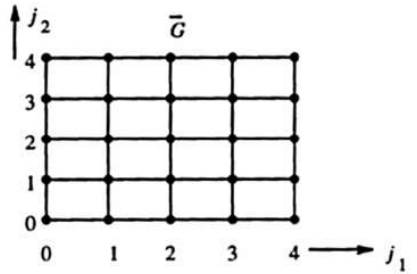

(a)

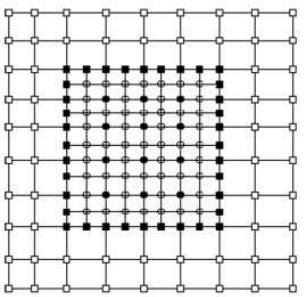

$(\partial)$

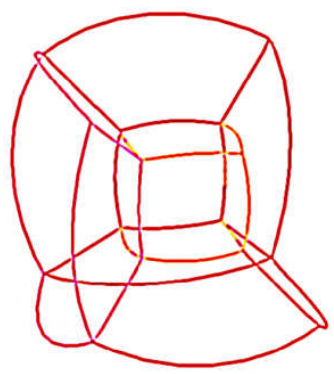

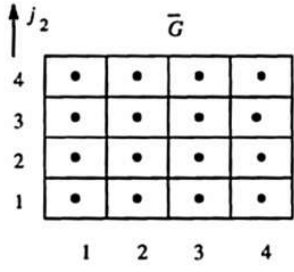

(б)

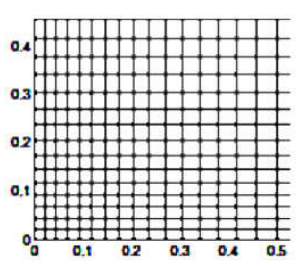

(b)

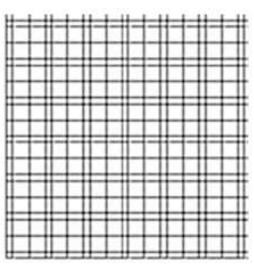

(2)

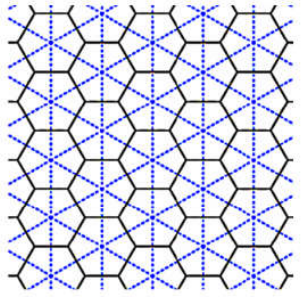

(e)

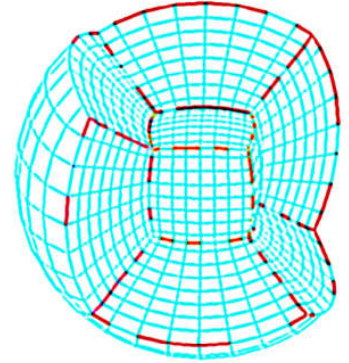

(K)

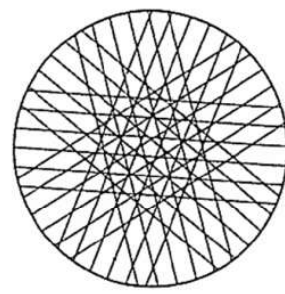

(ж)

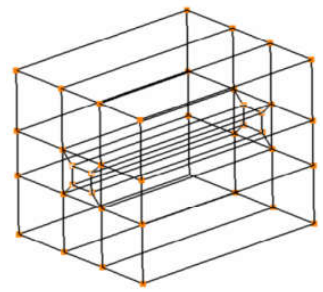

(u)

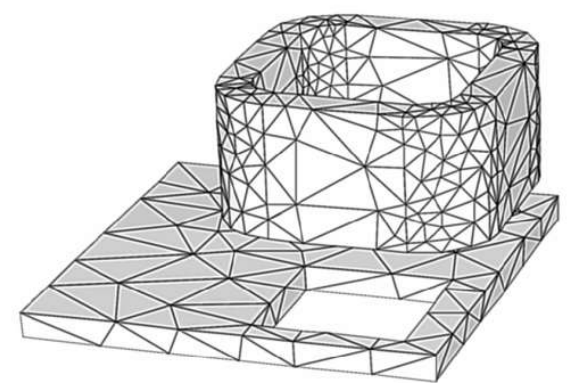

(л)

Рисунок 2 - Характерные разновидности расчётных сеток: (а)-(б) ортогональные регулярные с координатной привязкой (а) узлов сетки, (б) центров ячеек $[15, c .82]$; (в) ортогональная с линейно изменяющимися координатными шагами [16,c.36]; (г) ортогональная регулярная неуниформная [16,с.34]; (д) композиционная [17,c.41]; (e) шестигранная мозаичная с наложенной на неё мозаикой из равносторонних треугольников [18,c.16]; (ж) мозаика, образованная суперпозицией регулярных одномерных сеток $[19, \mathrm{c.5}]$; (и) "проволочное" обрамление моделируемой объёмной фригуры [20,с.4]; (к) контуры разрезов объёмной фригуры и их композиционная криволинейная сеточная модель [20,c.217]; (л) прямолинейная композиционная сетка, адаптированная к криволинейной поверхности моделируемого объекта $[21, \mathrm{c} .7]$.

Исходя из перечисленного, в качестве основного инструмента решения задач функционально-статистической оптимизации был выбран способ, известный как "метод точек и сеток" [13,c.281; 14,c.209]. Поскольку экспериментальная проверка одной из наиболее популярных разновидностей последнего - метода случайного поиска (МонтеКарло), - проведённая на первых этапах исследования, продемонстрировала его недостаточную надёжность, слабую предсказуемость и высокую затратность в 
отношении используемых ресурсов ЭВМ, выбор был остановлен на ускоренно развивавшихся в то время операциях над регулярными сетками.

Рисунками 2 и 3 иллюстрируются в обобщённом виде произошедшие за последние несколько десятилетий расширение областей применения и диверсификация исследовательских процедур, осуществляющихся сеточными методами.

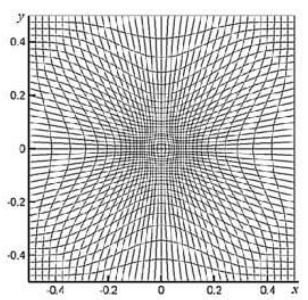

(a)

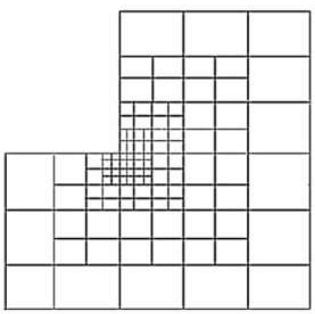

(c)

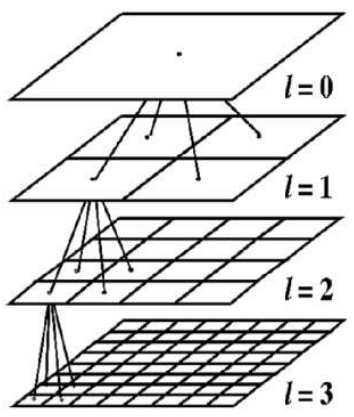

(ж)

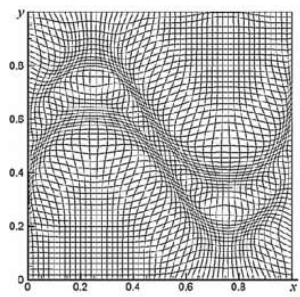

(б)

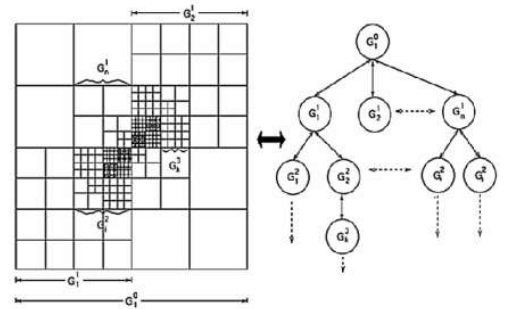

(d)

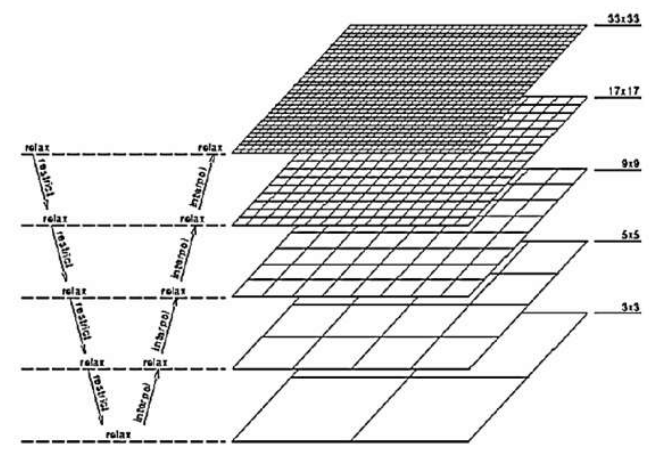

(u)

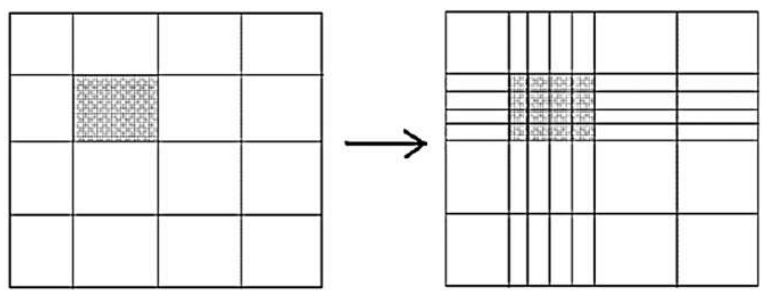

(8)

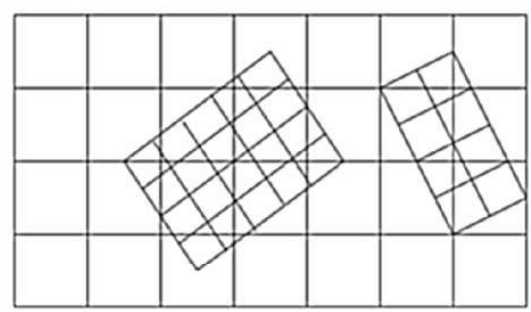

(e)

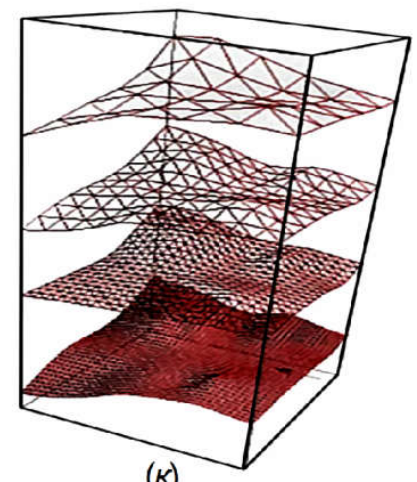

(

Рисунок 3 - Распространённые алгоритмические преобразования, выполняемые над расчётными сетками: (a)-(б) управление кривизной линий сетки [22,с.30]; (в)-(2) введение дополнительных наборов сеток $[17, \mathrm{c.39-40];} \mathrm{( \partial )} \mathrm{создание} \mathrm{сетки,} \mathrm{имеющей} \mathrm{структуру}$ направленного ациклического графа [23,c.5]; (e) создание композитной сетки наложением на исходную основу оптимально ориентированных мелкоячеечных сеточных фррагментов [24,c.7]; (ж) многосеточные преобразования по отношению к трёхмерным объектам, представляемым в виде "октодеревьев" [25,c.4; 26-27]; (u) схема решения разнообразных систем математических уравнений многосеточными рекурсивно-итерационными методами [28-30]; (к) схема реализации "конвергентного сеточного алгоритма" [31,с.189].

Наиболее интенсивно в последнее время развиваются сеточные методы, связанные с моделированием объёмных объектов и процессов в фризике, химии, аэрои гидродинамике, конструировании, архитектуре, визуализации и распознавании образов. Примеры соответствующих разновидностей расчётных сеток и преобразований над ними представлены на рисунках 2 (u-л) и 3 (ж-к).

В реализованном автором комплексном сеточно-градиентном алгоритме на первых его этапах (рисунок 1, блоки 4-8) используется многомерная квазирегулярная расчётная сетка вида рис. 2 (a). С регулярными сетками её объединяет ортогональность многомерного признакового пространства, предполагающая взаимную некоррелированность используемых признаков - параметров $\Theta$ 
функционалов (9), (12), (13). От строго регулярных выбранную разновидность сеток отделяет использование в составе параметров $\Theta$ разнородных величин, в том числе ранговых и категориальных признаков, в отношении которых является бессмысленным утверждение о регулярности, выражающейся в равенстве расстояний между соседними градациями сеточных координат. Противоречит определению используемой сетки как регулярной также наличие статистической либо иной неявно выраженной взаимосвязанности между некоторыми параметрами, что, как показывают многочисленные выполненные вычислительные эксперименты, в определённой степени компенсируется выбором оптимального значения метрики Минковского $r \quad$ B названных функционалах.

Способ сеточных преобразований, применённый в разработанном автором алгоритме, имеет своего терминологического двойника, схематично изображённого на рисунке $3(\kappa)$. Содержание описываемого в [31, с.393-398] "алгоритма сеточной конвергенции" (Convergent gridding algorithm) заключается в итеративно повторяющейся процедуре дробления ячеек сетки, являющейся первоначально грубой регулярной топологической моделью участка земной поверхности, и присвоения её вновь появляющимся многочисленным узлам значений, рассчитываемых на основе усреднения значений близлежащих опорных триангуляционных точек, выбираемых из их достаточного представительного исходного массива. Процесс описанной "сеточной конвергенции" заканчиваются после выполнения заданного количества его итераций или при достижении ячейками координатной сетки заданной минимальной величины.

Идея разработанного автором сеточного метода, схематично изображённого на рисунок 4, состоит в методичном уменьшении геометрических размеров квазирегулярной сетки при соответствующем увеличении её разрешающей способности, дополняемом её смещениям по осям координат, вплоть до как можно более полной конвергенции (слияния) сетки с отыскиваемой областью глобального минимума $M$ многомерной целевой функции $D(\Theta)$. Отыскание точного значения координат $\Theta_{M}$ глобального минимума фрункции осуществляется более адекватным в таком случае градиентным методом, описываемым далее.

Реализация процедур сеточной конвергенции, отображаемой на рисунке 1 блоками 4-8, начинается с построения грубой исходной расчётной сетки, охватывающей целиком область определения фрункции $D(\Theta)$ - рисунок 4, итерация I. Первоначальные границы этой области совпадают с диапазонами изменения всех фригурирующих в расчётах переменных величин. При проведении регрессионного анализа, как это иллюстрируется рисунком 4, текущая область определения функции $D(\Theta)$ в натуральном выражении постепенно уменьшается за счёт повторяющегося $K$ кратного сокращения шагов расчётной сетки по всем её координатам. При этом сама уменьшенная в размерах сетка смещается так, чтобы равномерно охватывать найденную на одной из предыдущих итераций точку, которой соответствует минимальное из найденных к данному моменту значений функции $D(\Theta)$. Границы, в пределах которых локализуются фрормируемые более мелкие сетки, остаются при этом неизменными, свойственными первой итерации конвергенционного цикла.

В отличие от изложенного, при анализе функциональной динамики изначально предусматривается возможность выхода текущих областей определения функции $D(\Theta)$ за границы её первоначально заданной области, сопровождающегося её соответствующим расширением. Этим обеспечивается выполнение операций экстраполяции по отношению к участвующей в анализе "ведомой" функции.

Критериями завершения процедуры сеточной конвергенции (рисунок 1, блок 8) могут быть выбраны: а) выполнение заданного количества итераций или, что эквивалентно, достижение шагом приращения выбранного параметра $\theta_{i}$ заданной минимальной величины; б) прекращение уменьшения очередных расчётных значений $D(\Theta)$ на протяжении заданного количества итераций рассматриваемого конвергенционного процесса. В зависимости от особенностей решаемой задачи могут быть использованы и другие критерии завершения конвергенционного цикла, в том числе его полное исключение из алгоритма. 

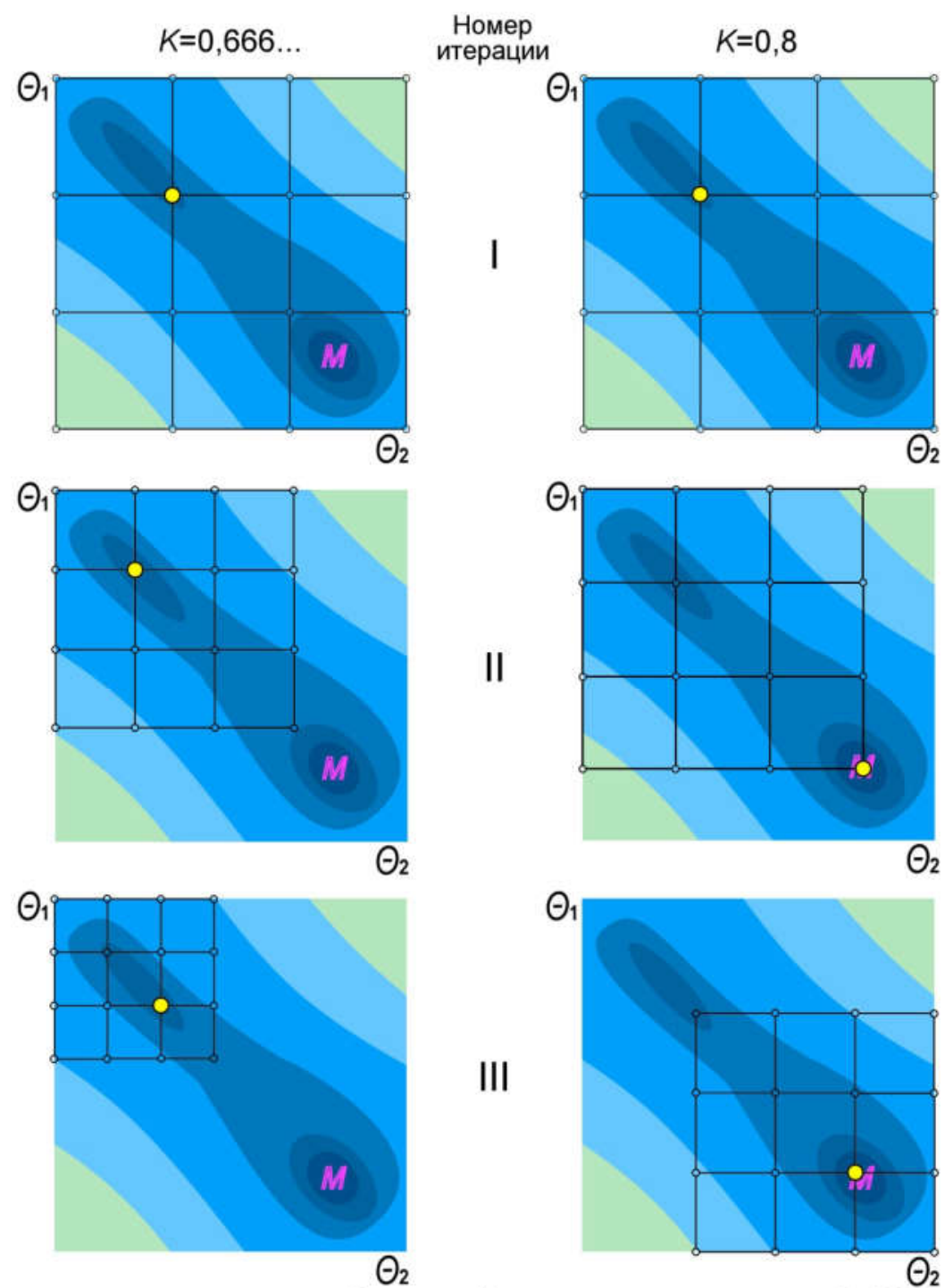

О - узел сетки, выбираемый по критерию минимума $D(\Theta)$

М - область глобального минимума

Рисунок 4 - Зависимость надёжности поиска глобального минимума целевой функции $D(\Theta)$ от значений коэффициента сеточной конвергенции $K$

Как это иллюстрируется рисунком 4, эффрективность сеточной оптимизации в существенной степени зависит от выбора величины коэффрициента конвергенции $K$. B частности, при сохранении незыблемым правила $0<K<1$ и при приближении этого коэфффициента к "1" (1-K $\rightarrow$ min) возрастает плотность покрытия признакового пространства $\{\Theta\}$ узлами последовательно сменяющих друг друга сеток, а вместе с этим увеличиваются надёжность и точность расчетов. Возрастающие при этом количество итераций и линейно зависящего от них времени работы программы в определённых пределах оправдывают себя. Общее же правило состоит в том, что как коэфффициент конвергенции $K$, так и условие окончания соответствующего цикла должны определяться особенностями решающейся задачи, а при необходимости результатами пробных расчётов.

Поскольку, как это следует из вышесказанного, конвергенционный алгоритм не обеспечивает абсолютных надёжности и точности получаемых результатов, возникает вопрос о преимуществах, обеспечивающих его конкурентоспособность по сравнению с другими сеточными методами. По отношению к популярному методу Монте-Карло это уже было сделано выше, поэтому есть смысл сопоставить предлагаемый метод с 
наиболее простым в реализации использованием регулярных сеток. Труднооспоримое преимущество конвергенционного алгоритма в этом случае состоит в многократном снижении размерности задачи и соответственно времени её решения на ЭВМ. Если при использовании “канонического" метода сеток и точек для получения заданных надёжности и точности расчётов требуется прибегать к построению чрезвычайно многомерных сеток, имеющих шаги приращения координат сопоставимые по величине с требующейся точностью расчётов, то при обращении к конвергенционному алгоритму достаточно ограничиться первоначальным выбором достаточно грубых сеток, разрешающая способность которых автоматически возрастает по мере продолжения итерационного процесса. Нарастающее при этом в арифметической прогрессии время, затрачиваемое на повторяющиеся итерации циклического процесса, не идёт в сравнение с тем растущим в геометрической прогрессии временем, которое расходуется на обсчёт многомерных сеток, наделённых требуемой разрешающей способностью.

С другой стороны, обращение к типам сеток и строящимся на них методам, приведённым в качестве примеров на рисунках 2 (в-ж) и 3 (a-e), во-первых, неизбежно сопряжено со значительным усложнением соответствующих вычислительных процедур и, во-вторых, требует знания, как правило, заранее неизвестных особенностей используемых в расчётах целевых функций $D(\Theta)$.

Отличаясь своими высокими экономичностью и скоростью решения, недостижимыми при использовании стандартного метода сеток и точек, сеточная конвергенция уступает последнему в отношении гарантируемых надёжности и точности получаемых результатов. Связано это, в частности, с неуклонным сокращением покрытия исходной области определения функции $D(\Theta)$ расчётной сеткой, уменьшающейся в процессе итераций по своим геометрическим размерам. При сложной конфигурации гиперповерхности, отображающей функцию $D(\Theta)$, это чревато возникновением ситуации, когда из-за своих малых размеров на всех последующих итерациях сетка перестаёт достигать области глобального минимума, находящейся, например, на дне вытянутого и извилистого жёлоба. В таких достаточно редких случаях в качестве отыскиваемого решения программой выдаётся некоторый его промежуточный результат, расчётные параметры $\left\{\hat{\theta}_{i}\right\}$ которого могут существенно отличаться от истинных.

Для избавления расчётов от подобных ошибок или, по крайней мере, снижения их величины и вероятности появления, сеточная конвергенция нуждается в дополнении градиентными методами. Поскольку экспериментальное опробование в этих целях стандартного метода наискорейшего спуска показало его недостаточную надёжность по отношению к решаемым задачам, ниже описывается один из реализованных автором подобных приёмов, проявивших себя с более выгодной стороны.

В основе приёма, названного интерполяционной оптимизацией, лежат представления об относительной гладкости фрункции $D(\Theta)$, характерной в первую очередь для её локальных участков. Из этих представлений вытекает, что на любом своём относительно малом участке данная многомерная функция может быть представлена в виде поверхности второго порядка в пространстве $\Theta$, описываемой уравнением:

$$
\begin{aligned}
& D(\Theta)=a_{1} \theta_{1}^{2}+a_{2} \theta_{2}^{2}+\ldots+a_{m} \theta_{m}^{2}+a_{m+1} \theta_{1}+\ldots+a_{m+2} \theta_{2}+\ldots \\
& +a_{2 m} \theta_{m}+a_{2 m+1} \theta_{1} \theta_{2}+a_{2 m+2} \theta_{1} \theta_{3}+\ldots+a_{M-1} \theta_{m-1} \theta_{m}+a_{M}
\end{aligned}
$$

где параметры $\theta_{1}, \theta_{2}, \ldots, \theta_{\mathrm{m}}$ выступают в качестве независимых переменных величин; $a_{1}, a_{2}, \ldots, a_{M}-$ коэфрфициенты уравнения, значениями которых определяется конфригурация многомерной поверхности в выбранной её точке; $M$ максимальный номер коэффрициента. Нетрудно убедиться, что $M$ численно равен 
количеству сочетаний из $m$ по $2: \quad M=C_{m}^{2}$.

Очевидно, что в области минимума функции $D(\Theta)$ уравнением (14) описывается геометрическая фигура, являющаяся гиперпараболлоидом в пространстве размерности $m$. Следовательно, найдя с помощью описанного выше итерационного процесса приближённое положение минимума фрункции $D(\Theta)$ и произведя её аппроксимацию в найденной области, мы получаем возможность вычислить положение вершины гиперпараболлоида, с большей точностью индицирующей отыскиваемые координаты минимума названной функции, а тем самым дающей более точное решение задачи фрункционально-статистического анализа.

Вытекающая отсюда последовательность действий такова.

1. В многомерном признаковом пространстве $\Theta$ отыскиваются координаты некоторого количества точек $\hat{\Theta}=\hat{\theta}_{1}, \hat{\theta}_{2}, \ldots, \hat{\theta}_{m}$, лежащих в окрестности найденной приближённой точки минимума, которые в совокупности с найденной точкой дают возможность построить систему из $M$ уравнений. Очевидно, таких дополнительных точек должно быть $M-1$.

2. В дополнительных точках вычисляются значения функции $D(\Theta)$.

3. Строится система из $M$ уравнений, в которой коэфрфициенты $a_{1}, a_{2}, \ldots, a_{M}$ выступают в качестве неизвестных величин. Одним из имеющихся стандартных способов отыскивается решение этой системы. Условием перехода к следующему шагу является неотрицательность первых $m$ коэфффициентов уравнения (14). Несоблюдение этого условия говорит о невозможности аппроксимации функции в данной её области с помощью гиперпараболлоида.

4. Считая найденные коэфффициенты $a_{1}, a_{2}, \ldots, a_{M}$ постоянными величинами, отыскиваются $m$ частных производных уравнения (14), приравниваемых к нулю. Например, частная производная по $\theta_{1}$ описывается уравнением:

$$
2 a_{1} \theta_{1}+a_{m+1}+a_{2 m+1} \theta_{2}+a_{2 m+2} \theta_{3}+\ldots+a_{3 m-1} \theta_{m}=0 .
$$

Выражения для производных компонуются в систему из $m$ уравнений; отыскивается решение этой системы.

5. Найденное решение, состоящее из $m$ значений параметров $\widetilde{\Theta}=\widetilde{\theta}_{1}, \widetilde{\theta}_{2}, \ldots, \widetilde{\theta}_{m}$, интерпретируется как уточнённое положение минимума функции $D(\Theta)$. В качестве окончательного решения уравнения выбирается тот набор значений параметров $\hat{\Theta}$ или $\widetilde{\Theta}$, при котором фрункция $D(\Theta)$ принимает минимальное значение.

Практическое использование описанной схемы уточнения результатов подтверждает её достаточно высокую эффрективность. Так, при значениях метрики Минковского $r$ близких к 2 интерполяционное уточнение в среднем на порядок повышает точность расчетов. В то же время логические рассуждения и практика решения задач показывают, что эта схема в некоторых случаях бывает неэффективной. Это, во-первых, обнаруживается тогда, когда в результате итерационного процесса положение минимума функции $D(\Theta)$, имеющей сложный рельеф, определено со значительной погрешностью. Отыскиваемое с помощью гиперпараболлической аппроксимации расчётное положение минимума, будучи в таких условиях слишком грубым, не даёт ожидаемого уточнения результатов.

Во-вторых, снижение эффрективности гиперпараболлической аппроксимации происходит при использовании значений метрики $r$, существенно отличающихся от 2.

Эти обстоятельства говорят о необходимости продолжения поиска эффективных способов уточнения и повышения надёжности результатов. Одна из идей, ждущих своей реализации, заключается в том, что вид применяемой аппроксимации должен соответствовать используемому в расчётах значению метрики Минковского. Например, 
при $r=1$ фрункция $D(\Theta)$ могла бы с большей эффективностью аппроксимироваться в виде гиперконуса в $m$-мерном пространстве $\Theta$.

Другая идея в общем виде заключается в следующем. Через точки $\hat{\Theta}, \widetilde{\Theta}$ и третью точку в пространстве $\Theta$, лежащую между двумя первыми, проводится линия второго порядка. Если эта линия оказывается выпуклой вниз параболой, её вершина может быть принята за искомое решение.

Ещё одна идея состоит в усложнении конвергенционного процесса за счёт включения в каждую его итерационную фазу этапа интерполяционного уточнения промежуточного результата. Это может ускорить сходимость процесса, особенно в тех нередких случаях, когда область минимума фрункции $D(\Theta)$ имеет сложную конфигурацию.

Примеры решения прикладных задач. Описанный выше алгоритм был реализован в серии последовательно совершенствовавшихся программ, которые параллельно с доработкой интенсивно использовались в многочисленных практических расчётах. Краткие изложения и результаты последних представлены в публикациях [9; 32-38]. Ниже описываются две конкретные задачи, при решении одной из которых был использован метод расширенной параметрической регрессии [34-38]. Решение другой сопровождалось множеством взаимосвязанных расчётов, строившихся на использовании аппарата анализа функционально-статистической динамики [9; 32; 33; 36; 39].

Пример 1. Расширенная параметрическая регрессия.

Отыскивается конкретный вид некоторого эмпирического статистического распределения, подчиняющегося обобщённому закону распределения случайных величин [40,c.43]:

$$
F(x)=A e^{-a x^{p}} x^{n-t}
$$

где $a, p, n$ - параметры, соответствующие индивидуальным особенностям кривых распределения; $A$ - постоянная, вводимая с целью нормирования функции (16). Таким законом описывается, например, гранулометрический состав дисперсных смесей, образующихся при добыче и переработке твёрдых полезных ископаемых.

В соответствии с имевшимися исходными данными решалась задача нахождения коэффицциентов несколько видоизменённого по сравнению с (16) регрессионного уравнения:

$$
\hat{y}=a_{0} \exp \left(-a_{1} d^{a_{2}}\right) d^{a_{3}}
$$

где $a_{0}, a_{1}, a_{2}, a_{3}$ - отыскиваемые параметры уравнения; независимая переменная $d$ - классификационный диаметр частиц в их дисперсной смеси; $\hat{y}$ - расчётная плотность объёма частиц данного классификационного диаметра. Исходные данные расчёта представлены в таблице 1, а его результаты, полученные при различных значениях метрики Минковского - в таблице 2 и на рисунке 5.

По виду поля рассеяния точек $d$ на рисунке 5, соответствующих исходным данным (таблица 1), можно априорно прийти к заключению об одномодальном характере распределения объёмов частиц, что делает оправданным применение фрормулы (17). По рисунку, кроме того, наглядно прослеживается зависимость дисперсии объёмов частиц различных классов $d$ от ожидаемой амплитуды функции плотности их распределения.

В программе, детальное описание которой из-за большого объёма не приводится, такому закону наложения ошибок с разной точностью отвечают пять задействованных способов их нормирования. 
Таблица 1 - Экспериментальное гранулометрическое распределение состава дисперсных смесей

\begin{tabular}{|c|c|c|c|c|c|c|c|c|}
\hline$i$ & $d$ & $y$ & $i$ & d & $y$ & $i$ & d & $y$ \\
\hline 1 & 0,07 & 0,007 & 21 & 0,58 & 0,28 & 41 & 4,46 & 0,055 \\
\hline 2 & 0,214 & 0,08 & 22 & 2,08 & 0,107 & 42 & 10,7 & 0,008 \\
\hline 3 & 0,5 & 0,58 & 23 & 5,0 & 0,06 & 43 & 0,357 & 0,023 \\
\hline 4 & 1,79 & 0,35 & 24 & 10,0 & 0,044 & 44 & 1,25 & 0,385 \\
\hline 5 & 5,7 & 0,05 & 25 & 0,166 & 0,02 & 45 & 4,46 & 0,103 \\
\hline 6 & 10,0 & 0,013 & 26 & 0,583 & 0,206 & 46 & 10,7 & 0,002 \\
\hline 7 & 0,179 & 0,12 & 27 & 2,08 & 0,215 & 47 & 0,25 & 0,047 \\
\hline 8 & 0,893 & 0,57 & 28 & 5,0 & 0,086 & 48 & 0,875 & 0,5 \\
\hline 9 & 2,14 & 0,22 & 29 & 10,0 & 0,009 & 49 & 1,875 & 0,414 \\
\hline 10 & 5,0 & 0,05 & 30 & 0,167 & 0,06 & 50 & 3,75 & 0,031 \\
\hline 11 & 10,9 & 0,08 & 31 & 0,583 & 0,411 & 51 & 8,75 & 0,001 \\
\hline 12 & 0,179 & 0,1 & 32 & 2,083 & 0,143 & 52 & 0,438 & 0,13 \\
\hline 13 & 0,893 & 0,39 & 33 & 5,0 & 0,092 & 53 & 1,56 & 0,42 \\
\hline 14 & 2,14 & 0,148 & 34 & 10,0 & 0,015 & 54 & 3,75 & 0,023 \\
\hline 15 & 5,0 & 0,065 & 35 & 0,357 & 0,231 & 55 & 7,5 & 0,009 \\
\hline 16 & 10,7 & 0,007 & 36 & 1,25 & 0,43 & 56 & 0,217 & 0,225 \\
\hline 17 & 0,416 & 0,129 & 37 & 4,46 & 0,062 & 57 & 0,76 & 0,88 \\
\hline 18 & 2,08 & 0,232 & 38 & 10,7 & 0,006 & 58 & 2,72 & 0,086 \\
\hline 19 & 5,0 & 0,07 & 39 & 0,357 & 0,294 & 59 & 10,9 & 0,003 \\
\hline 20 & 10,0 & 0,005 & 40 & 1,25 & 0,46 & & & \\
\hline
\end{tabular}

* $i$ - порядковый номер образца, $d$ - классификационный диаметр гранул дисперсной смеси, у эмпирическое значение фрункции плотности распределения.

Таблица 2 - Результаты решения регрессионного уравнения (17) при различных значениях метрики Минковского $r$

\begin{tabular}{|c|c|c|c|c|c|}
\hline $\boldsymbol{r}$ & $a_{0}$ & $a_{1}$ & $a_{2}$ & $a_{3}$ & $D_{r}(\theta)$ \\
\hline 0,3 & 0,6539 & 0,9976 & 0,8703 & 1,066 & 0,30418 \\
\hline 0,5 & 6,777 & 3,16 & 0,5087 & 1,565 & 0,35839 \\
\hline 0,75 & 2,985 & 2,003 & 0,9649 & 1,947 & 0,40076 \\
\hline 1,0 & 3,175 & 2,193 & 0,7748 & 1,757 & 0,43165 \\
\hline 2,0 & 3,332 & 2,35 & 0,7591 & 1,609 & 0,51888 \\
\hline 3,0 & 9,286 & 3,667 & 0,5811 & 1,935 & 0,57804 \\
\hline
\end{tabular}

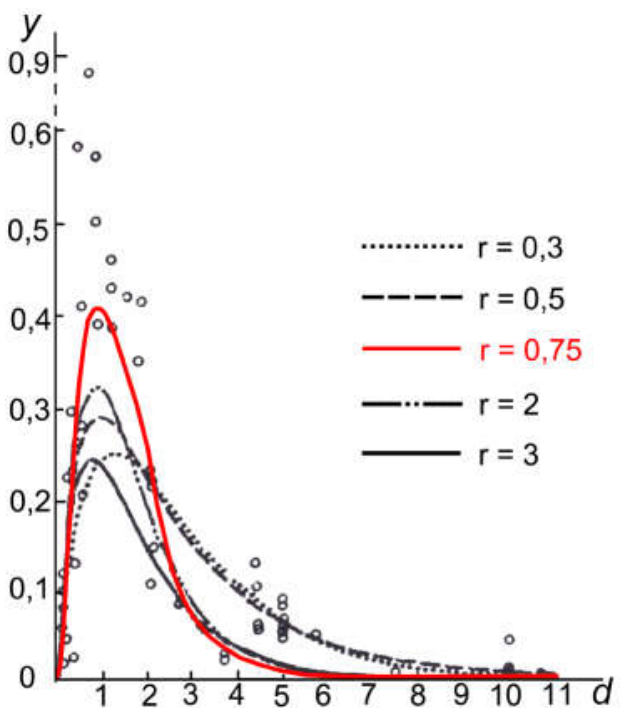

Рисунок 5 - Диаграмма рассеяния классификационного диаметра гранул $d$ и результаты решения уравнения (17) при различных значениях метрики Минковского $r$ 
С учётом имеющих место резко выраженных колебаний средних величин ошибок, коррелирующих с ожидаемой амплитудой фрункции плотности распределения, в качестве наиболее подходящего выбран вариант $z_{i}$ в фрункционале (9), описываемый выражением:

$$
z_{i}=\bar{y}_{i}\left(1+\hat{\sigma}_{i} / \bar{y}_{i}\right)
$$

где $z_{i}$ - нормировочный коэффрициент; $\hat{\sigma}_{i} / \bar{y}_{i}$ представляют собой обобщённые коэфрфициенты вариации откликов $y$, подсчитываемые на выделяемых особо участках этой зависимости.

Негативное влияние на точность расчётов неустановленного закона распределения ошибок и предполагаемой автокорреляции откликов устраняется, насколько это возможно, подбором наилучшего способа агрегирования регрессионных ошибок, определяемого значением метрики Минковского $r$.

На первый взгляд данные таблицы 2 малоинформативны в отношении выбора этого показателя. Действительно, значения суммы регрессионных остатков фрункции $D_{r}(\theta)$, монотонно уменьшающиеся с уменьшением $r$, - явление закономерное, не связанное исключительно с улучшением качества аппроксимации. Среди других расчётных величин наглядная закономерность прослеживается только у $a_{2}$ и $a_{3}$, достигающих максимумов при значении $r=0,75$. Аналогичная картина прослеживается и в отношении коэфрфициентов $a_{0}$ и $a_{1}$, хотя наблюдающиеся у них минимумы при $r=0,75$ являются лишь локальными.

Один из объективных критериев для выбора оптимального значения $r$ вытекает из сопоставления кривых, построенных по расчётным данным. Из рисунка 5 видно, что вместе с ростом значения $r$ в диапазоне от 0,3 до 3 фрорма кривых, описываемых уравнением (17), претерпевает плавную эволюцию. В частности, их модальное значение вначале растёт вместе с ростом $r$, а при $r>0,75$, столь же монотонно снижается. Вместе с этим визуально изменяется и степень соответствия получаемых кривых их ожидаемым очертаниям: кривая, соответствующая $r=0,75$, лучше остальных аппроксимирует исследуемую зависимость в её наиболее критичной модальной области.

Ещё один объективный критерий для выбора $r$ заключается в стабильности решения. Варьируя задаваемые границы диапазонов изменения $a_{0}, \ldots, a_{3}$, число циклов итерационного процесса, коэффициент конвергенции $K$ и другие параметры расчётов $\theta_{i}$, можно приходить к существенно различающимся результатам. Решение считается стабильным, если его результаты оказываются близкими друг к другу при достаточно широком варьировании описанных начальных условий. В рассматриваемом примере это соответствует значениям $r$ близким к 0,75 .

Таким образом, одновременно несколько критериев - особенности в эволюции коэфффициентов регрессионного уравнения, близость отображающей зависимость кривой к её ожидаемому виду, стабильность решения - приводят к одному значению метрики Минковского $r=0,75$, которое в данном случае с достаточными основаниями можно считать оптимальным. Соответствующее этому значению $r$ регрессионное уравнение имеет вид:

$$
\hat{y}=2,985 \times \exp \left(-2,003 \times d^{0,9649}\right) \times d^{1,947}
$$

Было бы опрометчивым выдавать полученное решение за заведомо безупречное, поскольку в иных условиях, - например, после тщательной выверки исходных данных и устранения возможных “загрязнений" выборки - сведённые в таблицу 2 расчётные параметры могут заметно измениться. Нельзя исключить вероятность того, что и само уравнение (17) не в полной мере соответствует исследуемому статистическому распределению. Замена же регрессионной модели 
другой, более адекватной, может иметь своим результатом выбор иного значения метрики Минковского.

В качестве, по крайней мере, любопытного фракта следует добавить, что значение метрики Минковского $r \approx 0,75$ оказалось близким к оптимальному и в ряде других выполненных автором расчётов с использованием реальных исходных данных.

Пример 2. Анализ функционально-статистической динамики.

Исходными данными для решения данной задачи явились анкеты, заполненные респондентами обширного социологического исследования, которым были охвачены 14 городов в различных регионах бывшего СССР [41]. Большинство из 257 вопросов анкеты были объединены в тематические группы, отражающие личностные и социальные характеристики респондентов, условия их жизни и трудовой деятельности, отношение к различным сторонам окружающей действительности. В частности фриксировались [39,с.114-117]: возраст, пол, уровень образования респондента; характер его трудовой и досуговой деятельности; интенсивность различных внепроизводственных занятий респондента; наличие в его квартире или доме бытовых удобств и предметов длительного пользования; субъективная сценка респондентом требований, предъявляемых к работе, и другие характеристики.

Из более чем трёх тысяч анкет, заполненных взрослыми жителями Хабаровска, полторы тысячи не имеющих нареканий к полноте и качеству заполнения были подвергнуты интенсивной компьютерной обработке с помощью разработанных автором фрормализованных методов, в том числе описываемых в статье. Результаты обработки вместе с исходными анкетами были переданы в единый информационный центр межрегионального исследования и использованы для совместно выполнявшихся анализов [32; 33].

Один из видов компьютерной обработки состоял в построении зависимостей, отражающих взаимосвязи различных видов внепроизводственной деятельности респондентов с их квалификационными характеристиками, Пример такого сопоставления представлен на рисунке 6.

Сравнивались между собой частоты участия рабочих и интеллигенции в различных досуговых видах деятельности, представляемые как фуункции их квалификационных уровней. При этом сами названные уровни выражались в разных показателях для рабочих и служащих. Более того, не совпадали даже соответствующие шкалы: в отношении рабочих использовалась пятизначная ранговая шкала, в отношении служащих - также ранговая, но представленная только четырьмя дискретными значениями.

Приведённые на рисунке результаты сопоставительного функциональностатистического анализа свидетельствуют о существенном сходстве культурнодосуговой активности, характерной для рабочих и служащих России в последней четверти XX в. Подтверждением этого являются значения $s \approx 0 \quad$ и $m \approx 1$ на рисунках 1 (a-2). С другой стороны, значительно отличающимися от названных значениями $s$ и $m$, приведёнными на рисунках $1(\partial, e)$, подтверждается наличие существенной разницы между двумя сравниваемыми социальными группами в отношении двух конкретных видов деятельности.

Следует заметить, что рисунком 6 иллюстрируются сугубо промежуточные результаты исследования, использовавшиеся для отладки разрабатываемых программ и оценки влияния, оказываемого на результаты расчётов используемыми в них варьируемыми параметрами. В частности, демонстрируемые данным рисунком результаты получены при значении метрики Минковского $r=0,75$ и выбранном способе экстраполяции зависимостей, соответствующем их продолжению из конечных точек в направлении общего линейного тренда каждой экстраполируемой зависимости. Такое сочетание устанавливаемых исследователем параметров оказалось предпочтительнее других опробовавшихся вариантов и было использовано в последующих массовых расчётах, проводившихся с тем же массивом исходных данных. 
a)

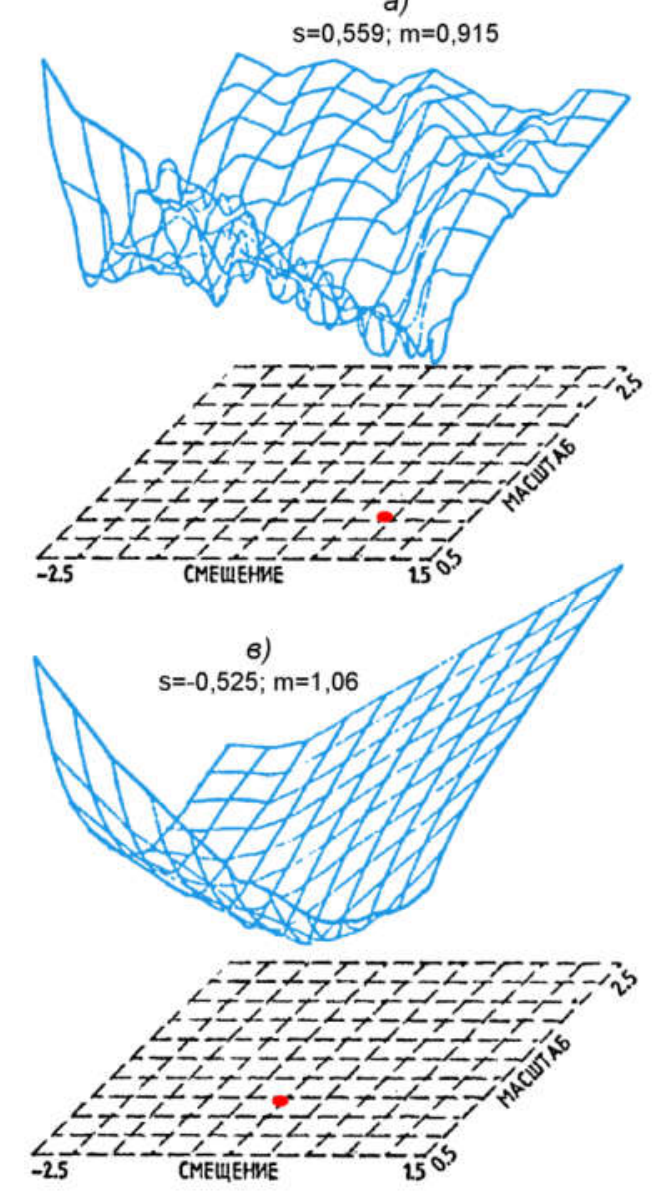

d)

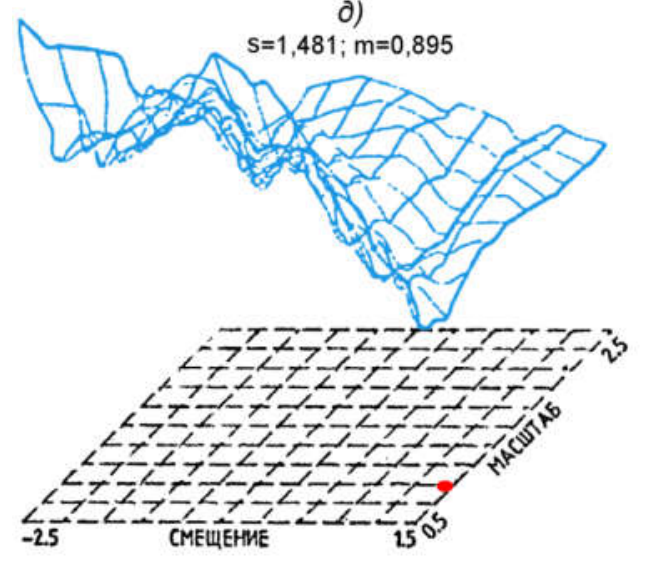

б)

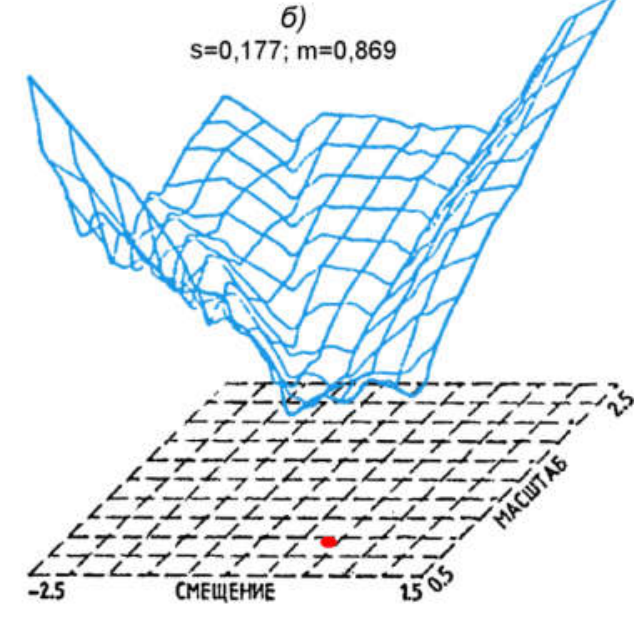

2)

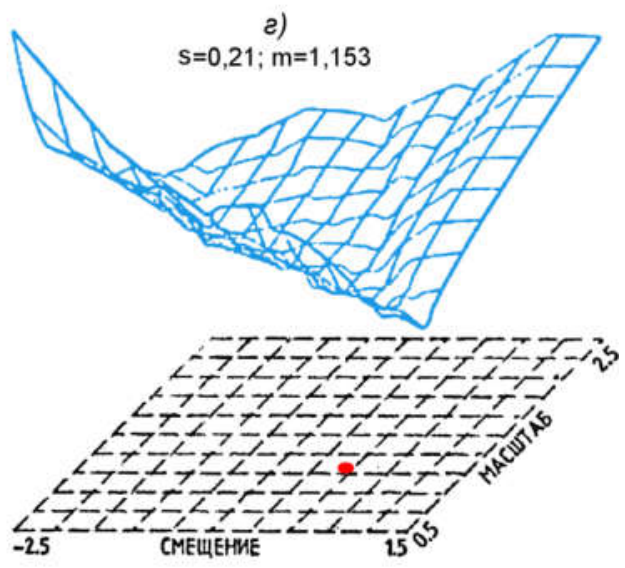

e)
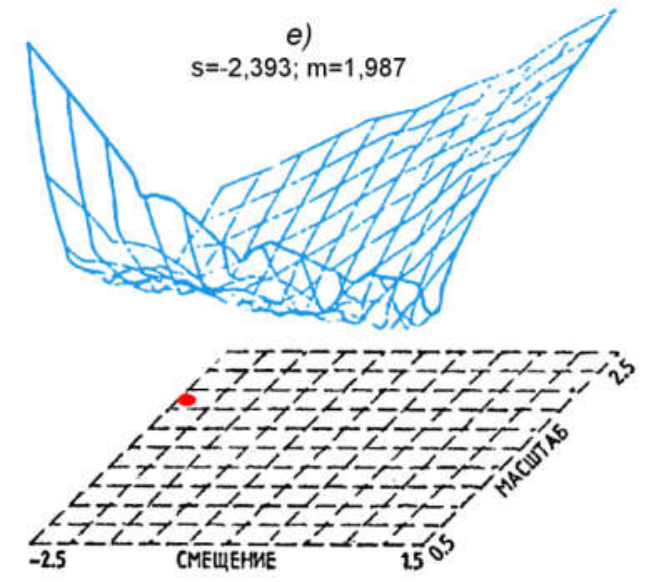

- - проекция глобального минимума функции на координатную плоскость (s,m)

Рисунок 6 - Сопоставление интенсивностей посещения рабочими и интеллигенцией различных культурных мероприятий в зависимости от их квалификационных уровней: а) кино, б) драмтеатра, в) концертов, г) оперы и балета, д) спортсостязаний, е) публичных лекций.

Определившие содержание рисунка 6 зависимости, характеризующие отдельные виды деятельности, в сгруппированном виде представлены на рисунке 7 (в). Особенность всех иллюстрируемых рисунком 7 обобщённых зависимостей состоит в их предельно упрощённом одномерном представлении - в виде точек на виртуальной оси, обозначенной как "интегральный уровень развития". В качестве "эталонных" (опорных) при этом выбраны зависимости, относящиеся к работникам преимущественно физического труда, ранжированным в соответствии с характером их трудовой деятельности по пяти категориям - начиная от неквалифицированных 
рабочих и заканчивая имеющими наивысшую квалификацию рабочимиинтеллигентами. Сопоставляемая с рабочими социальная группа служащих и интеллигенции классифицировалась по четырём категориям - от исполнителей без специального образования до специалистов, руководителей и творческой интеллигенции, чьи трудовые обязанности предполагают как минимум наличие высшего образования.

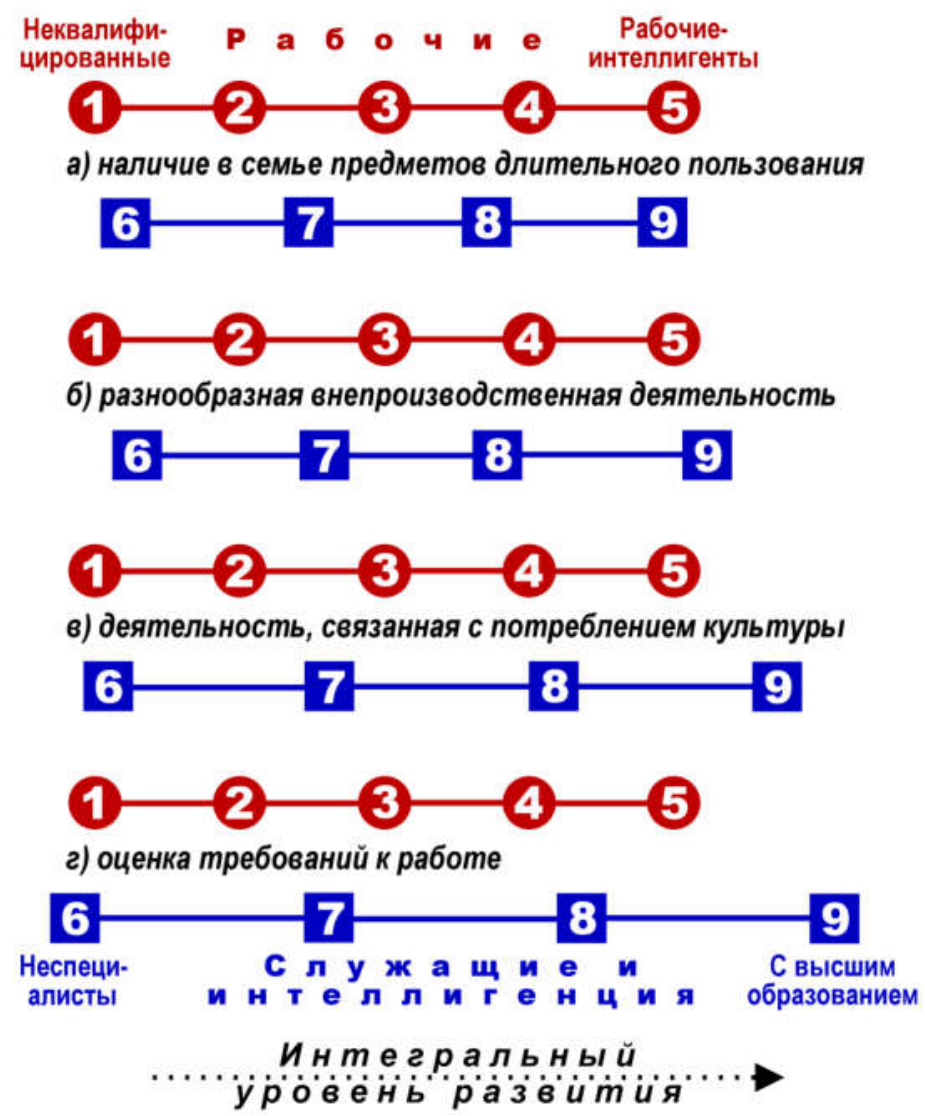

Рисунок 7 - Различия в социально-экономическом статусе, достигнутом рабочими и служащими разных квалификационных категорий, по отношению к уровням их семейного материального благосостояния (a) и отдельным сторонам производственной и внепроизводственной деятельности (б-2) [32,с.26; 33,с.29; 39,с.138].

В качестве примечания к рисункам 6 и 7 необходимо отметить, что фригурирующие на них зависимости являются результатами статистического обобщения большого объёма первичной анкетной информации, выполнявшегося кратко описанными выше методами. При этом чаще всего названные операции были многоступенчатыми: 1) вначале обобщались ответы на один и тот же одиночный вопрос анкеты множества респондентов, рассортированных по изучаемым группам; 2) при наличии "батарейных" (однотипных, взаимосвязанных) вопросов обобщались ответы на них; 3) предыдущие результаты обобщались по отдельности для каждой из выделенных на первом этапе групп респондентов; 4) при необходимости статистически суммировались ответы респондентов, разделённых на группы на предыдущих этапах. По возможности все статистические усреднения осуществлялись с помощью встроенных в компьютерные программы процедур и выполнялись по правилам обобщённых средних величин, описываемых выражением (3).

Обсуждение результатов. Как отмечено выше, описанный алгоритм и реализующие его программы разрабатывались на базе отечественных ЭВМ, достаточно мощных для своего времени и, тем не менее, значительно уступавших по своим техническим параметрам современным аналогам. В первую очередь это касается оперативной и особенно долговременной памяти, на несколько порядков 
уступавших по своим объёмам и быстродействию даже современным ноутбукам. Это наложило существенный отпечаток на структуру алгоритма и особенности его программной реализации. Положительное влияние данного обстоятельства выразилось в концентрации усилий на поиске и реализации программных решений, максимально экономичных в отношении используемых ресурсов ЭВМ, но в то же время приводящих к получению надёжных результатов. Отрицательный эффект ограниченности технических параметров ЭВМ проявился, например, в отказе от эффрективных в вычислительном отношении алгоритмических и программных приёмов, требующих для своей реализации ёмкой и быстродействующей машинной памяти.

Трудновосполнимый удар по идущим полным ходом и нередко весьма успешным исследованиям и разработкам, в том числе авторским, был нанесён произошедшим в конце 1980-х годов переводом отечественной науки на самофинансирование и самоокупаемость [42]. В отношении автора это выразилось в выставлении "задним числом" счёта за использованное машинное время, сумма которого равнялась десятилетней зарплате автора. Результатами этого стали вынужденная смена места работы и полный отказ от основывавшихся на интенсивном использовании ЭВМ теоретико-прикладных инициатив, внезапно ставших экстремально дорогостоящими и поэтому практически неосуществимыми.

Из уже обдумывавшихся и частично начавших осуществляться идей, разноуровневых по своей предполагаемой значимости и оставшихся нереализованными, можно назвать следующие.

- Теоретический поиск, обоснование и разработка вариантов программной реализации средств, аналогичных существующим в общепринятых разновидностях регрессионного и корреляционного анализов и позволяющих оценивать качество выполненных расчётов, проверять связанные с ними статистические гипотезы, устанавливать доверительные интервалы расчётных величин.

- Обоснование и программная реализация способов интерполяции и экстраполяции анализируемых зависимостей, существенно расширяющих возможности единственного реализованного кусочно-линейного способа интерполяции и трёх реализованных аналогичных способов экстраполяции.

- Экспериментальная проверка и практическая реализация нескольких вариантов совершенствования сеточно-градиентного метода функциональной оптимизации, рассчитанных на повышение его надёжности, существующих в настоящее время на уровне в разной степени обоснованных идей и пробных экспериментов.

- Переработка алгоритма и его программной реализации, рассчитанная на максимально полное использование технических и программных возможностей современных компьютеров - многократно возросших объёмов их памяти, расширившегося и обновлённого программного обеспечения, в том числе за счёт существующих пакетов математико-статистической обработки информации.

Несмотря на скоропостижное прекращение поисково-исследовательских и прикладных работ, достигнутыми, по крайней мере, на экспериментальнодемонстрационном, а частично и внедренческом уровнях можно считать следующие результаты.

1. Обоснована перспективность направления развития регрессионного анализа, связанного с расширением состава варьируемых величин, используемых в качестве параметров расчётов. Принципиальной новизной обладает, в частности, включение в состав параметров варьируемой метрики Минковского, позволяющей совместить в одной программе различные способы агрегирования регрессионных ошибок, в том числе далеко выходящие за рамки существующих, и тем самым сделать эту процедуру управляемой, обеспечивающей достижение оптимальных результатов.

2. Продемонстрировано, что многие считающиеся отдельными видами регрессионного анализа его по существу однотипные разновидности, различающиеся лишь конкретными особенностями используемых регрессионных моделей, характером переменных величин, способами интерполяции и экстраполяции зависимостей и т.д., могут быть унифицированы и объединены в одном алгоритме и его программной 
реализации. Это способствует упрощению прикладных исследовательских поисков и повышению их эффрективности.

3. Подтверждена возможность дополнения существующих методов математической статистики новым её направлением, обеспечивающим сопоставление сравниваемых фрункциональных и статистических зависимостей по их амплитуде, скорости протекания и взаимному смещению относительно выбранного ключевого параметра. Необходимость развития данного направления подтверждается наличием множества перспективных областей его приложений, относящихся к разнообразным отраслям производственной и научной деятельности.

4. Разработан и реализован в эффрективных компьютерных программах комбинированный сеточно-градиентный алгоритм, позволяющий при достаточных уровнях точности и надёжности получать искомые результаты при минимальных расходах времени работы ЭВМ и других её технических ресурсов. Существенным достоинством алгоритма является его универсальность, позволяющая сочетать в одной программе решение задач расширенной параметрической регрессии с реализацией прикладных направлений анализа функционально-статистической динамики.

\section{БИБЛИОГРАФИЯ}

1. Мудров В.И., Кушко В.Л. Метод наименьших модулей. - М.: Знание, 1971. 61 с.

2. Рогачёв А.Ф. Параметризация эконометрических зависимостей методом наименьших модулей. - URL: http://uecs.ru/instrumentalnii-metody-ekonomiki/item/3882011-04-04-09-10-38

3. Regression analysis. - URL: https://en.wikipedia.org/wiki/Regression_analysis

4. Андерсон Т. Статистический анализ временных рядов. - М.: Мир, 1976. 755 с.

5. Среднее степенное. - URL: https://ru.wikipedia.org/wiki/Среднее_степенное

6. Mean. - URL: https://en.wikipedia.org/wiki/Mean

7. Среднее Колмогорова. - URL: https://ru.wikipedia.org/wiki/Среднее_Колмогорова

8. Прилуков А.Н. Структура критериев как инструментов социально-экономических исследований и повседневных коммуникаций. - URL: http://modernsciencejournal.org/release/2017/USN_2017_3_tom.pdf

9. Прилуков А.Н. Анализ коллинеарности как инструмент параметрического сопоставления социально-экономических зависимостей. - URL: https://rjoas.com/issue-2017-03/article_13.pdf

10. Электронная вычислительная машина EC-1052. - URL: http://www.computermuseum.ru/histussr/2-52.htm

11. Справочник по ЭВМ. - Киев: Наукова думка, 1989. 544 с. - URL: http://www.pseudology.org/science/Spravochnik_EVM.pdf

12. Казакова И.А. История вычислительной техники. - URL: http://elib.ict.nsc.ru/jspui/bitstream/ICT/1262/1/histor.pdf

13. Дрейпер Н., Смит Г. Прикладной регрессионный анализ. - М.: Статистика, 1973. 392 C.

14. Дрейпер Н., Смит Г. Прикладной регрессионный анализ. Кн.2. - М.: Финансы и статистика, 1987. 351 с.

15. Wesseling P. Introduction to multigrid methods. - URL: https://ntrs.nasa.gov/ archive/nasa/casi.ntrs.nasa.gov/19950019975.pdf

16. Janka A. Multigrid for finite volumes: structured 2D case. - URL: http://perso.unifr.ch/ ales.janka/ papers/volume_aglomer.pdf

17. Мареев B.В., Станкова Е.H. Многосеточные методы. - URL: http://www.apmath.spbu.ru/ru/staff/stankova/publ/publ.pdf

18. Effinger-Dean L., Bailey D. The Empire Problem in Penrose Tilings. - URL: http://www.cs. williams.edu/ bailey/06le.pdf 
19. Bragg D. Tiling Spaces: Quasicrystals \& Geometry. - URL: https://www2.le.ac.uk/departments/mathematics/research/topological/documents/braggpresentation-of-thesis

20. GridPro GUI Manual Version 2.2. - URL: http://sp.gridpro.com/ docs/WS_GUI_Manual_v6.6.pdf

21. Sterz O., Hauser A., Wittum G. Adaptive Local Multigrid Methods for the Solution of Time Harmonic Eddy Current Problems. - URL: http://archiv.ub.uniheidelberg.de/volltextserver/5610/1/preprint.pdf

22. Вальгер С.А., Фёдороаа Н.Н. Применение алгоритма адаптации расчётной сетки к решению уравнений Эйлера. - URL: www.ict.nsc.ru/jct/getfile.php?id=1495

23. Mitra S., Parashar M., Browne J.C. DAGH: User's Guide. - URL: http://mgnet.org/ mgnet/Codes/dagh/tutorial.pdf

24. Flaherty J. E. Finite element analysis. - URL: http://www.cs.rpi.edu/ $\sim$ flaherje/feaframe.html

25. Virtualization-aware application framework for hierarchical multiscale simulations on a Grid. - URL: https://www.researchgate.net/profile/Aiichiro_Nakano/publication/ 228612748_Virtualization-aware_application_framework_for_hierarchical_multiscale_ simulations_on_a_Grid/

26. Октодерево. - URL: https://ru.wikipedia.org/wiki/Октодерево

27. Sundar H., et al. Low-constant Parallel Algorithms for Finite Element Simulations using Linear Octrees. - URL: http://sc07.supercomputing.org/schedule/pdf/pap117.pdf

28. Speh M., Ruede U., Heilmann M. What are Multigrid Methods? - URL: http://mgnet.org/mgnet/tutorials/MG/MG/MGwhat.html

29. The Multigrid Workbench: Linear Iterations. - URL: http://mgnet.org/mgnet/ tutorials/xwb/liniter.html

30. Многосеточный метод. - URL: https://ru.wikipedia.org/wiki/Многосеточный_метод

31. Schlumberger. Introduction to CPS-3. - URL: http://read.pudn.com/downloads130/ doc/556189/train/train/GF4_IntroCPS3_manual.pdf

32. Прилуков А.Н., Кирх А.В. Многомерность социальной структуры и интегральные показатели // Социологические исследования в прибалтийских советских республиках. Ч.2. - Вильнюс: 1986. С. 14-27.

33. Prilukov A., Kirch A., Kukk T. Multidimensionality of social structure and integral indicators // Sociological research in the Baltic Soviet Republics. Part 2. - Vilnius: 1986. P. 14-30.

34. Прилуков А.Н. Толерантный регрессионный анализ и пример его программной реализации. - Хабаровск, 1988. 40 с. Деп. в ВИНИТИ. № 8527-В88.

35. Прилуков А.Н. Толерантный регрессионный анализ: предпосылки, концепции, программная реализация. Препринт / ИГД ДВО АН СССР. - Владивосток, 1989. $48 \mathrm{c.}$

36. Прилуков А.Н. Новые фрормализованные методы анализа объектов и процессов минералопользования // Проблемы комплексного освоения георесурсов. Хабаровск, ИГД ДВО РАН, 2010. С. 197-202.

37. Прилуков А.Н. Идеи толерантного регрессионного анализа и их реализация. - URL: http://modernsciencejournal.org/release/2017/USNO_2017_1_tom.pdf

38. Прилуков А.Н. Расширенная параметрическая регрессия: основные идеи и их реализация. - URL: https://rjoas.com/issue-2017-07/article_03.pdf

39. Прилуков А.Н. Развитие социально-классовой структуры: показатели и методы измерения. - URL: http://search.rsl.ru/ru/record/01008035910

40. Авдеев Н.А. Об аналитическом методе расчёта седиментометрического дисперсионного анализа. - Ростов-на-Дону: Изд-во Рост.ун-та, 1964. 202 с.

41. Советский город: социальная структура. - М.: Мысль, 1988. 286 с. - URL: http://urss.ru/cgi-bin/db.pl?lang=Ru\&blang=ru\&page=Book\&id=133870

42. Шкабардня M.C. - URL: http://www.warheroes.ru/hero/hero.asp?Hero_id=20060 


\title{
DETERMINANTS ON AUDIT QUALITY OF CITY INSPECTORATES IN SOUTH SULAWESI PROVINCE
}

\author{
Usman Asri*, Nagu Nadhira, Syahrir, Sundari Sri \\ Accounting Study Program, Faculty of Economics and Business, \\ University of Hasanuddin, Indonesia \\ *E-mail: asriusman08@yahoo.com
}

\begin{abstract}
This study aims to identify and analyze the effect of leadership style on self-efficacy, the effect of leadership style on emotional exhaustion; self-efficacy influences the emotional exhaustion, and emotional exhaustion on audit quality. This study uses a quantitative approach. The population in this study was all auditors in city inspectorates in South Sulawesi Province, Indonesia. The sampling technique used in this research is purposive sampling where the sampling is based on the consideration or criteria in accordance with the purpose of research. These research data will be obtained by filling out a questionnaires, and direct interviews with respondents. Data are collected through questionnaires and interviews, and are analyzed using quantitative and descriptive analysis techniques.
\end{abstract}

\section{KEY WORDS}

Self-efficacy, leadership style, emotional exhaustion, quality, audit.

The quality of work of auditors relates to the quality of expertise, timeliness of completion of the work, the sufficiency of evidence examination and independence attitude towards clients. According to the regulations of the Minister of State for Administrative Reform No.Per / 05 / M.PAN / 03/2008 on Auditing Standards Government Internal Supervisory Apparatus (APIP) audit quality is affected by the membership stating that the auditor should have the knowledge, skills and other competencies needed to carry out their responsibilities to the criteria the auditor must have a minimum education level Starata one (S1), with competence in auditing, accounting, administration, communications and has been a certified auditor and follow the functional education and continuous professional training.

Adhere to established standards is an obligation that must be carried auditors in their duties, but the reality on the ground auditor doing a lot of deviation on auditing standards and code of conduct, offenses committed by auditors in the examination can be categorized as a deviation in the audit, such as completing audit assignments without through prosudur audit that has been set, changing prosudur previously been defined in the audit field, do not collect sufficient evidence on matters that material, process the data with inaccurate and reported the time of the audit with the total time is shorter than the actual time

Audit quality produced by city inspectorates in South Sulawesi is still in the spotlight. Based on the results of BPK first half of 2014 there were 14 financial statements of local government in South Sulawesi found143 cases of irregularities. Factors causing low quality of audit inspectorate officials is the lack of education and training apparatus functional in the field of supervision, lack of attention on the work, theirsaturation in doing the work that needs to be rotation or change of work regularly and their work unit causing mutations among experienced officers replaced by less experienced and less attention to improving incentives which refer to the changing needs of life erratic.

Empirical evidence from research shows that there are behavioral deviations encountered by the auditor in order to fulfill the responsibilities of his profession. The contributing factor is the individual's internal auditor factors such as self-efficacy, emotional exhaustion and external factor is the leadership style. Internal and external factors can cause irregularities alleged by the auditors in carrying out its duties, it is because the auditor with low self-efficacy, emotional exhaustion unstable and uncommunicative leadership style will work not according to predetermined rules. 
According to Bandura (1997) self-efficacy is a person's belief that he can master the situation and produce results (outcomes) were positive. Self-efficacy is an individual assessment of confidence in his ability to perform tasks that get results as expected.

Saturation in doing the job can lead to emotional exhaustion (emotional exhaustion). According to Cherniss (1980), emotional exhaustion as a response to excessive stress or as a result of dissatisfaction and boredom at work. Source emotional exhaustion can occur in individuals who have a perfectionist personality tendencies or demand excellence in every job (Caputo, 1991).

Self-efficacy and emotional fatigue is influenced by the style of leadership. Leadership create a work environment where individuals are motivated, inspired, challenged, and feel successful. A leader who easily communicate make employees have a say in resource allocation decisions and emotional exhaustion experienced lowered. Conversely, when employees are faced with a demand that is not fixed and notice the lack of their influence on the allocation of resources, they become frustrated, disappointed and dissatisfied. This shows that the leadership has a direct and indirect impact on job satisfaction. Indirect impact is reflected by emotional exhaustion.

\section{LITERATURE REVIEW}

Contingency Theory. Contingency theory approach to identify optimal forms of leadership under different operating conditions and try to explain how the leadership operating procedures. This approach is based on the premise that there is no universally leadership is always appropriate to be applied to any organization, but this depends on factors condition or situation that exists in the organization. Tthrough Home Visits contingency view that effective groups depend on the match between the leader's style that interacts with subordinate so that the situation becomes controllers and influence the leaders.

Theory of Motivation. Motivation is the driving force of one's heart to do or achieve something of interest, or can be regarded as a plan or desire for success and avoid failure of life. The basic principle of motivation is the level of ability (ability) and motivation of individuals who can be said that the performance of a person or group is a function of its ability and motivation. According to these principles there is no task that can be performed well without supported by the ability to carry it out. The ability of an individual talents / groups to perform tasks related to the purpose, but the ability is not sufficient to ensure the achievement of the best performance. The individual must have the desire (motivation) to achieve the best performance.

Resources Conservation Theory (COR). Resources Conservation Theory first popularized by Stevan Hobfoll (1988) which explains about the concept of human experience stress due to aging. This theory does not apply to the stress caused by the loss, investment, profits and trauma. Resources Conservation Theory is essentially a model for understanding the stress which this theory is not assume that people develop when they protect, acquire, maintain and conserve resources. The resources are defined as something valuable that meet the needs of an individual's life.

Self-efficacy. Self-efficacy is one of the self-regulating ability of the individual, the concept of self-efficacy was first proposed by Bandura. Self-efficacy refers to the perception of the individual's ability to organize and implement actions to display certain skills, (Bandura 1997; 391). Pervin (1997) gives a statement reinforcing Bandura above. Pervin states that self-efficacy is the perceived ability to shape the behavior relevant to the task or special circumstances, Pervin (1997) cited by (Smet 1994: 189).

Emotional exhaustion. Fatigue is a protective mechanism the body avoid further damage resulting in the recovery after the break. In this study, emotional exhaustion is "feeling which a person depressed and exhausted because of a job" (Maslach and Jackson 1981; 101). It often occurs when employees provide services, (Cordes and Dougherty, 1993). Professional services required to promote the welfare of their clients request which contains the diversity of cognitive, emotional and human behavior. Actually, the service workers on a 
regular basis often experience negative reactions of consumers and the verbal attack, it can make them faster to feel emotional exhaustion (Cordes and Dougherty, 1993).

Quality Audit. DeAngello (1981) defines quality audit (audit quality) as "market assess the possibility that the auditor will give a) the discovery of a breach in the client's accounting system; and b) any irregularity in the recording. "In the public sector, GAO (1986) defines quality audit is compliance with professional standards and according to the terms of the agreement, which must be considered. Another notion that is used in connection with studies on audit quality is an analysis of the quality in terms of regulations made by government officials. Then the approach of three Schroeder et.al (1986) and Carcello et al (1992) identified an association between the attributes of audit quality and audit quality perceived.

Empirical Overview. Research relating to the quality of leadership has long been investigated and has been done, one of the researchers who conducted the research among others Thorlakson and Murray (1998), which proves that there is a relationship that gained the leadership qualities of an organization or leader of the organization will be able to lead the organization toward more and can develop the potential of the organization.

Research conducted by Mulki et al., (2006) titled "Emotional exhaustion and organizational deviance: Can the right job and a leader's style of make a difference?". This study describes the emotional exhaustion and irregularities organization received more attention because of the negative effects they provide in a loss of productivity of the business sector, decreased job satisfaction, organizational commitment is low, and decreased performance. In this study, focused on the combination of the impact of leadership style and precise work of someone against emotional exhaustion using a sample of workers who provide health and social services in a metropolitan city.

Sigiro and Cahyono (2005) conducted a study of non-production employees of PT Kusumahadi Santoso Surakarta. The purpose of research is to know the difference of job satisfaction in terms of locus of control, personality type and self efficacy. The results of his research is that the external experience high job satisfaction compared with the internal. Then the person who has type A personality experienced higher job satisfaction than those with personality type B. Meanwhile, people who have high self-efficacy tend to have higher job satisfaction than those who have low self-efficacy.

\section{CONCEPTUAL FRAMEWORK AND HYPOTHESES}

Conceptual Framework Research. The conceptual framework of this research is based on the incorporation, development, and modification of some of the concepts and theories. The variables used in this study refers to the theories of motivation, contingency theory and Resources Conservation Theory (COR), as well as other support such a theory of selfefficacy theory, the theory of emotional exhaustion and audit quality.

This study also draws on resources Conservation theory to explore the impact of leadership style and self efficacy on emotional exhaustion. Theory of Conservation Resources shows that emotional exhaustion arises when workers noticed the lack of resources to do their job, (Halbesleben and Buckley, 2004; Janssent et al, (2004). When the workers / employees know that resources are not sufficient to meet the demand for jobs or when additional support personnel provide not the desired outcome emotional exhaustion can appear (Wright and Hofboll, 2004).

Based on the above, then formed a research model that is expected will be a guideline for solving the problems presented in this paper. The model in this study was the effect of leadership style on self-efficacy, emotional exhaustion and their impact on audit quality. The theoretical framework proposed in this study is seen from Figure 1. 


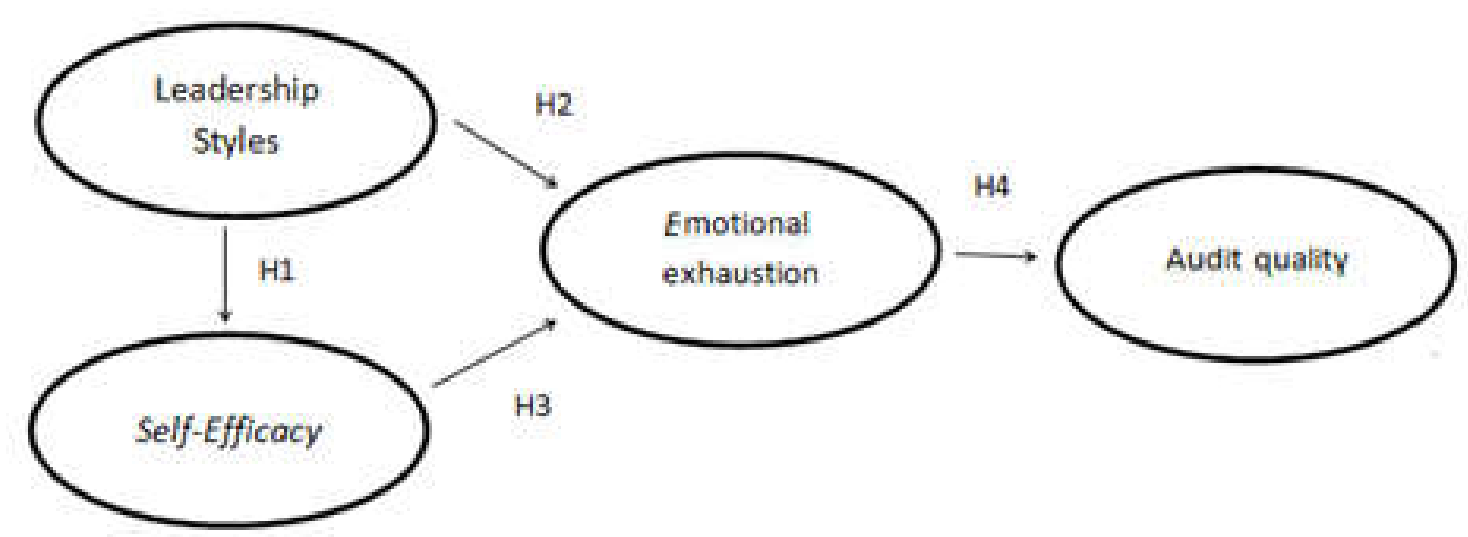

Figure 1 - The Theoretical Framework

The relationship between the variables and the formulation of hypotheses. Based on the formulation of the problem and the conceptual framework that is built, it can be stated logic and formulation of hypotheses as to the following description.

Leadership Style and Self-Efficacy. Leadership style, according to Luthan (2002), "...deals with the way leaders influence followers". Style of leadership with regard to the ways used by managers to influence subordinates. Leadership styles are norms of behavior that used a manager when it affects the behavior of his subordinates.

Self-efficacy is one of the self-regulatory capacity individu.Self-efficacy refers to the perception of the individual's ability to organize and implement action to display a particular skill, Bandura (1997: 391). Pervin et.al (1997) gives a statement reinforcing Bandura above. Pervin states that self-efficacy is the perceived ability to shape the behavior relevant to the task or special circumstances (Smet, 1994: 189-190).

Avolio et al.'s research (2004) concurred with the research Azwar conclude that participative leadership style managers play a very important role in creating confidence \{self-efficacy) for employees. How does a leader influence individuals to behave, behave, and motivate yourself to be one source of power of the individual in the emerging selfefficacy, thus also described by Wicaksono (2008) self-efficacy is an element that can change the vibration of ordinary thinking; of the finite mind, into a form equivalent into the spiritual corridor; and is the basis of all "miracles", as well as a mystery that can not be analyzed by means of science. then:

Hypothesis 1: The leadership style positive effect on self-efficacy.

Leadership Style and Emotional Exhaustion. Style of leadership with regard to the attitudes and behavior of workers; particularly with respect to the perception of the role, job anxiety, job satisfaction, the tendency to stop, and reciprocal Jones. (1996). Leadership styles have a direct influence on attitudes such as job satisfaction but also has an indirect impact on other variables (Anderson and Huang, 2005; Ruyter et al. 2001)

An organizational climate that is suffused with the goal of leadership path changing worker beliefs about their capabilities, minimizing the lack of aid and a loss of confidence, Abraham (1998), thereby decreasing emotional exhaustion. COR theory states that the leadership will produce a high emotional exhaustion since you feel less needed in the absence of a sound or control the resources available to meet demand fulfillment of work (Wright and Hofboll 2004). Results of research Mulki et al. (2006) concluded that leadership style is a key factor in reducing emotional exhaustion. Then:

Hypothesis 2: The leadership style negative effect on emotional exhaustion.

Self-Efficacy and Emotional Exhaustion. Self-Efficacy high performance and contribute to the reduction of the emotional exhaustion. Besides self-efficacy also benefit effectively to the individual to integrate, and use the information to improve the clarity of the role and performance ((Brown et.al 2001). Research Salanova et al, (2002) found no support for the role of moderator Self Efficacy against employees who have high emotional exhaustion and research Grau et al. (2001). Jex et al. (2001) Self Efficacy show that provide support for the 
role of moderator of the employees who have high emotional exhaustion. the results Bandura \& Locke (2003) concludes that individuals with self-efficacy height of more able to cope with threatening situations and difficult than individuals with self-efficacy is low, therefore an individual with self-efficacy height did not experience emotional exhaustion on improving the performance of higher, because people are trying to achieve the goal of employment compared with individuals with low self efficacy. Thus:

Hypothesis 3: Self-efficacy negative effect on emotional exhaustion.

Emotional Exhaustion on Audit Quality. Emotional fatigue resulting from a lack of leadership directives that are more directly linked to the organization rather than between colleagues. This is because workers are often viewed supervisor transform companies that often affect their lives (Strutton et al. 1993). Thus, both the supervisor and the lack of action measures that affect worker attitudes (job satisfaction and organizational commitment) and organizational behavior. and workers who are not satisfied because of the onset of emotional exhaustion on the job often misbehaves towards the organization, otherwise when the worker happy with his work, they reciprocate by helping the organization achieve its objectives (Judge et al., 2006).

Auditor as a profession that provides assurance about the information services of the audit report to the public are required to have knowledge and accounting skills and personal qualities enough. Personal qualities will be reflected in the behavior of his profession. Professional conduct of auditors can be realized in the form of audit irregularities avoiding behavior which in this study is categorized as one of the aberrations of the organization. Behavior audit irregularities in question is behavior that deviates from the auditor auditing standards in conducting audits that can degrade the quality of audit (Harini et al., 2010; 11). Based on these descriptions, then:

Hypothesis 4: Fatigue emotional impact directly and indirectly on audit quality.

\section{METHODS OF RESEARCH}

Research Approach. This study uses a quantitative approach. The focus of this study refers to the theories or hypotheses to be tested as the cause of a phenomenon. The phenomenon can be seen in a unit of analysis in this study is the auditor City inspectoratesin South Sulawesi Province. Data collection from respondents was conducted using a questionnaire and through an interview given to the auditor Inspectorate of the district / city in South Sulawesi Province. The time horizon of this study was cross sectional study at a certain time that is carried out from February to August 2016.

Population and Sampling Techniques. The population in this study were all auditors city inspectoratesin South Sulawesi. The sampling technique used in this research is purposive sampling, that the sampling is based on the consideration or criteria in accordance with the purpose of research. Criteria used investigators to determine the sample is the auditor city inspectoratesthat has a fundamental duty and functionin Rule regent / mayor, one of the points of the job description states "implement guidance, inspection, investigation, testing and assessment areas of development, finance and wealth.

Auditor city inspectoratesin South Sulawesi predicted about 620 auditors. Each district / city received / given a questionnaire based on the number of auditors who meet the established criteria, thus there are 620 questionnaires sent / filled by the auditor of the 25 districts / cities in South Sulawesi. Samples were selected in this study is based on questionnaires returned and deserves to be treated as many as 232 auditors.

Data Collection Techniques. These research data will be obtained by filling out a questionnaire, and direct interviews with respondents. Data were collected through questionnaires and interviews is analyzed using quantitative analysis techniques and descriptive.

Test Validity and Reliability:

Test Validity. Azwar (2003: 90) explained that the validity indicates the extent to which a measuring device (instrument) that measure what you want measured. A concept composed of multiple components or variables. If the validity test instrument invented an invalid 
component, it can be said that the components are not consistent with the other components to support a concept.

Test Reliability. Reliability is an index indicating the extent to which a measuring device is reliable or unreliable. If a measuring device is used twice to measure the same symptoms and the measurement results obtained are relatively consistent, the gauge is reliable. In other words, the reliability of the consistency of a gauge in measuring the same symptoms.

Data Analysis Techniques. Based on the framework of research that has been stated previously, data analysis techniques used in this research is Structural Equation Model (Structural Equation Modelling = SEM). The reason why it is used Structural Equation Modelling (SEM) in this study is based on the consideration that, SEM provides a method directly related to their multiple relationships simultaneously at once, so as to provide the efficiency of statistical analysis and SEM has the ability to examine the relationship comprehensively between the variables studied. Besides SEM is very useful in testing a series of mutually dependent relationship between variables simultaneously, ie when one dependent variable can be independent variables in the equation relationship further.

Operational Definition and Measurement:

Leadership style. Leadership style is the pattern of behavior exhibited by that person at the time affects the activity of other people as perceived others. The variables measured in this study is limited to the instruments directive leadership style and supportive leadership style. The indicators used for the two-dimensional variables above using 17 items of questions.

Self-Efficacy. Self-efficacy a belief in one's ability to perform the task. Self efficacy variable was measured with an instrument developed by Jones in 1996 consisting of seven of the questions.

Emotional Exhaustion. Emotional exhaustion experienced by a person is feeling depressed and exhausted because of a job (Maslach and Jackson, 1981: 101). This variable is measured with an instrument developed by Hobfoll $(1988 ; 1989)$ which consists of nine items of questions.

Audit Quality. Audit quality is a test carried out thorough and regular financial statements in assessing the consistency, accuracy and fairness of the application of generally accepted accounting standards

\section{RESULTS AND DISCUSSION}

Descriptive Analysis:

Leadership Styles. In this study, the measured variable is limited to the instruments directive leadership style and supportive leadership style. Perception auditor's leadership style variable for the dimensions of directive leadership style can be interpreted that the respondents rated it good / important, it can be seen from the average value of 4.02 . This means that auditors felt the team leader's involvement in giving assignments, understanding the assignment, deciding task to be done, providing the information required by the team members, and at the time of carrying out the work and give advice in completing the audit assignment. In addition the team leader is also scheduled work team members, maintaining the performance standards defined and team leaders ask team members to comply with the regulations and rules applicable standards.

Furthermore, the auditor's perception of the leadership style variable for the dimensions of supportive leadership style can be interpreted that the respondents rated it good / important, it can be seen from the average value of 3.93. This means that the auditor feels the team leader is a person who is friendly and easy to understand, treat all members are equal with him, paying attention to the progress of work of the team members, also explain how to complete the audit tasks to be performed by members of the team Besides the team leader also do those little things that make the audit team happy to be a member of the audit team, the team leader showing care and concern for the welfare of the team members and team leaders to help make his job so easy to do. 
The average overall of two-dimensional (directive and supportive leadership style) measurement of leadership style is 3.98. This illustrates that the style of leadership in the inspectorate, as measured by the dimensions and with each of the indicators above show leadership styles that can direct and give suppor / auitor support to carry out their duties.

Self Efficacy. Self efficacy variables measured with instruments, which consist of seven the questions. it can be seen that of the 232 people surveyed auditor auditor general perception towards self efficacy variables can be interpreted that the respondents rated it good / important, it can be seen from the average value of 4.22 . This suggests that selfefficacy is already well owned auditors with confidence in their ability to complete the audit work both challenging job or a job that requires the help of facilities and the help of friends.

Emotional Exhaustion. This variable is measured with an instrument that consists of nine items of questions. It can be seen that of the 232 people surveyed auditor general perception of the variables emotional exhaustion can be interpreted that the respondents give enough value, it can be seen from the average value of 2.63. This indicates that the auditor find a job as an auditor simply create emotional exhaustion.

Audit Quality (Y4). Based on the results of the study showed that of the 232 people surveyed auditor general perception auditor to audit quality variables can be interpreted that the respondents give enough value, it can be seen from the average value of 2.61. This suggests that auditors often find and report errors that it finds or it can be said that the quality of audits produced by the auditor Inspectorate of the district / city is still quite good.

Hypothesis testing:

Leadership style and self-efficacy. Leadership style has a significant positive effect on Self Efficacy with $P=0.000>0.05$ with a coefficient of 0634, this coefficient indicates that the style of leadership that will either make self efficacy auditor is getting stronger.

This indicates that the style of leadership that gives direction and support to auditors who carry out the audit work can increase and improve self-efficacy of auditor in completing the work. This finding is consistent with Azwar (1996) self-efficacy is a person's belief that he is capable of performing a specific task well where a person's beliefs to perform certain tasks properly influenced by the style of leadership, attitudes and behavior.

The above results are supported by the fact the field in a directive leadership style that the team leader who usually give advice to members of the audit team for the completion of the audit assignment. Furthermore, to the style of supportive leadership for example team leaders always pay attention to the progress of work of the audit team members, team leader also explains how the completion of audit tasks which must be performed by the audit team members, team leaders also help overcome the problems faced by members of the audit team until the completion of an audit until finish.

This study is in line with the theory of contingency Path goal for leader behavior is acceptable when the auditors looked at the direction and support (supportive) as a source of inspiration and motivation. Support auditor to the leader because of the experience and capacity that is owned by its leader is already quite mature it can be seen from the number of auditors whose age is above 36 years ranges from $46.55 \%$, where the age range have got the confidence as a team leader in a field audit assignment.

Leadership styles and emotional exhaustion. Leadership style no significant influence on the emotional exhaustion with $P=12: 08>0.05$ with a coefficient of 0183 , this coefficient indicates that a good leadership style does not make emotional exhaustion decreased. leadership not significant effect on emotional exhaustion auditor.

This means that the style of leadership that gives direction and support emotional exhaustion auditors carry out their duties in the face and still can happen. This finding is not in line with Ruyter et al., (2001), which states that the style of leadership has a direct influence on attitudes such as job satisfaction but also has an indirect impact on other variables such as emotional exhaustion.

The results of this study indicate that the leadership style does not affect emotional exhaustion. This is supported by the theory of the destination path (path-goal theory), leader behavior is acceptable when employees see it as a source of satisfaction, subordinate to 
actively support leaders as long as he considers that the actions leaders can improve the level of satisfaction with Hughes et al. (1999).

The results mentioned above are supported by the fact the field in a directive leadership style that the team leader always decide what and how to work to do its members, the team leader to schedule work to be done by team members other than the chairman of the team also provide the information necessary for the work of the audit team members but because of the quantity and frequency of audits of a number of SKPD to be covered so much so as to make the members of the audit team was tired with his work as an auditor responsibility. Similarly, in the style of supportive leadership that the team leader is always paying attention to the progress of work of the audit team members, in addition to the head of the team always pay attention and concern for the welfare of members of the team but it still makes team members feel tired in completing the work as an auditor in particular the existing auditor the team members who always expect the result of the occupation have to be perfect (perfect).

Self-efficacy and emotional exhaustion. Self efficacy has a significant negative effect on emotional exhaustion with $P=0.000>0.05$ with a coefficient of -0.468 , these coefficients indicate that self-efficacy is owned by auditors can reduce emotional exhaustion auditor.

This shows that with high confidence that the auditor to do the job can create emotional exhaustion auditor declined to employment faced. These findings are consistent with research conducted by Bandura (1997) concluded that individuals with self-efficacy height of more able to cope with threatening situations and difficult than individuals with self-efficacy is low, therefore an individual with self-efficacy height did not experience emotional fatigue on performance improvement more high, because people are trying to achieve the goal of employment compared with individuals with low self-efficacy.

The results mentioned above are supported by the facts on the ground that the auditor believes can complete any audit work assigned and can perform these tasks well even if the task is complex, especially if supported by a complete facility, this does not make the auditors feel tired of working, no need to deploy all the capacity and power to complete the audit work that is its responsibility. High trust (self Efficacy) Owned by an auditor selected for ability and experience lead as complicated and as much as any audit work encountered can be resolved, so that self-efficacy has an auditor who can lower or eliminate emotional exhaustion caused by the complexity and amount of work faced.

Emotional exhaustion and Audit Quality. Emotional exhaustion direct negative impact is not significant on audit quality of -0.026 , this coefficient indicates that the emotional kelehan does not affect the quality of auditing despite the negative direction.

The test results showed that emotional exhaustion negative direct effect and no significant effect on audit quality. This indicates that the audit team members who experience emotional exhaustion or not experience emotional exhaustion in performing his job does not affect the quality of their audit. This finding is consistent with Barnes (1980), which says there are several factors that affect the level of fatigue include hours of work, the physical condition of the working environment that influence physical comfort, attitude and mental labor is reduced or eliminated as far as possible in order to create favorable working conditions.

The above results are supported by the facts on the ground that the auditors feel pressured to audit work does not make the work of the auditor is qualified or not. The extent and the number of inspection items that must be completed by the auditor with the time that has been scheduled to make auditors vulnerableg experiencing emotional exhaustion, this does not affect the audit work resulting from audit work has become rutinuitas seoranga inspectorate auditor every day.

\section{CONCLUSION AND RECOMMENDATIONS}

Based on the research results, several conclusions can be made:

Leadership style positive effect on self-efficacy, it indicates that the style of leadership that will either make self-efficacy or confidence auditor higher. 
Leadership style has no effect on emotional exhaustion auditor; it shows that good leadership style does not make emotional exhaustion decreased.

Self-efficacy negative effect on emotional exhaustion, it shows that self-efficacy is owned auditor may reduce emotional exhaustion auditor.

Emotional exhaustion significant negative direct effect on audit quality, this indicates that the emotional exhaustion auditor does not affect the quality of auditing despite emotional exhaustion auditor in working low or declining.

Following the above conclusions, several suggestions can be made:

Auditor inspectorate still need training related to management leadership so that the auditor acting as team leader in audits can be more effectively lead their team members to be able to complete audits in lapanngan.

Confidence (self-efficacy) auditors tasks inspectorate to audit needs to be improved with a lot of training related to the duties as auditor.

To avoid emotional fatigue caused due to dense audit in the auditor inspectorate inspectorates need to understand the regulations and code of conduct audits, audit communication, technological mastery and taxation and audit psykologi.

\section{REFERENCES}

1. Abraham, R. 1998 Emotional dissonance in organizations: A conceptualization of consequences, mediators and moderators. Journal Leadership Organization Development 19 (3):137-46.

2. Anderson, R.E., Huang W-R. 2005. Empowering salespeople: Personal, managerial, and organizational perspectives. Psychol Market 23(2):139-59.

3. Avolio, B.J., Zhu, W., Koh, W., Bhatia, P. 2004. Transformational leadership and organizational commitment: Mediating role of psychological empowerment and moderating role of structural distance. Journal Organization Behavior, 25(8):951-68.

4. Azwar, S. 2003. Sikap Manusia: Teori dan Pengukurannya. Edisi Kedua. Yogyakarta: Penerbit Pustaka Pelajar.

5. Bandura, A. 1997. Self-efficacy: the exercise of control. New York: W.H. Freeman/Times Books.

6. Bandura, A. \& Locke, E.A. 2003. Self-efficacy and purpose of negative effects. Journal of Applied Psychology, 88, 87-99.

7. Barnes, R.M. 1980. Motion and Time Study, Design and Measurement of works. Seventh Edition. John Wiley and Sons, New ork.

8. Brown, Stevan P., Ganasan, Shankar and Challagalla, Goutam. 2001. "Self - Efficacy as a Moderator of Information Seeking Effectiveness". Journal of Applied Psychology. Vol. 86. No. 5.

9. Caputo, J. S., 1991. Stress and burnout in library service.Canada : the Oryx Press

10. Carcello, J.V, R.H. Hermanson, and N.T. McGrath. 1992. Audit Quality Attributes : The Perceptions of Audit Partners, prepares and Financial Statement users, Auditing : A journal of Practice \& Theory 11 (Spring) ; 1 - 15

11. Cherniss, C., 1980. Staf burnout : Job stress in human services. Baverly Hills ; Sage Publication.

12. Cooley, C.H. 1930. Sociological Theory and Social Research. New York: Henry Holt and Company.w and an integration of research on job burnout. Academy of Management Review 18, 621-656.

13. Cordes CL, Dougherty TW., 1993, A review and an integration of research on job burnout. Academy of Management Review, 18, 621-656.

14. DeAngelo, L. 1981. Auditor Independence, Low balling and disclosure regulation, journal of Accounting and Economics, Aug $113-127$

15. Gao JP, Chao, DY, and Lin, HX, 1986. "Understanding abiotic stress tolerance mechanisms ; recens studies on stress response in rice. Journal Integrate Biology. 75; 537-553. 
16. Grau, Artis A.B., Walters, J.H., Licata, J.W. 2001; Role Stressor, Service Worker Job Resourcefulness and Job Outcomes : An Empirical Analysis. Journal of Business Research 59, pp 779-791.

17. Halbesleben JRB, Buckley MR, 2004. Burnout in organizational life. J Manage; 30(6):859-79.

18. Harini, Dwi., Agus Wahyudin \& Indah Anisykurlillah. 2010. Analisis Penerimaan Auditor atas Dysfunctional Audit Behavior: Sebuah Pendekatan karakteristik personal auditor. Simposium Nasional Akuntansi XIII Purwokerto

19. Hobfoll, Steven E. The Ecology of stress. Hemisphere; New York 1988

20. Hughes, R.L., Giannett, R.C. \& Curphy, G.J, 1999. Leadership Enchancing the Lessons of Experince. New York; McGraw-Hill Irwin.

21. Janssen PPM, Peeters MCW, Jonge Jd, Houkes I, Tummers GER. 2004. Specific relationships between job demands, job resources and psychological outcomes and the mediating role of negative work-home interference. J Vocat Behav;65(3):411-29.

22. Jex, S. M. P.D. Bliese, S. Buzzell, and J. Primeau. 2001. The Impact og Self Efficacy on Stressors=Strain Relations : Coping Style as an Explanatory Mechanism. Journal of Applied Psychology. Vol. 86 (3), p. $401-409$.

23. Jones, G.R. 1996. Socialization tactics, self efficacy and newcomers adjustments to organizations. Academy of Management Journal, 29. Pp. 262-279..

24. Judge, Timothy A. 2006. Promote ob Satisfaction Through Mental Challenge. The Blackwell Handbook of Principles of Organizational Behavior. Blackwell Publishing: Victoria-Australia

25. Luthans, Fred. 2002. Organizational Behavior, Ninth Edition. Singapore: McGraw-Hill International Editions.

26. Maslach C. \& Jackson S.E., 1981, The measurement of experienced burnout. Journal of Occupational Behavior 2, 99-113.

27. Mulki, J. Prakash, F. Jaramillo, and W.B. Locander 2006. "Effect of Ethical climate and supervisory to trust on sales person's job attitudes and intentions to quit". Journal of Personal Selling and Sales Management. Vol. XXVI. No. 1. Winter, pp. 19-26

28. Pervin, L. A., \& John, O. P. 1997. Personality: Theory and research (7th edition). New York: John Wiley \& Sons, Inc.

29. Ruyter, K., Moorman, L. and Lemmink, J. 2001. Antacendents of commitment and trust in customer-supplier relationships in high technologi markets, Industrial Marketing Management, Vol. 30 No. 3, pp. 271- 86.

30. Salanova, M., Schaufeli, W. B., Llorens, S., Peiro, J, M., \& Grau, R. 2002. Desde el "burnout" al "engamement" : una nueva perspective (From "burnout" to "engagement" : A new Perspective). Revista de Psicologia del Trabajo de las Organizaciones, 16, 117-134.

31. Sigiro dan Cahyono, 2005, Analisis Perbedaan Tingkat Kepuasan Kerja ditinjau dari Locus of Control, Tipe Kepribadian dan Self Efficacy, Jurnal Bisnis dan Manajemen, Vol. 5, No. 2.

32. Smet, B. 1994. Psikologi kesehatan. Jakarta : PT. Gramedia Widiasarana. Indonesia.

33. Stevan Hobfoll. 1988. Resourcce Conservation as community psychology, Kent State University. Jurnal Komunitas Psikologi 21,128-147.

34. Strawser, Robert H, John M, Ivencevich., and Herbert L. Lyon, 1969. A Note on the Job Satisfaction of Accountang in Large and Small CPA Firms, Journal of Accounting Research, Vol 7No. 2 pp 339- 345

35. Thorlakson Alan J.H. \& Robert P. Murray, 1998, "An Empirical Study of Empowerment in the Workplace", Journal Group \& Organization Management, Vol. 21 No.1 pp: 67-83.

36. Trisnaningsih, S. 2004. Pengaruh Komitmen terhadap Kepuasan Kerja Auditor: Motivasi sebagai Variabel Intervening (Studi Empiris pada Kantor Akuntan Publik di Jawa Timur), Jurnal Riset Akuntansi Indonesia, Vol 6, No.2, Mei, 199-216.

37. Wicaksono, 2008. Pentingnya Sebuah Keyakinan Diri.

38. Wright TA, Hobfoll SE., 2004, Commitment and psychological well-being and job performance: An examination of conservation of resources (COR) theory and job burnout. Journal Business Management, 9(4): 399-416. 
DOI https://doi.org/10.18551/rjoas.2017-08.13

\title{
INNOVATIVE METHODS FOR WORK PROCESS DESIGN IN A HIGH TECHNOLOGY ENTERPRISE
}

\author{
Novikov S.V., Candidate of Economic Sciences \\ Moscow Aviation Institute (National Research University), Moscow, Russia \\ E-mail: ncsrm@mail.ru
}

\begin{abstract}
The article presents conceptual framework of work flow structure in a high-technology enterprise of science-based industries. Direct correlation of technology lag in work management level is considered. The article suggests new methods for work flow design based on organic connection of scientific and technological achievements with the contents, form, conditions and methods of work process structure.
\end{abstract}

\section{KEY WORDS}

High-technology manufacturing, methods for work process structuring, science-based industry, innovations in engineering, work process design.

In modern society, work process should be based on science and best practices achievements, on the connection between people and technology. This is due to the fact that the content of any work process is determined by a specific technology process and that the trends in scientific and technological progress determine the main changes in the content of the work process and, consequently, in human work activity. Due to the fact that overall trends of scientific and technological progress are related to some particular conditions of work process (somehow or other affecting a human body), a person is able to change a lot in the technological process itself and in the work and manufacturing structure. Being an important element of production force, technology is developing rather fast. However, only following the adoption of the new technology it is possible to develop the form, methods and conditions for the work process structure of the employees, working with the equipment, and this development process is not automatic. There are many examples of the lagging behind in the rapid pace of technological progress at the appropriate level of the work process structuring. On the basis of this inconsistency occur contradictions and imbalances in the development of technological progress, and the main direction of scientific and technological progress is the integrated automation and integration of production processes related to the introduction of advanced equipment (numerically controlled machines, flexible production modules, etc.) and automated management systems. Such progress tends to eliminate completely or partially parts of non-mechanized manual labour and to cause significant shifts in the structure of work process. By drastically reducing the use of manual labour, automation and integration create new types of work that require a thorough knowledge of production technology that is intellectually acquired but still involved in physical efforts. Thus, by improving the means of production and technology, people are also going through a famous self-improvement process.

Improving the nature and content of work in a context of production intensification requires continuous improvement in the organization of jobs and the design of work processes, taking into account technical, economic, psycho-physiological and social factors. Therefore, in order to increase efficiency in production, there is a need to organically link advances in scientific and technological progress with the content, forms, conditions and methods of the work structuring. It is impossible to turn production on the path of overall intensification, while preserving old organizational forms of work. The creation and largescale introduction of innovative technology, modernization of funds and production continuously alter the working environment, causing significant shifts in the structure of the work processes.

Employees have drastically different work process structures and functions. However, 
any work process has some amount of work functions that require a person's physical, emotional and intellectual effort. In light of all of the above, it is possible to outline the following work process structures: predominantly physical labour; predominantly emotionally stressful work; combining physical and emotionally stressful work.

While forming the best possible structure of the work process, which ensures the most appropriate use of the equipment, working time, production skills and creativity of each member of the team special attention should be paid to the design method independent of its structure.

The design of work processes refers to the creation of a working environment in which work processes are most efficient and least tedious. This is achieved through the selection of a suitable work position, the best possible external and internal layout of the workplace, the necessary equipment, the rational placement of the instrument and the use of best practices and working methods. The economic literature is not sufficient from the point of view of work process design. As a rule, most authors confine themselves to work process structure analysis and describe work process design as a design of individual components of the work process or parts of the work process project. This does not take into account the changes in the composition of the work process, its relationship and interaction, or social demands. The presenter is considered to be the holder of the necessary capacity. With regard to the work process design methods, the analysis of literature and methodological recommendations on the subject has shown that theory and practice now suggest the use of the following methods: analytic and regulatory; balancing; analytic and logical; line graphs; mass service theory; network diagram (graph); mock up.

Analytic and regulatory design method consists in setting the parameters of work processes on the basis of the already existing work regulations, equipment and other work conditions. This method, on the one hand, reduces the labour-intensive of designing of the constituent elements of the work process, since it eliminates the need for specific observations to be made in the workplace, but on the other hand all calculations of the parameters of the work process are approximate and far from the specific work conditions. Moreover, the analytic and regulatory method does not allow for the entire structure of the work process to be covered because of the limited number of work standards applied in practice. For example, there are no regulations on social aspects of human work. Accordingly, it may be applied only in a limited manner (mainly at the stage of production development of new types of products).

Balancing method consists in defining the parameters of the work process on the basis of experience in designing similar work processes considering production and technical conditions of a particular workspace. This method does not require special observations and sometimes makes it difficult to identify bottlenecks in the designed composite elements of the work process and, consequently, to increase the efficiency of workers.

The analytic and logical method is based on the monitoring of the existing work process in the workplace, followed by its comparison with a similar work process of the advance worker to identify ways of saving of working hours on the negative parameters of the work process being analyzed. In this case, the design of the work processes is limited to the development of appropriate recommendations to improve the negative parameters of the work process. In addition, the absence of a regulatory framework in this method (as well as in the balancing method) carries the potential for subjectivity in optimizing of design elements of the work process, which has a certain impact on work efficiency performance.

The methods of line graphs and mass service theory are based on the application of mathematical methods. However, these methods cannot describe the entire structure of the work process because of the multiplicity of factors that cannot be mathematically formalized, because they are based on qualitative information. Such factors include, for example, social factors. This leads to the fact that only some factors that influence the work process content are mathematically described in the design process; the designed constituent elements of the work process are not objective enough and are to a certain extent detached from an individual.

The network diagram method is used in the design of the work processes primarily to 
determine the total of succession or parallel work performed to implement the technological process. The difficulty of using this method is that the work process, because of its complexity and dynamism, is difficult to fix in a "sculpturesque" manner.

The mock-up method is based on an ergonomic approach to the design of the work process. The method only allows analysis of the organization of jobs.

It should be noted that the above-described methods of design of work processes aimed at improving the organization of work in enterprises have been applied mainly at a time when the level of technical sophistication of work processes has been relatively low and technological upgrading has been slow. In the context of scientific and technological progress acceleration, these methods cannot be used as universal. Due to their shortcomings, which can be summarized as follows. The existing methods basically allow for the design of the work process, not as a whole, but as scattered parts of the process. This results in a complete or partial mismatch of the constituent parts of the work process in the implementation phase, requiring additional work to fillet the parts and, consequently, additional capital investment. Eventually, this is reflected in an increase in the adoption time of the new product, which is undesirable in modern business environments.

As is well known, the production process and the related work processes in the context of scientific and technological progress are very dynamic and require constant improvement; however, the existing design methods do not take into account the dynamism of these systems, but rather build a model of the work process discretely, only for a certain amount of time. The latter sometimes results in the inadequacy of the designed work process and the production environment in the implementation phase.

It should be noted that the typical work process designs, which form the basis of typical labour structure designs, were developed by sectoral institutions in 1980-1988 in accordance with the above design methods and have similar disadvantages. New developments in this field are few in number and are mostly found in enterprises where lean manufacturing systems are in place. This leads to under-coverage of the elements of the work process and affects the economic and social performance of enterprises. Thus, the author's analysis of the design of work processes in the aviation industry over the past three years has revealed that the existing deficiencies in the design and structuring of work processes lead to: low amount of employees holding a second job. Thus, by the end of 2016, only 12 per cent of all workers had a side job, with only 5.8 per cent having three or more occupations; relative increase in the number of workers performing manual work, having access to machines and machinery equipment compared to the number of workers performing similar work by means of machinery to monitor and repair the machines. In this case, fewer performers are moved out of the process than there are involved (by the mechanization and the automation of the work processes); increase in the number of workers employed in manufacturing, production dept., and work with harmful working conditions; significant loss of time; every worker is not involved in the production 12 to 15 days annually; reduce in the level of capital productivity; lagging of the growth rate of labour productivity from the growth of its capital-to-labour ratio.

Thus, the issue of choosing a method of designing work processes that would have the merits of all the methods discussed above is now becoming relevant. And could serve as a universal basis for the design of work processes of any production and would be based on the principles of an integrated multidimensional approach, with a view to the organic connection of technological and economic, psycho-physiological and social aspects of human work. That is, the work process, in the diversity of the connections, functions, goals and objectives between its constituent parts during design process, must be seen as a single complex social and economic process.

\section{REFERENCES}

1. Novikov S.V., Meshankov D.V. Present-day personnel policy implementation in Russia: challenges and risks. Competitiveness in a globalized world: economy, science, technology. 2017. No. 3-3 (34). Pp. 113-115. 
2. Tikhonov A.I. Institutional aspects of state personnel policy in Russia. Management and business administration. 2017. No. 2. Pp. 25-32.

3. Nikolaev A.V., Tikhonov A.I., Novikov S.V. Civil statesmen professional activity efficiency assessment. Russian technology journal. 2014. No. 4 (5). Pp. 284-295.

4. Tikhonov A.I., Kraev V.M. Action against fraud in staff management. Teaching material / Stavropol, 2017.

5. Korzhueva L.M., Novikov S.V. The development of regulatory framework and background for forming an innovative educational complex. Collected book: Post-crisis outlining of innovative processes. Ed. by R.M. Nizhegorodtseva. 2010. Pp. 237-241.

6. Korzhueva L.M., Novikov S.V. Improving the efficiency assessment system of educational complex innovative target program. MAl works. 2010. No. 41. P. 25.

7. Gusakov A.G., Novikov S.V. Balanced system problems of motivating personnel in Russian enterprises. Collected book: Economy and management matters and issues in a present-day world. Collection of research papers summarizing the results of the international academic and research conference. 2016. P. 264-266.

8. Semina A.P., Fedotova M.A., Tikhonov A.I. Personnel training in present-day companies: problems and new fields. Moscow economic journal. 2016. No. 3. P. 33.

9. Kraev V.M., Tikhonov A.I. Risk management in dealing with personnel. Competitiveness in a globalized world: economy, science, technology. 2016. No. 8-2 (21). pp. 22-25. 
DOI https://doi.org/10.18551/rjoas.2017-08.14

\title{
ANALYZING AND MODELING THE ROLE OF HUMAN RESOURCE INFORMATION SYSTEM ON HUMAN RESOURCE PLANNING AT HIGER EDUCATION INSTITUTION IN INDONESIA
}

\author{
Susilo Heru*, Astuti Endang Siti, Wiyata \\ Department of Business Administration, Faculty of Administrative Science, \\ University of Brawijaya, Indonesia \\ *E-mail: herususilo@ub.ac.id
}

\begin{abstract}
The challenge of Human Resource Management in Higher Education Institutions is how to plan, organize, and assess the performance of human resources so as to contribute as much as possible to the achievement of high quality education objectives. To answer these challenges, the role of Human Resources Information System (HRIS) is needed to facilitate leadership both at the university and faculty level in preparing the needs planning and utilizing the advantages of human resources. This study aims to analyze the role of HRIS in human resource planning, especially in the stages of needs planning activities, recruitment and selection, human resources development, promotion and promotion, and assessment of work and remuneration. The output of research resulted in the form of HRIS-based human resource planning concepts for Higher Education Institutions. The research method was designed using qualitative descriptive approach. Data collection is done through observation technique and interview with research location in University of Brawijaya. The results show that the existing HRIS has not played an optimal role because the function of the system is still limited as a data gathering medium and the submission of employment reports that have not been able to contribute as a decision support system for leaders in HR planning.
\end{abstract}

\section{KEY WORDS}

Role, planning, higher education, institution.

Human Resources (HR) is an important factor in running the wheel of the organization The challenge of Human Resource Management (HR) in Higher Education Institutions is how to plan, organize, and assess the performance of human resources owned so as to contribute as much as possible to the achievement of high quality education goals. As universities grew bigger, with a growing number of students it was demanded to be able to provide better services, faster, and accurate although the number of human resources owned is limited. Therefore, the role of Human Resource Information System is very necessary to facilitate the leadership in preparing the needs planning and utilizing the benefits of human resources owned. HRIS is a systematic procedure for collecting, storing, maintaining, displaying and validating data required by the organization on human resources, human resource activities, and organizational unit characteristics (Kovach et al., 1999).

\section{LITERATURE REVIEW}

Human Resource Planning is a process that ensures an organization has the right amount of human resources and type at the right place and time and can streamline and streamline the task and achievement of all organizational goals (Nagendra and Deshpandi, 2014). Mondy \& Noe (1995) defines HRP as a process that systematically examines the state of human resources to ensure that quantities and qualities with appropriate skills will be available when they are needed. Cherian (2011) defines HRP as the process of forecasting demand and supply of human resources by recruiting the right employees, and having the right skills according to the needs of the organization. HRIS by Kavanagh, Thite, and Johnson (2012) is defined as a system used to search, store, process, reproduce, and distribute information related to human resources within the organization. HRIS (Human 
Resources Information System) is a system used to acquire, store, manipulate, analyze, retrieve and distribute relevant information with human resource organizations. McLeod (2001) reveals the conceptual system used in managing personnel called the Human Resource Information System (HRIS). HRIS serves to accelerate decision-making, development, planning, and HR administration processes because data is easily stored, updated, classified, and analyzed (Sadri and Chatterjee, 2003).

Nagendra and Deshpande (2014) undertook research on Human Resource Information Systems (HRIS) in HR planning and development in mid to large sized organizations. This study aims to identify the contribution of HRIS in the employment recruitment system to the organization, to investigate the contribution of HRIS to training and Developing the workforce of the organization, and exploring the overall contribution of HRIS in HR decision making and aligning HR strategies with organizational strategy. The study used descriptive qualitative methods, primary data were collected using questionnaires from 50 senior executives and junior managers in three organizations in Pune India. The results show that overall HRIS use has contributed greatly to the efficiency and effectiveness of HR planning.

Khera and Gulati (2012) in a research entitled Human Resource Information System and Its Impact on Human Resource Planning: A Perceptual Analysis of Information Technology Companies, conducted a study aimed at investigating the role of HRIS on HR planning in information technology organizations by taking a sample of 127 Respondents from 7 information technology companies. The research was designed using exploratory research method by taking primary data from survey and interview to employee and secondary data taken from company website, then data analyzed using SPSS statistical tool with factor analysis method. The results showed that HRIS correlated significantly to the accuracy of HR planning in several stages of HR planning including job description analysis with correlation coefficient of 568, accurate placement of employee placement accuracy of 0.892 , and the accurate identification of placement of employee by 0.677 .

Human resource planning (HRP) is generally overlooked in most organizations as the importance of HRP is not acknowledged (Vareta, 2010). Cherian (2011) defined HRP as the process of forecasting the demand and supply human resource and recruiting the correct number of employees, with right skills (as per the job) as per the need of the organization. The process of HRP was described by Pravin (2010) as seen from Figure 1.

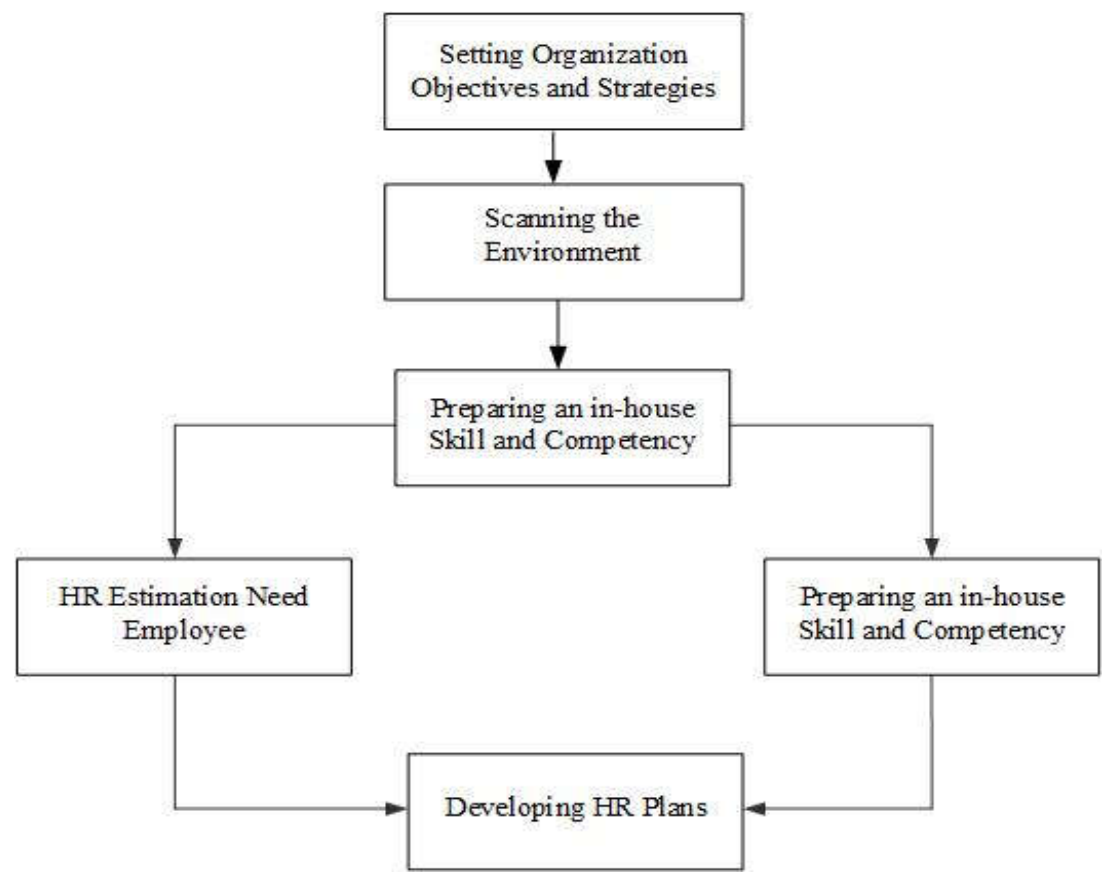

Figure 1 - Human Resource Planning Process

Source: Pravin Durai (2010), Human Resource Management, Pearson Education Publication. 


\section{METHODS OF RESEARCH}

This research is designed using descriptive exploratory approach with the purpose of describing clearly, in detail, and depth about the role of HR information system in human resource planning at one of the largest Higher Education Institutions in East Java. This method of approach allows researchers to obtain data and information from informant with the aim of building theory more than just testing (Myers and Avison, 2002). Data collection was conducted in November-December 2016 through observation techniques on existing HRIS system conditions and facilities and interviews with some of the leaders responsible for human resource development. Interviews were conducted with 15 informants including 5 leaders at top level management, 5 leaders in middle level management, and 5 leaders at low level management. Interviews were conducted semi-structured (Kvale, 1996) followed by in-depth interviews developed based on the question of the extent of HRIS's role in activities; (1) human resource needs planning; (2) recruitment and selection; (3) human resource development; (4) promotion of position; (5) performance appraisal.

The analytical technique uses a fixed comparison method between the observation results and the interview results by performing three stages of activity: preliminary analysis, formal analysis, and final data analysis (Rubin and Rubin, 1995). Preliminary analysis was conducted by observing the condition of the HRIS system, formal analysis was carried out at the time of interview based on the pre-prepared questionnaire, the final analysis was done by comparing the information of the interview result and the observation result. The result of the iterative process is further described, interpreted, and compiled the pattern of answers as material for drafting the concept model of human resource planning (Miles and Huberman, 1994).

\section{RESULTS AND DISCUSSION}

Results of Interview. Based on the results of the interview can be compiled summary as in Table 1.

Table 1 - Summary of Interview Results

\begin{tabular}{|c|l|c|c|c|}
\hline No. & \multicolumn{1}{|c|}{ Aspect } & Top Leaders & Middle Leaders & $\begin{array}{c}\text { Low } \\
\text { Leaders }\end{array}$ \\
\hline 1. & The role of HRIS in human resource planning & $\mathrm{X}$ & $\sqrt{ }$ & $\sqrt{ }$ \\
\hline 2. & The role of HRIS in Recruitment and Selection planning & $\mathrm{X}$ & $\mathrm{X}$ & $\sqrt{ }$ \\
\hline 3. & The role of HRIS in Human Resource Development & $\mathrm{X}$ & $\sqrt{ }$ & $\sqrt{ }$ \\
\hline 4. & The role of HRIS in promotion planning and promotion & $\mathrm{X}$ & $\mathrm{X}$ & $\sqrt{ }$ \\
\hline 5. & The role of HRIS in performance appraisal & $\sqrt{ }$ & $\sqrt{ }$ \\
\hline
\end{tabular}

The role of HRIS in Higher Education Institutions in human resource planning is still very low, from 15 selected informants consisting of executive officials in charge of human resources states the role of HRIS perceived benefits only when Reporting Lecturer Workload and proposing promotion of lecturers and academic staff. While for recruitment planning, selection, development of education and training, promotion, performance appraisal of education personnel, determination of remuneration has not felt its role.

Table 2 - Summary of Observation Results

\begin{tabular}{|c|l|l|}
\hline No. & \multicolumn{1}{|c|}{ System Features } & \multicolumn{1}{c|}{ Functions } \\
\hline 1. & $\begin{array}{l}\text { Human Resource Requirement } \\
\text { Planning }\end{array}$ & $\begin{array}{l}\text { - Only serves as a data source } \\
\text { - Not working as DSS yet }\end{array}$ \\
\hline 2. & $\begin{array}{l}\text { Recruitment and Selection } \\
\text { Planning }\end{array}$ & $\begin{array}{l}\text { - Only works for registration } \\
\text { - Not yet functioning as an employee selection system }\end{array}$ \\
\hline 3. & $\begin{array}{l}\text { Human Resource } \\
\text { Development Planning }\end{array}$ & $\begin{array}{l}\text { - Cannot display the list of lecturers who have to depart for further study } \\
\text { - Cannot display training needs yet }\end{array}$ \\
\hline 4. & $\begin{array}{l}\text { Planning promotion and } \\
\text { promotion of positions }\end{array}$ & $\begin{array}{l}\text { - Not working early warning system for employees whose time is } \\
\text { promoted }\end{array}$ \\
\hline 5. & Performance planning & - Has functioned as an instrument of lecturer's performance assessment. \\
\hline
\end{tabular}


The results of the observation of the system strongly support the interview result that the features available in HRIS are still intended as a medium for collecting employee data and submitting the recap report to the number of employees and the list of rank order, so it has not functioned as a decision support system in HR planning.

Analysis of the Role of HRIS in Human Resource Planning. The interview result shows that the role of HRIS is only enjoyed by leaders at low level and middle level, while for the top level leaders as decision makers have not felt the role of HRIS (Table 1). Top leaders stated: "... HRIS still not much help in human resource requirement planning. There is report of number of employees in every faculty based on education and class but there is no facility to know whether the number of lecturers and administrative staff is sufficient or not. Which sector human resources that need to be added ". Middle leaders explained; "... before preparing the HR plan requirements, every three months or six months once the head office staffing with the sub-division and staffing staff of the faculty carry out HRIS Data Reconciliation activities with the aim of synchronizing HRIS data with real data held by each faculty. Furthermore, the results of synchronization used as the preparation of Human Resource Mapping. The HR mapping report was then inputted into the Rector's Program Report ". While the operational manager or low leaders stated; "... we utilize HRIS data as material to prepare human resource planning needs. In HRIS there is a feature list of rank order report which lists the employees who have been sorted by rank / class, education, and occupation history. From there can be seen the number and qualifications of our employees as the material to make estimates of the needs of employees based on the ratio of lecturers and educational personnel to the number of students.

The statement is in accordance with the facts found during the observation that the features available in the HRIS function are still transactional and are not yet available features that can be utilized by the Executive Chiefs both at universities and faculty to estimate HR needs (Table 2). These findings indicate that the implementation of HRIS in Higher Education Institutions is still at the level of implementers of low leaders and middle leaders has not touched the needs of leaders at the top level as decision makers in the planning needs of human resources.

Analysis of the Role of HRIS in Recruitment and Selection Planning. In the process of recruitment and selection planning, HRIS's role is only felt by leaders at low level but has not contributed significantly to top level and middle level leaders. Top leader explains; "... the recruitment and selection planning process has been done manually because of many policy factors to be considered". Middle manager added "... recruitment and selection activities have not utilized HRIS to support these activities because of the GIVEN faculty of Head Office". While the low manager states; "... the process of recruitment and selection of civil servants entirely under the coordination of central committee of Kemenristek Dikti (Ministry of Higher Education and Research). Medium for Non-PNS (Civil servants) registration process began in 2015 already using the online registration system through e-recruitment application embedded in HRIS. It's just that the application for applicant to register only, the selection process is still manual because a lot of files that must be verified to continue the test in addition to written tests there are psycho-test and interviews that cannot be online ".

The observation results also prove that the existing HRIS is not yet provide adequate facilities starting from registration candidates, the selection process, until the announcement of the results of employee selection. Starting from the above problems, the ICT with the support of the university and faculty personnel department needs to conduct an audit along with any shortcomings of HRIS for further improvement and further development so that the recruitment process begins until the announcement of the selection result. Therefore, the coordination among officials in charge of human resources, among others are Vice Rector II, Vice Dean II, Head of General and Personnel Bureau, Head of Personnel Division, and Sub Division of Personnel with ICT Team is important to prepare standard procedure and requirements in process Business recruitment and employee selection, so the ICT Team can quickly build an integrated e-recruitment and e-selection information system on a single HRIS system.

Analysis of the Role of HRIS in Human Resource Development Planning. The role of 
HRIS in human resource development planning is not sufficient. It is implied from the expression of one of the top leaders who stated; "... human resources development planning is currently focused on education and training development programs. One of the educational development programs we have is the acceleration of doctors and professors because we want to improve the reputation of universities in Asia. The program certainly needs adequate data support, the problem we often do not get accurate data from HRIS anyone who has completed the task of learning, who is the task of learning, and who has not finished ". Middle manager "... at the Faculty of Animal Husbandry Insyallah always update its HRIS data so that most cannot be known who the time is dispatched S3 schools and anyone who needs to be warned anyone whose studies are not finished. While for training rarely use HRIS data because we send employees to training only when there is invitation either from Head Office or from Ministry ", low manager"... we use HRIS data to know lecturers who have time to departed further study, whereas for training activity rarely use HRIS because every opportunity and budget available we conduct training as much as possible to involve all employees in order to maintain harmony and togetherness such as conducting outbound or family gathering, as for structural training such as Pre-promotion or Leadership Training Program we propose every year whoever to be sent to participate in training ".

The result of the observation on HRIS existing condition is that the report presented is only the number of lecturers of current condition based on the level of education, the number of lecturers departing the study, the number of lecturers being studied, and the number of lecturers completed. The report is still an aggregation or recapitulation and cannot be used to monitor in detail the lecturers who have expired their studies and displays a list of lecturers who are planned to immediately carry out the task of learning. While for human resource development planning through training activities for lecturers and educational staff has not felt at all the role of HRIS by all leaders of both top leaders, middle leaders, and low leaders. Having observed that in HRIS there is not yet a feature for storing the training history of each employee as well as displaying a list of training that can be offered to lecturers and educational staff.

Analysis of the Role of HRIS in Promotion Plans. The role of HRIS to develop a promotion plan is sufficient where $57 \%$ of informants stated that HRIS had a role in preparing for promotion, while $43 \%$ stated otherwise. Top manager "... promotion, frankly, of this rank is not well planned, so far promotion proposal is done manually. I check in HRIS that there is only a list of rank order not the facilities of anyone who deserves to be promoted and whoever is taken care of promotion", Middle manager "... we use the list of order reports contained in HRIS as the basis for determining which employees are already promoted. From the list of order reports, it can also be known employees who deserve promotions based on the order of rank. If the rotation is the leader who decides when the time is rotated employees, low manage "... the employment department in cooperation with ICT will continue to try improve HRIS facilities. Currently we are still concentrating on improving the data by synchronizing the existing data in HRIS with the real data held by the faculty, so our target is to make HRIS as a valid and reliable data reference center. For promotional purposes, we use list of order reports data in HRIS which has been verified by faculty and then submitted to the assissment team ".

However, the observation of the HRIS facility shows that there is only 1 report related to promotion and rotation of the rank order. This report is used as a source of data to prepare lecturers and education personnel proposed promotion and rotation. So the information submitted is still very crude and needs to be processed again so it has not functioned as a support decision to give early warning (early warning system) to lecturers or educational staff who take care of promotion, and not yet able to provide information list of lecturers and decent educational staff Promoted.

Analysis of the Role of HRIS in Performance and Remuneration Assessment. Interview results show that most (86\%) of informants from top level management to low level management stated that HRIS has provided adequate role, while the rest (14\%) stated that it is not enough. Contribution is given primarily because in HRIS there is research facilities 
called as "Lecturer Performance Load" which proved to have functioned well so far. As for the assessment of the performance of educational staff HRIS contribution is still lacking yet there has been no standard assessment. Regarding remuneration all informants stated that they are still waiting for the implementation of remuneration system that is being done by Remuneration Team and ICT Team. Top manager "... performance is still referring to the Employee Target System (Sasaran Kerja Pegawai or SKP) issued by Indonesia's Ministry of Empowerment of State Apparatus in 2014, it's just that the system cannot be implemented in real time in the field, in other words still limited to formality. New employees will make SKP only when they want to take care of promotion because the requirement of promotion should have assessment report of SKP. So yes we have not used HRIS for performance appraisal. ", Middle manager; "... I think the lecturer's performance appraisal is standard using list of order reports instrument, which is difficult to measure the performance of educational personnel because the administrative work is rather difficult to determine the target and performance achievement. Similarly, in calculating remuneration points, remuneration of lecturers is more easily arranged its rubric than educational personnel. Until now, we are still waiting for the terms and system of remuneration calculation from the rectorate, my hope this system is integrated with HRIS so the data becomes more solid ", low manager" "... I think the lecturer's performance assessment is standard using list of order reports instrument, Measuring the performance of educational personnel because the administrative work is rather difficult to determine targets and performance achievements. Similarly, in calculating remuneration points, remuneration of lecturers is more easily arranged by its rubric than educational personnel. Until now we are still waiting for the terms and system of remuneration calculation from the rectorate, my hope this system is integrated with HRIS so the data becomes more solid". "...lecturer performance assessment through the lecturer's performance load and that the system is well established using HRIS, as for the performance of the education staff using SKP which is assigned to the attribute at the end of each year. Actually in HRIS it is available menu charging SKP but unfortunately no one has used, if SKP in HRIS filled with complete and correct remuneration calculation process is living activity of education personnel from HRIS because according to ICT team, the database is already integrated".

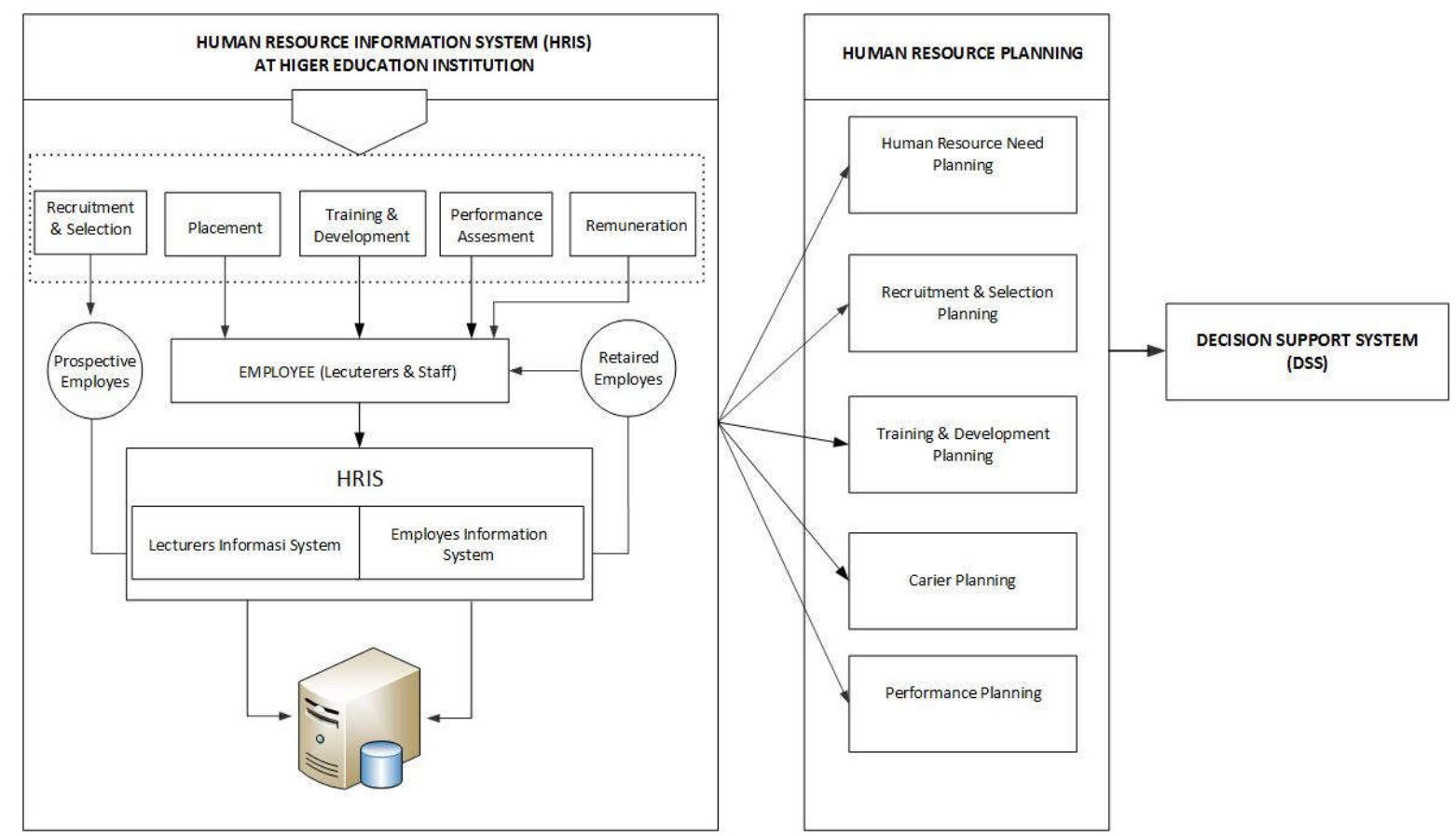

Figure 2 - HRIS Planning Concept Model based on HRIS at Higher Education Institution

The results of the system observation indicate that the features available in HRIS are complete enough from the recording of Tri Dharma (Three Principals) of Higher Institution 
activities by the lecturers concerned, the filling of list of order reports for educational activities, research, community service, supporting elements, as well as the special obligations of professors. Besides, the feature for assessment from list of order reports by Assessor has also run very well so that it can function as decision support system. Performance appraisal features for educational personnel are also available although still very simple in the form of inputs Employees Work Objective (SKP), SKP Assessment, and SKP validation. But this facility is still not utilized by all units of work proven from the results of checking to the database data is still empty. The remuneration system is apparently still in the development process proven yet to be seen in the HRIS menu, which is a remuneration simulator page for system simulation.

HRIS-Based Human Resource Planning Concept Model. Based on the results of the discussion on the role of HRIS in human resource planning in University of Brawijaya, it can be drawn up the concept model of HRM planning based on HRIS on the following institutions (Figure 2).

\section{REFERENCES}

1. Burch, J. and Grudnitski, G. (1986). Information System: Theory and Practice. John Wiley and Sons, New York.

2. Cherian, K.T. (2011), Human Resource Planning is a Systamatic Analysis of HR Needs. John Wiley and Sons, New York.

3. De Cenzo, D.A. and Robbins, S.P. (1996). Human Resource Management, 7nd Edition, John Wiley and Sons, New Jersey.

4. Durai, P. (2010), Human resource Management (Book), Pearson education Publications

5. Kavanagh, M.J., Thite, M., \& Johnson, R.D. (2012). Human resource information systems: basics, applications, and future directions. 2nd edition. United States of America: Thousand Oaks: SAGE.

6. Khera, S.N. and Gulati, K. (2012). Human Resource Information System and its Impact on Human Resource Planning: A Perceptual Analysis of Information Technology Companies, IOSR Journal of Business and Management.

7. Maier, C., Laumer, S., Eckhardt, A., Weitzel. (2012), Analyzing the Impact on HRIS Implementations on HR Personnel's job satisfaction and Turnover Intentio, Journal of Strategic Information Systems.

8. Mathis, R.L. \& Jackson, J. (2006). Human Resource Management, Edisi Kesepuluh, Jakarta, Salemba Empat.

9. McLeod, R. and Schell, G. P. (1998). Management Information Systems: Human Resource Information Systems. 10th edition. India, Prentice-Hall Publishers.

10. McLeod, R. and Anctis, Gerardine DeS (1995). A Resource-Flow Model Of The Human Resource Information System. Information Technology Management.

11. Mondy, W.R., and Noe, R. (2005). Human Resource Management. Pearson Education International, New Jersey, USA.

12. Nagendra, A. \& Deshpande, M. (2014), "Human Resource Information Systems (HRIS) in HR planning and development in mid to large sized organizations", Procedia - Social and Behavioral Sciences.

13. Noe, A.R. (2010). Manajemen Sumber Daya Manusia:Mencapai Keunggulan Bersaing Edisi-6 Buku 1. Jakarta: Salemba Empat.

14. Sadri, J. and Chatterjee, V. (2003). Building organizational character through HRIS. International Journal of Human Resources Development and Management.

15. Umamaheswari J.L (2014), Exploring internal quality of services in a manufacturing organization-A study in Lucus TVS, Chennai, Procedia Economics and Finance.

16. Werther, W.B and Davis, K. (2006). Human Resources and Personnel Management. Fifth Edition. McGraw Hill. Inc. New York. 


\title{
THE IMPLEMENTATION OF INDONESIAN NATIONAL QUALIFICATION FRAMEWORK CURRICULUM IN HIGHER EDUCATION INSTITUTION
}

\author{
Primastuty IImia Hidayatul Insani ${ }^{*}$, Noor Irwan, Mindarti Lely Indah \\ Master of Arts in Higher Education Program, Faculty of Administrative Science, \\ University of Brawijaya, Indonesia \\ *E-mail: miainsani1992@gmail.com
}

\begin{abstract}
Curriculum is a design of learning activities to develop the quality of learning in order to achieve educational goals, in this case especially at higher education. The curriculum that has been established by the Ministry of Research, Technology, and Higher Education of the Republic of Indonesia is the one based on the Indonesian National Qualification Framework (INQF). The curriculum should be applied by all universities in Indonesia both state and private universities. In this case, Public Administration Study Program in the Faculty of Administrative Science, University of Brawijaya, has implemented this curriculum since 2014 both to obey the regulation established by the government and to produce qualified alumni.
\end{abstract}

\section{KEY WORDS}

Curriculum, INQF, public administration, framework, education.

As with the issuance of Presidential Regulation Number 8 of 2012 on Indonesian National Qualification Framework and the Regulation of the Minister of Education and Culture of the Republic of Indonesia Number 73 of 2013 on the Implementation of the Indonesian National Qualification Framework for Higher Education, all the existing study programs in universities throughout Indonesia have to comply with the regulations. The purpose of the regulations is to produce qualified alumni as to prepare competent candidates in their fields in accordance with IQNF standards. In order to meet these requirements, in 2014 the Public Administration Study Program, Faculty of Administrative Sciences, University of Brawijaya has started to implement the policies as required by the central government.

The steps taken by the Public Administration Study Program in complying with the policy declared by the central government are (1) goal setting, (2) curriculum formulating process, (3) curriculum implementation, and (4) assessment on the effectiveness of curriculum implementation. Of the four stages, almost all have strong support from the communication, resource, disposition, and bureaucratic structures as described by Edward III (1980), except in the stages of implementation that lacks the support of disposition in the form of commitment from colleagues, seen from the incomplete Lesson Plans and the inconsistency of lecturers in writing Lecturing Journals. This makes the implementation of the curriculum not optimal.

\section{THEORETICAL REVIEW}

The Indonesian National Qualification Framework (IQNF). Based on the Act Number 20 of 2003 on the National Education System in Chapter I (Wahyudin, 2014), curriculum is defined as, "a set of plans and regulations about the aims, content, and material of lessons and the method employed as the guidelines for the implementation of learning activities to achieve given education objectives." Curriculum of higher education based on the Act Number 12 of 2012 Article 35 Paragraph 1 is, "a set of plans and regulations about the aims, content, and material of lessons and the method employed as the guidelines for the implementation of learning activities to achieve Higher Education objectives."

Curriculum based on the Indonesian Qualification Framework (IQNF) is "a stand-alone system and a bridge between education and training sectors to create qualified person and certified person through formal and non-formal education, as well as training and work 
experience." In this case, qualified graduates can be proven by certificates obtained from formal education in the form of diplomas and from non-formal education (courses for obtaining IELTS, TOEFL, TOEIC and other certificates). Certificates on competency prove certified graduates. These certificates are given after completing a competency test organized by the Training Providers and the Competency Test Institutions of the Professional Certification Agency under the auspices of the National Agency for Professional Certification.

Theory of Public Policy Implementation Model. Based on "the Handbook of Public Policy Analysis Theory, Politics and Methods" (2007), public policy implementation is divided into 3 models, i.e. top-down theories, bottom-up theories, and hybrid theories. The top-down implementation model is the implementation of a policy whose activities can only be done after the decision is made and formalized by the central government, while the bottom-up is a model of public policy implementation that starts from the 'bottom' by identifying the network of actors in policy submission. In other words, the implementer of the policy (organization under the central government) is given certain authority in implementing and developing the activities in accordance with regulations made by the central government in which the implementer of the policy will be obliged to account for the results of its activities to the central government. The hybrid public policy implementation model is a combination of topdown and bottom-up policy implementation models.

Factors that Support the Implementation of Public Policy. Four factors influence the success of public policy implementation based on Edward III (1980, in Suwarno, 2017). First is communication, i.e. the information is clear enough and detail from the policy maker so that the policy actors can understand the policy goals and objectives. Second is resource, i.e. adequate resources such as facilities, staff (human resources), authority, information, and adequate finance. Third is disposition, i.e. the existence of strong attitudes and commitments by policy actors such as being responsible, honest, consistent, and able to work together so the purpose of policy implementation can be realized. Fourth is the bureaucracy structure, i.e. the of Operational Procedure used as a guide in implementing the policy and the support of bureaucracy organization

\section{METHODS OF RESEARCH}

The research is descriptive qualitative method, and the data analysis technique refers to Yin (2011, pp. 178-179) consisting of: (1) compile database, (2) disassemble database, (3) reassemble database, (4) interpret data, and (5) conclude.

The focus of the study is on the implementation of IQNF Curriculum in the Public Administration Study Program at the level of Sarjana; this covers (a) the legal basis, (b) the purpose, (c) the policy actors, (d) the mechanism, (e) the curriculum structure and, (f) learning outcomes (LO). The next focus of the study is on factors that inhibit and support the implementation of IQNF Curriculum.

The study was done at the Faculty of Administrative Sciences, University of Brawijaya, Malang, Indonesia. The type of data used in this study is primary data and secondary data (Given, 2008). Three techniques of data collection, observation, interview and documentation, were employed.

\section{RESULTS AND DISCUSSION}

The findings and discussion cover the legal basis for the policy, the purpose of policy implementation, the policy actors, the mechanism of curriculum implementation, the structure of the curriculum, Learning Outcome, as well as supporting and inhibiting factors in the implementation of IQNF curriculum.

The Legal Basis for QNF Curriculum. Here are the legal bases that regulate the implementation of IQNF Curriculum at the Public Administration Study Program:

- Presidential Regulation Number 8 of 2012 on Indonesia National Qualification Framework; 
- Regulation of the Minister of Education and Culture of the Republic of Indonesia Number 73 of 2013 on the Implementation of the Indonesian National Qualification Framework for Higher Education; and

- Regulation of the Minister of Research, Technology, and Higher Education of the Republic of Indonesia Number 44 of 2015 on National Standards of Higher Education

The three regulations are the bases of the implementation of IQNF Curriculum by the central government mandated to the University of Brawijaya. This is written in the Decree of the Rector in the form of guidebooks. Furthermore, the Decree is mandated to the Faculty of Administrative Sciences, written in the form of the Decree of the Dean of Faculty of Administration Number 210 of 2014. Thus, it can be said that the implementation of IQNF Curriculum policy at the Public Administration Study Program follows the top-down model, as expressed in the "Handbook of Public Policy Analysis Theory, Politics, and Methods" (2007). Mazmanian \& Sabatier in Smith \& Larimer (2009) state the implementation of a policy could be done by the institution at the lowest level (in this case the Faculty of Public Administration) when there are official regulations made by top-level institutions (in this case the central government).

The Purpose of QNF Curriculum. Implementation of IQNF-based curriculum in the Public Administration Study Program has two kinds of objectives, i.e. to produce qualified human resources and certified graduates as stipulated in the regulations. Thus, the graduates are expected to be able to develop their knowledge and have high level of competitiveness in the world of work.

As for the reality in the field, Public Administration Study Program of the undergraduate level only focuses on how to produce qualified graduates. This is because the graduates only get a diploma and Diploma Supplement. The graduates cannot yet have a certificate of competency test as the National Agency for Professional Certification has not established the Professional Certification Agency on Public Administration.

The Actors of IQNF Curriculum. The actors who play a role in the policy implementation are actually all academic civitas in UB such as the Rector, Deans (Dean and Vice Dean I), study programs, departments, professors, lecturers, staff, and students. However, the most important actors in the implementation of IQNF Curriculum in Public Administration Program of the undergraduate level is the Study Program, the Department and the Vice Dean I. Thus, it can be said that the Rector assigns the Dean and the Dean assigns the Vice Dean I who then coordinates with the Department.

Furthermore, the Department coordinates intensively with the Study Program to prepare everything needed in implementing the curriculum policy. The Department must prepare the required budget and the lecturers as the resource. Then the Study Program team forms a team to formulate the policy implementation through intensive discussion to prepare a draft of curriculum that will be implemented. This form of coordination is one of the key issues in the implementation of the policy, i.e. 'communication' as stated by Edward III (1980, in Nugroho, 2008, pp. 447) that "communication concerns on how the policy is communicated to the organization and/or public, availability of resources to implement the policies, attitudes and responses of the parties involved, as well as how the organizational structure of the policy actors."

The pattern of implementation in the Administration Study Program is the top-down model. As expressed in the "Handbook of Public Policy Analysis Theory, Politics, and Methods" (2007) states that the implementation of top-down policy starts from the highest level of organization (macro-implementation level) to the lowest level of the organization (micro-implementation level). As seen from the autonomy of the lecturers in the preparing Lesson Plans, the content, method, and others, it can be said that the Public Administration Study Program uses bottom-up model. According to Berman (1978, in Liedl, 2011) that in the implementation of bottom up policy, micro-implementation level responds to the policy provided by macro-implementation level (the Vice Dean I) by developing the program (preparing the Lesson Plans). Both models are used simultaneously by the Public Administration Study Program level in implementing the IQNF curriculum policy, and thus it can be concluded that the policy implementation model uses the hybrid implementation 
model, a combination of top-down implementation model and bottom-up implementation model.

The Mechanism of IQNF Curriculum. The mechanism of implementation of IQNF Curriculum policy can be seen based on the compilation of IQNF Curriculum which refers to the regulations. It uses a hybrid model, i.e. a policy implementation model that combines the regulations set by the central government and the various aspirations that arise from below which in this case is the Public Administration Study Program. The Public Administration Study Program has implemented in accordance with the regulations made by macro-implementation level such as the Ministry of Research, Technology, and Higher Education of the Republic of Indonesia, the university, and the faculty. Furthermore, the Study Program coordinates with other parties at the same level and those under the Study Program (laboratories, study centers, lecturers' groups), as well as with stakeholders, practitioners, professionals, users, and alumni. These steps are standard steps set by the Directorate General of the Higher Education in order to produce certified and qualified alumni to meet the needs of the job market.

The IQNF Curriculum Structure of the Public Administration Study Program. The structure of the curriculum is the subjects which in this case refers to the courses that must be taken by students, as this is in accordance with the statement by Firmansyah (2007, p. 140) "the structure of the curriculum is a pattern and arrangement of subjects that must be taken by participants in learning activities." The curriculum structure in the Public Administration Study Program is formulated with Semester Credit System (SKS), for students to take in each lecture activity. Each lecture activity consists of 50 minutes face to face, 60 minutes of structured activity, and 60 minutes of independent study. The study loads taken by the students to graduate is 147 credits divided into 8 semesters consisting of 138 credits of lectures, 3 credits of apprenticeship, and 6 credits of thesis as stated in the form of the Faculty (2014, pp. 45):

"The undergraduate study program load is 147 credits consisting of 47 compulsory subjects (138 credits) and three (3) elective courses (9 credits). Each course offers 9 to 13 elective courses weighting of three (3) credits each as an effort to accommodate students' needs."

The curriculum structure of the Public Administration Study Program is prepared in 2014 based on the level of the materials consisting of subjects in the category of National Compulsory, University Compulsory, Faculty Compulsory, Major Compulsory, Study Program Compulsory, and Elective Courses.

Learning Outcomes (LO) of the IQNF Curriculum. Learning Outcomes (LO) based on the guidebook of Learning Achievement of the Study Program (2014) is a measure on the capabilities of students or alumni obtained after completing the learning process consisting of internalization of knowledge, attitudes, skills, competencies, and accumulated work experience (internship). The determining LO parameters set by the Directorate General of Higher Education consist of attitudes, general skills, special skills, and knowledge. As for the method of measurement of LO applied by the Public Administration Study Program is (1) quiz, (2) group discussion, (3) group work, (4) middle test and final test, and other methods which are prepared by the lecturers themselves. In determining the LO of the course, the Faculty refers to the regulations set by the Directorate General of Higher Education which is then applied by the Department with the Semester Course Design and the curriculum body.

Inhibiting and Supporting Factors of IQNF Curriculum. Theoretically, the supporting factors that influence the success of policy implementation according to Edward III (1980, in Suwarno, 2017) consists of communication factors, resources, dispositions, and bureaucratic structures. One of the communication factors in the implementation of IQNF policy in the Public Administration Program Study Program is done during curriculum preparation such as through Curriculum Workshop in 2014, conducted in cooperation with Indonesian Association for Public Administration (IAPA) team of East Java. The resource factor is the support derived from human resources consisting of educators and employees. The lecturers consist of 34 masters, 29 doctors, and 7 professors. Financial and material resources consisting of facilities and infrastructure such as buildings, reading rooms, laboratories, classrooms (AC, 
sound systems, LED TV or LCD projectors, desks, chairs, white boards, WIFI, etc.) Furthermore, the disposition factor is in the form of rules and commitment from internal stakeholders related to the change of several courses with rational arguments in order to achieve LO as a way to produce qualified graduates. This involves the professors and some competent doctors in the field to criticize the various proposals for subject changes. Factors supporting the structure of bureaucracy can be seen with the support of funding that is autonomously submitted by the Faculty to the Department and the Department hands the financial management over to the Study Program in accordance with the programs submitted to the Department. The other bureaucratic structure is in the form of handover of authority from the Dean to the Department to submit the composition of the review team and the drafter of the curriculum with all its activities.

The inhibiting factor comes from the disposition from lecturers. In the implementation, some lecturers do not write Lecturing Journals in accordance with the Lesson Plans prepared that the department and study program have difficulty to evaluate whether Lesson Plans have been implemented optimally. In addition, some lecturers still have not compiled complete Lesson Plans.

\section{CONCLUSION} drawn:

Based on the findings that has been described above, some conclusions can now be

The Public Administration Study Program of the undergraduate level of the Faculty of Administrative Sciences of the University of Brawijaya has implemented the public policy on IQNF Curriculum in accordance with applicable regulations.

The implementation of IQNF Curriculum only focuses on the creation of qualified graduates.

The Public Administration Study Program has received sufficient support in the form of communication support, resources, and disposition as well as from the bureaucratic structure of the Faculty. Although in fact the support of disposition has not been optimal.

\section{REFERENCES}

1. "Borang Institusi Fakultas IImu Administrasi". 2014. Fakultas IImu Administrasi. Universitas Brawijaya, Indonesia.

2. Firmansyah, F. 2007. Implementasi Kurikulum Tingkat Satuan Pendidikan (Struktur dan Kendalanya). Tadrîs. Volume 2. Nomor 1. 2007. Retrieved on January 20, 2016 from http://ejournal.stainpamekasan.ac.id/index.php/tadris/article/view/207/198

3. Given, L.M. 2008. The Sage encyclopedia of qualitative research methods. SAGE

4. Publications, Inc. United States of America

5. Liedl, C. 2011. Top-down vs. Bottom-up Does a top-down approach bear more advantages than a bottom-up approach within the implementation process of housing security projects?. Unpublished Undergraduate Thesis. Universiteit Twente. Netherlands. Retrieved on May 27, 2017 from http://essay.utwente.nl/61106/1/BSc_B_Liedl.pdf

6. Miller, G.J. \& Mara, S.S 2007. Handbook of Public Policy Analysis, Theory, Politics and Methods. CRC Press. USA

7. Nugroho, R. 2008. Public Policy. Jakarta: PT Elex Media Komputindo.

8. "Panduan Penyusunan Capaian Pembelajaran Lulusan Prigram Studi". 2014. Direktorat Pembelajaran Dan Kemahasiswaan Direktorat Jenderal Pendidikan Tinggi Kementrian Pendidikan Dan Kebudayaan. Retrieved on August 8, 2016 from http://belmawa.ristekdikti.go.id/dev/wpcontent/uploads/2015/11/6APanduanPenyusunanCP.pdf

9. "Panduan Penyusunan Capaian Pembelajaran Program Studi". 2014.. Retrieved on March 15, 2017 dari http://belmawa.ristekdikti.go.id/dev/wp-content/uploads/2015/11/6APanduan-Penyusunan-CP.pdf 
10. Smith, K.B \& Larimer, C.W. 2009. The Public Policy Theory Primer. Westview Press. USA

11. Suwarno. 2017. Implementasi Kebijakan Berbasis Kelembagaan, Komunikasi, Sumber Daya, Disposisi, dan Struktur Birokrasi Dalam Menggerakkan Pelatihan Menuju Prestasi Kerja. Disertasi. Fakultas IImu Administrasi. Universitas Brawijaya

12. Tim IQNF-Direktorat Akademik \& Ditjen Dikti-Depdiknas (n.d). Indonesian Qualification Framwork ppt. Indonesia

13. Yin, R.K. 2011. Qualitative Research from Start to Finish. The Guilford Press. United States of America. 


\title{
IDENTIFYING LOCAL WISDOM IN ELEMENTARY SCHOOL ANTI-CORRUPTION EDUCATION IN MALANG
}

\author{
Pratama Bayu Indra*, Kriyantono Rachmat, Febriani Nufian Susanti \\ Faculty of Social and Political Sciences, University of Brawijaya, Indonesia \\ *E-mail: bayuindrap@ub.ac.id
}

\begin{abstract}
There are very few discussions on instructional communication analysis or known as education communication focusing on anti-corruption and local wisdom. Instructional communication may become preventive solution to prevent corruption. The study discusses local wisdom-based anti-corruption instructional communication. Local wisdom becomes the focus of the study since culture acts as facilitator for internalization of anti-corruption principles. Malang is selected as the setting as the study due to its "arek" tradition. "Arek" tradition is transparent, straightforward and assertive; these are relevant to the principles of anti-corruption. The objective of the study was to identify local wisdom in anti-corruption education. The study was explorative qualitative and the method was focus group discussion. The subjects were teachers in SDN 2 Dinoyo Malang, SD Sang Timur Malang, and SD Insan Amanah Malang. These three elementary schools were selected as the setting because they have different religious orientation. The basis for selecting these schools was to describe different integration of the local wisdom and religious orientation each of the schools have. The findings stated that local wisdom had yet been utilized to facilitate the anticorruption education. Local wisdom was considered as government education embedded in the school activities. Some schools applied the program as a whole while some others were selective towards the program. Based on the findings, anti-corruption principles were embedded through religious and moral values that worked in the society.
\end{abstract}

\section{KEY WORDS}

Policies, education, society, values, communication.

Instructional communication is a type of communication studies focusing on the exchange of verbal and nonverbal messages that occur between teachers and learners (Sprague, 1992). It discusses factors, content, and teaching-learning settings that are communicative for the realization of teaching objectives. Instructional communication is closely related to educational psychology, pedadogy, sociology of education, and counseling (Book, 1989; Sprague, 1992). Instructional communication emphasizes on effective communication efforts in teaching and learning (Sprague, 1992).

Based on instructional communication, one should pay attention to the interaction between teachers and learners instead of doing so to either of them (McCorskey \& McVetta, 1978). Good interaction becomes the determinant factor in achieving learning objectives. Indicators for achievement of learning objectives in instructional communication are cognitive, affective, and psychomotor changes in the learners (Kearney \& Beaty, 1994). Another indicator of effective instructional communication is good relationships between educators and learners both during and outside the teaching and learning process (Powell \& Powell, 2015).

Some instructional communication research shows effective communication between teachers and learners would encourage behavioral change. Powell and Harville (1990) found that there was significant correlation between the teacher clarity, teacher's verbal and nonverbal ability to communicate with the learners and the learning outcomes. In addition, Cayanus (2004) also found that self-disclosure of experience from teachers would result in higher learning motivation and understanding of the learners.

Pragmatism in instructional communication can potentially be used for developing models that can be used to create social change in society (Waldeck, Plax, \& Kearney, 
2010). This obviously takes time. Small changes in teaching and learning can lead to longterm social change (Spector, 2005). Through educational institutions, anti-corruption principles can be internalized to the younger generation (He, 2000; Heilbrunn, 2004). Education becomes a means of preventing corruption. It is an effort to develop awareness about how much damage corruption brings and urgency of eradicating corruption into content in anti-corruption education (Korupsi, 2011).

Anti-corruption education can be one of the instructional communication agendas (Book, 1989; Wibowo, 2013). The roles of educational institutions are not to teach theoretical knowledge, but also moral values (Book, 1989; Dewantara, 2009). Such roles should be facilitated by adequate instructional communication models. Adequate instructional communication models refer to ones having both suitable content and methodology for anticorruption learning.

Corruption has become a cancer for Indonesia. Indonesia Corruption Watch (ICW) revealed that in 2015 the country lost 3.1 trillion because of corruption. The number of people commiting the act of corruptions increases annually.

Some studies discussed instructional communication and corruption. Chi-Ming Lee (2004) suggested that public institutions conducted critical thinking and civic classes as well as provide alternative teaching techniques to strengthen moral education. He stated that the critical thinking, civic classes and alternative teaching techniques that strengthened the existing moral education promoted the improvement of democratic and anti-corruption qualities in the country. Dawson (2011) explained that anti-corruption education was compulsory in Cambodian curriculum; it is taught at every level of education. The number of research in which the instructional communication and corruption become the focus is still relatively limited.

Although some studies show the effectiveness of instructional communication, some others found its shortcoming. Culture becomes one of the causes of instructional communication failure. For example, Sleeter and Grant (1987)'s study showed that cultural differences provided differences in delivery and receiving messages in the learning process. Even some processes were hampered and unsuccessful because of differences in cultural factors. Collier and Powell (1990) found that cultural settings determined the effectiveness of acceptance and the relationship between teachers and learners. Ngai (2015) through his research also mentioned that teachers should adapt more particularly to their students' cultural backgrounds in the teaching and learning process.

Findings of the studies show that cultural context is an inseparable part of instructional communication. There are four things to consider about the cultural context in instructional communication, namely teacher's background, student's background, content and teaching strategy. Teacher and student's background can be related to socio-economic condition, political stand, ethnicity, religion, and race. Content may be related to materials and types of messages the teachers deliver to the students while teaching strategies are related to technique the teachers used in the learning process (Moore, 2014).

Anti-corruption education should take cultural value of the target (audience) into account (Valentina \& Putera, 2013). Integration of culture increases acceptance of anticorruption messages. Local wisdom-based anti-corruption education in Indonesia is a rarity. The researchers found some research related to the topic. Some used the concept of local wisdom and anti-corruption but had yet associated them with instructional communication. For example a study conducted by Suryani (2014) that examined the role of advertising as a medium for anti-corruption education in Baduy society. Tanjung (2013) discussed local wisdom that influenced anti-corruption attitudes in the bureaucracy. There are several studies where the instructional communication models and anti-corruption have adopted moral values into learning content. As an example, Hakim (2012) developed a model combining Islamic values and anti-corruption education curriculum. In the study, Qur'an was the reference for anti-corruption principles. Another example is character-based anticorruption education (Manurung, 2012; Montessori, 2012). These had yet offered clear reference because it did not elaborate what character-based actually was. 
It is nearly impossible to generalize cultural diversity in Indonesia into uniform approach. Each cultural unit has different characteristics that require different approaches as well. Therefore, local wisdom-based anti-corruption instructional communication should be developed. Using local wisdom as the approach is in line with the long-term (2012-2025) and medium-term (2012-2014) National Strategy for Corruption Prevention and Eradication issued in 2012 Based on the elaboration, the researchs are interested in describing local wisdom element in anti-corruption education in elementary school.

Based on the background, the objective of the study is to describe local wisdom in anticorruption education in elementary schools in Malang.

\section{LITERATURE REVIEW}

Instructional Communication. Communication has educational or instructional function, which aims to educate and change one's behavior (Effendy, 2011). Education is right owned by every Indonesian citizen. The 1945 Constitution Article 31 Paragraph (1) states that "every citizen is entitled to education." Every citizen is also entitled to proper education to improve the quality of his/her life. It is also stipulated in the 1945 Constitution Article 28C Paragraph (1) that "every person shall have the right to develop himself or herself through the fulfillment of his or her basic needs, to be entitled to education and to benefit from science and technology, art and culture, to improve the quality of his or her life and for the welfare mankind."

Instructional communication is generally interpreted as the smallest part of education communication. Joseph (2010, p.2) describes instructional communication focusing solely on communication processes that are developed and designed specifically to change behavior of the target to a better direction within a particular community. Instructional communication consists of various variables such as strategy, process, technology and/or a formal system and mastery of concepts in order to change one's behavior towards the better (Yusuf, 2010). Myers mentions that "instructional communication is a unique study, because it stems from three different types of research, namely learning psychology, pedagogy and communication" (as cited in Fasset and Warren, 2010, p.149). Studies on instructional communication focus on communication factors that occur in the learning process.

Beebe dan Timothy (2012, h.1) explain that there are two approaches used in instructional communication, namely rethorical approach and relational approach. Based on the rhetorical perspective, teachers use verbal and non-verbal messages in order to affect or persuade students through materials that can change or improve their attitudes, beliefs, values or behaviors. McCroskey and Richmond explain "the function of rhetorical communication is to persuade others to do what we want/need and think about what we think" (in Beebe and Timothy, 2012, p.2). The focus of the approach is to get specific result using the message from particular source. In teaching and learning context, the desired outcome is process of learning.

McCroskey and Richmond also describe the relational approach as "a relational process between teachers and students that create and use verbal and nonverbal messages to develop relationship between the two " (in Beebe and Timothy, 2012, p.2). The approach emphasizes on affective or emotional responses, then their meaning is created together and disseminated between individuals. Another thing to emphasize in instructional communication is perception of teachers and students about welfare/harmony. The bottom line is the relational approach focuses on teaching, student's experience during the learning process and how students respond the process affectively. It affects the teacher's teaching motivation and the student's learning motivation.

In the study, the researchers adopted Beebe and Timothy (2012)'s rhetorical approach. The researchers used the rhetorical approach to see how teachers persuaded students through instructional communication. The researchers selected the approach in order to describe instructional communication taking place in the elementary schools clearly.

Anti-Corruption Education. Ethimologically-speaking, corruption is derived from Latin word "corruptus" which means a series of cruel image. Corruption is criminal act committed 
together in one or different institutions. Corruption is related to violation of position, power and authority to get personal interest and can potentially cause some loss for an institution (Dahlan, 1982). NACP (National Agency for Corruption Prevention) defines corruption as government apparatus or individual behavior that violates any authority given to him or her or violation of standardized ethics in order to benefit him or herself or other individuals.

Corruption in general consists of the following elements, namely authorities for decision-making relevant for the society, the law related to decision-making (legislation, principle, criteria, procedure), an individual or a group of people seeking for any decision that benefits him/her or them, exchange that benefit decision-maker and other related to the decision, violation of decision-making norm, causing loss for the society (Van Duyne, 2001).

Corruption can be analyzed using three perspectives (Getz, 2006). The first is functional perspective in which corruption refers to an act facilitating and learning exchange of goods, service or other financial transactions. The second perspective is one that considers corruption as interference or violation of decision-making process; it is known as dysfunctional perspective. The last one is normative perspective which means that corruption is violation of normative and correct value (Getz, 2006).

The Ministry of Education of Lithuania (2006) suggests both formal and informal anticorruption education at school. As formal education, elements of anti-corruption should be embedded into general education curriculum whereas, as informal education, the principles of anti-corruption should be embedded in extra-curricular activities, such as civil campaigns, student conferences and other events. The pivotal issue in anti-corruption education is to prevent corruption by introducing what corruption is and how to prevent it through the learning proces. The objective of anticorruption education is to develop value and improve the capacity needed for preparing students against corruption. The final outcomes are awareness towards how much damage corruption causes to the society and the national security of the state, negative attitudes towards corruption and finally, capability to eradicate corruption.

Local Wisdom. Local wisdom is local thought or ideas that contain values, wisdom and good conduct passed between generations (Radmila, 2011). Members of the society obey these values since they are believed to contain the truth. Local wisdom is called adi luhung or good conduct existed in the society that serves as a foundation of positive attitude and action leading towards harmonization. Local wisdom can be established through interaction and is accumulated in various moral teachings (ethics) Javanese use to the following term as reference for ethics or moral value, pepali, unggah-ungguh, suba sita, tata krama, tata susila, sopan santun, budi pekerti, wulang wuruk, pitutur, wejangan, wursita, and wewarah" (Purwadi, 2011, h.8). Local wisdom is spread through various means of communication such as folklore, words of mouth, informal discussion/ gathering, arts (ludruk, ketoprak, wayang or puppet show), folksong, proverbs and sanepa or sinoman (Javanese traditional organization). Local wisdom may be in the form of message (content) or strategy to deliver certain message (method). For example, suggestion to respect other people may be presented using ngoko or krama, two different dialects of Javanese kanguage depending upon the characteristics of the audience as an example of the local wisdom itself.

For Indonesian, the value of adi luhung is stated in the philosophy of the nation, The Five Pillars or Pancasila. Pancasila represents harmony between society in Indonesian. It is the peak of all good values the country has and the culmination of the society's perspective about themselves and their existence as objects and subjects with the universe. Pancasila is the ideal and fundamental condition (the philosophy of thought) of Indonesian people; it is reflected in its 36 points. Pancasila is harmony, the ideology of the nation (Kriyantono, 2012).

\section{METHODS OF RESEARCH}

Research Design. The objective of the study is to describe local wisdom in anticorruption education in elementary schools in Malang, Indonesia. In line with the onjective, the data were in the form of description related to local wisdom of Malang (Kriyantono, 2006; Neuman, 2013). The data are not in the form of numbers for statistical analysis (Neuman, 
2013). Thus, the approach of the study was constructivism and the design was explorative qualitative.

Reseach Methodology. The research methodology was Focus Group Discussion and intensive interview. Wimmer \& Dominick (2011) and Kriyantono (2006) mentioned that FGD and intensive interview functioned as both methodology and data collection technique. Through the Focus Group Discussion, researchers explore ideas and information as well as obtain some data related to perception, opinion, point-of-view, trust, response and attitude towards an issue, situation or product (Krueger, 1988). In the study, FGD was used to identify the local wisdom of Malang in elementary school anti corruption education in Malang. The researchers described the teachers' value, attitude and perspective towards the local wisdom related to anti-corruption. The intensive interview was the follow-up for the FGD. Some participants of the FGD were interviewed to obtain more elaborated piece of information.

Subject of the Study. The subjects of the stdudy were three elementary schools in Malang, namely SDN 2 Dinoyo, SD Sang Timur, and SD Insan Amanah. The schools were selected because each of them had different education orientation background. SDN 2 Dinoyo is public school, SD Sang Timur is a Catholic school, and SD Insan Amanah is an Islamic school. These different backgrounds were then related to their existence in Malang. It was expected the integration between the religious orientation of these schools and the characteristics of the native of Malang gained some insight about local wisdom-based anticorruption education.

Data Collection Technique. There were two types of data collection in the study. The first data collection technique was Focus Group Discussion (FGD) for the teachers in SDN 2 Dinoyo, SD Sang Timur, and SD Insan Amanah. The FGD was conducted in all three elementary schools. After conducting FGD, the researchers proceeded to in-depth / intensive interview. Some FGD participants were interviewed in the schools were they were working. The interviewees were selected based on the answer they gave during the FGD. The researchers would interview FGD participants who gave very little response or whose response was unclear. The purposes of the in-depth interview were to gain some more information in general and explore the interviewees' ideas further in particular.

Data Analysis Technique. The data analysis technique was thematic analysis (Neuman, 2013). Thematic analysis is in line with the objective of the study, identifying local wisdom-based anti-corruption education in instructional communication. The conversation taking place in the Focus Group Discussion (FGD) and the result of the in-depth interview were transcribed into texts. The Focus Group Discussion transcription was then analyzed to find similar themes from the entire data. The researchers would make some categories and classify the data based on these categories.

\section{RESULTS AND DISCUSSION}

The settings of the study were three elementary schools with different background and characteristics. SD Negeri Dinoyo is a public elementary school. SD IT Insan Amanah and SD Sang Timur are Islamic and Christian schools.

Despite having different background and characteristics, these three schools had the same perception about corruption. These schools considered stealing or taking other people's belonging is the example of corruption. Other examples were late coming, did not submit assignment, cheating and being irresponsible. In conclusion, they associated corruption to dishonesty.

The schools also had similar methods to apply the anti-corruption education. Formal and informal methods, practice or theory were the methods they use to develop the students' awareness against corruption. In SDIT Insan Amanah Malang, the teachers always asked their students questions related to praying; it is expected that such question develop the students' honesty. To validate the students' responses, the teachers communicated with the parents thorugh SMS gateway and whatsapp. SDIT Insan Amanah Malang also conducted various events and activities of which purpose was to teach what honesty was. One of the 
activities was Amal Jum'at where the students donated some money every Friday and reported how much money they collected without the teachers' help. Besides that, the students are accustomed of reporting to their teachers whenever they found unattended goods including money. Teachers would then make some notification. Those who owned them should contact their teachers to collect their lost items.

SDK Sang Timur taught honesty through kantin kejujuran, a self-service school canteen. The objective of kantin kejujuran is to develop students' honesty and responsibility. Another activity the school had was donation. Students donated parts of their weekly allowance every Friday. Without help of their teachers, the students took a donation box, put it in their classroom and at the end of the day returned it to their teachers.

SDN 2 Dinoyo Malang also had kantin kejujuran. When there was violation, the teachers would directly explain how important honesty was. The teachers also reminded the students that they should be honest in any occasion, for example while they were doing assignment, homework or borrowing stationery from their classmates. When a student was caught red handed, the teachers would give him or her some warning and advice. Another activity to develop the student's honesty was amal Jumat. Similar to one SDIT Insan Amanah Malang conducted, SDN 2 Dinoyo Malang donated some money every Friday. The students collected their donation and counted how much money they donated under the teachers' supervision.

Due to their background and characteristics, the schools applied different methods during the implementation of anti-corruption education. To develop their students' responsibility, SDIT Insan Amanah Malang conducted an activity called Bina Sholat for Grade 1 to Grade VI students. During the activities, the teachers informed students that there was strong correlation between prayer and daily activities. Besides that, the teachers encourage students to help each others and be honest, for example reporting unattended good to the teachers. To develop their students'honesty, the teachers introduced the wisdom of the Prophets and khulafaur rasyidin through story, video or movies. The teachers emphasized that honesty was integral part of Islam and God always knows and watches upon everyone. In conclusion, SD IT Insan Amanah used Islamic teaching as the foundation to develop the students' honesty and for the anti-corruption education.

Related to the local wisdom of Malang, all of the teachers agreed upon adopting the local culture for the learning activities. However, according to the teachers from SDIT Insan Amanah, they would select certain local wisdom that was not against Islamic teaching or syaria.

SDK Sang Timur developed their students' characteristics and moral value through a subject called pendidikan Ke-Sang Timur-an or Bina Iman. During Bina Iman program, the students learned Catholic teaching through movies. Having finished watching the movie, the students reported what their take out was. Anti-corruption education was implemented through two main principles, caring and respect (students were taught not to hurt or humiliate other people). The concept of discipline and responsibility was introduced through constant reminder to be punctual and attend the class on-time. Several students whom the teachers thought were the most responsible ones were awarded the title "Polisi Sekolah." Such reward was given to encourage other students to be honest and responsible.

SDK Sang Timur participated in the annual mask dance festival as an attempt to preserve the local culture. In addition, the school always greeted their guests with traditional dancing performance.

As heterogenous school, SDN Dinoyo 2 Malang had its own methods to conduct anticorruption education in the school. The first was to teach the anti-corruption principles in the classroom (formal education). Prior to the implementation of the 2013 Curriculum, ethics and anticorruption education is incorporated and integrated into Civics Education lesson. In the 2013 Curriculum 2013, these principles should be introduced in every subject. The pivotal personality traits the teachers should introduce were honesty, courtesy, and characterbuilding. The school principal also emphasized the importance of examples to the students regularly. The school also asked parents to teach the students to be honest, polite and responsible at home. 
SDN Dinoyo 2 introduced the local culture of Malang through both theory and practice. The students had dance class where they learned the mask dance of Malang and other traditional dancing from Malang. Topeng Malangan, traditional mask of Malang and lantern were two cultural items decorating all corners of the school. The school did not introduce the local cultural aspects that are against ethics and honesty such as bahasa walikan.

In conclusion, the three schools agreed that honesty, responsibility and discipline were the keys of the anti-corruption education. These schools introduced the concepts through formal and informal education or theory and practice. The examples were kantin kejujuran, weekly donation, and introducing moral values and ethics through stories, video or movie.

At the same time, each school had their own methods to introduce the anti-corruption principles to the students. SD IT Insan Amanah used Islamic teachings as the reference while SDK Sang Timur emphasized caring and respect through pelajaran ke-Sang Timuran or Bina Iman. SDN 2 Dinoyo adopted the 2013 Curriculum for character-building because the school was a heterogenous one.

These three schools also have their own programs to introduce the culture to the students. SD IT Insan Amanah adopted the local culture that reflected Islamic teaching. SDK Sang Timur introduced the local culture by participating in the cultural festivals and SDN 2 Dinoyo Malang conducted class on the traditional mask dance of Malang and other traditional dance from the area. The school also introduced bahasa walikan khas Malang, the local language of Malang but the use of the language at school was prohibited.

\section{DISCUSSION OF RESULTS}

Based on the findings, the schools had the same perspective about corruption. Corruption is taking other people's right. Corruption is not limited to material items but also non-material ones. The examples of material items are goods, money or objects belong to others while the non-material ones are time, job and rewards. The instance of the act of corruption related to time is coming to school late and violation of rights. Cheating or plagiarism is another example. Abandonment and under appreciaton are two examples of the act of corruption related to rewards.

The schools also put emphasis on honesty since it is considered as preventive measure against corruption. Corruption is associated to dishonesty. Lying may become the trigger of corruption because a lie leads to another. It is expected that the students will fight against corruption in their adulthood when they have thorough understanding on the concept of honesty.

Each school has their own methods to introduce the concept of honesty to the students. SDIT Insan Amanah used Islamic teaching as their main reference. The school also use the national or regional curriculum as reference but they should make some adaptation in order that Islamic teaching is represented in the curriculum. The school is not going to use or alter pedagogical concepts that do not represent Islamic teaching. At the opposite, SD Negeri Dinoyo 2 adopts the national curriculum as a whole. It is unable to make adjustment since the school is one of the instruments of the national education. SD Kristen Sang Timur combines the national curriculum, catholic teaching and moral education specifically designed by the foundation that owns the school to introduce the principles of anti-corruption.

The reference the schools used is dictated by the schools' visions and their students. All students of SDIT Insan Amanah are Moslem and have good economic situation. SD Negeri Dinoyo 2 and SD Kristen Sang Timur have more heterogenous students. As public school, SD Negeri Dinoyo 2 should accept anyone regarless of his or her background. The same practice occurs in SD Kristen Sang Timur because one of the primary targets of the school is students coming from low economic family.

The different orientation and students has implications towards the methods the school use to introduce the concept of honesty in each school. The concept is commonly taught in the formal situations (in the classroom) as well as outside the classroom. In the classroom, $S D$ Negeri Dinoyo 2 students embedded the concept in each classroom activities. When 
there is violation, the teachers immediately correct the behavior. Similar thing happens in the otwer two schools. The teachers at SD Kristen Sang Timur use humor as one medium to convey the importance of honesty. Another method is to use alias (animated character) to give examples about theonality traits to the students.

Besides through formal teaching, the teachers used other teaching media for the anticorruption education. SDIT Insan Amanah and SD Kristen Sang Timur use video downloaded from the internet. SDIT Insan Amanah allocated specific time for students to watch video about the Prophets, twice a month as the substitution for the flag ceremony. Different from SDIT Insan Amanah, the students of SD Kristen Sang Timur watch the videos during pelajaran Ke-Sang Timur-an class.

The content of the video in SDIT Insan Amanah and SD Kristen Sang Timur is not the same obviously. SDIT Insan Amanah played video/movies about the Prophets and their companionship. The videos/ movies are then related to Islamic teaching. In other words, the video helps the students to develop devotion towards Islam. On the other hand, SD Kristen Sang Timur does not have specific theme for the video they play for the students. Some of the videos describe daily activities. Having watched the video, the teachers ask the students to make comparison between the content of the video and Catholic teaching.

Unlike the other two elementary schools, SD Negeri Dinoyo 2 does not use video as teaching media. Character-building material (moral education) is embedded in each classroom activity. The school does not allocate specific time to discuss materials related to the topic either.

In line with their visions, the schools implement different types of rewards and punishment. Emphasizing on Islamic teaching, SDIT Insan Amanah introduce the concept of merit and sin. SD Kristen Sang Timur introduce cause-effect theory which means everything has consequences and one's decision is going to affect other people (positive and negative implication). Furthermore, SD Negeri Dinoyo 2 refers to the law, regulations and social value for their rewards and punishment system.

Furthermore, the schools have specific subject to introduce the concept of honesty to their students. East Sangria's Christian school instills honesty values through the education of Kesangtimuran. SD Kristen Sang Timur introduced the concept through a subject called pelajaran Kesangtimuran. The founder of Sang Timur Foundation, Sister Clara Fey inspired the class. The class discusses her live, activities and good conduct. In contrast, SDIT Insan Amanah has a subject called Bina Shalat of which purpose is to improve the students' devotion towards their religion. The teachers develop the students' discipline to pray 5 times a day. When there is violation, the teachers would discuss things with the students violating the rules. According to the school, prayer helps students to avoid any wrongdoing. SD Negeri Dinoyo 2 does not have any specific subject for incharacter-building. The concept of honesty and other positive traits were introduced in religion and civic classes. It has $5 \mathrm{~S}$ concept which stands for Senyum, Salam, Sapa, Sopan, and Santun. The concept basically reminds students to be polite.

The students are motivated to develop their honesty outside the class through several activities. SD Negeri Dinoyo 2 and SD Insan Amanah conducted donation every Friday in which the students collected some money as donation without their teachers' supervision. The students' honesty is evaluated during the charitable activity. SD Kristen Sang Timur does not conduct such activity every week; instead, the students and the teachers collected some money when one of the teachers or students is sick or hospitalized.

Another method to develop the students' honesty is kantin kejujuran. Both SD Negeri Dinoyo 2 and SD Kristen Sang Timur have one. In the beginning, there were some loss but the students have been getting accustomed of the system now. As an addition, the teachers constantly remind students how kantin kejujuran works and emphasize on the significance of honesty. Everything runs smoothly now. SDIT Insan Amanah does not have kantin kejujuran.

In relation to the local culture, each of the schools has different perspective. SD Negeri Dinoyo 2 thinks it is vital to preserve the local culture. They decorated the schools with local handicrafts such as traditional mask and lantern as suggested by the regional government. The school also has traditional dance class to introduce the students to the local culture. 
Similar to SD Negeri Dinoyo 2, SD Kristen Sang Timur also decorate the school with the local handicraft and conduct traditional dancing class. In addition, the school participates in the annual traditional mask dance festival conducted by the government of Malang. At last, the school greets their guests with traditional dancing performance.

At the opposite, SDIT Insan Amanah perceived the local culture of Malang such as mask and lantern against Islamic teaching. Therefore, the school did not encourage preservation of the local culture. In order to meet the government's regulation, the school modified the cultural aspects to match Islamic teaching. Every cultural aspects introduced to the students should represent Islamic teaching.

Even though the three schools have different perspective about the local wisdom of Malang, they have the same idea towards the correlation between culture and honesty. $S D$ Negeri Dinoyo 2, SD Kristen Sang Timur, and SDIT Insan Amanah unanimously stated that there is not any correlation between the local wisdom and character-building (honesty). These two are separated entities. All three schools do not encourage the use of Javanese language at schools and strictly prohibit the use of Javanese slang. In terms of Bahasa Walikan, the schools argued that the language is not relevant to the current society because it is the language used as the secret code among Indonesian to deceive the Dutch.

The schools realize that family members and environment affect the students' characteristics. Hence, each of them has their own methods to develop relationship between the school and the parents. SD Negeri Dinoyo 2 introduce their 5S concept to the parents who come to the school. The principal encourage the students to apply the concept at home because parents should set good example for their children. Besides that, the school directly involves the parents to solve students' problems. When there is violation, the school will invite the parents for discussion.

SDIT Insan Amanah also involves parents in dealing with the students' problems. The school even use specific applications to communicate with the students' parents or legal guardian. The first is sms gateway that the school uses to send some announcement and notification to the parents. The parents can also use the application if they have some suggestion or criticisms towards the school. The second is whatsapp. Each class teacher creates whatsapp group where he or she communicates with the parents. He or she can also directly send message to each parent. The objective of the whatsapp group is to facilitate better communication between the teachers and the parents. When students have issues at school, the teacher will directly contact the parents using either or both applications asking them to come to the school. The teachers also use the applications to make clarification or verification to the parents.

Different from SD Negeri Dinoyo 2 and SDIT Insan Amanah, SD Kristen Sang Timur does not directly involve the parents whenever there is violation by students. For minor issue, the teachers call on the students without informing their parents. The relationship between the school and the parents is limited to the class committee which consists of the students' parents' representatives and the school committee (Parent Teacher Association).

Based on the elaboration, it is concluded that the local wisdom of Malang has yet been embedded in the anti-corruption education in the three elementary schools. The schools assumed that there is not any correlation between culture and anti-corruption education. These schools used religious teaching and good moral conduct as the bases for their anticorruption education.

\section{CONCLUSION}

Based on the statement of the problem, how local wisdom is embedded into elementary school anti-corruption education in Malang, the conclusion is that local wisdom as local identity is embeeded into the teaching and learning process as well as extracurricular activities such as celebrating religious holiday. The teachers also introduce the local wisdom to the students by making integration between the local culture and learning methods, for instance "bahasa walikan," local language of Malang and other familiar culture aspects as an ice-breaker. 
Teachers have authority to introduce the local wisdom to their students, and also select which elements of the local wisdom suitable for their student's need and condition. In the public and Islamic schools, teachers introduce elements of local wisdom that meet the orientation of the schools. The teachers have been able to introduce cultural aspect and explain cultural development to their students. It is concluded that there is correlation between the content of local wisdom being taught and vision or mission of the schools.

The finding revealed that these schools have yet utilized local wisdom for anticorruption education. These schools perceive local wisdom as not more than government applied in school activities. Some schools take it as whole while some others are selective towards the program. The anti-corruption principles are embedded through religious and moral values exist in the society.

\section{REFERENCES}

1. Book, C. L. (1989). Communication education: Pedagogical content knowledge needed. Communication Education, 38(4), 315-321.

2. Cayanus, J. L. (2004). Effective instructional practice: Using teacher self-disclosure as an instructional tool. Communication Teacher, 18(1), 6-9. doi: 10.1080/1740462032000142095

3. Chi-Ming Lee. (2004). Changes and challenges for moral education in taiwan. Journal of Moral Education, 33(4), 575-595. doi: 10.1080/0305724042000315635

4. Collier, M. J., \& Powell, R. (1990). Ethnicity, instructional communication and classroom systems. Communication Quarterly, 38(4), 334-349. doi: 10.1080/01463379009369771

5. Dahlan, M. (1982). Pengawasan dari kacamata yang diawasi. Background paper ii, dalam masalah-masalah peningkatan kemampuan aparat pengawasan- himpunan bahan bahan sarasehan pengawasan pembangunan. Menteri Negara Pengawasan Pembangunan Dan Lingkungan Hidup. geography and government.

6. Dawson, W. (2011). Supplementary education in cambodia. IIAS Newsletter, 18-19.

7. Dewantara, K. H. (2009). Menuju manusia merdeka. Yogyakarta: Leutika.

8. Effendy, O. U. (2011). Ilmu komunikasi: teori dan prakteknya. Bandung: Remaja Rosdakarya

9. Getz, K. A. (2006). The effectiveness of global prohibition regimes : Corruption and the antibribery convention. Business Societ, 45(254).

10. Hakim, L. (2012). Model integrasi pendidikan anti korupsi dalam kurikulum pendidikan islam. Jurnal Pendidikan Agama Islam Ta'lim, 10.

11. He, Z. (2000). Corruption and anti-corruption in reform china. Communist and PostCommunist Studies, 33(2), 243-270.

12. Heilbrunn, J. R. (2004). Anti-corruption commissions: Panacea or real medicine to fight corruption. World Bank Institute, Washington, DC. The Many Faces of Corruption.

13. Kearney, P., \& Beaty, M. J. (1994). Measures of instructional communication. In R. B. Rubin, P. Palmgreen \& H. E. Sypher (Eds.), Communication research measures: A sourcebook (pp. 7-20). New York: Guilford.

14. Korupsi, T. P. B. P. A. (2011). Buku pendidikan anti korupsi untuk perguruan tinggi (M. E. S. Nanang T. Puspito, Indah Sri Utari, Yusuf Kurniadi Ed.). Jakarta: Kementerian Pendidikan dan Kebudayaan RI.

15. Kriyantono, R. (2006). Teknik praktis riset komunikasi: Disertai contoh praktis riset media, public relations, advertising, komunikasi organisasi, komunikasi pemasaran. Jakarta: Kencana.

16. Kriyantono, R. (2012). Etika dan filsafat ilmu komunikasi. Malang: UB Press.

17. Krueger, R. A. (1988). Focus groups: A practical guide for applied research. California: Sage Publications.

18. Manurung, R. T. (2012). Pendidikan antikorupsi sebagai satuan pembelajaran berkarakter dan humanistik. Jurnal Sosioteknologi(Vol 11, No 27 (2012)), 227-239. 
19. McCorskey, J. C., \& McVetta, R. W. (1978). Classroom seating arrangements: Instructional communication theory versus student preferences. Communication Education, 27(2), 99-111. doi: 10.1080/03634527809378281

20. Ministry of Education and Science of the Republic of Lithuania. (2006). Anti-Corruption Education At School: Methodical material for general and higher education schools. Lithuania: Modern Didactic Centre, Garnelis Publishing.

21. Montessori, M. (2012). Pendidikan antikorupsi sebagai pendidikan karakter di sekolah. Jurnal Demokrasi, 11(1).

22. Moore, K. D. (2014). Effective instructional strategies: From theory to practice. London: Sage Publications.

23. Myers, S. A. (2010). Instructional communications: the emergency of a field. In D.L. Fasset, \& J.T. Warren, The sage handbook of communication and instruction (h.149159). Los Angels: Sage Publications

24. Neuman, W. L. (2013). Metode penelitian sosial: Pendekatan kualitatif dan kuantitatif. Jakarta: Indeks.

25. Ngai, P. (2015). The impact of teachers' communication approach on children's cocultural adaptation. Journal of Intercultural Communication(37).

26. Powell, R. G., \& Harville, B. (1990). The effects of teacher immediacy and clarity on instructional outcomes: An intercultural assessment. Communication Education, 39(4), 369-379. doi: 10.1080/03634529009378816

27. Powell, R. G., \& Powell, D. L. (2015). Classroom communication and diversity: Enhancing instructional practice. London: Routledge.

28. Purwadi (2011). Etika komunikasi dalam budaya jawa. Jurnal IImu Komunikasi, 9(3).h. 139-249. ISSN 1693-3029

29. Radmila, S. (2011). Kearifan Lokal : Benteng Kerukunan. Jakarta: PT. Gading Inti Prima.

30. Sleeter, C., \& Grant, C. (1987). An analysis of multicultural education in the united states. Harvard Educational Review, 57(4), 421-445.

31. Spector, B. I. (2005). Fighting corruption in developing countries: Strategies and analysis: Kumarian Press Bloomfield, CT.

32. Sprague, J. (1992). Expanding the research agenda for instructional communication: Raising some unasked questions. Communication Education, 41(1), 1-25.

33. Suryani, I. (2014). Menggali keindahan alam dan kearifan lokal suku baduy (studi kasus pada acara feature dokumenter "indonesia bagus" di stasiun televisi net. Tv). Musãwa Jurnal Studi Gender dan Islam, 13(2), 179-194.

34. Tanjung, I. (2013). Kearifan lokal dan pemberantasan korupsi dalam birokrasi. MIMBAR (Jurnal Sosial dan Pembangunan), 29(1), 101-110.

35. Valentina, T. R., \& Putera, R. E. (2013). Buildng the local elements of national anti corruption integrity sistem in west sumatera. International Journal of Administrative Science \& Organization, 20(2), 78-84.

36. Van Duyne, P. (2001). Will 'Caligula' go transparent?. Forum on crime and society, 1(1), 74-76

37. Waldeck, J. H., Plax, T. G., \& Kearney, P. (2010). Philosopical and methodological foundations of instructional communication. In D. L. Fassett \& J. T. Warren (Eds.), The sage handbook of communication and instruction. London: SAGE Publicantions.

38. Wibowo, A. (2013). Pendidikan anti korupsi di sekolah. Yogyakarta: Pustaka Pelajar.

39. Wimmer, R.D \& Joseph R.D. (2011). Mass media research: An Introduction. (9thedition). USA: Wadsworth

40. Yusuf, P. M. (2010). Komunikasi Instruksional: teori dan praktet. Jakarta: PT. Bumi Aksara. 
DOI https://doi.org/10.18551/rjoas.2017-08.17

\title{
COMPARATIVE ANALYSIS OF TAX OBJECT SALES VALUE ON LAND AND BUILDINGS WITH INDONESIAN VALUATION STANDARD (SPI)-BASED VALUATION IN MALANG CITY
}

\author{
Gani I.F.*, Irianto G., Achsin M. \\ Master's Degree Program in Accounting, Faculty of Economics and Business, \\ University of Brawijaya, Indonesia \\ *Email: idafitria.gani@yahoo.com
}

\begin{abstract}
This research aimed to explore how the valuation/appraisal in determining land and building values at Tax Object Sales Value on Land and Buildings (NJOP PBB) in Malang City and to analyze the comparison between the valuation of Tax Object Sales Value on Land and Buildings (NJOP PBB) conducted in Malang and the valuation of land and buildings according to Indonesian Valuation Standards $(S P I)$. Through the qualitative research with a case study approach, it was obtained that the model of mass and individual appraisals on the valuation of Tax Object Sales Value on Land and Buildings (NJOP PBB) had the similar stages to the individual appraisal according to Indonesian Valuation Standards (SPI). Furthermore, from the results, the problems faced in valuing Tax Object Sales Value on Land and Buildings (NJOP PBB) by the Local Revenue Office of Malang City were also known. It can be used as a consideration for the improvement of regulation or procedure in valuing Tax Object Sales Value on Land and Buildings (NJOP PBB).
\end{abstract}

\section{KEY WORDS}

Property, valuation, taxes, land, buildings, standards.

In order to improve the service to the community and increase the independence of local government, Rural-and-Urban Land and Building Tax (PBB-P2) will be transferred into local tax according to the Law No.28/2009 on Regional Tax and Regional Retribution. It gives a positive impact as well as a challenge for the local government of Malang because, by the issuance of the Law, the entire Land and Building Tax (LBT or PBB) becomes the locallygenerated revenue $(P A D)$ that is one of the potential sources of revenue. It has been a challenge for the local government to be able to manage the Land and Building Tax (LBT or $P B B$ ) properly for the welfare and progress of the people of Malang. In connection with this, the local government of Malang City has conducted a data collection, valuation, determination, administration, billing/collection, and service regarding Land and Building Tax (LBT or PBB) starting on January 1, 2013.

The basis for the imposition of Land and Building Tax (LBT or PBB) is Tax Object Sales Value or also called 'Land and Building Tax Imposition Base' (NJOP). Therefore, the amount of Land and Building Tax to be paid depends on the Tax Object Sales Value (NJOP). The valuation of Tax Object Sales Value (NJOP) is done by two appraisal methods, which are mass appraisal for standard tax objects spread throughout Malang City area, and individual appraisal for non-standard tax objects. The distinction is more emphasized on the economic value and potential tax imposition of the object concerned. At this time, the mass appraisal is made on most tax objects whereas the individual appraisal is applied to some tax objects with relatively small amounts.

There are three approaches in the appraisals used either in valuing tax objects or in Indonesian Valuation Standard-based valuation, covering [1]. Market Approach is an approach used in estimating the value of tax objects by making a comparison with comparable data and adjusting it to the market if there is a difference between the valued tax object and the comparison data; [2]. Revenue Approach is an approach used to estimate the value of tax objects by making a projection of net revenue in the upcoming years and converting it to the present value; [3]. Cost Approach is an approach used to estimate tax 
objects by totalizing the market value of the land and the market value of the building, in which the market value of land is calculated using market methods while the market value of the building is calculated using cost methods. The approach used in valuing the tax objects of buildings in Malang City is done using Market Approach.

In accordance with the practices that have been done up to now, the Tax Object Sales Value on Land and Buildings (NJOP PBB) used as the basis for Land and Building Tax calculation in Malang City has not shown the real condition in the market and has a difference with the market value. There has not been any specific research conducted on the comparison between the valuation of Tax Object Sales Value on Land and Buildings and the valuation based on the Indonesian Valuation Standard in Malang City. However, the determination of Tax Object Sales Value in relation to the potential of local revenue that has huge advantages in order to generate the local economy has led to many studies on Tax Object Sales Value conducted. Most of the previous studies have examined whether there is a difference in the results of the valuation/appraisal of Tax Object Sales Value with the market value but there has been no research on how the valuation process is done in determining Tax Object Sales Value (NJOP), resulting in differences, particularly in Malang City.

Tretton (2007), in his study on the taxation valuation (reviewing the enhancement of computer-aided valuation model or Automated Valuation Model/AVM) in several countries such as America, Canada, Northern Ireland and Hong Kong, stated that the automated valuation program can assist in the valuation process but the quality of the data and appraiser is an important factor in generating accurate valuations for tax purposes. Moreover, Hefferan, in his journal published in 2010, examined on the mass appraisal of property tax in Australia and the adjustments to new environments. The results of his study suggest that the fundamental technique in the mass appraisal can be still relied upon by improving the appraisal system effectiveness by increasing the access to market information and good cooperation with the appraisal profession. Furthermore, Preston (2005), in his study, discussed the development and trend affecting the characteristics and needs of the valuation services of the world in the short and medium terms, stating that the popularity of property-based taxes grows with governments around the world either as a mass land tax system or a top-up revenue. Its appeal lies in the significant increase in property values of the market economy from the medium to the long term. The basic form of tax valuation is almost guaranteed to increase the income of the government. To ensure the fairness, a regular mass reappraisal of property values is needed to assure that the appraised value is closer to the market.

Pitt (2004), in his study, stated that the UK Central Government has used two disciplines in making the valuation that is reflected in Green Book (An Appraisal and Evaluation Book of the Central Government) and Red Book (A Valuation Standard Book used by Public Property Practitioners) for many years to help in assuring the efficiency of the property used by Taxpayers. Bowan (1996), in his journal entitled Perkembangan Metodologi Penilaian (Valuation Methodology Development), stated that, in overcoming problems or limitations of valuation methods, it is very important to not forget the market practices and its effects, such as general economic conditions. The theory has been and will continuously be the important part in identifying problems and shortcomings of valuation techniques.

The purpose of this study was to explore how the valuation in determining the value of land and buildings on the Tax Object Sales Value (NJOP PBB) in Malang City and to analyze the comparison between the valuation of Tax Object Sales Value on Land and Buildings (NJOP PBB) in Malang City and the valuation of land and buildings based on Indonesian Valuation Standard $(S P I)$.

\section{METHODS OF RESEARCH}

To obtain the complete description and explanation about the valuation of Tax Object Sales Value on Land and Buildings (NJOP PBB) conducted by the Local Revenue Office of Malang City, a qualitative research design with a case study approach was used in this 
research. Moleong (2009) argued that a qualitative research is a research conducted to understand the meaning of an event by digging or deepening descriptive data from the research subject (in the form of written or verbal words) and observing the behaviors in the natural context which is then analyzed to derive conclusions from the research results. A case study was used as the approach to this research because the researchers conducted a detailed and accurate investigation, and the data were collected using various data collection methods limited by time and activity (Cresswell, 2010). This research also used the question of "how" and "why", in which the researchers had no control over an event, in which the researchers only focused on the contemporary phenomena that had relation to the real life (Yin, 2014).

The quality of the research results was highly influenced by the quality of data collection. The data collection methods used in this research covered observation, interviews, and documentation. In the process of data collection, the three techniques were used simultaneously and carried out continuously until the information obtained was considered sufficient.

The stages of data analysis performed were based on the qualitative data analysis with an interactive analysis model presented by Miles and Huberman covering as follows:

- The data collection was done by means of observation, interview, and documentation.

- Observing the operational reality of the tax object valuation conducted by the Local Revenue Office, which in this case referred to the section of Land and Building Tax.

- Conducting semi-structured face to face interviews with the informants, giving indepth questions (both pre-prepared questions and developed questions)

- Making documentation by collecting the data from some documents, archives, and records/notes of the institute that were considered important and related to the problems being studied.

- The data reduction was made to the results of observation, interviews, and documentation concerned so that it could be presented valid and relevant information regarding the valuation of Tax Object Sales Value on Land and Buildings (NJOP PBB). The data reduction was performed by summarizing and selecting the main points, focusing on the important ones that were in relation to the problems being studied, seeking the pattern or theme, and omitting the points that were not necessary.

- The analysis of the comparison between the valuation of Tax Object Sales Value on Land and Buildings (NJOP PBB) and the valuation based on Indonesian Valuation Standard was conducted along with the discussion on the valuation case presented in the form of description covering narrative text and table to be more understandable. The data were also presented in certain relationship patterns so that the conclusions of information obtained from this research could be meaningful and easy to understand.

- The last stage was conclusion drawing or verification of all the data obtained, reduced, and presented as the research results.

\section{RESULTS AND DISCUSSION}

Mass Appraisal. In performing the activity of determining Tax Object Sales Value on Land and Buildings (NJOP PBB), the tax object to be valued or appraised by the Local Revenue Office were first classified, whether it belonged to mass or individual appraisal. The assets appraised in the mass appraisal conducted by the Local Revenue Office of Malang City were the assets of rural-and-urban standard tax objects covering the areas of agriculture, housing, offices, shops, and industries. Based on the observation, there were some objects of Land and Building Tax in mass appraisal although it had the criteria that should be appraised individually. In general, the tax objects were in the form of factories that have undergone land and building expansion. Meanwhile, according to Indonesian Valuation Standard $(S P I)$, it was stated that the appraised assets were a group of individual assets in large quantities without any limitation of criteria in which the value determination referred to 
the valuation equation, tables, and process developed through mathematical analysis sourced from the market data.

The objective of mass and individual appraisals conducted by the Local Revenue Office of Malang City was to determine the Tax Object Sales Value on Land and Buildings (NJOP PBB) of tax objects so that it could be in line with the rules, not incriminating the Taxpayers and not causing turmoil in the community. The mass appraisal was used to determine the Tax Object Sales Value on Land and Buildings (NJOP PBB) of standard tax objects. Because of the very great number of tax objects and the limitations of costs and human resources, the mass appraisal was done using the old data, unless there was a new data submission, mutation (rename), rectification/correction, and objection due to the increased NJOP PBB or the NJOP PBB relief request. The most important parts in the appraisal were the Tax Object Sales Value (NJOP PBB) that was determined not to burden the Taxpayers and the achievement of tax targets that have been established. The objective of mass appraisal, according to Indonesian Valuation Standards (SPI), was to provide a framework for the task of mass appraisal, one of which was for the tax purposes especially the property tax in Indonesia (determining NJOP PBB). In conducting the mass appraisal work, the appraisers must follow applicable laws or regulations that affected the assignment of mass appraisal.

The process of the appraisal work would result in accurate value if a person who had competence in carrying out the appraisal did it. The competence, in this case, included having an educational background that related to the appraisal field, having experience in joining a specific education and training in the field of appraisal, and being well experienced in conducting the appraisal/valuation work. Indonesian Valuation Standards $(S P I)$ required the appraisal work to be carried out by an appraiser that met the requirements in accordance with Indonesian Valuation Standard (SPI).

Due to the limited human resources in the Local Revenue Office of Malang City, the appraisal officer was only one with the educational background of economics degree and Diploma I of Economics School majoring in the Appraisal program. Of course, this became a problem, considering that the tax objects in Malang City reached 267,000 tax objects. To overcoming this problem, the field work was assisted by one contract employee in every district. The contracted employee was a retired employee of Tax Office (KPP Pratama) who has well experienced in the field of Land and Building Tax. Activities of data collection, as well as tax object and subject verification, have been ever conducted in some areas of Malang City with the help of third parties. Besides, there were also some contract employees who were on duty to assist the data collection process until printing the Notice of Land and Building Tax Payable (SPPT PBB). Thus, the recruitment of employees conducting the work of Land and Building Tax valuation/appraisal in the environment of the Local Revenue Office of Malang City has not followed the rules that have been determined.

In the implementation of registration, data collection, and valuation or appraisal of objects and subjects of Land and Building Tax, the Local Revenue Office of Malang City used the Information Management System of Tax Objects (SISMIOP). The system $(S / S M I O P)$ is an integrated system to process the object and subject information or data of Land and Building Tax with the aid of computer starting from data collection (through registration, data collection, and appraisal), tax object identity administration (Tax Object Number), data recording, database maintenance, printing outputs (in the form of Notification of Tax Due [SPPT], Tax Payment Slip [STTS], Tax Underpayment Collection List [DHKP], and so on), monitoring of the receipt and execution of tax collection, up to the services to Taxpayers through One Place Service. The Computer-Assisted Mass Appraisal (CAMA) used in mass appraisal according to the Indonesian Valuation Standards (SPI) was aimed at improving the efficiency and technical capabilities to increase the accuracy and consistency of the appraisal, tracking the ownership and releasing status, making a print, and others. Because the number of tax objects managed was very large, the use of computer technology was absolutely necessary.

Indonesian Valuation Standard $(S P I)$ suggested that mass appraisal required the formation of valuation model developed from the three approaches that were commonly 
used, namely market approach, cost approach, and income approach. In the mass appraisal, to calculate Tax Object Sales Value on Land and Buildings (NJOP PBB), a market approach was used to establish the appraisal equation that would be applied. The appraisal/valuation conducted by the Local Revenue Office of Malang City was used market approach for the tax object valuation of land and used cost approach for the tax object valuation of land and buildings. The value of land used was derived from Land Value Zone or ZNT (the Average Indication Value [NIR] on ZNT was obtained from the survey of comparison data contained in the ZNT location) while the value of the building was obtained automatically in the SISMIOP program. From the value of land and building, it could be summed up and known the NJOP (the Tax Object Sales Value).

Inspection activities conducted as a part of data collection was aimed at establishing and maintaining the land and building property database and were a part of the valuation process that was very needed in doing an analysis for the determination of Tax Object Sales Value on Land and Buildings (NJOP PBB). The data collection in relation to the valuation included the data collection of land and building tax object and comparison data collection used to analyze the land and building market values of tax objects. By inspecting the data used in the valuation process and valuation analysis, the determination of Tax Object Sales Value on Land and Buildings (NJOP PBB) would be more accurate so that the values resulted would reflect the market value. Due to the limited funds and human resources, the inspection activities conducted by the Local Revenue Office of Malang City often did not meet the inspection requirements in order to result in accurate and valid data which were very needed in the valuation process.

At the time of the acceptance of authority in managing Land and Building Tax, the Local Revenue Office of Malang City also received the tax object and subject data required in the valuation of NJOP PBB. The data related to the valuation covered the map of Land Value Zone (ZNT), Building Component Price List $(D B K B)$, the list of land classes, and Information Management System of Tax Objects (SISMIOP). Based on the inspection that has been conducted, there were still many deficiencies and errors contained in the data received. There were still many data that were not in line with the conditions in the field and, of course, it became a stand-alone problem in the valuation process to be able to produce accurate values that were in accordance with the market conditions if the data were used.

As for the inspection that has been done by the Local Revenue Office of Malang City, the registration, valuation, and determination of Land and Buildings were done based on the priority of areas that had a pretty high economic development. It could be seen from the property development that was high enough in which the areas were developed into commercial areas that were increasingly crowded, or due to the increase in property prices. In addition, the development of an area could be known from the tax payment information of Fees on Acquisition of Rights to Land and Buildings (BPHTB). The inspections carried out so far, in general, were only to update the land prices around the tax object appraised, while to verify the tax object, the measurement of land and buildings was only done if there were complaints made by the tax subjects.

Inspections were also conducted to collect the comparison data in sufficient quantities to be used in determining the valuation equation. According to the Indonesian Valuation Standard $(S P I)$, market approach estimated property values through statistical analysis including using multiple regression analysis that was by comparing the selling price of comparable properties and making adjustments. In the multiple regression analysis, it was determined dependent variables (such as land area, building area, asset location, and etc.) that can affect independent variables (market value). In mass appraisal done by the Local Revenue Office of Malang City, a multiple regression analysis was not used.

In the mass appraisal of Tax Object Sales Value on Rural-and-Urban Land and Buildings (NJOP PBB-P2) carried out by the Local Revenue Office of Malang City, the land market value of tax objects was determined from the land value zone. Land value zone is a geographical zone of a group of tax objects that have the same average indicative value or, in other words, has the same land market value of each square meter. Thus, the geographical boundaries had a great significance in determining Tax Object Sales Value 
(NJOP) of land. The inappropriate determination of the geographical boundaries of land value zone would cause a tax object to be in a land value zone with an indication of the average value that was different from the real condition.

The land market value on the land value zone was determined by conducting an appraisal using market approach. Of at least three comparison data in the form of property data sold and offered in the area of the land value zone, an analysis was done to determine the land market value on the land value zone. The comparison data could be in the form of empty land or building land. If the comparison data were in the form of building land, it must be estimated the building market value of the comparison data, which then was extracted to determine the land market value indication. From the comparison data, an adjustment and weighting were made to know the land market value. The market value of the asset buildings valued and the comparison data obtained from the Building Component Price List (DBKB) were reduced with the existing depreciations.

Inspections in mass appraisal, according to Indonesian Valuation Standards (SPI), were very important to be carried out in relation to collecting and maintaining property data covering geographical data, property characteristic data (eg. land data and buildingdevelopment data such as land area and the dimension, speciation and area of the buildings, etc.), and sale or supply price data. According to Indonesian Valuation Standard (SPI), the data must constantly be updated in facing changes caused by the development of property prices in the region, changes in property characteristic data caused by the development of new building models and the renovation, demolition, and destruction of properties, and so on. The inspections were also performed to obtain as much as possible comparison data to be used in determining the valuation equation. The accuracy of the values depended on the completeness and accuracy of the data required in the valuation of the tax objects. The data completeness and accuracy could be achieved if the inspections were conducted properly, carried out periodically in accordance with existing developments and changes as well as in line with applicable laws and regulations.

The Indonesian Valuation Standards $(S P I)$ of 2015 required the identification of the appraised properties in order to collect and maintain sufficient property characteristic data for classification, appraisal/valuation, and other purposes. The property data must be constantly updated in relation to changes in building models and the renovation, demolition, and destruction of the buildings. The unavailability of accurate property data certainly made the research results not accurate. In the mass appraisal carried out by the Local Revenue Office of Malang City, in general, there was no detailed tax object identification conducted to know the land area, land position, building area, and land/building condition of the tax objects. Most of the tax object information was based on the data obtained from the Tax Office (KPP Pratama).

To obtain property values that were appropriate with the market, an analysis of comparison data that were proportional to the object properties must be conducted in performing property object appraisal/valuation. Therefore, it was necessary to define comparable and consistent property areas between the appraised property objects and the used comparison data (SPI, 2015). That was, the comparison data were apple-to-apple data or as closely as possible to the property objects being appraised. It should be similar or almost similar in relation to the land and building location and area, asset condition, and so on. The comparison data used in the analysis to obtain the land Tax Object Sales Value (NJOP) of tax objects should use comparable data in order to obtain more accurate analysis results. Because the determination of land Tax Object Sales Value (NJOP) for mass appraisal used ZNT, the analysis conducted was not as detailed as in the comparison data analysis on the individual appraisal.

Based on the observation, interviews, archives, and documentation of the research, it was known that the model of the mass appraisal conducted by the Local Revenue Office of Malang City was almost the same with the individual appraisal. What distinguished was that the process of individual appraisal was conducted in more detail. As an example, the determination of land Tax Object Sales Value (NJOP) of Land and Building Tax (PBB) objects in mass appraisal was ruled by the location of the tax objects on ZNT, so the Tax 
Object Sales Value (NJOP) of land was an average indication value of land on the land value zone. Meanwhile, in individual appraisal, the Tax Object Sales Value was determined in detail by conducting inspections to find out the land value based on the analysis of supply/sales data that was comparable with the tax objects appraised.

The model of mass appraisal according on the Indonesian Valuation Standards (SPI) was very different with the individual appraisal of assets. The model of mass appraisal was an equation explaining the relationship between the value or estimation of selling price and the variables of supply and demand representing. The mass appraisal was an appraisal system based on available data using standard procedures and statistically tested on a group of properties. Therefore, the mass appraisal according to SPI was conducted by developing model structures reflecting the relationship between the characteristics affecting the market and model structure calibration to determine the contribution of individual characteristics affecting the value, and applying the conclusions reflected in the model with the property characteristics appraised.

Table 1 - Summary of Appraisal Comparison

\begin{tabular}{|c|c|c|c|}
\hline No. & Description & $\begin{array}{c}\text { The Appraisal of Tax Object Sales } \\
\text { Value on Land and Buildings (NJOP } \\
\text { PBB) in Malang City }\end{array}$ & $\begin{array}{l}\text { According to Indonesian } \\
\text { Valuation Standards }(S P I)\end{array}$ \\
\hline 1. & Appraised Assets & $\begin{array}{l}\text { All of the tax objects of Land and } \\
\text { Building Tax (PBB) except the } \\
\text { individual/specific tax objects }\end{array}$ & $\begin{array}{c}\text { A group of real assets of } \\
\text { individual properties in large } \\
\text { quantities }\end{array}$ \\
\hline 2. & Objectives & $\begin{array}{l}\text { Tax Object Sales Value on Land } \\
\text { and Buildings (NJOP PBB) }\end{array}$ & $\begin{array}{c}\text { Tax Object Sales Value on } \\
\text { Land and Buildings (NJOP } \\
\text { PBB) }\end{array}$ \\
\hline 3. & Accountability & Applicable laws or regulations & Applicable laws or regulations \\
\hline 4. & Human Resources & $\begin{array}{c}\text { Bachelor of Economics and Diploma } \\
1 \text { of Appraisal Program }\end{array}$ & Property Appraiser \\
\hline 5. & Technology Used & CAV (Computer Assist Valuation) & $\begin{array}{c}\text { CAMA (Computer-Assisted } \\
\text { Mass Appraisal) }\end{array}$ \\
\hline 6. & Approaches Used & Market and cost approaches & $\begin{array}{l}\text { Market, cost, and income } \\
\text { approaches using a multiple } \\
\text { regression analysis }\end{array}$ \\
\hline 7. & Field Inspection & Not always & Yes \\
\hline 8. & $\begin{array}{l}\text { Identification of the appraised } \\
\text { property }\end{array}$ & Yes & Yes \\
\hline 9. & $\begin{array}{c}\text { Definition of consistent and } \\
\text { comparable property market areas } \\
\text { for properties }\end{array}$ & Yes & Yes \\
\hline 10. & $\begin{array}{l}\text { Definition of supply and demand } \\
\text { characteristics affecting the } \\
\text { prevailing market value }\end{array}$ & Yes & Yes \\
\hline 11. & $\begin{array}{l}\text { Development of model structures } \\
\text { reflecting the relationship between } \\
\text { the characteristics affecting the } \\
\text { market }\end{array}$ & No & Yes \\
\hline 12. & $\begin{array}{c}\text { Calibration of model structures to } \\
\text { determine the contribution of } \\
\text { individual characteristics affecting } \\
\text { the value }\end{array}$ & No & Yes \\
\hline 13. & $\begin{array}{l}\text { Application of the conclusions } \\
\text { reflected in the model with } \\
\text { property characteristics appraised }\end{array}$ & No & Yes \\
\hline 14. & Review of mass appraisal results & $\begin{array}{l}\text { Yes (review for the Tax Object } \\
\text { Sales Value (NJOP) of Land) }\end{array}$ & $\begin{array}{c}\text { Yes (review for appraisal } \\
\text { model) }\end{array}$ \\
\hline
\end{tabular}

In the mass appraisal conducted by the Local Revenue Office of Malang City, a review was made to update Land Value Zone (ZNT). The review was started at the time of Land and Building Tax $(P B B)$ management delegation in which the Average Indication Value (NIR) was 
still considered very low compared to the existing market price. Moreover, the review was conducted based on the information about the developments in a region that led to an increase in land prices in the region.

From the results of observation, interviews, and documentation that have been carried out by the researchers, it was obtained a summary of appraisal comparison in the form of Table 1.

Individual Appraisal. Most of the mass appraisal stages conducted by the Local Revenue Office were the same with the individual appraisal. Table 2 shows the comparison derived from the research results on individual appraisal.

Table 2 - Comparison of Individual Appraisal

\begin{tabular}{|c|c|c|c|}
\hline No. & Description & $\begin{array}{c}\text { The Appraisal of Tax Object Sales Value } \\
\text { on Land and Buildings (NJOP PBB) in } \\
\text { Malang City }\end{array}$ & $\begin{array}{l}\text { According to Indonesian } \\
\text { Valuation Standards }(S P I)\end{array}$ \\
\hline 1. & $\begin{array}{l}\text { Identification of the assignor and } \\
\text { the report user }\end{array}$ & Yes & Yes \\
\hline 2. & $\begin{array}{c}\text { Determination of appraisal } \\
\text { objectives }\end{array}$ & Yes & Yes \\
\hline 3. & Determination of the basic value & Yes & Yes \\
\hline 4. & $\begin{array}{l}\text { Identification of appraisal objects } \\
\text { and ownership rights }\end{array}$ & Yes & Yes \\
\hline 5. & Determination of appraisal date & Yes & Yes \\
\hline 6. & Data collection and selection & Yes & Yes \\
\hline 7. & Data analysis & Yes & Yes \\
\hline 8. & Land value opinion & Yes & Yes \\
\hline 9. & Appraisal approach & Yes & Yes \\
\hline 10. & $\begin{array}{l}\text { Reconciliation of value indication } \\
\text { and final value opinion }\end{array}$ & No & Not always \\
\hline 11. & Appraisal report & Yes & Yes \\
\hline
\end{tabular}

The identification of the appraisal assignor of Tax Object Sales Value on Rural-andUrban Land and Buildings was the Head of the Local Revenue Office of Malang City, and the appraisal report user was the Local Revenue Office of Malang City itself. In the appraisal according to Indonesian Valuation Standards $(S I P)$, the identification of the appraisal assignor and the user of important-identified report was to avoid a misuse of the report of the appraisal results by irresponsible parties and to confirm that the appraiser was not liable if the appraisal report was used by parties not mentioned in the report.

An appraisal is the process of work to provide an estimate and opinion on the economic value of an appraisal object that can be used for various purposes. The objective of an appraisal conducted by the Local Revenue Office of Malang City as mentioned in the Regional Regulation of Malang City No.11 of 2011, Article 6 Paragraph 1 on Urban Land and Building Tax is to determine Tax Object Sales Value (NJOP). Tax Object Sales Value (NJOP) is set to calculate the amount of tax payable as the state of the tax object on January 1 of the tax year. It means that the NJOP must be set before the $1^{\text {st }}$ of January of the fiscal year, assuming no change since the date of the field inspection. According to Indonesian Valuation Standard $(S P I)$, the objectives of appraisal should be ascertained early in the appraisal process because it will determine the appraisal basic to be used. The basic value used is NJOP, which refers to the market value according to the Law explanation. The value of a property has a possibility to change over time. Therefore, the date determination of appraisal is very important.

Identification of the property appraised for the determination of Tax Object Sales Value on Rural-and-Urban Land and Buildings (NJOP PBB-P2) of individual tax objects that was conducted by the Local Revenue Office of Malang City was to find out the location/position of the tax objects as well as the physical condition of the land and buildings. The land and building areas were based on the documents received from the government institution (e.g. photocopy of certificates, building permit $(I M B)$ and etc.) or files received from Taxpayers. Meanwhile, according to Indonesian Valuation Standard $(S P I)$, the identification must be 
done to determine the real condition of the tax objects valued/appraised. Furthermore, the identification was done at the time of inspection by verifying the data owned with the real tax object condition as in the field.

Data collection and selection conducted by the Local Revenue Office to analyze the Tax Object Sales Value (NJOP) of land. The data used were the other similar objects that were close located, have the same function, and have known its selling prices as explained in the Regional Regulation of Malang City, Article 1 Paragraph 11 on Urban Land and Building Tax. The objective of the appraisal conducted in determining Tax Object Sales Value on Rural-and-Urban Land and Buildings (NJOP PBB-P2) was to determine the market value indication because the data used were derived from the market. Based on Indonesian Valuation Standard $(S P I)$, the data collected and analyzed included general data, specific data, demand and supply data. General data were external factors that affect value including government regulations and socioeconomic trends, and so on. Specific data were related to property objects appraised while demand and supply data were related to the asset demand and supply data that were proportional to the tax objects.

There were three approaches that can be applied in individual appraisal, either according to the applicable rules in the appraisal of Tax Object Sales Value on Land and Buildings (NJOP PBB) or Indonesian Valuation Standard (SPI). The implementation of the approaches depended on the type of properties appraised and the comparison data existing in the market, and it could be used one approach and more. According to Indonesian Valuation Standard (SPI), the appraisal/valuation could use more than one approach, which was then reconciled by weighing both the market values resulted. In the practice undertaken by the appraiser of Land and Building Tax in Malang, a market approach was used for land tax object and a cost approach was used for land and building tax objects. The cost approach was performed by estimating the land market value with a comparative method of the market data of the land around the comparable property objects appraised/valued. The market value of the building was derived from the cost method, which was an approach of NJOP by calculating the total cost incurred to obtain the objects at the time of the appraisal/valuation, reduced with the depreciation of the physical, functional, and economic conditions of the tax objects. The market value of the tax objects is derived by summing up the estimated market value of land and market value of buildings.

In analyzing land values using market methods, proportional comparison data were collected and selected. The comparison data were obtained by doing market research to find out market information about comparable property transactions or deals known as apple-toapple with the appraised objects. What "comparable/proportional" means here was the same type of properties, the location, condition, and quality of land and buildings, the same land use and etc. There was no specific rule regarding the amount of comparable/proportional data but it generally was three or four.

\section{CONCLUSION}

There are two appraisal models in determining Tax Object Sales Value on Land and Buildings (NJOP PBB), namely mass appraisal and individual appraisal. The appraisal methods conducted are almost similar to the individual appraisal according to Indonesian Valuation Standards $(S P I)$. The mass appraisal of NJOP PBB based on SPI uses an appraisal equation model tested statistically. Practically, the appraisal with an equation model is difficult to apply in Malang or in Indonesia generally although it is theoretically applicable. This is because it requires a lot of investment and adequate human resources to change the existing appraisal model.

The appraisal process undertaken in mass and individual appraisals by the Local Revenue Office of Malang City is similar, which in principle use a market approach to the appraisal of land tax objects and a cost approach for the appraisal of land and building tax objects (Land valuation using market method and building valuation using cost method). However, the individual appraisal is conducted in more detail in determining the selling value of land and building tax objects. This is because the number of tax objects that are 
appraised/valued in mass is much more than those appraised/valued individually. In addition, an individual tax object is non-standard tax object that has a much higher economic value than a standard tax object.

The problems faced in conducting the appraisal of Tax Object Sales Value on Land and Buildings (NJOP PBB) by the Local Revenue Office of Malang City are caused by the following matters:

- The appraisal process is less supported by the quality and quantity of valid accurate and accountable market database and information.

- There are two tax object components analyzed in the determination of NJOP PBB, namely land and buildings. Errors in one of the components in estimating NJOP PBB can give appraisal results that are not in line with the market. The calculation of the land market value of NJOP PBB is closely related to the accuracy of land value zoning, identification of land tax object and analysis of comparison data conducted. Based on the research that has been done, these things are still not done in detail and accurately which will ultimately produce appraisal outputs/results that do not match the value reflecting the market.

- To determine the market value of a building-tax object, it is calculated from the cost of a new replacement of the building-tax object appraised that is reduced with the depreciations in accordance with the existing conditions. The list of building cost components used in estimating the new building replacement in mass appraisal uses the data provided by Tax Office (KPP Pratama), which is not yet appropriate to the market. Thus, the market value calculation result of building-Tax Object Sales Value (NJOP PBB) is still not accurate.

- The absence of adequate human resources and the need for a large budget become an obstacle to improve the quality and quantity of the data required in the appraisal/valuation. In addition, the existing data are considered sufficient to meet the main objectives of the target of Land and Building Tax revenue. Moreover, there is no any appropriate policy encouraging the implementation of NJOP PBB to conduct the appraisal/valuation work correctly in order to obtain accurate appraisal/valuation of tax objects with broader objectives that do not increase the original revenue of the region only. The broader objective ias the national database that can be used for various purposes, not only for taxation (single value for multiple purposes).

\section{REFERENCES}

1. Bowman, R. 1996. Practice Paper: Price and worth Developments in valuation methodology. Journal of Property Valuation and Investment, Vol. 14 Iss 4 pp. $79-100$

2. Creswell, J. W. 1998. Qualitative Inquiry and Research Design: Choosing Among Five Tradition. SAGE Publications. London.

3. Hefferan, J, M. 2010. Property Taxation and Mass Appraisal Valuations in Australia adapting to a new environment. Journal of Poperty Management, Vol. 28, No. 3.

4. KSPI. 2015. KEPI \& SPI Edisi VI 2015. MAPPI. Jakarta

5. Miles, M dan Hubberman, A. 2014. Analisis Data Kualitatif: Buku Sumber Tentang Metode-metode Baru. Universitas Indonesia (UI-Press). Jakarta.

6. Moleong, L. J. 2013. Metodologi Penelitian Kualitatif. Cetakan Ke Tiga Puluh Satu. PT. Remaja Rosdakarya. Bandung.

7. Pitt, A. 2004. Property appraisal in Government. Journal of Property Investment \& Finance, Vol. 22 Iss 2 pp. $192-199$

8. Prawoto, A. 2012. Teori dan Praktek Penilaian Properti, Edisi Kedua. BPFE. Yogyakarta.

9. Preston, B. 2005. A vision for valuation. Journal of Property Investment \& Finance. Vol. 23 Iss 2 pp. $123-140$

10. Sugiyono. 2008. Metode Penelitian Kuantitatif, Kualitatif, dan RD. Alfabeta. Bandung.

11. Suharno. 2003. Pengelolaan Pajak Bumi \& Bangunan Dalam Era Otonomi Daerah. Direktorat PBB dan BPHTB. Jakarta.

12. Tretton, David. 2007. "Where is The World of Property Valuation for Taxation Purposes Going?" Journal of Property Invesment \& Finance. Vol. 25 Iss 5 pp. 482-514.

13. Yin, R. K. 2014. Studi Kasus Desain dan Metode. Cetakan ke tiga belas. Persada. 
DOI https://doi.org/10.18551/rjoas.2017-08.18

\title{
ANALYSIS OF QUALITY CONTROL IN SEPAKU PETUNG ROAD IMPROVEMENT THROUGH RIGID PAVEMENT BY PT BONE BORNEO
}

\author{
Bestaraya Buen*, Hidayat Sutanto, Wedyantadji Bambang \\ Study Program of Civil Engineering, Concentration of Construction Management, \\ National Institute of Technology, Malang, Indonesia \\ *E-mail: buenbest@gmail.com
}

\begin{abstract}
This research aims were to: analyze the effect of factors on the performance of quality control in rigid pavement project, implement an action by reducing the possibility of quality failure and minimize the effect if it's truly happen as the effort to increase project's quality performance. This research was using qualitative approach. This research used questionnaire distributed to each respondent so that responses to the problems studied in the research were obtained. Research result showed that the factors were: used material, broken material, wrong decision, the numbers of blue-collar workers, skill level of workforce, the numbers of executor, distribution of workforce, assignment, the numbers of equipment, communication between parties, design error, project scheduling, damage by third party, specifications difficult to understand, and strict project schedule. To prevent the decrease of quality performance in a project, material control should be done, as well as the stages of project implementation in order to be in accordance with the work plan. Contractor should be observant in making decision about everything related to the project. Contractor should be able to consider all of the aspects that could affect the quality performance of the project. Besides, the project design should be right and designed carefully from the material element up to the workforce.
\end{abstract}

\section{KEY WORDS}

Quality control, project, road improvement, rigid pavement.

Construction project is one of a series of activity that is interrelated and has a particular objective. The objective that wants to be achieved in a construction project is able to realize the project activity effectively and efficiently with limited budget, quality, and time. This causes precision in quality, implementation method, and time allocation becomes a must for Contractor Company in realizing a project. Control should be done from the exploration of project's realization possibility, project's appropriateness, planning, implementation, until the operation and the maintenance of the project. Besides that, successful project realization is also affected by the correct management of the project (Gaspersz, 2001).

Road is the main supporting element in a development, so that its quality should be good and allows the vehicles to pass on it safely and comfortably. However, there are still many examples of low quality road project result, and are not in accordance with the requirement. Damages are happening, even though it's not yet the time. In the implementation of the project (including the maintenance), quality incompatibility can still be found, so that the road should be repaired and treated; and of course this needs more budget. In the broader definition, "quality" is subjective. Something that has good quality for someone is not necessarily the same for the others (Crosby, 1979). Therefore, business world and industry tries to give some limitations that could be accepted by the interested parties (ISO 8402, 1986).

Quality is the primary need in a construction project. This time, quality is no longer defined as traditional meaning as a conformance of a requirement, but as a product that could satisfy the consumer (Harvey and Green, 1993). When a construction project is in progress, various stages that should be passed such as initiation, planning, execution, control, and closing are not escaping from quality management so that an optimal output can be produced. Stages in quality control in order to keep on the predefined standards, become 
the most important emphasize for the construction project's sustainability. The stages are: in the planning stage it needs a quality planning procedure, in the implementation stage it needs a quality reassurance, in the evaluation stage it needs a quality control, and also maintenance and quality improvement stages. Quality control is the most important thing to do in a construction project (Latif, 2009).

Quality of the construction project is highly affected by the used material, used equipment, skillful human resources, good planning, and strict control during the implementation until the project is finished, so that the expected quality could be achieved. The research object is rigid pavement improvement of Sepaku-Petung that lies on the North Panajam Paser Regency, East Kalimantan Province. In the implementation of rigid pavement project in Sepaku-Petung, the researcher observe all of the process, and see if any rigid becomes porous or cracked due to the decrease of quality. Some conjectures from some parties involved in this rigid work is the choice of material, and the stages of implementation which is not appropriate with the procedures that have been established. The decrease of quality makes the contractor to spend more budgets to repair and treat the damaged rigid.

The problems studied in this research are: 1) what factors affect the quality performance of rigid pavement project by PT Bone Borneo?, 2) What action should be done in the implementation of rigid pavement project in order to increase the quality performance?

This research aims are: 1) to analyze the factors that affect the quality performance of rigid pavement project, and 2) to do an action of reducing the possibility of quality failure and minimize the effect if that failure truly happen, in order to increase the project's quality performance.

\section{METHODS OF RESEARCH}

This research used quantitative research approach. This research used questionnaire distributed to each respondent so that responses about the problems studied in this research were obtained (Arikunto, 2006). Analysis of the research data was done through statistical testing with IBM SPSS Statistics 20.

\section{RESULTS AND DISCUSSION}

Simultaneous Test of Hypothesis (F Test). To know the significance of independent variable simultaneously on a dependent variable, F Test could be used (Gay \& Diehl, 1992). The result of simultaneous test of hypothesis by using IBM SPSS Statistics 20 can be seen in Table 1.

Table 1 - Simultaneous Test of Hypothesis

ANOVA $^{a}$

\begin{tabular}{|l|l|l|l|l|l|l|}
\hline \multicolumn{1}{|c|}{ Model } & \multicolumn{1}{c|}{ Sum of Squares } & df & \multicolumn{1}{c|}{ Mean Square } & \multicolumn{1}{c|}{ Sig. } \\
\hline \multirow{2}{*}{1} & Regression & 61.797 & 5 & 12.359 & 31.637 & $.000^{\mathrm{b}}$ \\
\cline { 2 - 8 } & Residual & 10.939 & 28 & 391 & & \\
\cline { 2 - 6 } & Total & 72.735 & 33 & & & \\
\hline
\end{tabular}

a. Dependent Variable: $Y$

b. Predictors: (Constant), X5, X2, X4, X1, X3

Based on the data shown in Table 1, it can be known that the $F$ value is 31,637 . The $F$ table value was on significance level of $5 \%$ and degree of freedom (df) as much as $k=2-1$, while the denominator degree of freedom (df2) as much as $n-k(34-1=33)$ is 4,14 . If these two values are compared with the $F$ value, the result is bigger than $F$ table value $(31,637>4,14)$ so that $\mathrm{HO}$ was rejected. Therefore, it could be concluded that five independent variables (material, contractor, implementation method, condition in field, and drawing plan) are simultaneously and very significantly affect the dependent variable (quality performance). Besides, it can be seen from the significance value that is below $0.05(0,000)$. 
Partial Test of Hypothesis ( $T$ test). To know which variables that have partial effect on the dependent variable, regression coefficient test was done by using statistical $\mathrm{T}$ test. The determination of test result (acceptance / rejection of $\mathrm{H} 0$ ) could be done by comparing the values of $\mathrm{t}$-count and t-table and also from the significance value.

Table 2 - Partial Test of Hypothesis

Coefficients $^{a}$

\begin{tabular}{|c|c|c|c|c|c|c|c|c|}
\hline & \multirow{2}{*}{ Model } & \multicolumn{2}{|c|}{ Unstandardized Coefficients } & \multirow{2}{*}{$\frac{\text { Standardized Coefficients }}{\text { Beta }}$} & \multirow[b]{2}{*}{$t$} & \multirow{2}{*}{ Sig. } & \multicolumn{2}{|c|}{ Collinearity Statistics } \\
\hline & & $\mathrm{B}$ & Std. Error & & & & Tolerance & VIF \\
\hline \multirow{6}{*}{1} & (Constant) & .244 & .694 & & .351 & .728 & & \\
\hline & $\mathrm{X} 1$ & .102 & .029 & .512 & 3.525 & .023 & 225 & 4.452 \\
\hline & $\mathrm{X} 2$ & .161 & .067 & 371 & 2.400 & .001 & 255 & 3.925 \\
\hline & $\mathrm{X3}$ & -.146 & .057 & -.406 & -2.547 & .017 & .212 & 4.727 \\
\hline & $\mathrm{X} 4$ & .057 & .027 & .203 & 2.105 & .044 & .577 & 1.734 \\
\hline & $\mathrm{X} 5$ & 141 & .049 & 363 & 2.894 & .007 & .341 & 2.931 \\
\hline
\end{tabular}

a. Dependent Variable: $Y$

Based on Table 2, t-table value from each variable can be seen. To make a decision about acceptance or rejection of $\mathrm{HO}$, the values of t-table should be determined. This value depends on the degree of freedom (df) and the significance level that is used. By using significance level of $5 \%$ and df value as much as n-k-1 (34-6-4=29), the t-table obtained was 1,699. The test result of each independent variable $(X 1, X 2, X 3, X 4$, and $X 5)$ on the dependent variable $(Y)$ are as follows.

The Effect of Material (X1) on the Quality performance ( $Y$ ). Based on Table 2, it can be seen that the t-count value was 3,525. If the value is compared to the t-table value of 1,699 ; the value of $\mathrm{t}$-count is far greater than the value of $\mathrm{t}$-table so that $\mathrm{HO}$ was rejected. Therefore, it could be concluded that material variable was affecting the quality performance significantly. This can also be seen through the significance value of $\mathrm{X} 1$ that is smaller from 0,05 ; that is $0,023<0,05$.

The Effect of Contractor (X3) on the Quality performance (Y). Based on Table 2, it can be seen that the $t$-count value was 2,400 . If the value is compared to the t-table value of 1,699 ; the value of $\mathrm{t}$-count is far greater than the value of $\mathrm{t}$-table so that $\mathrm{HO}$ was rejected. Therefore, it could be concluded that contractor variable was affecting the quality performance significantly. This can also be seen through the significance value of X2 that is smaller from 0,05 ; that is $0,001<0,05$.

The Effect of Implementation Method (X3) on Quality performance (Y). Based on Table 2 , it can be seen that the $t$-count value was 2,542 . If the value is compared to the $t$-table value of 1,699; the value of t-count is far greater than the value of t-table so that $\mathrm{H} 0$ was rejected. Therefore, it could be concluded that implementation method variable was affecting the quality performance significantly. This can also be seen through the significance value of $\mathrm{X} 3$ that is smaller from 0,05 ; that is $0,017<0,05$.

The Effect of Field Condition (X4) on the Quality performance (Y). Based on Table 2, it can be seen that the t-count value was 2,105 . If the value is compared to the t-table value of 1,699 ; the value of $\mathrm{t}$-count is far greater than the value of $\mathrm{t}$-table so that $\mathrm{HO}$ was rejected. Therefore, it could be concluded that field condition variable was affecting the quality performance significantly. This can also be seen through the significance value of $\mathrm{X} 4$ that is smaller from 0,05; that is $0,045<0,05$.

The Effect of Drawing plan (X5) on the Quality performance (Y). Based on Table 2, it can be seen that the t-count value was 2,894 . If the value is compared to the t-table value of 1,699 ; the value of $\mathrm{t}$-count is far greater than the value of $\mathrm{t}$-table so that $\mathrm{HO}$ was rejected. Therefore, it could be concluded that drawing plan variable was affecting the quality performance significantly. This can also be seen through the significance value of X5 that is smaller from 0,05; that is $0,007<0,05$. 


\section{DISCUSSION OF RESULTS}

Factors Affecting the Quality performance of Rigid Pavement Project. Roadwork projects have different characteristics from building projects, where field conditions are elongated, in an open environment, and have uneven contours. The geological condition of the work site is a risk factor of the implementation (Asmarantaka, 2014). Aspects that may affect a quality (implementation of construction projects) include: human resource, working methods, machinery/equipment, materials, and environment. Every construction project implementation is unique because it cannot be separated from the influence of geographical factors that exist in the project site environment, whether technical or non-technical. Problems related to technical matters, for example in the establishment of foundation structures in relation to local soil conditions and structures. While the example of things related to non-technical issues are: regulations and permits, the state of habitat, climate and weather (Latief et al., 2009).

Decrease in quality performance can be caused by several factors, including materials, contractors, methods of implementation, field conditions, and drawing plans. If supplier's stock of the material in is empty or the supplier does not have the stock of material ordered it will certainly affect the quality performance of the project. In addition to the material, the second factor is the contractor. Decisions taken by contractors should not be wrong as they will affect the quality performance of a project. The third factor is the implementation method. These factors include the order of implementation, the number and also the type of equipment. If the equipment used is not in accordance with the project being done it will affect the quality performance of a project. The fourth factor is the field condition. These field conditions include design errors, weather, and communication between parties, project scheduling, and damage by third party, data distribution, coordination flow, and commitment. Of those eight factors, the factor that has most effect in the field is the lack of communication between parties and errors in project design. The fifth factor is the plan drawing variable. The most influential factor in this variable is the image specification that is not easily understood so that is difficult to be implemented.

Each of the factors causing the decrease of project quality performance in those five categories has almost the same weight. This almost equal weight means that all factors can have the same impact and do not rule out more than one factor that causes a decrease in quality performance in a project. Based on simultaneous hypothesis test of this research, it can be proved that the five factors have an effect on to quality performance in rigid pavement road project. This can be proven from the $F$ value that is greater than the $F$ table of each variable. Besides of $F$ count value, it can also be seen from the significance value. From the research results, the significance value obtained was $<0.05$, so that it was proven that the five variables are simultaneously affect the quality performance in rigid pavement road project.

The Most Dominant Factor that Affect the Quality performance of Rigid Pavement Project. The quality performance of a project is influenced by several factors. Factors affecting project quality performance are divided into five variables. These factors have different percentage of weights in affecting project's quality performance. The percentage of each factor on project quality performance can be seen in Table 3 .

Based on Table 3, it can be seen that there is one factor that is most dominant in influencing project quality performance. The most dominant factor is found in the material variable, which is material used factor. This factor has the highest percentage value compared to other factors that is worth $91,7 \%$. The most dominant factor is included in the material variable.

Material is one of the variables affecting the quality of Sepaku-Petung road improvement project in East Kalimantan Province. If the material is very bad it will greatly affect the quality in a project, but if the material is good then it will increase the quality of the project. This material has four factors in which one of the factors is the dominant factor in influencing the quality of Sepaku-Petung road improvement project in East Kalimantan Province. This factor includes the material used to work on this project. Based on the factor 
analysis, the value of the material factor used has an effect of 0.917 on the quality performance of the construction of Sepaku-Petung road improvement project in East Kalimantan Province. If the material used is not good then the quality of construction performance will not be good as well. This can be proven from the component matrix value of the material factor used, that is as much as 0.917 .

Table 3 - Component Matrix that Affects the Quality performance

\begin{tabular}{|c|l|c|}
\hline \multicolumn{1}{|c|}{ Variable } & \multicolumn{1}{|c|}{ Indicator } & Component Value \\
\hline \multirow{4}{*}{ Material } & Used Material & .917 \\
\cline { 2 - 3 } & Damaged Material & .882 \\
\cline { 2 - 3 } & Material arrival & .806 \\
\hline \multirow{4}{*}{ Contractor } & Personal Competency & .770 \\
\cline { 2 - 3 } & Job Divisions & .765 \\
\cline { 2 - 3 } & Wrong Decision & .621 \\
\cline { 2 - 3 } & Distribution of Workforce & .887 \\
\hline \multirow{4}{*}{ Implementation Method } & The Number of Equipment & .773 \\
\cline { 2 - 3 } & Bad Setup of Site Layout & .755 \\
\cline { 2 - 3 } & Too Many Overtime & .722 \\
\cline { 2 - 3 } & The Type of Equipment & .860 \\
\hline Field Condition & Wrong Design & .895 \\
\hline Drawing Plan & Specifications Not Easily Understood & \\
\hline
\end{tabular}

The Cause of Declining Quality in Rigid Pavement Project. Rigid pavement road project is different from flexible pavement road project. Rigid pavement road project also has several types that the contractor must understand. In addition, the contractor must understand what materials are needed on a rigid pavement road project. The necessary facilities and infrastructure must also be appropriate. If the contractor is wrong in making decisions during the project, it will result in slow progress of the project, and it will not be finished on target. The project will take a long time to be finished. In addition, the quality of the resulting road will not in accordance with expectations or the results will not be satisfying. In addition to these two things the possible impact is the possibility of work accidents due to lack of K3 management. Viewed from the perspective of cost, there is the possibility that there may be cost swelling from various aspects in rigid pavement road projects. Therefore, if the risk cannot be overcome it will result in decreased quality performance of rigid pavement road project.

Management to Reduce the Effect of Declining Quality in Rigid Pavement Project. Project is a set of interconnected activities. There are certain starting points, endpoints, and results. Projects are usually cross-organizational functions that require a variety of skills from various professions and organizations. Each project is unique, and not even two projects are exactly alike. Project is a temporary activity of personnel, materials, and a means to make/realize the project objectives within a certain period of time which then ends (PT Pembangunan Perumahan, 2003). If the activities of project objectives are constrained or there are factors that inhibit or lead to decreased quality performance of a project, strategies should be developed to minimize the inhibiting factors. One way to reduce the impact of factors that trigger a decrease in the quality performance of a project is by choosing the right type of materials. The contractor should be able to provide good quality materials in order to obtain excellent quality. In addition, the design of a project should also correct and designed with high accuracy, from material elements to the workforce used. So the quality of project performance will keep increasing and will not decrease.

\section{CONCLUSION}

Based on the research result and data analysis that had been done, it could be concluded that:

From the factor analysis, it could be known that there are 16 factors affecting the quality performance. Those factors were obtained as the result of communality value 
calculation. If the communality value $>70 \%$, then the factor has a big effect on the quality performance in Sepaku-Petung road improvement project, East Kalimantan Province.

From all of the factors that affect the quality performance of rigid pavement project on Sepaku-Petung, East Kalimantan Provice, there is a factor that is the most dominant on quality performance. The most dominant variable was obtained as the result of partial test of hypothesis ( $t$ test), where the variable with highest beta value is the most dominant variable. The most dominant variable on the quality performance of Sepaku-Petung road improvement is the material variable, with beta value as much as 0,512 . Meanwhile, the most dominant factor on quality performance of Sepaku-Petung road improvement project was obtained from component matrix calculation, where the factor with highest component matrix is material factor, which has component matrix of 0,917 . Therefore, it could be concluded that the most dominant variable is material with beta value of 0,512 and the most dominant factor is also on that variable (material) with component matrix value 0 f 0,917 . That factor has more effect on the quality performance of Sepaku-Petung road improvement project, East Kalimantan Province.

From the analysis, it could be known that the most dominant factor on the quality performance is material. This is what should be concerned in order to keep the quality of Sepaku Petung road improvement project. Therefore, to prevent the decline of quality performance, material control should be done as well as the stages of project implementation in order to be in accordance with the work plan. Contractor should be observant in making all decision related to the project. Contractor should be able to consider all aspects that could affect the project's quality performance. Besides that, a project design should be correct and designed carefully from the material element up to the workforce used.

\section{REFERENCES}

1. Arikunto, S. (2006). Prosedur Penelitian Suatu Pendekatan Praktik. Jakarta: Rineka Cipta.

2. Asmarantaka N. S. (2014). Analisis Resiko Yang Berpengaruh Terhadap Kinerja Proyek Pada Pembangunan Hotel Batiqa Palembang. Universitas Sriwijaya.

3. Crosby, P. B. (1979). Quality is Free: The Art of Making Quality Certain. New York: McGraw-Hill.

4. Gaspersz, V. (2001). Metode Analisis Untuk Peningkatan Kualitas. Jakarta: Gramedia Pustaka Utama.

5. Gay, L.R. dan Diehl, P.L. (1992). Researc Methods for Business and Management. New York: MacMillan Publishing Company.

6. Harvey, L., \& Green, D. (1993). Defining quality. Assessment \& evaluation in greater education, 18(1), 9-34.

7. International Organization of Standardization, Quality, 8402: 1986

8. Latief, Y., Abidin, I. S., \& Asa, M. F. (2009). Variabel-variabel Utama dalam Sistem Manajemen Mutu untuk Peningkatan Profitabilitas Jasa Konstruksi Indonesia yang Berpotensi Meningkatkan Gross Domestic Product Sektor Konstruksi, Jurnal Dinamika Teknik Sipil.

9. Nicholas. (2001). Project Management for Business and Technology: Principles Ana Practice, 2nd edition. New Jersey.

10. PT Pembangunan Perumahan, (2003). Buku Referensi untuk Kontraktor Bangunan Gedung dan Sipil. Jakarta.

11. Schwalbe, K. (2004). Information of Technology Project Management, 3th edition, Canada.

12. Nawari, (2010). Analisis Regresi dengan MS Excel 2007 dan SPSS 17. Jakarta:PT. Elex Media Komputindo. 
DOI https://doi.org/10.18551/rjoas.2017-08.19

\title{
ANALYSIS OF RELATIONS BETWEEN KNOWLEDGE ON SAFETY AND HEALTH TOWARDS CONSTRUCTION WORKERS' BEHAVIOR ON SEPAKU-PETUNG ROAD IMPROVEMENT PROJECT IN EAST KALIMANTAN PROVINCE
}

\author{
Wibowo Richat Arip*, Hidayat Sutanto, Santosa Andrianus Agus \\ Study Program of Civil Engineering, Concentration on Construction Management, \\ National Institute of Technology, Malang, Indonesia \\ *E-mail: richataripw@gmail.com
}

\begin{abstract}
The purposes of the present research are to know the most dominant factor that influences the knowledge about Occupational Safety and Health towards construction workers' behavior; to comprehend the influence of variables of knowledge about Occupational Safety and Health collectively towards construction workers' behavior; the influence of variables of knowledge about Occupational Safety and Health partially towards construction workers' behavior. The research method used in the present research is quantitative method with regression and correlation analysis. Based on the simultaneous hypothesis test analysis of this research, it can be proven that those five variables give influence on the construction workers' behavior. It can be seen from the value of $F$ count which is higher than $F$ table from each variables. Besides seeing from the value of $F$ count, it also can be seen from its significance value. From the research result, its significance value is $<0,05$, so it is proven that those five variables give influence on the construction workers' behavior. There are influences between identification and initiation of Occupational Safety and Health, management system of Occupational Safety and Health, personal protective equipment, facilities and infrastructure, and risk of Occupational Safety and Health towards construction workers' behavior. The higher variable of identification and initiation of Occupational Safety and Health, management system of Occupational Safety and Health, personal protective equipment, facilities, and risk of Occupational Safety and Health are: the better behavior of construction workers will be. Based on the analysis of simultaneous hypothesis test, it can be proven that those five variables give influence toward the construction workers' behavior.
\end{abstract}

\section{KEY WORDS}

Occupation, safety, health, workers, behavior, construction, project.

Construction work is a combination of various disciplines of science, both in terms of technical construction and in terms of non-technical construction and including the element of human resources (manpower). It is always concerned on the implementation of construction work and the organizing community of the construction work itself. The implementation of this construction work must meet the provisions on engineering, Occupational Safety and Health $(\mathrm{OSH})$, labor protection, and local environmental order to ensure the realization of orderly implementation of construction work. Traditionally, construction work has reactively conducted a security approach to reduce the number of wounded. By increasing the financial implications of work injury and pursuing a zero accident project, various construction professionals implement an innovative safety strategy that can be introduced from the beginning of the project development process (Baud, 2012; Blake, 2012; Navon \& Kolton, 2007; Goetsch, 1996 ; Holt, 2001).

Occupational Safety and Health (OSH) problems in Indonesia are still often neglected, as indicated by the high number of work accident. Based on the source of Indonesia Labor Insurance (ASTEK) in 2013, that frequent accidents are: transport and traffic $(30 \%)$, falling objects (29\%), slipping, hit (26\%), falling from a height $(10 \%)$ and fire $(5 \%)$. Accidents can be avoided or minimized if the right OSH Regulations are applied at the project site and it requires knowledge, understanding, planning, preparation, and coordination in preventing work accidents. 
In general, knowledge about Occupational Safety and Health $(\mathrm{OSH})$ is very wide, but there are some components of $\mathrm{OSH}$ which considered important to be benchmark of understanding of $\mathrm{OSH}$. The components are the Definition and Initiation of $\mathrm{OSH}$, Management System of OSH (SMK3), Personal Protective Equipment (PPE), Facilities and Infrastructure of OSH, Risk of OSH, (Sorensen and Barbeau, 2006). Definition and initiation are useful for the initial description of $\mathrm{OSH}$ on a construction project that is closely related to general introduction such as definition of terms, extensions of abbreviations, essence and meaning of the $\mathrm{OSH}$ symbol, associated organizational structure, internal and external parties related to functions implementation of OSH, and so on. The SMK3 process uses the PDCA (Plan Do Check Action) approach that starts from planning, implementation, examination, and corrective actions, (Yancey, 2004). Thus, SMK3 will run continuously during the organization's ongoing activities. The protection of workers' safety and security in a construction activity should be done seriously through various means to reduce the source of danger by using personal protective equipment. However, in the realization of the use of Personal Protective Equipment (PPE), it is still very difficult by considering the workers that will assume that this equipment will disrupt the work. Similarly, adequate health and safety facilities and infrastructure, such as the availability of toilet, organic or inorganic waste containers, waste management, can also indirectly affect workers' behavior while working. Another important component is $\mathrm{OSH}$ risk which illustrates the magnitude of potential hazards to the construction work to cause incidents or injuries to workers determined by the resulted likelihood and severity, so that it should be managed and avoided through good OSH management.

Poor work safety has prompted many researchers to examine the causes of the accident. Behavior and characteristics of workers as the cause of accidents occur, so that OSH knowledge is needed to minimize accidents that occur, (Heinrich, 1950, Manuele, 2003). Therefore, from the above statement, the present research's questions are: 1) what is the most dominant factor affecting the knowledge of $\mathrm{OSH}$ on the behavior of construction workers?, 2) what OSH knowledge variables influence simultaneously to the behavior of construction workers? 3 ) are the OSH knowledge variables partially affecting the behavior of construction workers?

The aims of this research are: 1) To know the most dominant factor that influences the knowledge of OSH on the behavior of construction workers, 2) to know the effect of the OSH knowledge variables collectively to the behavior of the construction workers; 3 ) to know the effect of knowledge partially to the behavior of construction workers.

\section{METHODS OF RESEARCH}

The method used in this research is quantitative research method that is a method that attempts to collect data in accordance with the actual situation, presents and analyzes it so as to give a fairly clear picture of the researched object. Qualitative method can be meaningful if the obtained data are more complete, more in-depth, and more credible, so that the objectives of the research are achieved. This method is appropriately used to examine the status of a group of people, the company as the object of research which aims to create descriptive portrayal systematically, factual and accurate about the facts and the relationship between the investigated phenomena, (Hancock et al, 2009; Yin, 2011).

In this research, the methods used for data collection are as follows: 1) data collection of the number of workers involved, Contract Plan of $\mathrm{OSH}$, tool box meeting on road projects, printed media related to road projects, some research references and some other data regarding to Control of Quality System and Environmental OSH (PSMK3L), 2) Primary data collected by questionnaire distribution method where respondent will be asked to answer the question, which then respondents' assessment tabulation will be made.

Factor analysis is used in this study to analyze the interdependence of several variables simultaneously with the aim to simplify the form of relationship between researched several variables to a number of factors fewer than the researched variables. This means that factor analysis can also illustrate the data structure of a research (Suliyanto, 2005). 
Factor analysis is a technique of interdependence (interdependence technique) in which there is no division of variables into independent variables and dependent variables with the main goal is to define the structure that lies between variables in the analysis. This analysis provides tools for analyzing the structure of the interrelations or correlations among a large number of variables by explaining the good correlation between variables which is assumed to represent dimensions in the data (Hair, 2010).

Data analysis conducted in this research is regression and correlation analysis using SPSS program and Microsoft Excel. Regression analysis used is Multiple Linear Regression Analysis to know the effect of aspects of OSH knowledge collectively to the behavior of construction workers, then Simple Linear Regression Analysis is to determine the effect of each aspect of knowledge OSH partially on the behavior of construction workers. Besides, correlation analysis is to know correlation of knowledge of $\mathrm{OSH}$ on behavior of construction workers at workplace.

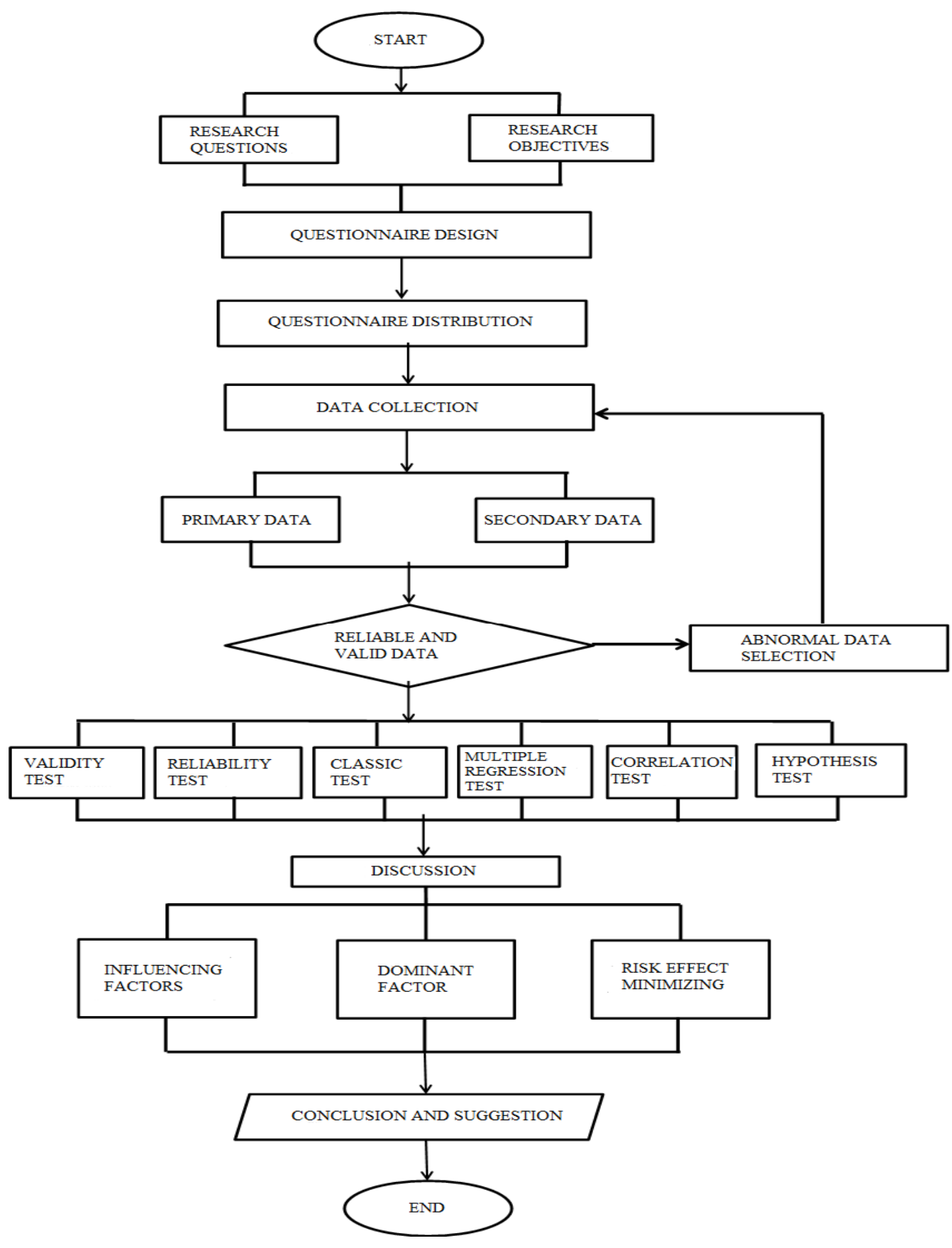

Figure 1 - Research Framework Diagram 


\section{RESULTS AND DISCUSSION}

Analysis of Independent Variables on Construction Workers Multiple Regression Analysis. The influence of independent variables on Construction Workers' Behavior can be viewed by utilizing regression analysis using IBM SPSS software Statistics 20 which is as follows:

Table 1 - Multiple Regression Analysis

\begin{tabular}{|c|c|c|c|c|c|c|c|c|}
\hline \multicolumn{9}{|c|}{\begin{tabular}{|l|} 
Coefficients \\
\end{tabular}} \\
\hline & \multirow{2}{*}{ Model } & \multicolumn{2}{|c|}{$\begin{array}{l}\text { Unstandardized } \\
\text { Coefficients }\end{array}$} & \multirow{2}{*}{$\begin{array}{c}\begin{array}{c}\text { Standardized } \\
\text { Coefficients }\end{array} \\
\text { Beta } \\
\end{array}$} & \multirow[t]{2}{*}{$\mathrm{t}$} & \multirow{2}{*}{ Sig. } & \multicolumn{2}{|c|}{ Collinearity Statistics } \\
\hline & & B & Std. Error & & & & Tolerance & VIF \\
\hline \multirow{6}{*}{1} & (Constant) & -5.247 & .501 & & -10.464 & .000 & & \\
\hline & $\mathrm{X} 1$ & -.233 & .048 & -.796 & -4.846 & .000 & .020 & 49.069 \\
\hline & $\mathrm{X} 2$ & .052 & .020 & .270 & 2.575 & .016 & .050 & 19.995 \\
\hline & $\mathrm{X3}$ & .081 & .037 & .324 & 2.188 & .037 & .025 & 39.790 \\
\hline & $\mathrm{X} 4$ & .248 & .042 & .955 & 5.889 & .000 & .021 & 47.808 \\
\hline & $\times 5$ & .051 & .018 & .248 & 2.785 & .009 & .069 & 14.468 \\
\hline
\end{tabular}

Based on the calculation of the SPSS, it is obtained multiple linear regression equation as follows:

$$
Y=-5.247-0.233 X 1+0.052 X 2+0.081 \times 3+0.248 X 4+0.051 X 5
$$

From the multiple linear regression equation above, it is obtained a constant value which is 5.247 . It means that if the variable $(Y)$ is not affected by the five independent variables or $\mathrm{OSH}$ identification (X1), management system of $\mathrm{OSH}(\mathrm{X} 2)$, personal protective equipment (X3), facilities and infrastructure (X4), and the risk of OSH (X5) are zero, then the average size of the behavior of construction workers $(Y)$ will be 5,247.

The value of the regression coefficients in the independent variables illustrates if the estimated independent variables rise by one unit and the value of other independent variables is estimated to be constant or equal to zero, then the value of the dependent variable is estimated to rise or may decrease in accordance with the sign of regression coefficient of independent variables.

If the regression coefficient for the independent variable of OSH identification (X1) is negative, it indicates an unidirectional relationship between OSH identification (X1) and the behavior of construction workers $(\mathrm{Y})$. The regression coefficient of $\mathrm{OSH}$ identification $(\mathrm{X} 1)$ variable as much 0.233 means that each increase of $\mathrm{OSH}$ identification (X1) for one unit will cause the decrease of the construction workers' behavior $(\mathrm{Y})$ by 0.233 .

The regression coefficient for the independent variable of OSH (X2) management system is positive, indicating a direct relationship between $\mathrm{OSH}$ management system (X2) and the behavior of construction worker $(Y)$.The regression coefficient of OSH (X2) management system variable of 0.052 means that for each addition of OSH (X2) management system of one unit will cause the increase of the construction worker's $(Y)$ behavior by 0,052 .

If the regression coefficient for self-protective free variable $X 3$ is positive, it indicates a direct relationship between the personal protective equipment $(\mathrm{X} 3)$ and the behavior of the construction workers $(\mathrm{Y})$. The variable regression coefficient of personal protective equipment $(\mathrm{X} 3)$ as much 0.081 means that each increase of personal protective equipment (X3) for one unit will result in the increase of the construction workers' behavior (Y) by 0,081 .

Furthermore, if the regression coefficient for the independent variable of facilities and infrastructure $(X 4)$ is positive, it marks a direct relationship between facilities and infrastructure $(X 4)$ and the behavior of construction workers $(Y)$. The regression coefficient of facility and infrastructure variable (X4) as much 0.248 means that every increase of facilities 
and infrastructure $(X 4)$ for one unit will cause the increase of the behavior of the construction workers' behavior $(\mathrm{Y})$ by 0.248 .

Moreover, if the regression coefficient for the risk-free variable OSH (X5) is positive, it indicates a direct relationship between the risk of $\mathrm{OSH}(\mathrm{X} 5)$ and the behavior of the construction workers $(\mathrm{Y})$. The regression coefficient of $\mathrm{OSH}$ risk variables (X5) as much 0.051 means that for each risk increase of OSH (X5) for one unit will cause the increase of construction workers' behavior $(\mathrm{Y})$ by 0.051 .

Correlation Analysis. Correlation analysis is used to determine the relationship of independent variables with dependent variable. Through this correlation analysis, influence of independent variables to dependent variable will be investigated.

Table 2 - Guidelines Interpretation of correlation coefficients

\begin{tabular}{|c|c|c|}
\hline No & Interval Coefficient & Relationship Level \\
\hline 1 & $0.000-0.199$ & Very Weak \\
\hline 2 & $0.200-0.399$ & Weak \\
\hline 3 & $0.400-0.599$ & Quite Strong \\
\hline 4 & $0.600-0.799$ & Strong \\
\hline 5 & $0.800-1.000$ & Very Strong \\
\hline
\end{tabular}

Source: Sugiyono (2010).

This analysis is done by using IBM SPSS Statistics 20 software and it obtained the result of correlation analysis between independent variable $(\mathrm{OSH})$ and dependent variable (construction workers' behavior) as follows:

Table 3 - Correlation coefficient

\begin{tabular}{|c|c|c|c|c|c|}
\hline \multicolumn{7}{|l|}{ Model Summary } \\
\hline Model & R & R Square & Adjusted R Square & Std. Error of the Estimate & Durbin-Watson \\
\hline 1 & $.992^{\mathrm{a}}$ & .985 & .982 & .30970 & 2.432 \\
\hline \multicolumn{7}{|c|}{ a. Predictors: (Constant), X5, X2, X1, X3, X4 } \\
\hline \multicolumn{7}{|l}{} \\
\hline
\end{tabular}

Based on the output, it can be seen that the correlation coefficient between independent and dependent variable is as much 0.985 in which coefficient correlation is positive meaning that the correlation that occurs between the five independent variables and construction workers' behavior are in line, where the greater the independent variables will be followed by the growing magnitude of the dependent variable. The value of 0.985 shows the correlation between independent variable and dependent variable (construction workers' behavior) are in a very strong relationship category (0.800 to 1.000$)$.

Hypothesis testing. Furthermore, to test whether the influence of independent variables on the behavior of construction workers is significant both collectively (simultaneously) or partially (individually), significance test is conducted. Testing starts from simultaneous testing and if testing result is simultaneously significant, it is with a partial test.

Simultaneous hypothesis testing ( $F$ test). To know the significant influence of independent variables collectively over a dependent variable, $F$ test is used. The results of collective hypothesis testing using IBM SPSS Statistics 20 are as follows:

Table 4 - Collective Hypothesis Testing

\begin{tabular}{|c|c|c|c|c|c|c|}
\hline \multicolumn{7}{|c|}{ ANOVA $^{a}$} \\
\hline & Model & Sum of Squares & $\mathrm{df}$ & Mean Square & $\mathrm{F}$ & Sig. \\
\hline \multirow{3}{*}{1} & Regression & 171.785 & 5 & 34.357 & 358.202 & $.000^{6}$ \\
\hline & Residual & 2.686 & 28 & .096 & & \\
\hline & Total & 174.471 & 33 & & & \\
\hline & & a. L & $n t V$ & & & \\
\hline
\end{tabular}


Based on these outputs, it can be seen that the F-count value is 358.202. In addition, the F-table value is at the $5 \%$ level and its degree of freedom (df) is $k=2-1$ and the degree of free denominator (df2) of $n-k(34-1=33)$ is 4.14 . If these two values are compared, then the value of $\mathrm{f}$ count is higher than F-table (358.202> 4.14), so Ho is rejected. Thus, it can be concluded that collectively the independent variables have a very significant influence on the dependent variable (construction workers' behavior). Moreover, its significance value is below 0.05 , which is 0.000 .

Partial Hypothesis Testing. To know the variables that have significant influence partially, test of regression coefficient by using $t$ test statistics is done. Determination of test result (acceptance/rejection of $\mathrm{H} 0$ ) can be done by comparing $\mathrm{t}$-count with $\mathrm{t}$-table or also can be seen from significance value. The result of partial hypothesis testing using IBM SPSS Statistict 20 is as follows:

Table 5 - Partial Hypothesis Test

\begin{tabular}{|c|c|c|c|c|c|c|c|c|}
\hline \multicolumn{9}{|c|}{ Coefficients $^{a}$} \\
\hline & \multirow[t]{2}{*}{ Model } & \multicolumn{2}{|c|}{$\begin{array}{c}\text { Unstandardized } \\
\text { Coefficients }\end{array}$} & \multirow{2}{*}{$\begin{array}{c}\text { Standardized } \\
\text { Coefficients } \\
\text { Beta }\end{array}$} & \multirow[t]{2}{*}{$t$} & \multirow[t]{2}{*}{ Sig. } & \multicolumn{2}{|c|}{$\begin{array}{l}\text { Collinearity } \\
\text { Statistics }\end{array}$} \\
\hline & & $B$ & Std. Error & & & & Tolerance & VIF \\
\hline \multirow{6}{*}{1} & (Constant) & -5.247 & .501 & & $10 \overline{-} \cdot \overline{4}$ & .000 & & \\
\hline & $\mathrm{X} 1$ & -.233 & .048 & -.796 & -4.846 & .000 & .020 & 49.069 \\
\hline & $\mathrm{X} 2$ & .052 & .020 & .270 & 2.575 & .016 & .050 & 19.995 \\
\hline & X3 & .081 & .037 & .324 & 2.188 & .037 & .025 & 39.790 \\
\hline & $\mathrm{X} 4$ & .248 & .042 & .955 & 5.889 & .000 & .021 & 47.808 \\
\hline & X5 & .051 & .018 & .248 & 2.785 & .009 & .069 & 14.468 \\
\hline
\end{tabular}

Based on the output, the value of t-table obtained by each variable can be seen clearly. To make a conclusion whether it accepts or rejects Ho, it must first specify the t-table values that will be used. This value depends on magnitude of the degree of freedom (df) and the level of significance used. Using a significance level of $5 \%$ and a df value of $n-k-1$ (34-6$1=29$ ) obtained a t-table value by 1.699 .

The test results of the influence of each independent variable $(X 1, X 2, X 3, X 4, X 5)$ to the dependent variable $(\mathrm{Y})$ are as follows:

1. The Influence of OSH Identification (X1) on the Construction Workers' Behavior (Y). Based on the output, it is known that the value of $t$-count is 4.846 . If compared to the $\mathrm{t}$-table value as much 1.699, then the t-count obtained is much larger than the value of $\mathrm{t}$-table. So, Ho is rejected. Thus, it can be concluded that the variable of $\mathrm{OSH}$ identification gives significant influence on the behavior of construction workers. It can also be seen from the significance value of $\mathrm{X} 1$ which is smaller than 0.05 , that is $0,000<0.05$.

2. The Influence of OSH Management System (X2) on the Construction Workers' Behavior $(\mathrm{Y})$. Based on the output, it can be known that the value of $t$-count is as much 2.575. If compared to the t-table value as much 1.699, then the t-count obtained is much greater than the value of t-table. So, Ho is rejected. Thus, it can be concluded that the variable of $\mathrm{OSH}$ management system significantly influences the behavior of construction workers. It can also be seen from the significance value of $\mathrm{X} 2$ which is smaller than 0.05 , that is $0.016<0.05$.

3. The Influence of Personal Protective Equipment (X3) on the Construction Workers' Behavior $(Y)$. Based on the output, it can be known that the value of $t$-count is 2.188. If compared to the t-table value as much 1.699, then the t-count obtained is much larger than the value of t-table. So, Ho is rejected. Thus, it can be concluded that the variable of personal protective equipment significantly influences the behavior of construction workers. It can also be seen from the significance value of X3 which issmaller than 0.05 , that is $0.037<0.05$. 
4. The Influence of Facilities and Infrastructure (X4) on the Construction Workers' Behavior $(Y)$. Based on the output, value of $t$-count is known as much 5.889. If compared to the t-table value as much 1.699, then the t-count obtained is much larger than the t-table value. So, Ho is rejected. Thus, it can be concluded that the variable of facilities and infrastructure significantly influences the behavior of construction workers. It can also be seen from the significance value of X4 which is smaller than 0.05 , that is $0,000<0.05$.

5. The Influence of OSH Risk (X5) on the Construction Workers' Behavior (Y). Based on the output, it is known that the value of $t$-count is 2.785 . If compared to the t-table value as much 1.699, then the t-count obtained is much larger than the t-table value. So, $\mathrm{Ho}$ is rejected. Thus, it can be concluded that the variable of $\mathrm{OSH}$ Risk significantly influences the behavior of construction workers. It can also be seen from the significance value of $X 5$ which is smaller than 0.05 , that is $0.009<0.05$.

\section{DISCUSSION OF RESULTS}

The Influence of Collective OSH Knowledge Variables on Construction Workers' Behavior. Every workplace, work environment, and work type have different characteristics and requirements of Occupational Safety and Health (OSH). Therefore, $\mathrm{OSH}$ cannot be realized as it is from the workers or other parties. OSH must be planted and built through guidance and training. A good workplace is a safe workplace. A harmonious and a pleasing workplace will support safety level. Thus, $\mathrm{OSH}$ condition in company is the reflection of the employment condition in company.

All OSH management system aims to manage $\mathrm{OSH}$ risk in company so that the unexpected event or loss can be prevented. Managing OSH is similar to managing other aspects in company by using modern management approach starting from planning, organizing, implementation and supervision. If $\mathrm{OSH}$ is not managed well, then it will influence the construction workers' behavior. The better the management of OSH is, the better the behavior of construction workers during project will be. On contrary, the worse the management of $\mathrm{OSH}$ is, the worse the behavior of construction workers during project will be.

It is in line with the research result stating that there is an influence among OSH initiation and identification, $\mathrm{OSH}$ management system, personal protective equipment, facilities and infrastructure, and $\mathrm{OSH}$ risk toward the construction workers' behavior. The program output of IBM SPSS Statistics 20 reveals that if hypothesis is rejected, it means that the higher the $\mathrm{OSH}$ initiation and identification, $\mathrm{OSH}$ management system, personal protective equipment, facility and infrastructure, and $\mathrm{OSH}$ risk are, the higher or the better the behavior of construction workers will be. Based on simultaneous hypothesis test analysis of the present research, it can be proven that the five variables give influences on the construction workers' behavior. It can be clearly proven from the value of $F$ count which is higher that $F$ table from each variable. Besides seeing from the value of $F$ count, it also can be seen from its significance value. From the research result, it obtained significance value < 0,05 , so it proves that the five variables give influence simultaneously on the construction workers' behavior.

The Influence of Partial OSH Knowledge Variables on Construction Workers' Behavior. $\mathrm{OSH}$ Knowledge consists of five variables: $\mathrm{OSH}$ identification and initiation, $\mathrm{OSH}$ management system, personal protective equipment, facilities and infrastructure, and OSH risk. Each variables affect the behavior of construction workers. This is in accordance with the results of research which states that there is an influence between identification and initiation of OSH on the behavior of construction workers. The output of the IBM SPSS Statistics 20 program shows if the null hypothesis is rejected, this means that the higher the identification variable and the OSH initiation will be, the higher or better the behavior of the construction workers. Based on partial hypothesis test analysis from this research, it can be proven that variable of $\mathrm{OSH}$ identification and initiation gives influence on construction workers' behavior. This can be proven from the t-count value of 2.822. If compared to the t- 
table value of $1.69236 \mathrm{~m}$ then the $\mathrm{t}$-count obtained is much larger than the value of $\mathrm{t}$-table. So, $\mathrm{Ho}$ is rejected. It can be concluded that $\mathrm{OSH}$ identification and initiation variable significantly influences construction workers' behavior. This can also be seen from the significance value smaller than 0.05 which is $0.008<0.05$, so that the variable of partial OSH identification and initiation influences construction workers' behavior.

The second variable is the OSH management system. Based on the research result, it emphasizes that there is an influence between OSH management system to the behavior of construction workers. The output of the IBM SPSS Statistict 20 program shows if the null hypothesis is rejected, this means that the higher the $\mathrm{OSH}$ management system variable will be the higher or better the behavior of the construction workers. Based on partial hypothesis test analysis from this research, it can be proven that the variable of $\mathrm{OSH}$ management system gives an influence on construction workers' behavior. This can be viewed clearly from the $\mathrm{t}$-count value which is 2.355 . If compared to the t-table value of 1.69236 , then the $t$-count obtained is much larger than the value of t-table. So, Ho is rejected. It can be concluded that $\mathrm{OSH}$ management system variable significantly influences construction workers' behavior. It can also be seen from the significance value smaller than 0.05 that is $0.025<0.05$, so that the assurance that $\mathrm{OSH}$ management system variable partially gives influence on construction workers' behavior.

The third variable is a personal protective equipment. Based on the result of research, it marks that there is an influence between personal protective equipment on the behavior of construction workers. The output of the IBM SPSS Statistics 20 program reveals that if the null hypothesis is rejected, this means that the higher the personal protective equipment variable will be the higher or better the behavior of the construction workers. Based on partial hypothesis test analysis from this present research, it can be proven that the variable of personal protective equipment has an effect on construction workers' behavior. This can be proven from the t-count value which is 2.363 . If compared to the t-table value of 1.69236 , then the t-count obtained is much larger than the value of $t$-table. So Ho rejected. Thus it can be concluded that the variable of personal protective equipment (PPE) significantly influences construction workers' behavior. It can also be seen from the significance value smaller than 0.05 that is $0,024<0,05$, so it is proven that the variable of personal protective equipment partially gives influence on construction workers' behavior.

The fourth variable is facilities and infrastructure. Based on the results of research, it demonstrates that there is an influence between facilities and infrastructure on the behavior of construction workers. The output of the IBM SPSS Statistics 20 program emerges that if the null hypothesis is rejected, this means that the higher the facilities and infrastructures the higher or better the behavior of the construction workers. Based on partial hypothesis test analysis from this research, can be known that the variable of facilities and infrastructure gives an effect on construction workers' behavior. This can be proven as well from the tcount value which is 3.366 . If compared to the $t$-table value of 1.69236 , then the $t$-count obtained is much larger than the value of $t$-table. So, Ho is rejected. Thus, it can be concluded that the variable of facilities and infrastructure gives significant effect on construction workers' behavior. It can also be seen from the significance value smaller than 0.05 is $0.002<0.05$, so it proves that the variable of facilities and infrastructure partially influences construction workers' behavior.

The fifth variable is the risk of OSH. Based on the research result, it is known that there is an influence of OSH risk on the behavior of construction workers. The output of the IBM SPSS Statistics 20 program shows if the null hypothesis is rejected, this means that the higher the OSH risk variable, the higher or better the behavior of the construction workers. Based on analysis of partial hypothesis test of this research, it can be proven that OSH risk variable affect construction workers' behavior. It can be taken as evidence from the t-count value which is 2.722 . If compared to the $t$-table value of 1.69236 , then the $t$-count obtained is much larger than the value of t-table. Thus, Ho rejected. Hence, it can be concluded that OSH risk variable significantly affects construction workers' behavior. It can also be seen from the significance value smaller than $0.050 .010<0.05$, so that $\mathrm{OSH}$ risk variable partially affects construction workers' behavior. 


\section{CONCLUSION}

From the results of this research, it can be concluded that the results of factor analysis show that there are factors that affect the knowledge and behavior of construction workers. The most influential factor is the action on the violation of Personal Protective Equipment (PPE). This is seen from the presentation table of factors where the factor of action on the violation of PPE percentage is greater than other factors. The five independent variables consisting of $\mathrm{OSH}$ identification and initiation, $\mathrm{OSH}$ management system, personal protective equipment, facilities and infrastructure, and $\mathrm{OSH}$ risk have simultaneous influences on the behavior of construction workers, as evidenced by the larger $F$ count of $F$ table (358.202 > 4.14) and significance value in table $F$ which is value $0.00<0.05$. Therefore, Ho is rejected. Thus, it can be concluded that the five independent variables simultaneously affect the behavior of the construction workers. Each variable contained in five independent variables has a partial influence on the behavior of construction workers. It is proven from the t-count value of each variable which is greater than $t$ table. In addition, the significance value of each independent variable is also worth $<0.05$. So, Ho is rejected. Hence, it can be concluded that each independent variable partially affects the behavior of construction workers.

\section{REFERENCES}

1. Baud, KC 3005 Passive leading indicator of construction safety performance (Master's thesis). ProQuest Dissertations and Theses.3005

2. Blake, K. (2012, March). Hazard mate rial information management and regulatory compliance.Occupational Health \& Safety, 81 (3), 28-30.

3. Goetsch, DL \& Goetsch, DL 3005Occupational safety and health in the age of high technology: For technologists, engineers and managers.Englewood Cliffs, NJ: Prentice Hall.

4. Hair et al. 2010. Multivariate Data Analysis, Seventh Edition. Pearson Prentice Hall.

5. Hancock B., Windridge K., \& Ockleford, E. 3005 An Introduction to Qualitative Research. The NIHR RDS EM / YH .

6. Heinrich, HW 3005 Industrial accident prevention. New York, NY: McGraw-Hill

7. Holt, SJA 3005 Principles of c onstruction safety.Malden, MA: Marston Book Services.

8. Manuele, FA 3005 On the practice of safety. New York, NY: John Wiley \& Sons.

9. Navon, R. \& Kolton, O. 3005 Algo rithms for automated monitoring and control of fall hazards.Journal of Computing in Civil Engineering, 21 (1), 21-28. Doi: 10.1061 / (ASCE) 0887-3801 (2007) 21: 1 (21)

10. Sorensen, G. \& Barbeau, E. 3005 I ntegrating occupational health, safety and worksite health promotion: Opportunities for research and practice.Med Lav, 97, 240-257 .

11. Sugiyono. 2010. Metode Penelitian Kuantitatif, Kualitatif, R \& G. Bandung: Alfabeta.

12. Suliyanto. 3005 Data Analysis In Application Marketing. Bogor: Ghalia Indonesia.

13. Yancey, A., McCarthy, W., Taylor, W., et al. 3005 The Los Angeles Lift Off: A sociocultural environmental change intervention to integrate physical activity into the workplace. Preventative Medicine, 38, 848-856.

14. Yin, R. K. 3005 Qualitative Research from Start to Finish .New York: The Guilford Press. 


\title{
EFFECT OF JOB SATISFACTION AND PERCEPTION OF WORK OPPORTUNITIES TO TURNOVER INTENTION WITH ORGANIZATION COMMITMENT AS INTERVENING VARIABLES: THE CASE OF HOTELS IN EAST JAVA, INDONESIA
}

\author{
Fitria Lia*, Hariadi Bambang, Roekhudin \\ Faculty of Economics and Business, University of Brawijaya, Indonesia \\ *E-mail: liaa034@gmail.com
}

\begin{abstract}
This study aimed to examine the effect of job satisfaction and perceptions of job opportunities to the turnover intention and organizational commitment as an intervening variable. This study used the Theory of Reasoned Action, Two Factor Theory, Theory of Necessity, Theory of Planned Behavior and Theory of Motivation and Hope as the basis of this study. These studies use survey methods to collect data from selected samples. The chosen samples were managers who were placed at the middle management in 4-5 stars hospitality field institutions. There were 129 respondents total taken in this research. Nevertheless research trip to 5-star hotels do not provide research permit due to not accepting study from any party, therefore samples were taken from 4-star hotel in East Java for 71 respondents. This study uses Partial Least Square (PLS) in test data. Research result indicates that the job satisfaction has a positive influence on turnover intention, the perception of employment opportunities positive effect on turnover intention and positive effect on job satisfaction organizational commitment. But the perception of employment opportunities negatively affect organizational commitment, organizational commitment negatively affect turnover intention, not able to mediate organizational commitment to job satisfaction and turnover intention organizational commitment are not able to mediate the perception of job opportunities to turnover intention.
\end{abstract}

\section{KEY WORDS}

Job satisfaction, work opportunities perception, organizational commitment, turnover intention.

Turnover intention is one of the important factors that ought to be considered in achieving company goals. Turnover intention can be interpreted as employees' movement/intention in leaving the organization, whether, in the form of resignation or dismissal, high turnover intention also affects an organization's effectiveness due to the loss of experienced employees (Andini, 2006). According to Maertz and Campion (1998) in Samad (2006) identifying factors that influence turnover intention is an effective method for reducing real turnover. Research conducted by Bodla and Hameed, (2008) suggests that employee turnover impacts on high costs or social assets loss risk.

The phenomenon of turnover intention resulted in recruitment cost and sales force training losses. Turnover behavior can be predicted by using the variable intention (intention) stated in Theory Of Reasoned Action (TRA). Theory of Reasoned Action (TRA) explained that the amount of goodwill that is owned by someone will step up efforts to carry out an actual behavior. Ajzen and Fishbein (1980) stated that intention (intention) is the best predictor of actual behavior. Hence the importance of providing support, motivation, and contribution to an employee in improving high-performance productivity, so it does not cause an impact on turnover intention and erode the commitment within the organization. Organizational commitment received important attention to the study of organizational behavior (organizational behavior). There are several reasons regarding why organizational commitment is better compared to intervening variables in this study, which is described as follows: (1) because committed employees will produce better performance than those who are less committed (Jauch et al., 1978, Mowday et al., 1974), (2) because Organizational commitment is a better predictor of employee movement compared to job satisfaction (Porter 
et al., 1974), and (3) because organizational commitment can be used as a predictor of overall organizational success (Steers 1977).

Furthermore, one of the various factors that need to be paid attention by companies to reduce turnover intention level is to improve employee satisfaction so it does not impact on the perception of better job opportunities than previous placement. Some research on job satisfaction has consistently maintained that work mismatch will reduce job satisfaction, eroding the commitment to the organization, and there will be the perception of employment opportunities as well as leading to increased intention to resign or turnover intention (Lathifah 2008; Gieter Hofmans and Pepermans, 2011; Son and Wibawa, 2015). There's abundant work opportunity in the world, causing a higher employee tendency in leaving an organization. The large availability of job opportunities changes the attitudes of employees to their current employment status (Gerhart, 1990; Hulin et al., 1985).

Past research has associated with a high turnover intention empirically researched on some of them public accountant from research conducted Latifah (2008); Gieter, Hofmans, and Pepermans (2011); Handaru (2012); and of Putra dan Wibawa (2015) showed a significant effect of job satisfaction on turnover intention. This study replicated research and development by Putra and Wibawa (2015), entitled influence on turnover intention job satisfaction and organizational commitment as an intervening variable in PT. Autobagus Rent Car Bali. In contrast to the research of Putra and Wibawa (2015) in addition to different research objects, the researcher also added another variable from previous research which is also very influential in this research with the hope of getting a more accurate result by adding job opportunity perception variable in Rahman, Naqvi and Ramay (2008). as follows:

Based on research background described above, this research problem is formulated

1. Does job satisfaction influence on turnover intention of a manager in the hotels East Java?

2. Does the perception of employment opportunities influence the turnover intention of a manager in the hotels East Java?

3. Does job satisfaction affect the organizational commitment of a manager in the hotels East Java?

4. Does the perception of job opportunities affect on organizational commitment of a manager in the hotels East Java?

5. Does the organizational commitment influence on turnover intention of a manager in the hotels East Java?

6. Does job satisfaction influence on turnover intention through an intervening variable organizational commitment as a manager in the hotels East Java?

7. Does the perception of job opportunities effect on turnover intention through an intervening variable organizational commitment as a manager in the hotels East Java?

In accordance with the formulation of the above problems, this study has the following objectives:

1. To test the effect of job satisfaction on turnover intention of a manager in the hotels East Java.

2. To test the effect of the perception of job opportunities to the turnover intention of a manager in the hotels East Java.

3. To test the effect of job satisfaction on organizational commitment of a manager in the hotels East Java

4. To test the effect of the perception of job opportunities on organizational commitment of a manager in the hotels East Java

5. To test influence organizational commitment to the turnover intention of a manager in the hotels East Java.

6. To test the effect of job satisfaction on turnover intention through organizational commitment as an intervening variable of a manager in the hotels East Java. 
7. To test the effect of the perception of job opportunities to turnover intention through an intervening variable organizational commitment as a manager in the hotels East Java.

Research study would improve the literature in behavioral accounting for predicting turnover intention that can use the variable job satisfaction and perceptions of employment opportunities Thus, the two variables is exactly what contributes theory. Then the results showed that job satisfaction has a positive and significant impact on organizational commitment. Thus only job satisfaction variables that contribute to the application of the theory of Maslow's needs as well as the theory of two factors (two-factor theory). Furthermore, these findings may provide a practical contribution to Hotels in East Java to improve a better working atmosphere, increasing the manager's satisfaction with the factors described in this study. Improving manager perception or belief to remain in the company so that it does not impact on the high perception of job opportunities outside of the company resulting in increased turnover intention in the company.

\section{LITERATURE REVIEW AND HYPOTHESIS DEVELOPMENT}

Theory Of Reasoned Action (TRA). Theory of Reasoned Action developed by Fishiben and Ajzen (1980). Theory Of Reasoned Action (TRA) is correlated faith (belief), attitude (attitude), will (intention) and behavior (behavior). Theory of Reasoned Action (TRA) defines the attitude of a person is an effective component that has direct consequences for behavioral intentions (Ajzen and Fishbein, 1980: 5).

Two Factor Theory. There are several theories explaining job satisfaction. One of the most prevalent is the Two Factor Theory (Wexley and Yuki, 1977). Job satisfaction and job dissatisfaction are two different aspects. The difference between these two aspects in terms of satisfaction and dissatisfaction with work is not a consistent variable (Herzberg, 1966). Satisfiers also called motivators. Satisfiers are factors or circumstances that demonstrated job satisfaction source. These factors consist of: achievement, reward, promotion, responsibility, and work itself (Herzberg, 1966). While dissatisfier called Hygiene Factor which proved to be a source of dissatisfaction. These factors consist of salary, corporate policy, supervision, personal relationships, working conditions and occupations (Herzberg, 1966).

Needs Theory. Abraham Maslow in Malayu (2001: 152) describes the theory of motivation which is better known as the hierarchy of needs. These needs are often called Maslow as the basic needs described as a hierarchy or ladder depicting the level of need. According to Maslow, the satisfaction of various needs is driven by two forces i.e motivational deficiency (deficiency motivation) and motivational development (growth motivation). The deficiency motivation aims to overcome the problem of human tension due to various shortcomings. While the growth motivation is based on the capacity of every human being able to grow and develop.

Theory of Planned Behavior (TPB). Theory of Planned Behavior (TPB) which is the development of the Theory of Reasoned Action (TRA). Ajzen (1980) developed this theory by adding constructs not available yet in the TRA. This construct is called by the perceived behavior control (perceived behavioral control). This construct is added to the TPB to control individual behavior limited by its shortcomings and the limitations of the inadequate resources used to perform its behavior.

Motivation Theory and Hope Theory. Robbins (1998) defines motivation as a willingness to expend high levels of effort for organizational goals and is conditioned by the ability to meet individual needs. Motivation is an important concept for behavioral science because organizational effectiveness depends on the individual or employee effort to play the role the organization expects. Expectancy theory (Expectancy theory) is an individual work motivation to perform a task depends on the belief in the rewards received.

Effect of Job Satisfaction on Turnover Intention. There are two types of needs factors, namely the need for health and maintenance. This is related to the nature of human beings endeavor to obtain outward tranquility. Previous research focusing on the effect of job 
satisfaction on turnover intention is research conducted by Gieter, Hofmans, and Pepermans (2011); Handaru (2012); Nugroho (2012) and Putra and Wibawa (2015) exhibits a significant positive influence on job satisfaction on turnover intention. Based on the research mentioned that higher job satisfaction caused smaller intention to leave the company and vice versa, the lower the job satisfaction increased intention to leave the company.

$\mathrm{H} 1$ : Job satisfaction influence on turnover intention of a manager in East Java hotels.

Influence Perception of employment opportunities to turnover intention. Granting compensation (reward) should be tied to job performance (performance). Even if the compensation has been based on performance criteria. Should workers perceive low, it would cause lower job performance and increased turnover and absenteeism (Robbins, 2003). Previous research that focuses on variable perception of job opportunities to turnover intention is conducted by Rahman, Naqvy, and Ramay (2008); Dardar, Jusoh and Rasli (2012); Saeed and Shabir (2013; and Saleem and Gul (2013), which exhibits significant positive influence on perceptions of job opportunities to turnover intention. Based on the above research states higher employment opportunities cause higher turnover intention, and vice versa lower perceptions of job opportunities will cause low turnover intention.

$\mathrm{H} 2$ : Perception of employment opportunities influence the turnover intention of a manager in East Java hotels.

The Influence of Job Satisfaction on Organizational Commitment. Previous research focusing on job satisfaction on organizational commitment is research conducted by Andini (2006); Sijabat (2009); Parwita (2013); Iqbal, Ehsan and Rizwan (2014) and Rismawan (2014) and showed a positive influence on job satisfaction and organizational commitment. The higher the job satisfaction the higher organization employee commitment, the lower the job satisfaction causes lower organization employee commitment.

H3: Job satisfaction influence the organizational commitment of a manager in East Java hospitality field.

The Influence of Job Opportunity Perception on Organizational Commitment. How far the employee's commitment to the organization they work in is crucial to the organization in achieving its objectives. When an employee feels that the company does not provide the desired resources for an organization, then the response is to find another way to find another better job. The higher the level of perception of employee job opportunities, the lower the level of commitment of employees in the organization. Previous research focusing on job opportunity perceptions of organizational commitment is a study by Thatcher, Stephina, and Boyle (2003): Rahman, Naqvy, and Ramay (2008) and Mushtaq. Et al., (2014) indicating that there is a significant negative influence on the perception of employment opportunities on organizational commitment.

H4: Perceptions of job opportunities influence the organizational commitment of a manager in East Java hotels.

Influence of Organizational Commitment on Turnover Intention. Employee commitment to the organization causes them to be loyal to the organization and work well for the benefit of the organization (Yuwalliatin, 2006). Past research has focused on variables influence organizational commitment to turnover intention is that research conducted by Utami (2009); Handaru and Muna (2012) and Tnay et.al., (2013); which indicates that the presence of a significant positive effect between organizational commitment to turnover intention. Some of the above research describes employees who receive support from the employer through an assessment of their contribution to the organization, it will increase the support of the organization and eventually become low turnover intention.

$\mathrm{H}$ 5: Organizational commitment influence on turnover intention of a manager in East Java hotels.

Effect of Job Satisfaction and Perceptions of Work Opportunities Against Turnover Intention Through Organizational Commitment As an intervening variable. Turnover on Attitude Traditional Theory, this theory explains that in predicting the behavior of turnover on employees affected by job satisfaction and organizational commitment as intermediate variables (Zhao and Liu, 2010). Previous research focusing on research on organizational commitment variables as intervening variables is research conducted by Devi (2009); 
Suryani (2011); Rismawan (2014); Putra and Wibawa (2015) indicating that there is indirect influence between independent variables and dependent variables through intervening variable.

H6: Job satisfaction influence on turnover intention through an organizational commitment to the hotel managers in East Java.

H7: Perceptions of job opportunities effect on turnover intention through an organizational commitment to the hotel managers in East Java.

\section{METHODS OF RESEARCH}

Research design. This study uses explanatory research, which describes a relationship between variables through hypothesis testing (Ghozali, 2002). This research is used to test the hypothesis on the relationship (cause and effect) between existing variables. In explanatory research, the approach used is survey method.

Population and Sample. The population in this research was managers at the middle management positions in the hospitality field institution in East Java. Those managers are posted in 5-star hotel and 4-star hotel. The number of 5 stars and 4-star hotels in East Java which used as the population in this research is 31 (thirty-one) hotels spread in Java area east which is 12 (twelve) hotel from 5-star hotels and 19 (nineteen) hotel of a 4-star hotel. Sampling technique in this research is nonrandom using convenience sampling, samples selected are manager posted in middle management at hospitality field institution such as 5 and 4 in East Java. There was 129 respondents total.

Data Collection Techniques. Data were collected through questionnaires. The questionnaire was delivered directly to the 5 star and 4-star hotels where respondents worked. The data collection was conducted in 3 ways, direct delivery, transmitted through a computer connected to the Internet via e-mail to the department of human resources (HR) and delivered through a smartphone connected to the Internet.

Variables Operational Definition:

Job satisfaction. Job satisfaction is a general attitude of a person to his work in the form of feelings or positive assessment of the work resulting from an evaluation that has been done by someone. Job satisfaction measurement was adapted from research conducted by Watson, Thompson, and Meade (2007) and Pradana and Salehudin (2015).

Perception of Employment Opportunities. On occurrence when the employee feels that the company does not provide the desired resources for an organization, then the response is to seek for a better job. To measure perceptions of employment opportunities, the method was adapted from research conducted by (Mowdey et al., 1984).

Organizational Commitment. Organizational commitment is a psychological state characterized by employee relationships with organizations that affect employee loyalty to the organization (Allen and Meyer, 1993). To measure organizational commitment, the researcher used a method adapted from research conducted by Mowday et al. , (1979), Meyer et al., And Luthans (2006).

Turnover Intention. Turnover intention reflects a person's desire to seek other better employment alternatives (Mukhlish and Salehudin, 2008). To measure the turnover intention, the method was adapted from research conducted by Mobley (1977) and Price (1977).

Data Analysis Technique. Hypothesis testing is done by conducting Partial Least Square (PLS) model approach through Smartpls software version 2.0. PLS is an analysis of variance-based structural equations that can simultaneously perform testing of measurement models as well as testing structural models.

\section{RESULTS AND DISCUSSION}

\section{Research Object Description}

The distribution of questionnaires to 5-star hospitality field institution was not accepted because hospitality field parties had not received any research from any party except for an internship at the hotel for three months, therefore said questionnaires that did not return from 
5-star hotels amounted to 34 questionnaires. Then questionnaire of 4-star hospitality field that did not return was 24 questionnaires. The total number of questionnaires that did not return was 58, then 71 questionnaires were returned and can be used from 129 distributed questionnaires. The following table is the distribution of respondents of 4-star hotels.

Table 1 - Distribution of respondents

\begin{tabular}{lcc}
\hline \multicolumn{1}{c}{ Name Hotels } & Questionnaires & Back \\
\hline Hotel Santika premiere gubeng & Deployed & 5 \\
Hotel Aria Centra Surabaya & 5 & 5 \\
Rich Palace hotel & 5 & 5 \\
Garden palace hotel & 5 & 5 \\
Java paragon hotel residence & 5 & 3 \\
Savana Hotel \& Convention & 5 & 5 \\
Aria Gajayana Hotel & 5 & 5 \\
Hotel Santika Premiere Malang & 5 & 3 \\
Best Western OJ Hotel & 5 & 5 \\
Harris Hotel \& Conventions Malang & 5 \\
Surya Hotel \& Cottages Prigen & 5 & 3 \\
Grand Surya Hotel Kediri & 5 & 5 \\
Crown Victoria Hotel & 5 & 3 \\
Aston Jember Hotel \& Conference Center & 5 & 2 \\
Aston Madiun Hotel \& Conference center & 5 & 5 \\
Baobab Safari Resort & 5 & 3 \\
Tretes Raya Hotel \& Resort & 5 & 2 \\
Beejay Bakau Resort & 5 & 3 \\
ljen Resort \& Villas & 5 & 71 \\
\hline
\end{tabular}

Evaluation of Formative Model Construct Validity. Table 2 indicator Y.6 yields Tstatistics value less than T-table (1.96), thus declared invalid indicators to measure the variables turnover intention. While other indicators produce more T-statistics than T-table (1.96), thus declared valid indicator to measure the variables turnover intention.

Table 2 - Convergent Validity Results Formative Model

\begin{tabular}{|c|c|c|c|c|}
\hline Variable & Indicator & Original Sample (O) & T Statistics (|O/STERR|) & Information \\
\hline \multirow{4}{*}{ Turnover Intention } & Y.1 & 0.345 & 4.630 & Valid \\
\cline { 2 - 5 } & Y.2 & 0.150 & 2.014 & Valid \\
\cline { 2 - 5 } & Y.3 & 0.337 & 5.098 & Valid \\
\cline { 2 - 5 } & Y.4 & -0.302 & 5.357 & Valid \\
\cline { 2 - 5 } & Y.5 & 0.180 & 2.166 & Valid \\
\cline { 2 - 5 } & $Y .6$ & 0.062 & 0.871 & Invalid \\
\hline
\end{tabular}

Evaluation of Conflict Model Reflective Validity. Based on the table above, it exhibits that all indicators are worth greater than 0.5. Thus the indicator is declared valid to measure the variable.

Table 3 - Loading Factor Results

\begin{tabular}{|c|c|c|c|c|}
\hline Variable & Indicator & Original Sample (O) & T Statistics (|O/STERR|) & Information \\
\hline \multirow{4}{*}{ Job Satisfaction } & $\mathrm{X} 1.3$ & 0.799 & 35.430 & Valid \\
\cline { 2 - 5 } & $\mathrm{X} 1.4$ & 0.787 & 29.095 & Valid \\
\cline { 2 - 5 } & $\mathrm{X} 1.5$ & 0.854 & 48.891 & Valid \\
\cline { 2 - 5 } & $\mathrm{X} 1.6$ & 0.855 & 40.547 & Valid \\
\hline \multirow{3}{*}{$\begin{array}{c}\text { Perception of Employment } \\
\text { Opportunities }\end{array}$} & $\mathrm{X} 2.1$ & 0.927 & 111.461 & Valid \\
\cline { 2 - 5 } & $\mathrm{X} 2.2$ & 0.835 & 30.902 & Valid \\
\cline { 2 - 5 } & $\mathrm{X} 2.3$ & 0.912 & 70.232 & Valid \\
\hline \multirow{3}{*}{ Organizational Commitment } & $\mathrm{Z} .6$ & 0.788 & 34.055 & Valid \\
\cline { 2 - 5 } & $\mathrm{Z} .7$ & 0.809 & 38.461 & Valid \\
\cline { 2 - 5 } & $\mathrm{Z} .8$ & 0.882 & 60.917 & Valid \\
\cline { 2 - 5 } & $\mathrm{Z} .9$ & 0.874 & 43.414 & \\
\hline
\end{tabular}


Table 4 - Average Variance Extracted (AVE) and Communality Results

\begin{tabular}{|c|c|c|c|}
\hline Variable & AVE & Commonality & Information \\
\hline Job Satisfaction & 0.680 & 0.680 & Valid \\
\hline Perception of Employment Opportunities & 0.796 & 0.796 & Valid \\
\hline Organizational Commitment & 0.704 & 0.704 & Valid \\
\hline
\end{tabular}

Table 4 exhibits all variables generate value Average Variance Extracted (AVE) and Communality Which greater than 0.5 . Thus the indicator is declared valid to measure the variable.

Table 5 - Cross Correlation Results

\begin{tabular}{|c|c|c|c|}
\hline- & Job Satisfaction & Perception of Employment Opportunities & Organizational Commitment \\
\hline $\mathrm{X} 1.3$ & 0.799 & -0.055 & 0.760 \\
\hline $\mathrm{X} 1.4$ & 0.787 & -0.053 & 0.687 \\
\hline $\mathrm{X} 1.5$ & 0.854 & 0.103 & 0.818 \\
\hline $\mathrm{X} 1.6$ & 0.855 & 0.033 & 0.849 \\
\hline $\mathrm{X} 2.1$ & 0.034 & 0.927 & 0.039 \\
\hline $\mathrm{X} 2.2$ & 0.094 & 0.835 & 0.118 \\
\hline $\mathrm{X} 2.3$ & -0.076 & 0.912 & -0.088 \\
\hline Z.6 & 0.744 & -0.067 & 0.788 \\
\hline Z.7 & 0.771 & 0.038 & 0.809 \\
\hline Z.8 & 0.824 & 0.062 & 0.882 \\
\hline Z.9 & 0.836 & 0.014 & 0.874 \\
\hline
\end{tabular}

Table 5 exhibits that all indicators produce a larger loading factor compared to cross correlation in other variables. Thus it can be stated that the indicator is able to measure the latent variables corresponding to the indicator.

Hypothesis Testing Results and Discussion:

Table 6 - Direct Coefficient Results

\begin{tabular}{|c|c|c|c|c|c|}
\hline Exogenous Variables & Endogen Variables & $\begin{array}{c}\text { Direct } \\
\text { Coefficient }\end{array}$ & $\begin{array}{c}\text { Standard } \\
\text { Error }\end{array}$ & T Statistics & Decision \\
\hline Job satisfaction & Turnover Intention & -0.461 & 0.142 & 3.253 & $\begin{array}{c}\text { Be } \\
\text { accepted }\end{array}$ \\
\hline $\begin{array}{c}\text { Perception of Employment } \\
\text { Opportunities }\end{array}$ & Turnover Intention & 0.520 & 0.035 & 15,013 & $\begin{array}{c}\text { Be } \\
\text { accepted }\end{array}$ \\
\hline Job satisfaction & $\begin{array}{c}\text { Organizational } \\
\text { Commitment }\end{array}$ & 0.947 & 0.008 & 114.543 & $\begin{array}{c}\text { Be } \\
\text { accepted }\end{array}$ \\
\hline $\begin{array}{c}\text { Perception of Employment } \\
\text { Opportunities }\end{array}$ & $\begin{array}{c}\text { Organizational } \\
\text { Commitment }\end{array}$ & 0.005 & 0.010 & 0.488 & Rejected \\
\hline Organizational Commitment & Turnover Intention & -0.018 & 0.149 & 0.124 & Rejected \\
\hline
\end{tabular}

Hypothesis 1: Table 6 exhibits T statistics value relationship between job satisfaction and turnover intention amounted to 3,253. The test results exhibit T statistics>1.96. Thus the first hypothesis is accepted. The research study was supported by previous research results conducted by Gieter, Hofmans, and Pepermans (2011), Nayaputera (2011), Handaru (2012), Nugroho (2012), Putra and Wibawa (2015) that job satisfaction has a positive influence on turnover intention. The results also support the Two Factor Theory (theory of two factors) that satisfiers are job satisfaction source factors. These factors are achievements, awards, promotions, responsibilities, and the work itself (Herzberg, 1966).

Hypothesis 2: Table 6 exhibits that T statistics relationship between perceptions of job opportunities to turnover intention amounted to 15013 . The test results show that $T$ statistics> 1.96. Hence hypothesis 2 is accepted. Research study support previous research results conducted by Rahman, Naqvy and Ramay (2008), Dardar, Jusoh, and Rasli (2012), Saeed and Shabir (2013), and Saleem and Gul (2013) that the perception of employment opportunities impacted positively on turnover intention. The results also support the Theory 
of Planned Behavior (TPB) that control the behavior of individuals is limited by the perceived shortcomings and limitations of a shortage of resources used to perform the behavior.

Hypothesis 3: Table 6 exhibits that T statistics relationship between job satisfaction and organizational commitment amounted to 114 543. The test results show that $\mathrm{T}$ statistics> 1.96. Thus hypothesis 3 is accepted. Research study supports several previous research results conducted by Andini (2006), Sijabat (2009), Parwita (2013), Iqbal Ehsan and Rizwan (2014) and Rismawan (2014) that job satisfaction positively affects organizational commitment. The results also support the Two Factor Theory (theory of two factors) that satisfiers or gratification is a situation that is demonstrated as a source of job satisfaction. The higher the job satisfaction of employees, the higher employee commitment itself.

Hypothesis 4: Table 6 exhibits T statistics relationship between perceptions of job opportunities on organizational commitment is equal to 0488. The test results show that $\mathrm{T}$ statistics $<1.96$. Hence hypothesis 4 is rejected. Research study supports several previous research results conducted by Thatcher Stephina and Boyle (2003), Rahman Naqvy and Ramay (2008) and Mushtaq. Et al., (2014) that there is a negative influence on the perception of employment opportunities and organizational commitment. The lower the perception of employment opportunities the higher the organization's commitment among employees. According to Thatcher, Stephina, and Boyle (2003) by growing positive beliefs about work and attitudes toward superiors, managers can increase their sense of engagement with the company.

Hypothesis 5: Table 6 exhibits that T statistics relationship between organizational commitment to turnover intention is equal to 0.124 . The test results show that $T$ statistics $<1.96$. Thus hypothesis 5 is rejected. The results support some of the previous research conducted by Andini (2006) and Ramay Naqvy Rahman (2008), Sijabat (2009) and Widodo (2010) that their negative influence significantly between organizational commitment to turnover intention. The high competition in finding jobs, compared to the limited job opportunity. The high competition in finding jobs that are not supported by extensive employment makes a person with a low organizational commitment choose to stay in the organization and refuse to move.

Indirect Effect Result:

Table 7 - Indirect Effect Results

\begin{tabular}{|c|c|c|c|c|c|}
\hline Exogenous Variables & $\begin{array}{c}\text { Endogen } \\
\text { Variables }\end{array}$ & $\begin{array}{c}\text { Intervening } \\
\text { Variables }\end{array}$ & $\begin{array}{c}\text { Indirect } \\
\text { Coefficient }\end{array}$ & $\begin{array}{c}\text { Standard Error } \\
\text { (STERR) }\end{array}$ & $\begin{array}{c}\text { T Statistics } \\
(\mid \text { O / STERR } \mid)\end{array}$ \\
\hline Job satisfaction & $\begin{array}{c}\text { Turnover } \\
\text { Intention }\end{array}$ & $\begin{array}{c}\text { Organizational } \\
\text { Commitment }\end{array}$ & -0.017 & 0.141 & -0.124 \\
\hline $\begin{array}{c}\text { Perception of } \\
\text { Employment } \\
\text { Opportunities }\end{array}$ & $\begin{array}{c}\text { Turnover } \\
\text { Intention }\end{array}$ & $\begin{array}{c}\text { Organizational } \\
\text { Commitment }\end{array}$ & 0.000 & 0.001 & -0.120 \\
\hline
\end{tabular}

Table 7 exhibits that the effect of job satisfaction on organizational commitment turnover intention through $T$ statistics obtained a value of -0124 . The test results show that $T$ statistics $<1.96$. Therefore, organizational commitment otherwise unable to mediate the effect of job satisfaction on the on turnover intention. Based on the research results are not in line with research conducted by Devi (2009), Rismawan (2014) and Putra dan Wibawa (2015). But this study is consistent with research conducted by Pareke, (2004) that there is no mediating role of job satisfaction on turnover intention and organizational commitment as an intermediary variable. Job satisfaction felt by an employee is not directly linked to the costs of financial losses that might he suffered while on the other hand connoted the organization's commitment to financial losses (Dunham et al., 1994).

Then influence the perception of job opportunities to turnover intention through organizational commitment $T$ statistics obtained a value of -0120 . The test results showed that $T$ statistics $<1.96$. Therefore, organizational commitment otherwise unable to mediate employment opportunities to influence the perception of the turnover intention. Based on the research results are not in line with research conducted by Suryani, (2011). But this study is consistent with research conducted by Thatcher, Stephina, and Boyle (2003), which showed 
that the alternatives job opportunities showed a negative correlation with organizational commitment. And alternative job opportunities showed a positive association with the intention of moving.

\section{CONCLUSION}

The findings of this study indicatesjob satisfaction has a positive influence on turnover intention. The study also found that the nature of jobs and promotions is an important factor in job satisfaction as a manager. The study's findings also indicate that the perception of job opportunities has a positive effect on turnover intention. The higher the perception of employment opportunities, the higher the turnover intention of a manager. The Research study indicate that job satisfaction has a positive influence on organizational commitment. The higher the job satisfaction of a manager, the higher the organizational commitment.

Perception of employment opportunities negatively affects organizational commitment a manager. A positive belief able to make the perception of job opportunities outside of the hospitality field field is not unthinkable in itself a manager but rather increase the commitment and motivation in them to always engage and persist in the company where he worked. Research result also exhibited that organizational commitment negatively affects turnover intention of a manager. The Research result also exhibits both job satisfaction and perceptions of employment opportunities negatively affect turnover intention through organizational commitment. This means that organizational commitment is not able to mediate the perception of job satisfaction and job opportunities to the turnover intention of a manager in 4 Stars hotel in East Java.

This study was unable to use simple random sampling (simple random sampling), but convenience sampling was applied. This study received permission to conduct research in the 5 stars hotel because said hospitality institution does not permit research from any party except those who participated in internships for at least three months. Only 4-stars hotel managers were included in the study population. Construct indicators of job satisfaction and organizational commitment each only four indicators for the construct validity of test current models of reflective, four indicators of job satisfaction variables and the five indicators of organizational commitment is removed to obtain better results.

This study could not explain all the factors that may affect turnover intention of a manager in East Java 4 starts hotel. Thus future research is expected to examine other factors beyond the variables used in this study or add the number of variables to complete the research models that predict turnover intention of a manager in the hospitality field, especially in 4 stars hotel East Java such as variable work load excess and work stress.

The implication of this research is aimed at practitioners, namely the owners and managers in 4 stars hotels hospitality institutions to better understand factors causing high turnover intention among managers. This research also provides implications for research, such as methods to minimize turnover intention among managers. Good governance system in hospitality can maintain the managers. They would continue to work in the Hospitality field and lower levels of turnover intention manager or look for another job opportunity.

\section{REFERENCES}

1. Ajzen, I., and Fishbein, M. 1980. Understanding Attitudes and Predicting Social Behavior. Prentice-Hall.

2. Allen, NJ and JP Meyer. 1991. The Measurement and antecedents of Affective, Continuance and Normative Commitment to the Organizational. Journal of Occupational Psychology. 63 (1): 1-18.

3. Andini, R., 2006. Influence Analysis Salary Satisfaction, Job Satisfaction, Commitment Organizational against Turnover Intention: A Case Study Roemani Muhammadiyah Hospital Semarang. Unpublished Graduate Thesis. University of Diponegoro. 
4. Bodla, MA and A. Hameed, 2008. Controllable vs. Uncontrollable Factors of Employee Turnover Intentions, An Empirical Evidence from Textile sector of Pakistan. Proceedings of the International conference on Business and Management at Bangkok.

5. Dardar, AHA Jusoh, A. Rasli, A. 2012. The impact of job training, job satisfaction and alternative job opportunities on job turnover in Libyan oil companie. Procedia - Social and Behavioral Sciences 40 (2012) 389 - 394.

6. Devi, EKD, 2009. Analysis of the influence of job satisfaction and motivation on employee performance with organizational commitment as an intervening variable (A Study on Employee Outsourcing PT. Semeru Karya Buana Semarang). Unpublished Graduate Thesis, Master of Management, Graduate School of Economics, University of Diponegoro.

7. Dunham, RB, Grube, JA, \& Castaneda, MB. 1994. Organizational commitment: the utility of an integrative definition. Journal of Applied Psychology, 79 (3): 370-380.

8. Gerhart, B. 1990. Voluntary turnover and alternative job opportunities. Journal of Applied Psychology, 75 (5), 467-476.

9. Ghozali, Imam. 2002. Applications Multivariate with SPSS. Semarang: Agency Publisher University of Diponegoro.

10. Gieter, D., S., Hofmans, J., and Pepermans, R. 2011. Revisiting the impact of job satisfaction and organizational commitment on turnover intention nurse: An individual differences analysis. International Journal of Nursing Studies 48 (2011) 1562- 1569.

11. Handaru, W.A. 2012. Effect of Salary Satisfaction and Organizational Commitment on Turnover Intention In Division PT. Social Security. Journal of Management Science Research Indonesia, Vol 3 No. 1.

12. Herzberg, F., Mausner, B., and Snyderman, BB 1959. The motivation to work. New York, NY: John Wiley \& Sons.

13. Hulin, CL, Roznowski, M., and Hachiya, D. 1985. Alternative opportunities and withdrawal decisions: Empirical and theoretical discrepancies and an integration. Psychological Bulletin, 97 (2), 233 -250.

14. Iqbal, S. Ehsan, S. and Rizwan, M. 2014. The impact of organizational commitment, job satisfaction, job stress and leadership support on turnover intention in educational institute. International Journal of Human Resource Studies ISSN 2162-3058 2014, Vol. 4, No. 2.

15. Jauch, LR, Glueck, WF, and Osborn RN 1978. Organizational Loyalty, Professional Commitment and Academic Research Productivity. Academy of Management Journal. March. Pp. 84-92.

16. Lathifah, I. 2008. Effects of Work-Family Conflict Against Trunover Intentions With Job satisfaction as an intervening variable. Empirical Study on the Public Accountant Auditor in Indonesia. Unpublished Graduate Thesis. Universitas Diponegoro.

17. Luthans, F, 2006. Organizational Behavior (Tenth Edition). Yogyakarta: Andi Offset.

18. Mobley, WH 1977. Intermediate Linkages in The Relationship between Job Satisfaction and Employee Turnover. Journal of Applied Psychology . 62: 237-240.

19. Mowday, RT, Koberg, CS, and McArthur, AW 1984. The psychology of the withdrawal process: A cross-validational test of Mobley's intermediate linkages models of turnover in two samples. Academy of Management Journal, 79-94.

20. Mowday, RT, RM Steers and Porter IW, 1979. The Measurement of Organizational Commitment. Journal of Applied Psychology, 84, p. 408-414.

21. Mowday, RT, Porter, LW and Dubin, R. 1974. Unit Performance, Situational Factor, and Employee Work Attitudes in spatially Separated Units. Organizational Behavior and Human Performance. October. Pp. 231-248.

22. Mukhlish, B., and Salehudin, I., 2008. Application of planned behavior framework in understanding the Influencing factors intention to leave among alumnae of the faculty of economics University of Indonesia Year 2000-2003. Proceedings of the 3rd International Conference on Business and Management Research. 3 (1), 99-106.

23. Nayaputra, Y. 2011. Analysis of Effect of Job Satisfaction and Job Stress on Customer Servise Employee Turnover Intention in PT. Plaza Indonesia Realty Tbk. Unpublished 
Graduate Thesis, Master Program Administration, Graduate Faculty of Social and Political Sciences, University of Indonesia.

24. Nugroho, AK, 2012. The effect of job insecurity, organizational commitment and job satisfaction of the desire out studies on Pera w at R S. PKU Muhammadiyah Surakarta. Unpublished Graduate Thesis, Master of Accounting Program, Faculty of Economics, University of Surakarta.

25. Pareke, J.F. 2004. Relations with the Justice and Satisfaction Desire Switching: The Role of Organizational Commitment As Pemediasi variables. JSB No. 9 Vol. 2 DECEMBER 2004157.

26. Parwita, GBS 2013. Effect of Job Satisfaction and Organizational Commitment Against Work Discipline Lecturer University Foundation Mahasaraswati In Denpasar. Unpublished Graduate Thesis, Master of Management, Graduate School of Economics, University of Udayana.

27. Porter, LW, Mowday, RT and Boulian, PV 1974. Organizational Commitment, Job Satisfaction and Turnover Among Psychiatric Technicians. Journal of Applied Psychology. October, pp. 603-609.

28. Pradana, A., and Salehudin, I. 2015. Work Overload and Turnover Intention of Junior Auditors In Greater Jakarta, Indonesia. The South East Asian Journal of Management, 9 (2), 108-124.

29. Price, JL 1977. The Study of Turnover. IA: lowa State University Press, Ames.

30. Son, M. and Authority, A. 2015. Influence of Job Satisfaction on Turnover Intention with Organizational Commitment As an intervening variable. E-Journal of Management Udayana University, Vol. 4, No. 4, 2015: 1100-1118.

31. Rahman, ASMM, Naqvi, R. and Ramay, IM 2008. Measuring Turnover Intention: A Study of IT Professionals in Pakistan. International Review of Business Research Papers Vol. 4 3 June 2008 Pp.45-55.

32. Rismawan, P. 2014. Role of Organizational Commitment Mediating Effects of Stress At work and Job Satisfaction Employee Out Of Intention. Udayana University Graduate Program.

33. Robbins, SP 1998. Organizational Behavior: Concepts, Controversies, Applications (8th ed). Upper Sadlle River, NJ: Prentice-Hall.

34. Robbins, SP. 2003. Organizational Behavior (Tenth Edition). Prentice-Hall, Jakarta.

35. Saeed, MM and Shabir, S. 2013. The impact of training and development on employees'skils enhancement and their subsequent intention to quit: the moderating role of perceived alternative job opportunities. ISSN 1993-8233. Academic Journals. Vol 7 (13), pp. 1030-1034, April 7, 2013.

36. Saleem, T. and Gul, S. 2012. Drivers of turnover intention in public sector organizatios: pay satisfaction, organizational commitment and employment opportunities. Middle-East Journal of Scientific Research 17 (6): 697-704, 2013. ISSN 1990-9233.

37. Samad, S. 2006. Predicting Turnover Intentions: The Case of Malaysian Government Doctors. The Journal of American Academy of Business, Cambridge, Vol.8, No.2, March.

38. Sijabat, J. 2009. Organizational Commitment Auditor At Large Firm in Jakarta, which is affiliated with the Foreign KAP (The Big Four). Accounting Studies, August 2009, p. 165177, ISSN: 1979-4886.

39. Steers, RM 1977. antecedents and Outcomes of Organizational Commitment. Administrative Science Quarterly. March. Pp. 46-56.

40. Suryai, R. 2011. Analysis of the influence the perception of organizational support to trnover intentions with the role of organizational commitment as mediation case study on PT. Mining. Unpublished Graduate Thesis, Master Program Administration, Graduate Faculty of Social and Political Sciences, University of Indonesia.

41. Thatcher, JB, Stepnia, LP and Boyle RJ 2003. Turnover of Information Technology Workers: Examining the Influence of Attitudes empirically, Job Characteristics and External Markets. Journal of Management Information Systems, Vol. 19, No. 3, pp. 231261. 
42. Tnay, E., Othman, A.E.A., Siong, H.C., Lim, S.L.O. 2013. The Influences of Job Satisfaction and Organizational Commitment on Turnover Intention. Procedia - Social and Behavioral Sciences 97 (2013) 201-208.

43. Utami, I., and Bonussyeani, S., E., N. 2009. Effect of Job Insecurity, Job Satisfaction and Organizational Commitment Against Switching Desire Job. Journals Accounting and Finance Indonesia, Volume 6 - Number 1, June 2009.

44. Watson, AM, Thompson, LF, and Meade, AW 2007. Measurement invariance of the job satisfaction survey work across Contexts. Proceedings of the 22nd Annual Meeting of the Society for Industrial and Organizational Psychology, New York.

45. Wexley, KN, and Yukl, G. 1977. Organization Behavior \& Personal Psychology. Illinois: Homewood.

46. Yuwalliatin, S, 2006. Influence of Organizational Culture, Motivation and Commitment And Its Effect on Performance of Competitive Advantage doses Unissula Semarang. Journal of Economics and Business, Vol. 7 No. 2, p. 241-256.

47. Zhao, Erdong and Liwei Liu. 2010. Comment Of Development of job embeddedness About Study To Turnover and ExplorationInto Application in Enterprises. Asian Social Science. 6 (6): pp: 63-64. 
DOI https://doi.org/10.18551/rjoas.2017-08.21

\title{
THE INFLUENCE OF PRODUCT AND COMPANY IMAGE ON SAVING DECISION THROUGH TRUST VARIABLE AT THE PEOPLE'S CREDIT BANK EKA BUMI ARTHA IN METRO CITY
}

\author{
Suharto*, Suhada Bambang \\ Management Study Program Faculty of Economics, University of Muhammadiyah Metro, \\ Indonesia \\ *E-mail: hartoumm@gmail.com
}

\begin{abstract}
This research uses product image, company image, trust, and saving decision variables. Data used in this research is primary data collected using explanatory survey method with the total population of 14,175 customers. The sample is 150 customer respondents. The instrument used in this research is a Likert scale at the Office of People's Credit Bank Eka Bumi Artha Metro. Testing of requirements instrument includes validity and reliability testing. Meanwhile, normality, homogeneity, linearity, and significance of regression testing are used in order to test the requirements analysis. Data analysis uses Structural Equation Modeling (SEM). The research result found that the product image has a positive effect on trust, the company image does not have direct postifive effect on the trust, product image has direct postifive effect on saving decision, the company image does not have direct postifive effect on the saving decision and the trust has direct postifive effect on the saving decision.
\end{abstract}

\section{KEY WORDS}

Product image, company image, trust, saving decision.

The measurement of the concept of customer saving decision in banking industry often becomes the topic of conversation for banking observer sector (Nilton Porto and J. Michael Collins, 2017). Bank can be regarded as one of the financial institutions that play a major role in building the economy of a country. The more developed the banking industry is the better the economic growth of the country. As stated by (Michal Bialek and Wim De Neys, 2017), that Bank as a financial institution serves to collect and distribute the fund to the community in order to improve the equity, economic growth and national stability for the improvement of community welfare. Thus, the bank can be the facilitator to collect and distribute fund to the community effectively and efficiently for the improvement of standard of living of the community (Triandaru, Sigit dan Totok Budisantoso, 2009).

The development of the banking industry will lead to a competition between banks to obtain customers. Evey bank will need a strategy in order to encourage the customers to save their fund in that bank. The customer is the major driver in the banking industry (Akos Nagy et al., 2014). A bank needs to understand why customers choose certain bank for their transaction and saving service. By understanding the character of the customers, a bank can determine the product development strategy and bank service according to each characteristic of the customer. Thus, one of the fundamental factors of a bank is the willingness from the management in order to obtain more customers (Asto Subroto, 2009).

There are several reasons as the consideration for the customer to be a customer of a bank. One of the reasons is the existence of product variance offered by the bank (Fabio Caldieraro, 2016). What has been perceived by the customer against a product, including product attributes, the benefit for the customer, the use of the product and the safety guarantee.

The image of the bank is another factor that can determine the saving decision when selecting the bank. The bank image can give a larger portion to influence the saving decision when selecting a bank Robert Azuayi. (2016). A good company image that attached to customer's mind will increase the customer satisfaction (Michael R. Solomon et al., 1992). The image describes the overall impression made by the public about a company and its 
product. Awareness and image of a product and service reputation will influence the customer's decision to buy in order to improve its selling (Seita M. Almandeel, 2017). Based on other expert's opinion, a good image showed by the bank to its customer through the reputation and product can give better response and higher trust from the customer against the banking products and it can generate customer's satisfaction (Govers, P.C.M. and J.P.L. Schoormans, 2005).

A positive image of a company or product in community's mind will encourage the customer's interest to save their fund in that bank (Yi Zhang, 2015; Suharto, 2016). There are so many types of savings offered by other banks, thus the management should be able to offer a saving type equipped with a number of attributes that can stimulate the community's interest to invest their money in the bank. If the company can provide a product with the attributes in accordance with the customer's needs and desires, the company will be able to encourage the customer to make the purchasing decision (Methaq Ahmed Sallam, 2016). The community's trust against the bank can be the crown of the company and they have to keep the reputation. The reason is that trust can support the banking industry's growth and development to be a larger and healthier industry.

A positive product image of a bank in the customer's mind will give more advantage to the bank. It can help to build the customer's trust against the product. The reason is that the customer tends to be more aware and more careful against a product they don't know very well. A good quality of a product will be embedded in the customer's mind when they make repurchasing, giving the recommendation to other people, or to influence other people or their family members when these people need to make a purchasing decision.

Banking image is the customer's perception of the overall component in the banking company. For example, the quality of the service, the product quality, responsiveness and so on. The company image can be created through the customer's trust against the bank. A positive company image will encourage the confidence of the customer to use the product of the bank. The consumer's trust is built based on careful consideration, through complete information when a customer will make a purchase and take the decision to make the purchase.

A well-formed product image will give positive effect for the company, which is to convince the customer to get consistent quality when buying a banking product and will always improve the customer's motivation to save their fund in that bank. The quality and good perception based on the customer's point of view against the banking product will create and build satisfaction after the transaction with the company.

The information about a bank is required for the prospective customer, either from the bank itself or from other people experience before deciding to save in a bank. A positive image of the customers through their experience in using their banking service will encourage them to tell that they have good experience to relatives and other people. Thus, encouraging new customer's decision to use the services, to save or keep their fund in that bank. A good image of a company will create the new experience that can be obtained while doing the transaction with other company.

Trust given by the customer and prospective customer on its product is one of the important factors in attracting the customer's interest and keeping the long term relationship between the members of the company. Trust is a descriptive owned by someone against something. The stronger the community's trust against the bank, the stronger the interest and decision of the community to keep their fund in that bank. Strong trust, which consumers acquire through stages and processes that take a long time, will create positive decisions, either decision made by their relative, family members or community.

Based on the background and conceptual framework, the research aims to test the hypothesis about the direct influence of product image against the trust, direct influence of banking image against the trust, direct influence of product image against the saving decision, direct influence of the company image against the saving decision, and direct influence of trust against the saving decision. 


\section{METHODS OF RESEARCH}

The conducted research approach is quantitative with survey method. The constellation in this research uses product image as an exogenous variable, banking image as the exogenous variable, trust as the endogenous variable, and costumers saving decision as the endogenous variable. The target population is all of the customers of People's Credit Bank in Metro City. The sample uses the formula (Slovin, 2013) with 150 respondents.

The instrument used in this study is multiple choice with 5 alternative options and using Likert scale model for product image, banking image, trust, and costumers saving decision variables. The instrument preparation steps include the development of dimension and indicator, instrument preparation, validity and reliability testing, instrument revision, finalization, and data collection.

Instrument validity testing uses biserial correlation, and reliability testing uses the consistency of the respondent. The scale of the product image, company image, trust, and saving decision, is tested its validity using "Product Moment" coefficient and its reliability testing using "Cronbach's Alpha" coefficient (Ghozali, 2011).

Analysis data technique includes descriptive statistical analysis and inflation statistics. The requirements analysis test uses normality, homogeneity, linearity, and significance of regression testing. Multivariate statistics use Structural Equation Modeling analysis.

\section{RESULTS OF STUDY}

Requirements Analysis:

Prior to the data analysis, requirements analysis is needed as follows.

Requirements Analysis Test of Data Normality. Normality test aims to see whether regression model of dependent variable (bound) and independent variable (free) have a contribution or not, normality test is conducted to see if data distribution is normal or not.

Table 1 - Requirements Analysis Test of Data Normality

\begin{tabular}{|c|c|c|c|c|c|}
\hline No. & Estimated Error of Regression & $\mathrm{L}_{\text {count }}$ & $\mathrm{L}_{\text {table }}$ & Decision & Conclusion \\
\hline 1 & $\mathrm{Y}_{1}$ over $\mathrm{X}_{1}$ & 0.064 & 0.072 & $\mathrm{H}_{0}$ accepted & Normal \\
\hline 2 & $\mathrm{Y}_{1}$ over $\mathrm{X}_{2}$ & 0.055 & 0.072 & $\mathrm{H}_{0}$ accepted & Normal \\
\hline 3 & $\mathrm{Y}_{2}$ over $\mathrm{X}_{1}$ & 0.091 & 0.072 & $\mathrm{H}_{0}$ rejected & Not Normal \\
\hline 4 & $\mathrm{Y}_{2}$ over $\mathrm{X}_{2}$ & 0.079 & 0.072 & $\mathrm{H}_{0}$ rejected & Not Normal \\
\hline 5 & $\mathrm{Y}_{2}$ over $\mathrm{Y}_{1}$ & 0.052 & 0.072 & $\mathrm{H}_{0}$ accepted & Normal \\
\hline
\end{tabular}

Requirements Analysis Test of Homogeneity. The result of this test is used to determine the relationship between variables, with the requirement that each variable must have a homogeneous relationship.

Table 2 - Requirements Analysis Test of Homogeneity

\begin{tabular}{|c|c|c|c|c|}
\hline No. & Homogenitas & $\mathrm{X}_{\text {count }}$ & $\mathrm{X}_{\text {table }}$ & Conclusion \\
\hline 1 & $\mathrm{Y}_{1}$ over $\mathrm{X}_{1}$ & 19.334 & 149.885 & Homogeneous \\
\hline 2 & $\mathrm{Y}_{1}$ over $\mathrm{X}_{2}$ & 13.362 & 146.567 & Homogeneous \\
\hline 3 & $\mathrm{Y}_{2}$ over $\mathrm{X}_{1}$ & 32.399 & 149.885 & Homogeneous \\
\hline 4 & $\mathrm{Y}_{2}$ over $\mathrm{X}_{2}$ & 20.998 & 146.567 & Homogeneous \\
\hline 5 & $\mathrm{Y}_{2}$ over $\mathrm{Y}_{1}$ & 48.799 & 143.246 & Homogeneous \\
\hline
\end{tabular}

Requirements Analysis Test of Linearity and Significance of regression. The result of this test is used to determine the relationship between variables, with the requirement that each variable should have a linear relationship and significance of regression. 
Table 3 - Summary of Requirements Analysis Test of Linearity and Significance of regression

\begin{tabular}{|c|c|c|c|c|c|c|}
\hline \multirow{2}{*}{ Variable } & \multicolumn{2}{|c|}{ Sig. Regresi } & \multirow{2}{*}{ The significance of regression } & \multicolumn{2}{|c|}{ Lin. Regression } & \multirow{2}{*}{ Regression Linearity } \\
\cline { 2 - 3 } & $\mathrm{F}_{\text {count }}$ & $\mathrm{f}_{\text {table }}$ & & $\mathrm{F}_{\text {count }}$ & $\mathrm{f}_{\text {table }}$ & \\
\hline $\mathrm{Y}_{1}$ over $\mathrm{X}_{1}$ & 137.76 & 2.12 & Regression is significant & 0.03 & 2.12 & Linear regression \\
\hline $\mathrm{Y}_{1}$ over $\mathrm{X}_{2}$ & 1.08 & 2.12 & Regression is not significant & 0.05 & 2.12 & Linear regression \\
\hline $\mathrm{Y}_{2}$ over $\mathrm{X}_{1}$ & 195.97 & 2.12 & Regression is significant & 0.04 & 2.12 & Linear regression \\
\hline $\mathrm{Y}_{2}$ over $\mathrm{X}_{2}$ & 0.18 & 2.12 & Regression is not significant & 0.08 & 2.12 & Linear regression \\
\hline $\mathrm{Y}_{2}$ over $\mathrm{Y}_{1}$ & 178.05 & 2.12 & Regression is significant & 0.08 & 2.12 & Linear regression \\
\hline
\end{tabular}

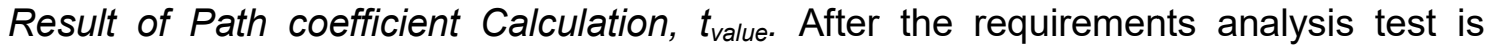
conducted, calculation and testing of each path coefficient as shown in the following table should be done:

Table 4 - Summary of Result of Path Coefficient

\begin{tabular}{|c|c|c|c|c|c|}
\hline \multirow{2}{*}{ No. } & \multirow{2}{*}{ Variable } & \multicolumn{2}{|c|}{ Path Coefficient $(\beta)$} & \multirow{2}{*}{ Decision } & \multirow{2}{*}{ Conclusion } \\
\cline { 3 - 5 } & & SLF $^{*}$ & $\mathrm{~T}_{\text {count }}$ & & \\
\hline 1 & $\mathrm{Y}_{1}$ over $\mathrm{X}_{1}$ & 0.70 & 8.16 & $\mathrm{H}_{0}$ rejected & Significant \\
\hline 2 & $\mathrm{Y}_{1}$ over $\mathrm{X}_{2}$ & -0.07 & -0.95 & $\mathrm{H}_{0}$ accepted & Not Significant \\
\hline 3 & $\mathrm{Y}_{2}$ over $\mathrm{X}_{1}$ & 0.35 & 3.33 & $\mathrm{H}_{0}$ rejected & Significant \\
\hline 4 & $\mathrm{Y}_{2}$ over $\mathrm{X}_{2}$ & 0.04 & 0.59 & $\mathrm{H}_{0}$ accepted & Not Significant \\
\hline 5 & $\mathrm{Y}_{2}$ over $\mathrm{Y}_{1}$ & 0.52 & 4.39 & $\mathrm{H}_{0}$ rejected & Significant \\
\hline
\end{tabular}

*Standardized Loading Factor.

Path Coefficient of Sub-Structure 1:

Analysis model of path coefficient sub-structure 1 is expressed in equation $Y_{1}=\beta_{31} X_{1}+$ $\beta_{32} X_{2}+\varepsilon_{1}$. This testing will provide decision-making of hypotheses testing 1 , and 2 .

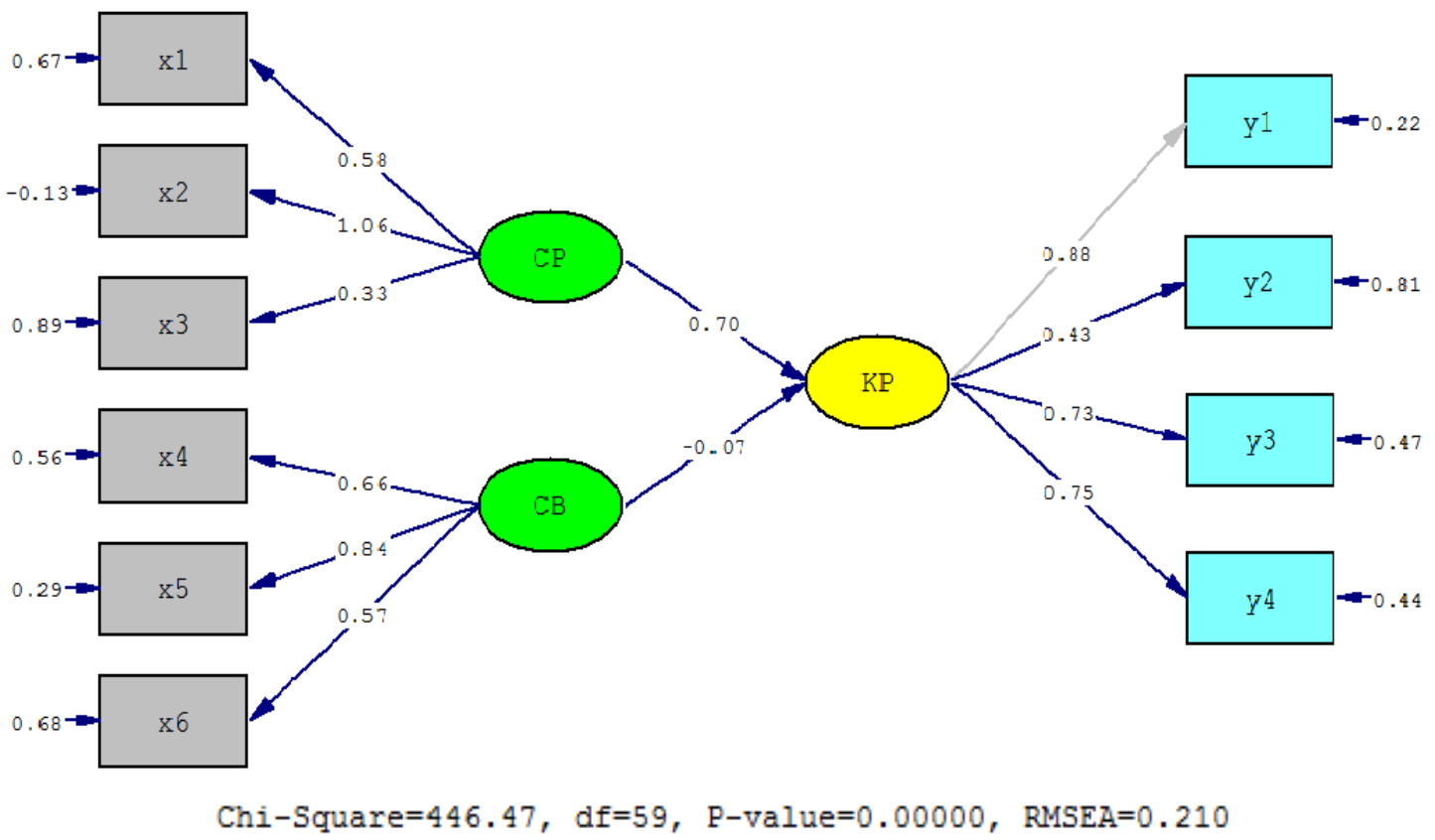

Figure 1 - Path Coefficient of Sub-Structure 1

The testing of sub-structure 1 found that path coefficient $\left(\beta_{31}\right)$ of 0.70 and the value of $t_{\text {count }}=8.16>t_{\text {table }(0.05: 150)}=1.97$ means that $H_{0}$ is rejected and path coefficient $\beta_{31}$ is significant. It shows that product image has direct positive effect on trust. The path coefficient $\left(\beta_{32}\right)$ of -0.07 and the value of $t_{\text {count }}=-0.95<t_{\text {table }(0,05: 150)}=1.97$ means that $H_{0}$ is accepted and path coefficient $\left(\beta_{32}\right)$ is not significants. It shows that banking image does not have direct potive effect on trust. 
Path Coefficient Sub-Structure 2:

Analysis model of path coefficient sub-structure 2 is expressed in equation $Y_{2}=\beta_{41} X_{1}+$ $\beta_{42} X_{2}+\beta_{43} Y_{2}+\varepsilon_{2}$. This testing will provide decision-making of hypotheses testing 3 , 4 , and 5 .

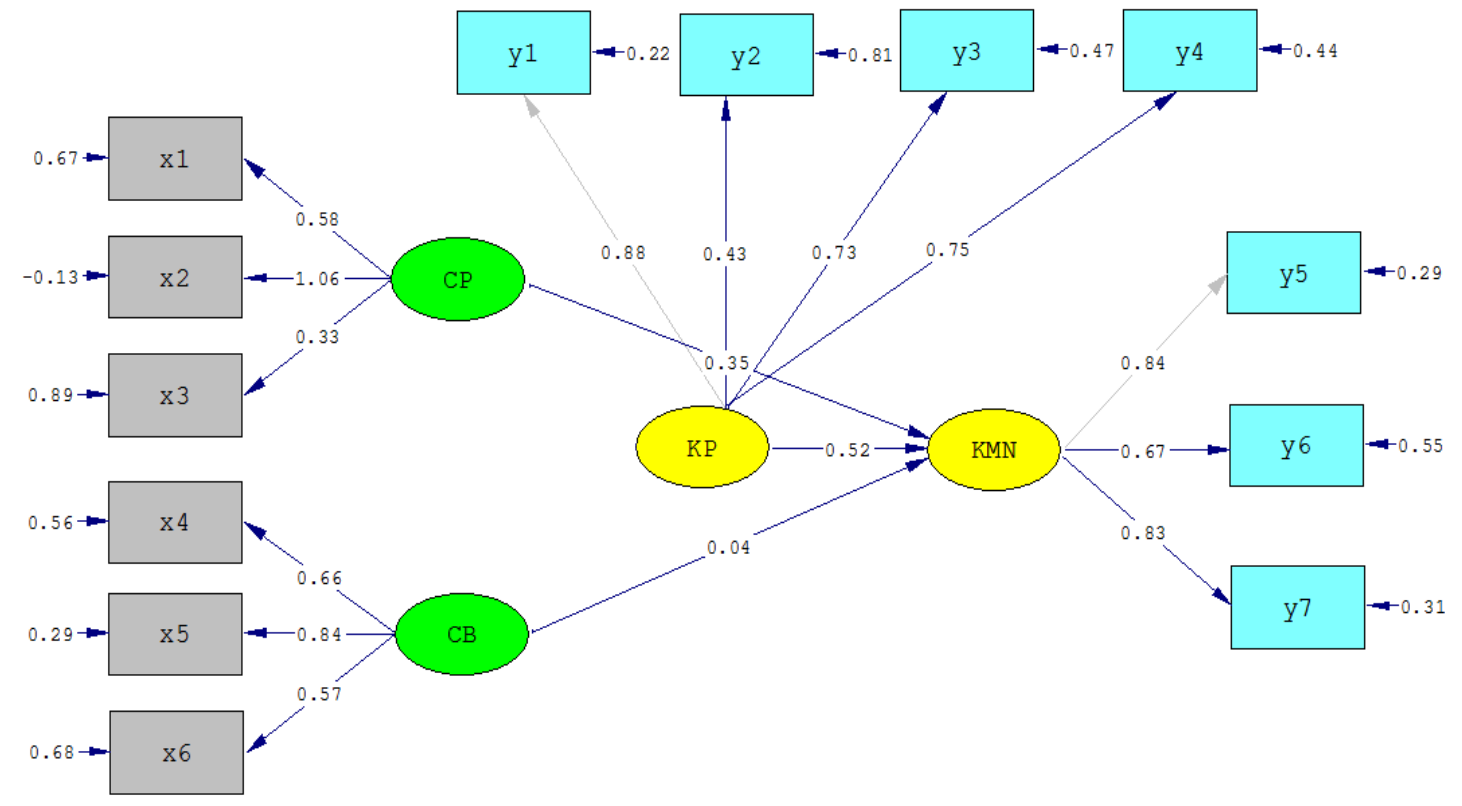

Chi-Square $=446.47, \mathrm{df}=59, \mathrm{P}-\mathrm{value}=0.00000, \mathrm{RMSEA}=0.210$

Figure 2 - Path Coefficient of Sub-Structure 2

Based on the sub-structure 2 testing, the path coefficient $\left(\beta_{41}\right)$ of 0.35 and the value of $t_{\text {count }}=3.22>t_{\text {table(0.05: } 150)}=1.97$ means that $H_{0}$ is rejected and path coefficient $\left(\beta_{41}\right)$ is significant. It means that product image has positive direct effect on the saving decision. Path coefficient $\left(\beta_{42}\right)$ of 0.04 and the value of $t_{\text {count }}=0.59<t_{\text {table(0.05: 150) }}=1.97$ means that $H_{0}$ is accepted and line coefficient $\left(\beta_{42}\right)$ is not significant. Thus, the banking image has no positive direct effect on the saving decision. Path coefficient of $\left(\beta_{43}\right)$ of 0.52 and the value of $t_{\text {count }}=$ $4.39>t_{\text {table(0.05: 150) }}=1.97$ means that $H_{0}$ is accepted and path coefficient $\left(\beta_{43}\right)$ is significant. Thus, trust has direct postifive influence on saving decision.

The calculation of path coefficient and t-value for decided hypothesis testing shows that not all of five path coefficient are sig, $<0.05$ and $t$-value $>1.97$. Thus, two lines that are not significant and three lines are significant.

Path Diagram of standardized solution. Overall the path diagram of standardized solution on each variable can be described as follows in Figure 3.

Based on figure 3 (Path Diagram of Standardized Solution), other than direct influence, there is total and indirect influence between exogenous variables $(X)$ and endogenous variables $(Y)$. Based on the output lisrel on standardized total effect shows that: (1) the value of total effect of product image $\left(X_{1}\right)$, banking image $\left(X_{2}\right)$, and trust $\left(Y_{1}\right)$ against the saving decision $\left(Y_{2}\right)$ is the same as the value of direct effect on each variable because they are not mediated by intervening variable, (2) the value of total effect of product image variable $\left(X_{1}\right)$, and banking image $\left(X_{2}\right)$ against trust $\left(Y_{1}\right)$ is the same with the value of direct effect on each variable because they are not mediated by intervening variable, (3) indirect effect of product image variable $\left(\mathrm{X}_{1}\right)$ against the saving decision of deposito customer $\left(\mathrm{Y}_{2}\right)$ by $0.70 \times 0.52=$ 0.364 , because of the variable intervening in the form of trust $\left(Y_{1}\right)$ by 0.52 . Meanwhile, the total effect is $0.35+0.364=0.714$ and (4) the indirect effect of company image variable $\left(\mathrm{X}_{2}\right)$ against the saving decision of deposito customer $\left(\mathrm{Y}_{2}\right)$ by $-0.07 \times 0.52=-0.27$ because of intervening variable in the form of trust $\left(\mathrm{Y}_{1}\right)$ by 0.52 , the total effect is $0.04-027=0.004$. 


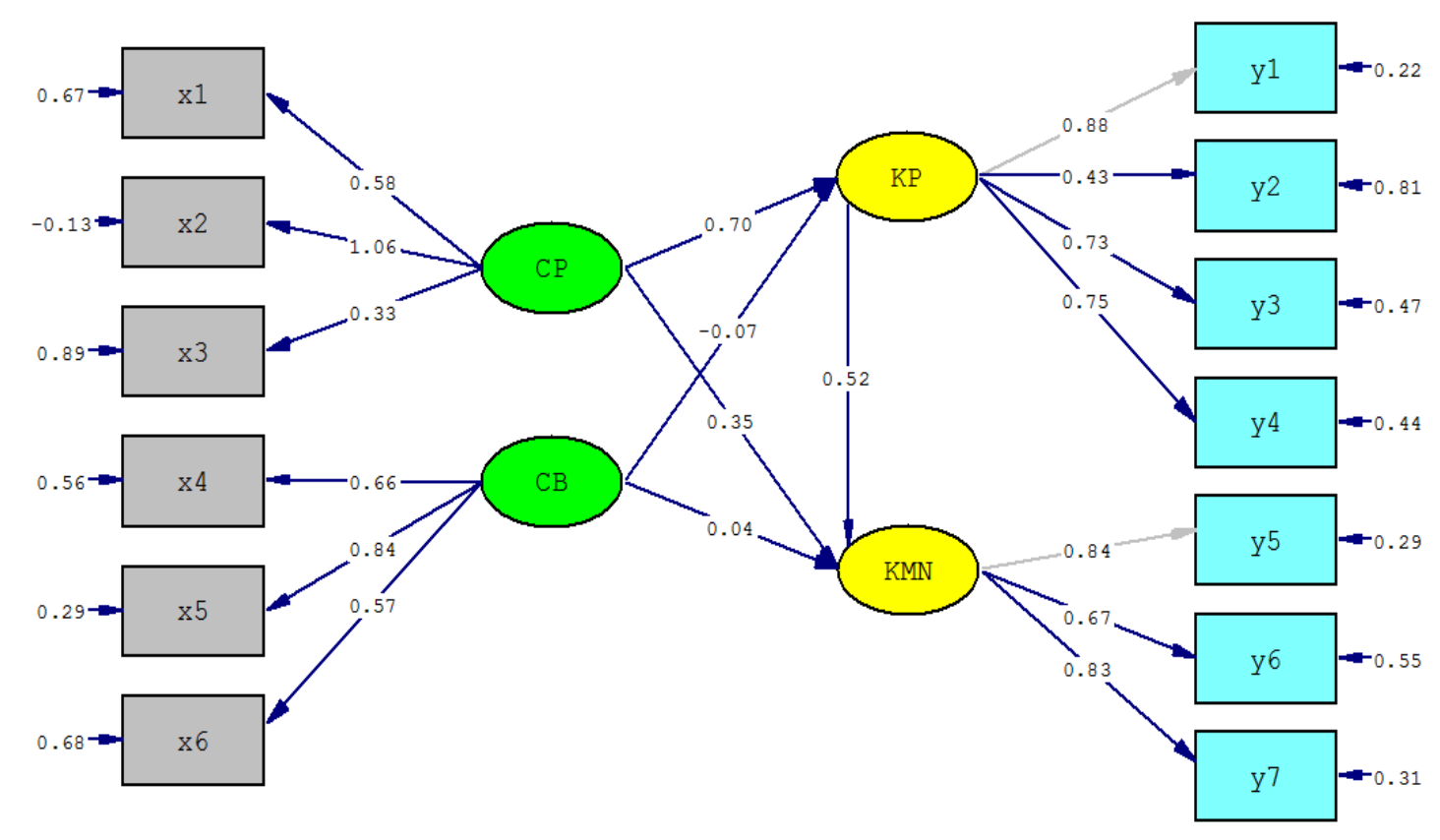

Chi-Square $=446.47, \mathrm{df}=59, \mathrm{P}-\mathrm{value}=0.00000, \mathrm{RMSEA}=0.210$

Figure 3 - Path Diagram of Standardized Solution

The above explanation of the total effect of exogenous variable $(X)$ against the endogenous variable $(Y)$ shows that variable $X_{1}$ has positive effect on $Y_{2}$ because of the existence of intervening (mediation) variable $Y_{1}$ has a greater value of influence compared to variables not mediated by another variable. Meanwhile, variable $X_{2}$ has no positive effect against $Y_{2}$ because of the existence of intervening (mediation) variable $Y_{1}$ that has smaller value of influence compared to variables not mediated by another variable. In other words, product image, banking image, and trust do not jointly influence the costumers saving decision because only product image $\left(X_{1}\right)$ that has a greater value of influence comparing to only one variable $(X)$ that affect the costumers saving decision. It also occurs in the trust variable, product image and banking product do not jointly influence the trust because only one variable $(X)$ that influences trust.

\section{DISCUSSION OF RESULTS}

The Influence of Product image against Trust. The research result found that product image has positive effect on trust. It shows that product of a bank can fulfill the customer's needs, be useful, and in accordance with the customer's expectation. Furthermore, product image also gives the good impression on the community's mind and can ensure them to trust the bank more.

The quality of the banking products that are in accordance with the customer's expectation and has an impressive attribute on the customer's mind. It is expected to increase the customer's trust to keep their fund in the bank.

This finding does not match with the research conducted by (Maliyah, Siti, 2015; Gordius Ago et al., 2015). They state that product image has significant influence on the trust.

Company Image Has Influence on Trust. The research result shows that banking image does not directly influence the trust. It shows that good image of the bank, such as having a social responsibility, having an identity and satisfying performance and service, do not foster the trust of the customer and community.

The finding is incompatible with the research conducted by (Aprilia Irfa'i, 2016; Methaq Ahmed Sallam, 2016) they state that banking image has a significant influence on the trust. 
Product Image Has Influence on Saving Decision. The research result found that product image has positive direct effect against saving decision. It shows that positive product image in the customer's mind, a product that can fulfill the customer's needs, useful banking product, and in accordance with the customer's needs, can influence the costumers saving decision.

The costumers saving decision is influenced by the product image, customer prefer to choose a product with the positive product image. Therefore, management should improve the quality of product owned. They have to pay attention to the product attributes tailored to the needs and expectation of the customers. The higher the image of a product, the better the significant influence on costumer saving decision.

This finding is in accordance with the research conducted by (Pratiwi, Made Suci dkk., 2014; H. Jessie Chen-Yu and Doris H. Kincade. 1996) they state that product image has significant influence on the customers buying decision which is assumed as the costumers saving decision.

Company Image Has Significant Influence on the Saving Decision. The research result suggests that the company image does not have a positive direct effect on the saving decision. This shows that good image of a bank, having a social responsibility, having an identity and satisfying performance and service, do not have a positive effect against saving decision.

This finding is inconsistent with the research conducted by (Aprilia Irfa'i, 2016; Nha Nguyen and Gaston LeBlanc. 1983) they state that the company image has a significant influence on the saving decision.

Trust Has Influence on the Saving Decision. The research result suggests that trust has positive direct effect on the saving decision. This shows that the performance of the employee is in accordance with the expectation. The trust in which the employee has applied necessary working principles, trust in which the company and its employee have a good reputation and trust in which the customer's fund is safe in the company. These things can influence the saving decision.

Trust can emerge because of the sense of belief in the organization that has a quality to bind the customer and find what is being expected. An employee of a certain company is expected to be consistent in conducting the company's activities in accordance with necessary working principles. They have to maintain the company's good image and create a sense of security for the customer in entrusting their fund. Thus, it can improve the customer's trust that can influence the saving decision.

This research result is consistent with the research conducted by Neysa Setyawan dan Edwin, 2014; Nha Nguyen and Gaston LeBlanc. 1983. They state that trust has significant influence on the costumers saving decision.

\section{CONCLUSION AND SUGGESTIONS}

Based on the collected data and the performed test, it can be concluded that:

Product image has a positive effect on trust. It shows that product of a bank can fulfill the customer's needs, be useful, and in accordance with the customer's expectation. Furthermore, image product also gives a good impression in the community's mind and can create senses of belief.

Product image has a positive effect on the costumers saving decision. This explains that positive product image on the customer's mind, a product that can fulfill the customer's needs, useful banking product, and in accordance with the customer's needs can influence the costumers saving decision.

Trust has positive effect on the costumers saving decision. This shows that the performance of the employee is in accordance with the expectation. The trust in which the employee has applied necessary working principles, trust in which the company and its employee have a good reputation and trust in which the customer's fund is safe in the company. These things can influence the saving decision. 
After conducting the research, the author has given several suggestions as follows:

Management should be able to maintain and improve the positive image of the company's product on the customer's mind; the employee has to quickly and accurately explain the products to the customer and by improving the quality of the company's product and its benefit in order to suit the needs of the customer.

Although the banking image has little Influence on the customer's trust, the positive banking image must be maintained and improved.

A positive image of the product on the customer's mind should be maintained all the time because a product with good impression can improve the trust and influence the costumers saving decision.

The banking image that has little influence on the costumers saving decision should be improved in order to maintain the positive image of the bank on the customer's mind.

Trust variable has a greater influence on the costumers saving decision comparing to other variables. Thus, management should be able to keep the commitment in a long term and keep the community's trust to manage their fund. This can be done through good communication, improving the service and applying necessary working principles.

\section{REFERENCES}

1. Akos Nagy, Ildiko Kemeny, Krisztian Szucs, Judit Simon, and Viktor Kiss. (2017). Are opinion leaders more satisfied? Results of a sem model about the relationship between opinion leadership and online customer satisfaction. Society and Economy: Journal of the Corvinus University of Budapest. 39.1 (Mar.) p.141. Word Count: 6383.

2. Aprilia Irfa'i, Farhana. (2016). Pengaruh Kualitas Produk Dan Citra Perusahaan Terhadap KePutusan Nasabah Dalam Menabung Di Bank Jatim Cabang SyariahKediri. Skripsi Fakultas Ekonomi dan Bisnis Ilsam Institut Agama Islam Negeri Tulungagung.

3. Asto Subroto. (2009). Pahami Keinginan Tersembunyi Nasabah. http//www.astosubroto.com/? p=119 (diakses 12 Januari 2017).

4. Fabio Caldieraro. (2016). The role of brand image and product characteristics on firms' entry and OEM decisions. Management Science. 62.11 (Nov.) p.3327. Word Count: 19587. From Gale Educational Database.

5. Ghozali, Imam. (2011). Aplikasi analisis multivanate dengan program SPSS. Semarang: Penerbit UNDIP.

6. Gordius Ago. Suharno. Sri Mintarti. Sugeng Hariyadi. (2015). Effect of Product Quality Perception, Trust, and Brand Image on Generic Drug Buying Decision and Consumer Satisfaction of Hospital Patients in East Kalimantan. European Journal of Business and Management. ISSN 2222-1905 (Paper) ISSN 2222-2839 (Online). Vol.7, No.14, 2015.

7. Govers, P.C.M. and J.P.L. Schoormans. (2005). Product personality and its influence on consumer preference. Journal of Consumer Marketing. 22.4 (Apr.) p.189. Word Count: 44.

8. H. Jessie Chen-Yu and Doris H. Kincade. (1996). Subject Area: Marketing. Effects of product image at three stages of the consumer decision process for apparel products: alternative evaluation, purchase and post-purchase. Journal of Fashion Marketing and Management: An International Journal. ISSN: 1361-2026.

9. Maliyah, Siti. (2015). Pengaruh Citra Merek, Kepercayaan (Trust) Dan Komitmen Terhadap Loyalitas Nasabah Pada PT. Henan Putihrai Asset Management. Jurnal IImiah Manajemen dan Bisnis Volume 1, Nomor 1.

10. Methaq Ahmed Sallam. (2016). Published by Canadian Center of Science and Education. The Impact of Brand Image and Corporate Branding on Consumer's Choice: The Role of Brand Equity. International Journal of Marketing Studies; Vol. 8, No. 1; ISSN. 1918-719X E-ISSN 1918-7203. College of Administrative Sciences, Najran University, Najran, Saudi Arabia.

11. Michael R. Solomon, Richard D. Ashmore, and Laura C. Longo. (1992). The Beauty Match-Up Hypothesis: Congruence Between Types Of Beauty And Product Images In Advertising. Journal of Advertising. 21.4 (Dec.) p.23. Word Count: 7026. 
12. Michal Bialek and Wim De Neys. (2017). Dual Processes And Moral Conflict: Evidence For Deontological Reasoners' Intuitive Utilitarian Sensitivity. Judgment and Decision Making. 12.2 (Mar.) p.148. Word Count: 13951.

13. Neysa Setyawan, Yohana, dan Edwin Japarianto. (2014). Analisa Pengaruh Kepercayaan, Jaminan Rasa Aman dan Aksesbilitas terhadap Minat Menabung Nasabah Bank Danamon di Surabaya. Jurnal Manajemen Pemasaran Petra Vol.2, No.1.

14. Nha Nguyen and Gaston LeBlanc. (1983). The mediating role of corporate image on customers' retention decisions: an investigation in financial services. International Journal of Bank Marketing. ISSN: 0265-2323.

15. Nilton Porto and J. Michael Collins. (2017). Word Count: 4102. (The Role Of Refund Expectations In Savings: Evidence From Volunteer Income Tax Preparation Programs In The United States). Journal of Consumer Affairs. 51.1. p.183.

16. Pratiwi, Made Suci, Suwendra dan Yuliantini. (2014). Pengaruh Citra Perusahaan, Citra Produk dan Citra Pemakai Terhadap Keputusan Pembelian Produk Foremost pada Distro Ruby Soho di Singaraja. Jurnal Manajemen. Volume 2.

17. Robert Azuayi. (2016). Arabian J Bus Manag Review. S2. International Branding Strategies of Global Companies: A Case Study of Sony Ericson. Arabian J Bus Manag Review, an Open Access Journal. Arabian Journal of Business and Management Review. ISSN: 2223-5833.

18. Seita M. Almandeel. (2017). The Mediating Role Of Transformational Leadership Style On Relationship Between Personality Type And Turnover Intention In Saudi Arabian Banking Context. International Journal of Organizational Leadership. (Jan.) p.109. Word Count: 13426.

19. Slovin, C.G. S. (2003). Riset Pemasaran dan Perilaku, Alih Bahasa oleh Umar Husein. Jakarta: PT. Gramedia.

20. Suharto. (2016). Responsiveness, Customer Relationship Management Confidence and Costomer Loyalty. Social and Economic Sciences, Scientific Jurnal Of PPI-UKM. ISSN No. 2356-2536. Vol.3 No. 2.

21. Triandaru, Sigit dan Totok Budisantoso. (2009). Bank dan Lembaga Keuangan Lain. Jakarta: Salemba Empat.

22. Yi Zhang. (2015). Published Online January in SciRes. The Impact of Brand Image on Consumer Behavior: A Literature Review. Department of Marketing, Management School, Jinan University, Guangzhou, China. Open Journal of Business and Management, 3, 58-62. Scientifid Research Publishing. 


\title{
LOCAL-WISDOM-BASED SPA TOURISM IN UBUD VILLAGE OF BALI, INDONESIA
}

\author{
Pradana Gede Yoga Kharisma*, Parwati Komang Shanty Muni \\ International Bali Institute of Tourism, Indonesia \\ *E-mail: yoga@stpbi.ac.id
}

\begin{abstract}
The purpose of this research is to be able to understand the existence of Spa tourism based on local wisdom in Ubud Village, Bali. This research is conducted because there is an inequality between assumption and reality in the field. Generally, Spa tourism using water medium modernly was done by a therapist in a special place for Spa. But, in Ubud, Spa tourism based on local wisdom, which is different from Spa tourism in general, interests tourists. The questions are: why does local-wisdom-based Spa tourism highly interest tourists in Ubud village?; what does the Spa look like?; what are the implications for the society and tourism industry in Ubud? This research was conducted by using qualitative method. Sources and types of research data, both primary and secondary, were obtained in the field through participant observation, interview, and literature study. All data that has been collected was then analyzed critically in the perspective of cultural studies. The results showed that: Local-wisdom-based Spa tourism is very attractive for tourists in Ubud because the price is cheap, but the workmanship and the resulted output are quite good; Localwisdom-based Spa tourism in Ubud Village was conducted in the form of home Spa; a Spa tourism conducted in society's houses by the local community as well as local workmanship and local-wisdom-based products; the development of local-wisdom-based Spa tourism in Ubud has implications for local communities, especially on improving the economy, employment opportunities, empowerment, conservation of local wisdom, emancipation of local communities in tourism, and implications as a new identity for the tourism industry in Ubud.
\end{abstract}

\section{KEY WORDS}

Spa tourism, local wisdom, ubud tourism village, bali tourism.

Bali is a popular cultural tourism destination in the world (Pichard, 2006). The uniqueness of Bali culture attracts many tourists to come again. The high number of tourist visits to Bali encourages the rapid development of tourism industry of this region. Various types of tourist products are now mushrooming in Bali. The growth is not just happening in the tourist areas that have developed before. But, it is also happening to the remote villages with various types of tourism products based on local wisdom of Bali.

The high interest of tourists to tourism products nuanced Balinese culture motivates local government committed to continue developing the area of Bali as a tourist destination based on the concept of "cultural tourism". This means that all industrialization of tourism developed by the community in this area is expected to have Balinese culture nuance. The strategic policy that delivers Bali as a world-renowned cultural destination is worth keeping in place. This is because even though Bali area is developed as a tourist destination of the world, but in reality the local culture of religious nuances are full of cultural values remaining sustainable. Even, many observers claim that the rapid development of Bali's tourism industry causes fertility increase of the growing culture of Bali (Ruastiti, 2010).

Ubud as one of tourist villages in Bali has potential which is adequate as a cultural tourist attraction. In addition to its beautiful natural environment, its friendly community culture is a special attraction for the growing wellness tourism in Ubud village. As one of the tourism objects, Ubud village plays and actively contributes as a host in providing Spa facilities through 97 kinds of business. Since it attracts high demand of tourists, Spa tourism was grown as a tourism mainstay in Ubud village. Based on observations in the field, it seems that the growth of Spa in Ubud Village has exceeded $100 \%$ within the period of 8 
years (Widjaja, 2011). Starting from 2003 until 2011, it has been identified about 410 Spas have been operating and spreading in tourism centers in Bali, including Ubud.

Ubud is famous among the foreign tourists because its location is placed between the rice fields and forest that present the beauty of natural scenery. On the other hand, Ubud is known for its culture, as there are art galleries, arts and dance arenas (Pichard, 2006). The tourists dare to pay expensively to stay in Ubud hotels, villas, and resorts because they want to enjoy the atmosphere of rural calmness in Bali while enjoying the taste of Balinese arts from hundreds of studios in remote villages.

Over the last 10 years, Ubud Village has developed wellness tourism based on local wisdom of Bali. Wellness tourism is a kind of health tourism (Jafari, 2000; Bookman, 2007; Reisman, 2010). The emergence of wellness tourism in Bali seems inseparable from these many areas which have a kind of traditional medicine, supported by the skills of the community in concocting and doing traditional healthcare. Bali natural beauty increasingly adds to the development of this type of tourism potential as a leading tourist in Ubud village. The number of tourists interest in the wellness tourism, particularly Spa, has impacted on the rise of Ubud resorts, such as hotels, inns, beauty clinics, and resorts to develop localwisdom-based Spa (Raiutama, 2011; Smith, 2009; Smith, 2014; Voigt et al, 2014). Spa as wellness tourism is a fitness center that tourists can use to recover their stamina from fatigue during their tour (Smith et al., 2014). In Spa site, the tourists can take care of health as well as relaxation (McKindsey, 2002; Dacanay et al., 2005).

Spa Tourism is considered as one of the most popular tourism attractions for tourists (Chen and Prebensen, 2009; Dun, 1973; Ardel, 1986). Spa as one of tourism types concerning on consumers fitness care, so it becomes a favorite choice for international tourists. In principle, Spa attempts to pamper tourists through treatment by using water medium. The development of a local-wisdom-based Spa in Ubud has created many opportunities for local people (Peris et al, 2015). This means that the development of Spa tourism products that require a lot of local therapists can open employment opportunities for local communities. Not only for tourism school graduates, but also it opens job opportunities for homebound people, housewives, who have traditional massage skills. Moreover, the regularity of the hospitality business environment and the reliability of Bali's infrastructure are increasingly supporting the development of Bali's tourism industry (Widjaja, 2011; UNWTO, 2015; UNECLAC, 2010).

It is interesting to note because so many tourists who come to visit the village of Ubud are not only willing to enjoy the natural scenery and cultural traditions of a unique community, but also because they want to enjoy the unique local-wisdom-based Spa in which they rarely meet elsewhere. In general, Spa tourism using water medium is done in modern way with sophisticated technology. But now, in Ubud Village, a different Spa tourism is developed. The questions are: how is the form of Spa tourism based on local wisdom in Ubud village?, and how are the implications for the community and the development of tourism industry in Ubud Village?

\section{METHODS OF RESEARCH}

The research method used to study the phenomenon of Spa based on local wisdom in Ubud village is qualitative research method. The sources and types of research data, both primary and secondary, were obtained directly in the field through participant observation, interview, and literature study. Primary data were collected using participant observation techniques and interviews (Ten Have, 2004; Travers, 2004). Besides, secondary data were collected by using literature study technique (Hammond and Wellington, 2013). The related informants were selected based on purposive sampling technique. Selected informants include community figures, tourism figures, village elders, and local communities. The addition of informants to complete the data that is considered less done by using snowball sampling technique. As it has been said that this study also uses secondary data obtained from literature studies through the search of similar research results that have been produced by previous researchers. After all data was collected, then the data were analyzed 
critically in the perspective of cultural studies. The results of the study showed, such as, as follows.

\section{RESULTS AND DISCUSSION}

Local-Wisdom-Based Spa Tourism in Ubud Village, Bali. Based on the results of research, it shows that Spa tourism based on local wisdom is very attractive to tourists in Ubud village because the price is cheap but the output is quite good. Although traditionally done, it is based on local wisdom done by ordinary housewives with their own processed products and techniques, but tourists who have enjoyed the local-wisdom-based Spa are satisfied. The nuance of typical house of Ubud village and the freshness of the body that they felt after the massage make many tourists like the type of tourism products.

The free market gives everyone space to compete freely in achieving economic benefits. The number of similar products sold in the market creates intense competition. Not only in price, but a competition is also there in product quality. The phenomenon creates every producer competing to offer good quality with a relatively inexpensive price. Such conditions certainly create a tight competition climate both in terms of quality and price offered. Competition will become more with the support of technology. This is because consumers will become easier to access the desired product information. It is also same as the competition of Spa tourism products in Ubud. The number of tourists who are interested in using Spa services encourage the emergence of local-wisdom-based Spa tourism products which is known as home Spa. Home Spa products offered are relatively low prices compared to Spa tourism that are offered by hotels and villas in Ubud make a lot of tourists turned and dropped their choice on Spa products based on local wisdom that is done by the local community in the homes of local residents.

The number of tourists interested in Spa products is considered as an opportunity by the community in Ubud to participate in offering Spa tourism products. By using their skills and culture, they seized the market. Tourists who mostly stay in the village of Ubud and have enjoyed a good and refreshing home Spa message make tourists use the product repeatedly.

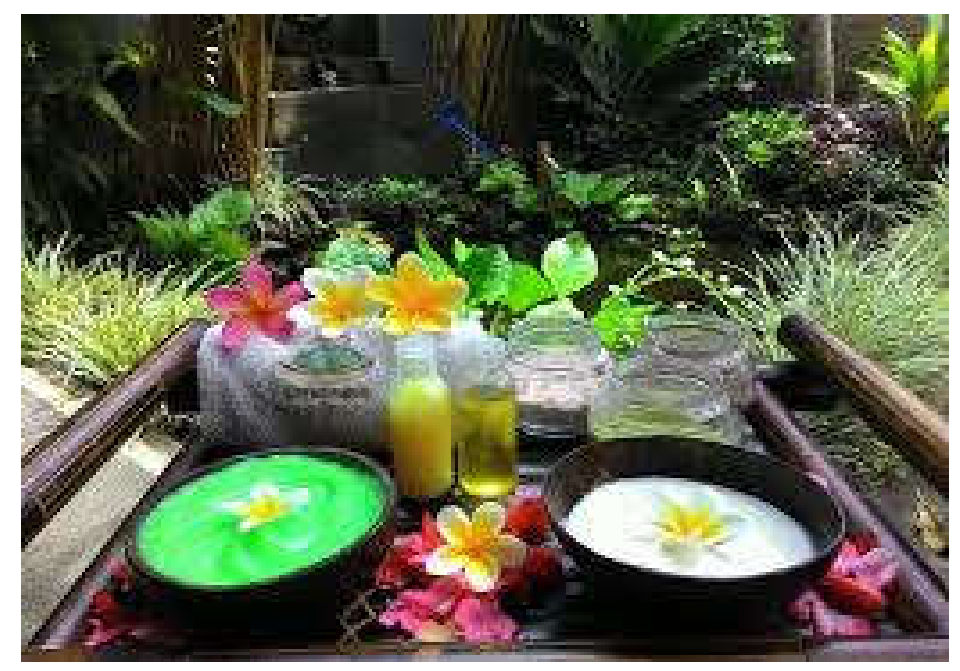

Figure 1 - Coconut Oil and boreh for Spa treatment Source: Courtesy of Yoga, 2017.

The natural potency of Ubud Village that has been beautifully accompanied by the skill of its community in concocting boreh (traditional mask), and massaging is an important factor in building the image and identity of home Spa products offered. With local wisdom, local people are able to gain an economic contribution to tourism development in Ubud. The tourists who are interested in home Spa makes housewives in the village is now beginning to 
glance at the opportunity as a way to seek fortune. Now, besides renting their houses as an accommodation for tourists, local people also provide home Spa services for tourists in Ubud. Below is one of the local-wisdom-based Spa done by the community in Ubud.

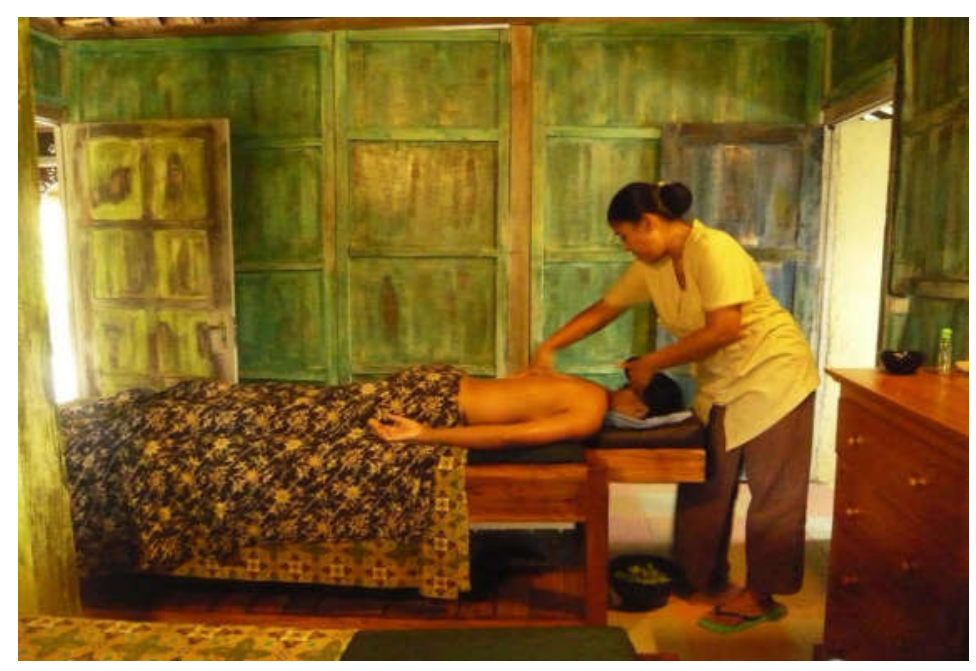

Figure 2 - Home Spa in Ubud Village

Source: Courtesy of Yoga, 2017.

Spa tourism based on local wisdom in the village of Ubud is done in form of home Spa. It can be seen from the products used, the way it is worked, the therapists who do it, the place, or the workmanship. Spa tourism based on local wisdom now attracts a lot of tourists in the village of Ubud. The number of tourists interested in the local-wisdom-based Spa tourism is responded positively by local community. It can be seen from the spread of Spa along the highway of Ubud village. Each Spa offers its own uniqueness. The rise of localwisdom-based Spa tourism in the village of Ubud would not be separated from the creativity of local communities in developing these tourism products. Ubud village as a tourist destination that has the beauty of panorama, natural scenery, accompanied by the amount of local community support in developing tourism into a potential capital in developing the village of Ubud as the world's cultural tourism industry. Below is one of the local-wisdombased Spa done by the community in Ubud.

The uniqueness of local-wisdom-based Spa tourism of Ubud village that is familiar seems to be the main attraction for tourists. The integration of various cultural elements of Ubud Village on a local-wisdom-based Spa in Ubud indirectly seems to open and expand employment opportunities for the community, housewives from the area. Since the high number of tourists is interested in the traditional Spa, now housewives who have low education get job opportunities as well as economic contribution to the development of tourism in the region.

Ubud Tourism Village which is now famous for home Spa; a typical Spa that is done traditionally in the house of residents, in addition to having its own interest in terms of workmanship, but also it has a special advantage in terms of production costs of the Spa tourism. It is caused by the simple workmanship that is his own house, the products used such as scrubbing, masks, massage to aroma therapy used is local production processed by local communities traditionally. But although traditional ingredients in the form of lotions with fine granules are smeared throughout the body when bathing, the Spa has feature to smooth blood circulation, and can remove toxins from the body, so that local-wisdom-based Spa is very attractive to tourists. Although home Spa is cheap, but the stiffness and fatigue of tourists are reduced especially if the body is masked by using traditional herbals in the form of powders made in accordance with the skin condition of tourists.

According to Mrs. Nyoman Kondri, one of the traditional Spa therapists, tourists are very happy with the way she massages. By pressing at certain points using her own aromatherapy oil, the tourists feel satisfied, even then often giving her tip, in the form of extra 
money to Mrs. Nyoman. Local-wisdom-based Spa treatment that now seems to be mushrooming in Ubud is dominantly done by local people using traditional products, with traditional craftsmanship techniques, all of which are based on the local wisdom of Ubud Village.

Local wisdom is part of the culture (Zaimah, 2007). Local wisdom can be defined as human intelligence possessed by certain ethnic groups through community experience (Appadurai, 1996). Meaning that local wisdom is the result of certain communities and not necessarily experienced by other communities. The value system inherent in the community is understood as a common property. Every truth value is defined as the common property of the community. The similarity of the truth value comprehension is gained through the long passage of time, throughout the existence of that society.

Local wisdom can be conceptualized as local intelligence (local genius) reflected from knowledge and local policy (local wisdom) (Wahono, 2005). Therefore, local wisdom can be interpreted as a thought about life. The mastery of local wisdom will shape the character of the community concerned on having a noble personality and wise in life. Hence, the development of local-wisdom-based Spa tourism which is done by local people using local cultural skills can be done synergistically in the field of tourism.

The important purpose of wellness tourism not only reaches the satisfaction of tourists on every visit to the tourist attractions, but also it makes their body fit again (Raiutama, 2011). Based on that orientation, there is a correlation between attitude and knowledge of the utilization of tourism facilities where knowledge of Ubud Village people influences the decision of tourists in making a tour to the village of Ubud. Many tourist visits to the village of Ubud aim to enjoy the natural scenery and the uniqueness of local culture. It is like a tit for tat because local people indeed expect tourists to visit their village, so that they can participate and get contribution from the development of tourism in their area. By developing localwisdom-based Spa tourism, they feel that not only earn economic contributions, but also can preserve their cultural traditions. The community's struggle in Ubud village seems able to make Bali as the best Spa destination in the world which is ever declared by one of Germany magazines namely SENSES at the Wellness Award in 2009 (Interview with Putu Sadia, January 2017). Based on the statement, it can be understood that the village of Ubud is not only known as a cultural destination, but also it is known as local-wisdom-based Spa tourist destination of Bali.

As the favorite choice of tourists, local-wisdom-based Spa tourism certainly cannot be separated from the touch of professionals in the field of tourism. The therapists of localwisdom-based Spa, mostly local housewives, are trained. By training, the housewives were able to do the treatment well. They use local spices, oil, and rice as product ingredients. By taking advantage of the opportunity, in practice, it empowers local women in the public sector as a therapist. With the development of local-wisdom-based Spa in the village of Ubud, the unemployed people in the area are reduced. Local-wisdom-based Spa that requires a lot of female workers indirectly impacts on the decline of the number of poverty. Moreover, the arrangement of home Spa interior is styled with elements of local culture seems that it provides economic opportunities significantly for local communities.

The practice of local-wisdom-based Spa in Ubud is very prospective. As stated by the Chairman of the Bali Spa and Wellness Association (BSWA), approximately BSWA members experienced a shortage of 2-3 therapists by 2016 (Denpost, 2016). Though being a therapist is very easy. Skill training done by local people no more than four months to gain about 2 millions salary at a number of Ubud resorts and villas. Ubud as a Tourism Village has contributed in increasing the number of Spa workers. It is noted that the number of Spa in Bali until the year 2016 has reached 1.100 units (Jumarani, 2009). Even if the Spa business competition in Ubud Village is tight; but with the implementation of certain operational standards, the quality of the products can be controlled. Quality products will certainly be able to influence consumer decisions to buy the product. This means that satisfactory service to consumers plays an important role in sustainability of product sales offered. However, in a number of resorts and villas that develop the concept of local-wisdom-based Spa by applying certain SOPs resulted in many therapists objecting and choosing to resign as workers. This 
has resulted in many resort and villa entrepreneurs developing Spa in Ubud frustrated by a shortage of therapists.

Based on observations in the field, it seems that lately the interest of tourists in Ubud to health tourism is very huge. The high interest of tourists in a product can be seen from the speed of product growth in the field (Maslow and Herzeberg, 1954; Pine and Gilmore, 1999). As Spa tour packages that seem to be a priority of tourists who visit Ubud, Ubud as one of the Cultural Tourism Villages is visited by many tourists because they want to enjoy a quality Spa. Spa tourism is made as the top choice because Spa in Ubud is known for its uniqueness and quality. As a cultural tourist destination when tourists come to visit Ubud, they feel like they were in their own houses. A homey and peaceful village atmosphere as well as hospitality attitude of the people encourages tourists to always want to come back to Ubud.

Local-wisdom-based Spa tourism developed by villas and hotels in Ubud is now much designed with the concept of open space. The design of Spa open spaces adopting the base of local wisdom not only has open rooms, but also it uses natural components. Natural environment such as rivers, green rice fields, and steep cliffs are widely used by villas and hotels in Ubud as a Spa. Local-wisdom-based Spa tourism often called 'home Spa' indeed adopts a home atmosphere. In addition to the interior design of the Spa on the products and equipment used, it also uses home appliances. It certainly has plus and minus. In one side, it indeed gives unique and artistic touch, but on the other side, the open space will be easier to be dusty and dirty. It certainly requires extra attention in maintaining the cleanliness of Spa spots. If cleanliness is not paid attention, then it will influence the hygiene treatment. The treatment results cannot be maximal. In service products like Spa, customer service is the most vital component in maintaining the sustainability of consumer interest. Good and bad servicing actors to consumers is the key success of a service business (Upshaw, 1995; Diaz, 2010; Lavado, 2011; Palmer, 2001).

Besides service, promotion of a service business is also important in maintaining the sustainability of these products. As the local-wisdom-based Spa in the village of Ubud which still uses a lot of promotions that are managed by the travel agent, quality of service must be concerned too so that tourists who have felt the good treatment of Spa, they will come back to the place. This means that local-wisdom-based Spa tourism in the village of Ubud is still less to do business promotion. Therefore, visitors of the Spa are very dependent on the tourists visit who already know and love Ubud and have enjoyed the treatment at the Spa.

Implication of Local-Wisdom-Based Spa Tourism for Local Community in Ubud. The development of local-wisdom-based Spa tourism in the village of Ubud indirectly implies on the preservation of traditional medicinal materials management way for treatment and traditional medicine through massage. The practice of local-wisdom-based Spa is very environmentally friendly. It can be seen from the components or products used, the place or location, and the equipment used in the Spa product. Local-wisdom-based Spa tourism uses a lot of natural media. This means that local-wisdom-based Spa treatment dominantly uses elements of local culture both in terms of products and ways to work.

Spa can be defined as hydrotherapy (Crebbin et al, 2005; O'brien, 2006). Through Spa services, it can make consumers feel relaxed, refresh mind, and make body fit again. Spa involves a series of therapeutic massage treatments, body scrubs, bleach masks, milk baths along with music therapy, aromatherapy, and warm drinks of ginger or hot tea (O'brien, 2006). In addition to a massage, in the Spa package, it sometimes also adds the treatment with hair Spa (creambath plus), pedicure-manicure, facial, and others (Crebbin et al, 2005). Spa therapy is widely chosen by consumers because it can be used to reduce headaches, aches, fatigue, anxiety, and so on (Herron, 2008). The added benefit of Spa treatments is feeling calm, comfortable, the skin becomes smoother, firmer, cleaner and muscles are more relaxed. Because of the high demand of women, Spa treatments are generally known as a place of beauty treatments, body care, fitness, health and comfort. Due to the contribution of treatment in the Spa, Spa tourism is identical with women. However, the fact in the field shows that the consumers of Spa tourism products actually are also men. 
The environment setting of Spa location which is made beautiful and easy to reach becomes the main concern for the development of Spa products based on local wisdom. The community makes the modern Spa become a unique and thick nuanced tourist products with the content of local culture. The increase of people's income through their participation in providing Spa's massage products and services encourages many local people to participate in such tourism activities. A tourism product that consumers demand will have implications for the economic improvement agents (Nordin, 2003; Al Jassmi, 2013). The development of a local-wisdom-based Spa in the village of Ubud opens job opportunities and triggers the creativity of local people to continue innovating in the field of Spa. Their growing creativity in the treatment and processing of Spa products increases their income. The access of local people in the tourism industry in Ubud becomes more real. The rotation of the economy over the development of Spa tourism products in Ubud is also increasing along with the increase of creative economic ethos in society.

The development of local-wisdom-based Spa tourism in Ubud Village indirectly has implications on strengthening and empowering local communities. Community participation in Spa tourism products seems to have provided a conducive atmosphere for community mobilizers to pay attention and care of Spa touris, areas. Their availability to cooperate actively and cooperatively has been able to build a sustainable tourism (Eagles, et al, 2002). At the same time, they manifest the situation by developing participation and empowerment of local communities through the Spa practice monitoring group in Ubud.

The development of local-wisdom-based Spa tourism in Ubud village indirectly implies on reducing the risk of crime and increasing emancipation of women in the public sector. Reducing the risk of criminality through productive activities in the field of Spa seems able to reduce the stereotype of local residents as well as minimize the inequality distance between groups that can lead to social jealousy as a potential crime. Although women in Ubud participate in public sector work as a Spa product workers, but they still do their traditional duties as housewives.

On the other hand, the development of local-wisdom-based Spa tourism in the village of Ubud indirectly has implications in maintaining the beauty of natural environment. It is because the therapists, that mostly the local community, use products and treatments that are environmentally friendly and still maintain the cleanliness of the environment. The need for extensive land for Spa location gets the local community's attention. Because they jointly carry out the practice of Spa, then they also face and conduct the preparation of the necessary natural location together. The beauty of Ubud Village is one of local-wisdombased Spa tourism's attractions. The more positive the assessment of tourists on the products offered, the more positive the tourists will choose the products back. It indirectly can maintain the function and sustainability of the local natural environment. Local people also enjoy living in the beautiful environment.

Besides, the development of local-wisdom-based Spa tourism in the village of Ubud indirectly influences the beauty of local wisdom in Ubud village. Local wisdom used as Spa products such as oil and rice for traditional boreh healing through treatment. In addition, the activities of Spa tourism conducted by the community in Ubud village indirectly have implications on opening the active local cultural involvement in legalizing the product and Spa treatment in Ubud Tourism Village. The institutioning process of local-wisdom-based Spa treatment indirectly seems to participate in maintaining ethics and morals of local communities, as treatment agents who can slightly reduce the tasks in terms of custom in order to maintain the good name of Ubud Tourism Village culturally.

\section{CONCLUSION AND SUGGESTIONS}

Based on the above explanation, it can be concluded that the results of research show that local-wisdom-based Spa tourism is very attractive to tourists in Ubud because the price is cheap, the workmanship is good, the atmosphere is more homey, and the body is more refreshed. Local-wisdom-based Spa tourism in Ubud Village is done in the form of home Spa. It can be seen from the place and the atmosphere of workmanship, the products used, 
the way it is worked, and the therapists who do it. The development of local-wisdom-based Spa tourism in Ubud village has implications for improving the economy, employment opportunities, empowerment, emancipation of local people, the preservation of local wisdom, and a new identity for tourism in Ubud.

The development of local-wisdom-based Spa tourism known as the home Spa in Ubud affects the development of tourism industry in Ubud. The contribution of the development of home Spa seems to add an icon for the village of Ubud as a tourist area of Spa because it has many good Spa services. Nowadays, Ubud is not only known as a cultural tourism destination, but also known as a Spa tourism destination.

Moreover, the development of Spa tourism has implications for improving the living standards, the economy, and the welfare of local communities. Success in offering Spa tourism based on local wisdom has been able to attract local people, especially housewives in focusing the profession as a housewive Spa therapist. It certainly means economic, as empowerment, and emancipation for the local community. The development of local-wisdombased Spa tourism has implications for the preservation of local wisdom. It can be seen from the utilization of boreh/spices mask, coconut oil, local rice, as Spa treatment ingredients, and so forth. In addition to the implications for the preservation of local culture, the development of home Spa also gives implications on the natural environment of Ubud village, the beauty of the natural environment, and the cleanliness of the surrounding natural environment. Besides, the development of local-wisdom-based Spa in Ubud Village has implications for economic improvement, job opportunities, empowerment, community emancipation, and the preservation of local wisdom.

As a suggestion, in order that the Spa tourism product can be developed continuously, it is necessary to cooperate with related parties, starting from community figures, traditional figures, security, government, community groups, and related experts (economists, Spa experts, tourism experts). In order to keep the quality maintained, regular training needs to be done so that the regeneration process can take place. Cooperation between all parties that are mutually beneficial is the basic capital that will be able to realize sustainable community-based tourism.

\section{REFERENCES}

1. Al Jassmi, L. (2013). Gulf Countries Cooperation Health Travel Market Experience and Opportunities International. Monaco: Medical Travel Exhibition and Conference.

2. Appadurai, A. (1996). Modernity at Large Cultural Dimensions of Globalization. London: University Of Minnesota Press.

3. Ardel, D.B. (1986). High Level Wellness: An Alternative to Doctors, Drugs and Disease. Berkeley CA: Ten Speed Press.

4. Bookman, M \& Bookman, K. (2007). Medical Tourism in Developing Countries. New York: Palgrave macmilian.

5. Chen, J.S. \& Prebensen, N. (2009). Wellness as Tourist Motivation. Case of Taiwan. In: Bushell, R. \& Sheldon, P.J. (Eds.) Wellness and tourism. Mind, Body, Spirit, Place (pp.231-238). New York: Cogniznat Communication.

6. Crebbin-Bailey, J., Harcup, J. W., Harrington, J., \& Habia. (2005). The Spa book: the official guide to Spa therapy. London: Thomson.

7. Dacanay, J. \& Rodolfo, M. (2005). Challenges in Health Service Trade: Phillippine Case. Disccussion Paper No. 2005-30. Makati: Phillipine Institute for Development Studies.

8. Denpost. (2016). Minat Warga Bali Bekerja ke Luar Negeri Tinggi. http://denpostnews.com/2016/10/22/minat-warga-bali-bekerja-ke-luar-negeri-tinggi/

9. Diaz, F. (2010). Tourism and Hospitality Development and Management: Competitive Strategies and Policies for Tourism Destinations: Quality, Innovation and Promotion. New York: Nova Sciences Publisher.

10. Dunn, L. (1973). High Level Wellness. Arlington: Beatty.

11. Eagles, P.F.J., McCool, S.F., \& Haynes, C.D.A. (2002). Sustainable Tourism In Protected Areas: Guidelines For Planning and Management. Cambridge: IUCN. 
12. Hammond, M. \& Wellington, J. (2013). Research Methods: The Key Concepts. Abingdon: Routledge.

13. Herron, T. (2008). The Spa \& Body Therapist: 5 Keys to Energy, Balance and Bliss. Ropley: O Books.

14. Jafari, J. (2000). Encyclopedia of Tourism. London: Routledge.

15. Jumarani, L. (2009). The Essence of Indonesian Spa: Spa Gaya Jawa dan Bali. Jakarta: Gramedia Pustaka.

16. Lavado, R. (2011). Profile of Private Hospitals in the Phillippines. Disscusion Paper No. 2011-Makati: Phillippine Institute for Development Studies.

17. Maslow, A. \& Herzeberg, A. (1954). Hierarcy of Needs: Motivation and Personality. New York: Harper.

18. Nordin, S. (2003). Tourism Clustering \& Innovation: Path to Economic Growth and Development. Sweden: Europan Tourism Research Institute.

19. O'Brien, K. (2006). Spa Style Asia-Pacific: Therapies, Cuisines, Spa. London: Thames \& Hudson.

20. Palmer, A. (2001). Principles of Services Marketing (3rd). London: McGraw-Lill.

21. Peris-Ortiz, M. \& Alvarez-Garcia, J. (2015). Health and Wellness Tourism: Emergence Of New Market Segment. Switzerland: Springer International Publishing Switzerland.

22. Pichard, M. (2006). Bali, Pariwisata Budaya dan Budaya Pariwisata. Jakarta: Gramedia.

23. Pine, B. J. \& Gilmore, J.H. (1999). The Experience Economy. Work Is Theatre \& Every Business a Stage. Boston: Harvard Business School Press.

24. Raiutama. (2011). Dimensions of Tourism Economics: Study on The Economic Impact and The Comparative Advantage of Tourism in Bali's Regencies and Cities. Denpasar: Dhayana Pura.

25. Reisman, D. (2010). Health Tourism: Social Welfare through International Trade. London: E.Elgar.

26. Ruastiti, N. M. (2010). Seni Pertunjukan Pariwisata Bali. Yogyakarta: Kanisius.

27. Smith, M. \& Puczko, L. (2009). Health and Wellness Tourism. London: ButterworthHeinemann.

28. Smith, M. \& Puczko, L. (2014). Health, Tourism and Hospitality: Spas, Wellness and Medical Travel (2nd Ed.). London: Routledge.

29. Ten Have, P. (2004). Understanding Qualitative Research and Ethnomethodology. London: SAGE Publications.

30. Travers, M. (2004). Qualitative Research through Case Studies. London: SAGE Publications.

31. United Nations Economic Commission for Latin America and the Carrebian. (2010). Medical Tourism: a Survey. Washington: UNECLAC.

32. Upshaw, L. (1995). Building Brand Identity: A Strategy for Success in Hospitality Marketplace. New York: John Wiley and Sons.

33. Voigt, C. \& Pforrs, C. (2014). Wellness Tourism: A Destination Perspective. New York: Routledge.

34. Wahono, F. (2005). Pangan, Kearifan Lokal dan Keanekaragaman Hayati. Yogyakarta: Penerbit Cindelaras Pustaka Rakyat Cerdas.

35. Widjaja. (2011). Otonomi Daerah dan Daerah Otonom. Jakarta: PT Raja Grafindo Persada.

36. World Tourism Organization (UNWTO). (2015). Collection of Tourism Expenditure Statistics. Madrid: World Tourism Organization.

37. Zaimah. (2007). Kearifan Masyarakat Kampung Kuta Bagi Kelestarian Sumberdaya Alam dan Lingkungan (Studi Kasus: Desa Karangpaninggal, Kecamatan Tambak Sari, Kabupaten Ciamis, Jawa Barat) (Tesis Lingkungan). Jakarta: UI (Tidak diterbitkan). 
DOI https://doi.org/10.18551/rjoas.2017-08.23

\title{
THE ROLE OF CORPORATE SOCIAL RESPONSIBILITY DISCLOSURE TOWARD COMPANY STOCK PRICE CRASH RISK
}

\author{
Handiyono Michella Yessica* \\ Postgraduate Program, Faculty of Economics and Business, University of Brawijaya, \\ Indonesia
}

Sukoharsono Eko Ganis, Saraswati Erwin

Faculty of Economics and Business, University of Brawijaya, Indonesia

*E-mail: michella.yessica@gmail.com

\begin{abstract}
This study aims to analyze the influence of corporate social responsibility disclosure to company stock price crash risk. If socially responsible companies are committed to high standards of information transparency and do not hide bad news, they will have a low risk of crash. However, if the manager reports CSR to distract the stakeholder from bad news, the CSR will be associated with a high risk of the company stock crash. The study was conducted at Indonesian manufacturing companies registered on the IDX (BEI) for the 2010-2015 period Hypothesis testing technique used a multiple regression analysis. The results showed that activities of the corporate social responsibility disclosure by the company did not have a significant relationship to the risk of the company stock price crash. This study also found that companies that conduct and report social responsibility activities simultaneously have a low risk of crashes on their company's stock price but cannot prove the relationship between the two. The implication is that social accountability reports in Indonesia are still limited to reports only and have not been considered as anything that can contribute to add value to the company or that may prevent the company from unethical behavior.
\end{abstract}

\section{KEY WORDS}

Social responsibility, crash risk, news, agency problem.

Trust from investors or potential investors will be very beneficial for a company. The more investors who believe in a company, the stronger the desire of investors to invest in the company will be. Stock prices are one of several indicators of the company success and good performance. If stock prices continue to rise, then investors will assume that the company is in good condition and holds a good performance as well (Zuliarni, 2013).

One of the factors that emerges as a prominent predictor of stock price crash risk is the tendency of management to withstand bad news from investors (Hutton et al., 2009; Kim et al., 2014). Kim et al. (2014) following Chen et al. (2001) defines the stock price crash risk as a conditional skewness of the stock return distribution. Such skewness can capture the asymmetry at risk, especially a downside risk. Knowing how much risk involved is important for investors to determine the investment measures.

Chen et al.(2001) expressed in his research that the overall return on the stock market has an asymmetric distribution. According to Chen, the biggest market movement is usually a decline occurs rather than an increase in stock prices and the stock market is likely to experience melt down. In his research Chen said that the return on the stock market reflects the existence of a negative skewness or the tendency of volatility to rise with a negative return.

Lack of information transparency will increase the risk of a future crash in the company's stock price by allowing managers to hide and accumulate bad news (Hutton et al., 2009; Kim and Zhang, 2010; Kim et al., 2011). If a manager within a company detains and accumulates 
bad news by not reporting company internal issues (such as delayed projects, decreased profits, CEO succession, etc.), then the stock price of the company will be overvalued. When accumulated, those bad news will finally reached a critical point, then all bad news will be suddenly released at once to the stock market. As a result simultaneously released bad news causes the stock price to crash (Kim et al., 2011). The manager's behavior is consistent with the agency theory. Manager's concerns about his career or incentives lead to the emergence of a variety of managerial misbehavior that is likely to harm the company (Kim et al., 2014). Kim et al .(2014) argued that manager misbehavior such as hiding bad news can be avoided if the company upholds high ethical standards.

Companies that have high ethical standards tend to have high social responsibility and tend to be more transparent in expressing financial statements (Sun et al., 2010; Dewi et al., 2014). Furthermore, several studies provide different views on the CSR implications on manager behavior like accumulating bad news and the transparency in the company's financial statements. Companies that are socially responsible tend to have a sense of responsibility in their behavior to report the company finance and show evidence of a lack of opportunistic behavior (Kim et al., 2012). The high corporate social responsibility shows the company's commitment to high ethical standards and has a positive impact on the quality of accounting information (Kim et al., 2014). Thus, the possibility of these companies are associated with the risk of stock price crash will be lower (Gelb and Strawser, 2001; Kim et al., 2014).

However, behind the positive popularity of CSR, Friedman (1970) expressed his concern that CSR is a form of agency problem within the company. Hemingway and Maclagan in Kim et al. (2014) also argue that one of the motivations for a company to adopt CSR is to cover managers misbehavior. The proof is that some researchers have found that CSR can be used to mask improper behaviors of the manager such as earning management practices (Sun et al., 2010; Scholtens and Kang, 2013). Furthermore, Kim et al. (2014) argues that managers have the possibility to use CSR as an investor distraction from bad news. Enron, for example, involved in massive accounting fraud and caused its collapse in 2001. Consistent with this view, some studies have found a positive relationship between CSR and earnings management (Petrovits, 2006; Prior et al, 2008).

In Indonesia, companies start implementing CSR since the issuance of Law no. 40 of 2007 concerning limited liability companies. The law explicitly requires companies engaged in business activities in the natural resource field to be obliged to carry out social and environmental responsibility (Art. 74 para. 1). In addition the company is also required to report on the implementation of social and environmental responsibility in the annual report (Art. 66 para. 2). The same applies to the Law No. 25 of 2007 concerning investment stating that every investor is obliged to carry out a corporate social responsibility (Art. $15 \mathrm{~b}$ ), and if there are violations the administrative and other sanctions will be imposed as provided in Article 34 (Dewi et al., 2014).With the obligation of CSR and various companies try to fulfill their corporate social responsibility, it becomes reasonable that in making investments, investors will consider companies that have good CSR performance as a candidate for investment place. This of course will make the implementation of CSR affects the stock of the company (Becchetti et al., 2012).

There are a variety of previous studies that review a CSR from all points of view such as improving the company financial performance (Roman et al., 1999; Jiao, 2010; Kim and Statman, 2012), lowering firm risk [1], As a shield of managers' unethical behavior such as earnings management (Petrovits, 2006; Prior et al, 2008; Sun et al., 2010; Bert and Kang, 2012), affect on stock prices and broad market movement (Becchetti et al., 2012; Kruger, 2015), etc. Similar research is also conducted in Indonesia (Hermawan, S., and Maf'ulah, A. N., 2014; Dewi et al., 2014).

A study of Kim et al. (2014) tries to take another point of view that highlights the disclosure of the corporate social responsibility focusing on each company (firm-specific). Kim found that corporate social responsibility has a mitigating effect on the stock price crash risk in 
the company but the role of the corporate social responsibility towards the occurrence of a stock price crash of a company is more visible when the company has ineffective corporate governance and low level of institutional ownership. Thus, the interesting phenomenon researched by Kim brings this research to replicate a research by Kim et al. (2014) that aims to analyze the role of corporate social responsibility disclosure to the risk of stock price crash in Indonesian manufacturing companies, particularly on 2010-2015 period.

\section{LITERATURE REVIEW}

Stakeholders Theory. Stakeholders are parties who have an interest in a company that can affect or can be influenced by the activities of said company (Zaenuddin, 2007). Freeman and McVea (2001) in their research argue that, the idea of a stakeholder approach shows that managers must formulate and implement a process that can meet and satisfy the needs of certain groups of interest in the business. The main task of this process is to manage and integrate the relationships and interests of shareholders, employees, consumers, suppliers, communities and other groups in a way that ensures long-term success of the company. The stakeholder approach emphasizes the active role of management in the company's business environment, its relationships, and promotes common interests (Freeman and McVea, 2001).

Robert (1992) in his research argues that the disclosure of corporate social responsibility is a means for companies to negotiate relationships between companies and their stakeholder. According to Jensen (2001), CSR is a way for managers of a company to satisfy their stakeholders. Robert (1992) states that the Stakeholder theory is the right foundation if used for empirical analysis of corporate social responsibility disclosure. Stakeholder theory forms the theoretical foundation for analyzing the impact of economic performance, strategic posture on social responsibility activities, and the intensity of stakeholder power at the level of corporate social responsibility disclosure.

Agency Theory. Jensen and Meckling (1976) and Ross (1973) define agency relationships as a contract in which one or more parties (principals) involve another party (agent) to do some things on behalf of the principal involving the delegation of some decision-making authority to the agent.

According to Roth and O'Donnell (1996) regarding the agency problem that occurred in the relationship between the principal and the agent is that the problem arises from a goal discrepancy between the principal and the agent (conflict of interest) and the principal difficulty in monitoring or verifying the agent's behavior. The non-conformance of the goal is based on the assumption that both the principal and the agent are utility maximizers. Thus, the agent will pursue his own interests, which may deviate from the principals' major interest.

Principals can limit the agency problems by conducting monitoring costs or by designing appropriate incentives for agents (Jensen dan Meckling, 1976; Roth and O'Donnell, 1996). In simple situations, principals can invest resources to directly monitor agency actions. However, in more complex situations, difficulty in monitoring or verifying the results of agent behavior will lead to information asymmetry. In reducing agent opportunistic actions, agency costs are required to take actions that minimize the occurrence of misbehavior by agents. There are three kinds of agency costs according to Jensen and Meckling (1976) include monitoring expenditures, bonding expenditure, and residual loss.

Corporate Social Responsibility and its Disclosure. A company is not only tied to the maximization of the shareholders wealth and assets. Companies must also care about the interests of employees and consumers, safeguarding the work opportunities of the less fortunate minorities, protecting the environment and ecology, etc. Carroll (1991) expressed his idea of a CSR image in a company in "the pyramid of corporate social responsibility".

In July 2007, Indonesia was the first country declaring the mandatory legislation on CSR, which applies to companies using natural resources. Stipulation of Law No. 40 Year 2007 in Indonesia does not appear to have a major effect on CSR activities and reporting on companies listed on the Indonesian stock exchange. Other law relating to CSR is Law No. 25 
of 2007 concerning investment, which in Article 15 (b) stipulates that every investor shall carry out the corporate social responsibility, and in Article 34 it regulates in detail the sanctions against businesses and individuals not performing CSR. However, in 2009 only 33 percent of the 392 large companies in Indonesia implemented the CSR (Dewi et al., 2014).

Company Stock Price Crash Risk. Harry Markowitz in his research regarding properties of distributive risk and return states that there are 4 moments in the return distribution. Those moments are mean, variance, directional skewness, and kurtosis (Mun, 2006). Kim et al. (2014) following Chen et al. (2001) in his research defines the crash risk in their research as a conditional skewness of the return distribution. Crash risk can capture the asymmetry at risk, especially the important downside risk for investment and risk management decisions. Conditional skewness is the third moment of the return distribution that can predict the accumulation of information hidden by market players that tend to occur when market conditions are declining by identifying whether a skewness is negative or positive.

The skewness provides information relating to the symmetry of a distribution If a skewness has a 0 value, then it indicates a symmetric return distribution. If a skewness is positive (right-skewed) that the investment made has a frequent low losses and some extreme gain. If the return distribution has a negative skewness (left-skewed) then the investment made has a frequent low gain and some extreme losses (Frömmel, 2013).

Using this understanding, Chen et al. (2001) and Kim et al. (2014) argues that the more negative the skewness curve the greater risk of stock price crash will be in a company. The company stock price crash risk is associated with the asymmetry of information that occurs between companies and investors. When a company's management engages in divergent behavior such as hiding bad news from investors, then sooner or later the cost to conceal bad news will become too big. Bad news that can no longer be detained and will simultaneously come out to the market and cause the stock price to fall immediately (crash). This is also called a bubble theory (Chen et al., 2001). If a skewness is negative, then the stock return distribution of the company has several possible high crash and vice versa (Kim et al., 2014).

The Effect of Social Responsibility Disclosure to Company Stock Price Crash Risk. Several studies have documented the distribution of stock returns showing large negative stock returns (or the occurrence of a crash) in stock prices have higher frequencies and more common in occurrence than large positive stock returns (Chen et al., 2001; Hong and Stein., 2003). In line with the research of Chen and Hong and Stein, several studies then tried to predict the cause of the crash on the stock price of a company. One of the biggest predictors found is the manager's tendency to conceal bad news from investors (Jin and Myers, 2006; Hutton et al., 2009).

Agency theory states that agency issues in a company arise because of a mismatch between the main objectives of the principal and the agent. According to agency theory, previous research mentions that managers hold bad news of the company from investors because they are concerned about career continuity and compensation (Ball 2009, Graham et al., 2005; Khan and Watts, 2009; Kothari et al., 2009). Bad news that are constantly collected and then accumulated and reach the point when bad news can be no longer detained, then all the bad news then released simultaneously and cause the stock price of a company to directly experience crashes (Chen et al., 2001; Hong and Stein., 2003). Hutton et al. (2009), Kim et al. (2011), and Kim and Zhang (2013) support the above view by providing that several factors such as unclear financial reporting, tax avoidance, and equity-based incentives for corporate executives can cause crashes.

In the stakeholder Theory it is mentioned that managers must formulate and implement a process that can meet and satisfy the needs of certain groups, in this regard is stakeholders. Robert (1992) in his research states that corporate social responsibility activities are one of manager activities to satisfy the company stakeholders and support the theory of stakeholders. However, previous research provides several different views related to the implication that the corporate social responsibility can prevent or minimize the behavior of managers who withstand bad news and transparency of financial statements. 
Some studies have found that socially responsible corporate also have a high responsibility for financial reporting and show low earnings management behavior, thereby it demonstrates that companies have a high ethical commitment and have a positive impact on the quality of accounting information (Kim et al., 2012; Sun et al., 2010). A study of Kim et al. (2014) also found that companies with high levels of social responsibility have low levels of bad news collection.

Similar to Kim, Gelb and Strawser (2001) found that companies carrying out social responsibility activities provide more financial disclosure. This is consistent with the idea that, the company sees the increase in such disclosure as a socially responsible form of behavior and included in the overall practices of the corporate social responsibility. Similarly, with a research conducted by Cho et al. (2013) which suggests that companies with a good quality of social accountability will minimize the occurrence of information asymmetry.

On the other hand, Jensen (2001) asserted that the stakeholder theory does not give managers a clear limit of the extent to which a manager can act to satisfy stakeholders. Similar concerns are also expressed by Friedman (1970) who argues that the corporate social responsibility can represent an agency problem that occurs within a company when used only to satisfy stakeholders. Hemingway and Maclagan (2004) and Bradley (2009) suggest that the company's motivation in adopting corporate social responsibility activities is to cover up corporate unethical behaviors. Kim et al. (2014) also noted that there are concerns that managers can use corporate social responsibility opportunistically to advance careers, retain compensation, and other personal agenda. This is supported by numerous studies that find a positive relationship between the corporate social responsibility and earnings management and tax avoidance (Hoi et al., 2013; Petrovist, 2006; Prior et al., 2008; Sun et al., 2010).

The relationship of the corporate social responsibility to the risk of a company's stock crash is then further investigated by Kim et al. (2014) who found that there was a mitigating effect of corporate social responsibility disclosure to the risk of the company's crash. Furthermore, Kim et al. (2014) found only a positive relationship between a disclosure of the corporate social responsibility to the risk of a company's stock crashes only when the company had weak corporate governance and low institutional ownership level.

Based on empirical theoretical and empirical studies of the relationship between the role of the social responsibility disclosure to the risk of previous company stock price crashes, it can be concluded that there are several different opinions and inconsistent research results. For that reason, the researcher wished to see the relation between the disclosure of the social responsibility of the company and the company stock price crash risk in Indonesia. Based on the rationale above, the theoretical review, and the results of previous research, the hypothesis of this study is the company social responsibility disclosure has an influence to the company stock price crash risk.

\section{METHODS OF RESEARCH}

Research Design and Sampling. This study uses companies in the manufacturing industry that go public as listed on the Indonesia Stock Exchange from 2010 to 2015 as a population. The sample of this research is chosen by using the purposive sampling method, that is a sample selection based on certain criteria. Sample selection criteria are as follows:

1. Manufacturing companies listed on the Indonesia Stock Exchange from 2010 to 2015.

2. Manufacturing companies that publish annual reports continuously from 2010 to 2015.

Based on established criteria, of the total population of 142 manufacturing companies listed on BEl in 2010 to 2015 , we obtained 61 companies with a total 233 research sample for 6 years. We used multiple regression analysis to test the hypothesis.

Operationalization and Measurement of Variables. As the independent variable, social responsibility disclosure are measured using the MSCI ESG index according to a study of Kim et al., (2014), which consists of two separate categories of strength and concern as listed in Table 1. 
Table 1 - MSCI ESG ratings

\begin{tabular}{|c|c|}
\hline STRENGTH+CONCERN & CONCERN \\
\hline Community & Alcohol \\
\hline Diversity & Gambling \\
\hline Employee Relation & Firearms \\
\hline Environment & Military \\
\hline Products & Nuclear Power \\
\hline
\end{tabular}

Source: KLD STATS and ESG Rating.

Such points are assessed from the sustainability report and annual report of the company, and also the CSR news. In case a company fails to release a sustainability report, then the data are taken from the annual report and CSR news. Each point is assigned by a value of 1 if the point is within the corporate social responsibility sequence, and is assigned a value of 0 if not present. According to a study of Kim et al. (2014), from the number of points in each category are then calculated under the total number (net count) of the disclosure of social responsibility that is:

NETcount: total strength - total concern

The net count results are then transformed according to the formula used in the research of Kim et al.(2014), to produce CSR scores with a range from 0 to 1.

$$
\text { CSR company i year } t=\frac{(\text { NETcount } x \text { firm CSRmin industry } \text { i year })}{(\text { firm CSRmax industry } i \text { year } \mathrm{t} x \text { firm CSRmin industry } i \text { year } t)}
$$

Company Stock Price Crash Risk (CRASH). Dependent variable in this research is the company stock price crash risk (CRASH). Company stock price crash risk as intended in this study its definition follows the research of Chen et al. (2001) and Kim et al. (2014) that is a conditional skewness in the distribution of return.

There are two models of company stock price crash risk calculation according to Chen et al. (2001) and Kim et al. (2014) that is NCSKEW and DUVOL model. NCSKEW is a crash risk calculation by calculating a negative conditional skewness of the weekly return of each company during a fiscal year. The higher the value of NCSKEW then indicates the greater crash risk.

$$
\operatorname{NCSKEW}_{j, t}=-\frac{\left[n(n-1)^{\frac{3}{2}} \Sigma W_{j, t}^{3}\right]}{(n-1)(n-2)\left(\Sigma W_{j, t}^{2}\right)^{3 / 2}}
$$

Where: $n$ is the total amount of weekly return in 1 year $t$ and $w$ is the weekly return firm $\mathrm{j}$ in year t.

DUVOL is used to calculate the down-to-up volatility for possible crashes. The weekly returns of each company are divided into two groups i.e.: up-week when returns are above the annual average and down-week when returns are below the annual average. DUVOL does not involve the third moment (skewness) so it is not affected by extreme weekly returns. The higher the DUVOL value indicates the greater crash risk (Chen et al., 2001; Kim et al., 2014).

$$
\text { DUVOL }_{\mathrm{j}, \mathrm{t}}=-\log \left\{\frac{\left(\mathrm{n}_{\mathrm{u}}-1\right) \sum_{\mathrm{Down}} \mathrm{W}_{\mathrm{j}, \mathrm{t}}^{2}}{\left(\mathrm{n}_{\mathrm{d}}-1\right) \sum \mathrm{Up}_{\mathrm{p}} \mathrm{W}_{\mathrm{j}, \mathrm{t}}^{2}}\right\}
$$


Where $n_{u}$ is the total up weeks in year $\mathrm{t}, n_{d}$ is the total down weeks in year $\mathrm{t}, W$ is the weekly return firm $\mathrm{j}$ in year $\mathrm{t}, \sum_{D o w n} W_{j, t}$ is the total weekly returns on down weeks of firm $\mathrm{j}$ on year $\mathrm{t}$, and $\sum_{U p} W_{j, t}$ is the total weekly returns on up weeks firm $\mathrm{j}$ on year $\mathrm{t}$.

Control Variable. This research uses several control variables following Chen et al. (2001) and Kim et al. (2014). Those variables are change in trading volume (CTV) which is a proxy from the intensity of opinion among investors (share turnover year $\mathrm{t}$ - share turnover year t-1), past return (PR), market-to-book ratio (MB), firm Size (FS), Stock Volatility (STVOL) which is stock price stability (standard deviation of weekly returns of firm $i$ in fiscal year $t$ ), Financial leverage (LEV), Profitability (ROA), and Earning Management (EM) using performance match discretionary accrual method by Kothari et al. (2005).

Data Collection Technique. Data collection techniques used in this study are archival and data sources are taken from the database (Jogiyanto, 2014). Data collection is taken from a third source and collected by copying the data of each sample company from information sources such as sustainability report, annual report, news, stock price on yahoo finance. In addition, library studies are also conducted from related sources such as books, journals, and articles related to this research.

Hypothesis Testing Technique. The method used in this research is a multiple regression analysis. The regression model used in this research is as follows:

$$
C R A S H=\beta_{0}+\beta_{1} C S R+\beta_{2} C T V+\beta_{3} P R+\beta_{4} M B+\beta_{5} F S+\beta_{6} S T V O L+\beta_{7} L E V+\beta_{8} R O A+\beta_{9} E M+\varepsilon_{i t}
$$

Where CRASH is the company stock price crash risk, $\beta_{0}$ is the constant, $\beta_{1 \ldots 9}$ are the regression coefficients, CSR is corporate social responsibility disclosure, CTV is change in trading volume, $\mathrm{PR}$ is past return, MB is the market to book ratio, FS is the firm size, STVOL is for stock volatility, LEV for financial leverage, ROA for profitability, EM for earning management, and $\varepsilon$ it for the error.

\section{RESULTS AND DISCUSSION}

Descriptive Statistic. In descriptive statistics table, the descriptive can be seen from NCSKEW average value obtained is equal to -0.6944884 . Minus value obtained in the average value of NCSKEW shows that the stock prices in firms under study have a small tendency to experience crashes that are affected by the third moment or where there is an extreme weekly return. While on DUVOL, it has an average value of -0.0668059 . The average value of DUVOL, which is also below zero, indicates that the manufacturing firms under study have a very small crash risk if unaffected by the extreme weekly returns on their stock prices. Lower DUVOL average value than NCSKEW indicates that when a company's stock is affected by extreme weekly returns, the risk of crashes will be greater.

Table 2 - Descriptive Statistic

\begin{tabular}{|c|c|c|c|c|c|}
\hline Variable & $\mathrm{N}$ & Minimum & Maximum & Mean & Std. Deviation \\
\hline NCSKEW & 223 & -3.90021 & 2.60401 & -.6944884 & 1.15445407 \\
\hline DUVOL & 223 & -.59247 & .44584 & -.0668059 & .17584565 \\
\hline CSR & 223 & -.04348 & 1.00000 & .5752454 & .26644590 \\
\hline CTV & 223 & -2.96 & .06 & -1.0820 & .77850 \\
\hline PR & 223 & -.02043 & .02206 & .0021137 & .00761053 \\
\hline MB & 223 & .0135 & 1.8674 & 1.011721 & .4371381 \\
\hline FS & 223 & .03147 & .03810 & .0349140 & .00174416 \\
\hline STVOL & 223 & .00000 & .11566 & .0550970 & .02056936 \\
\hline LEV & 223 & .03312 & 1.03249 & .4937512 & .20696068 \\
\hline ROA & 223 & -.0015 & .0852 & .048795 & .0190022 \\
\hline EM & 223 & .04 & .30 & .2090 & .04460 \\
\hline
\end{tabular}

Source: Statistic Calculation. 
CSR variable reflecting the social responsibility of the firm, from the average value that the variables obtained can be seen that the company in this study has a social responsibility value that ranges around 0.5752454 or about $57.5 \%$ on average, not high and not too low. This result indicates that those companies have not carried out social responsibility in their maximum capacity and need further development.

CTV is a change in trading volume as a proxy of the intensity of disagreements among investors, with a mean value of CTV on -1.0820 , which is below zero indicating a low change in annual trade volumes on average. Based on these results, the intensity of disagreements among investors over the company's stocks is quite low and affecting the volatility and liquidity of stock prices in the market. Past return of the company is described by the PR variable. Based on the average value of the PR variable indicates that the average stock return earned by the company is quite low by only $0.2 \%$ on average per period.

Furthermore, there are $\mathrm{MB}$ variables that describe the market-to-book ratio. The Average value of MB (1.011721) indicates that some firms have high market-to-book ratio which can indicate that the average of the companies has a high range of stock price. High stock prices on a company can indicate that investors are optimistic about the company's growth. The firm size is represented by the FS variable. From the data, if the minimum value $(0.03147)$ describes the small company and the maximum value $(0.03810)$ describes the large company, it can be seen that most of the companies included in this research sample tend to be medium size company (mean $=0.0349140$ ).

Stock volatility is represented by the STVOL variable. Based on the minimum and maximum value of STVOL, the standard of stock volatility of the studied company has a range between $0 \%$ to $11.566 \%$ with an average value of $5.50970 \%$, it can be concluded that the average firms studied to have low stock volatility level. The company leverage is represented by LEV variable. Based on the obtained average value it shows that most companies still have a balanced comparison between the total composition of debt and capital.

Meanwhile, for ROA Variable that reflects profitability, the average value of 0.048795 means that the company is able to generate the net profit up to $4.9 \%$ of total company asset employed. In addition, based on minimum and maximum values, the smallest value of ROA that can be generated is $-1.5 \%$ and the largest is $8.5 \%$. Finally, it is the profit management variable represented by EM. Based on the average discretionary accrual value obtained (0.2090) which is closer to the maximum rather than the minimum, it shows that the manufacturing company in Indonesia on 2010 until 2015 take earnings management action with profit maximization pattern.

\section{RESULTS OF STUDY}

Based on the results of hypothesis testing it can be seen that the corporate social responsibility has no significant relationship to the company stock price crash risk. Thus it can be concluded that the results of this study receives a $\mathrm{H} 0$ that there is no influence between the disclosure of the corporate social responsibility and the company stock price crash risk and rejects a that there is an influence between CSR and the Crash risk in the company.

In addition there are 8 control variables in this research included past returns, market-to-book ratio, firm size, profitability, earning management, change in trading volume, stock volatility, and financial leverage. Of the eight variables, there are 4 variables that significantly affect in the role of the corporate social responsibility to the risk of the corporate stock crash include past returns stock volatility, change in trading volume, and profitability.

Based on the results of this study, it was found that activities of the corporate social responsibility disclosure have no influence towards the company stock price crash. The results of this study are not in line with a research conducted by Kim et al.(2014) who find the mitigating effect between CSR and the company stock price crash risk. The results of this study indicate that the high or low CSR reporting scores of a company does not affect the size of the risk of stock price crash at the companies. The results of this study indicate that 
managers do not use the performance of the corporate social responsibility to distract stakeholders from existing bad news. This does not mean the company has no agency problems, or the managers do not conceal bad news from stakeholders.

Table 3 - Summary of Multiple Regression Test Results

\begin{tabular}{|c|c|c|c|c|c|c|c|}
\hline \multicolumn{5}{|c|}{ NCSKEW } & \multicolumn{4}{c|}{ DUVOL } \\
\hline Variable & B & T-count & Sig & Variable & B & T- count & Sig \\
\hline Constant & -2.974 & -1.849 & .066 & Constant & -.249 & -.870 & .385 \\
\hline CSR & -.206 & -.833 & .406 & CSR & -.011 & -.258 & .797 \\
\hline PR & -92.843 & -9.513 & ${ }^{* * *} .000$ & PR & -9.598 & -5.533 & ${ }^{* * *} .000$ \\
\hline MB & .172 & .901 & .369 & MB & .042 & 1.247 & .214 \\
\hline FS & 64.085 & 1.407 & .161 & FS & 7.125 & .880 & .380 \\
\hline STVOL & -8.941 & -2.728 & ${ }^{* *} .007$ & STVOL & -.986 & -1.693 & ${ }^{*} .092$ \\
\hline LEV & .284 & .857 & .393 & LEV & -.023 & -.393 & .695 \\
\hline EM & .244 & .141 & .888 & EM & -.030 & -.098 & .922 \\
\hline ROA & 8.991 & 1.907 & ${ }^{*} .058$ & ROA & .406 & .485 & .628 \\
\hline CTV & -.042 & -.478 & .633 & CTV & .028 & 1.822 & ${ }^{*} .070$ \\
\hline${ }^{*}$ Statistical significance $10 \%{ }^{* *}$ Statistical significance $5 \%{ }^{* * *}$ Statistical significance 1\% \\
$\mathrm{R}^{2}$ NCSKEW $=0.412 \mathrm{R}^{2} \mathrm{DUVOL}=0.199$ \\
\hline
\end{tabular}

Source: Statistic Calculation.

As some studies have found that the activity and performance of a company's social responsibilities have an effect on stock prices and their market performance (Becchetti et al., 2012; Hill et al., 2007), but the results of this study find the performance of a company's social responsibility cannot fully illustrate the condition of the company, so that investors cannot use the performance of a company's social responsibility to assess future company prospects. There is no evidence in this study on the relationship between corporate responsibility disclosure and the risk of crashes in company stock prices, but based on table 2, the descriptive shows that company who implementing CSR have a low stock price crash risk simultaneously. Those result shows that the social responsibility disclosure here simply indicates that the company has carried out their accountability obligation to the environment and social community, but does not describe the company's internal conditions.

If further reviewed with the conditions in Indonesia and associated with the implementation of CSR in Indonesia, it may refer to the laws governing the CSR disclosure. As stated in Law no. 40 of 2007 concerning limited liability companies requiring a company carrying on its business in natural resources must exercise the social and environmental responsibility (Art. 74 para. 1) and companies shall report on the implementation of social and environmental responsibility (Art. 66 para. 2), the results of this study prove that the implementation of social and environmental responsibility in Indonesia is only limited to the report mandated and required by law.

New companies use CSR reports as a complement to their annual reports but the CSR itself has not coexisted with the company's vision and mission. The results of this study also show that, investors have not been able to consider CSR reports into their analysis. This is because the role of the corporate social responsibility disclosure in Indonesia has not been maximized. Furthermore, the results show that the most significant value in influencing the risk of the stock price crash are companies with high past return, stock volatility, Profitability, and the high volume of changes in trading.

\section{CONCLUSION AND SUGGESTIONS}

This study aims to analyze the relationship between a disclosure of the corporate social responsibility and the company stock price crash risk or the risk of stock price crash. This study also includes supporting factors that could affect the company's stock price crash risk. 
Supporting factors under control include past returns, market-to-book ratio, firm size, profitability, earning management, change in trading volume, stock volatility, and financial leverage.

The study was conducted at manufacturing companies registered on the IDX (BEI) for the 2010-2015 period This study uses 61 companies with a total of 233 samples. The study found that average manufacturing firms in Indonesia have small corporate stock price crash risk levels, especially when not affected by extreme weekly returns. This study also found that companies that conduct and report social responsibility activities simultaneously have a low risk of crashes on their company's stock price but cannot prove the relationship between the two.

This study proves that a disclosure of the corporate social responsibility has no role in increasing (or decreasing) the risk of crash on a company's stock price. The implication is that social accountability reports in Indonesia are still limited to reports only which is due to the obligation to carry out the activities of social responsibility by law. This reports cannot be used by investors to predict the internal condition of a company as of yet. This is becase social responsibility has not become an integral part with the corporate vision or mission.

In addition, the results of this study found that past returns, stock volatility, profitability and change in trading volume on a firm can affect the crash risk of company stock price. This study found that the higher the past return and stock volatility the lower the crash risk of corporate stock price become. Meanwhile, the higher level of profitability and change in trading volume of a company, the higher the risk of crash on company stock price. This study found no relationship between market-to-book-ratio, firm size, earnings management, and leverage against the risk of crashes on the company's stock price.

This research has not explored the aspect of good corporate governance in the corporate social responsibility disclosure. We take out good corporate governance aspect of the $\mathrm{MSCl}$ ESG index used to assess CSR because it differs from the social and environmental dimensions represented by other categories. So it is suggested to add this element to the next research in order to carry out a comparative influence of CSR without GCG and CSR with GCG aspect to the company stock price crash risk.

This research does not include the human rights aspects in CSR assessment because the research instrument of those aspects is not suitable with the situation in Indonesia. The items in the CSR assessment index may be modified to better align with the environment in Indonesia. The next researcher may also consider survey methods to assess CSR by using the same index. Further research can be conducted on industries other than manufacturing to see the effect of CSR disclosure on stock price crash risk on another industry

\section{REFERENCES}

1. Albuquerque, R. A., Durnev, A., dan Koskinen, Y. (2014). Corporate social responsibility and firm risk: Theory and empirical evidence. ECGI-Finance Working Paper, (359).

2. Ball, R. (2009). Market and political/regulatory perspectives on the recent accounting scandals. Journal of Accounting Research, 47(2), 277-323.

3. Becchetti, L., Ciciretti, R., Hasan, I., dan Kobeissi, N. (2012). Corporate social responsibility and shareholder's value. Journal of Business Research, 65(11), 1628-1635.

4. Bradley Jr, R. L. (2009). Corporate social responsibility and energy. Culture and civilization, 1, 181-197.

5. Brammer, S., Brooks, C., dan Pavelin, S. (2006). Corporate social performance and stock returns: UK evidence from disaggregate measures. Financial management, 35(3), 97-116.

6. Carroll, A. B. (1991). The pyramid of corporate social responsibility: Toward the moral management of organizational stakeholders. Business horizons, 34(4), 39-48. 
7. Chen, J., Hong, H., dan Stein, J. C. (2001). Forecasting crashes: Trading volume, past returns, and conditional skewness in stock prices. Journal of financial Economics, 61(3), 345-381.

8. Cho, S. Y., Lee, C., dan Pfeiffer, R. J. (2013). Corporate social responsibility performance and information asymmetry. Journal of Accounting and Public Policy, 32(1), 71-83.

9. Dewi, D. M., Sudarma, M., Djumahir; Sukoharsono, E. G. (2014) .CSR Effect on Market and Financial Performance. International Journal of Business and Management Invention.3(1).56-66,

10. Du, S., Bhattacharya, C. B., dan Sen, S. (2010). Maximizing business returns to corporate social responsibility (CSR): The role of CSR communication. International Journal of Management Reviews, 12(1), 8-19.

11. El Ghoul, S., Guedhami, O., Kwok, C.C., dan Mishra, D. R. (2011). Does corporate social responsibility affect the cost of capital?. Journal of Banking dan Finance, 35(9), 2388-2406.

12. Freeman, R. E., dan McVea, J. (2001). A stakeholder approach to strategic management.)

13. Friedman, M. (1970). The social responsibility of business is to increase its profits. New York, 122-124.

14. Frömmel, M. (2013). Portfolios and investments. BoD-Books on Demand.

15. Gelb, D. S., dan Strawser, J. A. (2001). Corporate social responsibility and financial disclosures: An alternative explanation for increased disclosure.Journal of Business Ethics, 33(1), 1-13.

16. Graham, J. R., Harvey, C. R., dan Rajgopal, S. (2005). The economic implications of corporate financial reporting. Journal of accounting and economics, 40(1), 3-73.

17. Harvey, C. R., dan Siddique, A. (2000). Conditional skewness in asset pricing tests. The Journal of Finance, 55(3), 1263-1295.

18. Hemingway, C. A., dan Maclagan, P. W. (2004). Managers' personal values as drivers of corporate social responsibility. Journal of Business Ethics, 50(1), 33-44.

19. Hermawan, S., dan Maf'ulah, A. N. (2014). Pengaruh Kinerja Keuangan Terhadap Nilai Perusahaan Dengan Pengungkapan Corporate Social Responsibility Sebagai Variabel Pemoderasi. Jurnal Dinamika Akuntansi,6(2).

20. Hill, R. P., Ainscough, T., Shank, T., dan Manullang, D. (2007). Corporate social responsibility and socially responsible investing: A global perspective. Journal of Business Ethics, 70(2), 165-174.

21. Hong, H., dan Stein, J. C. (2003). Differences of opinion, short-sales constraints, and market crashes. Review of financial studies, 16(2), 487-525.

22. Hutton, A. P., Marcus, A. J., dan Tehranian, H. (2009). Opaque financial reports, R 2, and crash risk. Journal of financial Economics, 94(1), 67-86.

23. Jensen, M. C., dan Meckling, W. H. (1976). Theory of the firm: Managerial behavior, agency costs and ownership structure. Journal of financial economics, 3(4), 305-360.

24. Jensen, M. C. (2001). Value maximization, stakeholder theory, and the corporate objective function. Journal of applied corporate finance, 14(3), 8-21.

25. Jin, L., dan Myers, S. C. (2006). R 2 around the world: New theory and new tests. Journal of financial Economics, 79(2), 257-292.

26. Jiao, Y. (2010). Stakeholder welfare and firm value. Journal of Banking dan Finance, 34(10), 2549-2561.

27. Jogiyanto, Hartono. (2014). Metodologi Penelitian Bisnis. Edisi 4. BPFE-Jogjakarta

28. Khan, M., dan Watts, R. L. (2009). Estimation and empirical properties of a firm-year measure of accounting conservatism. Journal of accounting and Economics, 48(2), 132-150.

29. Kim, J. B., Li, Y., dan Zhang, L. (2011). Corporate tax avoidance and stock price crash risk: Firm-level analysis. Journal of Financial Economics, 100(3), 639-662.

30. Kim, Y., Li, H., dan Li, S. (2014). Corporate social responsibility and stock price crash risk. Journal of Banking dan Finance, 43, 1-13. 
31. Kim, Y., dan Statman, M. (2012). Do corporations invest enough in environmental responsibility?. Journal of Business Ethics, 105(1), 115-129.

32. Kim, J. B., dan Zhang, L. (2013). Accounting conservatism and stock price crash risk: Firm-level evidence. Contemporary Accounting Research, Forthcoming.

33. Kothari, S. P., Leone, A. J., \& Wasley, C. E. (2005). Performance matched discretionary accrual measures. Journal of accounting and economics, 39(1), 163-197.

34. Kothari, S. P., Shu, S., dan Wysocki, P. D. (2009). Do managers withhold bad news?. Journal of Accounting Research, 47(1), 241-276.

35. Krüger, P. (2015). Corporate goodness and shareholder wealth. Journal of financial economics, 115(2), 304-329.

36. Mun, J. (2006). Modeling risk: Applying Monte Carlo simulation, real options analysis, forecasting, and optimization techniques (Vol. 347). John Wiley dan Sons.

37. Petrovits, C. M. (2006). Corporate-sponsored foundations and earnings management. Journal of Accounting and Economics, 41(3), 335-362.

38. Prior, D., Surroca, J., dan Tribó, J. A. (2008). Are socially responsible managers really ethical? Exploring the relationship between earnings management and corporate social responsibility. Corporate Governance: An International Review, 16(3), 160-177.

39. Roberts, R. W. (1992). Determinants of corporate social responsibility disclosure: An application of stakeholder theory. Accounting, Organizations and Society, 17(6), 595-612

40. Roman, R. M., Hayibor, S., dan Agle, B. R. (1999). The relationship between social and financial performance repainting a portrait. Business dan Society,38(1), 109-125.

41. Ross, S. A. (1973). The economic theory of agency: The principal's problem. The American Economic Review, 63(2), 134-139.

42. Roth, K., dan O'Donnell, S. (1996). Foreign subsidiary compensation strategy: An agency theory perspective. Academy of management Journal, 39(3), 678-703.

43. Scholtens, B., dan Kang, F. C. (2013). Corporate social responsibility and earnings management: Evidence from Asian economies. Corporate Social Responsibility and Environmental Management, 20(2), 95-112.

44. Sun, N., Salama, A., Hussainey, K., dan Habbash, M. (2010). Corporate environmental disclosure, corporate governance and earnings management.Managerial Auditing Journal, 25(7), 679-700.

45. Zaenuddin, A. (2007). Faktor-Faktor Yang Berpengaruh Terhadap Praktek Pengungkapan Sosial Dan Lingkungan Pada Perusahaan Manufaktur Go Publik (Doctoral dissertation, program Pascasarjana Universitas Diponegoro).

46. Zuliarni, S. (2013). Pengaruh Kinerja Keuangan Terhadap Harga Saham Pada Perusahaan Mining And Mining Service Di Bursa Efek Indonesia (BEI).Jurnal Aplikasi Bisnis, 3(1)a. 
DOI https://doi.org/10.18551/rjoas.2017-08.24

\title{
REVIEW OF LOCALLY-GENERATED REVENUE AND CAPITAL EXPENDITURE IN IMPROVING DISTRICTS AND MUNICIPALITIES'S ECONOMY GROWTH IN NORTH MALUKU PROVINCE
}

\author{
Rudin M.*, Lecturer \\ STIE Panca Bhakti, Palu, Indonesia \\ Amir A.M., Lecturer \\ Tadulako University, Palu, Indonesia \\ Bakarbessy M.L.F., Doctoral Student \\ Tadulako University, Palu, Indonesia \\ *E-mail: rudin.ternate@gmail.com
}

\begin{abstract}
The aims of the present research are to comprehend and to analyze the Effects of Locallygenerated Revenue and Capital Expenditure in Improving Districts and Municipalities's Economy Growth in North Maluku. This research is categorized as verificative research. The data source was taken from Central Bureau of Statistics of Districts/Municipalities in North Maluku, Central Bureau of Statistics of the Republic of Indonesia and Ministry of Finance of the Republic of Indonesia. The population of this research was Finance Report in 8 regencies and 2 municipalities in period of 2006-2015. In terms of data type, the present research uses panel data. Besides, the data collection uses EViews 6 Program. On the other hand, the research result shows that: Locally-generated Revenue and Capital Expenditure give positive and significant effects on Economic Growth; Locally-generated Revenue has positive and significant effects toward Economic Growth; Capital Expenditure gives positive and significant effects on Economic Growth in North Maluku.
\end{abstract}

\section{KEY WORDS}

Capital expenditure, economic growth, locally-generated revenue, economy.

The realization of local autonomy in the Unitary State of the Republic of Indonesia nowadays is referred to Law No. 9 of 2015 regarding Local Government, in which in Article 1 Verse 6 it is mentioned that the implementation of local autonomy is the right, authority, and obligation of autonomous region to manage and organize its own governance in the system of the Unitary State of the Republic of Indonesia.

The Unitary State of the Republic of Indonesia in conducting decentralization gives authorities to local government to freely manage its own resources independently. Every region is granted an authority and demanded to improve its region independence, so that it is free to organize its region's resource independence for the sake of realizing a fair and balance region development. The main funding source of local government is from regional revenue used for development realization in every region. The main target of region development is to make economic growth and equitable development, including equity of community income in region and local government revenue, (Widjaja 2002).

Local government is freely to manage its region's resources like taxes and charges. Regional revenue can be enhanced if the region's economy growth is improved as well. The challenges faced by local government are the improvement of regional revenue, the independence of development with constraints on the availability of resources in restricted area. The enhancement of region development is marked by the economy activities that increase the community's income so that it fixes and increases the level of welfare. The development in region is always in line with the roles of local government in using the available resources as the efforts to increase regional revenue. The increase of regional 
revenue must be supported by integrated region development in order to make people and local government welfare, (Arsyad 1997).

The local government is asked to be independent in managing regional revenue addressed for restructurization process of region development. The investment increase in region will influence the region's economic growth. An economy is considered experiencing growth if the level of economic activities achieved in the present is is higher than what is achieved previously. If the physical quantities and goods produced in the economy increase in number from previous years, then it can be stated that there has been economic growth, (Halim and Iqbal 2012).

The region's economic growth becomes the most important factor in the success of region's economy, both for short-term and for long-term effect. The region's economic growth is influenced by regional revenue and capital expenditure. The economic growth of a region can be seen from the value of GRDP (Gross Regional Domestic Product) (Halim 2004). GRDP is one of economy indicators that can give a clue of how far the economic growth and economic structure of a region. Gross National Product (GNP) or Gross Domestic Product (GDP) can be considered as the indicator of community welfare increase in general (Sirojuzilam 2005). Then, Halim (2001) expresses that Locally-generated Revenue gives effects on economic growth. The growth of economic development in districts/municipalities in North Maluku Province is shown on the following table.

Table 1 - Districts and Municipalities Economic Growth in North Maluku Province

\begin{tabular}{|c|l|c|c|c|c|c|c|c|c|c|}
\hline No & Regency/City & 2006 & 2007 & 2008 & 2009 & 2010 & 2011 & 2012 & 2013 & 2014 \\
\hline 1 & Central Halmahera & 4.17 & 4.26 & 5.42 & 5.46 & 6.89 & 5.26 & 5.02 & 5.3 & -1.29 \\
2 & Ternate & 6.92 & 7.85 & 8.02 & 7.97 & 8.13 & 9.65 & 9.04 & 7.65 & 8.87 \\
3 & West Halmahera & 3.65 & 4.21 & 4.17 & 4.46 & 5.74 & 6.03 & 5.90 & 5.75 & 5.40 \\
4 & East Halmahera & 6.27 & 10.20 & 6.93 & 7.17 & 7.34 & 6.95 & 5.79 & 5.83 & -10.26 \\
5 & South Halmahera & - & 5.93 & 5.99 & 5.60 & 5.59 & 6.25 & 6.78 & 6.51 & 6.72 \\
6 & North Halmahera & - & 5.51 & 5.55 & 6.93 & 7.31 & 5.94 & 6.00 & 5.03 & 6.57 \\
7 & Sula Islands & - & 5.62 & 5.23 & 5.32 & 6.27 & 6.10 & 6.22 & 6.26 & 5.97 \\
8 & Tidore & 5.91 & 5.94 & 5.84 & 5.92 & 6.73 & 6.43 & 6.35 & 6.11 & 6.89 \\
9 & Morotai Island & - & & & & 0.00 & 4.48 & 6.47 & 6.02 & 6.23 \\
10 & Taliabo Island & - & & & & & & & & 6.00 \\
\hline
\end{tabular}

Source: Center Bureau of Statistics of Indonesia, 2017.

Based on Table 1, it shows that in the previous 2006-2015, the highest economic growth in all regencies and municipalities in North Maluku is Ternate. The factor that causes the economic growth of Ternate higher than other regencies or municipalities in North Maluku is the infrastructure of Ternate that has been good, which is really helpful in economic growth, if compared to other regencies and municipalities in North Maluku.

Infrastructure is one of important elements in region's economy. A good and equitable infrastructure can accelerate the turnover of goods among regions in North Maluku. This infrastructure gap is the cause of uneven development. To support the economic growth in North Maluku, then economic infrastructures like road, irrigation, bridge, harbour, electricity, and airport are highly essential. The lack of infrastructure both in quantity and quality in Maluku is suspected to cause economic growth to decline from 2006 to 2015.

Generally, districts and municipalities in North Maluku, in research period of 20152016, shows that its economic growth is still below national economic growth. The cause is 
the investment low from relatively-poor region to relatively-rich region. This phenomenon is caused by the market mechanism in which there has been a combination of two factors: (1) Savings in poor areas, although it is small in number, but it cannot be used effectively due to the lack of investment demand of the areas; (2) Savings will be invested to relatively-rich areas because it will be more guaranteed and it will give bigger profit, so that in development process, the newly-expanded districts and municipalities are becoming difficult to be developed areas.

\section{THEORETICAL REVIEW}

Locally-generated Revenue. Laws No. 33 of 2004 explicates that Locally-generated Revenue is the source of regional income obtained in the region to be used by local government to fund development and region businesses to minimize the funding dependence from central government. Locally-generated Revenue comprises of taxes, charges, separated regional wealth, and other legitimate local revenue. The areas that have adequate facilities and infrastructure can attract investors to invest in the area, so that it will increase the locally-generated revenue. If local revenues are linked to regional autonomy, then local revenues are the important sources of income to finance governance and regional development.

Capital Expenditure. Capital Expenditure is used for expenditure made for the sake of the purchase/procurement or construction of tangible fixed assets that have a benefit value of more than 12 months for use in government activities, such as in form of land, equipment and machinery, buildings, roads, irrigation and network, and other fixed assets. Capital Expenditure represents expenditure made in the context of capital formation in form of adding fixed assets/inventories that provide benefits over an accounting period, including expenditure for maintenance costs that are in the nature of maintaining or adding to the useful life, increasing the capacity and quality of assets. A fixed asset has tangible characteristics, will increase government assets, has a useful life more than a year, and its value is relatively material. On the other hand, other asset characteristics are intangible, will increase government assets, has a useful life of more than a year, and its value is relatively material.

\section{METHODS OF RESEARCH}

Model of Panel Data. Nachrowi and Usman, (2006) stated that panel data is the combination of cross section data and time series data with model as follows:

Linier regression model uses cross section data and time series data.

$$
\begin{aligned}
& Y_{i}=\alpha+\beta_{i}+\varepsilon_{i} i=1,2 \ldots \ldots \ldots \ldots . . . N(1) \\
& N=\text { the number of cross section data } \\
& Y_{i}=\alpha+\beta_{t}+\varepsilon_{t} t=1,2 \ldots \ldots \ldots \ldots . . T(2) \\
& T=\text { the number of time series data }
\end{aligned}
$$

Panel data is the combination of cross section data and time series data represented by model as follows:

$$
Y_{i t}=\alpha+\beta_{i t}+\varepsilon_{i t} i=1,2 \ldots \ldots \ldots \ldots . . N t=1,2 \ldots \ldots \ldots . . T
$$

Where: $\mathrm{N}=$ the number of observation; $\mathrm{T}=$ the number of time; $\mathrm{N} \times \mathrm{T}=$ the number of panel data.

Based on the above panel data model, then the model of panel data used in this research is portrayed as follows:

$$
Y_{i t}=\alpha+\beta_{1} \log P A D+\beta_{2} \log \beta_{7} \log B M+\varepsilon_{i t}
$$


Where: $Y=$ Economic Growth; Log PAD = Locally-generated Revenue; Log BM = Capital Expenditure; $\mathrm{I}=$ cross section unit of every districts and municipalities in North Maluku; $\mathrm{t}=$ The number of researched years from 2006 to 2015; $\beta=$ Parameter of related variables; $\varepsilon=$ Fault Parameter; $\alpha=$ Constants.

\section{RESULTS AND DISCUSSION}

The Analysis Result of Panel Data Regression. According to Gujarati and Porter (2009), method of panel data regression has some superiority if compared to time series or cross section data, so that it does not need any classical assumption test anymore. The use of panel data hyphothesis aims to know the effect of independent variable towards dependent variable as well as model competency in explicating the value of economic growth. Thus, the testings are categorized into whole testing and partial testing. The summary of data analysis result is presented on Table 2 below.

Table 2 - The Result of Data Analysis

\begin{tabular}{|l|l|l|}
\hline \multicolumn{1}{|c|}{ Variables } & \multicolumn{1}{c|}{ Prob } & \multicolumn{1}{c|}{ Details } \\
\hline Locally-generated Revenue & 0.0000 & Significant \\
\hline Capital Expenditure & 0.0000 & Significant \\
\hline R-squared & 0.7175 & Model competency \\
\hline Adjusted R-squared & 0.6458 & Model competency \\
\hline S.E. of regression & 2.0738 & Panel regression error standard. \\
\hline F-statistic & 115.03 & Whole Testing \\
\hline Prob(F-statistic) & 0.0000 & Probability of F Statistics test value \\
\hline Durbin-Watson & 1.7512 & Autocorrelation \\
\hline
\end{tabular}

Source: Output of EViews 6.0.

\section{DISCUSSION OF RESULTS}

Locally-generated Revenue is one of local income sources that is also the basic capital of local government in obtaining balance funds and fulfilling capital expenditure. The essential success indicator of region finance performance is reflected on the ability of a region in digging its Local Revenue to fund direct and indirect expenditures which influence the region's economic growth. The economic growth will be achieved if capital expenditure done by region is used for the sake of funding the development realization in the region. A good funding management from local government in districts and municipalities in North Maluku as well as effective expenditure allocation can lead its service goal for community achieved and the welfare level of community arises as well. The increase of community's welfare level will lead to the increase of the region's economic growth.

\section{The Effects of Locally-generated Revenue towards Economic Growth}

The result of this research reveals that Locally-generated Revenue in districts and municipalities in North Maluku gives significant and positive effects on economic growth. It can be explained that Locally-generated Revenue in districts and municipalities in North Maluku increases so that its economic growth increases as well. In contrast, if Locallygenerated Revenue in districts and municipalities in North Maluku decreases, then its economic growth decreases too.

The significant and the positive effects of Locally-generated Revenue in districts and municipalities in North Maluku towards economic growth are there because Locallygenerated Revenue is one of region's expenditure sources, so that if Locally-generated Revenue increases, then funds owned by the region in expenditure, especially for infrastructure development, will increase as well. Through good infrastructure, it can improve economic activities which eventually can increase the economic growth of districts and municipalities in North Maluku.

The increase of Locally-generated Revenue in districts and municipalities in North Maluku is caused by (1) The increase of vehicles object in districts and municipalities in 
North Maluku (2) The development of infrastructure like road and bridge construction that can facilitate the motor vehicle traffic so that it encourages community to buy new vehicles; (3) The betterment of national and global economy condition so that the selling price of some agricultural commodities improves and strengthens the purchasing ability of community to buy vehicles and to pay local taxes; (4) The enhancement of local government's performance; (5) The improvement of supervision and control realization on Locallygenerated Revenue management; (6) The socialization regarding to local taxes is more intense; (7) The effectivity of taxes collection techniques guidance and BBN-KB in Technical Implementation Unit on Revenue in Districts and Municipalities in North Maluku; (8) The increase of monitoring and delinquent revenue realization in Department of Local Revenue; (9) The increase of community's awareness in paying local taxes in districts and municipalities in North Maluku, (Tresnasari, 2013). Locally-generated Revenue of Districts and Municipalities in North Maluku influences economic growth because it is one of region finance resources that can be used for region needs like construction of road, bridge, market, and other facilities so that the activity of goods and services increases that causes region's economic growth is achieved from year to year. Locally-generated revenue of districts and municipalities in North Maluku which its management is done by making taxes or charges effective and making its way of collecting on existing objects and subjects efficient through making a calculation of tax potency, illumination, improvement of supervision and service. These have improved Locally-generated Revenue that gives positive and significant towards economic growth in the region.

The management of Locally-generated Revenue of Districts and Municipalities in North Maluku conducted covers aspect of management, administration and organization, policy and qualified personel supporting power that have been giving biggest contribution towards North Maluku dominated by receipt of local taxes, other legal locally-generated revenue and region charges. While, the receipt of Local Budget profit/the management result of separated region wealth has lowest contribution towards Locally-generated Revenue. In other words, those three sectors mentioned above are the very potential sectors that cause turnover of goods and services improved and those automatically give effects on region's economic growth.

Locally-generated Revenue of districts and municipalities in North Maluku is improved through active contribution of community in succeeding economic growth. The activity of local government in empowering existing community has improved the community's welfare so that the ability of community in paying local taxes or local charges that become the main source of Locally-generated Revenue will also increase. The increase of Locally-generated Revenue of districts and municipalities in North Maluku expanded in accordance with the plans has improved economic growth.

Locally-generated Revenue of districts and municipalities in North Maluku as the source of local expenditure has made a number of new economic activities in community. The increase of economic activities in community will lead to the increase of goods and services outputs which consequently will increase the cashflow in terms of expenditure done by both local government and community. Thus, it can increase economic growth in districts and municipalities in North Maluku.

The present research result is in line with the theory of Neo Classic economic growth expressed by Keynes stating that economy cannot be granted completely to market mechanism. It is because market is not a perfect site. Market also some weaknesses, such as: market cannot provide public goods and services, market cannot solve negative externality caused by man's productive economy activities, and market cannot solve injustices. Therefore, the government is obliged to interfere economy system like through monetary policy or fiscal policy. For Jhon Maynard Keynes, the keyword to achieve economic growth is a real investment that can bear multiplier effect. The example of real investment is infrastructure project, (Alamsyah, 2010).

Furthermore, the result of the present research is in line with the research result done by Gunantara and Dwirandra (2014), Guntur (2014), William and Andrew (2014), Masuduzzaman (2014), Orley (2014). Asmaul (2013), Arini (2015), Dwi Puspaningsih and 
Aryani (2016) expressing that Locally-generated Revenue gives positive and significant effects towards economic growth.

Moreover, the results of research finding that locally-generated revenue gives negative effects on economic growth are the research results conducted by Febrian (2014), Setiyawati and Hamzah (2007). In addition, the researches conducted by Hidayah (2011) and Santoso (2013) also agree that locally-generated revenue has negative effects towards economic growth.

\section{The Effects of Capital Expenditure towards Economic Growth}

The result of this research shows that capital expenditure gives positive and significant effects on economic growth in districts and municipalities in North Maluku. Capital expenditure in the present research is defined as expenditure used by government of districts and municipalities in North Maluku for purchasing/procurement or fixed assets development in which its benefit value is more than a year, and or the use of services in running local government's program and activity. The asset formation covers the procurement of land, heavy equipment, transportation equipment, workshop tools, agricultural equipment, office equipment, computer, furniture, water, kitchen utensils, room decoration, studio tools, communication tools, measuring equipment, medical devices, laboratory equipment, road construction, bridge, water networks, street lighting, parks and urban forests, electrical and telephone installations, buildings, books or libraries, art, livestock and crops, as well as weapons or security.

Capital expenditure of districts and municipalities in North Maluku needs to get special attention because not all capital expenditure gives effects on public services. Therefore, capital expenditure needs to be reviewed in detail to find the capital expenditure that gives effects on public services, for instance capital expenditure of infrastructure. By seeing the structure of capital expenditure, then it needs redefinition towards expenditure for the sake of obtaining region finance analysis that supports the stakeholder of local government.

For improving community's welfare in region, the central government keeps advising local government to always improve the percentage of capital expenditure to be 30 percents. The percentage is even two percents higher than the target in 2015 which is 28 percents. Unfortunately, local government of districts and municipalities in North Maluku still faces difficulties to achieve the target. The percentage addition of capital expenditure is not difficult because it is conducted gradually: starting from 24 percents and then 26-27percents, so that it just needs to add three percents in 2015 . Nowadays, there have been some regions that have achieved 30 percents.

Regarding to tendency from year to year, capital expenditure of districts and municipalities in North Maluku has demonstrated an increase. However, the increase should be accelerated. This effort is considered giving more support on economy sector which is more beneficial for region than it is expended for local officers' salary payment. The way of adding capital expenditure allocation is by skimping the officers' expenditure and goods expenditure. Officers' expenditure is pushed by not recruiting new officers except teachers, doctors, and nurses. Besides, goods expenditure is skimped by minimizing unnecessary business trip, so that local revenue can be expended effectively.

Locally-generated revenue of districts and municipalities in North Maluku is not only from fund transfer of central government, but it is also from Locally-generated Revenue comprising of local taxes and local charges as well as the outcome of separated regional wealth management. On the other hand, local government generally relies on fund transfer of region. However, it is unfortunate if the fund is mostly expended for officers' expenditure. Ideally, the proportion of capital expenditure is improved to be 35 percents, so that development in region can be improved as well.

The result of the present research is in line with the research result conducted by Purnama and Adigorim (2012), Prio (2013) and Recky et al 2014 concluding that capital expenditure gives positive and significant effects towards economic growth. These research results are different from the results obtained by Hendarmin (2012), Febrian (2014) concluding that capital expenditure does not give significant effects on economic growth. 


\section{CONCLUSION AND SUGGESTIONS}

Based on the research result and analysis conducted by the researcher, so it can be concluded that:

Locally-generated Revenue and Capital Expenditure gives positive and significant effects towards economic growth in districts and municipalities in North Maluku;

Locally-generated Revenue gives positive and significant effects towards economic growth in districts and municipalities in North Maluku;

Capital Expenditure gives positive and significant effects towards economic growth in districts and municipalities in North Maluku.

Based on the above conclusion, the suggestions in the present research are as follows:

It is expected for local government of districts and municipalities in North Maluku to increase Locally-generated Revenue through activities like: (1) Improving Officers' Resources quality through training and education, (2) Maximizing data system and information in terms of region finance management, (3) Enhancing socialization regarding to local taxes and local charges, (4) Developing adequate tourism facilities and infrastructure.

Local government of districts and municipalities in North Maluku needs to make Coordination Team which is in charge of analyzing realization of monthly Local Revenue, so that it makes coordination between SKPD easier in managing region finance both in phase of planning, implementing, or responsibility of Local Budget use and it makes region easier to solve problems especially regarding to implementation of direct expenditure in funding governance activities in the region.

\section{REFERENCES}

1. Alamsyah, A. (2010). Strategi Penguatan Good Governance dalam Mendorong Pertumbuhan Ekonomi Lokal di Era Otonomi Daerah. Jurnal Dinamika, 3(6), 1-15.

2. Arini, M. D. S. M. (2015). Pengaruh Pendapatan Asli Daerah dan Belanja Tidak Langsung Terhadap Kemiskinan Melalui Pertumbuhan Ekonomi di Provinsi Bali Tahun 2007-2013, E-Jurnal Ep Unud, 4 [9]: 1140-1163 ISSN: 2303-0178, diakses 17 Juni 2016.

3. Arsyad, L. (1997). Ekonomi Pembangunan, Edisi Ketiga. BP STIE, Yogyakarta.

4. Asmaul, H. (2013). Pengaruh Pendapatan Asli Daerah dan Dana Perimbangan Terhadap Pertumbuhan Ekonomi Dalam Pengembangan Wilayah Kabupaten Bintan Provinsi Kepulauan Riau, Universitas Maritim Raja Ali Haji Riau, Jemi,Vol.4, No.2, Desember 2013, diakses 27 Maret 2017.

5. Dwi Puspaningsih, D.P \& Aryani. N. K. L. M. (2016). Kinerja Keuangan Daerah Sebagai Pemoderasi Pengaruh Dana Bagi Hasil dan Belanja Langsung Terhadap Pertumbuhan Ekonomi Kabupaten/Kota di Provinsi Bali, ISSN:2302-8556, E-Jurnal Akuntansi Universitas Udayana, 15(3) Juni (2016): 2213-2239, Diakses 12 Juni 2017.

6. Febrian, D. P. (2014). Analisis Pengaruh Pendapatan Asli Daerah dan Pengeluaran Pemerintah Daerah Terhadap Pertumbuhan Ekonomi (Studi Kasus. Di Kabupaten/Kota Jawa Timur Tahun 2008-2012), Jurnal Ilmiah Universitas Brawijaya Malang 105020105111001, http://jimfeb.ub.ac.id/index.php/jimfeb/article/download/1295/1193, diakses 24 Maret 2017.

7. Gujarati \& Porter. (2009). Dasar-Dasar Ekonometrika. Jakarta: Salemba Empat.

8. Gunantara, P. C \& Dwirandra, A.A.N.B. (2014). Pengaruh Pendapatan Asli Daerah Dan Dana, Alokasi Umum Pada Pertumbuhan Ekonomi dengan Belanja Modal Sebagai Variabel Pemoderasi di Bali, E-Jurnal Akuntansi Universitas Udayana 7.3 (2014): 529546 ISSN:2302-8556. diakses 24 Juni 2017.

9. Guntur, H. (2014). Pengaruh Pendapatan Daerah Terhadap Pertumbuhan Ekonomi Dengan Belanja Modal Sebagai Variabel Mediasi, diakses 23 Mei 2017.

10. Halim, A. \& Iqbal, M. (2012). Pengelolaan Keuangan Daerah, edisi ketiga, UPP STIM YKPN, Yogyakarta.

11. Halim, A. (2001). Manajemen Keuangan Daerah (Bunga Rampai). Yogyakarta: Penerbit UPPAMPYKPN, 
12. Halim, A. (2004). Akuntansi Keuangan Daerah, Edisi Revisi, Salemba Empat, Jakarta.

13. Hendarmin. (2012). Pengaruh Belanja Modal Pemerintah Daerah dan Investasi Swasta Terhadap Pertumbuhan Ekonomi, Kesempatan Kerja dan Kesejahteraan Masyarakat di Kabupaten/Kota Provinsi Kalimantan Barat, Jurnal ekonomi dan bisnis SSN 1693 - 9093 Volume 8, Nomor 3, Oktober 2012 Universitas Tarumanegara, Jalan Ahmad Yani Pontianak 78124 diakses 19 Juni 2017.

14. Hidayah, M. (2011). Analisis Pengaruh Pendapatan Asli Daerah, Belanja Modal dan Belanja Pegawai Terhadap Pertumbuhan Ekonomi Pada Pemerintah Kabupaten/Kota Di Provinsi Kalimantan Timur, http://etd.repository.ugm.ac.id/index.php?, Universitas Gadjah Mada, Yogyakarta, diakses 18 Juni 2017.

15. Masuduzzaman, M. (2014). Workers' Remittance Inflow, Financial Development and Economic Growth: A Study on Bangladesh, International Journal of Economics and Finance; Vol. 6, Nomor 8; 2014 ISSN 1916-. 971X E-ISSN. 1916-9728, Published by Canadian Center of Science and Education Online Published: July 25, 2014. diakses 12 Desember 2016.

16. Nachrowi, D. \& Usman, H. (2006). Pendekatan Populer dan Praktis EKONOMETRIKA Untuk Analisis Ekonomi dan Keuangan, Penerbit Fakultas Ekonomi Universitas Indonesia, Jakarta.

17. Orley M. A. Jr, (2014). Evidence of Increasing Regional Income Variation in the United States: 1969-2006, Modern Economy, 2014, 5, 520-532, Department of Economics and Legal Studies, Oklahoma State University, Stillwater, USA diakses 24 Desember 2016.

18. Prio, H.T. (2013). Pengaruh Pengeluaran Pemerintah Terhadap Pertumbuhan Ekonomi Kabupaten/Kota di Provinsi Jawa Tengah Tahun 2007-. 2011, Economics development analysis journal, Universitas Negeri Semarang, http:// journal.unnes.ac.id/edaj, diakses 17 Juni 2017.

19. Purnama, I.G.D.P \& Adigorim, I.M. (2012). Pengaruh Belanja Langsung dan Belanja Tidak Langsung Terhadap Pertumbuhan Ekonomi Bali. Jurnal Ekonomi Pembangunan Universitas Udayana 7.3 (2014): 529-546, Vol. 1 Nomor 2 http://Ojs.Unud.Ac.Id/Index.Php/Eep/Article/View/2037/118, diakses. 17 Juni 2017.

20. Recky H. E. S., Jen T., \& Yesi H.S. 2014. The Economic Growth And The Regional Characteristics: The Case Of Indonesia, Buletin. Ekonomi Moneter dan Perbankan, Juli 2013, diakses 12 Desember tahun 2016.

21. Santoso, B. (2013). Pengaruh Pendapatan Asli Daerah dan Dana Perimbangan Terhadap Pertumbuhan ekonomi, Pengangguran dan Kemiskinan 33 Provinsi di Indonesia, Jurnal Keuangan dan Bisnis, 5(2).

22. Setiyawati, A. \& Hamzah, A. (2007). Analisis Pengaruh PAD, DAU, DAK dan Belanja Pembangunan Terhadap Pertumbuhan Ekonomi, Kemiskinan, dan Pengangguran. Jurnal Akuntansi dan Keuangan Indonesia. Universitas Indonesia, diakses 5 Mei 2017.

23. Sirojuzilam. (2005). Beberapa Aspek Pembangunan Regional, ISEI Bandung.

24. Tresnasari, A. (2013). Analisis Pengelolaan Pemungutan Bea Balik Nama Kendaraan Bermotor (BBN-KB) Pada Kantor Unit Pelaksanaan Teknis Pendapatan Wilayah I Kota Palu, Tesis Universitas Tadulako Palu.

25. Undang-Undang Negara Republik Indonesia, Nomor 33 Tahun 2004 Tentang Perimbangan Keuangan Pemerintah Pusat dan Daerah.

26. Undang-Undang Negara Republik Indonesia, Nomor 9 Tahun 2015 Tentang Pemerintah Daerah.

27. Widjaja, H.A.W., 2002. Otonomi Daerah dan Daerah Otonomi, PT. Raja Grafindo Persada, Jakarta.

28. William G. G., \& Andrew A. S. 2014. Effects of Income Tax Changes on Economic Growth, The Brookings Institution and Tax Policy Center, Andrew. A.Samwick, Dartmouth College and National Bureau of Economic Research. B Economic Studies at Brookings. diakses 12 Mei 2017. 


\title{
THE EFFECT OF CORPORATE GOVERNANCE DISCLOSURE ON INVESTOR REACTIONS WITH PROFITABILITY AS MODERATING VARIABLE
}

\author{
Hariadi Krisna Langit*, Sutrisno, Rahman Aulia Fuad \\ School of Graduate Studies, Faculty of Economics and Business, \\ University of Brawijaya, Indonesia \\ *E-mail: krisna.langit.92@gmail.com
}

\begin{abstract}
The aim of this research is to understand how Corporate Governance affects investor's reaction in capital market by profitability as a moderating variable. This research uses secondary data obtained from Indonesian Stock Exchange. Investor's reaction is measured by Cumulative Abnormal Return, which happened around the time of annual report publication. Corporate Governance are measured by Institutional ownership, ownership by board of commissioner, audite commite, and independent commissioner. Profitability as moderating variabel is measured by Return on Asset. This research was done to 25 companies which were listed in Indeks LQ 45 in Indonesian Stock Exchange during 20152016. Data analysis techniques used in this research are regresion analysis and moderated regresion analysis (MRA). The result shows that corporate governance (Institutional ownership, ownership by board of commissioner, audite commite, and independent commissioner) negatively affect Cumulative Abnormal Return. Profitability as a moderating variable was able to explain the relationship of corporate governance (ownership by board of commissioner and audite commite) affect significantly to Cumulative Abnormal Return partially. Corporate governance does not have any impact to Cumulative Abnormal Return value, because of the implementation of corporate governance in Indonesia is not provide optimum results mean while in the process of considering corporate governance practices take time to know the benefits.
\end{abstract}

\section{KEY WORDS}

Cumulative abnormal return, investor's reaction, corporate governance, economy, benefits.

According to Nogi the purpose of an established company is to increase the value of the company by providing benefits and increase the prosperity of the owner or its shareholders (Nogi, 2003: 116). However, managers as corporate managers have different objectives, especially in terms of increasing individual achievement and compensation, which will lead to falling investor expectations about returns on the funds they have incurred. This is in line with Agency Theory which says that there is a difference of interest between principal and agent. Therefore, the need for a system that bridges the separation of interests between owners and managers within a company. This separation is expected to align the interests of owners or shareholders with the interests of managers as managers of the company. The system is with corporate management (Good Corporate Governance - GCG). Given Corporate Governance (CG) is expected to serve as a tool to give investors confidence that they will receive return on the funds they have invested.

In addition, based on the phenomenon that occurs, the insistence on the implementation of corporate governance caused by the existence of World Bank report in 1999 (Sutedi, 2011: 50). The report explained that the economic crisis in East Asia was caused by systematic failure of corporate governance practices derived from weak legal framework systems, inconsistent accounting standards and auditing standards, poor banking practices, ineffective supervision, and lack of rights Minority shares. In its review, the Asian Development Bank draws the conclusion that the economic crisis affecting ASEAN countries is the result of a bad corporate governance system in the economy.

Corporate governance is a concept for improving corporate performance through the formation of common goals and supervision of management performance and ensures 
accountability of management to stakeholders by basing on the regulatory framework (Nasution and Setiawan, 2007). Owen (2005) says that Enron's case in America has led companies to pay more attention to more transparent reporting and upholding corporate social independence and accountability.

Related to this, there are some researchers who relate it to investor reactions that are reflected from abnormal return. Indriastuti (2011) analyzed the Influence Principles of corporate governance on Abnormal Return, with the results of the principles of corporate governance proved to have a significant effect on abnormal return. In addition, other researchers in line with Tristiarini (2005), analyzed the Influence of Corporate Governance Implementation on Abnormal Return at the Financial Statement Announcement 2003. With the result that the implementation of corporate governance proved to have a positive effect on abnormal return.

Different results were performed by other researchers, such as Pratiwi and Suryanawa (2014). With the results of corporate governance research has no significant effect on stock returns, because it has not been able to attract investors to invest their capital. Another research with the same results done by Budiharjo (2016), With the results of research found that corporate governance does not affect the stock return.

Information is considered useful if the information can change the confidence of investors. Information about the company is required by the investor to serve as the basis for making the decision to invest in the company or not, this is in line with the theory of signaling. The Signaling Theory stresses the importance of companies having a desire to provide information to those in need. The importance of information because information presents things that happen in the company whether that happened in the past, the present, or to predict future events and to know the stock market.

One of the information that can be used in analyzing company performance to predict stock return is profitability ratio. Profitability ratio describes the ability of companies in generating profits from sources of funds owned (Untung and Sugiono, 2008). The greater the level of corporate profits indicates that the better the management in managing the company.

Based on background explanation above problem, the difference of research result that make it research gab research so that need to be researched by entering company profitability information as moderating variable derived from signaling theory as described previously.

People, especially investors, have learned a lot from the recent cases and accounting scandals as a result of weak corporate governance practices. Therefore, the researcher is interested to further investigate investor's reaction to corporate governance practices.

Description of problem formulation:

- Does corporate governance practice affect investors' reactions to companies listed in the LQ 45 period 2015-2016?

- Does the profitability of firms reinforce the relationship of corporate governance practices to investor reactions to companies listed in LQ 45 period 2015-2016?

The purpose of this study:

- Test and analyze the influence of corporate governance practices on Investor reactions on companies listed in LQ 45 period 2015-2016.

- Testing and analyzing the profitability of the company strengthens the relationship of corporate governance practices to investor reactions on companies listed in LQ 45 period 2015-2016.

Contribution of Research. Providing input for the development of theory, especially Agency Theory, which underpins the emergence of corporate governance mechanisms. Based on the results of the research can be used to add test evidence empirically to researches that have been done previously. In addition, provide input thoughts for investors to be the basis of decision making in investing. 


\section{LITERATURE REVIEW}

Agency Theory. Jensen and Meckling (1976) stated that Agency theory has two distinct interests in a company, namely agent and principal. Therefore, a new instrument is needed that is Corporate Governance to ensure that management is running well in accordance with the company's vision and mission (Siallagan and Machfoedz, 2006). Corporate governance deals with how investors believe that managers will benefit them, that managers will not steal / embezzle or invest into unprofitable projects with funds invested by investors, and how investors control Managers (Shleifer and Vishny, 1997) in (Ujiyanto and Pramuka, 2007).

Information Asymmetry Theory. One of the conditions causing the difference in information between the agent and the principal, in addition to the agency problem is information asymmetry which results in the great chance of managers to do things that are beneficial to their interests. According Husni (2012) some companies that run business transactions will likely have an advantage in terms of information than others.

Signaling Theory. Signalling theory explains why firms have an incentive to provide financial statement information to outsiders. Firms can increase company value by reducing asymmetry information. One way to reduce asymmetry information is to signal external parties (Lokollo and Syafruddin 2013). The provision of this information may make the external party more confident about the profit distributed by the company in its financial statements is purely a result of company performance is not a profit direkayasakan by the company in order to provide a positive signal for external parties (Lokollol and Syafruddin 2013).

Brigham and Houston (2009) state that cues are an action taken by a company management that gives investors a clue as to how management looks at a company's prospects. The conclusion that profitability ratios will signal investors and make the market more likely to react positively if the market interprets an improved profitability ratio as a bright signal and a bright outlook for the company in the future. Basic selection of these variables, where the company gives a positive signal to investors who are expected to affect the cumulative abnormal return of positive stocks as well.

Good Corporate Governance. In corporate governance there are 4 indicators based on the principles of Good Corporate Governance (KNKG, 2006: 5-7), which consists of:

Institutional Ownership. According Kartikasari (2011), institutional ownership is the ownership of shares of companies by financial institutions such as insurance companies, banks, pension funds, and investment banking. The greater the institutional ownership the more efficient the utilization of company assets. Institutional ownership generally acts as a party to monitor the company in general and managers as managers of the company in particular.

Management Ownership. Jensen and Meckling (1976) stated that to minimize agency conflict is to increase managerial ownership within the company. Managerial ownership is the ownership of a company's shares by the management. With managerial ownership, management not only functions as a company manager but also as a shareholder. Ross et al (in Naftalia, 2013) states that the greater the ownership of management within a company then management will tend to seek to improve its performance for the benefit of shareholders and for its own interests.

Audit Committee. According to Ningsaptiti (2010), the audit committee has the primary responsibility to assist the board of commissioners in carrying out its responsibilities primarily with issues related to the company's accounting policies, internal controls, and financial reporting systems. Based on the Circular Letter of the Jakarta Stock Exchange Circular Number SE-008 / BEJ / 12-2001, the membership of the audit committee shall consist of at least three persons including the chair of the audit committee. Gradiyanto (2012) revealed that the audit committee is closely related to the review of the risks facing the company and the compliance of applicable regulations.

Independent Commissioners. In Naftalia (2013), an independent commissioner is a mechanism that oversees and guides the management of the company. In general, independent board of commissioners is responsible for overseeing the performance of the 
company's management, and the realization of accountability. The existence of an independent commissioner of an enterprise may affect the integrity of a financial statement produced by management.

Basic Concept of Stock Return. According Jogiyanto (2015: 416), return is the result of investment. There are two types of stock returns, namely return on realization and expected return. Return realization is a return that has occurred that is calculated based on historical data. While the expected return is the expected return of investors in the future.

Basic Concept of Profitability. ROA is one of several profit ratios (profitability ratio). $\mathrm{ROA}$ is an indicator that is widely used by investors because ROA calculates the return on assets and investments made by investors in a company. According to Horne and Wachowicz (2012) high ROA often reflects the company's acceptance of good investment opportunities and cost-effective management. According to Harahap (2009), the greater the ROA ratio the better because the company is considered capable of using assets owned effectively to generate profits. This means that ROA can be used by investors in assessing the company's ability to generate profits on assets owned.

\section{RESEARCH CONCEPT FRAMEWORK}

Conceptual Framework for Research. Corporate governance mechanisms consist of institutional ownership, management ownership, audit committees, and independent commissioners. Other information that allegedly contributed to the existence of Abnormal Return shares is the ratio of profitability. According Harahap (2009) profitability ratio is the ability of the company's management in gaining overall profit. To better understand how the thinking of this research, then made a flowchart of research thinking. The flowchart of the conceptual framework of this study is as follows:

Corporate governance Profitability Investor Reaction

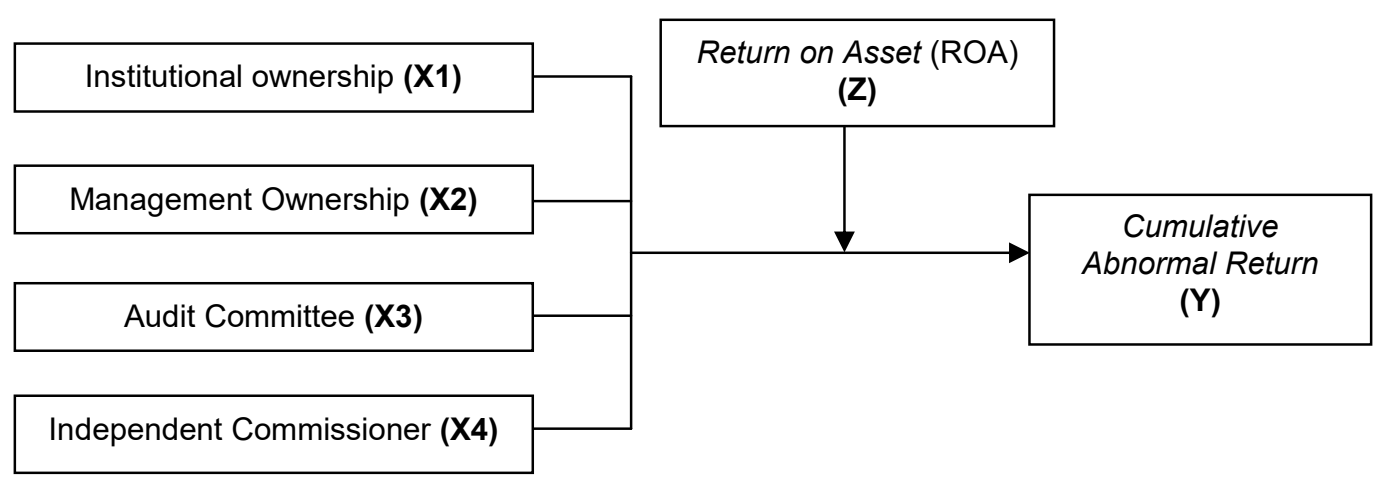

Figure 1 - Conceptual Research Framework

Development of Hypotheses:

With the implementation of corporate governance is expected to provide more value that is visible from the abnormal return of the company concerned. Moreover, coupled with the information company profitability ratios. Then the hypothesis in this study as follows:

Effect of Institutional Ownership on CAR. The first component of corporate governance in this study is institutional ownership. With dominant ownership by institutional investors, the supervision and analysis carried out on an enterprise will be conducted strictly than for minority investors. Research by Robert and Yuan (2006) shows that institutional ownership can significantly reduce lending costs. (Shleifer \& Vishny, 1997) stated that institutional investors play an important role in creating corporate governance systems within the company by independently overseeing management to respond to management policies that are not considered effective in managing the company.

$\mathrm{H} 1 \mathrm{a}$ : Institutional ownership is related to CAR. 
Effect of Institutional Ownership on CAR moderated by ROA. Institutional ownership is the percentage of shares owned by the shareholder institution. The results of the study by Cyert et al. (1998) found that sole and dominant ownership (blockholder) had a significant effect on firm value. In this case Holderness and Sheehan (1988) specifically find a significant positive influence between blockholder against cumulative abnormal return of stock. This opinion is supported by empirical evidence from Barclay and Holderness (1990), which suggests that a significant positive effect on the degree of institutional ownership of a company's value. Pound (1998) discloses that individual investors with low shareholding rates have a tendency to utilize or borrow voting power owned by majority shareholders to oversee management performance. While the research conducted Sudarma (2003) found different results that institutional ownership negatively affect the value of the company. Researchers suspect there are other factors that support one of the factors of institutional ownership of the abnormal return of shares of ROA. So from the results of this study is expected to bridge the differences of research results into research GAB this research.

$\mathrm{H} 1_{\mathrm{b}}$ : ROA strengthens the institutional ownership relationship to CAR.

Effect of Management Ownership on CAR. The separation between ownership and management of a company has the potential to create agency conflicts based on different interests. Differences of interests between management and shareholders may cause harm to either party. This is because of the different objectives between managers and shareholders, on the one hand management is responsible for increasing shareholder wealth from funding received, but management also wants to expand its business further with the benefits gained from the results of the management company. Research conducted by Soliha \& Taswan (2002) also found a significant and positive relationship between management ownership of firm value. Thus, it can be assumed that agency conflicts can be minimized if management also has a share of ownership within the company.

$\mathrm{H} 2_{\mathrm{a}}$ : Ownership of management has an effect on CAR.

Effect of Management Ownership on CAR is moderated by ROA. Management ownership is the percentage of shares owned by executives and directors. Ownership management is an important issue in agency theory since it was published by Jensen and Meckling (1976). The results of Rahayu and Faisal (2005) stated that the greater the projected ownership of management in a company then management will work harder to meet the interests of shareholders who are also themselves. While Sudarma (2003) who found that managerial ownership does not significantly affect the value of the company. Researchers suspect there are other factors that support one of the factors of institutional ownership of the abnormal return of shares of ROA. So from the results of this study is expected to bridge the differences of research results into research GAB this research.

$\mathrm{H} 2_{\mathrm{b}}$ : ROA strengthens the ownership relationship of management to CAR.

Effect of the Audit Committee on CAR. The Company is required to have an Audit Committee as a fulfillment of corporate governance practices (Turley and Zaman, 2004). The existence of an audit committee is enabled to assist the board of commissioners in reviewing the results of the company's financial statements, the company's compliance with the rules indicating that the existence of the audit committee is related to the integrity of the company's financial statements. This is supported also by Turley and Zaman (2004) research that examines the influence of corporate governance and audit committees, found that evidence suggests a positive relationship between the audit committee and the quality of financial statements and company performance.

$\mathrm{H}_{\mathrm{a}}$ : Audit Committee influences the cumulative abnormal return of shares moderated by ROA.

ROA moderates the influence of the Audit Committee on CAR. According to Siallagan and Machfoedz (2006) stated that the audit committee has the duty of assisting the board of commissioners to ensure that the company has presented the financial statements fairly in accordance with generally accepted accounting principles, the company has implemented internal control, risk management and corporate governance, external audit function And internal audit has been running well. When reporting quality gets better, then the value of stock prices will increase. This is supported also by Turley and Zaman (2004) found that 
evidence indicates a positive relationship between the existence of the audit committee with the quality of financial statements and company performance against stock prices. However, research conducted by Ramdiani and Yadnyana (2013) concluded that statistically the number of audit committee members has no effect on stock prices. Researchers suspect there is another factor that is ROA. So from the results of this study is expected to bridge the differences of research results into research GAB this research.

$\mathrm{H}_{\mathrm{b}}$ : ROA strengthens the audit committee's relationship to CAR.

Effect of Independent Commissioners on CAR. Dengan adanya kondisi komisaris independen yang baik, pengawasan terhadap transparansi, akuntabilitas, dan praktek keadilan dapat lebih terjamin (Susiana dan Herawaty, 2007). Penerapan tata kelola perusahaan yang berkualitas dapat mempersingkat proses bisnis, dan hal tersebut berujung pada kinerja operasional yang lebih baik dan pengeluaran modal yang lebih rendah, sehingga memberi kontribusi pada pertumbuhan penjualan dan keuntungan yang secara simultan mengurangi kebutuhan dan pengeluaran modal (Gompers, 2001). Penelitian yang dilakukan Chtourou (2001) menunjukkan bahwa komisaris independen secara umum memiliki pengawasan yang lebih baik terhadap manajemen sehingga mempengaruhi kemungkinan kecurangan dalam menyajikan laporan keuangan.

$\mathrm{H} 4_{\mathrm{a}}$ : Komisaris independen berpengaruh terhadap CAR.

Effect of Independent Commissioners on CAR. Given the conditions of good independent commissioners, oversight of transparency, accountability and fairness practices can be more assured (Susiana and Herawaty, 2007). The implementation of good corporate governance can streamline business processes, leading to better operational performance and lower capital expenditure, contributing to sales growth and profits simultaneously reducing capital needs and expenditures (Gompers, 2001). Research conducted Chtourou (2001) shows that the independent commissioner in general has better supervision of the management thus affecting the possibility of fraud in presenting the financial statements.

$\mathrm{H} 4_{b}$ : Independent commissioners have an effect on CAR.

Test of Equation Research Model. MRA equation (Moderating Regression Analysis) statistics of this research are:

Equation I:

$$
C A R=\alpha_{0}+\alpha_{1} K P I N+\alpha_{2} K P M J+\alpha_{3} K M A U+\alpha_{4} K M I N+e
$$

Equation II:

$$
\begin{gathered}
C A R=\alpha_{0}+\alpha_{1} K P I N+\alpha_{2} K P M J+\alpha_{3} K M A U+\alpha_{4} K M I N+\alpha_{5} R O A+\alpha_{6}\left(K P I N{ }^{*} R O A\right)+ \\
\alpha_{7}\left(K P M J{ }^{*} R O A\right)+\alpha_{8}\left(K M A U{ }^{*} R O A\right)+\alpha_{9}\left(K M I N{ }^{*} R O A\right)+e
\end{gathered}
$$

Note:

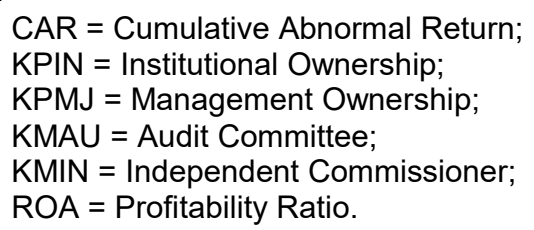

\section{METHODS OF RESEARCH}

This research is a type of hypothesis testing research. Indriantoro and Supomo (2006: 89) states that, Research that aims to test the hypothesis (hypothesis testing) is generally a study that explains the phenomenon in the form of relationships between variables.

Population and Sample Determination. The population in this study are all companies listed on the Indonesia Stock Exchange. Selection of sample using purposive sampling method, with criterion:

1. Companies listed on the Indonesia Stock Exchange 2015-2016

2. Companies listed in the LQ 45 Index for the period 2015-2016 
3. Companies that issue annual reports for the period 2015-2016.

4. The Company displays data on the date of submission of annual report to Bapepam for the period 2015-2016..

Types and Data Sources. The data in this study is polled data. This study used a short window period ie three days prior to the publication of the annual report, during the publication of the annual report and three days after the publication of the annual report. Researchers use short-term windows because the amount of information on the market will affect stock prices.

Dependent variable used in this research is CAR. Before calculating the CAR then first calculated the amount of abnormal return, which is the difference between return realitation minus the expected return. In this study, the abnormal return formula used, namely (Hartono, 2009: 558):

$$
\mathrm{RTN}_{\mathrm{i}, \mathrm{t}}=\mathrm{R}_{\mathrm{i}, \mathrm{t}}-\mathrm{E}\left[\mathrm{R}_{\mathrm{i}, \mathrm{t}}\right]
$$

After calculating the amount of abnormal return, then the calculation of cumulative abnormal return which is the sum of abnormal return the previous day in the event period for each securities as follows:

$\mathrm{ARTNi}, \mathrm{t}=\sum_{t-3}^{t+3} R T N i, a$

Institutional ownership is the ownership of shares of companies by financial institutions such as insurance companies, banks, pension funds, and investment banking (Siregar dan Utama, 2005 in Guna and Herawaty, 2010).

$$
\text { KPIN }=\frac{\text { Number of shares owned by institutional investors }}{\text { Total share capital outstanding }}
$$

Ownership of management is a share owned by management in private and shares owned by the relevant company and its affiliates (Susiana and Herawaty, 2007, in Guna and Herawaty, 2010.

$$
\text { KMAU }=\frac{\text { Number of external audit committee members }}{\text { Total of audit committee }}
$$

Audit Committee according to Kep. 29 / PM / 2004 is a committee established by the board of commissioners to perform the task of supervising the management of the company (Isnata, 2008, in Guna and Herawaty, 2010).

$$
\mathrm{KMAU}=\frac{\text { Number of external audit committee members }}{\text { Total of audit committee }}
$$

Independent commissioners are measured using a ratio scale through the percentage of commissioner members coming from outside the company of all sizes of the members of the company's board of commissioners (Isnata, 2008, in Guna and Herawaty, 2010).

$$
\text { KMIN: } \frac{\text { Number of members of the board of commissioners from outside }}{\text { sall members of the board of commissioners of the company }}
$$

This study uses profitability as a moderating variable. Profitability in this research is measured by ROA ratio (Guna and Herawaty, 2010):

$$
\text { ROA }=\frac{\text { Net profit after tax }}{\text { Total Assets }}
$$


Data analysis technique. The classical assumption tests used are:

1. Residual Normality Test;

2. Multicolinearity Test;

3. Heterocedasticity Test;

4. Test Autocorrelation.

Ghozali (2009: 87) states that the accuracy of sample regression function in estimating the actual value can be measured from three things, namely:

1. Coefficient of Determination (R2)

2. Individual Parameter Significance Test ( $t$ test)

\section{RESULTS OF STUDY}

Descriptive Statistics. Based on Table 1 above, several conclusions can be drawn as follows:

1. CAR variables derived from the sample of 50 companies have an average of 0.031 with a standard deviation of 0.338 . The CAR has a positive average indicating that most firms receive a higher than expected abnormal return. The standard CAR deviation score greater than the average indicates that the CAR experienced by the sample company has a relatively large difference.

2. The institutional ownership variable shows the lowest value of 0,000 . This indicates that overall, the company is performing well on its policy of percentage of institutional ownership. The maximum value of this variable can reach 0.991 . The average of this variable as a whole reaches 0.376 with a standard deviation of 0.325 . This means that the company is very concerned about the implementation of policies towards institutional ownership to the public who need information about the company.

3. Managerial ownership variable has a minimum value of 0,000 and a maximum value of 0.920 . The average achieved is 0.036 with a standard deviation of 0.132 . This indicates that almost all firms have relatively high percentage of managerial ownership. Only a small percentage of firms have low managerial ownership percentages.

4. Audit committee variable has an average value of 0.768 with a standard deviation of 0.220 . The lowest value is 0.400 , while the highest value can reach 1,000 . The average value may suggest that the sample company has a good percentage of audit committee. This is evident from the average value that reached 0.768 .

5. This variable has an average of 0.430 . From this data indicates that the sample company has not done the policy about the percentage of independent commissioners well, it can be seen from the achievement of the average value is only 0.430 .

6 . The sample company ROA variable is 50 which has the highest value of 0.685 with the lowest value of -0.055 and has an average of 0.099 with the standard deviation of 0.144 . These figures illustrate that the company's ability to generate profits when compared to the total assets held vary across companies.

Table 1 - Descriptive statistics

\begin{tabular}{|l|c|c|c|c|c|}
\hline \multicolumn{1}{|c|}{$\mathrm{n} / \mathrm{n}$} & $\mathrm{N}$ & Minimum & Maximum & Mean & STD. Deviation \\
\hline Institutional Ownership & 50 & 0,000 & 0,991 & 0,376 & 0,325 \\
\hline Management Ownership & 50 & 0,000 & 0,920 & 0,036 & 0,132 \\
\hline Audit Committee & 50 & 0,400 & 1,00 & 0,768 & 0,220 \\
\hline Independent Commissioner & 50 & 0,286 & 0,667 & 0,430 & 0,108 \\
\hline ROA & 50 & $-0,055$ & 0,685 & 0,099 & 0,144 \\
\hline Institutional Ownership*ROA & 50 & 0,000 & 0,181 & 0,031 & 0,040 \\
\hline Management Ownership*ROA & 50 & $-0,001$ & 0,094 & 0,004 & 0,016 \\
\hline Audit Committee*ROA & 50 & $-0,022$ & 0,514 & 0,075 & 0,101 \\
\hline Independent Commissioner*ROA & 50 & $-0,018$ & 0,310 & 0,041 & 0,058 \\
\hline Institutional Ownership*ROA & 50 & $-1,001$ & 1,078 & 0,031 & 0,338 \\
\hline Valid N (listwise) & 50 & \multicolumn{5}{l}{-} \\
\hline
\end{tabular}


Normality test. Table 2 shows that the value of Asymp. Sig. for institutional ownership of 0.385; Managerial ownership 0.505; Audit committee 0.860; Independent commissioners 0.957 and ROA 0.995. Of all variables has a value greater than 0.05 . This indicates that all data variables are normally distributed.

Table 2 - Kolmogorov-Smirnov Test Results

\begin{tabular}{|c|c|c|c|c|c|c|}
\hline$n / n$ & & $\begin{array}{l}\text { Institutional } \\
\text { Ownership }\end{array}$ & $\begin{array}{c}\text { Management } \\
\text { Ownership }\end{array}$ & $\begin{array}{c}\text { Audit } \\
\text { Committee }\end{array}$ & $\begin{array}{l}\text { Independent } \\
\text { Commissioner }\end{array}$ & ROA \\
\hline $\begin{array}{l}\mathrm{N} \\
\text { Parameter Normal } \\
\text { Most Extreme } \\
\text { Differences } \\
\text { Kolmogorov-Smirnov Z } \\
\text { Asymp. Sig. (2-tailed) }\end{array}$ & $\begin{array}{l}\text { Mean } \\
\text { Std. Deviation } \\
\text { Absolute } \\
\text { Positive } \\
\text { Negative }\end{array}$ & $\begin{array}{l}50 \\
0,37554 \\
0,325468 \\
0,128 \\
0,128 \\
-0,124 \\
0,906 \\
0,385\end{array}$ & $\begin{array}{l}50 \\
0,03596 \\
0,132224 \\
0,393 \\
0,358 \\
-0,393 \\
0,824 \\
0,505\end{array}$ & $\begin{array}{l}50 \\
0,76772 \\
0,219782 \\
0,275 \\
0,148 \\
-0,275 \\
0,603 \\
0,860\end{array}$ & $\begin{array}{l}50 \\
0,429620 \\
0,107540 \\
0,196 \\
0,196 \\
-0,144 \\
0,510 \\
0,957\end{array}$ & $\begin{array}{l}50 \\
0,09894 \\
0,143633 \\
0,281 \\
0,281 \\
-0,230 \\
0,417 \\
0,995\end{array}$ \\
\hline
\end{tabular}

a. Test distribution is Normal

b. Calculated from data.

Test of Multicollinearity. Multicollinearity test results Table 3 shows the VIF value of each independent variable in the range of 1 with a tolerance value approaching 1 . Thus, it can be concluded that there is no multicollinearity between independent variables.

Table 3 - Multicollinearity Test Results Coefficients ${ }^{a}$

\begin{tabular}{|l|c|c|}
\hline \multicolumn{1}{|c|}{ Model } & \multicolumn{2}{c|}{ Collinearity Statistics } \\
\cline { 2 - 3 } & Tolerance & VIF \\
\hline Institutional Ownership & 0,935 & 1,070 \\
\hline Management Ownership & 0,861 & 1,162 \\
\hline Audit Committee & 0,902 & 1,109 \\
\hline Independent Commissioner & 0,708 & 1,412 \\
\hline ROA & 0,838 & 1,194 \\
\hline Institutional Ownership*ROA & 0,771 & 1,296 \\
\hline Management Ownership*ROA & 0,774 & 1,292 \\
\hline Audit Committee*ROA & 0,843 & 1,187 \\
\hline Independent Commissioner ${ }^{*}$ ROA & 0,873 & 1,145 \\
\hline
\end{tabular}

a. Dependent Variabel: CAR.

Heteroscedasticity Test. In Figure 1 it appears that the existing dots form irregular patterns and spread evenly above or below the zeros on the $Y$ axis. This shows that there is no heteroscedasticity in the regression model in this study.

Scatterplot

Dependent Variable: CAR

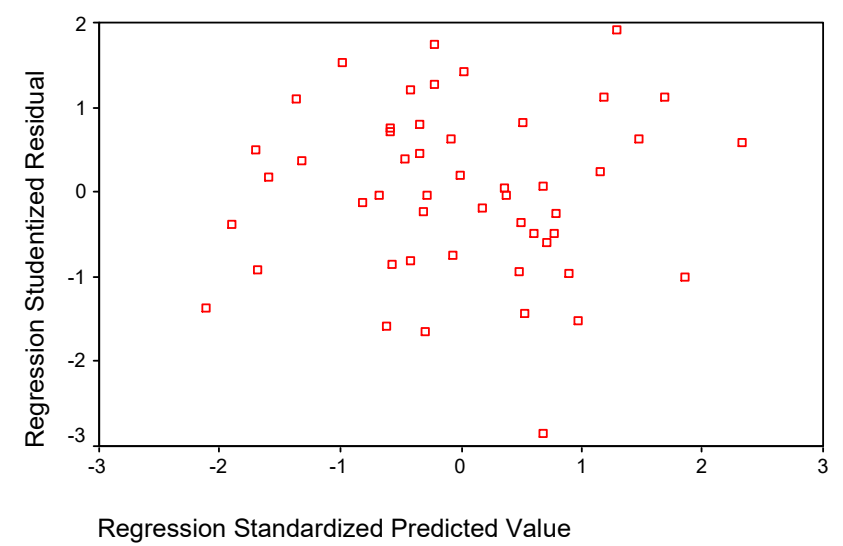

Figure 1 - Scatterplot Heterosceptasticity Test 
Test Autocorrelation. Test results show that there is no autocorrelation problem. Table 3 shows that the autocorrelation test results meet the requirement that there is no problem of autocorrelation both positive and negative in the regression model built. This is seen from the DW count of 1.822 . The number is in the range range between -2 to 2 .

Table 3 - Results of Autocorrelation Testing

Model Summary ${ }^{b}$

\begin{tabular}{|c|c|}
\hline Model & Durbin-Watson \\
\hline 1 & $1.822^{\mathrm{a}}$ \\
\hline
\end{tabular}

a. Predictors: (Constant), Institutional Ownership ${ }^{*} R O A$, Management Ownership ${ }^{\star} R O A$, Audit Committee, Management Ownership, Audit Committe ${ }^{\star} R O A$, Independent Commissioner ${ }^{*} O A$, ROA, Independent Commissioner.

b. Dependent Variable: CAR

Testing Regression Equation Modeling. Table 4 shows that the magnitude of R2 value of 0.034 adjusted R2 is -0.052 . This means that the independent variable can explain the dependent variable of $3.4 \%$. The remaining $96.6 \%$ is explained by other variables not included in the regression model.

Table 4 - Coefficient of Determination

Model Summary

\begin{tabular}{|c|c|c|c|c|}
\hline Model & $\mathrm{R}$ & $\mathrm{R}$ Square & Adjusted R Square & Std. Error of the Estimate \\
\hline 1 & $0.185^{\mathrm{a}}$ & 0.034 & -0.052 & 0.346226 \\
\hline
\end{tabular}

a. Predictors: (Constant), Independent Commissioner, Management Ownership, Audit Committee, Institutional Ownership.

Partial Significance Test Results (Test $t$ Statistics):

Table 5 - Hypothesis test results coefficients ${ }^{a}$

\begin{tabular}{|l|l|l|l|l|l|}
\hline \multicolumn{1}{|c|}{$\mathrm{n} / \mathrm{n}$} & \multicolumn{3}{|c|}{ Unstandardized Coefficients } & \multicolumn{3}{c|}{ Standardized Coefficients } \\
\hline Model & $\mathrm{B}$ & Std. Error & Beta & $\mathrm{t}$ & Sig. \\
\hline (Constant) & -0.088 & 0.307 & & -0.287 & 0.776 \\
\hline Institutional Ownership & 0.074 & 0.174 & 0.072 & 0.427 & 0.672 \\
\hline Management Ownership & 0.335 & 0.387 & 0.131 & 0.865 & 0.392 \\
\hline Audit Committee & 0.001 & 0.238 & 0.001 & 0.006 & 0.995 \\
\hline Independent Commissioner & 0.181 & 0.520 & 0.058 & 0.347 & 0.730 \\
\hline
\end{tabular}

a. Dependent Variable: CAR.

Significance $<0.05$

a. The value of $t$ arithmetic for the institutional ownership variable (X1) is 0.427 with a significance value of 0.672. Institutional ownership has no partial effect on CAR. So the decision taken is H1a rejected.

b. The value of $t$ arithmetic for managerial ownership variable (X2) is 0.865 with a significance value of 0.392 . Partial managerial ownership has no effect on CAR. So the decision taken is $\mathrm{H} 2 \mathrm{a}$ rejected.

c. The value of $t$ arithmetic for audit committee variable (X3) is 0,006 with significance value 0,995. Audit committee partially has no effect on CAR. So the decision taken is H3a rejected.

d. The value of $t$ arithmetic for independent commissioner variable (X4) is 0.347 with a significance value of 0.730, independent Commissioner partially has no effect on CAR. So the decision taken is H4a rejected.

The test results on the regression coefficients for the entire sample based on Table 5.7 yield the following model of regression equation:

$$
C A R=-0,088+0,074 K P I N+0,335 K P M J+0,001 K M A U+0,181 K M I N
$$

Moderating Regression Analysis (MRA). Table 6 shows that the magnitude of $\mathrm{R} 2$ value of 0.657 adjusted R2 is 0.580 . Thus, the independent variable can explain the dependent variable of $65.7 \%$. The remaining $34.3 \%$ is explained by other variables not included in the regression model. 
Table 6 - Hypothesis Test Results

Model Summary

\begin{tabular}{|c|c|c|c|c|}
\hline Model & R & R Square & Adjusted R Square & Std. Error of the Estimate \\
\hline 1 & $0.811^{\mathrm{a}}$ & 0.657 & 0.580 & 0.218764 \\
\hline
\end{tabular}

a. Predictors: (Constant), Institutional Ownership ${ }^{\star} R O A$, Independent Commissioner, Management Ownership, Audit Committee, Institutional Ownership, Institutional Ownership ${ }^{\star} R O A$, , Audit Committee ${ }^{\star} R O A$, Independent Commissioner ${ }^{*} O A, R O A$.

Partial Significance Test Result (Test $t$ Statistics). Partial test is used to determine the influence of each independent variable and control variable to the dependent variable.

Table 7 - Hypothesis test results

Coefficients $^{\mathrm{a}}$

\begin{tabular}{|l|c|c|c|c|c|}
\hline \multirow{2}{*}{ Model } & \multicolumn{2}{|c|}{$\begin{array}{c}\text { Unstandardized } \\
\text { Coefficients }\end{array}$} & \multicolumn{3}{c|}{$\begin{array}{c}\text { Standardized } \\
\text { Coefficients }\end{array}$} \\
\cline { 2 - 6 } & $\mathrm{B}$ & Std. Error & Beta & $\mathrm{t}$ & Sig. \\
\hline (Constant) & -0.255 & 0.228 & & -1.118 & 0.270 \\
\hline Institutional Ownership & 0.270 & 0.164 & 0.261 & 1.650 & 0.107 \\
\hline Management Ownership & -2.893 & 1.029 & -1.133 & -2.812 & 0.008 \\
\hline Audit Committee & -0.234 & 0.189 & -0.153 & -1.240 & 0.222 \\
\hline Independent Commissioner & 0.672 & 0.421 & 0.214 & 1.598 & 0.118 \\
\hline ROA & 2.915 & 2.629 & 1.240 & 1.109 & 0.274 \\
\hline Institutional Ownership*ROA & -1.341 & 1.537 & -0.160 & -0.873 & 0.388 \\
\hline Management Ownership*ROA & 32.830 & 10.247 & 1.527 & 3.204 & 0.003 \\
\hline Audit Committee* ROA & 3.445 & 1.555 & 1.028 & 2.215 & 0.033 \\
\hline Independent Commissioner ${ }^{*}$ ROA & -10.960 & 6.089 & -1.869 & -1.800 & 0.079 \\
\hline
\end{tabular}

a. Dependent Variable: CAR

Significance $>0.05$

Table 7 can be concluded as follows:

a. The value of $t$ arithmetic for institutional ownership variable moderated by ROA is -0.873 with a significance value of 0.388. Thus, institutional ownership moderated by ROA has no partial effect on CAR. So the decision taken is $\mathrm{H} 1 \mathrm{~b}$ rejected.

b. The value of $t$ arithmetic for managerial variables moderated by ROA is 3.204 with a significance value of 0.003. Thus, the managerial ownership moderated by ROA partially influences the CAR. So the decision taken is $\mathrm{H} 2 \mathrm{~b}$ accepted.

c. The value of $t$ arithmetic for audit committee variables moderated by $R O A$ is 2,215 with a significance value of 0.033. Thus, the audit committee moderated by ROA partially influences the CAR. So the decision taken is H3b accepted.

d. The value of $t$ arithmetic for independent commissioner variables moderated by ROA is -1.800 with a significance value of 0.79 . Thus, an independent commissioner moderated by ROA has no partial effect on the CAR. So the decision taken is H4b rejected.

The result of the description above shows that in this regression equation model there is influence to partially variable which have significant effect to CAR, that is managerial ownership variable with significance value 0,003 and audit committee variable with significance value 0,033 while institutional ownership variable with value of significance 0,388 and variable of commissioner Independent with a significance value of 0.079 is not significant. So it can be concluded that ROA is a moderating variable, but ROA is not a direct moderation variable, but rather an indirect moderation variable. The test results on the regression coefficients for the entire sample based on Table 5.8 yield the following model of regression equation:

$$
\begin{gathered}
C A R=-0,255+0,270 K P I N-2,893 K P M J-0,234 K M A U+0,672 K M I N+2,915 R O A-1,341(K P I N \\
\left.{ }^{*} R O A\right)+32,830\left(K P M J{ }^{*} R O A\right)+3,445\left(K M A U{ }^{*} R O A\right)-10,960\left(K M I N{ }^{*} R O A\right)+e
\end{gathered}
$$

\section{DISCUSSION OF RESULTS}

\section{Effect of Institutional Ownership on CAR}


The results show that the proportion of institutional ownership does not affect the stock CAR. The higher institutional ownership of the company does not necessarily encourage the CAR of Shares to be higher. Based on Agency Theory which states that there is a difference of interest between Agent and Principal, it is expected that the high proportion of institutional ownership is expected to take a role in improving investor confidence in the issue derived from Agency Theory. But the research results are different from the theories already mentioned. In line with the results of research conducted by Sudarma (2003) who found the results of institutional ownership negatively affect the value of the company.

\section{Effect of Institutional Ownership on CAR moderated by ROA}

$\mathrm{ROA}$ is the ratio of corporate profitability that describes the company's ability to generate profits compared to total assets owned by the company. The higher ROA ratio a company can attract investors to invest. In line with this is in accordance with the signaling theory put forward by experts, where the company, provide a positive signal so that investors respond with a positive also reflected in the CAR. But the results of the study contradict the Signaling Theory, the results show that ROA, can not moderate the influence of institutional ownership of CAR Shares. Although the proportion of institutional ownership of a company that is high but not necessarily can attract investors to invest when viewed from the side of ownership of its shares. The higher proportion of institutional ownership of the company does not necessarily encourage higher stock CARs. However, the ROA variable can deliver the institutional ownership variable to the stock CAR. This is evidenced by the second hypothesis testing $(\mathrm{H} 1 \mathrm{~b})$ which states that the ROA becomes a moderator variable relationship between institutional ownership of the stock CAR.

\section{Effect of Management Ownership on CAR}

The results show that management ownership does not affect the stock CAR. The higher ownership of the company's management is not necessarily pushed CAR Shares to be higher. Researchers suspect that there are other variables that can strengthen or weaken the relationship between management ownership of stock CARs. The results of this study contradict the results of research conducted by Rahayu and Faisal (2005) states that the greater the proportion of ownership ownership management in a company then management will work harder to meet the interests of shareholders who also is himself. But the same result with Sudarma (2003) found that managerial ownership had no significant effect on firm value.

\section{Effect of Ownership CAR management is moderated by ROA}

ROA is the ratio of corporate profitability that describes the company's ability to generate profits compared to total assets owned by the company. The higher ROA ratio a company can attract investors to invest. In line with this is in accordance with the signaling theory put forward by experts, where the company, provide a positive signal until the investors responded with a positive also reflected in the CAR. In line with the Signaling Theory, the results show that ROA can moderate the effect of management ownership on stock CARs. With the increasing ratio of high management ownership of a company certainly can attract investors to make an investment when viewed from the side of ownership of its shares. The higher Management Ownership of the company turned out to be able to encourage CAR shares to be higher as well. So it can be concluded ROA can deliver ownership of management to CAR. This is evidenced by the testing of hypotheses to the four H2b which states that the variable ROA be a moderator variable relationship between management ownership of the stock CAR.

\section{Effect of the Audit Committee on CAR.}

The results show that audit committee has no effect on stock CAR. The higher proportion of corporate audit committees does not necessarily lead to higher CAR shares. This is evidenced by the hypothesis testing of the fifth $\mathrm{H} 3 \mathrm{a}$. Researchers suspect that there are other variables that can strengthen or weaken the relationship between the audit committee and the stock CAR. The results of this study in line with the results of research conducted by Ramdiani and Yadnyana (2013) concluded that statistically the number of members of the audit committee does not affect the stock price. However, the results of research contradict the results of Turley and Zaman (2004) research that examines the effect of corporate 
governance and audit committees, the results of the study found that evidence indicates a positive relationship between the existence of the audit committee with the quality of financial statements and firm performance against stock prices.

The influence of the Audit Committee influences the CAR is moderated by ROA

$\mathrm{ROA}$ is the ratio of corporate profitability that describes the company's ability to generate profits compared to total assets owned by the company. The higher ROA ratio a company can attract investors to invest. In line with this is in accordance with the signaling theory put forward by experts, where the company, give a positive signal until the investors responded with a positive as well. In line with the Signaling Theory, the results of the study show that ROA can moderate the influence of audit committee's proportion to CAR of Shares. With the proportion of audit committee of a high company certainly can attract investors to invest when viewed from the proportion of audit committee. The higher the proportion of audit committees the company can turn CAR shares higher. So it can be concluded ROA variable can deliver variable audit committee to stock CAR. This is evidenced by the testing of the six hypothesis $\mathrm{H} 3 \mathrm{~b}$ states that the ROA becomes a moderator variable relationship between the audit committee on the CAR.

\section{Influence of Independent Commissioner's Influence on CAR}

The results show that independent commissioners have no effect on the CAR of Shares. The higher the company's independent commissioner is not necessarily pushing the stock CAR to be higher. H4a's seventh hypothesis testing states that independent commissioners can not affect the CAR of Shares. Based on Agency Theory which states that there is a difference of interest between Agent and Principal, it is expected that the high independent commissioner's proportion is expected to take a role in improving investor confidence in the issue derived from Agency Theory. But the research results are different from the theories already mentioned. Researchers suspect that there are other variables that either strengthen or even weaken the relationship between independent commissioners against stock CARs. In line with the results of research conducted by Ramdiani and Yadyana (2013) concluded that statistically the proportion of independent commissioners has no effect on stock prices.

Effect of Independent Commissioners on Cumulative Abnormal Return Shares are moderated by ROA

ROA is the ratio of corporate profitability that describes the company's ability to generate profits compared to total assets owned by the company. The higher ROA ratio a company can attract investors to invest. In line with this is in accordance with the signaling theory put forward by experts, where the company, provide a positive signal until the investors responded with a positive also reflected in the CAR. But the results of the research differ from existing theories, which show that the ROA variable can not moderate the influence of independent commissioners against the stock CAR. Although the high proportion of independent commissioners of a corporation may not necessarily attract investors to invest in terms of the proportion of independent commissioners. The higher the proportion of the company's independent commissioners does not necessarily push CAR shares higher. So it can be concluded ROA variable can not deliver independent commissioner to stock CAR. This is evidenced by the testing of the eighth hypothesis H4b.

\section{CONCLUSION AND SUGGESTIONS}

The partial test results show that the factors of each proportion: institutional ownership, management ownership, audit committee, and independent commissioner have no effect on CAR. Corporate governance does not have an impact in raising the CAR because the implementation of corporate governance in Indonesia still has not given an autonomous outcome considering the process in corporate governance practices takes time to know its benefits. So researchers suspect that there are other factors that can strengthen or weaken the relationship between institutional ownership, management ownership, audit committees, and independent commissioners of the CAR. This is evidenced by the results of research on hypothesis $2 \mathrm{~b}$ that proved to have a positive value significantly between management ownership with CAR moderated by ROA. This means that an increase in the proportion of 
management ownership is followed by a CAR increase which is supported by an increase in ROA ratio. In addition, hypothesis $3 \mathrm{~b}$ also has a significant positive result. ROA can moderate the relationship between audit committees to CAR. Which means that, the increase in the proportion of audit committees is followed by the increase in CAR supported by the increase in ROA ratio.

The first limitation of the research is the unavailability of data, both annual reports and stock prices. The sample used should be all companies included in LQ 45 period 2015-2016. Researchers can only find 50 annual reports of companies, either from the source website of the Indonesia Stock Exchange or related company website. In addition, there are some companies whose stock price data can not be found.

Further research can be developed using cross-sectional data types. By extending the study period. This is done in order to obtain more varied results again so as to increase the results of empirical testing that has been done before.

\section{REFERENCES}

1. Barclay, M.J. \& C.G. Holderness. 1990. Private benefits from control of public corporations, Journal of Financial Economics, Vol. 2. No. 25. Hal. 371-395.

2. Brigham, Eungene F. \& Joel F. Houston. 2009. Fundamentals of Financial Management (Dasar-Dasar Manajemen Keuangan). Buku 1. Edisi 10. Jakarta: Salemba Empat. Hal. 34.

3. Budiharjo, Roy. 2016. Pengaruh good corporate Governance Terhadap Return Saham dengan Profitabilitas sebagai Variabel Intervening dan Moderating (Studi Empiris Pada Perusahaan Peraih CGPI Yang Terdaftar di Bursa Efek Indonesia Tahun 2010-2012). Tekun. Vol VII. No.01.

4. Carningsih. 2009. Pengaruh Good Corporate Governance Terhadap Hubungan Antara Kinerja Keuangan Dengan Nilai Perusahaan (Studi Kasus Pada Perusahaan Property dan Real Estate yang Terdaftar di Bursa Efek Indonesia). SKRIPSI. Jakarta: Jurusan Akuntansi Fakultas Ekonomi: Universitas Gunadarma.

5. Chtourou, SM., Jean Bedard, \& Lucia Courteau. 2001. Corporate Governance and Earnings Management. Working Paper. Universite Laval, Quebec City, Canada.

6. Cyert, R.M., \& March, J.G. 1998. Behavioral Theory of the Firm, Wiley-Blackwell. Edisi ke-2. Hal. 117.

7. Ghozali, Imam. 2016. Aplikasi Analisis Multivariate dengan Program SPSS. Cetakan Keempat: Badan Penerbit Universitas Diponegoro. Semarang. Hal. 11.

8. Gompers, P.A., Ishii, J.L., \& Metrick, A. 2001. Corporate Governance and Equity Prices, Working Paper.

9. Gradiyanto, Andrean. 2012. Pengaruh Komite Audit Terhadap Praktik Manajemen Laba (Studi Kasus Pada Perusahaan Manufaktur Di Bursa Efek Indonesia Tahun 2009 2011). Accounting Business Management Journal. Vol 3. HIm 87-91.

10. Gradiyanto, Andrean. 2012. Pengaruh Komite Audit Terhadap Praktik Manajemen Laba (Studi Kasus Pada Perusahaan Manufaktur Di Bursa EfekIndonesia Tahun 2009 - 2011). Accounting Business Management Journal.

11. Guna, Welvin I, \& Arleen Herawaty. 2010. Pengaruh Mekanisme Good Corporate Governance, Independensi Auditor, Kualitas Audit, dan Faktor Lainnya Terhadap Manajemen Laba. Jurnal Bisnis dan Akuntansi. Vol. 12. Hal. 34.

12. Harahap, Sofyan Syafri. 2009. Analisis Kritis Atas Laporan Keuangan. Jakarta: Raja Grafindo Persada. Hal 77.

13. Hartono, Jogiyanto. 2009. Teori Portofolio dan Analisis Investasi. Edisi Keenam. Yogyakarta: Fakultas Ekonomika dan Bisnis Universitas Gadjah Mada. Hal. 558.

14. Holderness, C.G. \& Sheehan, D.P. 1988. The role of majority shareholders in publicly held corporations: an exploratory analysis, Journal of Financial Economics. Vol. 20. No. 2. Hal. 317-346.

15. Husni, Raudhatul. 2012. Pengaruh Mekanisme Good Corporate Governance, Leverage dan Profitabilitas Terhadap Manajemen Laba (Studi Empiris Perusahaan Property Dan 
Real Estate Yang Terdaftar Di Bursa Efek Indonesia Tahun 2008-2010. Jurnal Ekonomi dan Bisnis. Vol 2. No 2. Hal 77-93.

16. Indriantoro, Nur \& Bambang Supomo. 2011. Metodologi Penelitian Bisnis untuk Akuntansi dan Manajemen. Edisi Pertama. Yogyakarta: BPFE. HIm 89.

17. Indriastuti, Maya. 2012. Pengaruh Prinsip - prinsip Corporate Governance terhadap Abnormal Return (Studi Kasus pada Perusahaan yang melakukan SEO dan Listing di BEI). Solusi. Vol 11. No. 1. HIm $89-102$.

18. Jensen, Michael C. \& William H. 1976. Meckling. Theory of the Firm: Managerial Behavior, Agency Costs and Ownership Structure. Journal of Financial Economics. Hal. 135, 305-360.

19. Jogiyanto H.M. 2015. Teori Portofolio dan Analisis Investasi. Edisi Ketujuh. Yogyakarta: BPFE. HIm 416.

20. Kartikasari, Desi. 2011. Pengaruh Good Corporate Governance terhadap Manajemen Laba (Studi Empiris pada Perusahaan Perbankan di BEI Tahun 2007 - 2009. Accounting Business Management Journal. Vol 2. HIm 112-130.

21. Lokollo, Antonius \& Muchamad Syafruddin. 2013. Pengaruh ManajamenModal Kerja Dan Rasio Keuangan Terhadap Profitabilitas Pada IndustriManufaktur Yang Terdaftar Di Bursa Efek Indonesia (Bei) Tahun 2011. Diponegoro journal of accounting. Vol. 2. No. 2.

22. Mamduh M. Hanafi \& Abdul Halim. 2005. Analisis Laporan Keuangan. AMP-YKPN. Yogyakarta. Hal. 97.

23. Naftalia, Veliandina Chivan. 2013. Pengaruh Leverage Terhadap Manajemen Laba dengan Corporate Governance Sebagai Variabel Pemoderasi. Accounting Business Management Journal. Vol 1. HIm 35-51.

24. Nasution, Marihot \& Doddy Setiawan. 2007. Pengaruh Corporate Governance Terhadap Manajemen Laba di Industri Perbankan Indonesia. Simposium Nasional ke X Makasar.

25. Ningsaptiti, Restie. 2010. Analisis Pengaruh Ukuran Perusahaan dan Mekanisme Corporate Governance Terhadap Manajemen Laba (Studi Empiris pada Perusahaan Manufaktur yang terdaftar di Bursa Efek Indonesia 2006-2008). Accounting Business Management Journal. Vol 1. Hal 113-127.

26. Nogi, S. Hessel, Tangkilisan. 2003. Mengelola Kredit Berbasis Good Corporate Governance. Yogyakarta: Balairung \& Co. Hal 116.

27. Owen, D. 2005. CSR after Enron: A Role for The Academic Accounting Profesion?. European Accounting Review. Vol. 14. No 2. Hal 293-404.

28. Pound, J. 1988. Proxy Content and the Efficiency of Shareholder Oversight. Journal of Financial Economics. Vol. 20. Hal. 237-265.

29. Pratiwi, Nining \& Suryanawa, I. Kt. 2014. Pengaruh Good Corporate Governance dan Corporate Social Responsibility Disclosure Pada Return Saham. E-Jurnal Akuntansi Universitas Udayana. Vol. 9, No. 2.

30. Rahayu, Dyah Sih \& Faisal. 2005. Pengaruh Kepemilikan Manajerial dan Institusional pada Struktur Modal Perusahaan. Jurnal Bisnis dan Akuntansi. Vol. 7. No. 2. Hal. 190203.

31. Ramdiani, Ni Nyoman dan Yadnyana, I Ketut. 2013. Pengaruh Penerapan Corporate Governance dan Kinerja Keuangan Pada Harga Saham Perbankan yang Terdaftar di Bursa Efek Indonesia Tahun 2009-2011. Bali. E-Jurnal Fakultas Ekonomi: Universitas Udayana. Vol 3. Hal 217-232.

32. Robert, Gordon S \& Yuan, Liangzeng., 2006. Does Institutional Ownership Affect the Cost of Bank Borrowing. Journal of Social Science Reasearch Network. Vol 5. Hal 314347.

33. Sarwoko. 2005. Dasar-dasar Ekonometrika. Yogyakarta: Andi. Hal. 286

34. Sekaran, Uma. 2006. Metodologi Penelitian Untuk Bisnis. Jakarta: Salemba Empat. Hal 77, 162, 177.

35. Shleifer, A. \& R.W. Vishny. 1997. A Survey of Corporate Governance. Journal of Finance. Vol 52. No 2. Hal 737-763. 
36. Siallagan, Hamonangan dan Mas. Ud. Machfoedz. 2006. Mekanisme Corporate Governance, Kualitas Laba dan Nilai Perusahaan. Artikel Simposium Nasional Akuntansi (SNA) IX, Padang.

37. Soliha, E. \& Taswan. 2002. Pengaruh Kebijakan Hutang terhadap Nilai Perusahaan serta Beberapa Faktor yang Mempengaruhinya. Jurnal Bisnis dan Ekonomi. Vol. 9. No. 2. Hal. 149-163.

38. Sudarma, Made. 2003. Pengaruh Struktur Kepemilikan Saham, Faktor Intern, Faktor Estern terhadap Struktur Modal dan Nilai Perusahaan. Disertasi Program Pascasarjana, Universitas Brawijaya. Malang.

39. Susiana \& Arleen Herawaty. 2007. Analisa Pengaruh Indepedensi, Mekanisme Corporate Governance, Kualitas Audit Terhadap Integritas Laporan Keuangan. SNA X. Universitas Hasanudin Makasar.

40. Sutedi, Adrian. Good Corporate Governance. 2011. Jakarta: Sinar Grafika. HIm 50.

41. Tristiarini, Nila, 2005, Pengaruh Penerapan Corporate Governance terhadap Abnormal Return Pada Saat Pengumuman Laporan Keuangan 2003, Tesis, Universitas Diponegoro, Semarang.

42. Turley S., Zaman M. 2007. Audit committee effectiveness: informal processes and behavioural effectsAccounting. Auditing \& Accountability Journal. Vol. 20. No. 5, Hal. 765-788.

43. Ujiyanto, Muh. Arief \& Pramuka, Bambang Agus. 2007. Mekanisme Corporate Governance, Manajemen Laba dan Kinerja Keuangan (Studi Pada Perusahaan go public Sektor Manufaktur). SNA X. Makasar.

44. Untung, Edi \& Sugiono Arif. 2008. Panduan Praktis dan Dasar Analisis Laporan Keuangan. Grasindo. Jakarta. HIm 71.

45. Van Horne, James C. and John M. Wachowicz. 2005. Fundamentals of Financial: Management Prinsip-Prinsip Manajemen Keuangan. Translated by: Dewi Fitriasari \& Deny Arnos Kwary. Penerbit Salemba Empat: Jakarta. Hal. 216. 
DOI https://doi.org/10.18551/rjoas.2017-08.26

\title{
DYNAMIC CAPABILITIES AND CREATING ORGANIZATIONAL KNOWLEDGE: IMPORTANT LINKAGE FOR BUILDING COMPETITIVE ADVANTAGE
}

\author{
Arif Sugiono* \\ Doctoral Candidate of Business Administration, University of Padjadjaran, Indonesia
}

\author{
Ria Arifianti, Sam'un Jaja Raharja, Erna Maulina \\ Business Administration Department, University of Padjadjaran, Indonesia
}

\author{
Yudith Diah Hapsari \\ Management Department, Faculty of Economics, University of Katolik Atma Jaya, Indonesia
}

*E-mail: arifsugiono01@gmail.com

\begin{abstract}
As a concept derived from the resource-based view, dynamic capabilities essentially have an important linkage with activities related to the creation of organizational knowledge. Using literature study method, this paper aims to discuss the linkage between the creation of dynamic knowledge capabilities and the creation of knowledge company. The study shows that the discussion of dynamic capabilities creation finally puts both learning and knowledge in an important position. Correspondingly, the relationship between a growth strategy that is generally chosen by the organization brings a consequence that the creation of organizational knowledge becomes something that can not be ignored. In order to make the process of knowledge creation in line with dynamic capabilities creation within a growth strategy creation framework, we need a dynamic process of knowledge creation. Among the various models of knowledge creation, $\mathrm{SECl}$ model still becomes a relevant model within organizational knowledge creation framework. In general, this study is still theoretical, therefore, more empirical subsequent discussions are expected.
\end{abstract}

\section{KEY WORDS}

Dynamic capabilities, knowledge, company.

Every organization has resources consisting of human resources, physical resources, organizational resources, and financial resources. Barney \& Clark (2007) affirmed that good resource management will take a firm achieves a competitive advantage. However, these resources should have several characteristics such as Vrin which is valuable, rare, and immutable. However, firm capability does not guarantee that an organization will be able to adapt continuously amidst the ever-changing dynamics of the environment. Therefore, a dynamic capability is required to have a successful business. (Simon, 2010).

Basically, a resource-based view is used to explain the success or failure of a company to build competitive advantage through the diversity of resources which are generally owned by a company in the midst of environmental dynamics occurred. Armed with resources owned, every organization has a capability that is generally in the form of operational capabilities used to perform everyday activities of the company in order to build a sustainable competitive advantage. (Barney, 1991; Grant, 1991; Peteraf, 1993; Teece, et.al, 1997; Simon, 2010; Parayitam \& Gharna 2010; Ahenkora \& Aedji, 2012; Tseng \& Lee, 2012).

The dynamic of environmental change has brought consequences that the success of the company is due to the company's ability to create dynamic capability characterized by its ability to maintain appropriate capabilities to the dynamic environment through a systematic and continuous learning process. A dynamic capability is an approach that can explain a company's success in building competitive advantages in the midst of rapid environmental change (Esterby et al., 2009; Ahenkora \& Aedji, 2012; Tsheng \& Lee, 2012). In contrast, the failure to create sustainable competitive advantage, amidst the rapid environmental 
dynamics and hyper competitive competition, is largely due to the inability of the company to create a competitive strategy based on resources that are not merely routine but dynamic capabilities to take advantage of available opportunities. In other words, the company is only focused on a patterned, repetitive, and non-innovative activity so that the market forces become weak (Leonard \& Barton, 1992; Winter, 2003)

Dynamic Capabilities and Knowledge Activity. In the discussion of dynamic capabilities creation, most researchers place their learning and knowledge into something important (Zollo \& Winter, 2002; McGiard \& Gordon, 2010; Lewin and Massini; 2004; Soo, et al, 2004; Gourlay, 2004; Haefliger \& Krogh , 2004; Chen \& Huang, 2012). Referring to the researcher's discussion above, the understanding of dynamic capabilities from knowledge perspective becomes important. In conclusion, similar to what is presented by Kianto \& Ritala (2010) by looking at the study of dynamic capabilities from the perspective of knowledge, the discussion of dynamic capabilities can be conceptualized as an effort to make organizational knowledge functioned as something that works to enlarge, develop, and update the system of the company. Within this framework, knowledge is an important resource for an organization which can be gained through learning mechanisms.

Furthermore, Kianto \& Ritala (2010) said that knowledge perspective, in relation to dynamic capabilities, is able to bring the organization on higher order capacity. They also assert that departing from the literature study of knowledge, there are three very fundamental reasons on why knowledge can be the basis for a company in the creation of dynamic capabilities to follow the dynamics of the environment. Those three fundamental reasons include: (i). Connectivity means that knowledge mechanism takes place in the context of existing social relationships and available social constellations which significantly influence the possibilities and the potential for knowledge development (Cohen \& Levinthal, 1990; Brown \& Duguid, 1991; Nonaka \& Takeuchi, 1995). (ii). Learning is an essential mechanism that allows the organization to develop and update its capabilities. Therefore, the learning culture can be defined as the organizational capacity which serves to develop a more flexible and adaptable way as another form of dynamic capabilities (March 1991; Zollo \& Winter; 2002; Ferdinand et al., 2004). (iii). Although knowledge can not be fully managed, the possibilities of development and exploitation can be enhanced through the provision of various means of communication technology and various forms of information system to support, enhance, and provide knowledge for its development (Sher \& Lee, 2004; Nielsen, 2006; Capeda \& Vera, 2007).

Organization Strategy and Knowledge Activity. As a consequence of the importance of knowledge for the creation of dynamic capabilities, dynamic capabilities are part of the strategic management process in formulating an organizational strategy. Besides that, discussing the linkages between the chosen strategy and the activities related to knowledge also becomes relevant. There is a link between knowledge-related activities in an organization and strategies chosen by an organization (Ichijo, 2007). Therefore, analyzing what kind of appropriate strategy for the company is a must and this step can not be ignored. To ensure the accuracy of the strategy chosen, a company strategy model developed by Wheelen \& Hunger $(1990,2000)$ can be used. This corporate strategy model offers nine options of strategies based on 2 dimensions (the vertical dimension indicates industry attractiveness while the horizontal dimension indicates the strength of the business or the competitive position of the organization) which can be seen in Table 1 below.

Among the various options of strategies above, growth strategy, in general, becomes the choice of managers. Therefore, they generally always trying to improve the strength/position of their business by using various ways. The main reasons why the growth strategy becomes the choice of business people are: (I). The bigger the better/more efficient because growth is positively correlated with economies of scale; (li). Growth increases the likelihood of survival; (lii). Growth is defined as a synonym of effectiveness and is identical to power (Robbins, 1990). The importance of the growth of a firm can also be seen from a macro and micro perspective. In a macro perspective, the growth of a firm is identical to employment provision which labor absorption acts as a result (Acs \& Armington, 2006). 
Meanwhile, in the micro perspective, the key indicators of a firm are that the products are accepted by the market and the hallmark of the business's success. (Gilbert, B.A.et.al, 2006)

Table 1 - Model of Corporate Strategies

\begin{tabular}{|c|c|c|c|c|}
\hline & \multicolumn{3}{|c|}{$\begin{array}{l}\text { Business Strengths/ } \\
\text { Competitive Position }\end{array}$} \\
\hline & & Strong & Average & Weak \\
\hline \multirow{3}{*}{ 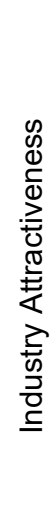 } & $\frac{\text { 음 }}{\text { ำ }}$ & $\begin{array}{c}\text { Growth } \\
\text { Concentration via Vertical } \\
\text { Integration }\end{array}$ & $\begin{array}{c}\text { Growth } \\
\text { Concentration via Horizontal } \\
\text { Integration }\end{array}$ & $\begin{array}{l}\text { Retrenchment } \\
\text { turned around }\end{array}$ \\
\hline & $\begin{array}{l}\frac{\varepsilon}{3} \\
\frac{2}{0} \\
\frac{1}{2}\end{array}$ & $\begin{array}{c}\text { Stability } \\
\text { (Pause or Proceed with Caution) }\end{array}$ & $\begin{array}{c}\text { Growth } \\
\begin{array}{c}\text { Concentration via Horizontal } \\
\text { Integration }\end{array} \\
\text { No Change or Profit Strategy }\end{array}$ & $\begin{array}{c}\text { Retrenchment } \\
\text { Captive Company or selling } \\
\text { out }\end{array}$ \\
\hline & 3 & $\begin{array}{c}\text { Growth } \\
\text { Concentric Diversification }\end{array}$ & $\begin{array}{c}\text { Growth } \\
\text { Conglomerate Diversification }\end{array}$ & $\begin{array}{c}\text { Retrenchment } \\
\text { Bankruptcy or Liquidation }\end{array}$ \\
\hline
\end{tabular}

Source: Wheleen \& Hunger (2005).

In line with the concept as stated above, Ichijo $(2006,2007)$ connects the strategies taken by the organization and the organization's activities related to the knowledge. If an organization chooses a survival strategy, the implications of the organization's activity on knowledge are more oriented on knowledge sharing and knowledge protection. However, if the strategy was chosen is a growth-oriented strategy, growth/advancement, the implications are more on knowledge creation, knowledge protection, and knowledge discarding. Table 1 shows more details of the strategic framework.

Table 2 - Strategic Framework for Knowledge

\begin{tabular}{|c|c|c|c|c|c|}
\hline Strategy & $\begin{array}{l}\text { Competitive } \\
\text { Advantage }\end{array}$ & $\begin{array}{c}\text { Sources of } \\
\text { Competitive } \\
\text { Advantage }\end{array}$ & Role of Knowledge & $\begin{array}{c}\text { Important } \\
\text { Knowledge } \\
\text { Activity }\end{array}$ & Result \\
\hline Survival & $\begin{array}{c}\text { Current } \\
\text { profitability } \\
\text { Not implemented } \\
\text { by competitors } \\
\text { Those who try } \\
\text { cannot replicate } \\
\text { the original } \\
\text { advantages }\end{array}$ & $\begin{array}{l}\begin{array}{c}\text { Economies } \\
\text { of Scale }\end{array} \\
\text { Economies of } \\
\text { Scope }\end{array}$ & $\begin{array}{l}\text { Valuable, difficult to } \\
\text { imitate, difficult to } \\
\text { substitute } \\
\text { Exclusively held or } \\
\text { in public } \\
\text { The ability to } \\
\text { transfer may more } \\
\text { important than the } \\
\text { content }\end{array}$ & $\begin{array}{l}\text { Knowledge } \\
\text { Sharing } \\
\text { Knowledge } \\
\text { Protection }\end{array}$ & $\begin{array}{l}\text { Profitability is } \\
\text { higher than the } \\
\text { average of the } \\
\text { industry }\end{array}$ \\
\hline Advancement & $\begin{array}{c}\text { Future } \\
\text { profitability } \\
\text { Not implemented } \\
\text { by competitors } \\
\text { Those who try } \\
\text { cannot replicate } \\
\text { the original } \\
\text { advantages }\end{array}$ & $\begin{array}{c}\text { Potential } \\
\text { economic of scale } \\
\\
\text { Potential } \\
\text { economies of } \\
\text { Scope } \\
\text { Potential } \\
\text { product/service } \\
\text { differentiation }\end{array}$ & $\begin{array}{l}\text { New knowledge for } \\
\text { process/product } \\
\text { innovation } \\
\text { Transferable new } \\
\text { knowledge }\end{array}$ & $\begin{array}{l}\text { Knowledge } \\
\text { creation } \\
\text { Knowledge } \\
\text { protection } \\
\text { Knowledge } \\
\text { discarding }\end{array}$ & $\begin{array}{c}\text { Future } \\
\text { profitability is } \\
\text { higher than the } \\
\text { average of the } \\
\text { industry. }\end{array}$ \\
\hline
\end{tabular}

Source: Ichijo (2006, 2007). 
The importance of the learning process in relation to activities related to the creation of knowledge in the creation of dynamic capabilities process and growth chosen by the organization has given rise to an increasingly strong assumption that knowledge is a key for a company to build a sustainable competitive advantage. (Nonaka, 1994; Nelson, 1991; Leonard \& Barton, 1995; Nonaka \& Takeuchi, 1995, Grant, 1996, Nonaka et.al 2008). The discussions about the contribution of knowledge to an organization have also been made by many parties with different perspectives including the discussion of the role of knowledge management in relation to the concept of knowledge creation (Glisbi \& Holden, 2003), the creation of knowledge company in the transition era (Gorman, 2004), knowledge management for technological innovation in organization (Heffner, 2006), the utilization of knowledge management system in automotive companies (Keki, 2008), the prospect of creating future knowledge (Chen\&Huang,2013), the value chain of knowledge management and its relation to quality management (Salajeghe, 2014).

Therefore, as a follow-up to the implementation of the strategic management model and the strategic framework for activities related to the creation of dynamic capabilities, the concept of knowledge creation becomes unavoidable within the framework of the dynamic capabilities creation. Thus, the discussion of knowledge creating concept becomes relevant for the discussion. In describing the concept of knowledge creation, SECI theory developed by Nonaka and Takeuchi (1995) is still relevant to be discussed. This model provides a philosophical foundation that is clearer and provides complete ontological and epistemological dimensions besides other theories.

Philosophically, this theory was born because it wanted to confront the traditional view which placed the organization in static and passive position and tended to be mechanistic, monotonous from day to day, used the pattern of command and control leadership as the recipient and processor of information, soil, material and energy as energy source, hierarchical structures, authority is in producers and is generally constraints in capital. The traditional view puts the organization to be more than a system that processes information or solves the problem. Traditional view asserted that the main function of the organization is to make an efficient and effective process of information and decision management in an uncertain environment. This paradigm attempts to be "criticized" by Nonaka (1994) as a passive and static paradigm since the hierarchy of its input-process-output solutions depends heavily on obtaining information obtained instead of creating information.

Seen from the ontological dimension, the creation of knowledge developed by Nonaka et al., (1995) explains that the creation of knowledge begins with the role of the individual where the creation of organizational knowledge should be interpreted as a process of creating individual/employee's knowledge, organized, managed, and crystallized through an organizational process. In its development, Nonaka et al., (2008) developed the SECI model within the framework of knowledge creation by placing individuals (individual recognition), organization, and the environment in a dialectical process that sustainably combines and moves through the SECI spiral rooted in the conversion between tacit and explicit. On the other hand, the epistemological dimension shows that there are differences and interactions between two types of knowledge namely tacit knowledge and explicit knowledge.

In other terms, the above explanation is metaphorically called as a bio-management. Thereby, the organization must become a model that is a living creature doing a biological activity to maintain its existence within the sense that mimics the way living creatures feed themselves (Sawidji, 2009). The consequence of the above metaphor is that the organization will be more defined as an organism and its ecosystem or living organism, along with its autonomous leadership patterns for employees, placing information and science as a source of value, independent organizational structure, placing the consumer as an economic authority (market was driven), and creativity as a general constraint.

In its development, Nonaka et al., (2008) developed an SECl-based dynamic model (Socialization, Externalization, Combination, and Internalization) which illustrates the various factors that influence the knowledge creation process. This model is dynamic because it involves a sustainable blend of real and abstract experiences in a specific context to build a universal theory by not forgetting the dynamic interaction in the environment. Figure 2 shows 
that this model consists of seven basic components that provide direction and energy into the $\mathrm{SECl}$ process. The seven basic components are SECl process itself, knowledge vision, driving objective, dialogue and practice, place/location in the physical/virtual sense to interact, knowledge assets, and the environment.

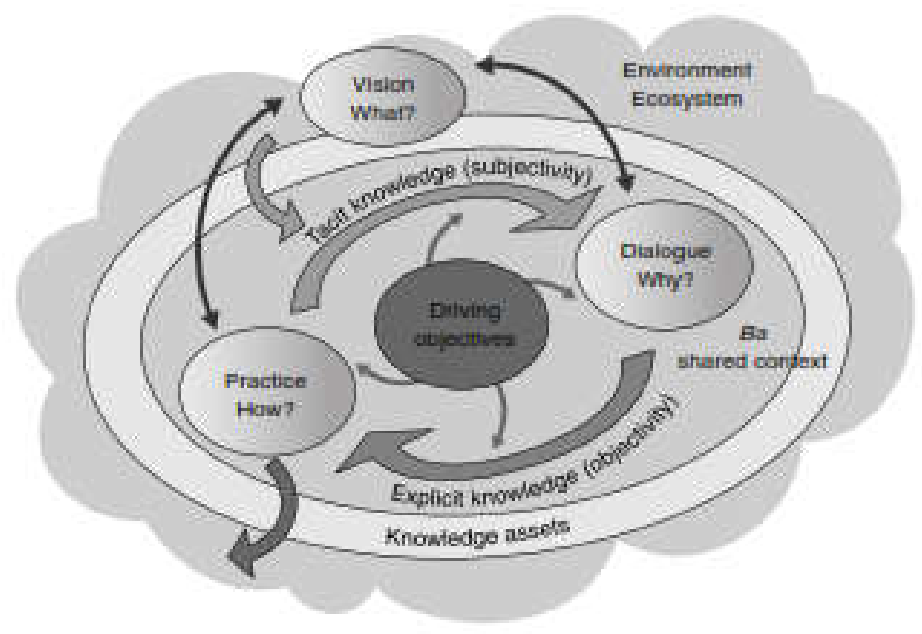

Source: Nonaka, et.al (2008)

Figure 1 - Process of the Knowledge-based firm

Bratinau \& Orzea (2010) also presented an overview of the state-of-the-art of organizational knowledge creation theory. In their description, there are at least four models of knowledge creation that they described. The four models consist of Nonaka model, Nissen model, Boisot model, and EO-SECl model. Three (Nissen model, Boisot model, and EO SECl model) out of the four models are basically the result of the model developed by Nonaka with different pressure points

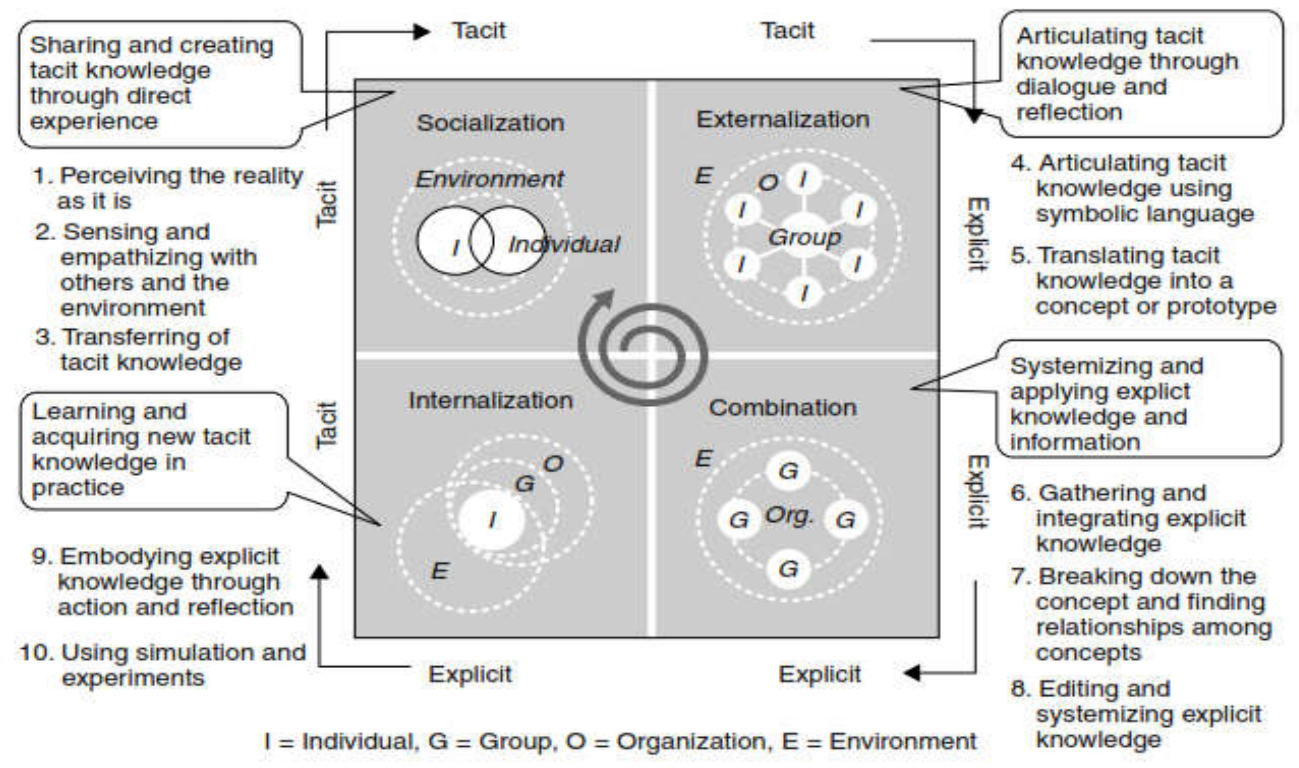

Source: Nonaka dan Toyama 2003, Nonaka et al, (2008)

Figure 2 - SECI Model for the Creation of Corporate Knowledge

If the dynamic of knowledge conveyed by Nonaka is based on the conversion of knowledge through social interaction, this will be different with the model of Nissen (2006) 
who argue that the dynamics of knowledge are based on flowing ideas. That opinion departs from an assumption that a firm is a place where knowledge flows continuously toward some direction and moves through the organization. In the context of organizational performance, the flow of knowledge lies and moves in the critical path of work that allows them to flow (Nissen, 2006). Nissen, basically, takes two models developed by Nonaka (epistemology and ontology) and adds two new dimensions namely life cycle and time flow. The life cycle refers to the different sequences of activities related to the flow of knowledge, such as the creation of knowledge, the spread of knowledge, and the use of knowledge. Meanwhile, time flow refers to the time duration expressed in minutes, days, or years of knowledge required to move from one person, organization, place or time to another (Nissen, 2006).

Moreover, Castro et al., (2007), also developed a more dynamic knowledge creation model that is EO-SECI Knowledge. Basically, this model is the development of Nonaka model, SECl, by considering the two dimensions (epistemology and ontology) which are dynamically linked at four different levels: individuals, groups, organizations, and inter organizational. The name of this model comes from: E-epistemological dimension; Oontological dimension; S-socialization; E-externalization; C-combination; I-internalization.

Furthermore, a more abstract knowledge creation model was developed by Boisot, 1999 in Bratinu \& Orzea (2010) that is based on information theory supported by l-space as a generic domain characterized by three dimensions: codification, abstraction, and diffusion. I-Space is a conceptual framework that shows information and the flow of knowledge in a group of people or organizations with respect to the three dimensions above: codification, abstraction, and diffusion. For example, the flow of knowledge towards more abstraction and codification will show greater availability to a particular population with the fact that all other things are considered the same. This I-Space model helps us to understand the creation and dissemination of new knowledge within the organization more easily as well as to understand the way it works depicted by the social learning cycle.

This cycle consists of six major phases (sequential): The first cycle is scanning, identifying opportunities in the external business environment such as signals and trends. Scanning can be done quickly when knowledge is well-coded and abstract, whereas, opportunities will be missed if scanning is done slowly. Second, problem-solving means to find solutions to problems which are both well identified and defined. The third cycle is an abstraction that is generalizing the application of new codified knowledge to a larger spectrum of applications. Fourth is diffusion, sharing of new knowledge created within groups or organizations. Fifth is absorption, means to integrate new knowledge into the learning cycle. Lastly, the impact, the relationship between abstract knowledge and its real practice. The order above does not need to run linearly. All of which can be run at the same time so that some could be developed simultaneously. The Boisot model of knowledge dynamics remains more abstract than other models and can be used as a complement to understanding the dynamics of knowledge within an organization (Boisot, 1999 in Bratinu \& Orzea 2010).

Soo et al., (2004) offered a relatively different approach compared to the previous four approaches and is relatively simple by taking the input-process-output perspective. Input is the stage of the source of knowledge where the creation of knowledge is derived from the dynamics of the external environment. The next stage of the process is the stage that knowledge and information are used to find solutions and take decisions on the problems faced. Last but not least, at the output stage there is an innovation that the impact of the innovation can be perceived at the organizational level. Although the research tried to display a model that was relatively different from the previous models, the research was in the same basic argument when it came to the model of knowledge creation. They realized the potential of "bounded rationality" in each individual so that they preferred to place the organization, not as an information processing engine that serves as a "composer" and performs the tasks assigned. In other words, the organization is limited to be an "engine" of information retrieval that process it from the environment to solve problems and adapt to the environment based on the predetermined goals. 
They all agree that the creation of knowledge will be better if it is conceptualized as a dialectical thinking process in which various contradictions are synthesized through the dynamic interaction among individuals, organizations, and the environment. By placing the company as a dialectical organ, the strategy and its organization must be re-examined as a manifestation of the synthesis and transcending process of the organization itself rather than from the logical analysis of the structure or action. Nonaka \& Toyama (2003) are believed to place the organization as organic integration that was conceptualized as an integral in a movement capable to transcend time, space, and organizational boundaries to create a living organism.

\section{CONCLUSION}

As a bundle of resources, understanding the organization of resource-based view approach is also relevant to the competitiveness of an organization. Dynamic capabilities which are a derivative concept of resource-based view organization increasingly shows its contribution when the dynamics of the environment of an organization is increasing. Along with the increasingly dominant role of knowledge in relation to the competitive advantage of an organization, the creation of dynamic capabilities from the perspective of knowledge becomes important to be considered with various arguments that have been discussed by some researchers.

Since the dynamic capabilities are an integral part of the strategic management process (strategy creation) and that the strategy chosen by the organization is generally a growth strategy, there is a linkage between strategy with activities related to knowledge in the organization. In other words, if an organization chooses a growth strategy, there will be several choices of activities related to knowledge such as knowledge protection, knowledge creation, or knowledge discarding. The linkage among dynamic capabilities, growth strategy, and the creation of knowledge is still theoretical. Therefore, it is expected that, in the future, there is a more empirical discussion focusing on how significant the impact or influence of that relationship or even the contribution of the three concepts.

\section{REFERENCES}

1. Acs, Z. J., \& Armington, C. (2006). Entrepreneurship, Geography and American economic growth. New York: Cambridge University Press.

2. Ahenkora, Kwaku \& Adjei Esther, 2012. A Dynamic Capabilities Perspective on the Strategic Management of an Industry Organization. Journal of Management and Strategy. Vol.3. No.3.

3. Barney, J.B. 1991. Firm Resources and Sustained Competitive Advantage. Journal of Management. (17)1. P.99-121.

4. Barney, J.B. 1991. The Resource Based View of Strategy: Origins, Implications, and Prospects. Editor of Special Theory Forum in Journal of Management, 17:97-211.

5. Barney, Jay. B, \& Clark, Derlwyn, N, 2007. Resourced Based Theory: Creating \& Sustaining Competitive Advantage. Oxford University Press.

6. Bratianu Constantin \& Orzea Ivona. 2010. Organization Knowledge Creation. Management Marketing for Knowledge Society. Vol.5, No.3.P 41-62

7. Brown, J.S \& P Duguid. 1991. Organizational Learning and Communities of Practice: Towards a unifying view of working, learning and innovation. Organization Science, 2(1): 40-57.

8. Capeda, G \& D Vera. 2007. Dynamic Capabilities and Operational Capabilities: A Knowledge Management Perspective. Journal of Business Research.60 (5).426-437.

9. Castro, Gregorio Martin De, et.al. 2007. Knowledge Creation Process: Theory and Emipirical Evidence from Knowledge-Intensive Firms. Palgrave Macmillan

10. Chen Der Chao \& Huang-Lung Huang.2013. Knowledge Creating theory in retrospect and prospect. Knowledge Management Research \& Parctice.11.P.405-409. 
11. Chen Der Chao \& Huang-Lung Huang.2013. Knowledge Creating theory in retrospect and prospect. Knowledge Management Research \& Parctice.11.P.405-409.

12. Cohen, W \& D Levinthal, 1990. Absorbtive capacity: A New perspective on learning and innovation. Adminsitrative Science Quarterly,35 (1).128-52.

13. Easterby-Smith, M., Lyles, M. A., \& Peteraf, M. A. 2009. Dynamic capabilities: Current debates and future directions. British Journal of Management, 20: S1-S8.

14. Ferdinand, J.M et.al. 2004. Dynamic Capabilities: Tracking the development of a concept, in proceedings of Organizational Learning, Knowledge and Capabilities, Innsbruck 2-3 April 2004. Austria.

15. Glisbi Martin \& Nigel Holden. 2003. Contextual Constraints in Knowledge Management Theory: The Cultural Embeddedness of Nonaka's Knowledge-Creating Company. Knowledge and Process Management. Vol 10.1.P 29-39.

16. Gorman, Margareth De Lanny, 2004. Creating Organization Knowledge during Transformational Change: A Multi Site Case Study Using An Action Theory Approach. Disertation. The George Washington University.

17. Gourlay, Stephen. 2004. Knowing as Semiosis: Step towards a Reconceptualization of 'tacit knowledge'. Dalam Tsoukas Haridimos dan Nikolaos Mylonopoulos.(Editor). Organizations as Knowledge System. Palgrave Macmillan.

18. Gilbert, B. A., McDougal, P. P., \& Audretsch, D. B. 2006. New venture growth: A review and extension. Journal of Management, 32 (6).P. 926-950.

19. Grant, R. 1996. Toward a knowledge-based theory of the firm. Strategic Management Journal, 17, Winter special issue.109-122.

20. Grant, R. M, 1991. The Resource-based Theory of Competitive Advantage: Implications for Strategy Formulation. California Management Review, Spring: 114-35

21. Haefliger Stefan \& Georg Van Krogh 2004.Knowledge Creation in Open Source Software Development. Dalam Tsoukas Haridimos dan Nikolaos Mylonopoulos.(Editor). Organizations as Knowledge System. Palgrave Macmillan.

22. Heffner, Michael Clifford, 2006. Knowledge Management For Technological Inovation for Organizations: The Fusion Process For Creating Intellectual Capital. Disertation. University Of Meryland. University College.

23. Ichijo, Kazuo.2006."Strategic Management of Knowledge-Based Competence: Sharp Corporation" dalam Takeuchi Hirotaka \& Tsutomu Shibata (Ed). Japan Moving Toward a More Advanced Knowldge Economy: Advance Knowledge-Creating Companies. Washington DC. World Bank Institute.

24. The Strategic Management Knowledge.in Knowledge Creation and Management: New Challenges for Managers (2007). P.121-145.Oxford University Press.

25. Keki, loana Ch. 2008. Creating a Lesson Learned Knowledge Management System For The Egnatia Motorway Company. Thesis. University Of London.

26. Kianto Aino \& Ritala Paavo. 2010. Knowledge-Based Perspective on dynamic capabilities dalam Strategic Reconfiguration \& Building Dynamic Capabilities in Rapid Innovationbased Industries. Edward Elgar. UK.

27. Leonard-Barton, D. 1992. Core capabilities and core rigidities: A paradox in managing new product development. Strategic Management Journal: 111-125.

28. Leonard-Barton. D.1995. Wellsprings of Knowledge. Building and sustaining the sources of innovation, Boston. Harvard Business School Press.

29. Lewin Arie $Y$ dan Silvia Massini. 2004. Knowledge Creation and Organizational Capabilities of Innovating and Immitating Firms. Dalam Tsoukas Haridimos dan Nikolaos Mylonopoulos. (Editor). Organizations as Knowledge System. Palgrave Macmillan.

30. March, J.G. 1991. Exploration and exploitation in organization learning. Organization Science, 2 (1).101-23

31. Mc Carthy, Ian \& Brian Gordon, 2010. Leveraging dynamic capabilities: a contingent management control system approach. Edward \& Elgar.

32. Nelson, R.R. 1991. Why do firms differ and why does it matters?. Strategic Management Journal,12 (1),61-75. 
33. Nielsen, A. 2006. Understanding dynamic capabilities through knowledge management. Journal of Knowledge Management, 10(4): 59-71.

34. Nissen, Mark E. 2006. Harnessing Knowledge Dynamic: Principled Organizational Knowing \& Learning. IRM Press.

35. Nonaka, I, 1994.A Dynamic Theory of Organizational Knowledge Creation. Organization Science 5 (1).14-37.

36. Nonaka I \& Takeuchi, H, 1995. The Knowledge Creating Company. Oxford University Press. New York.

37. Nonaka, I, Toyama R and Toru Hirata, 2008. Managing Flow: A Process Theory of the Knowledge-Based Firm. Palgrave Macmillan.

38. Parayitam Satyanarayana, 2010. Economic of Resource Based and Dynamic Capabilities view: A Contemporary Framework. Academy of Strategic Management Journal. Volume 9, Number 1.

39. Peteraf, M.A,1993. The Cornerstones of Competitive Advantage: A Resource-based View. Strategic Management Journal,14:179-91.

40. Robbins, Stephen P. 1990. Organization Theory: Structure, Design and Applications. Prentice hall. New Jersey USA.

41. Salajeghe, Sanjar et.al. 2014. Analysis of the role of quality management in creating knowledge management value chain. International Journal of Academic Research in Business and Social Research.

42. Sawidji, Widoatmodjo, 2009. Remodeling the Business. Elex Media Komputerindo.

43. Sher, P \& V Lee. 2004. Information technology as a facilitator for enhancing dynamic capabilities through knowledge management, Information \& Management, 41(8): 933-44.

44. Simon, A., 2010. Resources, Dynamic Capabilities and Australian Business Success. Journal of Global Business and Technology, Vol.5 No.2, 13-30.

45. Soo, et.al. 2004. The Role of Knowledge Quality in Firm Performance. Dalam Tsoukas Haridimos dan Nikolaos Mylonopoulos. (Editor). Organizations as Knowledge System. Palgrave Macmillan.

46. Teece, D. J. 2007. Explicating Dynamic Capabilities: The nature and microfoundations of (sustainable) enterprise performance. Strategic Management Journal, 28: 1319-1350.

47. Tseng Mei Shu \& Pei Shan Lee, 2012. The effect of Knowledge management capability and dynamic capability on organizational performance. Journal of Enterprise Information Management. Vol 27.No.2.P.158-179.

48. Winter, S. G. 2003. Understanding dynamic capabilities. Strategic Management Journal, 24: 991-995.

49. Wheelen D T. \& Hunger, D.2005. Strategic Management. Prentice Hall.

50. Zollo, M., \& Winter, S. G. 2002. Deliberate learning and the evolution of dynamic capabilities. Organization Science, 13(3): 339-351. 


\title{
ANALYSIS OF FACTORS AFFECTING THE AMOUNT OF REMITTANCE DELIVERY TO HOMETOWN OF GOLD MINING WORKFORCES OF PT AMMAN MINERAL NUSA TENGGARA IN WEST SUMBAWA REGENCY
}

\author{
Hidayat Rahmad*, Suman Agus, Sakti Rachmad Kresna \\ Faculty of Economics and Business, University of Brawijaya, Indonesia \\ *E-mail: rahmadhidayat360@gmail.com
}

\begin{abstract}
Some of non-permanent workforces send a portion of their revenue home to their families in the form of remittance. Remittance provides positive impacts for both workforces' hometown and government. In this case, there are several factors that determine the amount of remittance delivery to these towns. This study aims at investigating the influences of revenue, education, duration of stay, number of dependents towards the amount of remittance sent home by non-permanent workforces of PT Amman Mineral Nusa Tenggara in West Nusa Tenggara Regency. Today, West Sumbawa becomes the work destination for labors coming from several places of Indonesia. Data used in this study are primary data obtained through observation and interview with 96 respondents of PT Amman Mineral Nusa Tenggara workforces who work in West Sumbawa. It was analyzed using multiple linear regression technique. The results suggest that simultaneously dependent variable is influenced by four independents variables. On the other hand, partially, revenue and number of dependents positively has positive influence and duration of stay has negative influence as well as three variables significantly influence on $10 \%$ of significance level. Education has positive influence and is not significantly on $10 \%$ if significance level.
\end{abstract}

\section{KEY WORDS}

Remittance, non-permanent migrants, amount of remittance.

The most essential factor in economic growth is people's welfare in a country. There are many issues appeared due to high population growth, including health, gaps, employment, education, and narrow settlement that becomes slum. The tendency of rural people to visit and stay in urban areas is caused by their intention to improve living standard (Kasto, 2002). Social mobility can be divided into two, such as permanent and nonpermanent social mobility. In permanent social mobility, migration done is intended to live in a destination. Meanwhile, in non-permanent social mobility, migration is carried out without any intentions to live there.

The reason as to why people do mobility is because of their regional economy that slowly grows, so that people mostly expect to have a better job and revenue in their destination (Kasto, 2002). Nowadays, the main target of social mobility is West Sumbawa Regency. It occurs because of the existence of new industries in the mining area. This existence has given its own value to those who are looking for job. Currently, PT Amman Mineral Nusa Tenggara has employed approximately 3.486 employees who are from various places, as follows: 1.006 employees from West Sumbawa, 1.504 employees from outside West Sumbawa Regency, 973 employees from outside West Nusa Tenggara, and 5 foreign employees. It is depicted as in the figure 1.1 The hometowns of PT AMNT 2017 employees.

West Sumbawa, for some people, is the giant magnet that is able to attract a thousand of people who are from both rural and urban area to work in the city of gold. West Sumbawa and other hometowns that have industries really attract visitors' attention to get a job there. It is due to the fact that industrial sectors offer more amount of revenue than agricultural sectors. Another reason of people migrating to West Sumbawa is to get a better job, higher revenue, and live with parents and relatives.

Connell 1980 as cited in (Sudibia, 2011) stated that migrants are strongly related to their hometown in which it causes special phenomenon of social mobility, such as 
transferring either money or goods which is called as remittance. Furthermore, such strong relation manifests remittance where migrants can participate in bearing their members who are in hometown (Ardana, 2011).

Interesting phenomenon that takes place in PT AMNT mining industry has given a new nuance in West Sumbawa Regency, especially in the mining surroundings. The impact of this industry's existence has triggered migration occurs, conflicts in society, and family bonds weaken and these lead to individualistic lifestyle. As the matter of fact, the worst thing is the existence of prostitution places are legalized by local government. On the other hand, according to economic perspective, gold mining industries offer entrepreneurship opportunities to people. Increase or decrease in revenue level of society is various which is based on job type and work competence in mining sector. The average of migrants in this study is males who live near to the mining area. A challenge faced by these migrants is whether they have to send more amount of revenue home to fulfill family's needs or they have to use higher amount of money by themselves during the stay in destination area. Based on the background above, the research questions are formulated below:

1. Does revenue level of PT AMNT gold mining workforces influence the amount of remittance sent to home?

2. Does education of PT AMNT gold mining workforces influence the amount of remittance sent to home?

3. Does duration of work of PT AMNT gold mining workforces influence the amount of remittance sent to home?

4. Does amount of dependents in hometown influence the amount of remittance sent to home by PT AMNT gold mining workforces?

\section{THEORETICAL FRAMEWORK AND STUDY HYPOTHESIS}

Manpower. In the Indonesian Act No. 25 of 1997, manpower is defined as each man or woman, who is or will be working in order to generate either products or services to fulfill people's needs. Meanwhile, in Department of Manpower and Transmigration of Republic of Indonesia 2003, in chapter I article 1 subsection 2, it is mentioned that manpower is everyone who is able to work in order to generate products or services in order to fulfill his own need or people's need. Mulyadi (2003) also adds that those who belong to manpower are those whose ages have reached the working age (15-16 years old), or the entire people of a nation that can produce products or services in case they are requested and they will to participate in those activities.

Concept and Definition of Migration. Migration is one of demographic components that influence the social dynamic beside fertility and mortality. It is in line with the theory proposed by LFR (Lewis-Fei-Rannis) who asserts that basically, migration is caused by diversity existence between more developed city than undeveloped area (Mulyadi, 2003). Someone is considered a migrant if he crosses the provincial boundary and his duration of stay in destination area is at least six month. Area boundary generally uses administrative boundary, for example: province, regency, district, village, and hamlet. A research done by Mochtar (1984) found that social mobility of Minangkabau tribe use Minang cultural boundary as its area boundary. It is also mentioned that those who are migrants are those that cross the provincial or regional boundary (Firman, 1994).

Push and Pull Theory. In general, social mobility takes place because there is a diversity between two areas. In a book written by Everett S Lee (1978) entitled "Theory of Migration" explained that the volume of migration grows based on diversity of the area. Both hometown and destination area have positive factors (+), negative factors (-), and neutral factors (0). Positive factors refer to the factors that give benefits if they live there, while negative factors refer to the factors that negatively affect during the stay there where someone wants to move on to another place since his certain need is not fulfilled. By the existence of diversity, it causes social migration.

In individual context level of decision-making, there are many theoretical approach models that can be used. One of them is Todaro model (2000) in which in this model, the 
main cause of migration is rational economy consideration toward benefit and cost both in terms of finance and psychology. In 1970 until the beginning of 1990, the most influential theory regarding individual migration decision from geographical perspective was Everett Lee's theory, 1992 (Mantra, 2000). Decision to migrate is influenced by four factors including a) factor at hometown, b) factor at destination area i.e. high amount of wage, available job vacancy, developed area, and complete facilities availability, c) barrier factor i.e. transportation, area and distance topography, d) factor of individual.

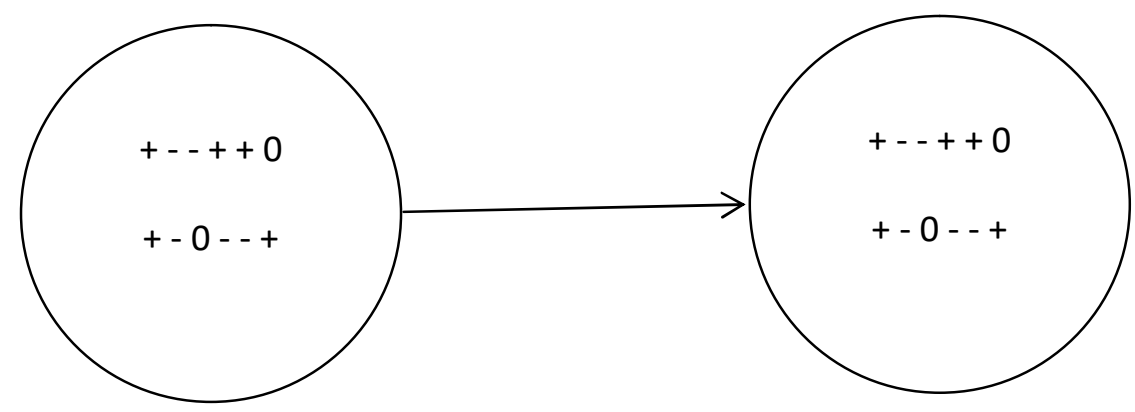

Note:

(+) Renewable need factor

(-) Unfulfilled need factor

(0) Neutral factor

2. Obstacles between

1. Hometown 3. Destination area

Figure 1 - Factors that influence migration decision (Mantra, 2000)

Internal Migration. Weeks (2004) stated that someone migrates because of economy issue. However, it does not necessarily mean that the internal migrant feels no force. The instance of internal migration category is natural disaster or war that cause certain community in a country move to the place where its residents relatively few. A study done by Alatas (1999) regarding internal migration pattern in Indonesia reveals that social mobility level in Indonesia which initially was 4,49 percent in 1971 and it reached 8,25 percent in 1990. The main destination area after DKI Jakarta is West Java. DKI Jakarta is considered no longer interesting as it is signed by the migrants from DKI Jakarta move on to West Java, in particular Bogor, Tangerang, and Bekasi. From the other side, the increase of eastern parts of Indonesia development changes the migration pattern in which slowly flows to the East.

Non-permanent migrants. Horizontal or geographical social mobility can be divided into permanent and non-permanent social mobility. Non-permanent social mobility is migration done one place to another place without intention to live there. Therefore, the difference between permanent and non-permanent social mobility is on migrant's intention whether to live or not. If someone moves to another place with intention to return to his hometown, then it is called circulation, not migration. Circular social mobility is divided into commuting mobility and migrating mobility (Mantra, 1994). Beside economy factor, hometown's situation also becomes the reason to do mobility. Infertile farmland, drought, and limited job vacancy are the situations faced by migrants in their hometown (Wijono, 1994). Meanwhile, Naomi Goma (1993) views the main factor of migration is the difference economy states between two regions (hometown and destination area).

Revenue. Revenue is the receipt for a person as the remuneration. It can be in the form of wage, interest, rent, and profit depending on production factor that involved in production process (Yuliana Sudremi, 2007). Meanwhile, Suyanto (2000) defines revenue as the amount of funds obtained from benefits of owned-production. It is in line with Reksoprayitno (2004) who argues that revenue can be defined as the amount of money that is received in certain period of time. As a result, it can be concluded that revenue is payment received by social members in certain period of time as remuneration or production factor that have been donated (Reksoprayitno, 2004). 
Remittance. Initially, remittance is defined as money or things transfer by a migrant to his hometown while he is in destination place (Connel, Jhon, Biplab, Dasgupta, Roy Laishley, 1976). It is similar as what Caldwell (1969) stated in (Murdiyanto, 2001). Additionally, since it has been developed, remittance is not merely about money and goods, but also skills and ideas are involved (Connel, 1980). Experiences got in the destination area will give benefits to people in migrant's hometown. Curson (1981) says remittance is the delivery of money, goods, and developed ideas sent from destination area to hometown. It is the important instrument in society and economy aspects. Based on economic perspective, the existence of remittance is very essential because it is able to improve family's economy as well as development of society.

Remittance Determination Factors. In a study conducted by Hugo (1978), 14 villages that were located in West Java showed that remittance sent by circular migrants were 47,7 percent of the family revenue in hometown, whereas for permanent migrants, it was only 8,00 percent. High or low amount of remittance that is sent by migrants is very depending on the characteristics of migration and migrants itself. The characteristics are such as migrant's duration of stay, educational level, revenue, and relationship between migrant and his family in hometown. In regard to it, Lucas (1985) argues that the longer migrant stays in destination area, the smaller remittance sent to his hometown is.

Furthermore, remittance sent to hometown depends on how migrant's relationship with his family over there. In this case, family in hometown is divided into two parts, including: core family which consists of husband, wife, and children as well as family outside the core family. It is stated by Mantra (1994) that remittance will be sent in much amount by migrant if his family in hometown is family core. In contrast, remittance will be sent in small amount by migrant if his family is not family core.

Remittance Delivery Purpose. It is undeniable that migrants deliver remittance with purposes. Therefore, it brings benefits to his hometown. Based on the previous studies, there are various purposes in delivering remittance, such as to fulfill family's daily needs, for investment, special days, and pension plan.

Curson (1981) in (Sudibia, 2007) formulates six purposes of remittance delivered by migrants to hometown, including: 1) to support family's life, 2) celebrate family cycle, 3) flow of money for continuous migration, 4) debt payment, 5) investment, and 6) pension plan.

\section{METHODS OF RESEARCH}

This study took place in West Sumbawa Regency. The respondents of this study are the gold mining workforces of PT. Amman Mineral Nusa Tenggara that actively sent remittance every month to hometown. The approach applied in this study is quantitative research. The influential variables are revenue, education, duration of stay, and amount of dependents. In order to make the variables being analyzed clearer, the operational definition of each variable is necessary. Amount of remittance $(\mathrm{Y})$ is the amount of money or goods that are sent by non-permanent migrants to hometown. It is sent in Rupiah (Rp) unit. Revenue (X1) is the entire revenue got by gold mining workforces in a month. This variable is measured with Rupiah (Rp) unit. Education (X2) is the latest education of gold mining workforces that is measured in a year. Duration of stay (X3) is the length of migrant's stay in destination area which is measured in a year. Amount of dependents (X4) is the number of family members that should be backed up in hometown.

The data used was primary data which was obtained through face-to-face interview with gold mining non-permanent workforces in West Sumbawa Regency. This study applied multiple linear regression technique in order to find out the influential factors towards remittance delivered by non-permanent workforces to hometown. The general model of multiple linear regressions is as follows:

$$
Y=\alpha+\beta_{1,} X_{1}+\beta_{2,} X_{2}+\beta_{3,} X_{3}+\beta_{4}, X_{4}+e
$$


Where:

$\mathrm{Y}=$ remittance amount;

$\alpha=$ constant;

X_1 = Revenue;

$X-2=$ Education;

X_3 = Duration of stay;

$X 44=$ Amount of dependents;

$\beta \overline{1}, \beta 2, \beta 3, \beta 4=$ Regression coefficient;

$\mathrm{e}=$ term of error.

Before analyzing multiple linear regressions, the test of classic assumption was conducted, and then $\mathrm{F}$ test and $\mathrm{t}$ test.

\section{RESULTS OF STUDY}

Hypothesis Test Results. Hypothesis test in this study used multiple linear regression through SPSS 16.0. The results yielded as follows:

Tabel $1-$ Coefficients $^{a}$

\begin{tabular}{|l|c|c|c|c|c|}
\hline \multirow{2}{*}{ Model } & \multicolumn{2}{|c|}{ Unstandardized Coefficients } & $\begin{array}{c}\text { Standardi } \\
\text { zed Coefficients }\end{array}$ & \multirow{2}{*}{$\mathrm{t}$} & \multirow{2}{*}{ Sig. } \\
\cline { 2 - 4 } & $\mathrm{B}$ & Std. Error & Beta & & \\
\hline (Constant) & .490 & .576 & & .852 & .397 \\
Revenue & .562 & .057 & .770 & 9.891 & .000 \\
1 Education & .122 & .116 & .074 & 1.055 & .294 \\
Duration of Stay & -.081 & .040 & -.163 & -2.048 & .043 \\
Amount of Dependents & .292 & .123 & .167 & 2.384 & .019 \\
\hline
\end{tabular}

a. Dependent Variable: Remittance amount.

Source: Primary data, 2017.

Based on coefficients results above, it is obtained equality model as follows:

$$
Y=0,490+0,562 X \_1+0,122 X \_2+(-0,081) X \_3+0,292 X \_(4)+e
$$

Constant $(\alpha)$ is 0,490 which mean that if revenue, education, duration of stay, and amount of dependents in hometown result nothing or its value is 0 , then amount of remittance sent home is 0,490 .

In statistical test, it was obtained that coefficient regression of revenue variable is 0,562 meaning that when it increases every 1 percent, it will increase 0,562 of the amount as well towards the remittance to hometown with assumption that other variables are constant. This variable has t-count value $>$ t-table $(9,891>0,1661)$ or it is in rejection of $\mathrm{Ha}$, then $\mathrm{HO}$ is accepted and rejects $\mathrm{H} 1$. Sig value is $0,000<0,1(\alpha=10 \%)$. As a result, revenue variable has positive and significantly influence towards remittance delivery to hometown.

In education variable, it is statistically obtained that coefficient regression result of education variable is 0,122 meaning that education increases 1 percent will make increase towards remittance delivery which is 0,122 with assumption that the other variables are considered constant. This variable has t-count value $>$ t-table $(1,055<1,661)$ or in acceptance of $\mathrm{Ha}$ then $\mathrm{H} 0$ is accepted and rejects $\mathrm{H} 1$. Sig value is $0,294>0,1(\alpha=10 \%)$. It is therefore education has positive and insignificant influence towards remittance delivery to hometown.

In relation with duration of stay variable, it is statistically obtained that coefficient regression of it is $-0,081$ which mean that when this variable increase 1 percent will decrease remittance delivery that is $-0,081$ with assumption that the other variables are considered constant. This variable has t-count value $>$ t-table $(-0,048<1,661)$ or is in rejection of $\mathrm{Ha}$, then $\mathrm{HO}$ is accepted and rejects $\mathrm{H} 1$. Sig value is $0,043<0,1(\alpha=10 \%)$, then it is stated that 
duration of stay has negative and significant influence towards remittance delivery to hometown.

Moreover, amount of dependents variable is statistically obtained coefficient regression which is 0,292 meaning that when it increases 1 percent, it will increase 0,292 amount of remittance to hometown as well with assumption that the other variables are constant. This variable has t-count value $>$ t-table $(2,384>0,1661)$ or is in rejection of $\mathrm{Ha}$, then $\mathrm{HO}$ is accepted and rejects $\mathrm{H} 1$. Sig value is $0,019<0,1(\alpha=10 \%)$ which means that amount of dependents has positive and significant influence towards remittance delivery to hometown.

Revenue variable influence towards remittance sent home. Revenue variable positively and significantly influences remittance delivery to hometown. This can be seen from significant value obtained was $0,000<0,1(\alpha=10 \%)$, with coefficient regression of it was 0,562 . It means that when it increases every 1 percent, it will increase $56,2 \%$ of the amount as well towards the remittance to hometown with assumption that other variables are constant. As a result, revenue variable has positive and significantly influence towards remittance delivery to hometown.

It can be concluded that the more workforces of gold mining are, the higher probability of remittance delivery is. In contrast, if revenue amount sent is small, it is then used for consumption. Such circumstance occurs because of daily needs that grow rapidly. The small amount of remittance is used to fulfill daily needs by family in hometown. Therefore, the more revenue received by workforce, the more amount of remittance sent will be.

This is in line with Rizal Ichsan and Putro's (2015) study that there is positive and significant relationship between revenue amount and remittance delivery to hometown. It is also strengthened by Adisavitri (2016) that revenue shows positive impact toward remittance sent.

Education variable influence towards remittance sent home. Educational level variable positively and insignificantly influences remittance delivery to hometown. It can be seen from significant value that $0,294>0,1(\alpha=10 \%)$, with coefficient variable of it was 0,122 . It implies that educational level does not influence in remittance delivery to hometown. In other words, those who have higher educational level does not determine amount of remittance sent to hometown, instead it is used for own needs.

It is related to a study done by Ranathunga (2011) that those who graduated from latest education have negative impacts towards decision taken to send remittance. This study shows that respondents whose education is high, their revenue are used for his education, so that it is not possible to send remittance home.

Duration of stay variable influence towards remittance sent home. Duration of stay variable negatively and significantly influence remittance delivery to hometown. It is displayed by the significant value $0,043<0,1(\alpha=10 \%)$, with coefficient regression was 0,081 . It means that when this variable increases 1 percent will decrease remittance delivery that is $-0,081$ with assumption that the other variables are considered constant. It is related to Lucas (1985) who argues that the longer migrants stay in destination area, the lesser amount of remittance sent home. It is caused by the negative influence of long duration of stay in which there are no more family members to be financially supported in hometown (his children got a job already in hometown). Also, it is due to the social bond of family that is no longer strong.

Amount of dependents variable influence towards remittance sent home. Amount of dependents variable positively and significantly influences remittance delivery. It can be seen from significant value $0,019<0,1(\alpha=10 \%)$, with coefficient regression value 0,292 . Such state means that amount of dependents influence migrant's decision in allocating remittance sent home. It is seen from amount of dependents had by gold mining workforces in hometown.

This study is related to another study conducted by Ardana (2011) that number of family members in hometown significantly influences remittance delivery. Remittance amount will get increased if the remittance receiver is family core which manifests responsibility and moral supports of a family to another family get higher. 


\section{CONCLUSION AND SUGGESTIONS}

Based on data analysis and discussion above, it can be summed up that revenue and amount of dependents positively and significantly influences, whereas duration of stay negatively and significantly influences towards remittance delivery to hometown. Meanwhile, education does not significantly influence remittance sent home. It indicates that education background does not determine amount of remittance sent to home.

Such productive ages of migrants will make them easier in performing their job in destination area in order to reach something expected. Remittance amount sent by workforce of PT Amman Mineral Nusa Tenggara in West Sumbawa Regency is approximately 3 million $>9$ million in a month. The different amount of remittance sent home is determined by four independent variables (revenue, education, duration of stay, and dependents amount). The higher revenue received by workforces, the larger proportion of revenue sent home is as well.

Based on the results discussion and conclusion, the suggestions are as follows:

By seeing large number of workforces that come from outside West Sumbawa Regency for work, especially work in mining industrial sector, it is expected to the government to improve human resources quality, particularly in terms of skills and abilities in working. Therefore, it is also hoped that local male youth to be prioritized to work in their hometown, i.e. in gold mining industrial sector.

Government as a simulator and facilitator whose job does not only to attract investors to enter and take advantage of natural resource, but also needs to understand development management, especially trade sector development and pushes services sector to improve regional economy.

Having many migrants working in West Sumbawa should make government maximize their efforts in providing facilities, safety, and comfort to migrants. Hence, their revenue is not completely sent to hometown, but also used to buy something in which by building proper facilities, these migrants will spend some of their revenue in destination area.

\section{REFERENCES}

1. Adisavitri, A. A. (2016). Pengaruh Faktor Ekonomi, Sosial dan Demografi Terhadap Pengiriman Remitan Migran Warga Desa Pandak Gede Yang Bermukim Di Kabupaten Jembrana, XII, 48-56.

2. Alatas, S. (1999). "Macro Patterns of Internal Migration in Indonesia, 1971- 1990." Lembaga Demografi, Fakulatas Ekonomi, Universitas Indonesia.

3. Connel, Jhon, Biplab Dasgupta, Roy Laishley, M. L. (1976). Migration From Rural Areas, The Evidence from Village StudiesMigration From Rural Areas, The Evidence from Village Studies. Delhi: Oxford University Press.

4. Connel, J. (1980). Remmitances and Rural Development: Migration, Dependency and Inequality in The South Pacific. Dalam Occasional Paper No.22. The Australian National University.

5. Curson, P. (1981). Remittances and Migration The Commerce Of Movement. In Gurdev Singh Gosal (Ed), Population Geography Vol 3, No2: hal 77-95.

6. Departemen Tenaga Kerja dan Transmigrasi R.I. (2003). Undang-undang Republik Indonesia Nomor 13 Tahun 2003 Tentang Ketenagakerjaan.

7. Firman, T. (1994). Migrasi Antarprovinsi dan Pengembangan Wilayah di Indonesia.

8. Hugo, Graeme, J. (1978). Population Mobility in West Java. yogyakarta: Gadjah Mada University Press.

9. I Ketut Ardana. (2011). Faktor-Faktor yang Mempengaruhi Besarnya Pengiriman Remitan ke Daerah Asal Studi Kasus Tenaga Kerja Magang Asal Kabupaten Jembrana di Jepang, 1-24.

10. Kasto. (2002). Mobilitas Penduduk dan Dampaknya Terhadap pembangunan Daerah:Kumpulan Tulisan Tentang Mobilitas Penduduk Indonesia-Tinjauan Lintas Disiplin. yogyakarta: Pusat Studi Kependudukan dan Kebijakan UGM. 
11. Lucas, R. (1985). Motivation to Remit: Evidence from Botswana. Journal of Political Economy, 93 (5), 901-918.

12. Mantra, I. B. (1994). Mobilitas Sirkuler dan Pembangunan Daerah Asal. (Warta Demografi. Vol.3;, Ed.). yogyakarta: PPK-UGM.

13. Mantra, I. B. (2000). Demografi Umum. yogyakarta: Pustaka Pelajar.

14. Mochtar, N. (1984). Merantau Pola Migrasi Suku Minangkabau (Cetakan K). Jogjakarta: Gadjah Mada University Press.

15. Mulyadi, S. (2003). Ekonomi Sumber Daya Manusia. Jakarta: PT Raja Grafindo Persada.

16. Murdiyanto E. (2001). Remitan migran sirkuler dan gejala perubahan struktur sosial di perdesaan Jawa. Institut Pertanian Bogor. Retrieved from Bogor

17. Naomi Goma, J. (1993). Mobilitas Tenaga Kerja Flores Timur ke Sabah Malaysia dan Pengaruhnya Terhadap Daerah Asal, Studi Kasus Desa Neleren Kecamatan Adomaru Kabupaten Flores Timur. Yogyakarta. UGM.

18. Perera, fernando, Warnakulasaruria, dan R. (2011). International Breastfeeding Juornal, (diakses 23 juni 2017). Retrieved from htt://www.internationalbreasfeedingjournal.

19. Reksoprayitno. (2004). Sistem Ekonomi dan Demokrasi Ekonomi. Jakarta: Bina Grafika.

20. Sudibia I Ketut. (2007). Mobilitas Penduduk Nonpermanen Dan Kontribusi Remitan Terhadap Kehidupan Ekonomi Dan Sosial Rumah Tangga Di Daerah Asal. Dalam Jurnal Piramida, Vol. 3, No 1. Denpasar: Pusat Penelitian Kependudukan Dan PSDM Universitas Udayana.

21. Suyanto. (2000). Refleksi dan Reformasi Pendidikan di Indonesia Memasuki Milenium III. yogyakarta: Adicita, 80.

22. Undang-udang Nomer 25 tahun 1997. (n.d.). Undang-undang Republik Indonesia, Nomor 25 Tahun 1997 Tentang Ketenagakerjaan. Jakarta: Departemen Dalam Negeri.

23. Weeks, J. R. (2004). Population: An Introduction to Concepts and Issues (9th editio). Belmont, California: Wadsworth Publishing.

24. Wijono, N. (1994). Mobilitas Penduduk dan Revolusi Potensi Konflik. Warta Demografi, No 6: 4 -7.

25. Yuliana Sudremi. (2007). Pengantar Sosial Ekonomi SMA/MA 2 Kelas XI. Jakarta: Bumi Aksara. 


\title{
DEVELOPMENT OF EXTERNAL CONTROL BASED ON THE AVIDIN GENE OF BIRDS FOR POLYMERASE CHAIN REACTION IN REAL TIME
}

\author{
Tolstikh N.A., Candidate of Biological Sciences \\ Yushkov Y.G., Doctor of Agricultural Sciences \\ Gordov V.S., Candidate of Biological Sciences \\ Leonov S.V., Senior Researcher \\ Siberian Federal Scientific Center of Agrobiotechnologies of the Russian Academy \\ of Sciences, Novosibirsk, Russia \\ Kashapova S.V. ${ }^{*}$, Candidate of Veterinary Sciences \\ Novosibirsk State Agrarian University, Novosibirsk, Russia \\ *E-mail: setochka07@mail.ru
}

\begin{abstract}
Intensive development of poultry farming is directly connected with the development of new methods of diagnosing diseases. One of these methods, allowing an accurate diagnosis in a short time, is a polymerase chain reaction. The basic principles of PCR are firmly established in the daily practice of research and clinical laboratories. This article presents the results of the development of external control for polymerase chain reaction in real time for the diagnosis of bird diseases. The reaction has specificity and a sensitivity of 200 copies per $\mathrm{ml}$. The calibration graph is used to estimate the number of birds' genome per reaction.
\end{abstract}

\section{KEY WORDS}

Polymerase chain reaction, real time, gene, avidin, infection, biomaterial, bird, primers.

During recent years, more and more molecular-biological methods find use in agriculture, especially in veterinary medicine. One of such methods is -Polymerase Chain Reaction (PCR), allowing to accumulate section of deoxyribonucleic acid (DNA) inside of a test tube in almost unlimited quantities $[9,13,14]$. Basic principles of polymerase chain reaction for the detection of DNA was proposed by Kleppe and co-authors in 1971 [5]. Currently, polymerase chain reaction (PCR) is the "gold standard" in the diagnosis of many viral and bacterial infections of human beings and animals. Register the result of the PCR is possible at the end of the reaction («endpoint»), or throughout the reaction («real-time»)[15, 3, 4, 2, 10]. In the early 90 s of last century, the researchers proposed to register the accumulation of DNA during PCR $[11,12]$. Registration of the reaction product in «real time» helps to determine not only the presence/absence of DNA/RNA pathogen in the sample of biological material, but also to determine its concentration. The obtained data can provide high value of the flow of epidemic process in the population, and also play an important role in study of the infectious process.

The main problem for quantitative analysis by PCR «in real time» is the standardization of methods of selection of the material $[20,1,7,19]$. For detecting quantities of DNA causative agent of infectious disease in scrapes, of blood or other body fluids, it is sufficient to use a standardized intake method of the biomaterial, and the same methods of DNA extraction $[6,16]$. Working with samples of organs or tissues, it is impossible to create a standardized method of sampling of biological material because they have different structure and density, respectively a different number of cells. In this case, quantification of the DNA matrix of the infectious agent is conducted in relation with the number of the reference matrix, which is often presented by the DNA of the host, so-called «external control». To quantify an infectious agent is used the ratio of the number of DNA of external control to the amount of DNA of the infectious agent. Once selected conditions of "real-time» quantitative PCR execution for determination of the external control, it is possible to use this reaction with all reactions, aimed 
at the quantitative detection of DNA infectious agents in the biomaterial. Problems listed in the introduction led to the goals and objectives of the study.

Goal of study is to develop an external control for quantifying DNA infectious agents of birds for polymerase chain reaction «in real time».

To achieve the goal, were formulated following tasks: selection a target for the development of the external standard PCR «in real time»; selection of specific oligonucleotide primers; testing of the temperature modes of PCR «in real time».

\section{METHODS OF RESEARCH}

Material for choice of the target was the sequence of the gene which is coding a protein of the avidin, deposited on the website http://www.ncbi.nlm.nih.gov.

The spleens of broiler chickens were exposed to the DNA isolation and subsequent «real-time» PCR. For the selection of the sequences of the primers was used the software «Primer Premier 5.0» and «DNAstar». For the detection of the external control was chosen the method of interaction of double-stranded DNA with the intercalating dye SYBR Green as the most common and affordable.

\section{RESULTS AND DISCUSSION}

The normalization of the results of the polymerase chain reaction is necessary in order to correct the variation between the samples. The starting material obtained from various sources usually differs in weight, number of cells, preservation, and amount of DNA. The ideal gene for normalization should be expressed at the same level in all cells of the body, regardless of the conditions. $[17,18]$. Such properties are possessed by the gene of avidin.

For the development of external controls for quantitative PCR diagnostics of pathogens of birds' diseases was chosen the avidin gene. The nucleotide sequence of the avidin gene consists of 1133 base pairs.

Based on the analysis of the genome were selected following primers: direct 5'TGCAGTGCTCGCTGACTGGG-3' complementary sequence at position 173 - 192 BP; reverse 5'-AGGTGGGCTGGCAGGCTCT-3' complementary sequence at position $334-352$ BP PCR was carried out on a fragment at position 173-352п.N. 5'Tgcagtgctcgctgactgggaaatggaccaacaacctgggctccatcatgaccatcagggctgtgaacagcagaggtgaattc gcaggcacctacctcacagctgtagcagataatccaggaaacatcaagctatcaccactgcttgggatccaacacaaaagagcct gccagcccacc3'.

Components of the reaction to study single DNA sample: $10 \times$ buffer $\mathrm{pH}$ of 8.8 and 2.5 ál; dNTPs $(0.5 \mathrm{~mm}$ each) and $2.5 \mu \mathrm{l}$; a mixture of primers $(10 \mathrm{~mm}$ each) $-0.3 \mu \mathrm{l}$; autoclaved bidistilled water and $5.0 \mu \mathrm{l}$; Taq polymerase at a concentration of $5000 \mathrm{u} / \mathrm{ml}$ at a dilution of $1: 16$ a 0.5 ál; SYBR Green (1:250) and $0.25 \mu \mathrm{l}$.

The reaction was performed in a real-time amplifier using the software.

In the first phase of the work needed to build a specific amplicon and to identify its melting temperature. Evaluation of reaction was carried out based on the schedules, reflecting the synthesis of amplicon and its quality. Data analysis was performed using melting curve. At the end of the PCR the tube was slowly heated from 54 to $95^{\circ} \mathrm{C}$, simultaneously recording the change in fluorescence. For the developed reaction it is equal to $86^{\circ} \mathrm{C}$.

The next step was to establish the optimal annealing temperature. For this, we carried out the reaction in the temperature gradient in the range of $63.3-54.1^{\circ} \mathrm{C}$. The optimal primer annealing temperature was $58^{\circ} \mathrm{C}$.

To determine the number of genome equivalents in a PCR product, we used the conversion of known concentrations of DNA with a known sequence in molar concentration. For this, we carried out the electrophoresis obtained in the course of PCR products in $6 \%$ polyacrylamide gel. From the gel were cut out the phase, which contained DNA relevant to the calculated length and the extraction of the fragment. In the fluid obtained after selection was determined DNA concentration on the spectrophotometer, using the reagent kit HS DNA according to the Protocol. The conversion of the concentrated DNA into the molar 
concentration was conducted using the program «Conversion: weight - moles (for Nucl. acid)» (http://molbiol.ru/scripts/01_07.html). Through a series of tenfold dilutions of PCR product with known molar concentration, were received samples used as calibrators. The analytical sensitivity of the reaction was 200 copies of DNA avidin birds in $1 \mathrm{ml}$, which corresponds to the 31 threshold cycle in PCR «in real time».

To study the specificity of the reaction were used human, dog, cat, pigeon, chicken and pig DNA samples. A positive result was detected in samples from pigeons and chickens. Thus, the developed reaction is specific.

To quantify external control of PCR «in real time» we developed the calibration curve (Figure 1).

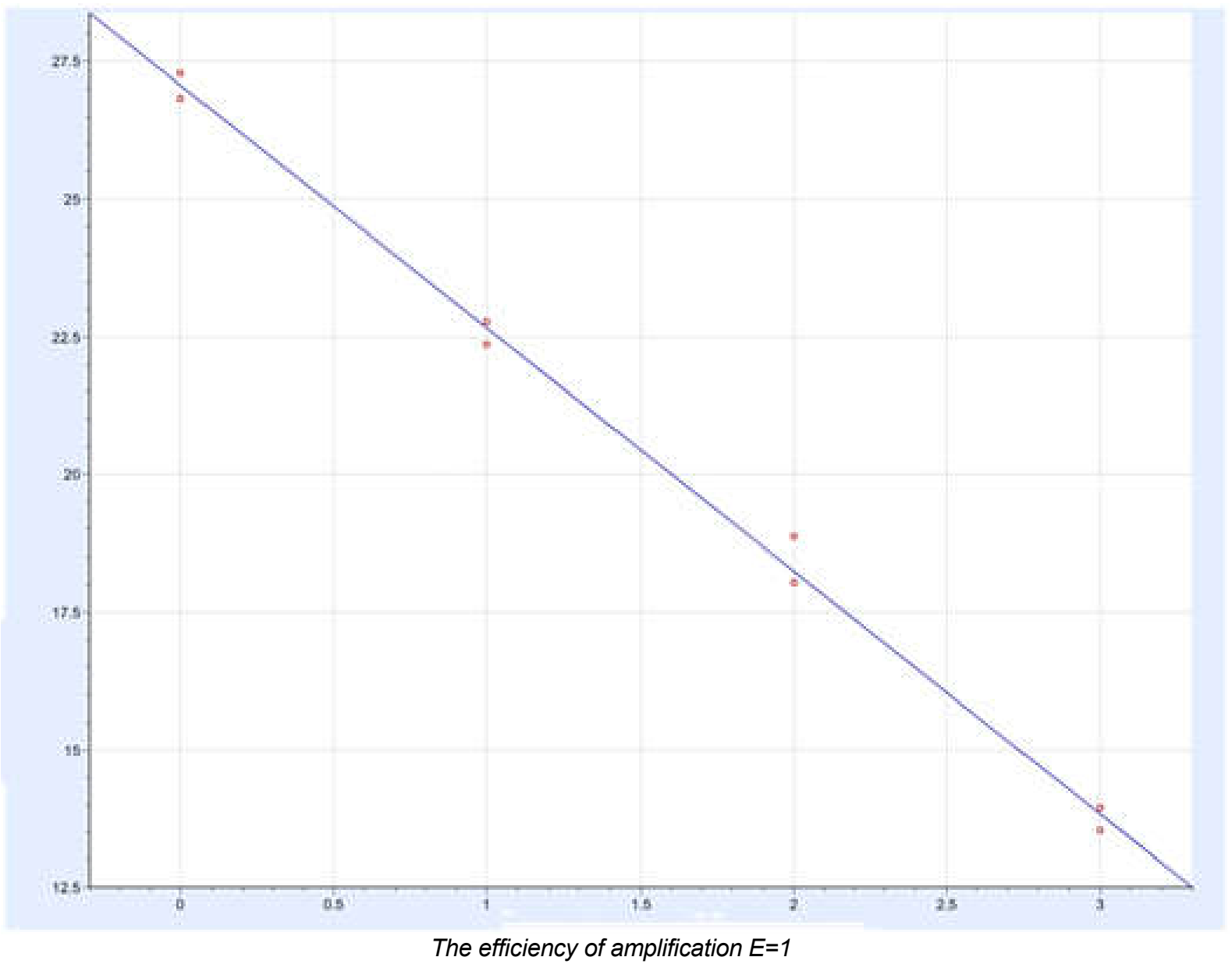

Figure 1 - Calibration chart for determination of avidin concentration

Evaluating the calibration curve, efficiency of the reaction is quite important, for each batch of reactions it must be $100 \%(E=1)$. Small differences in the efficiency of the reaction lead to significant differences of results obtained during PCR [15].

The obtained calibration graph allows determining the concentration of avidin in the cells and tissues of the poultry organism.

\section{CONCLUSION}

The avidin gene of birds was chosen as the target for the development of external PCR control «in real time». It is present in all cells of the body of the bird and is expressed in the same amount. To perform this reaction, primers flanking the avidin gene sequence of birds at position 173-352 bp were chosen. The optimum annealing temperature of the impurities was $58^{\circ} \mathrm{C}$. By means of the developed «real time» PCR on the avidin gene of birds, which is 
taken as the external control, it is possible to estimate the copy number of the genome of birds. The reaction is specific; its sensitivity is 200 copies of DNA avidin of birds in $1 \mathrm{ml}$.

\section{REFERENCES}

1. Annoscia, G. A new PCR assay for the detection and differentiation of Babesia canis and Babesia vogeli / G. Annoscia [ et al.] // Ticks and Tick-borne Diseases. - 2017. - №17. www.ncbi.nlm.nih.gov/pubmed/28739301

2. Arezi, B. Amplification efficincy of termostsble DNA polymerases / B. Arezi [ et al.] // Analitical biochemistry. - 2003. - №321. - P. 226-235.

3. Atallah, Z. K. Multiplex real-time quantitative PCR to detect and quantify Verti-cillium dahliae colonization in potato lines that differ in response to Verticillium wilt / Atallah, $Z$. K. [ et al.] // Phytopathology. - 2007. -№97. - P.865-872.

4. Bates, J. A. The application of real-time PCR to the identification, detection and quantification of Pyrenophora species in barley seed / Bates, J. A. [ et al.] //Mol. Plant Pathol.- 2001. - №2. - P.49-57.

5. Borsu, L. Clinical Application of Picodroplet Digital PCR Technology for Rapid Detection of EGFR T790M in Next-Generation Sequencing Libraries and DNA from Limited Tumor Samples/ L. Borsu [et al.] // J Mol Diagn. - 2016. - №18(6). - P.903-911.

6. Chiu, C.H. Clinical characteristics and treatment outcomes of lung adenocarcino-mas with discrepant EGFR mutation testing results derived from PCR-direct se-quencing and real-time PCR-based assays / C.H. Chiu // J Thorac Oncol. - 2014. -№9(1). - P.91-6.

7. Denis, J.A. Droplet digital PCR of circulating tumor cells from colorectal cancer patients can predict KRAS mutations before surgery // Mol Oncol. - 2016. -№10(8). P.1221-31

8. Glynn, N. C. Evaluation of PCR assays for quantifying seed-borne infection by Fusarium and Microdochium seedling blight pathogens // J. Appl. Micr. - 2010. - №108. - P.81-87.

9. Graaf, A. Real-time reverse transcription PCR-baced sequencing-independent pathotyping of Eurasian avian influenza A viruses of subtype H7 // Virol J. - 2017. - №14

10. Gudmestad, N. C. A real-time PCR assay for the detection of Clavibacter michi-ganensis subsp. sepedonicus based on the cellulase A gene sequence/ N. C Gud-mestad // Plant Dis. - 2009. - №93. - P.649-659.

11. Higuchi, R. Kinetic PCR analysis: Real-time monitoring of DNA amplification reaction / R. Higuchi [ et al.] // Biotechnology. - 1993. - №11. - P. 1026-1030.

12. Higuchi, R. Simultaneous amplification and detection of specific DNA sequences / R. Higuchi [ et al.] // Biotechnology. - 1992. - №10(4). - P. 413-417.

13. Lee, KY Predictors of mortality in autoimmune disease patients with concurrent cytomegalovirus infections detected by quantitative real-time PCR / K.Y. Lee [ et al.] // PLoS One. - 2017. - №7. - e0181590.

14. Medrano, G. Comprehensive selection of reference genes for quantitative RT-PCR analysis of murine extramedullary hematopoiesis during development / G. Medrano [et.al.] // PLoS One. - 2017. - №7. - e0181881

15. Real-time PCR : a textbook / D. V. Rebrikov [ et al.]; ed. by D. V. Rebrikov. - 2nd ed. Rev. and additional - M: BINOM. Knowledge laboratory, 2008. - 223 p.

16. Sarier,a M., Results of Real-time Multiplex Polymerase Chain Reaction Assay in Renal Transplant Recipients With Sterile Pyuria / M. Sarier [et.al.] //Transplantation Proceedings. - 2017. - №6. - P. 1307-1311

17. Schmittgen, T.D. Effect of experimental treatmen onhouskeeping gene expression: validation by real-time, quantitative RT-PCR / T.D. Schmittgen, B.A. Zakrajsek // J Biochem Biophys Metods. - 2000. - №46. - P. 69-81

18. Studies on polynucleutides. XCVI Repair replication of short synthetic DNA's as catalyzed DNA polymerase // Journal of Molecular Biology. - 1971. - №56. - P. 341-361.

19. Vandesomple, J. Accurate normalization of real-time quantitative RT-PCR data by geometric averaging of multiple internal control genes // Genome boil.- 2002: 3.

20. Zhang, B.O Comparison of droplet digital PCR and conventional quantitative PCR for measuring EGFR gene mutation // Exp Ther Med. - 2015. - №9. - P.1383-1388. 
DOI https://doi.org/10.18551/rjoas.2017-08.29

\title{
GENETIC DEFECTS OF BEEF CATTLE AND NECESSITY OF THEIR MANAGING
}

\author{
Konovalova E.N., Leading Researcher \\ Institute of Animal Husbandry named after L.K. Ernst, Podolsk, Russia \\ E-mail: konoval-elena@yandex.ru
}

\begin{abstract}
One of the ways to increase profitability of beef production is development of meat cattle breeding through formation good breeding base. Creation the high value herds are impossible without attraction of the best genetic resources. However, even high value animals can carry undesirable alleles of genetic conditions and using such animals in breeding programs without control can cause serious economic losses instead expected benefit. And so it's important to managing of genetic defects avoiding their manifestation in populations. In our study, we have analyzed mechanisms of appearance and inheritance of genetic conditions and principles of their classification. We have followed the dynamics of appearance of genetic diseases in XX-XXI centuries and established that the distribution of genetic abnormalities has been associated with the development of artificial insemination approach. We also have revealed that genetic defects occur in all cattle breeds independent from productivity direction. Using the data of American Aberdeen Angus Association we have counted that the frequency of the most of common genetic defects is reduced thanks of development of DNA technologies. Moreover, we have familiarized with the approaches of the breed associations of different countries in relation to genetic abnormalities. Based on obtained data we have developed the guidelines for control of genetic defects of beef cattle to prevent their spread in populations.
\end{abstract}

\section{KEY WORDS}

Genetic defects, beef cattle, breeds, congenital abnormalities, disease, genetic anomalies, genetic conditions, heredity diseases.

The agricultural development and control of agricultural market is one of the points of the State program [1]. The most important role for the fast development of the area will belong to good breeding base due attraction the best of foreign and domestic breeding resources. In relation to quantity and quality of females and bulls, the breeding base must be respond to modern requirements of breeding of the most perspective beef breeds.

The animals of Aberdeen Angus, Hereford and Limousine breeds are especially interesting for this purpose. Thanks to the excellent acclimatization ability of animals of these breeds are well adapted to various weather conditions, possess such valuable qualities as the rapid economic and physiological maturity, good reproductive ability and a high genetic potential for meat productivity indexes [2, 3].

However, almost all breeds have been identified genetic defects, the distribution of which instead of the expected profit can cause serious economic damage [4].

The reasons for such defects are gene mutations, leading to disruption of the synthesis of vital proteins and, as a result, violation the functions of body [5]. Most of them have simple recessive model of inheritance. It means that mutation causing the defect determines of recessive allele and for appearance of the disease the animal must inherit recessive alleles from both parents. In case if the animal inherits normal dominant allele from one parent and mutant recessive allele from another one it won't show clinical signs but it's a carrier of the defect.

To date, there were developed methods for accurate diagnostics based on DNA analysis for almost all of the described defects [6].

In this regard, there is a need for such measures as the careful genetic control of breeding material, which is a possible thanks to the development of modern methods of molecular genetics. 
Classification of beef cattle genetic defects. The most common genetic defects of these breeds animals classified in table 1. As shown in the table, all genetic defects are divided into two categories depending from the severity of clinical signs. Defects in class I are lethal, significantly disrupt or reduce reproductive performance. Defects in class II are not lethal or do not have a significant effect on reproduction, growth or meat productivity, however, are expressed in anomalous characteristics, are economically undesirable [7]. From table 1 it's seen that the most of the meat cattle defects impress the organs of the nervous system, musculoskeletal system and skin. Moreover, if the vast majority of skin diseases refer to the class II defects, the vast majority of nervous diseases - defects of class I, i.e. lethal. Defects of the musculoskeletal system belong to two classes, but it is likely that in the case of I class defects also affects the nervous system.

Table 1 - Classification of the genetic defects

\begin{tabular}{|c|c|c|}
\hline \multirow{2}{*}{$\mathrm{n} / \mathrm{n}$} & \multicolumn{2}{|c|}{ Class } \\
\hline & I & II \\
\hline Nervous system & $\begin{array}{c}\text { Multiplex arthrogriposis }(\mathrm{AM})^{\star} \\
\text { Neuropathic hydrocefaly }(\mathrm{NH}) \\
\text { Alfa-mannosidosis }(\mathrm{MA}) \\
\text { Pulmonar hepoplasia with anasarca }(\mathrm{PHA})\end{array}$ & Idiopathic epilepsy (IE) \\
\hline Musculoskeletal system & $\begin{array}{l}\text { Osteopetrosis (OS) } \\
\text { Tibial hemimelia (TH) }\end{array}$ & $\begin{array}{c}\text { Contractual arachnodactyly (CA) } \\
\text { Double mussling (M1) } \\
\text { Polimelia (DD) } \\
\text { Syndactilia (SY) } \\
\text { Dwarfism (D2) }\end{array}$ \\
\hline Skin & - & $\begin{array}{c}\text { Hypotrichosis (HY) } \\
\text { Iridis heterochromia }(\mathrm{HI}) \\
\text { Color dilution (DL) } \\
\text { Protoporfiria (Proto) } \\
\text { Oculocutaneous hypopigmentation }(\mathrm{OH})\end{array}$ \\
\hline
\end{tabular}

Note: * in parentheses is given the generally accepted abbreviation of the defect.

Dynamics of appearance of genetic defects in $X X-X X I$ centuries. To date, most information on genetic defects in animals collected in the OMIA database (online Mendelian inheritance of animals), which contains information about genes of 189 animal species. Its analysis has shown that, of 506 genetic mutations of cows (Bos taurus) genetic defects recognized 465 mutations, because they lead to structural and functional changes of the body [8]. The remaining 41 mutation are the cause of only morphological changes, without disturbing the life of the animal (the formation of various blood groups, growth rate, temperature tolerance, fecundity, change in color, fur structure, minor scars on the skin, resistance or sensitivity to the hemolytic action of leukotoxin, color of fat) and therefore are not considered as defects. The analysis has also revealed that genes, mutations of which cause the birth defects are known only for 138 mutations, accounting for $27.3 \%$ of their total number. That is, the vast majority of genetic defects are in fact not studied.

Analysis of the dynamics of genetic defects has detected that in the first half of the twentieth century there were a small number of occurrences of congenital abnormalities. Most of them were isolated cases, related to deformities according to clinical signs. Such a low number of mutations could be due to the low degree of inbreeding and pedigree quality and diagnostic work, in particular, the absence of registration of such cases. Beginning from 1950 the number of genetic abnormalities increased twice. It happened probably due to the use of artificial insemination and, as a consequence, increases the degree of inbreeding in populations. 40 years later (1990) the number of anomalies has grown rapidly that could be related to the best of their diagnosis through the development of DNA methods. In 2000 the frequency of manifestation of genetic defects has decreased dramatically (2.4 times), but in the last decade it is at the same high level as in the 1990, that demonstrates that this problem is not solved (Figure 1). 


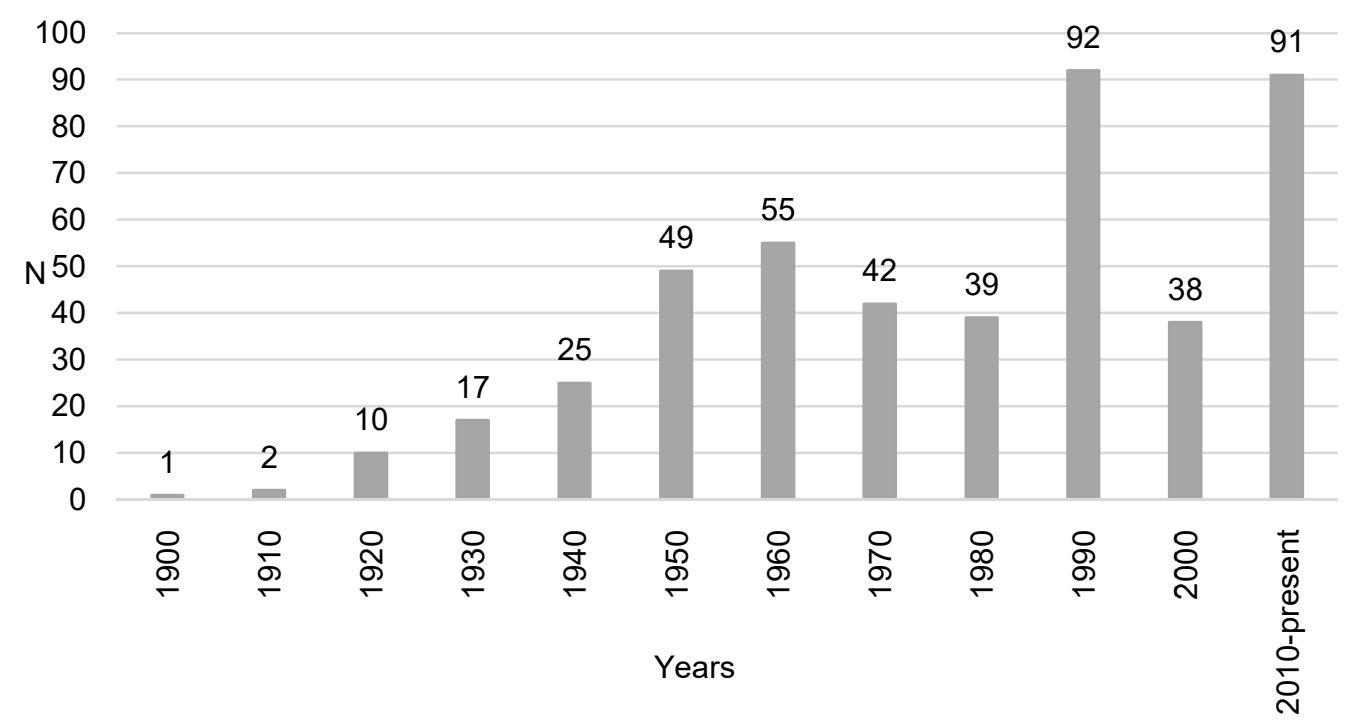

Figure 1 - Dynamics of manifestations of genetic defects in the $X X-X X I$ centuries

Analyzing the degree of manifestation of genetic defects depending on the direction of productivity (Figure 2), we have revealed that in dairy cattle the frequency of manifestation of genetic defects was almost two times more than in meat cattle (37\% and $19 \%$, respectively). Despite this fact, the largest share of genetic defects was in animals of universal direction of productivity $(44 \%)$. This allows us to conclude that genetic defects of the development in dairy and beef cattle are manifested equally.

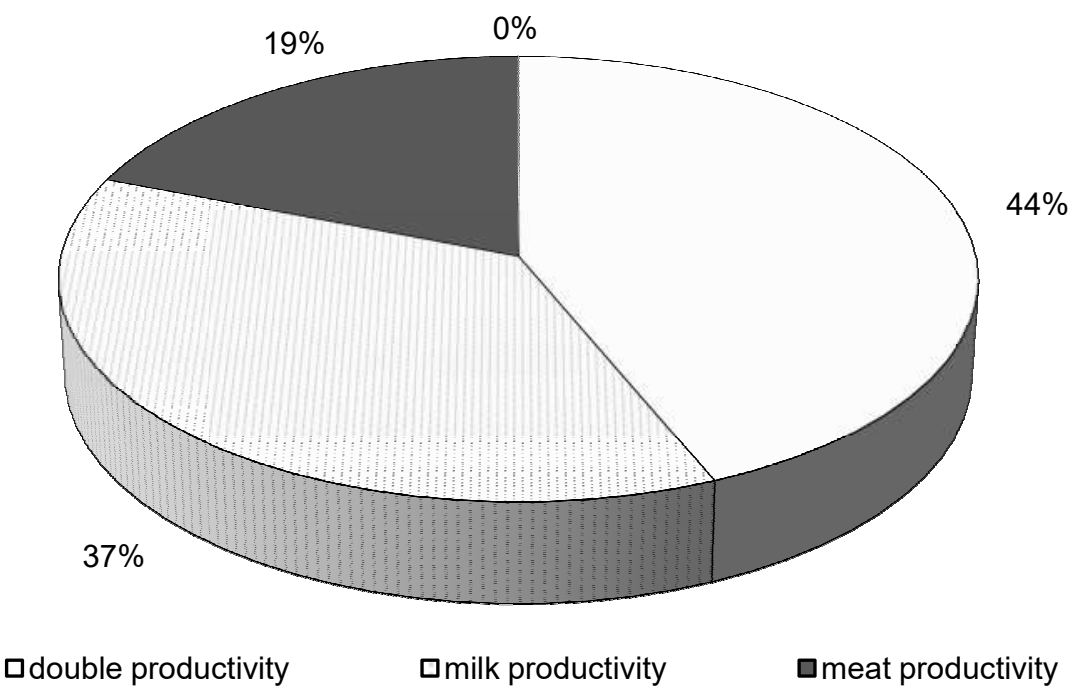

Figure 2 - The frequency of occurrence of genetic defects in cattle, depending on the direction of productivity

Analysis of frequency of the genetic defects. Presently, American Association of the Aberdeen Angus breed (AAA) has most data on the prevalence of genetic defects [9]. We have analyzed this database and found that currently (March 2017) the incidence of genetic defects ranging from 0.3 to $20.4 \%$ (table. 2). Moreover, the frequency of lethal genetic defects is relatively high. Among of the investigated animals $1.7 \%$ were carriers of osteopetrosis, $7.8 \%$ - of multiple arthrogryposis and $18.2 \%$ - of neuropathic hydrocephalus.

It is noteworthy that currently carriers of certain genetic defects $(\mathrm{NH}, \mathrm{CA}$ and $\mathrm{AM})$ are only females moreover with relatively high frequencies (11.3-26.2\%). Bulls among carriers of these defects do not exist (Figure 3). 
Table 2 - Frequency of genetic defects in 2017

\begin{tabular}{|l|c|c|}
\hline \multicolumn{1}{|c|}{ Defect } & $\mathrm{n}$ & Frequency, \% \\
\hline Polimelia (DD) & 4645 & 20,4 \\
\hline Neuropathic hydrocefalus (NH) & 648 & 18,2 \\
\hline Contractural arachnodactilia (CA) & 1015 & 8,5 \\
\hline Multiple arthrogriposis (AM) & 538 & 7,8 \\
\hline Double muscling (nt821) & 444 & 4,9 \\
\hline Osteopetrosis (OS) & 2314 & 1,7 \\
\hline Oculocutaneous hypopigmentation (OH) & 5347 & 0,3 \\
\hline
\end{tabular}

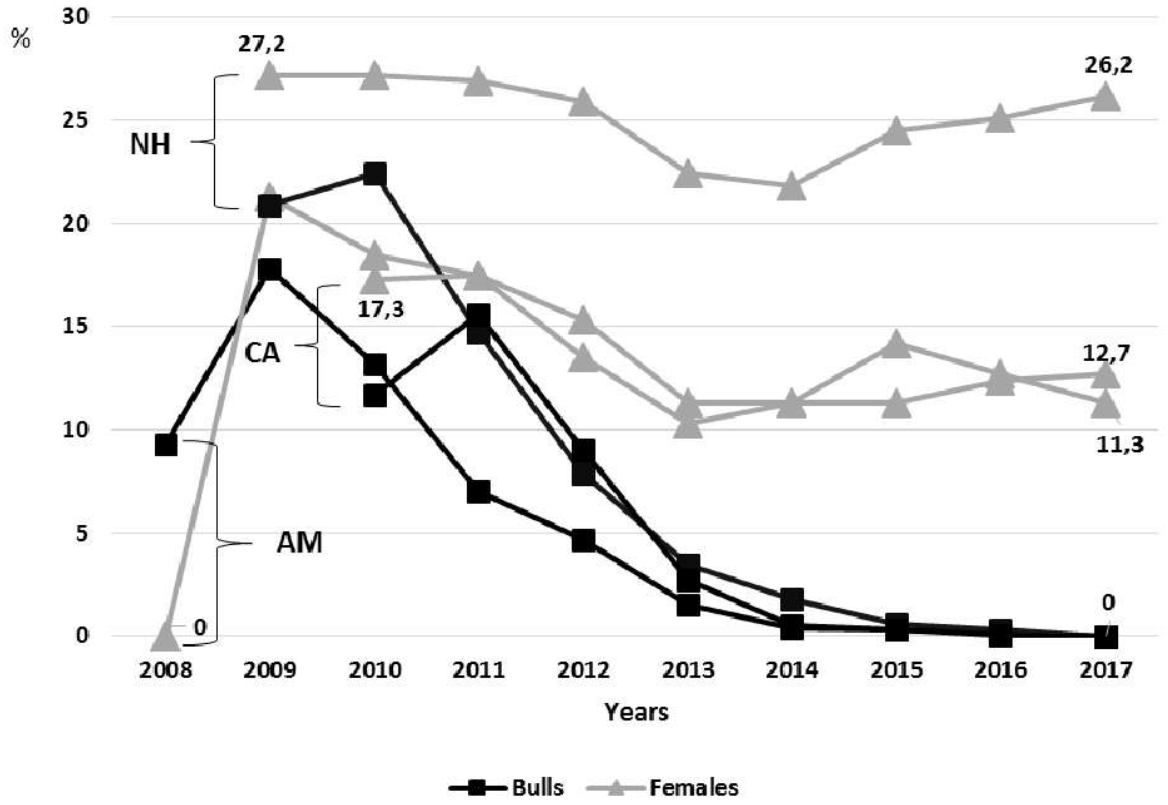

Figure 3 - The dynamics of the frequencies of multiple arthrogryposis, neuropathic hydrocephalus and contractural arachnodactyly depending on the sex of animals

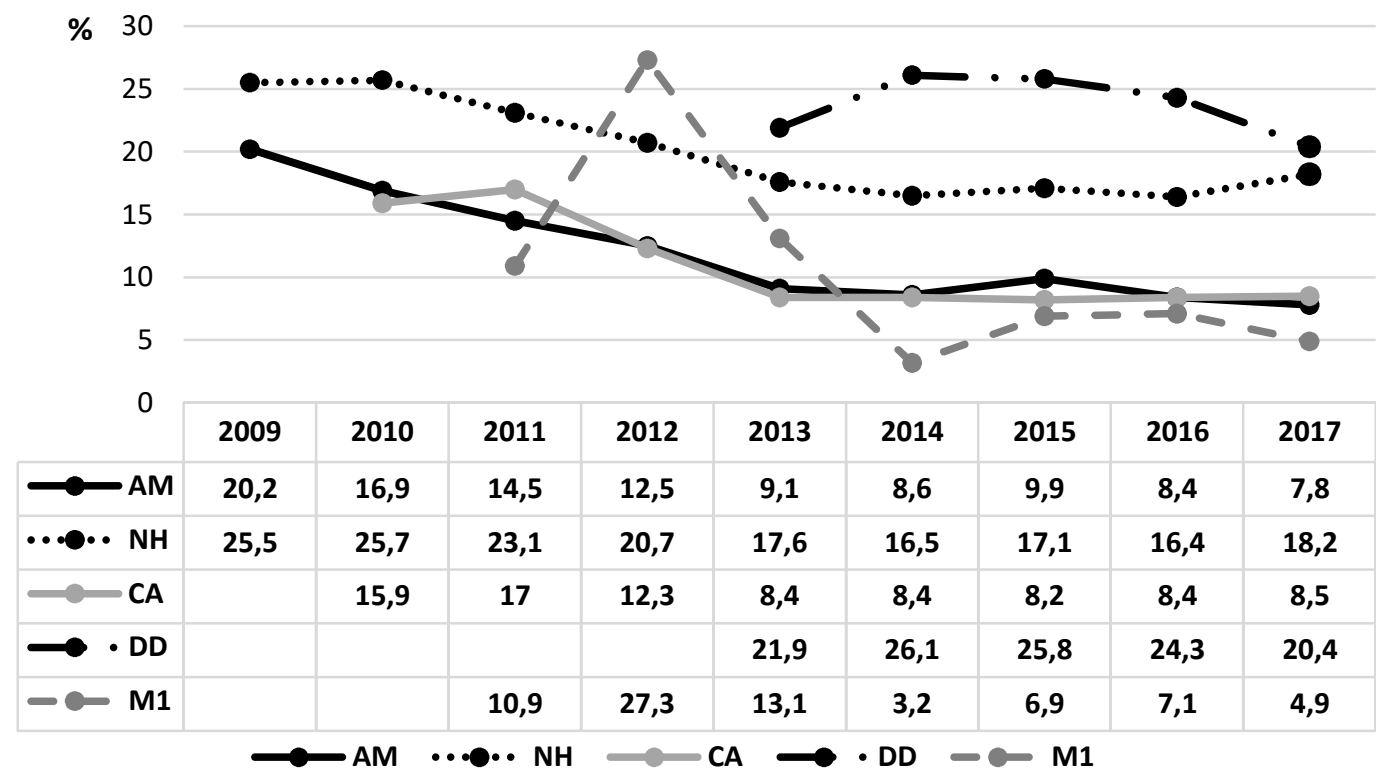

Figure 4 - Dynamics of the frequencies of genetic defects

In addition, the analysis of the occurrence frequency of various defects from 2009 to the present has shown that due the application of DNA technology, there is a downward trend in the number of genetic defects carriers (Figure 4). If at the beginning of the 
diagnostics, the frequency of many defects was more than $20 \%$, to date it does not exceed $10 \%$. Exceptions are developmental duplication and neuropathic hydrocephalus defects, the frequency of which remains high (with $20.4 \%$ and $18.2 \%$, respectively).

Management strategy of genetic defects. When in the herd there are animals with signs of hereditary diseases there are various options for further action, ranging from a complete disregard of the problem and ending full culling of sick animals and their relatives. The most correct, according to most experts $[4,10]$, is the accurate identification of the genetic defect and identify its carriers through DNA diagnostics.

It is important to understand the principle of the genetic defects inheritance. As in most cases, the model of inheritance is simple recessive defect, in order to be born sick calf must cross two carriers of the mutation. Even such crossing the resulting offspring will have a genetic defect in only $25 \%$ of cases.

Thus, if the complete ignoring of genetic defect cases contributes to its manifestation, on the other hand, full culling of animals-carriers can delete from the herd the animals with the best production values that will affect negatively for economic growth [10].

Currently, most genetic defects, occurring in animals of the Aberdeen Angus and Hereford breeds have been investigated, and are controlled by breed associations [11-19]. These organizations were organized in some countries for successful breeding of certain breeds. In addition to providing support in the purchase or sale of animals, these organizations attract of scientific experts in various areas of animal husbandry for the development of methods of optimal content to maintain animal health and particularly of control over genetic defects. All data relating to genetic anomalies are recorded in the pedigrees and registration certificates of animals. As the study of the defect and developing of methods for its diagnosis, the Association members are offered genetic testing for their animals. The registration rules of animals-carriers of genetic diseases or having similar ancestors, clearly written, as well as rules for the using of biological material from these animals. The largest Associations of the Aberdeen Angus, Hereford and Limousine breeds of cattle are in USA, Canada and Australia. Depending on the specific geographical conditions and breed, Association prescribes in its rules the list of genetic defects which animal should be tested. Without the activity of these structures, progress in the fight against genetic defects would be impossible.

Recommendations. For the prevention of congenital genetic defects, in our opinion it is necessary to take the following measures: to create breed associations on example of the existing; within breed associations to conduct ongoing analysis of all available data on the incidents of any defects in animals to have information about how economic damage can be expected from their symptoms; to make a list of possible defects specific to the breed that can constantly monitor and, if necessary, to replenish; to create a shared database of known animal-carriers of genetic defects to be able the best use of breeding material; to develop test systems based on DNA-analysis for studies of breeding material for carriers of genetic defects; to carry out a detailed study of breed origin (pedigree) the newly imported animals, and in the presence of crossbred animals to examine for the defects common to two or more breeds; constantly to educate breeders of breeding farms, explaining the benefits of the information obtained from DNA-testing of animals for genetic anomalies, and that in the event of defect, there is no need to immediate culling of animals-carriers.

Conclusion. It is no secret that there is not any animal species free from mutations. Due to the fact, mutations occur in each generation, genetic defects can never be completely eradicated [5]. However, modern genetics techniques significantly accelerate the process of identification of animals-carriers of mutations that allows us to develop effective methods for the removal of defective genes from the breeds [20-24]. If during the appearance of the first case of dwarfism that took several years to cope with the disease, now to the solution of such problems takes only a few weeks [25]. It's safe to say that it is easier to prevent the appearance of genetic disease than later to fight it, experiencing considerable economic losses. Today, the meat industry uses modern science to solve problems, which is a good example of cooperation of science and production, and, thus, are able to find answers to important questions that appear in the meat industry. 


\section{REFERENCES}

1. Agriculture development program 2013-2020. Approved by the government of the Russian Federation of July 14, 2012 № 717, p. 66.

2. Cattle Cow at first calving (firstborn) Aberdeen Angus. OAO "Rosagroleasing". Available from https://www.rosagroleasing.ru/catalog/554866/.

3. Limousin. Meat encyclopedia Meatinfo.ru. Available from http://meatinfo.ru/info/show?id=217.

4. Whitlock B.K. (2010). Heritable Birth Defects in Cattle. Applied Reproductive Strategies Conference Proceedings. Nashville, TN, pp. 146-151.

5. Petrova E. V. (1997). Fundamentals of classical genetics. Saratov, Dobrogea, 80 p.

6. Jolly R.D., Windsor P.A. Genetic diseases of cattle. Diseases of cattle in Australia. Chapter: 21, Publisher: VetLearn Foundation, Wellington, New Zealand. 2010. P.760-761

7. Amerchanov Kh.A., Zinovieva N.A (2009). Analysis of national accounting systems and genetic evaluation of Angus cattle in the USA. Guidance, pp. 16-20.

8. OMIA - on-line Mendelian inheritance in animals. Available from www.omia.angis.org.au.

9. Genetic conditions and Factors. American Angus Association. Available from http://www.angus.org.

10. Beever J. (2009). Managing Genetic Abnormalities/ Range Beef Cow Symposium 2009 Casper, WY December 1.

11. Genetic defects: policy and related rules abnormalities and genetic defects American Angus association. Available from http://www.angus.org.

12. Genetic conditions. Angus Australia. Available from www.angusaustralia.com.au.

13. Genetic defects monitored by RAAA. Red Angus Association of America. Available from http://redangus.org.

14. Genetic conditions. Canadian Angus Association. Available from www.cdnangus.ca.

15. DNA testing. Hereford Australia. Available from www.herefordsaustralia.com.au.

16. AHA Rules and Regulations. American Hereford Association. Available from www.hereford.org.

17. DNA instructions. Canadian Hereford Association. Available from www.hereford.ca.

18. Managing Genetic Abnormalities. Canadian Hereford Association. Available from www.hereford.ca.

19. NALF's Policy concerning specific genetic conditions. North American Limousin Foundation. Available from www.nalf.org.

20. Beever J., Marron B.M. (2011). Screening for arthrogryposis multiplex in bovines. USA Patent № US 2011/0151440 A1.

21. Beever J. (2006). Tibial hemimelia (TH) and pulmonary hypoplasia with anasarca (PHA) what are they, where are they and how are they relevant.

22. Markey AD, JF Taylor, RD Schnabel, SD McKay, MC McClure and JE Beever. (2010). A Deletion Mutation In KRT71 Is Associated With Congenital Hypotrichosis In Hereford Cattle. Poster P552 at Plant \& Animal Genomes XVIII Conference, San Diego, CA.

23. Nietfield J. (2007). Osteopetrosis in calves. Diagnostic Insights. p. 3.

24. Grobet, L.; Royo Martin, L.J.; Poncelet, D.; Pirottin, D.; Brouwers, B.; Riquet, J.; Schoeberlein, A.; Dunner, S.; Menissier, F.; Massabanda, J.; Fries, R.; Hanset, R.; Georges, M. (1997). A deletion in the myostatin gene causes double muscled phenotype in cattle. Nat. Genet.; 17, pp.71-74.

25. Cavanagh J.A., Tammen I., Windsor P.A., Bateman J.F., Savarirayan R., Nichoals F.W., Raadsma H.W. (2007). Bulldog dwarfism in Dexter cattle in caused by mutations in ACAN. Mamm Genome.; 18(11), pp. 808-14. 
DOI https://doi.org/10.18551/rjoas.2017-08.30

\title{
THE EFFECT OF DRYING METHOD AND TYPES OF NATURAL FIXATIVE ON THE COIR OF KELAPA GADING (COCOS NUCIFERA EBURNEA) TOWARD COLOR INTENSITY AND COLOR DURABILITY OF BATIK CLOTH
}

\author{
Dewanti Beauty Suestining Diah*, Wijana Susinggih, Hapsari Ravenska Narendra \\ Department of Industrial Technology of Agriculture, Faculty of Agricultural Technology, \\ University of Brawijaya, Indonesia \\ *E-mail: beauty dewanti@yahoo.com
}

\begin{abstract}
The purpose of this study is to know the effect of drying method of Kelapa Gading fiber or coir, and fixation material toward color intensity and color durability in batik cloth by using natural colorant. The study uses Factorial Randomized Block Design (FRBD). The first factor is the method of drying the fiber, i.e. sun drying and wind drying. The second factor is the type of fixation materials that is alum, quicklime (calcium oxide), and iron or tunjung. The best treatment result using Multiple Attribute method is sun drying with quicklime $(\mathrm{CaO})$ fixator on the concentration of $15 \%(\mathrm{w} / \mathrm{v})$. Color intensity value that is brightness $\mathrm{L}^{*} 46.8, \mathrm{a}^{*}$ value (red color intensity) 24.13 and $b^{*}$ value (yellow color intensity) 16.93; the color difference is 13.6 which means a big influence exists. The dryness and wetness test shows SS (Staining Scale) value of 4 (good) and 4 (good). The color durability test for shows SS value of 4-5 (good) and GS (Gray Scale) value of 4 (good). The result of color intensity test of $L^{*}$ indicates that the alum fixator can bind $L^{*}$ (brightness level) more strongly. Quicklime fixator is capable of binding the value of $a^{*}$ (red color) and $b^{*}$ (yellow color) more strongly. The fixation material of iron produces weaker $L^{*}, a^{*}$ and $b^{*}$ values. The sun dried coir of Kelapa Gading binds more red $\left(a^{*}\right)$ and yellow $\left(b^{*}\right)$ color. The longer the drying time, the higher the oxidation process and the higher the tannin content which makes the product more damaged.
\end{abstract}

\section{KEY WORDS}

Fixation, color, durability, intensity, drying, Kelapa Gading fiber.

Batik craft in Indonesia has been growing rapidly, in technique, technology, and development of related motives and cultures. Based on data from the Ministry of Industry (2014), since 2011 to 2015 , batik industry has grown $14.7 \%$ from 41,623 units to 47,755 units of batik business. Batik was previously only known in the palace environment in Java and was made with hand-made system whereas the dyes used were all coming from nature both plants and animals (Atikasari, 2005).

Batik industry generally uses synthetic dyes in the process of dyeing batik cloth, but some use natural dyes. According to Kristijanto and Hartati (2013), synthetic dyes generally have a fixed composition, with brighter coloration results, good color intensity, more color durability, and contain heavy metals not easily degraded, which can pollute the environment and have a direct impact on health for humans. Natural dyes for textile can be produced from plant extracts such as roots, stems, leaves, skins, flowers and seeds, and natural dyes are more easily degraded (Aliya, 2010).

Examples of natural dye substances are chlorophyll, carotenoid, anthocyanin, and tannin. The substances have distinctive colors difficult to be imitated by synthetic dyes. Natural colorant is environmentally friendly and non-toxic. One of the plants containing natural dyes or colorant that has not been used much for textile industry is Kelapa Gading. The part of coconut that can be extracted as natural colorant is the fiber or coir. According to Sari et al. (2005), coir can be used as a natural dye because it contains tannins of the flavonoid group - when it is soaked in water, it will result in reddish brown color. The downside of natural coloring is the need of fixation to lock the color as to avoid fading; some materials used in fixation include alum, lime, and iron (Palupi, 2015). 
Dried coir is generally used as fuel, board, and briquettes. It has not been used much as a raw material for natural dyes. Coir drying can be done under the sun, wind, or using special dryer. Drying temperature and time will affect the levels of tannin and will cause browning due to enzyme activity (Astutik, 2008). The higher the temperature and the long the drying process, then the higher the oxidation process and the content of tannins will be.

Fixation is the most important stage in the process of batik coloring. Fixation changes the color of natural substances in accordance with the type of metal binding it; fixation helps to lock the color entering the fiber (Agoes, 2007). The materials used for the fixation is alum, lime $(\mathrm{CaO})$ and iron $\left(\mathrm{FeSO}_{4}\right)$.

\section{MATERIALS AND METHODS OF RESEARCH}

The tools used for preliminary research among others are trays, pans, stoves, thermometers, measuring cup, digital scales, mixer, filter, screen cloth, scissors, glue, hairdryer, staplers, boards, brushes, and plankan. Tools for the test include Laundry meter, Crock meter, Grey Scale, and the Staining Scale. The materials used include coir of Kelapa Gading, wax, primissima cloth, wax, and water as a solvent. Fixation materials used are alum, lime ( $\mathrm{CaO})$, and iron (FeSO4). as follows:

The study uses Factorial Randomized Block Design (FRBD), consisting of two factors,

The first factor $(A)$ is the method of coir drying:

$A_{1}$ : Sun drying

$A_{2}$ : Wind drying

The second factor $(B)$ is the fixation material:

$B_{1:}$ Alum $15 \%$

$\mathrm{B}_{2}$ : Lime $15 \%$

$B_{3}$ : Iron $15 \%$

The process in drying coir of Kelapa Gading is as follows:

- $1 \mathrm{~kg}$ of coir is cut into small pieces of $10 \mathrm{~cm}$;

- the pieces of coir are arranged on the trays;

- the pieces of coir are divided into two-the first half for sun drying for 5 days (8 hours/day, from 08:00 to 15:00) and the second half for wind drying for 7 days;

- the dried pieces of coir is scaled; and

- the dried coir is ready.

The fixation process of the dried coir is as follows:

- dry cloth is soaked into the natural dye solution as many as 15 times;

- the dried batik cloth goes through fixation (using alum, lime, and iron);

- wax removing (nglorod) is done on the batik cloth; and

- last step is to wash and dry the batik cloth.

Observations made include a test on color durability and color intensity. The test on color durability is against rubbing (SNI 0288-2008) and against leaching (SNI ISO 105C06:2010). The selection on the best alternative uses Multiple Attribute (Zelleny, 1982).

\section{RESULTS AND DISCUSSION}

Test on $a^{*}$ Value. The results of the analysis of variance shows different methods of drying brings significant influence. The different types of fixatives show significant influence against $a^{*}$; thus, a DMRT at the level of significance of $5 \%$ on each factor must be done. The results of DMRT are presented in Table 1.

Tabel 1. The Effect of Different Drying Methods and Fixatives toward the Average Value of $a^{*}$ on the Batik Cloth Produced

\begin{tabular}{lll}
\hline \multicolumn{2}{l}{ Treatment } & $\begin{array}{l}\text { Average } \\
\text { Value of }\end{array}$ JNT Notation \\
\hline
\end{tabular}




\begin{tabular}{lllll}
\hline Method & & $\mathbf{a}^{*}$ & & \\
\hline Sun & Alum & 21.47 & 0.57 & $\mathrm{~d}$ \\
& Lime & 24.13 & 0.76 & $\mathrm{f}$ \\
& Iron & 11.83 & 0.49 & $\mathrm{a}$ \\
Wind & Alum & 20.80 & 0.53 & $\mathrm{c}$ \\
& Lime & 22.13 & 0.63 & $\mathrm{~b}$ \\
& Iron & 13.20 & 0.51 & $\mathrm{e}$ \\
\hline
\end{tabular}

Note: Different notations show significant difference of treatment based on DMRT at significance level of $5 \%$

Table 1 shows different drying method, and different fixatives bring significant difference in the batik cloth produced; the different notations on each factor show this. The highest $a^{*}$ value is for lime, followed by alum and iron. Lime produces the highest $a^{*}$ value for both sun and wind drying. This shows that lime as fixative produces the best red color, for both drying methods, compared to alum and iron as fixatives. According to Failisnur and Sofyan, (2014) $\mathrm{Ca}^{2+}$ ions form bigger molecules inside the pores of coir creating redder color, tending to be darker. The color occurs due to the ionic reaction between tannins (tannic acid) and $\mathrm{Ca}^{2+}$ ions in lime.

Alum $\left(\mathrm{Al}_{2}\left(\mathrm{SO}_{4}\right)_{3}\right)$ produces a color similar to the original one or golden yellow. This happens because of ionic reactions between tannins (tannic acid) with $\mathrm{Al}^{3+}$ ions and iron $\left(\mathrm{FeSO}_{4}\right)$, especially $\mathrm{Fe}^{+}$ions, forming green to dark green color that produces a complex salt (ferrous tanat). The complex salts are formed by the presence of covalent coordination between metal ions with non-metal ions (Taofik et al., 2010).

Sun drying with lime fixative produces higher red color intensity compared to wind drying. This is affected by the drying of extracts-the higher the temperature and the longer the drying process, the higher the oxidation and the tannin content, leading to change in color. Formation of brown color is caused the phenolic compounds induced in coir, which acts as a substrate in the process of enzymatic browning. According to Rahmawati (2008), browning is the process of formation of yellow pigment instantly transformed into dark brown. Browning is influenced by the activity of polyphenols oxidase enzyme with the help of oxygen to change the cluster mono phenol became O-hydroxyl phenols, which further modified again into O-Quinones. This cluster of O-Quinones forms brown color. Changes that occur during drying are hydrolysis enzymatic, accompanied by a change of color and aroma due to the enzyme activity, polymerization, and oxidation (Manoi, 2006).

Test on $b^{*}$ Value. The average values of $b^{*}$ produced in color intensity test of coir with different methods of drying and fixatives is 12.77 to 16.93 . Different methods of drying and different fixatives bring significant difference. Interaction of both brings significant difference. The highest value of $b^{*}$ is for lime, followed by alum and iron. Sun drying with lime as fixative indicates the highest value of $b^{*}$ compared with wind drying. The average value of $b^{*}$ can be seen in Table 2.

Table 2 - The Effect of Different Drying Methods and Fixatives toward the Average Value of $b^{*}$

\begin{tabular}{|c|c|c|c|c|}
\hline \multicolumn{2}{|c|}{ Treatment } & \multirow{2}{*}{ Average Value of $b^{*}$} & \multirow[b]{2}{*}{ JNT } & \multirow[b]{2}{*}{ Notatior } \\
\hline Drying Method & Fixatives & & & \\
\hline \multirow{3}{*}{ Sun } & Alum & 16.43 & 1 & C \\
\hline & Lime & 16.93 & 0.84 & $d$ \\
\hline & Iron & 12.77 & 0.66 & a \\
\hline \multirow{3}{*}{ Wind } & Alum & 13.77 & 0.68 & $a$ \\
\hline & Lime & 15.43 & 0.76 & c \\
\hline & Iron & 14.33 & 0.71 & $b$ \\
\hline
\end{tabular}

Note: Different notations show significant difference of treatment based on DMRT at significance level of $5 \%$. 
The value of $b^{*}$ shows significant difference on the different methods of drying as there is a difference in the ability of coir to absorb the color of natural colorant, and also a difference in fixatives. This is because the drying method affects the color of the extract absorbed by coir. Lime binds a lot of yellow pigment on the coir. According to Kristijanto and Soetjipto (2013), tannin with $\mathrm{Ca}^{2+}$ ion in lime will produce yellow pigment. $\mathrm{CaO}$ is able to form a stronger yellow pigment compared with alum $\left(\mathrm{Al}_{2}\left(\mathrm{SO}_{4}\right)_{3}\right)$ and iron $\left(\mathrm{FeSO}_{4}\right)$ which is unable to form yellow pigment.

According to Fitrihana (2011), alum serves to retain the original color of the natural colorant and to lock it during staining. Iron serves to produce darker color due to the formation of complex salts by $\mathrm{Fe}^{2+}$ ions. Complex salt (ferrous tanat) is formed due to the covalent bond between the metal ions and non-metal ions that produce the blackish green color (Taofik et al., 2010).

The brown color on the coir will get darken due to the oxidation reaction of the phenol enzyme with the substrate of the materials in the browning process. The intensity of yellow color is also triggered by the lime fixation due to ionic reaction of $\mathrm{Ca}^{2+}$ with tannin (tannic acid) which produces more yellow pigment.

The formation of brown color is triggered by oxidase reactions catalyzed by the phenol oxidase or polyphenol oxidase enzyme. Both enzymes can catalyze the oxidation of phenol compounds into Quinone and then polymerized into a brown melanin pigment (Mardiah, 1996).

Test on $L^{*}$ Value. The result of variance analysis shows that the average value of $L^{*}$ (bright and dark level with a range of 0-100) treatment with different methods of drying and fixatives from 22.16 until 27.65. Different methods of drying and different fixatives bring significant difference toward $L^{*}$ value. Their interactions show no significant difference. The effect of different fixatives can be seen in Table 3.

Table 3 - The Effect of Different Drying Methods and Fixatives toward the Average Value of $L^{*}$

\begin{tabular}{|c|c|c|c|c|c|}
\hline \multicolumn{2}{|c|}{ Fixatives } & $\begin{array}{l}\text { Alum } \\
27.65\end{array}$ & $\begin{array}{l}\text { Lime } \\
23.86\end{array}$ & $\begin{array}{c}\text { Iron } \\
22.16\end{array}$ & Notation \\
\hline Alum & 27.65 & & 3.79 & 5.49 & $a$ \\
\hline Lime & 23.86 & & & 1.7 & b \\
\hline Iron & 22.16 & & & & $c$ \\
\hline
\end{tabular}

Note: Different notations show significant difference of treatment based on DMRT at significance level of $5 \%$.

Table 3 shows the mean value of BNT test on different types of fixatives - all show a significant difference. According to Pomeranz and Meloans (1994), the $L^{*}$ values indicate the direction of bright and dark color, where 0 denotes a black or very dark tendency and 100 denotes a bright or tendency toward white. The alum fixator produces the brightest color direction with the $L^{*}$ value of 27.65 when compared to the lime and iron. This is due to the reaction of $\mathrm{Al}^{3+}$ ions in alum to tannin (tannic acid), where alum $\left(\mathrm{Al}_{2}\left(\mathrm{SO}_{4}\right)_{3}\right)$ has a valence 3 so it can bind 3 dye molecules (Sasas et al., 2000). Iron produces darker shades, this is because tannins containing phenol groups have $\mathrm{OH}$ groups that bind to form complex compounds with metals. The complex salts are formed by the presence of covalent bonds of metal ions with non-metal ions resulting in a greenish brown color (Yusmeiarti, 2007). Tannins that react with $\mathrm{CaO}$ and ferrous sulfate will become unstable resulting in brownish color intensity in lime and blackish greenish in iron. The color intensity decreases due to damage to the active group of the dye pigment resulting in bleaching. The high brightness level indicates the fading color of the extract, and the vice versa, low brightness indicates high color duration (Saati, 2004).

Lime produces darker color than alum does because $\mathrm{Ca}^{2+}$ ions form larger molecules in the pore of the fibers so the color becomes darker or reddish. The color occurs because of the ionic reactions between tannins (tannic acid) and $\mathrm{Ca}^{2+}$ ions in lime (Failisnur and Sofyan, 2014). Tannins that react with $\mathrm{CaO}$ and ferrous sulfate will become unstable resulting in brownish color intensity in lime and blackish greenish in iron. The color intensity decreases 
due to damage to the active group of the dye pigment resulting in bleaching. In general, drying duration (sun drying) affects the stability of dye (Rini and Kasmurdjo, 2006).

Test on Color Durability against Rubbing. The test results on the type of drying method and the types of fixatives show Color Different (CD) values ranging from 4 to 5.87 . In primissima cloth with sun drying method, the lowest Color Different (CD) value is for lime (4.53), and if converted to SS (Staining Scale) then the value is 4 (good). Figure 1 shows the results of color durability against dry rub test.

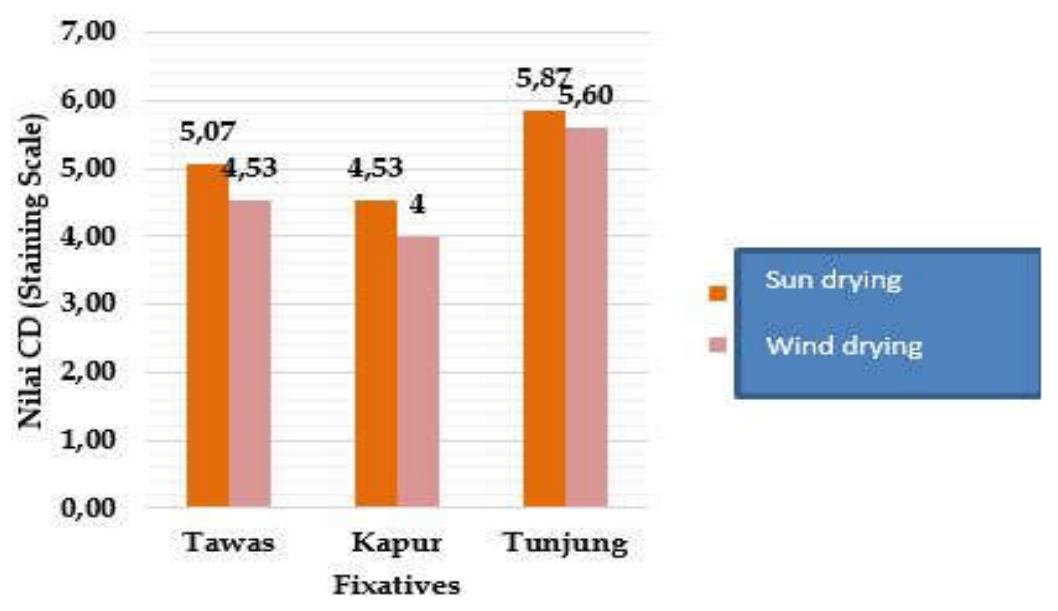

Figure 1 - The Average Value for Dry Rub

Figure 1 shows that iron as fixative shows the highest $C D$ value, for both sun drying and wind drying. The lower CD value affects color durability against dry rub. According to Moerdoko et al. (1975), the lower the value of CD, the better the color durability will be. The lowest value of $C D$ is for lime. According to Sulaeman (2000), the presence of $\mathrm{Ca}^{2+}$ ions from lime solution or $\mathrm{Al}^{3+}$ ions from the alum solution will create bond with tannin in coir making the molecule inside the natural dye bigger. According to Farida et al. (2011), with the addition of fixatives (alum, lime, or iron), tannins will not be released in the fibers and cause a change in the direction of the color according to fixatives.

Wind drying shows better color durability than sun drying, as sun-dried coir has the most concentrated color so natural dye is only attached to the surface of the fabric. At the time of dry rub test, the dye on batik cloth more easily comes out and leaves stain on the test cloth. According to Atikasari (2005), the breaking of the bond between the fabric and the auxochrome leads to low color durability, as cloth or fabric loses its ability to absorb color.

The intensity of sunlight affects the speed of water evaporation on coir and the extracted tannin compound in coir will be darker than wind drying. Wind drying causes coir to get less light, making the process of enzymatic browning on the material is shorter. The changes that occur during drying are enzymatic hydrolysis, browning with changes in color and aroma and enzyme activity, oxidation, and polymerization (Manoi, 2006). According to Rahmawati (2008), oxidation reaction and catalyze by phenol oxidase or polyphenol oxidase enzyme affects the formation of brown color.

Color Durability against Wet Rub Test. The test result on primissima cloth on color durability against wet rub shows CD (Color Different) value from 3.33 to 10.20. Lime with wind drying method shows the lowest CD value of 3.33, if converted to SS (Staining Scale) value, it equals to 4 (good). The results of wet rub indicate the presence of poor color durability, this is indicated by the greater value of the CD. Figure 2 shows the results of color durability against wet rub test.

Wet rub shows that natural dye of coir can adhere to the surface of plain white primissima cloth. Sun drying shows higher pattern compared with wind drying. The durability of fabric may reduce in wet rub, as according to Herlina (2007), the presence of water in wet 
rub test will cause the bulking of fibers, and molecules of natural dye will be carried by water, making the color to easily fade.

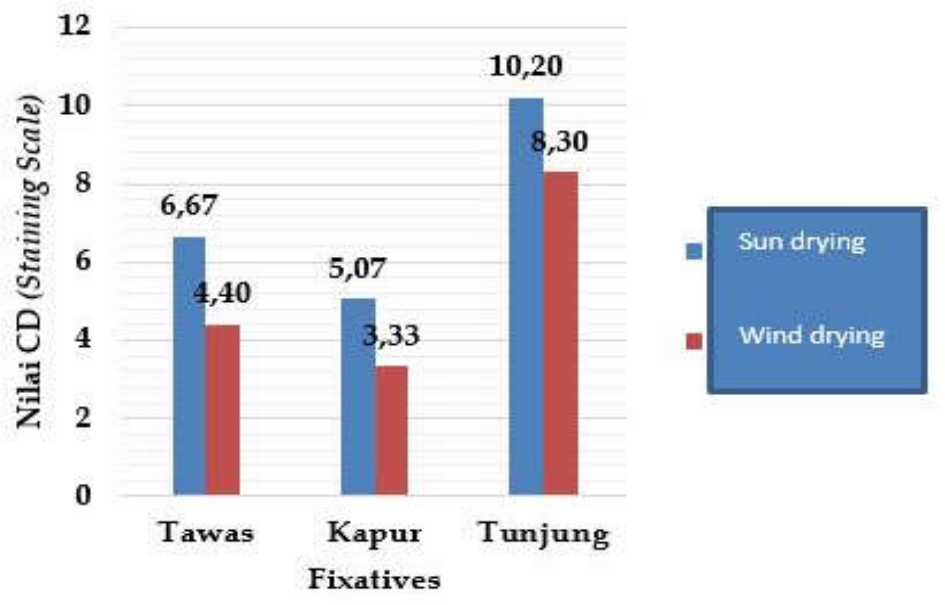

Figure 2 - The Average Value for Wet Rub

The less ability of dye materials to enter the fiber is due to the broken bond between the auxochrome fibers so the fabric loses its ability to absorb color and this makes the dye only attached to the surface of the fabric (Atikasari, 2005). Drying of coir also affects color durability of batik cloth. Good color durability is caused because the dye extracted from the wind drying can be well absorbed by the fabric fiber. The heat energy that attacks the dye molecule can break the dye molecule chain causing the color to fade (Taofik et al., 2010).

Test on Color Durability against Washing. The test result on primissima cloth on color durability against washing shows CD (Color Different) value between 5.87 to to 1.33. Lime with wind drying method shows the lowest CD value of 1.33, if converted to SS (Staining Scale) value, it equals to 4-5 (good). Figure 3 shows the results of color durability against washing test.

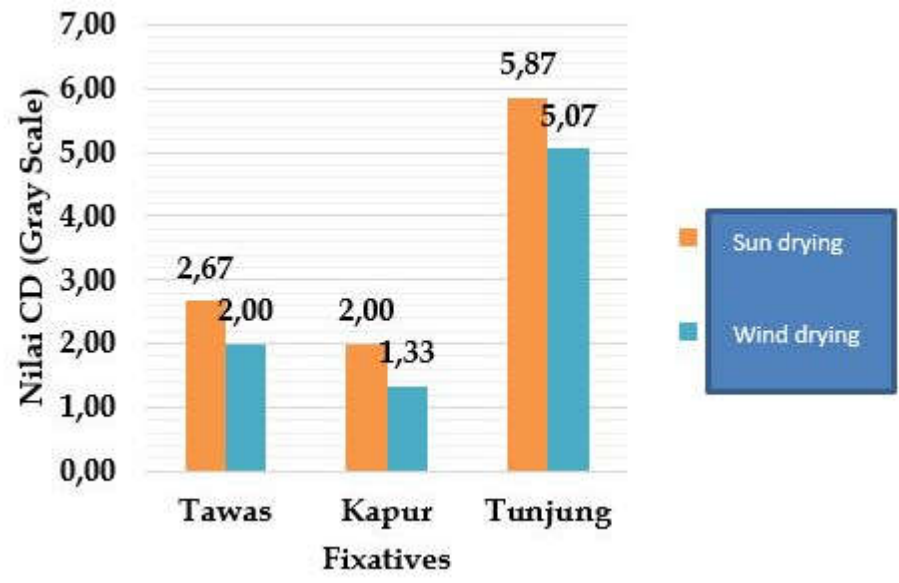

Figure 3 - The Average Value of Staining Scale

The results in Figure 3 with different methods of drying and different fixatives show that lime has the highest CD value (5); the higher the CD value, the better the color durability will be. This is because lime as fixative is able to bind the dye. Hasanudin and Widjiati (2002) state that the bond between the cloth fiber and dyestuff determines color durability. Test of textile materials soaked in soap solution undergoing mechanical movements show that chemicals and mechanical motions will bind the color of textile materials. If the bond between the dye and the cloth fiber is strong, then the color will not easily fade. Higher CD values 
indicate poor color durability. Iron is unable to hold or bind the dye in the cloth fiber so the dye molecule leaves the cloth surface easily.

The drying factor of coir also affect the color durability against washing, in which sun drying has a more intense brown color than wind drying. This is because the temperature in sun drying is higher making the tannin level and oxidation process higher. The higher the tannin makes the color will be more concentrated, but the color durability against washing is better for wind drying than sun drying. According to Wiley-Blackwell (2012), enzymatic browning reaction is responsible for the colors and aroma formed on the dryers.

Gray Scale. The results of primissima cloth test on the color change with different drying method and different fixatives show the lowest $C D$ value on alum that is 1.50 and 1.27 with GS value 4-5 (good). The color durability level against washing is presented in Figure 4.

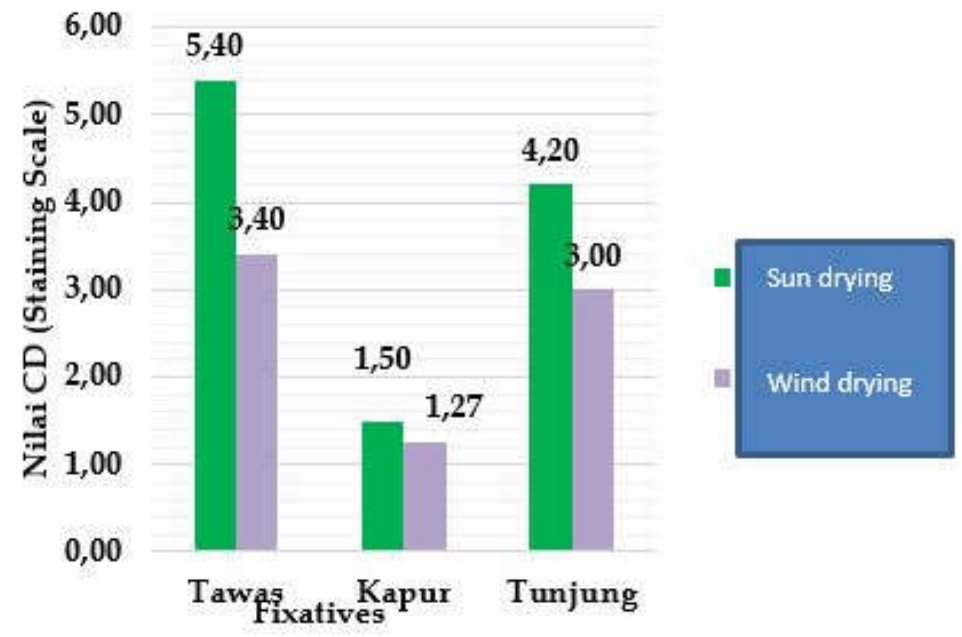

Figure 4 - The Average Value of Gray Scale

Batik cloth fixated by alum cannot survive in alkaline condition (washing), the value of color durability against washing is low. Lime and iron are able to survive in an alkaline atmosphere so color durability against washing is higher.

Herlina (2007) states that the result of fixation is minimal with a CD value of 3.00 . Washing using $\mathrm{Na}_{2} \mathrm{CO}_{3}$ and teepol makes the fabric undergo a different color change compared with the fabric without washing. The results of color durability of sun-dried and wind-dried coir show the same value for lime. This is influenced by the $\mathrm{pH}$ of the alum, lime, and iron which reacts with the detergent in the washing process. Tawas has an acid $\mathrm{pH}$, lime has an alkaline $\mathrm{pH}$, and iron has an alkaline $\mathrm{pH}$, whereas $\mathrm{Na}_{2} \mathrm{CO}_{3}$ has an alkaline $\mathrm{pH}$ included in the salt base type. This causes a change in the color direction to becomedarker than before the washing test.

The color of coir extract from sun drying is not concentrated or light brown because of the lower intensity of light and drying temperature making lower tannin level. According to Manoi (2006), the longer the drying time, the higher the tannin and oxidation process to make the resulting product experience browning with the change of color, aroma, enzyme activity, oxidation, and polymerization.

The Best Treatment. The best fabric resulted from coloring using coir of Kelapa Gading, done with Multiple Attribute, is batik cloth with sun drying and lime as fixative. The best treatment results based on the color intensity can be seen in Table 4 . The best treatment results based on color durability can be seen in Table 5 .

The best treatment results show color different value of 13.6 between the treatment using sun drying and lime as fixative with control treatment (sun drying without fixative)-this shows significant difference toward color intensity. $L^{*}$ value for sun drying and lime as fixatiive resulting in darker color is 46.8 , and 56.8 for control treatment of lighter color. The $a^{*}$ value for sun drying with lime as fixative results in higher red intensity of 24.13 , and 21.1 for control treatment. The $b^{*}$ value for sun drying with lime as fixative is 16.93 , and 16.1 for 
control treatment. This is because lime as fixative binds more dye compared to the control treatment. This is also due to higher tannin content due to browning in sun drying process. Enzymatic browning makes the color becomes darker or dark brown. This is in line with the statement by Alreza (2012) that phenolic compound can become a substrate in enzymatic browning. The browning in coir is triggered by oxidation process of phenolic compound to become Quinone of brown color.

Table 4 - The Best Treatment Results based on the Color Intensity

\begin{tabular}{cccc}
\hline \multirow{2}{*}{ Parameter } & \multicolumn{2}{c}{ Treatment } & Color Different \\
\cline { 2 - 3 } & Sun drying and lime as fixative & Control & $(\Delta \mathrm{E})$ \\
\hline $\mathrm{L}^{*}$ Value & 46.8 & 56.8 & 13.6 \\
$\mathrm{a}^{*}$ Value & 24.13 & 21.1 & \\
$\mathrm{~b}^{*}$ Value & 16.93 & 16.1 & \\
\hline
\end{tabular}

Table 5 - The Best Treatment Results and Control (Without Fixatives)

\begin{tabular}{ccc}
\hline \multirow{2}{*}{ Parameter } & \multicolumn{1}{c}{ Treatment } & No Fixatives \\
\cline { 2 - 3 } & Fixatives (Lime / Wind drying) (A2B2) & 5.86 \\
Dry rub & 4 & 7.2 \\
Wet rub & 3.3 & 5.8 \\
Staining Scale (SS) & 1.3 & 4.8 \\
Gray Scale (GS) & 1.27 & \\
\hline
\end{tabular}

Treatment results are compared with control treatment (no fixation). The dry rub test for wind drying and lime as fixative with control treatment has a difference of 1.86 , the wet rub test has a difference of 3.9 , the washing test against color staining (SS) has a difference of 4.5 and color change has a difference of 3.5. The best treatment result shows that the CD value for control treatment is greater than that wind drying and lime as fixative. This is presumed that in the control treatment, the molecules of substances absorbed by the fabric are more easily leaving the pores of fabric resulting from chemicals and mechanical movement during the washing test against color change and color staining. Herlina (2007) states that the result of fixation is minimal with a CD value of 3.00 .

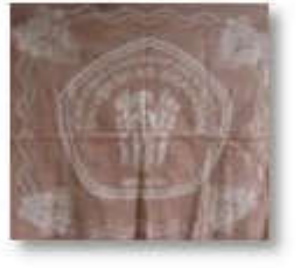

No Fixatives

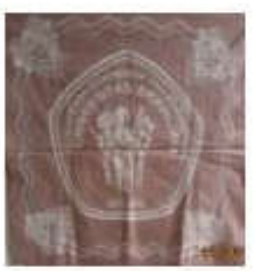

Lime

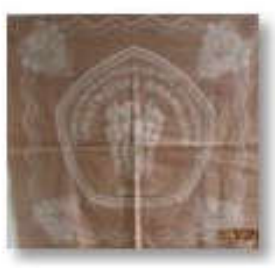

Alum

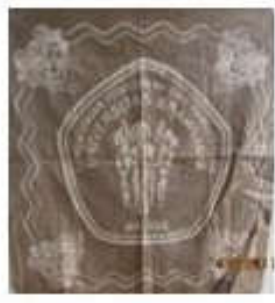

Iron

Figure 5 - Sun Drying

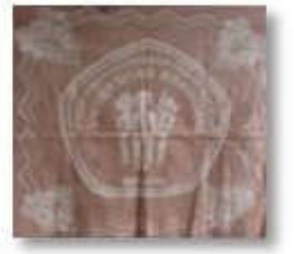

No Fixatives

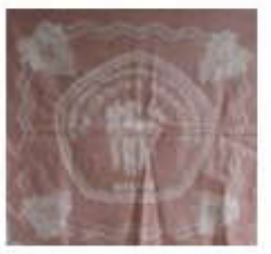

Lime

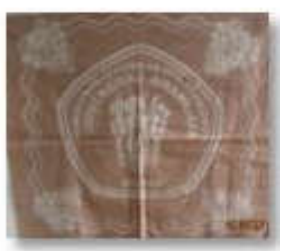

Alum

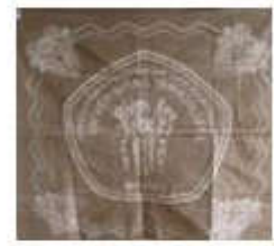

Iron

Figure 6 - Wind Drying

In wind drying, the fabric absorbs the dyestuff maximally so during rubbing and washing there has not been much do stain. According to Sulasmingsih (2006), the strong color durability against washing is associated with the occurrence of tannin bonds capable to get into the fabric fiber forming strong bond with fabric fibers. The addition of a fixative is able to lock and bind the absorbed dyestuff into the fiber material and produce different color 
changes such as alum $\left(\mathrm{Al}_{2}\left(\mathrm{SO}_{4}\right)_{3}\right) . \mathrm{Al}^{3+}$ and $\mathrm{Ca}^{2+}$ ions will cause ionic reactions between the ions with tannin so the natural dye molecules is inside the fiber becomes larger. This results in the dye molecule being difficult to get out of the pores of the fibers and strengthen color durability.

Consumers' Level of Preference. Consumers prefer batik cloth dyeing with natural colorant of coir of sun drying method with brownish red color and bright or light color. Consumers prefer sun drying and wind drying method with lime as the fixative. Consumers also prefer batik cloth with the logo of University of Brawijaya processed using sun drying with lime as the fixative. Consumers prefer bright batik cloth to dark batik cloth. The results of batik cloth using sun dried coir is presented in Figure 5, and using wind dried coir is presented in Figure 6.

\section{CONCLUSION}

The results of color intensity test show that alum as fixative, for both sun drying and wind drying method, has a higher $L^{*}$ value (27.65) compared to lime or iron as fixative. Lime as fixative can bind the red color with $a^{*}$ value of 24.13 and yellow color with $b^{*}$ value of 16.93. Color durability against rubbing and washing shows that lime as fixative has the best color durability. The best treatment is chosen using Multiple Attribute. The best treatment based on color intensity is sun drying with lime as fixative. The best treatment based on color durability is wind drying with lime as fixative.

\section{REFERENCES}

1. Aliya, 2010. Batik Pekalongan. Jakarta Timur: CV. Rama Edukasitama.

2. Alreza, Rahmad. 2012. Pengaruh Bahan Pelapis Terhadap Karakteristik Kelapa Muda Siap Saji Selama Penyimpanan. Skripsi. Fakultas Teknologi Pertanian. Institut Pertanian Bogor. Bogor

3. Astutik, Sri Mulia 2008. Teknik Pengeringan Bawang Merah Dengan Cara Perlakuan Suhu dan Tekanan Fakum. Teknik Pertanian, Vol. 13 No. 2

4. Atikasari, A. 2005. Kualitas Tahan luntur Warna Batik Cap di Griya Batik Larissa Pekalongan. Universitas Negeri Semarang Press. Semarang.

5. Blackwell, Wiley, 2012. Food Biochemistry and Food Processing, 2nd (ed). New York.

6. Failisnur \& Sofyan. 2014. Sifat tahan Luntur Dan Intensitas Warna Kain sutera Dengan Pewarna Alam Gambir (Uncaria gambir Roxb) Pada Kondisi Pencelupan Dan Jenis Fiksator Yang Berbeda. Jurnal Litbang Industri: 14 (1):1-8.

7. Farida, Iswartini, B. Gamal, Ruwanto, V. Atika \& Kamijana. 2011. Penelitian Zat Warna Alam Dari Rumput Laut Untuk Industri Batik. Balai Besar Kerajinan dan Batik Yogyakarta. Yogyakarta.

8. Hasanudin \& Widjiati. 2002. Penilaian Proses Pencelupan Zat Warna Soga Alam Pada Batik Kapas. Departemen Perindutsrian dan Perdagangan Republik Indonesia. Balai Besar Penelitian dan Pengembangan Industri Kerajinan Batik. Yogyakarta.

9. Herlina, S. 2007. Fiksasi Bahan Alami Buah Markisa dan Jeruk Nipis dalam Proses Pewarnaan Batik dengan Zat Warna Indigisol. Seni dan Budaya Yogyakarta. Yogyakarta.

10. Kristijanto, A., Soetjipto H. 2013. Pengaruh Jenis Fiksatif Terhadap Ketuaan dan Ketahanan Luntur Kain Mori Batik Hasil Pewarnaan Limbah Teh Hijau. Proceeding, Seminar Nasional Sains dan Pendidikan Sains VII, Fakultas Sains dan Matematika, Salatiga. Vol 4, No.1.

11. Manoi, F. 2006. Pengaruh Cara Pengeringan Terhadap Simplisia Mutu Sambiloto. Bul. Littro, Vol XVII: $1-5$.

12. Manurang, M. 2012. Aplikasi Kulit Buah Manggis (Garcia mangostana L.) Sebagai Pewarna Alami Pada Kain Katun Secara Pre-Mordanting. Universitas Udayana. Bukit Jimbaran.

13. Mardiah. E. 1996. Penentuan Aktivitas dan Inhibisi Enzim Polifenol Oksidase dari Apel (Pyrus malus Linn). Jurnal Kimia Andalas, 2:2. 
14. Rahmawati, I. 2008. Penentuan Lama Pengeringan Pada Pembuatan Serbuk Biji Alpukat (Persea Americana mill). Unpublished Undergraduate Thesis. Faculty of Agricultural Technology. Universitas Brawijaya.

15. Sari, P., Agustina, F., Komar, M., Unus, Fauzi, M., \& T. Lindriati. 2005. Ekstraksi dan Stabilitas Antosianin Dari Kulit Buah Duwet (Syzygium cumini). Jurnal Teknologi dan Industri Pangan, XVI (2):102-108.

16. Sasas, K, Sunaryati, S, G Isminingsih, \& Santosa. 2000. Usaha Peningkatan Waste Kayu Bakau Sebagai Zat Warna Tekstil. Balai Besar Penelitian dan Pengembangan Industri Tekstil. Bandung.

17. Taofik, E., Yulianti, A. Barizi, E.K Hayati. 2010. Isolasi dan Identifikasi Senyawa Aktif Ekstrak Air Daun Paitan (Thitonia diversifolia) Sebagai Bahan Insektisida Botani Untuk Pengendalian Hama Tungau Eriophyidae. Universitas Maulana Malik Ibrahim. Malang.

18. Yusmeiarti. 2007. Penelitian Stabilisasi Dalam Penyimpanan Limbah Pengolahan Gambir Sebagai Pewarna Tekstil. Research Report, Balai Riset dan Standardisasi Industri Padang. 
DOI https://doi.org/10.18551/rjoas.2017-08.31

\title{
ВЛИЯНИЕ АГРОТЕХНИЧЕСКИХ ПРИЁМОВ ВОЗДЕЛЫВАНИЯ НА ПРОДУКТИВНОСТЬ НОВЫХ СОРТОВ ОВОЩНЫХ И КОРМОВЫХ БОБОВ THE INFLUENCE OF AGROTECHNICAL METHODS OF CULTIVATION ON PRODUCTIVITY OF NEW VEGETABLE AND FODDER BEANS' VARIETIES
}

Телих К.М. ${ }^{*}$, научный сотрудник Telikh K.M., Researcher

Тульский научно исследовательский институт сельского хозяйства, Тульская область, Россия

Tula Research Institute of Agriculture, Tula Region, Russia

Булынцев С.В., кандидат сельскохозяйственных наук Bulyntsev S.V., Candidate of Agricultural Sciences

Кубанская опытная станция, Федеральный исследовательский центр «Всероссийский институт генетических ресурсов растений им. Н.И.Вавилова», Краснодарский край, Россия

Kuban Experimental Station, Federal Research Center «All Russian Institute of Plant Genetic named after N.I. Vavilov», Krasnodar Krai, Russia

$$
\text { *E-mail: tniisx@mail.ru }
$$

\begin{abstract}
АННОТАЦИЯ
В статье представлены элементы агротехники для новых высокопродуктивных сортов кормовых (Дружные) и овощных (Анна, Находка) бобов, полученных методом селекции и отбора отделом зернобобовых ВИР имени Н.И. Вавилова совместно с отделом кормопроизводства Тульского НИИСХ. Установлено, что наиболее выгодным для всех трёх сортов является стандартный посев с шириной междурядий 0,45 м, нормой высева 500 тыс.шт./га в самые ранние сроки.
\end{abstract}

\section{ABSTRACT}

The article presents elements of agrotechnology for new highly productive varieties of fodder (Druzhnye) and vegetable (Anna, Nakhodka) beans obtained using selection methods by the Department of Leguminous Crops of All Russian Institute of Plant Genetic named after N.I. Vavilov along with the Department of Fodder Production of Tula Research Institute of Agriculture. It is established that the most profitable for all three varieties is the standard sowing with a row spacing of $0.45 \mathrm{~m}$, with a seeding rate of 500 thousand pieces per hectare at the earliest sowing dates.

\section{КЛЮЧЕВЫЕ СЛОВА}

Овощные бобы, кормовые бобы, сорт, структура сева, агротехнические мероприятия.

\section{KEYWORDS}

Vegetable beans, fodder beans, variety, sowing structure, agrotechnical methods.

Культуру бобов трудно переоценить. Это холодостойкая, высокобелковая, технологичная и вместе с тем умеренно засухоустойчивая и самая урожайная среди бобовых культура. В 1962 году посевные площади под бобами в СССР составляли 684 тыс. га, в 1966 году всего 14 тыс. га (12). С 2011 года посевов под бобами в Тульской области нет (10). Уменьшение посевных площадей произошло вследствие широкого внедрения в 60-х годах посевов кукурузы, а сейчас сои и нута. Но эти растительные мигранты в климатических условиях Лесостепной зоны полностью не могут проявить свой продуктивный потенциал. Им не хватает тепла в 50\% лет $(6,7,8)$. 
Для установления зависимости состояния посевов и урожая бобов от некоторых агротехнических мероприятий использовались прямые наблюдения за этими фракторами в период 2006 -2016гг. За этот период на полях Тульского НИИСХ и Пушкинских лабораторий ВИР было изучено более 200 коллекционных образцов и селекционных линий кормового и овощного направлений из коллекции ВИР (5). В результате многолетнего изучения коллекционных образцов и селекционных линий бобов, в 2010 году был создан сорт кормовых бобов - Дружные. Уникальность сорта в детерминантном типе роста стебля и одновременном созревании бобов, что позволяет проводить уборку на зерно прямым комбайнированием. Отличается относительной засухоустойчивостью (11). По сравнению с другими районированными сортами, в засушливые годы потери урожая незначительные. Сорт можно использовать в качестве поддерживающей культуры для гороха и вики, так как сроки их созревания совпадают. Даже при длительном перестое семена сохраняют свои товарные качества. Бобы не растрескиваются. Содержание белка в семенах - 29,3\%, масла 4\%. Питательность корма - 1,22 кормовых единиц. При нормальных условиях агротехники и погоды, без внесения удобрений, сорт может формировать урожай 3-4 т/га фуражного зерна $(1,2)$.

В 2013 году в Государственном реестре охраняемых селекционных достижений РФ был зарегистрирован сорт овощных бобов Анна, селекции ВИР и Тульского НИИСХ. Сорт был создан путем многократного массового отбора белоцветковых растений из образца и.№ 579969 - Express (Франция). В течение восьми лет (2006-2013 г.г.) в условиях Ленинградской и Тульской областей сорт выделился по признакам высокой семенной продуктивности, скороспелости и нерастрескиваемости бобов. В засушливом 2010 году урожайность сорта в условиях Тульской области оказалась самой высокой среди 25 изучаемых коллекционных образцов различного географического происхождения. Семена сорта Анна отличаются высокими вкусовыми качествами, отсутствием или пониженным содержанием антипитательных веществ вицина и конвицина $(3,4)$.

Краткая характеристика нового сорта овощных бобов Анна. Высота растений 80100 см, высота прикрепления нижнего боба 42-48см. Число стеблей 2-3, число плодущих узлов 5-7, число бобов в плодущем узле 2-3, число бобов на 1 одном растении 16-21, длина боба 9,5-10,5 см, ширина боба 1,6-1,8 cм, число семян в бобе 35. Масса 1000 семян 800-860 г. Потенциальная урожайность зерна 4,5-5.5 т/га. Период от всходов до цветения 34-38 дней, от цветения до созревания 41-44 день. Вегетационный период 81-90 дней. От всходов до технической спелости 45-50 дней. Содержание белка $26,5 \%$, общих сахаров $7,12 \%$, моносахаров $3,59 \%$, сахарозы $3,53 \%$, масла 8,6\%.

На оба сорта получены патенты и авторские свидетельства. Патентообладатели ФГБНУ ВИР и ФГБНУ Тульский НИИСХ (5).

В 2016 году принят на Государственное сортоиспытание новый сорт бобов Находка. Сорт пищевого и кормового использования. Оригинаторы сорта сотрудники ВИРа и Тульского НИИСХ. Сорт получен методом индивидуального отбора с последующим многократным массовым отбором из коллекционного образца К-2271 (Бельгия). Не полегает, отличается высокой семенной продуктивностью - до 6,5 т/га, среднеспелый, пригоден для механизированного возделывания. Содержание белка в семенах - 21,42 \%, питательность корма - 1,22 кормовых единиц, масса 1000 семян от 469 до 539 г. Белоцветковый с отсутствием антипитательных веществ в семенах, пригоден для консервирования. Вкусовые качества очень хорошие. Пригоден для возделывания в интенсивных технологиях. При выращивании на семена, необходимо соблюдать пространственную изоляцию до 500м от посевов других сортов бобов (13).

\section{МАТЕРИАЛЫ И МЕТОДЫ ИССЛЕДОВАНИЙ}

Методика исследований - полевой мелкоделяночный опыт (учётная площадь делянок - $12 \mathrm{~m}^{2}$ ) по методикам Всероссийского НИИ растениеводства имени Н.И. 
Вавилова (9) и Агрохолдинга МТС «Агро-Альнс». Программа исследований состояла из наблюдений за шириной междурядий $(0,70,0,45$ и 0,15 м) при норме сева 500 тыс. шт./га, нормы высева семян (500, 400 и 300 тыс.шт./га), нормы внесения минеральных удобрений $\left(1,2\right.$ и 3 ц/га аммофоски $\left.\mathrm{N}_{16} \mathrm{P}_{16} \mathrm{~K}_{16}\right)$ и некоторыми методами борьбы с сорняками, вредителями и болезнями в посевах бобов. Стандарт - посев с шириной междурядий 0,45 м с нормой сева 500 тыс.шт./га. Расстояние растений в ряду в этом посеве 4-5 см. Почвы выщелоченный чернозём, тяжёлый суглинок. Так как бобы растение длинного дня, целесообразна ориентация сева с севера на юг. В этом случае в полуденные часы растения не так перегреваются.

\section{РЕЗУЛЬТАТЫ ИССЛЕДОВАНИЙ И ИХ ОБСУЖДЕНИЕ}

В таблицах 1, 2, 3 отмечаются зависимости продуктивности этих сортов от некоторых агротехнических приёмов возделывания. При посеве бобов с шириной междурядий 0,70 м и нормой сева 500 шт./га расстояние между растениями 2-3 см. Освещённость в середине травостоя при полном развитии недостаточная, то есть растения испытывают световое голодание, хотя на верхней границе травостоя наблюдается достаточная освещённость. Растения вытягиваются, нижние листья рано отмирают и, как правило, посев полегает даже при незначительных неблагоприятных погодных условиях (2015-2016гг). Этот процесс усугубляет ещё повышенная засорённость междурядий. Так как междурядья хорошо освещены солнцем, это способствует быстрому развитию сорняков, несмотря на междурядные обработки. При недостатке влаги в почве, при засухе, часть растений гибнет задолго до конца вегетации. Урожай всегда значительно ниже стандартного посева, число щуплых семян выше, а число сохранившихся растений ниже.

Таблица 1 - Элементы продуктивности при некоторых агротехнических приёмах на кормовых бобах Дружные, ФГБНУ «Тульский НИИСХ»

\begin{tabular}{|c|c|c|c|c|c|c|}
\hline Годы & $\begin{array}{l}\text { Элементы } \\
\text { опыта }\end{array}$ & $\begin{array}{c}\text { Вес зерна } \\
\text { с } 1 \mathrm{M}^{2}, \text { г }\end{array}$ & $\begin{array}{c}\text { Мacca } 1000 \\
\text { семян, г }\end{array}$ & $\begin{array}{c}\text { \% щуплых } \\
\text { зёрен }\end{array}$ & $\begin{array}{c}\text { Средняя густота } \\
\text { растений при уборке, } \\
\text { шт./м² } \\
\end{array}$ & $\begin{array}{c}\text { Полегание, } \\
\%\end{array}$ \\
\hline \multicolumn{7}{|c|}{ Ширина междурядий } \\
\hline \multirow{3}{*}{2012} & 0,15 & 298,0 & 444,1 & 1 & 43 & - \\
\hline & 0,45 & 276,0 & 450,5 & 1 & 34 & - \\
\hline & 0,70 & 220,0 & 419,3 & 1 & 29 & - \\
\hline \multirow{7}{*}{2013} & 0,15 & 83,8 & 333,2 & 12 & 52 & - \\
\hline & 0,45 & 159,8 & 312,3 & 12 & 27 & - \\
\hline & 0,70 & 47,4 & 227,8 & 22 & 36 & - \\
\hline & \multicolumn{6}{|c|}{ Внесение аммофоски $\left(\mathrm{N}_{16} \mathrm{P}_{16} \mathrm{~K}_{16}\right)$, ц/га } \\
\hline & $\begin{array}{c}\text { Без. } \\
\text { удобрений }\end{array}$ & 237,1 & 261,0 & 12 & 42 & - \\
\hline & 1 & 248,3 & 277,8 & 13 & 43 & - \\
\hline & 2 & 306,4 & 324,6 & 8 & 50 & - \\
\hline
\end{tabular}

При посеве бобов с шириной междурядий 0,15 м с равномерным размещением семян в ряду расстояние между ними 13-15 см. Но пока в производстве нет таких высевающих агрегатов. При этом такой посев необходимо размещать на слабо засорённом поле или применять гербициды. Урожай такого посева, как правило, не превышает стандартного посева (с междурядьями 0,45м). Поэтому ни зерновые сеялки, где семена высыпаются беспорядочно, приспосабливаемые для посева бобов или кукурузные СУПН-8 не могут обеспечить оптимальную густоту и ожидаемую урожайность. В первом случае перерасход семян на посев увеличивается в два раза и, как правило, такие посевы полегают. Во втором густота посева 70-110 тыс.шт./га при оптимальной 500 тыс.шт./га и повышенная засорённость междурядий.

Внесение аммофоски $\mathrm{N}_{16} \mathrm{P}_{16} \mathrm{~K}_{16}$, перед культивацией не зависимо от условий увлажнения почвы, способствует росту урожайности на $10-30 \%$ только при норме внесения 1-2 ц/га. При внесении 3 ц/га аммофоски начинается снижение роста 
урожайности на всех трёх сортах. Это обуславливается значительным развитием листовой поверхности, низкой освещённостью в середине травостоя и затем ранним отмиранием нижних листьев. Растения питательные вещества тратят на поддержание жизнедеятельности сильно развитой листовой поверхности (табл. 1, 2, 3).

Таблица 2 - Элементы продуктивности при некоторых агротехнических приёмах на овощных бобах Анна, ФГБНУ «Тульский НИИСХ»

\begin{tabular}{|c|c|c|c|c|c|c|}
\hline Годы & $\begin{array}{c}\text { Элементы } \\
\text { опыта }\end{array}$ & $\begin{array}{c}\text { Вес зерна } \\
\text { с } 1 \mathrm{M}^{2}, \text { г }\end{array}$ & $\begin{array}{c}\text { Мacca } 1000 \\
\text { семян, г }\end{array}$ & $\begin{array}{c}\text { \% щуплых } \\
\text { зёрен }\end{array}$ & $\begin{array}{c}\text { Средняя густота } \\
\text { растений при уборке, } \\
\text { шт./м² }\end{array}$ & $\begin{array}{c}\text { Полегание, } \\
\%\end{array}$ \\
\hline \multirow{13}{*}{2014} & \multicolumn{6}{|c|}{ Внесение аммофроски $\left(\mathrm{N}_{16} \mathrm{P}_{16} \mathrm{~K}_{16}\right)$, ц/га } \\
\hline & $\begin{array}{c}\text { Без. } \\
\text { удобрений }\end{array}$ & 260,0 & 899,0 & 5,6 & 43 & - \\
\hline & $1 ц / г а$ & 266,7 & 870,5 & 7,0 & 39 & - \\
\hline & 2 ц/га & 278,9 & 812,5 & 5,0 & 42 & - \\
\hline & 3 ц/га & 266,7 & 807,3 & 6,9 & 41 & - \\
\hline & \multicolumn{6}{|c|}{ Ширина междурядий, м } \\
\hline & 0,15 & 223,3 & 783,3 & 8,7 & 44 & - \\
\hline & 0,45 & 203,3 & 873,3 & 6,1 & 42 & - \\
\hline & 0,70 & 207,4 & 863,0 & 8,4 & 42 & - \\
\hline & \multicolumn{6}{|c|}{ норма высева семян (ширина междурядий 0,45м) шт./м² } \\
\hline & 50 & 203,3 & 873,3 & 6,1 & 42 & - \\
\hline & 40 & 170,2 & 853,0 & 6,8 & 38 & - \\
\hline & 30 & 156,7 & 809,3 & 10,8 & 26 & - \\
\hline \multirow{13}{*}{2015} & \multicolumn{6}{|c|}{ Внесение аммофоски $\left(\mathrm{N}_{16} \mathrm{P}_{16} \mathrm{~K}_{16}\right)$, ц/га } \\
\hline & $\begin{array}{c}\text { Без. } \\
\text { удобрений }\end{array}$ & 422,5 & 807,0 & 2,0 & 31 & 5 \\
\hline & 1 ц/га & 466,7 & 797,9 & 1,8 & 32 & 5 \\
\hline & 2 ц/га & 491,7 & 810,8 & 1,5 & 30 & 5 \\
\hline & 3 ц/га & 483,3 & 812,9 & 1,6 & 33 & 5 \\
\hline & \multicolumn{6}{|c|}{ Ширина междурядий, м } \\
\hline & 0,15 & 416,7 & 788,4 & 2,0 & 35 & нет \\
\hline & 0,45 & 466,7 & 794,9 & 1,8 & 37 & 5 \\
\hline & 0,70 & 284,2 & 818,0 & 2,0 & 61 & 60 \\
\hline & \multicolumn{6}{|c|}{ норма высева семян (ширина междурядий 0,45м) шт./м² } \\
\hline & 50 & 493,3 & 794,9 & 1,8 & 43 & 5 \\
\hline & 40 & 485,0 & 806,8 & 2,0 & 37 & 5 \\
\hline & 30 & 402,5 & 739,5 & 2,0 & 27 & 10 \\
\hline
\end{tabular}

Таблица 3 - Элементы продуктивности при некоторых агротехнических приёмах на овощных бобах Находка, ФГБНУ «Тульский НИИСХ»

\begin{tabular}{|c|c|c|c|c|c|c|}
\hline Годы & $\begin{array}{c}\text { Элементы } \\
\text { опыта }\end{array}$ & $\begin{array}{c}\text { Вес зерна } \\
\text { с } 1 \mathrm{M}^{2}, \Gamma\end{array}$ & $\begin{array}{c}\text { Macca } 1000 \\
\text { семян, г }\end{array}$ & $\begin{array}{c}\text { \% щуплых } \\
\text { зёрен }\end{array}$ & $\begin{array}{c}\text { Средняя густота } \\
\text { растений при уборке, } \\
\text { шт./м² } \\
\end{array}$ & $\begin{array}{c}\text { Полегание, } \\
\%\end{array}$ \\
\hline \multirow{13}{*}{2016} & \multicolumn{6}{|c|}{ Внесение аммофосски $\left(\mathrm{N}_{16} \mathrm{P}_{16} \mathrm{~K}_{16}\right)$, ц/га } \\
\hline & $\begin{array}{c}\text { Без. } \\
\text { удобрений }\end{array}$ & 470,8 & 525,0 & 6 & 39 & - \\
\hline & 1 ц/га & 535,0 & 500,0 & 3 & 40 & - \\
\hline & 2 ц/га & 563,3 & 520,0 & 7 & 46 & - \\
\hline & 3 ц/га & 562,5 & 550,0 & 6 & 44 & - \\
\hline & \multicolumn{6}{|c|}{ Ширина междурядий, м } \\
\hline & 0,15 & 519,2 & 540,0 & 5 & 42 & - \\
\hline & 0,45 & 524,2 & 510,0 & 5 & 39 & - \\
\hline & 0,70 & 358,3 & 560,0 & 12 & 31 & 50 \\
\hline & \multicolumn{6}{|c|}{ норма высева семян (ширина междурядий 0,45м) шт./м² } \\
\hline & 50 & 499,2 & 510,0 & 4 & 45 & - \\
\hline & 40 & 443,8 & 525,0 & 9 & 41 & - \\
\hline & 30 & 279,5 & 540,0 & 9 & 28 & - \\
\hline
\end{tabular}

Из таблиц 2 и 3 видно, что овощные бобы на семена можно высевать нормой 350-400 тыс.шт./га. Но наиболее выгодным для всех трёх сортов является 
стандартный посев с шириной междурядий 0,45 м, нормой высева 500 тыс.шт./га в самые ранние сроки. Уход - две междурядные обработки до фразы начало цветения бобов. При третьей обработке проводят окучивание растений.

В период 2012-2014 гг. вследствие весенне-летних засух и слабого линейного роста растений полегания на бобах всех сортов не отмечалось. В эти годы вследствие потери тургора в большую часть вегетационного периода растения теряли листья значительно раньше фразы пожелтения листьев. Из-за недостатка влаги в почве урожай зерна был значительно ниже возможного для этих сортов.

В таблице 4 приведена агроэкономическая оценка выращивания бобов с условием выхода 65\% семян от урожая (около 20 ц/га). Коэфффициент экономической эффрективности (Кээ) у всех сортов больше единицы, то есть технология возделывания бобов считается эфрфективной даже в условиях засухи 2012 года. Кроме того от урожая семян остаётся ещё остаток (35\%) в виде фуража.

Таблица 4 - Агроэнергетическая эффективность технологии выращивания семенного зерна кормовых и овощных бобов в условиях опыта 2012 г., ФГБНУ «Тульский НИИСХ»

\begin{tabular}{|l|c|c|c|}
\hline \multicolumn{1}{|c|}{ Показатели } & $\begin{array}{c}\text { Кормовые бобы, } \\
\text { Дружные }\end{array}$ & $\begin{array}{c}\text { Овощные } \\
\text { бобы, } \\
\text { Анна }\end{array}$ & $\begin{array}{c}\text { Овощные бобы, } \\
\text { Находка }\end{array}$ \\
\hline \multicolumn{1}{|c|}{ Выход с 1 га: } & 20,6 & 24,8 \\
\hline Урожай ц/га & 27,6 & 16229,72 & 20088,453 \\
\hline Валовой энергии (ВЭ), мдж. & 21799,254 & 11097,90 & 13581,75 \\
\hline Обменной энергии (ОЭ), мдж. & 14914,224 & 11,80 & 13,93 \\
\hline Сухого вещества (СВ), ц & 15,42 & 2,2567 & 2,960 \\
\hline Переваримого протеина (Пп), ц & 3,2752 & 0,826 & 1,073 \\
\hline Кормовых единиц (к.е.), ц & 1,172 & 10900 & 10900 \\
\hline Затраты совокупнй энергии (СЭ), мдж. & 10900 & 1,489 & 1,843 \\
\hline Энергетический коэффрициент (ЭК) & 1,999 & 1,018 & 1,246 \\
\hline $\begin{array}{l}\text { Коэффрициент энергетической } \\
\text { эфрфективности кормов (Кээ) }\end{array}$ & 1,368 & & \\
\hline
\end{tabular}

Для уничтожения сорняков в посевах бобов проводились исследования по применению почвенных гербицидов Зенкошанс для ручной обработки (5 мл. раствора/1л воды) и Шансгард (15 мл. раствора/1л воды) по методикам Агрохолдинга МТС «Агро-Альнс». Гербицид Зенкошанс малоэффрективен - рост даже однолетних сорняков задерживал не более двух недель. Увеличение его дозы от рекомендованной приводило к гибели растений бобов. Внесение почвенного препарата Шансгард уничтожало все однолетние сорняки до конца вегетации. На многолетние сорняки он не оказывал никакого действия. Зато рост и урожай бобов снижался на $10-30 \%$ по сравнению с посевом без обработок. Внесение раствора керосина (1л/10л воды) сразу после сева бобов также губительно действовал на однолетние сорняки (щирица, куриное просо, щетинник мышиный и др.) до конца вегетации. На многолетние сорняки (вьюнок, розовый и жёлтый осот, чистец болотный) не действовал. К концу вегетации они составили до 4 баллов в посеве. Но внесение раствора керосина не снижало рост и урожай бобов по сравнению с посевом без обработок и превышал его на $2 \%$. На $4 \%$ был выше урожая с одной прополкой за сезон. Это объясняется тем, что под действием солнечного света находящиеся на поверхности семена сорняков быстро прорастают, а раствор керосина губительно действует на их проростки.

С появлением вредителей (долгоносик, тля) на борьбу с ними применялись инсектициды (Молния, КЭ, Каратошанс, КЭ) по рекомендованным нормам. Появление грибных заболеваний (черноватая, бурая (шоколадная) пятнистость) приходилось на фазы конец цветения - образование бобов применялся препарат Шансил Ультра нормой 25мл/10л воды с использованием ручного опрыскивателя. После обработки дальнейшее распространение заболевания прекращалось, что способствовало оттоку пластических веществ из листьев в семена. Этот же препарат и по той же норме использовался для протравливания семян перед посевом. 
Заключение. На основании проведенных исследований было установлено, что наиболее выгодным для всех трёх сортов является стандартный посев с шириной междурядий 0,45 м, нормой высева 500 тыс.шт./га в самые ранние сроки. Уход - две междурядные обработки до фазы начало цветения бобов. При третьей обработке проводят окучивание растений. Агроэкономическая оценка выращивания бобов показала, что коэфффициент экономической эффрективности (Кээ) у всех сортов больше единицы, то есть технология возделывания бобов считается эффеективной даже в условиях засухи.

\section{БИБЛИОГРАФИЯ}

1. Булынцев С.В. Создание сортов бобов кормового и пищевого использования с отсутствием антипитательных веществ (Для Центрального и Северозападного регионов Российской Федерации) /С.В. Булынцев// - С.Петербург, 2012. - 20с.

2. Булынцев С.В. Особенности сортовой технологии возделывания на зерно кормовых бобов Дружные в условиях Лесостепной зоны. (Практические рекомендации) / С.В. Булынцев, К.М Телих// - Тула: Гриф, 2013 - 40с.

3. Булынцев С.В. Селекция овощных бобов в Тульской области / С.В. Булынцев, К.М Телих// - Кормопроизводство, 2015. - № 11. - С. 37-39.

4. Булынцев С.В. Бобы, как ценный кормовой компонент в севооборотах Центрального и Северо-Западного регионов Российской Федерации /С.В. Булынцев, Г.А. Гриднев, Е.А. Сергеев, В.И. Макаров, К.М. Телих// Материалы Международной научно-практической конференции, посвящённой 100-летию кафедры луговодства СПГАУ «Ресурсосберегающие технологии в луговом кормопроизводстве» - СанктПетербург, 2013. - С.129-134.

5. Булынцев С.В., Телих К.М. Новые сорта овощных и кормовых бобов, созданные на основе коллекции ВИР. В книге: Пути повышения эффективности использования генетических ресурсов зернобобовых в селекции. Тезисы докладов Международной научной конференции. Федеральное агентство научных организаций (ФАНО России), Федеральный исследовательский центр Всероссийский институт генетических ресурсов растений им. Н.И. Вавилова (ВИР) / С.В. Булынцев, К.М Телих// - СанктПетербург, 2016. - С. 21-23.

6. Вавилов П.П. Бобовые культуры и проблемы растительного белка / П.П.Вавилов, Г.С. Посыпанов // - М.: Россельхозиздат, 1983. - 250 с.

7. Косолапов В.М. Горох, люпин, вика, бобы: оценка и использование в кормлении сельскохозяйственных животных /В.М.Косолапов, А.И.Фицев, А.П. Гаганов и др.// - М., 2009. - 374 с.

8. Медведев П.Ф. Кормовые растения Европейской части СССР / П.Ф.Медведев, А.И. Сметанникова// - Ленинград, 1981. - 336 с.

9. Методические указания. Коллекция мировых генетических ресурсов зерновых бобовых ВИР. Пополнение, сохранение и изучение. - С. Петербург, 2010 - 141с.

10. Посевные площади сельскохозяйственных культур по категориям хозяйств Тульской области. Статистический сборник Федеральной службы государственной статистики. - Тула, 2011 - 94с.

11. Телих К.М. Агроклиматические фракторы, определяющие возделывание кормовых бобов сорта дружные в Тульской области. В сборнике: Фотосинтетическая деятельность и продукционные процессы фритоценозов Материалы Международной дистанционной конференции / К.М Телих, С.В. Булынцев // - Орел, 2014. - С. 196-200.

12. Телих К.М., Булынцев С.В. Начало процесса возделывания кормовых бобов в России. В сборнике: Veda a vznik - 2013/2014 Materiały X Mezinarodni vedecko - prakticka konference / К.М Телих, С.В. Булынцев // - Praha, 2014. - С. 81-83.

13. Телих К.М., Булынцев С.В. Опыт выращивания новых сортов овощных бобов на черноземных почвах Тульской области/ К.М Телих, С.В. Булынцев // - Научный обозреватель, 2016. - № 10. - С. 56-58. 
DOI https://doi.org/10.18551/rjoas.2017-08.32

\title{
ВЛИЯНИЕ ПОГОДНЫХ УСЛОВИЙ И АГРОТЕХНИЧЕСКИХ ПРИЕМОВ НА СЕМЕННУЮ ПРОДУКТИВНОСТЬ ФАЦЕЛИИ \\ THE INFLUENCE OF WEATHER CONDITIONS AND AGRONOMIC PRACTICES ON SEED PRODUCTION OF PHACELIA
}

\author{
Серегина Н.В., научный сотрудник \\ Seregina N.V., Researcher \\ Тульский научно исследовательский институт сельского хозяйства, \\ Тульская область, Россия \\ Tula Research Institute of Agriculture, Tula Region, Russia \\ E-mail:tniisx@mail.ru
}

\begin{abstract}
АННОТАЦИЯ
В статье изложены результаты исследований нетрадиционной медоносной культуры фрацелия сорта Радуга. Установлено, что закладка семенных травостоев фацелии рядовым и широкорядным способами посева и нормой высева 6-12 кг/га позволяет сформировать слабо-полегший семенной травостой, обеспечивающий получение 186 394 кг семян с гектара. Для формирования высокопродуктивного слабо-полегающего семенного травостоя фрацелии Радуга оптимальной нормой азотных удобрений является 60 кг/га д.в. при применении в весенний период. При этом урожайность семян в среднем составила 357 - 394 кг/га, что соответственно выше на 47,9 - 38,4\% чем сбор семян, полученных на фонах без внесения NPK. Наиболее оптимальные условия для сохранности растений к уборке прямым комбайнированием обеспечиваются при широкорядном способе посева с шириной междурядий 45 см, нормой высева 6-8 кг/га всхожих семян.

\section{ABSTRACT}

In the article results of researches of nonconventional honey-bearing culture of a phacelium of Rainbow variety are stated. It has been established that the laying of seedlings of phacelia by ordinary and broad-row seeding methods and seeding rate of 6-12 kg / ha makes it possible to form a weakly-sheltered seed herb providing 186 to $394 \mathrm{~kg}$ of seeds per hectare. For the formation of a highly productive low-flowing seed herbage of the Phacelia Rainbow, the optimum norm for nitrogen fertilizers is $60 \mathrm{~kg} / \mathrm{ha}$. When applied in the spring. At the same time, the yield of seeds averaged $357-394 \mathrm{~kg} /$ ha, which is $47.9-38.4 \%$ higher than collection of seeds obtained on backgrounds without NPK introduction. The most optimal conditions for the preservation of plants for harvesting by direct combining are provided for a wide-row seeding method with a row spacing of $45 \mathrm{~cm}$, seeding rate of 6-8 kg / ha of virgin seeds.
\end{abstract}

\section{КЛЮЧЕВЫЕ СЛОВА}

Фацелия, сорт, норма высева, срок уборки, урожайность, семенная продуктивность, способ посева.

\section{KEY WORDS}

Phacelia, variety, seeding rate, harvesting time, yield, seed productivity, method of sowing.

Фацелия рябинолистная (Phacelia tanaceti folia Benth) - однолетнее растение семейства водолистниковых [1]. Сильный медонос, отлично посещается пчёлами [2]. Это также и питательный корм для сельскохозяйственных животных. По данным Всероссийского института кормов, по питательности фрацелия не уступает такому ценному корму как викоовёс [3]. В молодом возрасте фацелию можно скашивать на сено [4]. Хорошо её высевать в смеси с овсом, викой, донником на зелёный корм; с кукурузой, подсолнечником - на силос. В молодом возрасте и в травосмесях волосков 
на растениях образуется значительно меньше, стебли бывают более тонкие и нежные, тогда скот их охотно поедает [5]. Фацелия обладает холодоустойчивостью, может осенью переносить заморозки до $-7 . . .-9{ }^{0} \mathrm{C}$. Поэтому фацелию можно использовать как пожнивную культуру. Расширение ее посевных площадей обусловлено дефицитом семян из-за недостаточной разработанности технологии возделывания [6]. В связи с отличительными биологическими особенностями развития и хозяйственно-полезными признаками фацелии требуется разработка приёмов агротехники в семеноводстве, в частности, системы удобрений. Из литературных данных известно, что на улучшение агротехники фрацелия отвечает увеличением нектаровыделения, а выход семян и их посевные качества повышались при внесении в оптимальной дозе полного удобрения $\left(\mathrm{N}_{60} \mathrm{P}_{60} \mathrm{~K}_{60}\right)$, тогда как при более высоких дозах всех компонентов или при значительном преобладании азота названные показатели ухудшались, а при избытке азота снижались и урожайные свойства семян [7]. В полевых опытах с фрацелией установлено значительное повышение нектаропродуктивности и урожая семян при внесении полного удобрения на 133,1\% [8].

\section{МАТЕРИАЛЫ И МЕТОДЫ ИССЛЕДОВАНИЙ}

В 2014-2016 годах в отделе кормопроизводства Тульского НИИСХ проводились исследования по разработке технологии производства ффацелии сорта Радуга. В исследованиях (2014-2016 гг.) изучались два способа посева с разной шириной междурядий (15 см и 45 см) и две нормы высева (6-8 кг/га и 10-12 кг/га), внесение дозы известковой селитры (1:1:1) перед посевом, изучалось в 2016 году. Агротехника возделывания - запольная, общепринятая для трав в южных районах Тульской области. Повторность опыта трёхкратная, размещение вариантов систематическое с юга на север, предшественник - яровой рапс. Посев проводили сеялкой $\mathrm{CH}-16$, уборку семян - малогабаритным селекционным комбайном «Wintersteiner-Classik». Сразу же после уборки семенную массу подсушивали в сушилках и пропускали через машину первичной очистки. Учёты и наблюдения в опыте проводили в соответствии с «Методическими указаниями по проведению полевых опытов с кормовыми культурами» [9]. Агрохимические показатели почвы определяли в аналитической лаборатории ФГБНУ «Тульского НИИСХ»: гумус - по Тюрину (ГОСТ 262113-91); рНсол потенциаметрически (ГОСТ 26487-85); содержание фоссфора и калия - по Масловой (ГОСТ 50446-93). Статистическую обработку урожайных данных проводили методами дисперсионного и корреляционного анализов по Б.А. Доспехову [10].

\section{РЕЗУЛЬТАТЫ ИССЛЕДОВАНИЙ И ИХ ОБСУЖДЕНИЕ}

Полевые исследования проводились на выщелоченном тяжелосуглинистом чернозёме с содержанием гумуса в пахотном горизонте 6,7\%, подвижного фросфора 96 мг/кг, обменного калия 47,3 мг/кг почвы, $\mathrm{pH}$ - 4,61. Оптимальные сроки сева фрацелии приходятся на 25 апреля - 5 мая, одновременно с севом ранних яровых культур, так как при посеве после 10 мая всходы бывают недружные, период цветения растягивается, созревание семян происходит неравномерно, а урожай семян заметно снижается. Посев был проведён в 2014 году - 25 апреля, в 2015 году - 8 мая, в 2016 году - 4 мая.

Погодные условия периодов активной вегетации (май-август) 2014 и 2015 годов характеризовались теплой и сухой погодой. Средняя температура воздуха была выше средней многолетней на $1,6 \ldots 0,8^{\circ} \mathrm{C}$ соответственно, осадков выпало в 2014 году $54 \%$, а в 2015 году - 88,5\% от среднемноголетней нормы. Агроклиматические условия 2016 года отличались от среднемноголетних данных и характеризовались повышенным температурным фоном и обильными осадками и были менее благоприятными, чем два предыдущих года (табл. 1). Благодаря потеплению климата в целом за вегетационный период сумма эфффективных температур $\left(>+10^{\circ} \mathrm{C}\right)$ превысила среднемноголетний показатель на $1,5^{\circ} \mathrm{C}$ среднесуточно, а количество дней с такими 
температурами - на 16 дней. Осадков за этот период выпало 471 мм, это 163\% от нормы (норма 289,2 мм). Дата прекращения вегетации наступила позже предыдущих сроков на 2 недели.

Таблица 1 - Тепло и влагообеспеченность вегетационного периода фацелии, 2014-2016 гг.

\begin{tabular}{|c|c|c|c|c|c|c|c|c|}
\hline \multirow{2}{*}{ Месяц } & \multicolumn{4}{|c|}{ Температура, ${ }^{\circ} \mathrm{C}$} & \multicolumn{4}{c|}{ Осадки, мм } \\
\cline { 2 - 9 } & $\begin{array}{c}\text { Среднемноголетняя } \\
\text { температура, }{ }^{\circ} \mathrm{C}\end{array}$ & 2014 & 2015 & 2016 & $\begin{array}{c}\text { Среднемноголетние } \\
\text { осадки, мм }\end{array}$ & 2014 & 2015 & 2016 \\
\hline Май & 13,2 & 16,7 & 14,5 & 13,8 & 48,8 & 44,1 & 46,6 & 101,4 \\
\hline Июнь & 16,9 & 15,6 & 17,7 & 17,5 & 78,3 & 66,5 & 131,3 & 89,6 \\
\hline Июль & 18,4 & 20,3 & 18,4 & 20,3 & 91,8 & 17,8 & 76,7 & 126,2 \\
\hline Август & 16,9 & 19,3 & 18 & 19,1 & 73,8 & 29,3 & 4,5 & 154,2 \\
\hline
\end{tabular}

Высота растений фацелии в 2015 году была больше, нежели в 2014 и в 2016 годах, и варьировала в среднем от 112,2 см в широкорядном посеве до 104 см в узкорядном, против 85,3 и 91,0 см соответственно в 2014 году, 74,4 и 70,2 см в 2016 году (табл. 2).

Таблица 2 - Влияние способов посева и норм высева на семенную продуктивность фацелии

\begin{tabular}{|c|c|c|c|c|c|c|c|c|c|c|}
\hline Способы посева & Норма высева & \multicolumn{3}{|c|}{ Высота растений, см } & \multicolumn{2}{c|}{ Вес снопа с 1 м², г } & \multicolumn{3}{|c|}{ Вес зерна в снопе, г } \\
\cline { 3 - 11 } (ширина междурядий) & семян, кг/га & $2014 г$. & $2015 г$. & $2016 г$. & $2014 г$. & $2015 г$. & $2016 г$. & $2014 г$. & $2015 г$. & $2016 г$. \\
\hline Рядовой, 15 см & $10-12$ & 91,0 & 104,0 & 70,2 & 1276 & 910 & 630 & 31,7 & 21,0 & 18,6 \\
\hline Широкорядный, 45 см & $6-8$ & 85,3 & 112,2 & 74,4 & 1503 & 1110 & 890 & 53,3 & 35,0 & 24,3 \\
\hline
\end{tabular}

В среднем, за время исследований лучше развивались растения в вариантах с меньшей густотой стояния. С увеличением нормы высева полнота всходов, сохранность растений за период вегетации и к моменту уборки на семена снижалась. Наиболее оптимальные условия для сохранности растений к уборке обеспечиваются при невысоких нормах высева - при широкорядном посеве с шириной междурядий 45 см и нормой высева 6-8 кг/га всхожих семян. При широкорядном посеве сохранность растений к уборке была выше, чем при рядовом способе на $36,5 \%$.

Основными элементами структуры урожая, определяющими семенную продуктивность фрацелии являются: количество генеративных побегов на одном растении, количество растений на $1 \mathrm{~m}^{2}$, вес учётного снопа, масса семян с $1 \mathrm{~m}^{2}$. Количество ветвей первого и второго порядков зависело от густоты стояния и условий вегетации. Растения имеют прямостоячий стебель, очень хрупкий с сидячими перисторассечёнными листьями (11). В среднем, при широкорядном посеве и меньшей норме высева развилось больше боковых ветвей первого и второго порядка. В благоприятных агротехнических условиях произрастания фрацелия сформировала больше крупных боковых побегов, а, следовательно, больше соцветий. Известно, что количество развитых цветков на растении зависит от способа посева - при широкорядном их бывает до 930-1400, при сплошном - 130-180 (7).

Метеоусловия 2016 года привели к осыпанию большого количества семян, поэтому урожайность культур в этом году была ниже прошлогодних данных. В первую очередь осыпались более мелкие семена с верхней части соцветия. Осыпавшиеся семена были менее полновесными (масса 1000 семян 1,82 - 2,09г), чем семена основной массы урожая (2,36 - 2,68 г). В фразу полной спелости масса 1000 семян, оставшихся в соцветиях, превышала массу осыпавшихся на 8-14\%, так как на последних этапах созревания были затяжные дожди, и начинал доминировать процесс осыпания более полновесных семян.

Рациональное использование удобрений в семеноводстве трав - один из основных приёмов повышения их урожайности $(12,13)$. В проведённых исследованиях азотное удобрение оказало существенное влияние на формирование элементов структуры семенных травостоев. Удобрения оказывали большое влияние на формирование и рост как вегетативных, так и репродуктивных органов растений фрацелии. При этом количество семян в пересчёте на число цветков в результате 
уменьшилось, то есть положительный фризиологический эффект был достигнут при отрицательном производственном. Так, число растений к моменту уборки было максимальным в вариантах с полной дозой удобрений при узкорядном и широкорядном способах посева (табл. 3). Прибавка от внесения удобрений в рядовом посеве составила $12,4 \%$, а в широкорядном посеве 13,7\%. Применение удобрений положительно сказалось и на других элементах структуры урожая фрацелии. В вариантах с применением удобрений прослеживалась тенденция в прибавке по высоте по сравнению с контролем (без удобрений). Самыми высокими были растения на делянках с полной дозой удобрений в широкорядном посеве. Количество ветвей возрастало в обоих посевах примерно одинаково по отношению к контролю, в среднем оно менялось на 5 - 6 шт. при полной и половинной дозе удобрений.

Таблица 3 - Влияние агротехнических приёмов на семенную продуктивность фацелии

\begin{tabular}{|c|c|c|c|c|c|c|c|c|}
\hline $\begin{array}{c}\text { Способы посева } \\
\text { (ширина } \\
\text { междурядий) }\end{array}$ & $\begin{array}{c}\text { Норма } \\
\text { высева } \\
\text { семян, } \\
\text { кг/га } \\
\end{array}$ & $\begin{array}{c}\text { Доза } \\
\text { удобрений }\end{array}$ & $\begin{array}{c}\text { Число } \\
\text { растений, } \\
\text { шт/м² }\end{array}$ & $\begin{array}{c}\text { Высота } \\
\text { растений, } \\
\text { см }\end{array}$ & $\begin{array}{c}\text { Длина } \\
\text { соцветий, } \\
\text { см }\end{array}$ & $\begin{array}{c}\text { Число } \\
\text { ветвей на } \\
\text { растении }\end{array}$ & $\begin{array}{c}\text { Bec } \\
\text { снопа } \\
\text { с } 1 \mathrm{~m}^{2} \\
\mathrm{r}\end{array}$ & $\begin{array}{c}\text { Вес } \\
\text { зерна в } \\
\text { снопе, г }\end{array}$ \\
\hline \multirow{3}{*}{ Рядовой, 15 см } & \multirow{3}{*}{$10-12$} & $5 / y$ & 54 & 70,2 & 6,8 & 18 & 630 & 18,6 \\
\hline & & $\mathrm{N}_{30} \mathrm{P}_{30} \mathrm{~K}_{30}$ & 63 & $.77,7$ & 8,3 & 23 & 860 & 22,4 \\
\hline & & $\mathrm{N}_{60} \mathrm{P}_{60} \mathrm{~K}_{60}$ & 67 & 80,8 & 11,6 & 29 & 920 & 35,7 \\
\hline \multirow{3}{*}{$\begin{array}{c}\text { Широкорядный, } \\
45 \text { см }\end{array}$} & \multirow{3}{*}{$6-8$} & $5 / y$ & 43 & 74,4 & 9,3 & 21 & 890 & 24,3 \\
\hline & & $\mathrm{N}_{30} \mathrm{P}_{30} \mathrm{~K}_{30}$ & 54 & 80,7 & 12,7 & 27 & 960 & 29,6 \\
\hline & & $\mathrm{N}_{60} \mathrm{P}_{60} \mathrm{~K}_{60}$ & 59 & 84,9 & 14,4 & 32 & 1320 & 39,4 \\
\hline
\end{tabular}

Под влиянием удобрений формировались более удлиненные соцветия. Так, если их длина на фоне без удобрений была 6,8-9,3 см, то при внесении минерального удобрения в зависимости от дозы она достигла 8,3-11,6 см и 12,7-14,4 см соответственно, то есть стало больше на $18,1-41,3 \%$ и $26,8-35,5 \%$.

Исследования показали, что фактический сбор семян при внесении $\mathrm{N}_{30} \mathrm{P}_{30} \mathrm{~K}_{30}$ составил 22,4-29,6 г/м, что было выше, чем в контрольных вариантах на 17-18\%. Аналогичная закономерность отмечена и на посевах с применением полной дозы удобрений, прибавка от их применения составила 17,1-15,1 г/м. Таким образом, установлено, что на фацелии возможно применение оптимальных доз удобрений в весенний период, которое приводит к увеличению фактической урожайности семян с хорошими посевными качествами.

Заключение. В результате исследований установлено, что закладка семенных травостоев фацелии рядовым и широкорядным способами посева и нормой высева 612 кг/га позволяет сформировать слабо-полегший семенной травостой, обеспечивающий получение 186 - 394 кг семян с гектара. Для фрормирования высокопродуктивного слабо-полегающего семенного травостоя фрацелии Радуга оптимальной нормой азотных удобрений является 60 кг/га д.в. при применении в весенний период. При этом урожайность семян в среднем составила 357-394 кг/га, что соответственно выше на 47,9-38,4\% чем сбор семян, полученных на фронах без внесения NPK. Наиболее оптимальные условия для сохранности растений к уборке прямым комбайнированием обеспечиваются при широкорядном способе посева с шириной междурядий 45 см, нормой высева 6-8 кг/га всхожих семян.

\section{БИБЛИОГРАФИЯ}

1. Губанов И.А. Определитель сосудистых растений /И.А. Губанов, К.В. Киселёва, В.С. Новиков, В.Н. Тихомиров// - М.: МГУ, 1992. - 400 с.

2. Копелькиевский Г.В. Улучшение кормовой базы пчеловодства/ Г.В. Копелькиевский, А.Н. Бурмистров// - М.: Россельхозиздат, 1965. - 166 с.

3. Косолапов В.М. Горох, люпин, вика, бобы: оценка и использование в кормлении сельскохозяйственных животных /В.М.Косолапов, А.И.Фицев, А.П. Гаганов и др.// М., 2009. - 374 c. 
4. Пономарёва Е.Г. Кормовая база пчеловодства и опыление сельскохозяйственных растений /Е.Г. Пономарёва // - М.: Колос, 1980. - 255 с.

5. Кривцов Н.И. Специально для пчёл / Н.И. Кривцов // Пчеловодство. - 2008. - №7 C. $20-24$.

6. Золотарёв В.Н. // Научные принципы создания и уборки высокопродуктивных семенных агрофитоценозов кормовых культур / В.Н. Золоторёв, Н.И. Перепрово, С.В. Серегин / Сб. науч. тр.«Кормопроизводство: Проблемы и пути решения» - М., 2007 - с. 40-47.

7. Глухов М.М: Медоносные растения/ М.М. Глухов // - М.: Сельхозгиз, 1955. - 512 с.

8. Зауралов О.А. Растения и нектар / О.А. Зауралов. Саратов: Издательство Саратовского университета. - 1982. - 180 с.

9. Методические указания по проведению полевых опытов с кормовыми культурами. М.: ВИК, 1997. - 156 с.

10. Доспехов Б.А. Методика опытного дела /Б.А.Доспехов - М.: Агропромиздат, 1985. 351c.

11. Федоров А.А. Флора европейской части СССР, том V / Коллектив авторов. Отв. ред. А.А.Федорова//- Л.: Наука, 1981. - 380 с.

12. Большаков Н.В. О семеноводстве нетрадиционных кормовых культур/ Н.В. Большаков, Г.Н. Полонская // - Калуга: Труды региональной научно-практической конфреренции: «Научные основы повышения эффективности систем земледелия и животноводства», апрель 2011 г. - С.100-105.

13. Серегина Н.В. О семеноводстве нетрадиционной медоносной культуры фацелии / Н.В.Серегина// Научный обозреватель. - 2016. - №11 (71). - С. 58-61. 
DOI https://doi.org/10.18551/rjoas.2017-08.33

\title{
ПРАВОВЫЕ ОСНОВЫ И ПОЛИТИЧЕСКИЕ ПОТРЕБНОСТИ РЕФОРМИРОВАНИЯ УПРАВЛЕНИЯ АКАДЕМИЧЕСКОЙ НАУКОЙ НА РУБЕЖЕ ХХ И ХХІ ВЕКОВ LEGAL BASIS AND POLITICAL NEEDS OF THE REFORM OF THE MANAGEMENT OF ACADEMIC SCIENCE AT THE TURN OF THE XX AND XXI CENTURIES
}

\author{
Осипов Г.В., аспирант \\ Osipov G.V., Post-graduate student \\ Московский государственный университет имени М.В. Ломоносова, \\ Москва, Россия \\ Lomonosov Moscow State University, Moscow, Russia \\ E-mail: witter.com/MSU_1755
}

\begin{abstract}
АННОТАЦИЯ
В статье рассматриваются правовые основы реформирования системы управления академическими институтами, характерные для 90-х годов XX века. Особенность подхода автора и изложение материала заключается в использовании социологических методов анализа правовых явлений, что вписывается в такое направление современного развития юридической науки, как социология права. В связи с этим анализируются указы Президента СССР М.С. Горбачева и первые законодательные акты Президента России Б.Н. Ельцина, дается представление об объемах бюджетного фринансирования учреждений науки в 1991-1999 годах, отражается процесс накопления кризисных явлений в научных подразделениях Российской академии наук. Определенное внимание уделяется деятельности отечественных и зарубежных фондов, оказывавших содействие в реализации научных проектов, дается представление об основных законодательных актах и постановлениях Правительства Российской Федерации, регламентировавших деятельность академических институтов на рубеже XX-XXI веков.
\end{abstract}

\section{ABSTRACT}

The article discusses the legal basis for reforming the management system of academic institutions related to the 90 s of the XX century. A feature of the author's approach and presentation of the material is the use of sociological methods of analysis of legal phenomena, which fits into the direction of the modern development of legal science, as the sociology of law. In this regard, the decrees of the President of the USSR M.S. Gorbachev and the first legislative acts of the President of Russia B.N. Yeltsin, gives an idea of the volume of budgetary funding of science institutions in 1991-1999, reflects the process of accumulation of crisis phenomena in the scientific divisions of the Russian Academy of Sciences. Particular attention is paid to the activities of domestic and foreign foundations that assisted in the implementation of scientific projects; an idea is given of the main legislative acts and resolutions of the Government of the Russian Federation that regulated the activities of academic institutions at the turn of the XX-XXI centuries.

\section{КЛЮЧЕВЫЕ СЛОВА}

Правовое обеспечение, управление наукой, социология права, эффрективность деятельности.

\section{KEY WORDS}

Legal support, science management, sociology of law, performance.

Социологические опросы, проводившиеся в России в годы «перестройки» (19851991 гг.) отличались тенденциозными подходами и являлись эмпирической основой для дискредитации советского периода отечественной истории. Их отличительные особенности - конъюнктурная сообразительность публицистов, объявивших себя 
социологами, и гиперболизация пороков советского строя, что приводило к дезориентации общественного мнения, но содействовало проведению радикальных реформ.

Главным объектом критического анализа стала Академия наук. Как важнейший социальный институт, созданный во времена императора Петра Великого (императорский Указ вышел 8 февраля 1724 года), Академию наук СССР удалось сохранить, хотя стремления политиков западной ориентации уничтожить ее как «оплот тоталитаризма» были не менее настойчивы, чем борьба с КПСС и партгосноменклатурой.

Это в значительной степени предопределило реформирование системы управления наукой. Еще более существенным было то, что необходимость перемен хорошо осознавали в самой Академии наук СССР, ее институтах и подразделениях.

К осени 1986 года созрели планы некоторой децентрализации управления, наделения большими полномочиями научно-исследовательских институтов Академии наук СССР и отделений самой Академии. Наряду с этим ставился вопрос о демократизации их внутренней жизни. В числе наиболее актуальных был вопрос о координации деятельности академической, отраслевой и вузовской науки.

В концентрированном виде подходы руководителей страны и ответственных за развитие науки и реформирование отрасли отражены в Указе Президента СССР М.С. Горбачева о статусе АН СССР (23 августа 1990 г.), в соответствии с которым АН СССР становилась независимой от государственных структур ${ }^{1}$. Эта независимость подкреплялась передачей имущества АН в виде земель, зданий, оборудования в ее полноправную собственность, о чем говорилось во втором пункте Указа. Согласно третьему пункту поддержка гарантировалась не только Академии наук в качестве институциональной структуры, но и фундаментальной науке в целом, которая, в отличие от прикладной науки, не может напрямую встраиваться в рыночные отношения, что предполагает гарантированное фринансирование со стороны государства ${ }^{2}$.

В истории правления М.С. Горбачева это был, пожалуй, единственный Указ, отвечавший национальным интересам страны. Однако между содержанием Указа и реальной практикой сначала образовался разрыв, а затем - пропасть. Знанию из движущей силы прогресса предстояло превратиться в товар и встроиться в примитивные «рыночные» отношения. На смену приоритетному фринансированию науки шло новое правительственное отношение к ней как к «прочей» статье бюджета ${ }^{3}$. В сфреру финансового обеспечения научных исследований, начиная с 1990 года, пришли инвестиционные фонды; финансировалась не наука, а отдельные ученые и их проекты; постепенно фрормировались методы торможения мотивационной структуры науки.

После развала СССР начались бурные дискуссии по поводу статуса Академии наук. 24 января 1990 года Указом Президиума РСФСР была учреждена Российская Академия наук. АН СССР была распущена. Ее правопреемницей стала Российская академия наук, которая была образована Указом Президента России Б.Н. Ельцина от 21 ноября 1991 года. РАН получила государственный статус высшего научного учреждения. За ее учреждениями закреплялись здания, основные фонды и другое имущество.

3-6 декабря 1991 г. прошли выборы в РАН.

17-20 декабря 1991 г. состоялось Учредительное общее собрание выборщиков Российской академии наук, на котором был избран ее президент - академик Ю.С. Осипов. 90-е годы XX столетия были самыми сложными в истории РАН. Доля расходов на науку в это время неуклонно снижалась. Ассигнования

1 См.: Указ Президента СССР от 23 августа 1990 г. № 627 "О статусе Академии наук», Вестник АН СССР - М., 1990 - № 11, с. 3-4.

2 См.: Н.Н. Гиндилис "От советской к Российской Академии наук: конец 80-х - 90-е годы»; в кн. «Науковедческие исследования», 2014, с. 129.

3 См.: Отечественные записки, М. 2002, № 7, с.43. 
на науку из средств федерального бюджета в процентах к ВВП составляли: 1991 г. 1,9\%; 1992 г. - 0,9\%; 1993 г. - 0,9\%; $1994-0,7 ; 1995-0,6 ; 1996-0,6 ; 1997-0,8 ; 1998$ 0,4; в 1999 г. - 0,5\%. Основная часть базового фринансирования шла на оплату коммунальных расходов, аренду помещений и зарплату. На фринансирование исследований денег не оставалось ${ }^{4}$.

Академические институты перестали получать иностранную периодику, не было средств на зарубежные поездки, международные конференции проходили с небольшим количеством ученых из России.

Начался отток научных кадров. Он развивался в двух направлениях: часть талантливых ученых покинула Россию и своими достижениями обогащала мировую науку, в том числе стратегических соперников; другая часть переходила на работу внутри страны, прежде всего в коммерческий сектор и занимала хорошо оплачиваемые, но не требующие высокой квалификации должности.

Мотивационная система рухнула, стимулов, способных влиять на поведение работников у руководителей академических институтов не было. Оставались в России лишь преданные своему делу ученые и сотрудники. Но в целом приток в науку молодежи сократился.

При всей сложности фринансово-экономического положения страны начавшаяся повальная приватизация госсобственности не вовлекла в свой водоворот имущество Российской академии наук. Препятствием этому стало Постановление Верховного совета Российской Федерации от 1 апреля 1993 г. № 4729-1 «О Российской Академии наук» ${ }^{5}$. Решающую роль в принятии Постановления сыграло влияние Председателя Верховного совета РФ, члена-корреспондента РАН Р.И. Хасбулатова и его заместителей, прежде всего В.Б. Исаева и С.П. Горячевой, имевших богатый опыт прокурорской работы.

1992-1994 гг. - период формирования и деятельности различных научных фондов, позволявших на конкурсной основе поддерживать наиболее перспективные научные исследования. В эти годы, помимо РФФИ, были созданы Российский фонд технологического развития - РФТР (1993), Российский гуманитарный научный фонд РГНФ (1994), Фонд содействия развитию малых фрорм предприятий в научнотехнической сфере (1994). Создание научных фондов являлось одним из направлений реформирования науки, позволявших реализовать идею конкурсного финансирования научных проектов. Усилилось влияние научной общественности, что выражалось в создании экспертных советов и экспертизе научно-исследовательских программ ${ }^{6}$.

Определенную, хотя и неоднозначную помощь в этот тяжелый для российской науки период оказали ей зарубежные фонды, прежде всего Международный научный фонд Дж. Сороса, учрежденный в декабре 1992 г. для поддержки фундаментальной науки в странах СНГ и Балтии. Европейское экономическое сообщество также выделило средства на расширение грантов и совместных проектов с Россией. Поддержку научному сообществу России в 90-е годы оказали Национальный центр научных исследований (Франция), Фонд Александра фон Гумбольдта (Германия), Фонд Д.Д. и К.Т. Макартуров (США). Таким образом, в крайне тяжелый период научное сообщество получило поддержку из-за рубежа ${ }^{7}$

Фондовая поддержка не могла решить проблем большинства академических научно-исследовательских институтов. Если в 1985 г. средняя заработная плата научных работников и занятых в научном обслуживании по абсолютной величине впервые за многие годы превысила зарплату в промышленности (и даже в 1990 г. все еще превышала ее), то уже в 1992 г. она составляла 50-60\% от средней зарплаты в промышленности, а в 1993 г. (по сообщению Совета профсоюзов РАН) по уровню зарплаты сотрудники РАН занимали последнее или предпоследнее место среди всех отраслей народного хозяйства. Зарплата научных сотрудников (13 разряд - 12960

\footnotetext{
4 См.: «Отечественная наука и научная политика в конце XX века», М., Изд-во МГУ, 2011, с. 147-148.

5 См.: Вестник Академии наук, М., 1993, № 7, с. 579.

6 См.: Н.Л. Гиндилис, Указ. соч., с. 135

7 Там же.
} 
руб.) не обеспечивала физиологического минимума проживания самого сотрудника и одного ребенка (14 тыс. в Москве на фревраль 1993 г. $)^{8}$.

Нельзя сказать, что Президент России Б.Н. Ельцин и его администрация вообще не интересовались состоянием дел в РАН: 2 января 1994 года были введены стипендии для выдающихся молодых ученых, устанавливались оклады академикам (150 000 руб.) и членам-корреспондентам РАН (75 000 руб.). За учреждениями РАН закреплялись ранее выделенные им земельные участки в бессрочное пользование, им разрешалось сдавать в аренду свободные площади научных учреждений, а также вести на них хозяйственную деятельность.

Дискуссии о статусе Российской академии наук продолжились в перманентном режиме. Их особенность состояла в том, что оппоненты широко использовали исторические, фрилософские, статистические данные, проводили сравнения, занимались экскурсами в прошлое, предрекали мрачное будущее России, если она останется без фундаментальной науки.

Слабость аргументов защитников РАН состояла в том, что в эти годы не использовались возможности конкретных социологических исследований и возможности социологии права. В силу этого реальное положение дел в российской науке было известно лишь частично, а анализ принимаемых в отношении РАН законов, Указов Президента, Постановлений Правительства Российской Федерации на улучшение или ухудшение положения дел носил поверхностный, в основном, политизированный характер. Между тем, нормативно-правовая база была исключительно солидной. Ограничимся лишь перечислением части принятых решений:

- 26 сентября 1995 г. вышло Постановление Правительства РФ «О государственной поддержке ведущих научных школ РФ»;

- 27 марта 1996 г. Указ Президента Б.Н. Ельцина «О некоторых мерах по усилению государственной поддержки науки и высших учебных заведений РФ»;

- 15 апреля 1996 г. - Указ Президента РФ «О мерах по развитию фундаментальной науки в РФ и статусе Российской академии наук»;

- 13 июня 1996 г. вышел Указ Президента России «О доктрине развития российской науки» и др.;

- 23 августа 1996 года был принят первый в новейшей истории России Закон «О науке и государственной научно-технической политике»;

- 26 ноября 1996 г. была утверждена Федеральная научно-техническая программа на 1996-2000 гг. «Исследования и разработки по приоритетным направлениям развития науки и техники гражданского назначения»;

- в мае 1997 г. вышло Постановление Правительства РФ «О неотложных мерах по усилению государственной поддержки науки в Российской Федерации»;

- 18 мая 1998 г. - Постановление Правительства РФ «О концепции рефрормирования российской науки на период 1998-2000 годов» и т.д.

В период интенсивной законотворческой и нормативно-распорядительной деятельности особенно важно было на основе социологии права изучить правопонимание учеными деятельности законодателя, проанализировать правоприменительную практику и выработать на этой основе ясное представление об эфффективности принятых мер и определить степень влияния принятых решений на формирования мотивационных фракторов, позитивно влияющих на трудовое поведение научных работников. Но социология права с этой задачей не справилась, хотя уже были опубликованы труды выдающихся правоведов В.Н. Кудрявцева, М.Н. Козимирчука, других ученых, вышли первые учебники по курсу «социология права».

Масштабную социологическую картину состояния российской науки в 90-х годах XX века получить удалось не сразу, но, оценивая ситуацию в рамках включенного наблюдения, академик В.Н. Страхов в марте 1998 г. верно заметил: «Моральное состояние нашего научного войска определяется сейчас двумя крайними позициями:

8 См.: Н.Л. Гиндилис, Указ. соч., с. 136. 
одни ни во что не верят, другие бьются только за себя... Моральное разложение величайшее... Люди не ходят на работу, потому что подрабатывают на стороне, а это неизбежно ведет за собой потерю профессионализма... Используемое в институтах оборудование давным-давно устарело, и делать на нем науку принципиально невозможно... Отставание от мирового уровня колоссальное» ${ }^{9}$.

Лучшие традиции советской научной политики достоянием демократической общественности, в том числе по вине самой академии, не стали. Просветительскую деятельность РАН не вела, на позицию СМИ, в основном недоброжелательную, академического влияния практически не оказывалось.

275-летие Российской Академии наук (1999 г.) не стало государственно значимым праздником отечественной науки.

XXI век получил в наследство две совокупности проблем, одна из которых может быть разрешена только на уровне правового обеспечения государственной научной политики, вторая - полностью зависит от работника, его компетенции, нацеленности на достижение значительных результатов.

\section{БИБЛИОГРАФИЯ}

1. Указ Президента СССР от 23 августа 1990 года № 627 «О статусе Академии наук».

2. Указ Президента РСФСР от 11 июля 1991 года № 1 «О первоочередных мерах по развитию образования в РСФСР».

3. Указ Президента России Б.Н. Ельцина от 21 ноября 1991 года № 228 «Об организации Российской академии наук».

4. Постановление Правительства РФ от 26 сентября 1995 г. № 957 «О государственной поддержке ведущих научных школ Российской Федерации».

5. Указ Президента Б.Н. Ельцина от 27 марта 1996 г. № 424 «О некоторых мерах по усилению государственной поддержки науки и высших учебных заведений РФ».

6. Указ Президента от 15 апреля 1996 года № 558 «О мерах по развитию фундаментальной науки в РФ и статусе Российской академии наук».

7. Указ Президента РФ от 13 июня 1996 года № 884 «О доктрине развития российской науки».

8. Федеральный закон от 23 августа 1996 года № 127-Ф3 «О науке и государственной научно-технической политике».

9. Постановление Правительства Российской Федерации от 23 ноября 1996 года № 1414 «Об утверждении федеральной целевой научно-технической программы на 1996-2000 годы «Исследования и разработки по приоритетным направлениям развития науки и техники гражданского назначения».

10. Постановление Правительства РФ от 7 мая 1997 года № 543 «О неотложных мерах по усилению государственной поддержки науки в Российской Федерации».

11. Постановление Правительства Российской Федерации от 18 мая 1998 года № 453 «О Концепции реформирования российской науки на период 1998 - 2000 годов».

12. Н.Н. Гиндилис «От советской к Российской Академии наук: конец 80-х - 90-е годы», кн. «Науковедческие исследования», 2014.

13. Жуков В.И. Российские преобразования: социология, экономика, политика. - М.: Академический проспект, 2003.

14. Отечественные записки, М. 2002, № 7.

15. «Отечественная наука и научная политика в конце XX века», М., Изд-во МГУ, 2011.

16. Вестник Академии наук, М., 1993, № 7.

17. Вестник Академии наук, М., 1998 - № 8.

18. Осипов Г.В., Миндели Л.Э. Россия и мир в начале XXI века. - М.: Наука, 2007;

19. Садовничий В.А. Россия. Московский университет. Высшая школа. - М: Изд-во МГУ, 1999.

${ }^{9}$ Вестник Академии наук, М., 1998 - № 8, с. 702. 


\section{ABOUT JOURNAL}

Russian Journal of Agricultural and Socio-Economic Sciences (ISSN 2226-1184) is an interdisciplinary open access journal of agriculture and socio-economic studies. Topical coverage includes: agriculture and rural development, agricultural economics, management, agribusiness, agrarian policy, information systems, social economy and rural sociology.

The electronic publication is registered by the Federal Service for Supervision of Communications and Mass Media of Russian Federation. Registration certificate EI No. FS 77-51446 of October 19, 2012.

Since December 1, 2015 RJOAS is considered to be included in the List of peer-reviewed scientific publications in which should be published basic scientific results of dissertations for the degree of Candidate of Science, for the degree of Doctor of Science (http://vak.ed.gov.ru/87) by the Order of the Ministry of Education and Science of the Russian Federation on July 25, 2014 №793, as amended by the Order of the Ministry of Education and Science of the Russian Federation on June 3, 2015 № 560 (registered by the Ministry of Justice of the Russian Federation on August 25, 2014, registration number 33863).

\section{Editor-in-Chief:}

- Researcher, Candidate of Agricultural Sciences Sergey Plygun (All-Russian Research Institute of Phytopathology, http://www.vniif.ru, Moscow Region, Russia).

Editorial Board:

- Scientific officer, Doctor in biology Andrei Orlinski (European and Mediterranean Plant Protection Organization (EPPO/OEPP), http://www.eppo.int, Paris, France);

- Prof. Dr. Wilhelm Windisch (TUM Technische Universitat Munchen, http://lte.wzw.tum.de, Freising, Germany);

- Professor, Dr. Sait Engindeniz (Ege University, http://www.ege.edu.tr, Bornova-Izmir, Turkey);

- Professor, Russian Federation Honored Scientist Vasily Lobkov (Orel State Agrarian University, http://www.orelsau.ru, Orel, Russia);

- Professor, Russian Federation Honored Scienitist Anatoly Stifeev (Kursk State Agricultural Academy, http://www.kgsha.ru, Kursk, Russia);

- Professor Yuri Kirichenko (Moscow State Mining University, http://www.msmu.ru, Moscow, Russia);

- Professor Nikolai Pimenov (Moscow State Academy of Veterinary Medicine and Biotechnology named after K.I. Skryabin, http://www.mgavm.ru, Moscow, Russia);

- Dr. Vikash Pratap Singh Bhadauria (Eshan college of Engineering, http://www.eshancollege.com, 28-B Ramchandra Puri, India);

- Dr. Rab Nawaz Lodhi (Institute of Business and Management, University of Engineering and Technology, http://www.uet.edu.pk, Sahiwal, Pakistan);

- Researcher Mohammad Ali Shariati (Islamic Azad University, http://www.azad.ac.ir, Tehran, Iran);

- Researcher Alexey Glinushkin (All-Russian Research Institute of Phytopathology, http://www.vniif.ru, Moscow Region, Russia);

- Researcher Andrey Polukhin (All-Russian Research Institute of Agricultural Economics, http://www.vniiesh.ru, Moscow, Russia);

- Associate Professor Igor Podkovyrov (Volgograd State Agricultural Academy, http://www.volgau.com, Volgograd, Russia);

- Associate Professor Dmitry Neuymin (Michurinsk State Agrarian University, http://www.mgau.ru, Michurinsk, Russia);

- Associate Professor Tatiana Sabetova (Voronezh State Agrarian University named after Peter the Great, http://www.vsau.ru, Voronezh, Russia).

Official sites: http://www.rjoas.com, http://www.rjoas.ru

Current indexing includes: AGRIS (International Information System for the Agricultural Sciences and Technology); DOAJ (Directory of Open Access Journals); CAB Abstracts; Open Access Infrastructure for Research in Europe (OpenAIRE); Research Papers in Economics (RePEc); Bielefeld Academic Search Engine (BASE); EBSCOhost; AgroKnow Stem; OCLC WorldCat; Russian Science Citation Index; Cyberleninka; ELS of Publishing House "Lan"; ELS of Publishing House "InfraM"; ELS "IPRbooks"; GlobalF5; SocioNet. 


\section{Find us on $f$ acebook:}

http://www.facebook.com/pages/Russian-Journal-of-Agricultural-and-Socio-EconomicSciences/336145216497494 
OPEN

ACCESS 


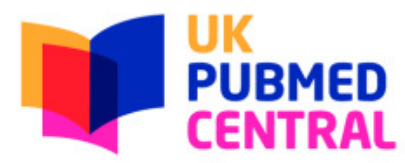
ukpmc.ac.uk
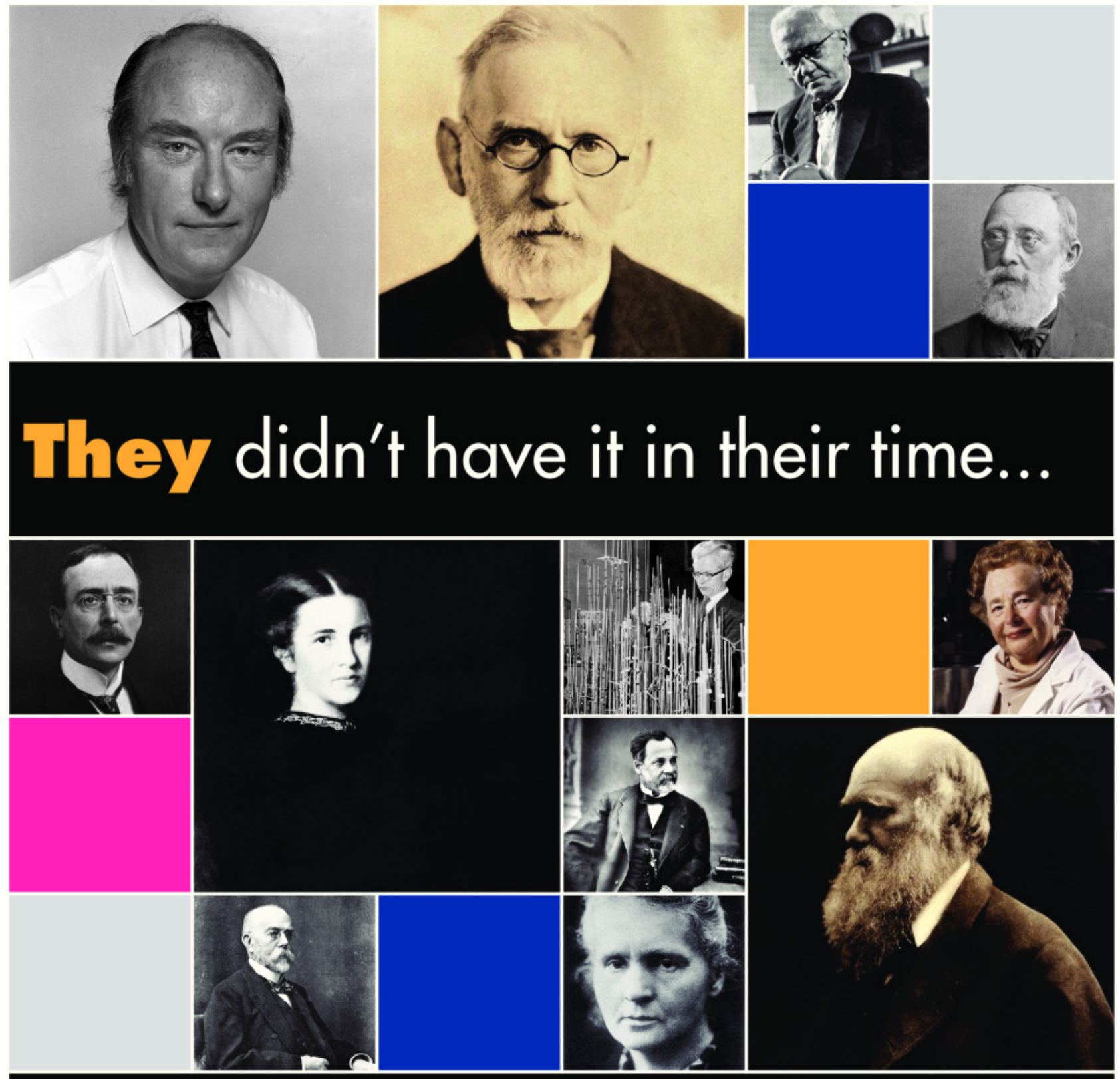

...imagine what y०u could achieve with it now

Images of Francis Crick and John Kendrew courtesy of MRC Loboratory of Molecular Biology. All other images courtesy of Wellcome Library, London

\section{UK PubMed Central}

A unique, free, information resource for biomedical and health researchers ukpmc.ac.uk

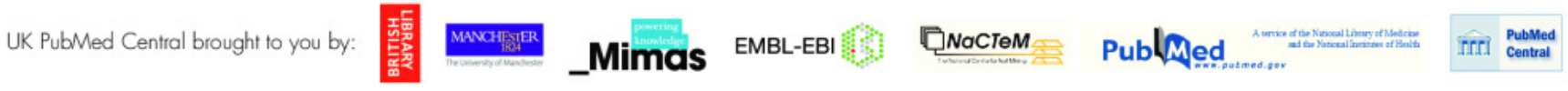

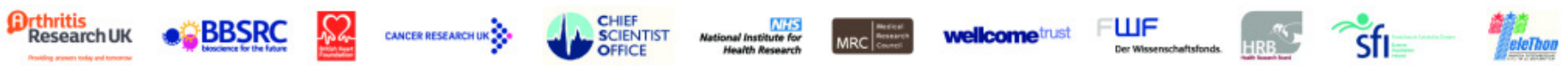

